This document was too large to scan as a whole document; therefore, it is divided into smaller sections.

DOCUMENT NUMBER: HNE-EP-0884

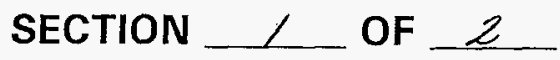

Table of Contents THru Referewees

TITLE:

HANFORD LOW-LEVEL TANK WASTE

INTERIM PERFORMANCE ASSESSMENT

DATE:

$9101 / 97$

REV:

ORIGINATOR: Fim,MAN, C.R.EIHOLZER,Y.CHEN, NW.KLINE,

CO:

A.H. LU, B.P.MC GRAL, P.D. RITIMANN

PHMC, DOE

REFERENCES:

KEYWORDS:

PROJECTS:

TFARM, TWRS 


\section{Hanford Low-Level Tank Waste Interim Performance Assessment}




\title{
Hanford
}

\section{Low-level Tank Waste}

\section{Interim Performance Assessment}

\author{
F.M. Mann, C.R. Eiholzer, Y. Chen, \\ N.W. Kline, A.H. Lu, B.P. McGrail, \\ and P.D. Rittmann
}

G.F. Williamson, WHC Project Manager (1996)

J.A. Voogd, PHMC Project Manager (1997)

N.R. Brown, DOE Project Manager (1996)

P.E. LaMont, Doe Project Manager (1997)

September 1997 


\title{
RELEASE AUTHORIZATION
}

Document Number:

Document

Title:
HNF-EP-0884, Rev. 1

Hanford Low-Level Tank Waste Interim Performance Assessment

\section{This document, reviewed in accordance with DOE} Order 1430.1D, "Scientific and Technical Information Management," and DOE G 1430.1D-1, "Guide to the Management of Scientific and Technical Information," does not contain classified or sensitive unclassified information and is:

\section{APPROVED FOR PUBLIC RELEASE}

\author{
Al-

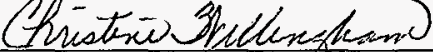 \\ Christine Whlingham \\ Lockheed Martin Services, Inc. \\ Document Control/Information Clearance
}

$9 / 12 / 97$

Reviewed for Applied Technology, Business Sensitive, Classified, Copyrighted, Export Controlled, Patent, Personat/Private, Proprietary, Protected CRADA, Trademark, Unclassified Control led Nuclear Information.

LEGAL DISCLAIMER. This report was prepared as an account of work sponsored by an agency of the United states Government. Heither the United States Government nor any agency thereof, not any of their employees, nor any of their contractors, subcontractors or their employees, makes any warranty, express or implied, or assumes any legal liability or responsibility for the accuracy, completeness, or any third party's use or the results of such use of any information, apparatus, product, or process disclosed, or represents that its use would not infringe privately owned rights. Reference here in to any specific comercial product, process, or service by trade name, trademark, manufacturer, or otherwise, does not necessarily const itute or imply its endorsement, recommendation, or favor ing by the United States Government or any agency thereof or its contractors or subcontractors. The views and opinions of authors expressed herein do not necessarily state or reflect those of the United States Government or any agency thereof. This report has been reproduced from the best avai lable copy. Printed in the United States of America. 
THIS PAGE INTENTIONALLY LEFT BLANK 
(2) Title

Hanford Low-level Tank Waste Interim Performance Assessment

CHANGE CONTROL RECORD

\begin{tabular}{|l|l|} 
(3) Revision & (4) Description of Change - Replace, Add, and Delete Pages \\
\hline 0 & $\begin{array}{l}\text { (7) WHC-EP-0884, Rev, O Hanford Low-level } \\
\text { Tank Waste Interim Performance } \\
\text { Assessment, EDT 618551 }\end{array}$ \\
\hline 1 & $\begin{array}{l}\text { HNF-EP-0884, Rev, 1 Hanford Low-Tevel Tank } \\
\text { Waste Interim Performance Assessment. } \\
\text { Complete document has changed. } \\
\text { Replace WHC-EP-0884, Rev. 0 with HNF-EP- } \\
\text { 0884, Rev 1. }\end{array}$ \\
\hline
\end{tabular}
F.M. Mann H0-31

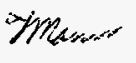

Authorized for Release

(5) Cog. Engr. (6) Cog. Mgr. Date 
LEGAL DISCLAIMER

This report was prepared as an account of work sponsored by an agency of the United States Government. Neither the

United States Government nor any agency thereof, nor any of their employees, nor any of their contractors, subcontractors or their employees, makes any warranty, express or implied, or assumes any legal liability or responsibility for the accuracy, completeness, or any third party's use or the results of such use of any information, apparatus, product, or process disclosed, or represents that its use would not infringe privately owned rights. Reference herein to any specific commercial product, process, or senvice by trade name, trademark, manufacturer, or otherwise, does not necessarily constitute or imply its endorsement, recommendation, or favoring by the United States Government or any agency thereof or its contractors or subcontractors. The views and opinions of authors expressed herein do not necessarily state or reflect those of the United States Government or any agency thereof.

This report has been reproduced from the best available copy.

Printed in the United Ststes of America

DISCLM-2.CHP (1-91) 


\section{HNF-EP-0884 \\ Rev. 1}

\section{EXECUTIVE SUMMARY}

The Hanford Low-Level Tank Waste Interim Performance Assessment examines the long-term environmental and human health effects associated with the disposal of the low-level fraction of the Hanford single- and double-shell tank waste in the Hanford Site 200 East Area. This report was prepared as a good management practice to provide needed information about the relationship between the disposal system design and performance early in the disposal system project cycle. The calculations in this performance assessment show that the disposal of the low-level fraction can meet environmental and health performance objectives.

\section{BACKGROUND}

The Hanford Site in south-central Washington State has been used extensively as a location for defense materials production by the U.S. Department of Energy (DOE) and its predecessor agencies. Over the last 50 years, radioactive and mixed waste from materials production and related activities have been stored on the Hanford Site, primarily in underground single- and double-shell tanks in the 200 Areas.

As part of Hanford's environmental restoration and waste management mission, DOE is proceeding with plans to retrieve the waste from the tanks, to seperate the waste into a small quantity of high-level waste and a much larger quantity of low-level waste, to immobilize both waste streams, to storge the immobolized high-level waste until it can be sent to a federal geologic repository, and to dispose of the immobolized low-level waste on-site in near-surface low-level tank waste disposal facilities. This plan is based on Revision 6 of the Hanford Federal Facility Agreement and Consent Order (Tri-Party Agreement) ${ }^{3}$ and on the Record of Decision for the Tank Remediation Systems, Hanford Site, Richland, Washington ${ }^{2}$. Over $200,000 \mathrm{~m}^{3}\left(6,000,000 \mathrm{ft}^{3}\right)$ of low-level waste will be disposed of under this plan. This quantity is among the largest amounts in the DOE Complex and contains one of the largest inventories of long-lived radionuclides at a low-level waste facility.

DOE Order 5820.2A, Radioactive Waste Management ${ }^{3}$ is the primary regulation currently governing management and disposal of radioactive waste at DOE facilities. The interim performance assessment uses the techniques, methods, and rigor of the final performance assessment described in DOE Order 5820.2A where possible. Much of the data for this interim performance assessment is based on information from other projects or programs. As more of

1 Washington State Department of Ecology, United States Environmental Protection Agency, United States Department of Energy, Hanford Facility Agreement and Consent Order, Sixth Amendment, February 1996. The document is available from any of the parties.

2 Record of Decision for the Tank Waste Remediation System, Hanford Site, Richland Washington, Federal Register, Volume 62, page 8693, February 26, 1997.

3 "Radioactive Waste Management", DOE Order 5820.2A, U.S. Department of Energy, Washington, D.C., September 26, 1988. 
the design effort is completed and more data are collected, the preliminary and final performance assessments, which are required by DOE Order 5820.2A, will be prepared.

DOE Order $5820.2 \mathrm{~A}$ is being revised. The existing drafts require similar information and effort as required by DOE Order 5820.2A. The preliminary and final performance assessments will follow the DOE regulations then in effect.

\section{DATA SOURCES}

The data used in the interim performance assessment are documented in Data Packages for the Hanford Low-Level Tank Waste Interim Performance Assessment ${ }^{4}$. The base analysis and sensitivity cases are provided in Definition of the Base Analysis Case of the Interim Performance Assessment 5 .

Many of the decisions concerning the disposal of the low-level fraction of the Hanford tank waste have not yet been made. These include the choice of waste form, the selection of the disposal site, and the design of the disposal facility. Therefore, enabling assumptions were made.

The release rate of contaminants from the waste form (4.4 parts per million per year) used in the base analysis case is based on the Request for Proposal ${ }^{6}$ (DOE-RL 1996) issued by the Richland Operations Office for the seperation and immobilization of tank waste. Sensitivity cases were also performed for a typical low-level waste glass using computer simulation to estimate the rate at which the glass would release the contaminants.

The location of the disposal facility is assumed to be in the Hanford Site 200 East Area, just southwest of the PUREX facility. The disposal facility is assumed to consist of

- a surface cover (to minimize the amount of water or other intrusion entering the facility),

- a sand-gravel capillary barrier (to divert water around the waste form), and

4 F. M. Mann, Data Packages for the Hanford Low-Level Tank Waste Interim Performance Assessment, HANF-SD-WM-RPT-166, Revision 0, Westinghouse Hanford Company, Richland, Washington, July 1995.

$5 \quad$ F. M. Mann, C. R. Eiholzer, R. Khaleel, N. W. Kline, A. H. Lu, B. P. McGrail, P. D. Rittmann, and F. Schmittroth, Definition of the Base Analysis Case of the Interim Performance Assessment, HANF-SD-WM-RPT-200, Revision 0, Westinghouse Hanford Company, Richland, Washington, December 1995. Prospective Offerors, U.S. Department of Energy, Richland, Washington, February 20 , 1996. These conditions have now been incorporated into contracts with British Nuclear Fuels Limited and with Lachute Martin Advanced Environmental Services, Incorporated. 


\section{HNF-EP-0884}

Rev. 1

- a concrete vault that is assumed to degrade in 500 years.

Geologic, hydraulic, geochemical, and water infiltration data obtained for the 200 Area plateau were used in this analysis and are considered to be representative of the disposal area.

The inventory of contaminants in the waste form is based on estimates for the tank waste inventory and using a conservative estimate to project the low-level fraction of radionuclides immobilized in the waste form after the seperation and immobilization processes. The tank waste inventory estimate is based on computer simulations of the production reactor history and the known reprocessing histories. The estimate for the most important radionuclide in this analysis $\left({ }^{99} \mathrm{Tc}\right)$ is in agreement with actual tank sampling data.

\section{RESULTS}

\section{A. Introduction}

Performance objectives were established ${ }^{7}$ to protect:

- The general public

- The inadvertent intruder

- Groundwater resources

- Surface water resources

- Air resources.

The three-dimensional PORFLOW computer code was used to simulate the flow and transport of contaminants from the waste form through the vadose zone to the groundwater. The three-dimensional VAM3D-CG computer code simulated the flow and transport in the groundwater. The results from PORFLOW and VAM3D-CG were combined with inventory and dosimetry data using the INTEG code to provide concentrations in groundwater and dose rates. Explicit calculations were conducted to 100,000 years after disposal with extrapolations used to extend the results to 65 million years. For inadvertent intruder analyses, a spreadsheet was used with calculations extending from 100 to 1,000 years.

Because of the very slow predicted release of contaminants from the waste form (hundreds of thousands of years), the estimated concentration of radionuclides in the groundwater does not show a peak, but rather a broad plateau (see, for example, the beta/photon drinking water dose rate shown in Figure ES-1). This contrasts with most other environmental assessments, in which the contaminant release time is short compared to the contaminant travel time resulting in a peaked response. Richland, Washington, December 1994. 
Figure ES-1. Beta/Photon Drinking Water Dose Rates for the Base Analysis Case at a Well 100 Meters Downgradient from the Disposal Facility. The performance objective is 4.0 mrem in a year for the first 10,000 years.

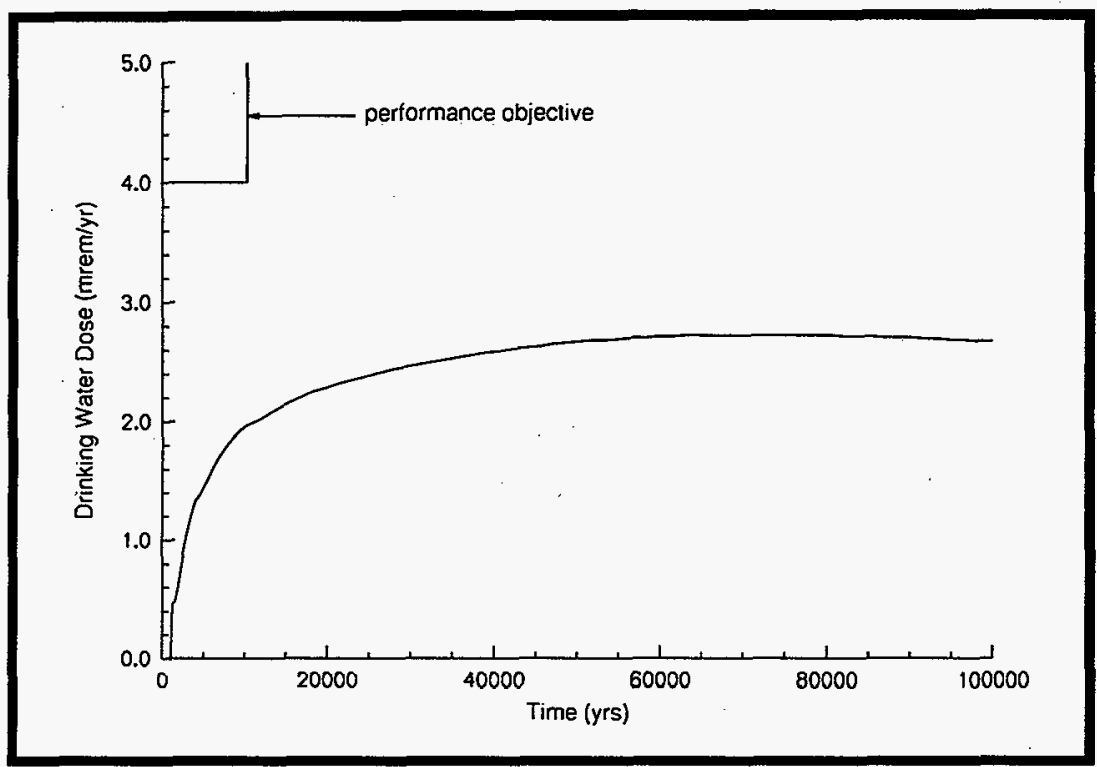

\section{B. Protection of the General Public}

Table ES-1 compares the performance objectives for protecting the general public with the results from the base analysis case calculations over the time of compliance $(10,000$ years). The estimated all-pathways doses are significantly lower than the performance objectives. The sensitivity cases show that for the all-pathways performance objective to be exceeded would require one or more of the following:

- A waste form not having a long-term release rate whose value is the small as for the short-term release rate specified in the Request for Proposal

- A high infiltration rate and a disposal facility design without a sand-gravel diverter

- A significantly larger inventory of selenium, technetium, or uranium. 


\section{HNF-EP-0884}

Rev. 1

During the first 10,000 years (the time of compliance), the estimated doses are at most $1 / 3$ of the performance objective ( $25 \mathrm{mrem}$ in a year as stated in the DOE order). ${ }^{99} \mathrm{Tc}$ is estimated to contribute 58 percent of this dose. The peak all-pathways dose ( 23 mrem in a year) is estimated to occur at about 50,000 years. At the peak, uranium and its daughters are the main contributors.

The other two performance measures (all-pathways including other Hanford actions and a design that produces doses as low as reasonably achievable [ALARA]) are not expected to exceed 100 mrem in a year or 500 persons-rem per year at any time.

Table ES-1. Comparison of Estimated Impacts with Performance Objectives for Protecting the Public. Time of Compliance is 10,000 Years. Place of Compliance is Well 100 Meters Downgradient of Facility.

\begin{tabular}{|l|c|c|}
\hline \hline Performance Measure & $\begin{array}{c}\text { Performance } \\
\text { Objective }\end{array}$ & $\begin{array}{c}\text { Estimated } \\
\text { Impact }\end{array}$ \\
\hline All-pathways [mrem in a year] & 25.0 & 6.4 \\
\hline $\begin{array}{l}\text { All-pathways, including other Hanford } \\
\text { Site sources [mrem in a year] }\end{array}$ & 100.0 & $<19.0$ \\
\hline ALARA (all-pathways) [persons-rem/y] & 500.0 & 5.0 \\
\hline
\end{tabular}

\section{Protection of Inadvertent Intruders}

Table ES-2 compares the estimated impacts to the performance objectives for protecting the inadvertent intruder (the values for which are given in the DOE order). A one-time dose (an acute exposure) scenario as well as a continuous exposure scenario (a homesteader) are defined. Both performance objectives are met.

Table ES-2. Comparison of Estimated Impacts with Performance Objectives for Protecting the Inadvertent Intruder. Time of Compliance is 500 years.

\begin{tabular}{|l|c|c|}
\hline Performance Measure & $\begin{array}{c}\text { Performance } \\
\text { Objective }\end{array}$ & $\begin{array}{c}\text { Estimated } \\
\text { Impact }\end{array}$ \\
\hline Acute exposure [mrem] & 500. & 5.5 \\
\hline Continuous exposure [mrem in a year] & 100. & 27.5 \\
\hline
\end{tabular}

The acute dose (estimated by assuming a person drills a well through the disposal facility) is much less than the performance objective. The continuous dose (which includes the ingestion of contaminated food and water, the inhalation of air, and direct radiation exposure) is over a factor of 3 lower than the performance objective. At the time of compliance (500 years)

${ }^{126} \mathrm{Sn}$ contributes over 95 percent of the dose. 


\section{Protection of Groundwater Resources}

Table ES-3 compares the estimated impacts to the performance objectives for protecting the groundwater resources. The performance objectives are based on the federal drinking water standards. The time of compliance is 10,000 years and the point of compliance is at a well 100 meters down gradient of the disposal facility. The estimated impact from beta emitters is a factor of 2 less than the performance objectives and a factor of 5 less than the performance objective for the alpha emitters. The concentration of radium is insignificant.

The most important drivers are the inventory of technetium and uranium, the release rate from the waste form, the amount of mixing in the aquifer, and the area of the disposal facility. For the impact for alpha emitters, the amount of retardation experienced by the uranium isotopes in the vadose zone is also important.

Table ES-3. Comparison of Estimated Impacts with Performance Objectives for Protecting Groundwater Resources. Time of Compliance is 10,000 Years. Place of Compliance is a Well 100 Meters Downgradient of Facility.

\begin{tabular}{||l|c|c|}
\hline \hline Performance Measure & $\begin{array}{c}\text { Performance } \\
\text { Objective }\end{array}$ & $\begin{array}{c}\text { Estimated } \\
\text { Impact }\end{array}$ \\
\hline Beta/Photon Emitters [mrem in a year] & 4. & 2.0 \\
\hline Alpha emitters [pCi/l] & 15. & 1.7 \\
\hline Ra [pCi/l] & 3. & $<0.001$ \\
\hline
\end{tabular}

For the most part, other geotechnical data (water infiltration rate, hydraulic parameters, and geochemical factors) are less important, because they mainly affect the time at which the plateau is reached. However, there are two exceptions. If the water infiltration rate is a factor of 5 lower than assumed (which is $0.5 \mathrm{~mm} / \mathrm{y}$ for the first 1,000 years [the period during which the surface barrier is assumed to function] and $3.0 \mathrm{~mm} / \mathrm{y}$ thereafter), then the most mobile radionuclides do not reach the groundwater in significant quantities during the compliance period. Alternatively, if the infiltration rate is a factor of 30 higher than assumed and if no capillary barrier is in place to divert the infiltration, then the uranium group arrives in significant amounts at the water table during the compliance period.

The beta/gamma drinking water dose rate is not estimated to exceed 4 mrem in a year for 750,000 years, reaching a maximum value of $14 \mathrm{mrem}$ in a year at the end of the simulation period (65 million years). The concentration of alpha emitters is estimated never to exceed 15.0 $\mathrm{pCi} / \ell$, reaching a maximum of $8.2 \mathrm{pCi} / \ell$ at 50,000 years. 


\section{E. Protection of Surface Water Resources}

Table ES-4 displays a comparison of the estimated impacts to the performance objectives for protecting the surface water resources. The time of compliance is 10,000 years and the point of compliance is at a well intersecting the groundwater just before the groundwater mixes with the Columbia River. Because of the large flow of the Columbia River, tremendous mixing occurs in the river and the predicted impacts would be far lower. The estimated impacts are over an order of magnitude lower than the performance objectives. The calculations indicate that the impacts never reach the values given as performance objectives.

Table ES-4. Comparison of Estimated Impacts with Performance Objectives for Protecting Surface Water Resources. Time of Compliance is 10,000 Years. Point of Compliance is a Well just before the Groundwater Mixes with the Columbia River.

\begin{tabular}{|l|c|c|}
\hline \hline Performance Measure & $\begin{array}{c}\text { Performance } \\
\text { Objective }\end{array}$ & $\begin{array}{c}\text { Estimated } \\
\text { Impact }\end{array}$ \\
\hline Beta/Photon Emitters [mrem in a year] & 1. & 0.070 \\
\hline Alpha emitters [pCi/l] & 15. & 0.058 \\
\hline Ra [pCi/ll] & 3. & $<0.001$ \\
\hline
\end{tabular}

\section{F. Protection of Air Resources}

Table ES-5 compares the estimated impacts to the performance objectives for protecting air resources (the values for which are given in federal clean air regulations). The time of compliance is 10,000 years and the point of compliance is just above the disposal facility. The estimated impacts are significantly lower than the values prescribed in the performance objectives.

Table ES-5. Comparison of Estimated Impacts with Performance Objectives for Protecting Air Resources. Time of Compliance is 10,000 Years. Place of Compliance is just above the disposal facility.

\begin{tabular}{||l|c|c||}
\hline Performance Measure & $\begin{array}{c}\text { Performance } \\
\text { Objective }\end{array}$ & $\begin{array}{c}\text { Estimated } \\
\text { Impact }\end{array}$ \\
\hline Radon $\left[\mathrm{pCi} \mathrm{m}^{-2} \mathrm{~s}^{-1}\right]$ & 20. & $<0.001$ \\
\hline Other radionuclides [mrem in a year] & 10. & $<10^{-8}$ \\
\hline
\end{tabular}




\section{DISCUSSION}

Because of the early stage of this project, conservative assumptions have been used. Given such assumptions, it is gratifying that all the estimated impacts meet the performance objectives.

The numerous sensitivity cases that were run show that the results presented in this assessment are quite robust. The computer simulations of dissolution rates for low-level glass (LD6-5412) show that the 4.4 parts per million per year rate can be met. Concerning radionuclide inventory, the calculations are most sensitive to the amount of technetium. For the base analysis case no credit is taken for enhanced chemical separation or separation occurring during immobilization. Possible increases in the amounts of ${ }^{90} \mathrm{Sr}$ and ${ }^{137} \mathrm{Cs}$ over the amounts assumed in the base analysis case have no significant impacts at the intruder time of compliance of 500 years. Computer simulations of flow and transport under a wide variety of conditions show that slightly increased impacts may occur, but that most changes would result in larger decreases. Finally, calculations show that disposing of some of the tank waste in the existing TWRS grout vaults, which are east of the PUREX facility, will not significantly affect the results.

The preliminary and final performance assessments (required by DOE Order $5820.2 \mathrm{~A}$ ) will benefit from knowledge of the waste form, the disposal facility location, and the disposal facility design as well as from an extensive data collection activity for the generation of sitespecific estimates for geochemical data, hydraulic parameters, and water infiltration rates and waste form release rates. The performance assessments are expected to show that the on-site disposal of the low-level Hanford tank waste can meet the performance objectives with a high degree of assurance. 


\section{HNF-EP-0884 \\ Rev. 1 \\ TABLE OF CONTENTS}

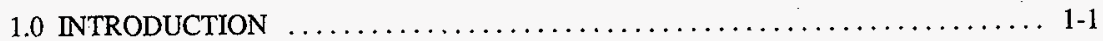

1.1 PURPOSE $\ldots \ldots \ldots \ldots \ldots \ldots \ldots \ldots \ldots \ldots \ldots \ldots \ldots \ldots \ldots \ldots \ldots \ldots \ldots \ldots \ldots, 1$

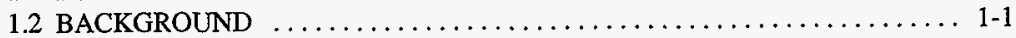

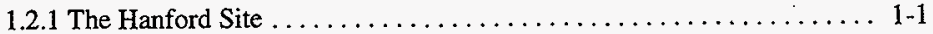

1.2.2 Other Hanford Performance Assessments $\ldots \ldots \ldots \ldots \ldots \ldots \ldots \ldots . \ldots \ldots$

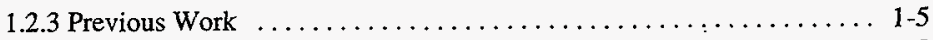

1.2.4 Review of Data Packages for Interim Performance Assessment ...... 1-5

1.2.5 Relationship With Other Parts of the Project $\ldots \ldots \ldots \ldots \ldots \ldots \ldots .1-5$

1.3 GENERAL DESCRIPTION OF THE FACILITY $\ldots \ldots \ldots \ldots \ldots \ldots \ldots \ldots, 1-5$

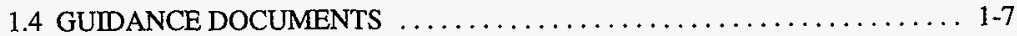

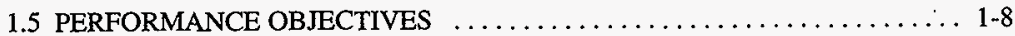

1.5.1 Overview ................................ 1-8

1.5.2 Regulations and Other Performance Assessments ........... 1-10

1.5.3 Programmatic Requirements . . . . . . . . . . . . . . . . .

1.5.4 Public Involvement ............................ $1-14$

1.6 APPROACH AND MAJOR DATA SOURCES $\ldots \ldots \ldots \ldots \ldots \ldots \ldots \ldots, 1-15$

1.7 STRUCTURE OF THIS PERFORMANCE ASSESSMENT $\ldots \ldots \ldots \ldots \ldots 1-16$

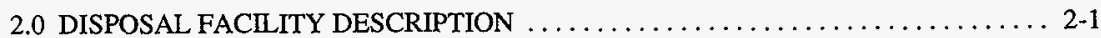

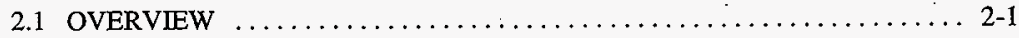

2.2 HANFORD SITE CHARACTERISTICS $\ldots \ldots \ldots \ldots \ldots \ldots \ldots \ldots \ldots \ldots, 2-1$

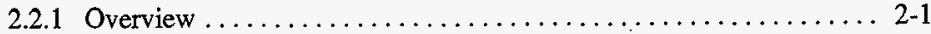

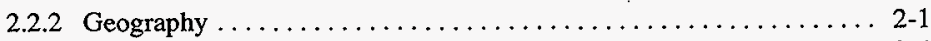

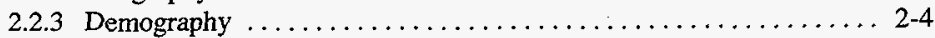

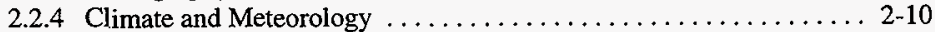

2.2 .5 Regional Geology ............................. 2-13

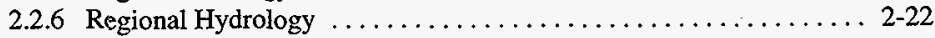

2.2.7 Geology and Hydrology of the Proposed Immobilized Low-activity Tank Waste Disposal Facility Location $\ldots \ldots \ldots \ldots \ldots \ldots \ldots .2-30$

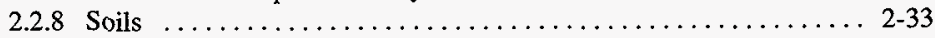

2.2.9 Ecology and Biotic Conditions .................... 2-33

2.2.10 Regional Background Contamination and Hanford Site

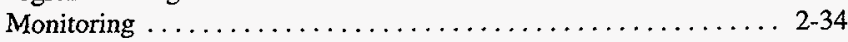

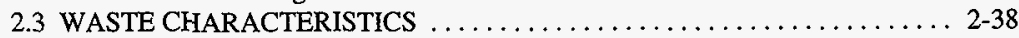

2.3.1 Overview .................................. 2-38

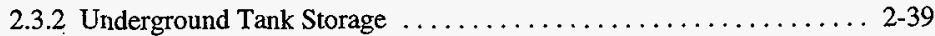

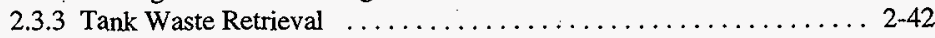

2.3.4 Separations ................................ 2-42

2.3.5 Immobilization of the Low-Activity Waste $\ldots \ldots \ldots \ldots \ldots \ldots \ldots .2-43$

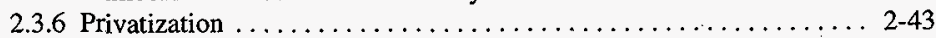

2.3.7 Packaging and Certification $\ldots \ldots \ldots \ldots \ldots \ldots \ldots \ldots \ldots \ldots \ldots \ldots \ldots \ldots \ldots$ 


\section{HNF-EP-0884}

Rev. 1

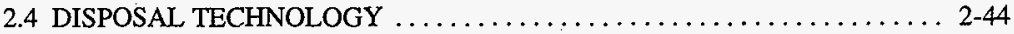

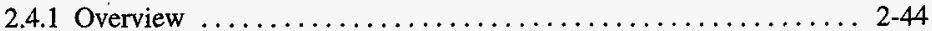

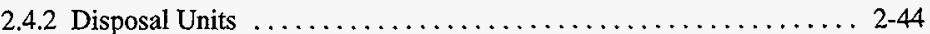

2.4.3 Waste Handling and Interim Storage Operations $\ldots \ldots \ldots \ldots \ldots .2-48$

2.4.4 Waste Emplacement ............................. 2-48

2.4.5 Disposal Unit Closure and Stabilization $\ldots \ldots \ldots \ldots \ldots \ldots \ldots .2-49$

2.4.6 Disposal Site Closure .......................... 2-49

3.0 ANALYSIS OF PERFORMANCE $\ldots \ldots \ldots \ldots \ldots \ldots \ldots \ldots \ldots \ldots \ldots \ldots \ldots \ldots \ldots \ldots \ldots, 1$

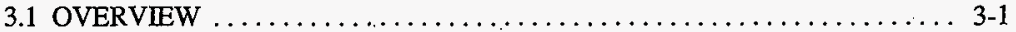

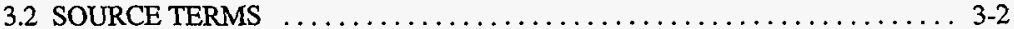

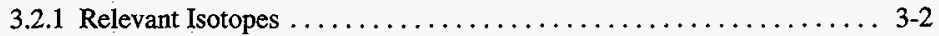

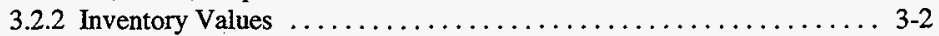

3.2.3 General Description of the Development of Estimated Immobilized Low-

Activity Waste Radionuclide Inventory $\ldots \ldots \ldots \ldots \ldots \ldots \ldots, 4$

3.2.3.1 Introduction .......................... 3-4

3.2.3.2 Calculated Radionuclide Production ............. 3-5

3.2.3.3 Hanford Production Processing and Storage ......... 3-6

3.2.3.4 Separation and Vitrification Losses . ............... 3-6

3.2.3.5 Modeling of Decay Chains . .................. 3-7

3.2.4 Tank-to-Tank Variations $\ldots \ldots \ldots \ldots \ldots \ldots \ldots \ldots \ldots \ldots \ldots \ldots \ldots \ldots \ldots, 7$

3.2.5 Release Rate from Waste Form $\ldots \ldots \ldots \ldots \ldots \ldots \ldots \ldots \ldots \ldots \ldots \ldots \ldots \ldots$

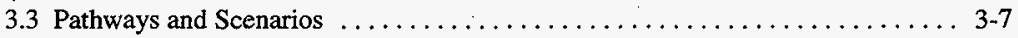

3.3.1 Overview ................................... 3-7

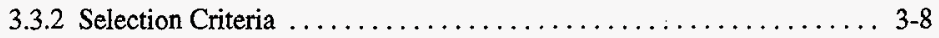

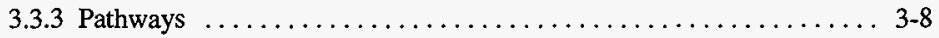

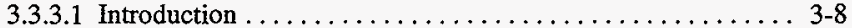

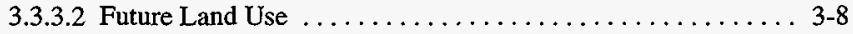

3.3.3.3 Land-Use-Driven Scenarios ................. 3-10

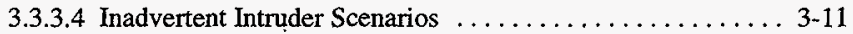

3.3.3.5 Natural Event Scenarios . . . . . . . . . . . . . . . 3-13

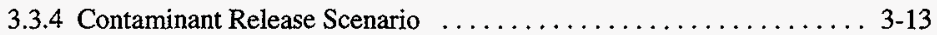

3.3.4.1 General Description $\ldots \ldots \ldots \ldots \ldots \ldots \ldots \ldots \ldots \ldots$ 3-14

3.3.4.2 Contaminant Release Based on Glass Corrosion ....... 3-14

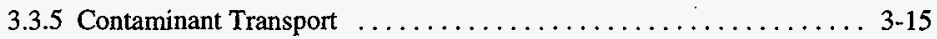

3.3.5.1 Overview ............................ 3-15

3.3.5.2 Moisture Movement $\ldots \ldots \ldots \ldots \ldots \ldots \ldots \ldots \ldots \ldots$ 3-15

3.3.5.3 Advective, Dispersive, and Diffusive Transport ...... 3-16

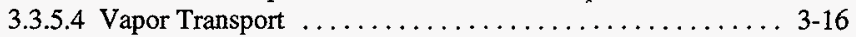

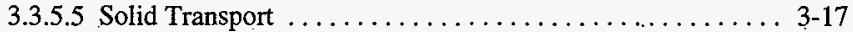

3.3.6 Exposure Scenarios ........................... 3-17 


\section{HNF-EP-0884}

Rev. 1

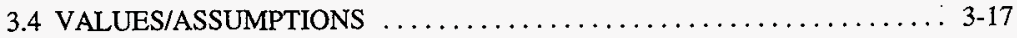

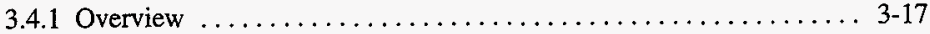

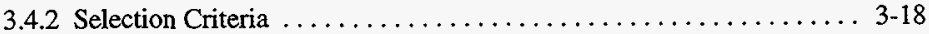

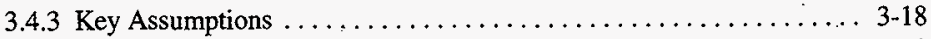

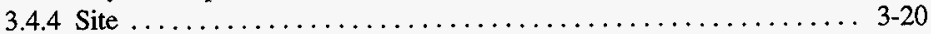

3.4.4.1 Introduction ........................... 3-20

3.4.4.2 Location and Stratigraphy $\ldots \ldots \ldots \ldots \ldots \ldots \ldots . .3-20$

3.4.4.3 Vadose Zone Hydrologic Parameters .............. 3-21

3.4.4.4 Vadose Zone Geochemical Retardation Factors ........ 3-25

3.4.4.5 Unconfined Aquifer Properties ................ 3-26

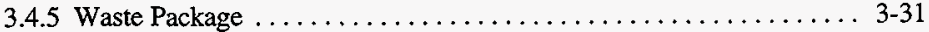

3.4.5.1 Introduction $\ldots \ldots \ldots \ldots \ldots \ldots \ldots \ldots \ldots \ldots \ldots \ldots \ldots, 3-31$

3.4.5.2 Container ............................. 3-31

3.4.5.3 Waste Form ......................... 3-31

3.4.5.4 Waste Form Radionuclide Release Rate ............ 3-31

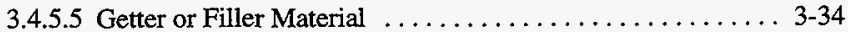

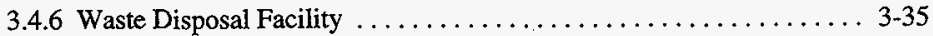

3.4.6.1 Introduction $\ldots \ldots \ldots \ldots \ldots \ldots \ldots \ldots \ldots \ldots \ldots \ldots \ldots, 3-35$

3.4.6.2 Surface Barrier ....................... 3-35

3.4.6.3 Sand-Gravel Capillary Barrier $\ldots \ldots \ldots \ldots \ldots \ldots \ldots . .3-35$

3.4.6.4 Water Conditioning Layer $\ldots \ldots \ldots \ldots \ldots \ldots \ldots \ldots .3-36$

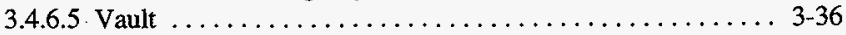

3.4.6.6 Filler Material ......................... 3-36

3.4.6.7 Existing TWRS Disposal Facilities Sensitivity Study .... . 3-39

3.4.6.8 Degradation of the Waste Disposal Facility ........... 3-39

3.4.7 Infiltration Rate $\ldots \ldots \ldots \ldots \ldots \ldots \ldots \ldots \ldots \ldots \ldots \ldots \ldots \ldots \ldots \ldots \ldots, 3-40$

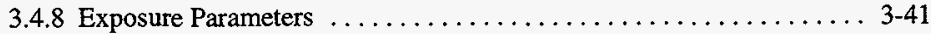

3.4.8.1 Overview ........................... 3-41

3.4.8.2 Internal and External Dose Conversion Factors ........ 3-42

3.4.8.3 Drinking Water and All-Pathways Dose Conversion Factors 3-42

3.4.8.4 Inadvertent Intruder Parameters . . . . . . . . . . . . 3-43

3.4.8.5 Other Scenarios ........................... 3-45

3.4 .8 .6 Half-lives. ........................... 3-45

3.5 PERFORMANCE ANALYSIS METHODOLOGY $\ldots \ldots \ldots \ldots \ldots \ldots \ldots, 3-48$

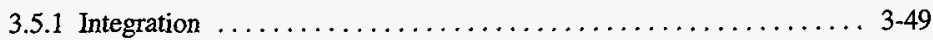

3.5.1.1 Strategy . ............................ 3-49

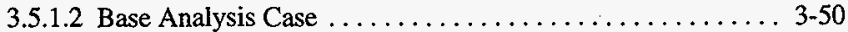

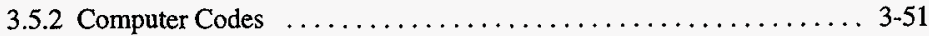

3.5.2.1 General Selection Criteria for Computer Codes ......... 3-51

3.5.2.2 AREST-CT . . . . . . . . . . . . . . . . . . . . . . . .

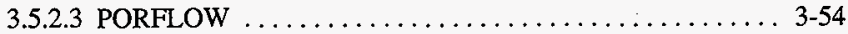

3.5.2.4 VAM3D-CG $\ldots \ldots \ldots \ldots \ldots \ldots \ldots \ldots \ldots \ldots \ldots \ldots, 3-56$

3.5 .2 .5 INTEG $\ldots \ldots \ldots \ldots \ldots \ldots \ldots \ldots \ldots \ldots \ldots \ldots, 3-58$

3.5.2.6. Spreadsheets .......................... 3-59 


\section{HNF-EP-0884}

Rev. 1

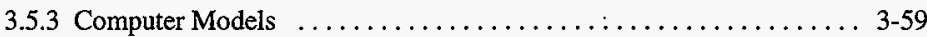

3.5.3.1 Overview ............................ 3-59

3.5.3.2 Disposal Facility Model $\ldots \ldots \ldots \ldots \ldots \ldots \ldots \ldots . \ldots .6 .60$

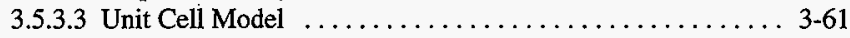

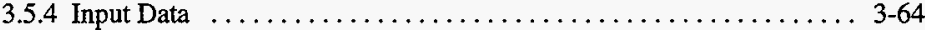

3.5.4.1 Overview .......................... 3-64

3.5.4.2 Contaminant Release Modeling . . . . . . . . . . . 3-64

3.5.4.3 Vadose Zone Modeling $\ldots \ldots \ldots \ldots \ldots \ldots \ldots \ldots . \ldots \ldots . \ldots \ldots$

3.5.4.4 Aquifer Modeling. . . . . . . . . . . . . .

3.5.4.5 Integration of Results. . . . . . . . . . . . . . . . 64

3.5.4.6 Inadvertent Intrusion . . . . . . . . . . . . . . . . . . 3-67

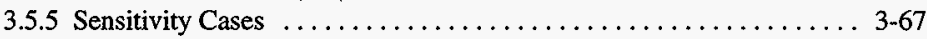

3.5.5.1 Overview .......................... 3-67

3.5.5.2 Scenario-Dependent Sensitivity Cases . . . . . . . . . 3-73

3.5.5.3 Inventory-Dependent Sensitivity Cases ........... 3-74

3.5.5.4 Infiltration-Dependent Sensitivity Cases .......... 3-74

3.5.5.5 Geology-Dependent Sensitivity Cases ............ 3-74

3.5.5.6 Facility-Dependent Sensitivity Cases ............. 3-75

3.5.5.7 Facility Degradation-Dependent Sensitivity Cases . . . . . . 3-75

3.5.5.8 Hydrologic Parameter-Dependent Sensitivity Cases ..... 3-76

3.5.5.9 Waste Form-Dependent Sensitivity Cases . . . . . . . . 3-76

3.5.5.10 Geochemical-Dependent Sensitivity Cases ......... 3-77

3.5.5.11 Exposure Parameter-Dependent Cases ............ 3-77

3.5.5.12 Location of the Facility. ................ 3-77

3.5.5.13 Calculational Assumption-Dependent Sensitivity Cases .. 3-77

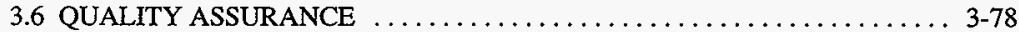

3.6.1 Overview ................................ 3-78

3.6.2 Pacific Northwest National Laboratory $\ldots \ldots \ldots \ldots \ldots \ldots \ldots \ldots . \ldots \ldots$

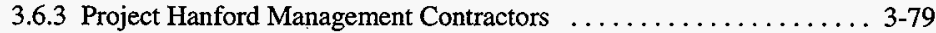

3.6.4 Other Contractors . . . . . . . . . . . . . . . . . . . . . . . . . .

3.6.5 Hanford Environmental Dose Overview Panel ............. 3-79

3.6.6 Technical Reviews of Supporting Efforts .............. 3-80

3.6.7 Review of the Performance Assessment ............... 3-80

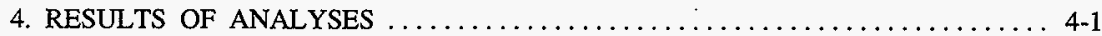

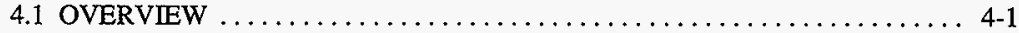

4.2 RESULTS FOR INADVERTENT INTRUDER SCENARIO $\ldots \ldots \ldots \ldots \ldots$ 4-1

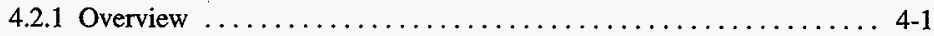

4.2.2 Driller Scenario $\ldots \ldots \ldots \ldots \ldots \ldots \ldots \ldots \ldots \ldots \ldots \ldots \ldots, 4-2$

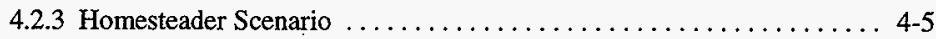

4.2 .4 Summary ............................... 4-13

4.3 RESULTS OF GROUNDWATER SCENARIOS - BASE ANALYSIS CASE . 4-14

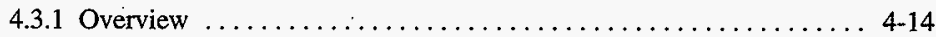

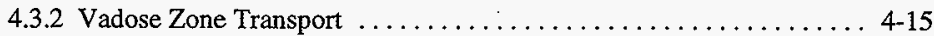

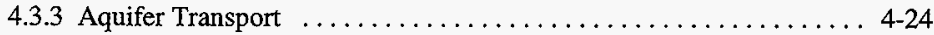

4.3.4 Integration $\ldots \ldots \ldots \ldots \ldots \ldots \ldots \ldots \ldots \ldots \ldots \ldots \ldots \ldots, 4,30$ 


\section{HNF-EP-0884}

Rev. 1

4.4 RESULTS OF GROUNDWATER SCENARIOS - BASE SENSITIVITY

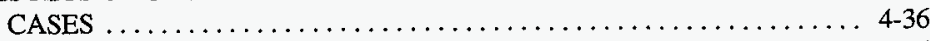

4.4 .1 Overview. .................................. 46

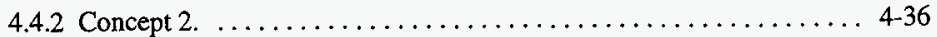

4.4.3 Unit Cell Model. ............................. 4-39

4.5 RESULTS OF GROUNDWATER SCENARIOS - WASTE FORM SENSITIVITY

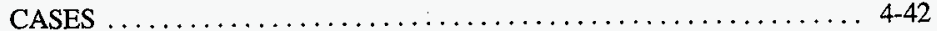

4.5 .1 Overview $\ldots \ldots \ldots \ldots \ldots \ldots \ldots \ldots \ldots \ldots \ldots \ldots \ldots, 4-42$

4.5.2 Contaminant Release Rates from Waste Form $\ldots \ldots \ldots \ldots \ldots \ldots$ 4-42

4.5.3 Impact on Exposure Calculations .................... 4-45

4.6 RESULTS OF GROUNDWATER SCENARIOS - DISPOSAL FACIITY

SENSITIVITY CASES $\ldots \ldots \ldots \ldots \ldots \ldots \ldots \ldots \ldots \ldots \ldots, 4-50$

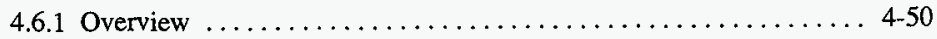

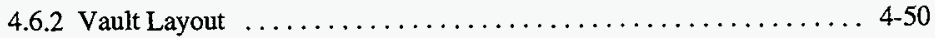

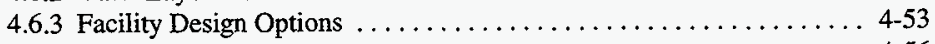

4.6.4 Degradation .............................. 4-56

4.7 RESULTS FOR GROUNDWATER SCENARIOS - TRANSPORT SENSITIVITY

CASES .................................... $4-57$

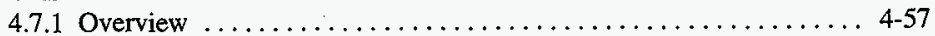

4.7.2 Hydraulic Parameters . . . . . . . . . . . . . . . . . . 57

4.7 .3 Geochemical $\ldots \ldots \ldots \ldots \ldots \ldots \ldots \ldots \ldots \ldots \ldots \ldots \ldots, 4.62$

4.7.4 Infiltration Rate ............................ 4-64

4.8 RESULTS OF GROUNDWATER SCENARIOS - OTHER SENSITIVITY

CASES ................................... 4-68

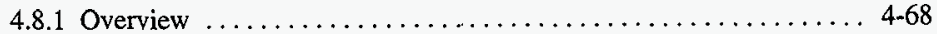

4.8.2 Inventory $\ldots \ldots \ldots \ldots \ldots \ldots \ldots \ldots \ldots \ldots \ldots \ldots \ldots \ldots \ldots \ldots, 4,68$

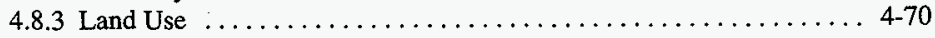

4.8.4 Dosimetry Parameters ........................ 4-72

4.8.5 Location of the Facility . . . . . . . . . . . . . . . . . . . . 43

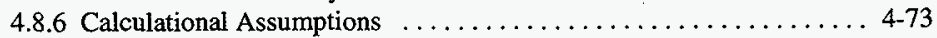

4.8.7 Neglected Processes and Conditions. . ............... 4-74

4.9 IMPACT OF OTHER HANFORD ACTIONS ON GROUNDWATER $\ldots \ldots 4.75$

4.10 SUMMARY OF GROUNDWATER SCENARIO $\ldots \ldots \ldots \ldots \ldots \ldots \ldots 4-76$

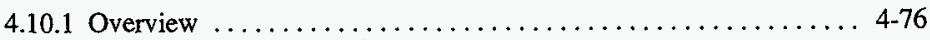

4.10.2 Maximum Impact of the Groundwater Scenario ........... 4-77

4.10.3 Impact of the Groundwater Scenario at 10,000 Years .......... 4-80

4.11 RESULTS OF SCENARIOS WITH RELEASES TO THE AIR $\ldots \ldots \ldots \ldots 4-83$

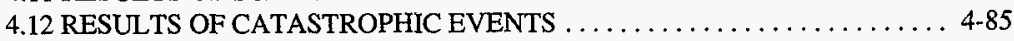




\section{HNF-EP-0884}

Rev. 1

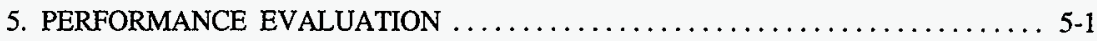

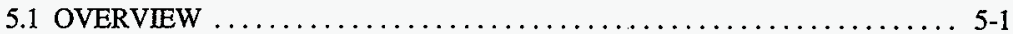

5.2 COMPARISON OF ESTIMATED IMPACTS TO PERFORMANCE

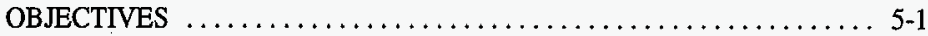

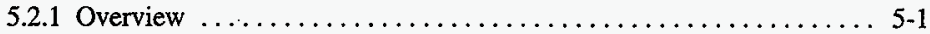

5.2.2 Protection of General Public $\ldots \ldots \ldots \ldots \ldots \ldots \ldots \ldots \ldots \ldots, 5-1$

5.2 .3 Protection of Inadvertent Intruders $\ldots \ldots \ldots \ldots \ldots \ldots \ldots \ldots \ldots, 5,2$

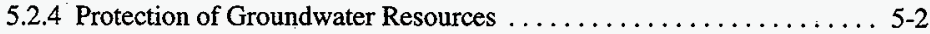

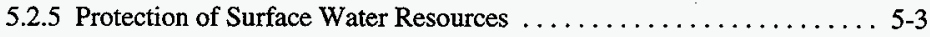

5.2.6 Protection of Air Resources ...................... 5-4

5.2.7 Application to Existing TWRS Disposal Facility $\ldots \ldots \ldots \ldots \ldots \ldots .5-4$

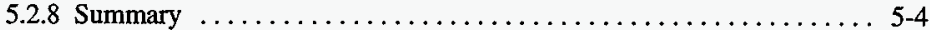

5.3 CHANGES REQUIRED TO MEET PERFORMANCE OBJECTIVES $\ldots \ldots \ldots$ 5-5

5.4 WASTE ACCEPTANCE CRITERIA $\ldots \ldots \ldots \ldots \ldots \ldots \ldots \ldots \ldots, 5-5$

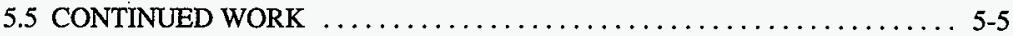

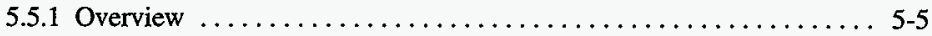

5.5 .2 Overall Schedule $\ldots \ldots \ldots \ldots \ldots \ldots \ldots \ldots \ldots \ldots \ldots \ldots, 5-6$

5.5.3 Data Collection Activities $\ldots \ldots \ldots \ldots \ldots \ldots \ldots \ldots \ldots \ldots, 5-6$

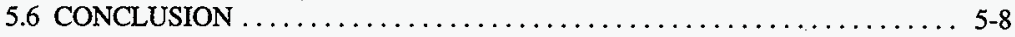

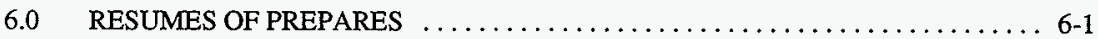

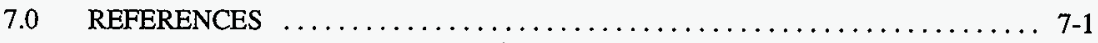

APPENDICES

APPENDIX A $\quad$ SPECIFICATIONS FOR IMMOBILIZATION $\ldots \ldots \ldots \ldots \ldots$ A-1

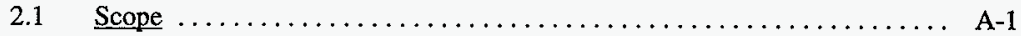

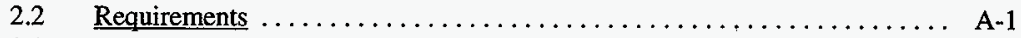

2.3 Inspection and Acceptance $\ldots \ldots \ldots \ldots \ldots \ldots \ldots \ldots \ldots \ldots \ldots \ldots \ldots \ldots \ldots \ldots$

APPENDIX B DOSIMETRY DOSE FACTORS $\ldots \ldots \ldots \ldots \ldots \ldots \ldots \ldots$ B-1

APPENDIX C WASTE FORM RELEASE COMPUTER CODES $\ldots \ldots \ldots \ldots \ldots . \mathrm{C}-1$

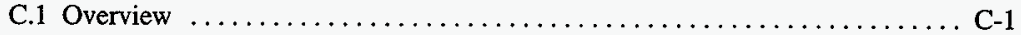

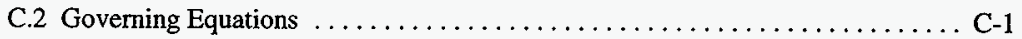

C.2.1 Mass Conservation of Aqueous Solutes $\ldots \ldots \ldots \ldots \ldots \ldots \ldots \ldots$, C -1

C.2.2 Texture Dynamics . . . . . . . . . . . . . . .

C. 2.3 Contaminant Release Rate From Glass $\ldots \ldots \ldots \ldots \ldots \ldots \ldots \ldots, \mathrm{C}-3$

C.2.4 Reactions Considered $\ldots \ldots \ldots \ldots \ldots \ldots \ldots \ldots \ldots \ldots \ldots, \mathrm{C}-3$

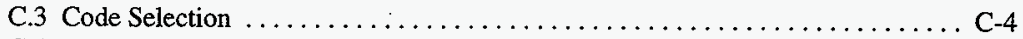

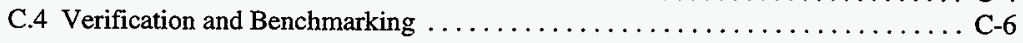




\section{HNF-EP-0884}

Rev. 1

\section{APPENDIX D MOISTURE FLOW AND CONTAMINANT TRANSPORT}

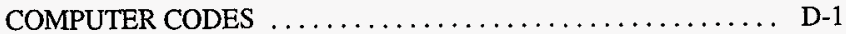

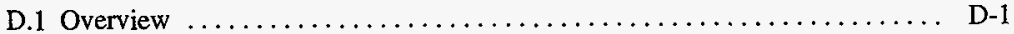

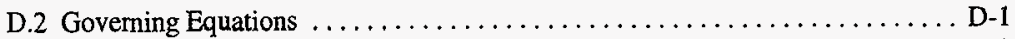

D.2.1 Overview $\ldots \ldots \ldots \ldots \ldots \ldots \ldots \ldots \ldots \ldots \ldots \ldots \ldots \ldots \ldots, D-1$

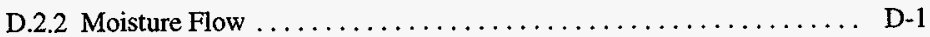

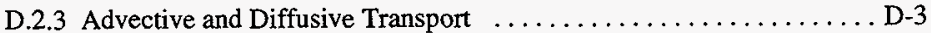

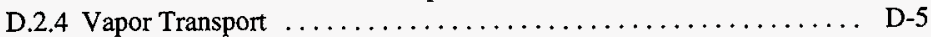

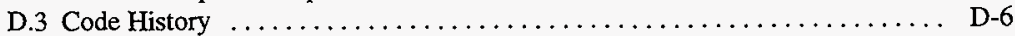

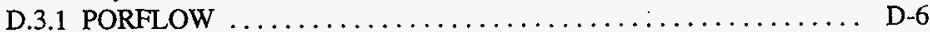

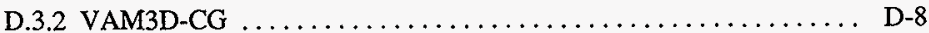

D.4 Verification and Benchmarking $\ldots \ldots \ldots \ldots \ldots \ldots \ldots \ldots \ldots \ldots \ldots \ldots \ldots \ldots \ldots \ldots, 8$

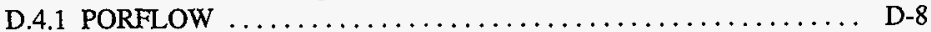

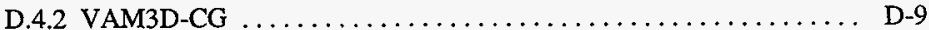

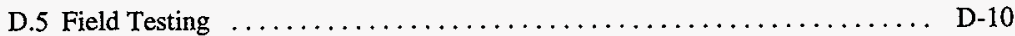

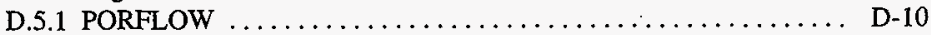

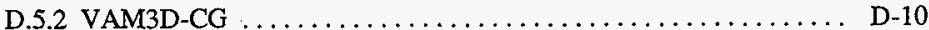

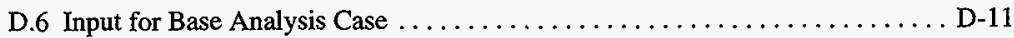

D.6.1 Disposal Facility Model (Concept 1) - PORFLOW ........... D-11

D.6.2 Unit Cell Model - PORFLOW . . . . . . . . . . . . . . . D-26

D.6.3 Pump Model - VAM3D-CG . . . . . . . . . . . . . . . . . D-29

D.6.4 Site Groundwater Model . . . . . . . . . . . . . . . . . . D-29

D.6.5 INTEG . . . . . . . . . . . . . . . . . . . . . . . . .

APPENDIX E DETALED RESULTS $\ldots \ldots \ldots \ldots \ldots \ldots \ldots \ldots \ldots \ldots$ E-1

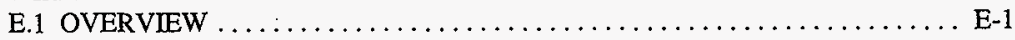

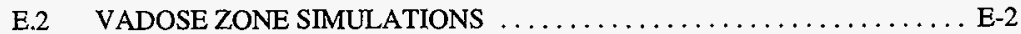

E.2.1 Overview . ................................ E-2

E.2.2 Extension of Calculation to Long Times $\ldots \ldots \ldots \ldots \ldots \ldots \ldots, \mathrm{E}-2$

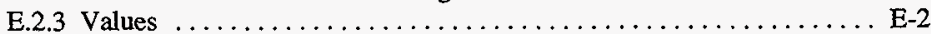

E.3 UNCONFINED AQUIFER SIMULATIONS $\ldots \ldots \ldots \ldots \ldots \ldots \ldots \ldots$ E-20

E.4 CALCULATION OF DOSE ........................... E-26

E.5 WASTE FORM RELEASE CALCULATIONS $\ldots \ldots \ldots \ldots \ldots \ldots \ldots \ldots$ E-39

E.5.1 Simulation Domain and Physical Conditions ............... E-39

E.5.2 Glass Composition and Dissolution Kinetics .............. E-39

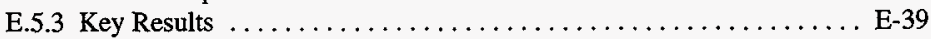




\section{HNF-EP-0884}

Rev. 1

APPENDIX $F \quad$ COMMENTS BY REVIEWERS $\ldots \ldots \ldots \ldots \ldots \ldots \ldots \ldots$ F-1

F.1 EXTERNAL REVIEW BOARD $\ldots \ldots \ldots \ldots \ldots \ldots \ldots \ldots \ldots \ldots \ldots$ F-1

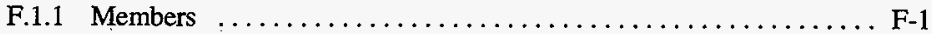

F.1.2 Board Materials $\ldots \ldots \ldots \ldots \ldots \ldots \ldots \ldots \ldots \ldots \ldots \ldots \ldots$ F-1

F.1.3 Report of the External Review Board $\ldots \ldots \ldots \ldots \ldots \ldots \ldots \ldots$ F-2

F.1.4 Responses to Board Comments .................... F-45

F.2 Department of Energy - Richland Operations $\ldots \ldots \ldots \ldots \ldots \ldots \ldots \ldots$ F-66

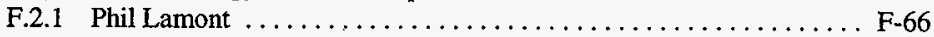

F.2.2 Comments of Doug Hildebrand $\ldots \ldots \ldots \ldots \ldots \ldots \ldots \ldots \ldots \ldots \ldots \ldots \ldots$

F.3 Nuclear Regulatory Commission $\ldots \ldots \ldots \ldots \ldots \ldots \ldots \ldots \ldots \ldots$ F-82

F.3.1 Letter from NRC Requesting Additional Information $\ldots \ldots \ldots \ldots$ F-82

F.3.2 Response to NRC Letter ..................... F-87

F.3.3 Letter from NRC on Classification of Hanford Low-Activity Tank Waste

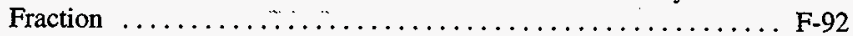

F.4 U.S. Department of Navy . . . . . . . . . . . . . . . . . . . . F-95

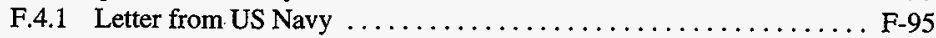

F.4.2 Response to letter ............................. F-97

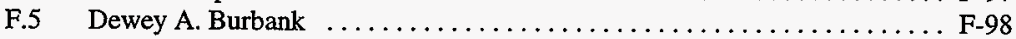

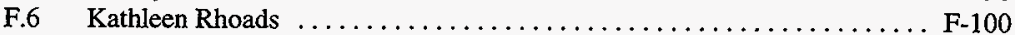

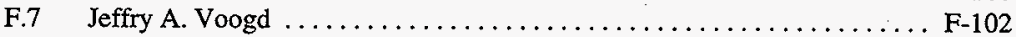

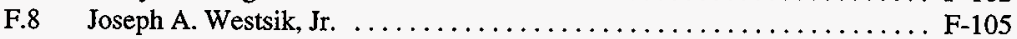

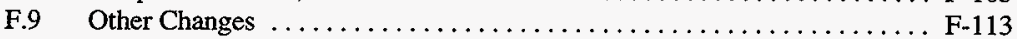




\section{HNF-EP-0884}

Rev. 1

\section{LIST OF FIGURES}

1-1. Map of the Hanford Site Showing the Assumed Location of the Hanford Low-Level Tank

Waste Disposal Facility (HLLTWDF) $\ldots \ldots \ldots \ldots \ldots \ldots \ldots \ldots \ldots \ldots \ldots \ldots \ldots \ldots \ldots \ldots \ldots, 2$

1-2. Activities Schedule for the LLW Disposal Subproject $\ldots \ldots \ldots \ldots \ldots \ldots \ldots \ldots \ldots$ 1-6

2-1. Hanford Site in Washington State. ............................. 2-2

2-2. Hanford Site Map Showing Public Highways. ................... 2-3

2-3. Activities in the 200 Areas. . . . . . . . . . . . . . .

2-4. Population Centers Within an 80-kilometer Radius of the Hanford Site. . . . . . . . . 2-6

2-5. Geologic Structures of the Pasco Basin and the Hanford Site ............ 2-14

2-6. Divisions of the Intermontane Physiographic and Adjacent Snake River Plains

Provinces. ...................................... 2-15

2-7. Landforms of the Pasco Basin and the Hanford Site. ................. 2-16

2-8. Generalized Stratigraphy of the Suprabasalt Sediments Beneath the Hanford Site . . . 2-18

2-9. Comparison of Seismic Hazard for Various Regions of the Hanford Site ........ 2-22

2-10. Hydrologic Basins Designated for the Washington State Portion of the Columbia

Platean .................................... 2-23

2-11. Location of Water Disposal Ponds on the Hanford Site .............. 2-24

2-12. Hindcast Water Table Map of the Hanford Site, January 1944 (ERDA 1975) . . . . . . 2-27

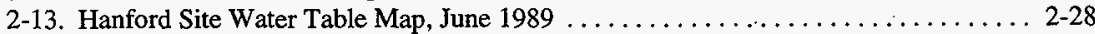

2-14. Stratigraphic Units and Lithology at the Proposed Location of the Tank Waste

Remediation System Immobilized Low-activity Tank Waste Disposal Facility . . . . 2-32

2-15. Averages for Natural and Human-Produced Sources of Radiation $\ldots \ldots \ldots \ldots \ldots$ 2-38

2-16. Strategy for the Hanford Tank Waste Remediation System ................ 2-40

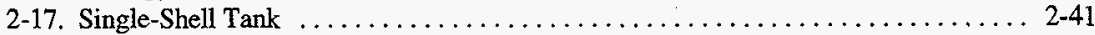

2-18. Double-Shell Tank. ....................................... 2-41

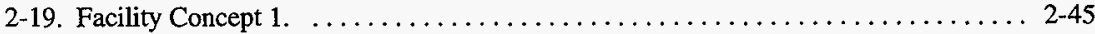

2-20. Facility Concept $2 . \ldots \ldots \ldots \ldots \ldots \ldots \ldots \ldots \ldots \ldots \ldots \ldots \ldots \ldots \ldots \ldots \ldots \ldots \ldots \ldots, 2-46$

2-21. Facility Concept 2, Cross Section of Concept. .................. 2-47

3-1. Predicted Groundwater Flowlines for Post Hanford Conditions. . . . . . . . . . . 3-12

3-2. Hydrologic-Conductivity Sample Locations. . . . . . . . . . . . . .

3-3. Zone Map for the Upper Layers of the ERC Hanford Sitewide Groundwater Model . . 3-29

3-4. Zone Map for the Lower Layers of the ERC Hanford Sitewide Groundwater Model . . 3-30

3-5. Waste Package Spacing for Disposal Facility Concepts 1 and 2 (from Eiholzer 1996). 3-38

3-6. Eight Sequential Steps for the Groundwater Pathway $\ldots \ldots \ldots \ldots \ldots \ldots \ldots \ldots .6 \ldots$

3-7. Zone Map for Disposal Facility Model $\ldots \ldots \ldots \ldots \ldots \ldots \ldots \ldots \ldots \ldots \ldots \ldots . \ldots \ldots \ldots$

3-8. Zone Map for Unit Cell Model. . . . . . . . . . . . . . . . . $62 \ldots \ldots \ldots \ldots \ldots \ldots$

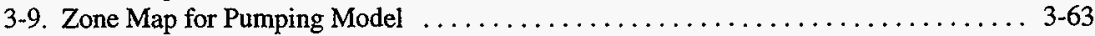

4-1. Inadvertent Intruder Results for the Driller Scenario - Base Analysis Case. . ....... 4-2

4-2. Inadvertent Intruder Results for the Homesteader Scenario - Base Analysis Case. . . . . 4-6

4-3. Ratio of Predicted Homesteader Doses for Different Availability of Radionuclides for Ingestion and Inhalation. . . . . . . . . . . . .

4-4. Contribution of Major Radionuclides for the Base Analysis Case and When Ingestion is

Allowed. ....................................... 4-11

4-5. General Characteristics of Vadose Zone Transport. ................ 4-16

4-6. Moisture Content and Flow Lines for the Base Analysis Case at 1,000 Years ..... 4-19 
4-7. Moisture Content and Flow Lines at 1,000 Years with Emphasis on the Edge of the Disposal Facility. .................................. 4-20

4-8. Moisture Content and Flow Lines at 4,000 Years (Steady State) with Emphasis on the Edge

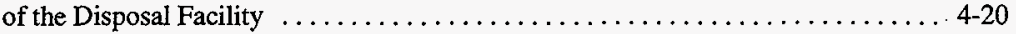

4-9. Moisture Content and Flow Lines for the Base Analysis Case at 4,000 Years

(Steady State) . . . . . . . . . . . . . . . .

4-10. Normalized Contaminant Flux to the Aquifer for $\mathrm{K}_{\mathrm{d}}=0,0.1$, and $0.6 \mathrm{~m} \ell / \mathrm{g}$ -

Base Analysis Case. ............................... 4-22

4-11. Concentration Ratios 120 Years after Contaminants Enter Aquifer. .......... 4-25

4-12. Concentration Ratios as a Function of Time at Points of Maximum Concentration 100 Meters Downgradient and at the 200 East Boundary .............. 4-26

4-13. Flow Paths for Distant Well Sites ......................... 4-27

4-14. Concentration Ratio Contours 400 Years after the Contaminants Enter the Aquifer. . 4-28

4-15. Concentration Ratio Histories at Downstream Hypothetical Wells. ........... . 4-29

4-16. Drinking Water Doses for the Base Analysis Case at a Well 100 Meters

Downgradient. . . . . . . . . . . . . . . . .

4-17. Alpha-Emitting Radionuclide Concentrations for the Base Analysis Case at a Well

100 Meters Downgradient from the Disposal Facility. .............. 4-32

4-18. All-Pathways Doses for the Base Analysis Case at a Well 100 Meters Downgradient. 4-34

4-19. Normalized Contaminant Flux to the Unconfined Aquifer for $\mathbf{K}_{\mathrm{d}}=0 ., 0.1$, and

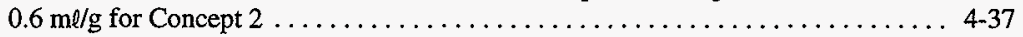

4-20. Normalized Contaminant Flux to the Unconfined Aquifer for $\mathbf{K}_{\mathrm{d}}=0 ., 0.1,0.6$, and

3. $\mathrm{m} \ell / \mathrm{g}$ using the Unit Cell Model. ........................ 4-40

4-21. Normalized Contaminant Flux from the Disposal Facility to the Vadose Zone using the

Unit Cell Model ................................. 4-40

4-22. Glass Dissolution Rate as a Function of Time and Space in the Disposal Vault. . . . . 4-43

4-23. Estimated Release Rates through the Vault Floor. ................. 4-44

4-24. Normalized Tc Fluxes Through the Vault Floor for Various Assumptions. . . . . . . 4-45

4-25. Normalized Flux to the Aquifer for $K_{d}=0$ for Concept 2 Simulations Using Constant

Contaminant Release and Using Contaminant Release Proportional to Surface Area 4-46

4-26. Beta/Photon Drinking Water Dose When Using Glass Release as a Source Term for a

Well 100 Meters Downgradient of a Concept 1 Facility (Unit Cell Model). . . . . . 4-49

4-27. Normalized Flux to the Aquifer for $K_{d}=0$ Elements from Concepts 1 and Concept 2. 4-52

4-28. Moisture Values of Unit Cell Model for steady state. ................ 4-55

4-29. Estimated Unretarded Contaminant Flux to Aquifer for Concept 1 for Different Diffusion

Coefficients (Full Facility Model). . . . . . . . . . . . . . . . .

4-30. Normalized Unretarded Contaminant Flux Entering the Unconfined Aquifer for Three

Different Sets of Hydraulic Properties in the Vadose Zone . . . . . . . . . . 4-60

4-31. Normalized Contaminant Fluxes at the Unconfined Aquifer for Unretarded Contaminants

for Various Infiltration Rates. (Unit Cell Model) . . . . . . . . . . . . . . 4-65

4-32. Normalized Contaminant Fluxes at the Unconfined Aquifer for $\mathrm{K}_{\mathrm{d}}=0.6 \mathrm{~m} / \mathrm{g}$

Contaminants for Various Infiltration Rates. (Unit Cell Model) . . . . . . . . . . 4 4-66

4-33. Normalized Unretarded Contaminant Fluxes at the Unconfined Aquifer Using the Concept

2 Geometry For Infiltration Rates of 3 and $100 \mathrm{~mm} / \mathrm{y} \ldots \ldots \ldots \ldots \ldots \ldots$ 
E-1. Comparison of $\mathrm{Kd}=3 \mathrm{mg} / \mathrm{l}$ Using Computer Simulations and An Approximation ... E-3 E-2. Simulated Post-Hanford Operations Water Table and Well Location . . .......... E-20 E-3. Simulated Aquifer Thickness - Post Hanford Operations

E-4. Simulated Streamlines for Various Pumping Rates $\left(10 \mathrm{~m} / \mathrm{day}, 50 \mathrm{~m}^{3} / \mathrm{day}\right.$,

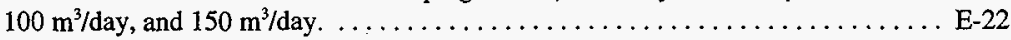

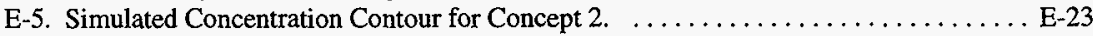

E-6. Simulated Concentration Contour for Irrigation North of the 200 Area. . . . . . . . E E 24

E-7. Simulated Concentration Contour for Existing TWRS Disposal Facilities. . . . . . . E E-25

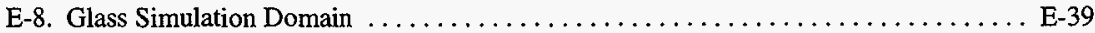

E-9. Computed $\mathrm{pH}$ when Ion Exchange Reaction is NOT Considered. . . . . . . . . . . E-40

E-10. Glass Dissolution Rate as a Function of Time and Space when NOT Considering Ion Exchange Reaction. ................................. E-40

E-11. Calculated Total Aqueous ${ }^{99} \mathrm{Tc}$ Concentration as a Function of Time and Space. . . . E E-42

E-12. Computed $\mathrm{pH}$ in Disposal Vault When Ion Exchange Is Included. .......... E-42 


\section{HNF-EP-0884}

Rev. 1

\section{LIST OF TABLES}

2-1. Approximate Probability of Exceeding Given Ground Motions During Selected Time Periods. .................................... 2-21

2-2. Activity of Radionuclides in Hanford Sitewide Background Data Set ......... 2-35

2-3. Provisional Background Values for Hanford Site Groundwater .............. 2-35

3-1. Inventories for Interim Performance Assessment. ${ }^{2}$ Inventory is decayed to 2010 . . . . . 3-3

3-2. Stratigraphy Used for the Base Analysis Case. ................... 3-20

3-3. Values for Hydrologic Parameters for the Vadose Zone for the Base Analysis Case. . . 3-23

3-4. Values for Hydrologic Parameters for Construction Materials for the Base Analysis

Case ...................................... 3-24

3-5. Chemical Distribution Coefficients $\left(K_{d}\right)$ for the Base Analysis Case .......... 3-26

3-6. Hydraulic Parameters for Unconfined Aquifer Immediately Around the Disposal Site . 3-27

3-7. Element Material-Zone Flow Properties. . . . . . . . . . . . . . . . . . . 3-28

3-8. Relative Radionuclide Release Rate from the Waste Form for the Base Analysis Case 3-34

3-9. Dimension of a Vault Bay for Base Analysis Case . . . . . . . . . . . . . . . 3-37

3-10. Vault Layout for Base Analysis Case . . . . . . . . . . . . . . . . . . . . . 3-37

3-11. Infiltration Rates for Base Analysis Case. . . . . . . . . . . . . . . . . . . . . . . .

3-12. Halflife and Other Decay Information $\ldots \ldots \ldots \ldots \ldots \ldots \ldots \ldots \ldots \ldots \ldots . \ldots \ldots$ 3-45

3-13. Base Analysis Case Input Data for the Disposal Facility and Unit Cell Models. . . . . . 3-65

3-14. Important Input Parameters for the Base Analysis Case Inadvertent Intrusion Analysis 3-67

3-15. List of Sensitivity Cases ............................... 3-68

4-1. Driller Intruder Dose (mrem) at Various Intrusion Times (years) $\ldots \ldots \ldots \ldots \ldots \ldots$ 4-3

4-2. Homesteader Intruder Dose (mrem in a year) at Various Intrusion Times (years) . . . . . 4-7

4-3. Fractional Mass Balance Error as a Function of Time for Modeling Concept 1

Simulations . .................................. 4-17

4-4. Major Parameters Describing the Normalized Contaminant Flux to the Aquifer . . . . 4-23

4-5. Concentration Ratios at Hypothetical Wells $\ldots \ldots \ldots \ldots \ldots \ldots \ldots \ldots \ldots . \ldots \ldots$ 4-26

4-6. Estimated Impact From Base Analysis Case at a Well 100 Meters Downgradient from the Disposal Facility at 10,000 years. . . . . . . . . . . .

4-7. Major Contributors at 10,000 Years to the Estimated Beta/Photon Drinking Water Dose at a Well 100 Meters Downgradient from the Disposal Facility for the Base Analysis Case.

4-8. Major Contributors at 10,000 Years to the Alpha-Emitting Radionuclide Concentration at a Well 100 Meters Downgradient of the Disposal Facility for the Base Analysis Case. ............................... 4-33

4-9. Major Contributors at 10,000 Years to the All-Pathways Dose at a Well 100 Meters Downgradient of the Disposal

4-10. Estimated Impact From Base Analysis Case from Groundwater Just Before Mixing with the Columbia River at 10,000 Years.

4-11. Estimated Maximum Impact From Base Analysis Case Using the Groundwater Scenario.

4-12. Major Parameters Describing the Normalized Contaminant Flux to the Aquifer for Concept 2.

4-13. Estimated Impact Using Concept 2 Geometry at a Well 100 Meters Downgradient from the Disposal Facility at 10,000 Years. 


\section{HNF-EP-0884}

Rev. 1

4-14. Estimated Maximum Impact Using Concept 2 Geometry at 100 Meters Downgradient from the Disposal Facility. ............................ 4-38

4-15. Major Parameters Describing the Normalized Contaminant Flux to the Aquifer Using the Unit Cell Model. . ............................. 4-39

4-16. Estimated Impact at 10,000 Years from Groundwater at a Well 100 Meters

Downgradient Using the Unit Cell Model . .................... 4.41

4-17. Estimated Maximum Impact from Groundwater at a Well 100 Meters Downgradient Using the Unit Cell Model for Concept 1 Design . . . . . . . . . . . . . . . 4-41

4-18. Maximum Release Rate through Vault Floor as Calculated by AREST-CT. . . . . 4 4-44

4-19. Major Parameters Describing the Normalized Contaminant Flux to the Aquifer for Concept 2 Using Constant Contaminant Release $\ldots \ldots \ldots \ldots \ldots \ldots \ldots \ldots .447$

4-20. Sensitivity of Impacts Caused by Different Interpretations of Waste Immobilization

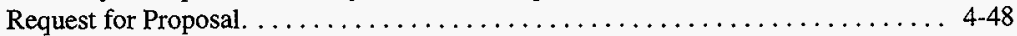

4-21. Estimated Impacts When Using Calculated Glass Release Rates at a Well 100 Meters Downgradient from a Concept 1 Facility (Unit Cell Model). . . . . . . . . . . . . 4-49

4-22. Effect of Facility Design Options on Estimated Impacts at 10,000 Years . . . . . 4 4-54

4-23. Estimated Beta/Photon Drinking Water Dose at 10,000 years at a Well 100 Meters Downgradient for Different Diffusion Coefficients. ................ 4-58

4-24. Estimated Impact at 10,000 Years Assuming Different Strata (and hence Hydraulic

Properties). ................................ 4-59

4-25. Normalized Contaminant Flux Reaching the Unconfined Aquifer at 10,000 years as a Function of Water Table Position. .......................... 4-61

4-26. Effect of Dispersion on $\mathrm{K}_{\mathrm{d}}=0.6 \mathrm{~m} / \mathrm{g}$ Normalized Contaminant Fluxes to the Aquifer, Unit Cell Model. . ................................ 4-62

4-27. Effect of Geochemical Parameters on Impacts at a Well 100 Meters Downgradient at 10,000 Years. . . . . . . . . . . . . . . . . . . . . . . . . . . . . .

4-28. Effect of Infiltration Rates on Estimated Impacts at 10,000 Years for a Well 100 Meters

Downgradient from the Facility. . . . . . . . . . . . . . . . . . . 65

4-29. Effect of Inventory Changes on Estimated Results at 10,000 Years at a Well 100 Meters

Downgradient from the Facility. ........................ 4-69

4-30. Effect of Pumping Rates on Aquifer Mixing Ratio at a Well 100 Meters Downgradient of

Facility .................................... 42

4-31. Effect of Different Dose Factor Libraries on the Beta/Photon Drinking Water Dose and

All-Pathways Dose at a Well 100 Meters Down Gradient at 10,000 Years. ...... 4-73

4-32. Test of Unit Cell Calculational Assumptions: Normalized Flux Entering Unconfined

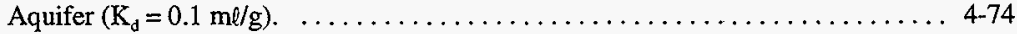

4-33. Mixing Factors from Other Sources for a Well 100 Meters Downgradient of the Low-

Level Tank Waste Disposal Site ......................... 4-76

4-34. Maximum Contribution from Contaminants at 10,000 Years at a Well 100 Meters

Downgradient from the Facility, Assuming INSTANTANEOUS Vadose Zone Transport, a Constant Waste Form Release Rate of $4.4 \mathrm{ppm} / \mathrm{y}$, and Concept $1 . \quad \ldots \ldots \ldots \ldots .4-78$

4-35. Inventory of ${ }^{222} \mathrm{Rn}$ as a Function of Time. . . . . . . . . . . . . . . .

5-1. Comparison of Estimated Impacts with Performance Objectives for Protecting

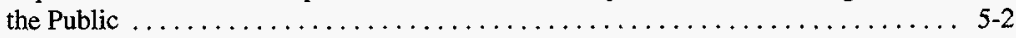

5-2. Comparison of Estimated Impacts with Performance Objectives for Protecting the Inadvertent Intruder. 


\section{HNF-EP-0884}

Rev. 1

5-3. Comparison of Estimated Impacts with Performance Objectives for Protecting Groundwater Resources.

5-4. Comparison of Estimated Impacts with Performance Objectives for Protecting Surface Water Resources.

5-5. Comparison of Estimated Impacts with Performance Objectives for Protecting Air Resources. ..................................... 5-4

5-6. Schedule of Major Events in Performance Assessment Activity $\ldots \ldots \ldots \ldots \ldots \ldots$ 5-6

B-1. Drinking Water Scenario Dose Factors $\quad \therefore \ldots \ldots \ldots \ldots \ldots \ldots \ldots \ldots \ldots$ B-1

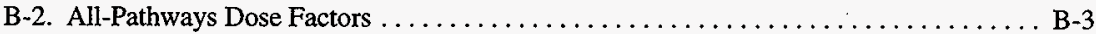

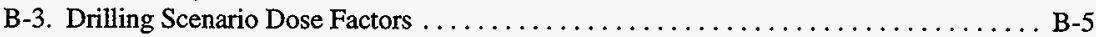

B-4. Intruder Scenario Dose Factors $\ldots \ldots \ldots \ldots \ldots \ldots \ldots \ldots \ldots \ldots \ldots \ldots$ B-7

B-5. Ratio of Intruder Dose Factors for $2500 \mathrm{~m}^{2}$ garden relative to $500 \mathrm{~m}^{2}$ garden. . . . . . . B-12

C-1: List Of Reactions Considered in Glass Performance .................. C-5

E-1. Summary of Vadose Zone Simulations for the Normalized Contaminant Flux

Reaching the Unconfined Aquifer. $\ldots \ldots \ldots \ldots \ldots \ldots \ldots \ldots \ldots \ldots \ldots \ldots \ldots \ldots \ldots$

E-2. Summary of Dose Calculations. . . . . . . . . E 


\subsection{INTRODUCTION}

\subsection{PURPOSE}

The purpose of the interim performance assessment is to examine the long-term environmental effects of the planned Hanford Low-Level Tank Waste Disposal Facility as early as possible in its project life. That facility is proposed for the disposal of low-level radioactive waste that is derived from the treatment of waste currently stored in the Hanford single- and double-shell tanks. The Hanford tank waste will be separated into high-activity and low-activty components with the low-activity component immobilized and placed in a disposal facility.

This interim performance assessment is being prepared as a good management practice to provide information needed about the relationship between the disposal system performance and its design. Department of Energy (DOE) Order 5820.2A, Radioactive Waste Management (DOE $1988 \mathrm{a}$ ) is the primary regulation governing management and disposal of radioactive waste at DOE facilities. This assessment uses the techniques, methods, and rigor of the final performance assessment described in DOE Order 5820.2A where possible. Unlike the database for a final performance assessment, much of which is based on experiment and is design specific, much of the database for this assessment is based on information from other projects or programs. As more of the design effort is completed and more data are collected, the preliminary and final performance assessments, which are required by DOE Order $5820.2 \mathrm{~A}$, will be prepared.

\subsection{BACKGROUND}

This section provides background information on the Hanford Site and on other recent performance assessments prepared at the Hanford Site. This document builds on earlier Hanford performance assessments and on previous efforts to analyze the long-term effects of various design options of the disposal facility.

\subsubsection{The Hanford Site}

The Hanford Site, in south-central Washington State (Figure 1-1), has been used extensively as a location for defense materials production by DOE its predecessors, the U.S. Atomic Energy Commission and the U.S. Energy Research and Development Administration. Starting in the 1940s, Hanford Site operations were dedicated primarily to producing nuclear weapons materials. In the 1960 s, operations were expanded to producing electricity from a dualpurpose reactor, conducting diverse research projects, and managing waste. In the late 1980s, the Hanford Site's original mission ended.

Today, the Site's mission is environmental restoration, energy-related research, and technology development. A large inventory of radioactive and mixed waste from the decades of nuclear materials production has been accumulated in buried single- and double-shell tanks in the Hanford Site 200 Areas. 


\section{HNF-EP-0884}

Rev. 1

Figure 1-1. Map of the Hanford Site Showing the Assumed Location of the Hanford LowLevel Tank Waste Disposal Facility (HLLTWDF).

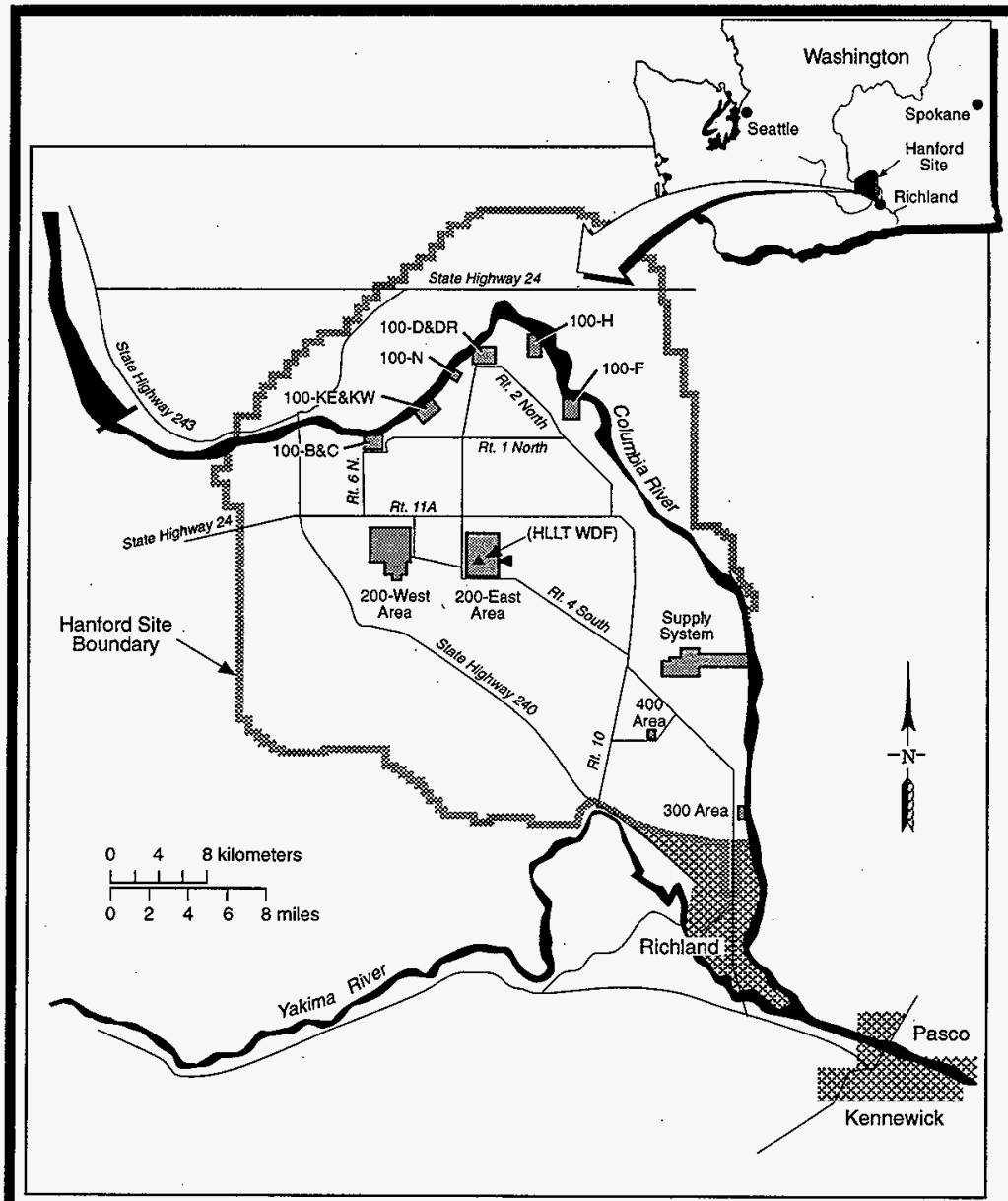




\section{HNF-EP-0884 \\ Rev. 1}

As part of the new mission, DOE is proceeding with plans to permanently dispose of this waste. The plans are based on Revision 4 of the Hanford Federal Facility Agreement and Consent Order (Tri-Party Agreement) (Ecology 1996-1) and on the Record of Decision for the Tank Waste Remediation Systems Environmental Impact Statement (DOE 1997). These documents call for the waste to be retrieved from Hanford's single- and double-shell tanks, then treated to separate the low-level fraction (renamed low-activity fraction) from the high-level and transuranic waste. Both fractions will then be immobilized.

The two products (the small volume of high-level immobilized waste and the much larger volume of low-activity waste) will be disposed of in different locations. The high-level waste will be stored on the Hanford Site until disposed of in a federal geologic repository. The lowactivity immobilized waste will be disposed of on the Hanford Site in a near-surface disposal system. Over $200,000 \mathrm{~m}^{3}\left(6,000,000 \mathrm{ft}^{3}\right)$ of low-activity immobilized waste will be disposed under this plan. This is among the largest amounts within the DOE Complex (DOE 1995) and has one of the largest inventories of long-lived radionuclides at a low-level waste disposal facility.

\subsubsection{Other Hanford Performance Assessments}

1.2.2.1 Overview. This interim performance assessment builds on the previous performance assessments prepared for the Hanford Site. Performance assessments that have been prepared under the requirements of DOE Order 5820.2A for other Hanford Site disposal actions are discussed in the following paragraphs. These documents are in various stages of review and approval. All performance assessments prepared under Order 5820.2A are reviewed by the Peer Review Panel (established by the order) for technical adequacy. This panel performs a preliminary review, a completeness review, and a final review for each performance assessment. Then, DOE-Headquarters reviews the documents and may provide approval for the disposal action if the performance assessment satisfies the requirements of Order 5820.2A.

\subsubsection{Long-Term Performance Assessment of Grouted Phosphate/Sulfate Waste from $N$}

Reactor Operations (Stewart 1987). This performance assessment forms the basis of the environmental assessment (DOE 1986a) for the disposal of low-level radioactive waste generated by decontamination operations and other activities associated with the operation of the $\mathrm{N}$ Reactor on the Hanford Site. Since this performance assessment predates the DOE Order on radioactive waste management, the review was through the review of the environmental assessment.

\subsubsection{Performance Assessment of Grouted Double-Shell Tank Waste Disposal at Hanford} (Kincaid 1995). The grout performance assessment dealt with disposing of low-level liquid waste from the double-shell tanks. The waste was to be combined with cement, flyash, and clay to form a grout, which would be poured into large subsurface vaults-located to the east of the 200 East Area.

The grout performance assessment was approved in principle by the Peer Review Panel (Wilhite 1994). DOE (Lytle 1995) found that the analysis performed in this document was 


\section{HNF-EP-0884}

Rev. 1

"technically adequate and provides reasonable assurance that the selected performance objectives would be met." Noting, however, that the grout project had been canceled, DOE also stated that a new or revised performance assessment would be needed for routine disposal of waste in the Grout Disposal Facility.

\subsubsection{Performance Assessment for the Disposal of Low-Level Waste in the 200 West Area} Burial Grounds (Wood 1994b). The 200 West Area solid waste performance assessment dealt with the solid waste from operations at the Hanford Site and from other sites. This waste is placed into trenches in the western part of the 200 West Area and then covered with a Resource Conservation and Recovery Act of 1976 (RCRA)-compliant barrier. The Peer Review Panel found the performance assessment to be technically acceptable. The 200 West Area performance assessment has been "conditionally accepted" by DOE-Headquarters (Cowan 1996). The conditions being related to added documentation.

\subsubsection{Performance Assessment for the Disposal of Low-Level Waste in the 200 East Area} Waste Burial Grounds (Wood 1996). The 200 East Area solid waste performance assessment addresses waste that is similar to that addressed in the 200 West Area performance assessment. However, the disposal trenches for this waste are in the northern part of the 200 East Area. The final performance assessment for this action has been submitted to DOE for review.

\subsubsection{Environmental Remediation Disposal Facility Performance Assessment (Wood 1995).}

The Environmental Remediation Disposal Facility (ERDF) accepts waste generated by the cleanup of the Hanford Site. Most of this waste is expected to be contaminated soil. Trenches are planned to be the main means of disposal at the facility. A preliminary performance assessment has been written for ERDF. Because ERDF is regulated under the Comprehensive Environmental Response, Compensation, and Liability Act of 1980 (CERCLA), this performance assessment will not be submitted to the Peer Review Panel. However, a remedial investigation and feasibility study report (DOE-RL 1993d) was written.

\subsubsection{Compliance Assessment for Hanford Site. In recommendation 94-2 to the} Secretary of the Department of Energy [DNFSB 1994], the Defense Nuclear Facilities Safety Board noted the need for a risk assessment that investigated the environmental impacts of all radioactive waste disposal actions or leaks at a DOE Site. The first version of this analysis is due to be published by December 1997. The authors of the compliance assessment are working with the authors of the previous performance assessments to maximize consistency in data and methods.

\subsubsection{TWRS Environmental Impact Statement (TWRS EIS). The environmental} impact of various options to manage Hanford's tank wastes were analysed in an environemntal impact statement (DOE 1996b) with the record of decision issued early the next year (DOE 1997). Because of the scope of the EIS, the analyses performed in the EIS relied on data less complete and less project-specific than this interim performance assessment. 


\subsubsection{Previous Work Related to the Proposed Disposal Action}

The long-term environmental impact of various design features for the low-level tank waste disposal facility has been analyzed. The first analysis is given in Revision 0 of Impacts of Disposal System Design Options on Low-Level Glass Waste Disposal System Performance (Rawlins 1994). Revision 1 (Mann 1995d) updated that analysis based on better data and on the comments received concerning Revision 0 . However, neither report is as comprehensive as this performance assessment.

\subsubsection{Review of Data Packages for Interim Performance Assessment}

Some of the information used for the interim performance assessment has already been reviewed by external groups to ensure its acceptability by peers and stakeholders. The performance objectives and scenarios used in this performance assessment were reviewed by Hanford Site stakeholders. The results of the review were transmitted in a letter report (Murkowski 1995). The dosimetry results presented in this report were reviewed by members of the Hanford Environmental Dose Overview Panel. The results of the review were transmitted in a letter report (Rhodes 1996). The external review board for the Interim Performance Assessment (Appendix F.1) also reviewed the data packages.

\subsubsection{Relationship With Other Parts of the Project}

Figure 1-2 illustrates the current baseline planning logic for the Immobolized LowLactiveity Disposal Subproject within TWRS. The performance assessment activity is closely connected with other parts of the LLW Disposal Subproject. The schedule for the major events of the LLW Disposal Subproject, the performance assessment activity is iterative, consisting of an interim performance assessment (this document), a preliminary performance assessment, and the final performance assessment. The results from the interim and preliminary performance assessments feed into design activities. Approval of the Preliminary Performance Assessment also allows detailed design of the disposal facility to proceed. The design activities feed back into the preliminary and final performance assessments. The approval of the final performance assessment by the DOE is one of the conditions for the startup of the disposal facility and will be an important input for the full-scale immobilization of Hanford Site tank waste.

\subsection{GENERAL DESCRIPTION OF THE FACILITY}

The disposal facility has not yet been designed. However, conceptual ideas (Eiholzer 1995) envision immobilized waste being disposed in metal containers of approximately 1 to 2 meters in each direction. These containers would be placed into concrete vaults, with 6 vaults forming a row. Sand-gravel capillary barriers would be placed over and along side the vaults to divert water around the vault to minimize infiltration. The disposal facility would be capped by a surface barrier to minimize water, plant, animal, and human intrusion. Two concepts are being considered and evaluated in this performance assessment. The main difference between the 
Figure 1-2. Activities Schedule for the IlW Disposal subproject.

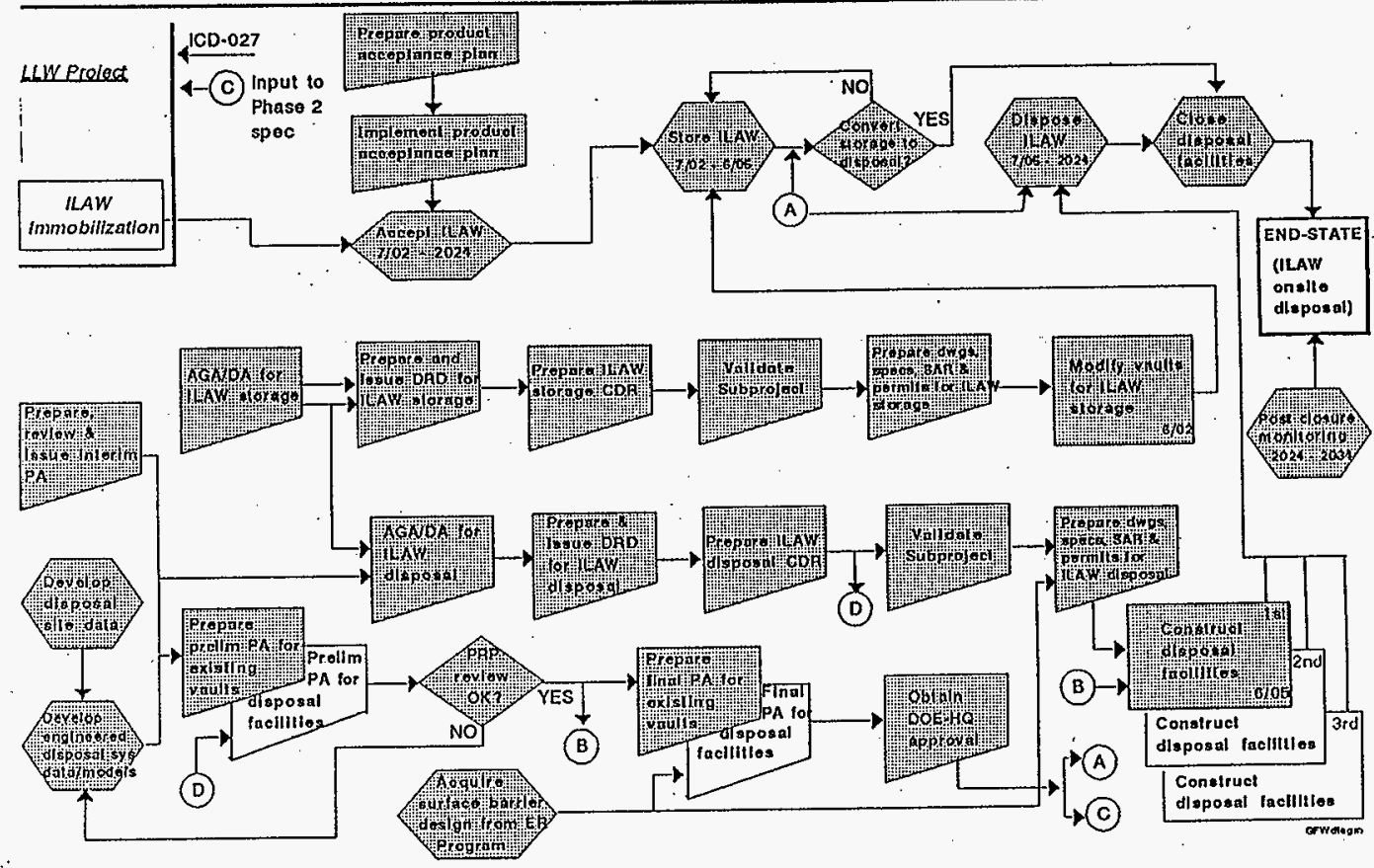




\section{HANF-EP-0884 \\ Rev. 1}

concepts is whether the vault rows are separated by soil or not. Section 2.4 provides more details on both two concepts.

The DOE is proceeding (DOE-RL 1996) to procure privatized services for treating and immobilizing the tank waste. Depending on the outcome of that process, different waste forms or containers may emerge, which may affect the disposal facility concept.

\subsection{GUIDANCE DOCUMENTS}

The format and content of this document are based on guidance from the Peer Review Panel and on other performance assessments submitted to the Peer Review Panel for their review. The recommendations made in the following documents were used as guidance in preparing this interim performance assessment:

- Recommended Format and Content for DOE Low-Level Waste Disposal Facility Radiological Performance Assessment Reports, DOE/LLW-81 (Case 1989)

- Performance Assessment Review Guide for Low-Level Radioactive Waste Disposal Facility, DOE/LLW-93 (Dodge 1991)

- $\quad$ Proceedings of the Department of Energy Performance Assessment Briefing, Denver, Colorado, October 29, 1991, DOE/LLW-138 (NLLWP 1992)

- Performance Assessment Task Team Progress Report, Revision 1, DOE/LLW157 (Wood 1994a)

- A Compilation of DOE Performance Assessment Peer Review Panel Review Comments and Recommendations, DOE/LLW-216 (RWSTP 1994).

- DOE Headquarters Review of the "Performance Assessment of Grouted DoubleShell Tank Waste at Hanford" (Lytie 1995).

- Implementation Plan, Defense Nuclear Facilities Safety Board Recommendation 94-2, Compliance with Safety Standards at Department of Energy Low-Level Nuclear Waste Sites (DOE 1996a).

DOE is in the process of revising the DOE order on radioactive waste management. Because the draft documents concerning the new order (DOE O 435.1) are subject to change, the documents listed above were used as the main sources of guidance. 


\section{HANF-EP-0884}

Rev. 1

\subsection{PERFORMANCE OBJECTIVES}

\subsubsection{Overview}

The DOE's requirements for waste disposal (DOE 1988a and DOE-RL 1993) can be summarized as follows:

- Protect public health and safety

- Protect the environment.

Most of the requirements are general (for example, the requirement to "protect groundwater resources consistent with Federal, State, and local requirements") or indirectly reference other requirements (for example, the requirement that "releases to the atmosphere shall meet the requirements of $\left.40 \mathrm{CFR} 61^{\prime \prime}\right)$. A few of the requirements state quantitative limits such as the limit of 25 mrem in a year for all exposures.

For this interim performance assessment, the following methods were used to establish the quantitative performance objectives explained in Performance Objectives of the Tank Waste Remediation Systems Low-Level Waste Disposal Program, (PAT 1995a):

- Investigating all potentially applicable regulations as well as interpretations made by the Peer Review Panel

- Working with Storage and Disposal Project management to establish their needs

- Working with the Hanford Site stakeholders to understand the values of residents in the Pacific Northwest.

These efforts produced the performance objectives that were used in this interim performance assessment. "Performance Objectives presented in Table 1-1 are values in additional to any existing amounts or background."

Table 1-1. Performance Objectives. ${ }^{a, b}$

\begin{tabular}{|lr|}
\hline \multicolumn{2}{|c|}{ Protection of General Public and Workers } \\
\hline all-pathways dose from only this facility & 25 mrem in a year ${ }^{c, e, i}$ \\
all-pathways dose including other Hanford sources & 100 mrem in a year $^{c, f_{j},}$ \\
ALARA (treated as an integrated all-pathways dose) & 500 persons-rem/year pre, $^{c, e}$ \\
\hline
\end{tabular}


Rev. 1

\section{Protection of an Inadvertent Intruder ${ }^{\mathrm{d}, \mathrm{g}}$}

acute exposure

500 mrem

continuous exposure

100 mrem in a year

Protection of Groundwater Resources ${ }^{c, e, I}$

alpha emitters

${ }^{226} \mathrm{Ra}+{ }^{228} \mathrm{Ra}$

$5 \mathrm{pCi} / \ell$

all others (total)

$15 \mathrm{pCi} / \mathrm{l}$

beta and photon emitters

4 mrem in a year

Protection of Surface Water Resources ${ }^{\text {c.h }}$

alpha emitters

${ }^{226} \mathrm{Ra}+{ }^{228} \mathrm{Ra}$

$0.3 \mathrm{pCi} / \ell^{\mathrm{k}}$

all others (total)

$15 \mathrm{pCi} / \ell^{1}$

beta and photon emitters

1 mrem in a year $^{\mathrm{m}}$

Protection of Air Resource ${ }^{c, g, n}$

Radon

$20 \mathrm{pCi} \mathrm{m}^{-2} \mathrm{~s}^{-1}$

All other radionuclides

10 mrem in a year

a Taken from PAT 1995a, except for limit that includes other Hanford sources which is taken from DOE 1996

${ }^{\text {b }}$ All doses are calculated as Effective Dose Equivalents (EDE); all concentrations are in water taken from a well. Values given are in addition to any existing amounts or background.

' Evaluated for 10,000 years, but calculated to the time of peak or 10,000 years, whichever is longer.

${ }^{d}$ Evaluated for 500 years, but calculated to 1,000 years

${ }^{e}$ Evaluated at point of maximal exposure, but no closer than 100 meters ( 328 feet) from the disposal facility

${ }^{f}$ Evaluated at the 200 East Area fence

${ }^{8}$ Evaluated at the disposal facility

${ }^{h}$ Evaluated at the Columbia River, no mixing with the river is assumed

${ }^{i}$ Main driver is DOE Order 5820.2A, Radioactive Waste Management (DOE 1988a)

' Main driver is DOE Order 5400.5, Radiation Protection of the Public and the Environment (DOE 1993)

${ }^{\mathrm{k}}$ Main driver is DOE/RL Implementing Directive 5820.2A, Radioactive Waste Management (DOE-RL 1993)

${ }^{1}$ Main driver is National Primary Drinking Water Regulations (40 CFR 141)

${ }^{m}$ Main driver is Washington State Surface Water Standards (WAC 173-201A)

${ }^{n}$ Main driver is National Emission Standards for Hazardous Air Pollutants (40 CFR 61H and 40 CFR 61Q). 


\section{HANF-EP-0884 \\ Rev. 1}

The proposed revision of the DOE order on radioactive waste management was not . considered in setting the performance objectives because the revision is still undergoing review as this document is being written. The major changes caused by the order revision would be in the time of compliance for environmental protection being reduced from 10,000 years to 1,000 years. established.

The following sections summarize how the quantitative performance objectives were

\subsubsection{Regulations and Other Performance Assessments}

1.5.2.1 Introduction. Several federal and state regulations potentially apply to how well the public health and safety and the environment must be protected. These regulations were reviewed for relevance to this proposed disposal action. The following categories of requirements were reviewed:

- Protection of the general public

- Protection for workers

- Protection of the inadvertent intruder

- Protection of groundwater resources

- Protection of surface water resources

- Protection of air resources.

Appendix B of the performance objectives document (PAT 1995a) lists the regulations that were reviewed and judged to be potentially relevant to this proposed disposal action. Some regulations and general environmental acts were judged not relevant for one or more of the following reasons:

- Requirements are the responsibility of others of the Disposal Subproject (for example, ensuring compliance with the National Environmental Policy Act [NEPA])

- Requirements are for different environmental actions (for example, the Comprehensive Environment Response, Compensation, and Liability Act of 1980 [CERCLA])

- Requirements deal with general environmental concerns (protection of endangered species) which are thought to be adequately protected for the long-term by regulations presented here

- Requirements are only at a preliminary stage and are likely to change. \{e.g., the "Radiation Site Cleanup Regulation" [proposed Title 40 Code of Federal Regulations (CFR) 196] and "Environmental Radiation Standards for Management and Disposal of Low-Level Waste" [proposed 40 CFR 193] from the U.S. Environmental Protection Agency\}. The development of these 


\section{HANF-EP-0884}

\section{Rev. 1}

requirements will be closely followed and incorporated as appropriate.

Performance assessments of low-level waste disposal in the DOE complex were also reviewed to identify any regulations relevant to this proposed disposal action. These assessments provide "case law" interpretations. Appendix C of PAT (1995) lists the other performance assessments in the DOE complex, as well as their performance objectives.

1.5.2.2 Protection of the General Public. For the interim performance assessment, the performance objective for the protection of the general public is 25 mrem (EDE) in a year (EDE, Effective Dose Equivalent). The value is consistently used in all the regulations and past performance assessments. Although there are other methods for determining body dose (PAT 1995a), the effective dose equivalent method was selected because regulations normally use this method. The location for compliance is at the point of maximal exposure, but not less than 100 meters (328 feet) from the disposal facility (Wood 1994a).

The Defense Nuclear Facilities Safety Board (DNFSB 1994) noted that a member of the public could receive exposures from several sources at a DOE site. Guidance from DOEHeadquarters (DOE 1996a) is that protection of the general public from multiple sources should be based on Radiation Protection of the Public and the Environment, DOE Order 5400.5, (DOE 1993-1). This order sets a limit of 100 mrem in a year from all sources. The interpretation of DOE Order 5400.5 places the point of compliance at the fence line of the future site. For the Hanford Site, this is considered to be a fence surrounding the present Hanford 200 Areas. In contrast, DOE Order 5820.2a provides a more restrictive standard ( $25 \mathrm{mrem}$ in a year at a location not less than 100 meters from the facility) to enable the design of the disposal facility to occur without considering the effect of other facilities.

Little guidance is provided on the interpretation of ALARA (as low as reasonably achievable). For this assessment, the requirements of DOE, Richland Operations Office (RL) Implementing Directive 5820.2A, Radioactive Waste Management (DOE-RL 1993), were used. This requirement gives AlARA doses as an integrated dose for all pathways of 500 person-rem in a year.

The compliance time for this performance assessment is 10,000 years. (The compliance time is the time starting 100 years from the present over which the predicted dose must remain below the performance objectives.) However, the calculation was carried out to the time of maximum impact if that time is longer than 10,000 years. The compliance time used is consistent with the compliance time used in the Grout Performance Assessment (Kincaid 1995-1) and the 200 West Area Solid Waste Performance Assessment (Wood 1994b-1). Using the 10,000 years compliance time is also consistent with the draft U.S. Nuclear Regulatory Commission (NRC) branch technical position on performance assessment for low-level waste disposal facilities (NRC 1997).

1.5.2.3 Protection for Workers. For this performance assessment as with others performed under 5820.2A, no distinction is made between performance objectives for workers and for the general public. Since the protection requirements are more restrictive for the general public than 


\section{HANF-EP-0884 \\ Rev. 1}

for the workers, the workers will be adequately protected. Protection for workers during construction and operations will be addressed in the Safety Analysis Report that will be written for the LLW Disposal Subproject.

1.5.2.4 Protection of the Inadvertent Intruder. The exposure limits for protecting a hypothetical inadvertent intruder are consistent with the regulations and with earlier performance assessments. (Appendices Tables B-2 and C-2 in PAT 1995a, respectively, give details). These limits are 500 mrem (EDE) for a one-time (acute) exposure and 100 mrem(EDE)/year for a continuous exposure. These limits are used in this performance assessment.

The compliance time for protecting an inadvertent intruder is defined different than the time of compliance for protecting the general public or the environment. For inadvertent intrusion, the compliance time is defined as the time after which the estimated dose is below the performance objective.

The inadvertent intrusion time of compliance time differs slightly between regulations. RL directive 5820.2A (DOE-RL 1993) allows a compliance time of 500 years if passive barriers and markers are used. The current DOE-HQ order (DOE 1988a) does not mention using such barriers or markers and stipulates a compliance time of 100 years. The Hanford Grout Performance Assessment (Kincaid 1995-1) used the 500 years compliance time based on the assumption that passive barriers and markers would be present. The performance assessments for the disposal of Hanford solid Waste (Wood 1994b and Wood 1996) have also used a compliance time of 500 years. This is consistent with the NRC requirement for Class $\mathrm{C}$ waste (10 CFR 61-1) that inadvertent intruders be protected for 500 years. Other previous performance assessments have assumed that the disposal facility will be under active control for at least 100 years and have used 100 years as the compliance time.

Following the precedent of the other Hanford performance assessments, the 500-year compliance time was used in this assessment because passive barriers and markers are planned for this proposed disposal action. Therefore, protection of an inadvertent intruder shall be considered met if the exposure limits are met at 500 years after closure. Calculations were run from 100 years after time of disposal to 1,000 years to obtain the doses as a function of time.

1.5.2.5 Protection of Groundwater Resources. This is the most complicated requirement to determine. The protection of groundwater is usually based on its intended use. However, predicting future groundwater use is highly subjective given the long time frames involved in a performance assessment. The quantities being limited (decay rate and dose) differ in the various regulations. Moreover, different regulatory agencies approach the protection of groundwater resources using different methods. In addition, earlier DOE performance assessments have taken different approaches.

Previous performance assessments have generalized the requirements from the National Primary Drinking Water Regulations (40 CFR 141) for determining whether the disposal action met the groundwater protection requirement. The scenario used is based on a public drinking 


\section{HANF-EP-0884 \\ Rev. 1}

water system servicing about 25 people and located not less than 100 meters (328 feet) downstream from the disposal facility. The previous performance assessments set a limit for the total exposure from all radionuclides for an individual drinking the water at less than $4 \mathrm{mrem}$ (EDE) in a year. The National Primary Drinking Water Regulations, however, use the limit of 4 mrem in a year not for all radionuclides, but just for beta and gamma emitters. The distance of 100 meters is given in the RL Implementing Directive 5820.2A. Four (4) mrem (EDE) in a year was chosen for two reasons. The value corresponds to the risk-based limit found in the National Primary Drinking Water Regulations (40 CFR 141). Also, for most of the radionuclides, the value is more restrictive (see Table B-3 of PAT 1995a) than decay rate concentration limits specified in the Washington State regulations (WAC 173-200).

The requirements for alpha emitters are the same in both the Washington State (WAC 173-200) and federal (10 CFR 141) regulations. Both the state and federal regulations limit alpha emitters, not by annual dose, but by decay rate concentration limits. In addition, both sets of requirements limit the same subsets of alpha emitters ${ }^{22}{ }^{2 \mathrm{Ra}}$, total radium, and other) and set the same quantitative limits. These decay rate concentration limits (Table 1-2) are used for this performance assessment.

Washington State's requirements for beta emitters are based on a screening level previously used by the U.S. Environmental Protection Agency (EPA). These screening levels were selected because the requirements are easily verified in the field. (The current EPA regulation are based on risk limitation.) The current state screening level ensures that even for beta emitters emitting high-energy gamma radiation, the dose limit will be met. However, for low-energy beta emitters, the state screening level is overly conservative by about a factor of 100. This high degree of conservatism exists for radionuclides, such as ${ }^{99} \mathrm{Tc}$, that are important in this performance assessment.

For this performance assessment, the federal standards are used. This follows the precedent of the Tank Waste Remediation System Environmental Impact Statement (TWRS EIS) (DOE 1996b), a joint publication of the Washington State Department of Ecology and DOE. That is, the current EPA regulation governing drinking water (40 CFR 141) is used to protect groundwater. Thus the performance objective is an effective dose equivalent (EDE) of $4 \mathrm{mrem}$ for beta/photon emitters and a concentration of $15 \mathrm{pCi}$ per liter for alpha emitters. Although uranium is not restricted in the regulations, for this analysis it is included under other alpha emitters. The values are displayed in Table 1-1. A dose of $4 \mathrm{mrem}$ (EDE) in a year for 70 years corresponds to an incremental health risk of 0.0001 (EPA 1989b).

Only the "National Primary Drinking Water Regulations" (40 CFR 141) were used for determining the protection of the groundwater resources. The "National Secondary Drinking Water Standards" (40 CFR 143) were not used because they are stated only as goals.

To ensure compliance with the intent of federal and state groundwater regulations, the limits shown in Table 1-1 are applied to a well 100 meters downgradient from the disposal facility for a time of 10,000 years after closure (the same time of compliance as for protection of the general public). The hypothetical well from which the water is drawn is sized to serve the 
minimal public drinking water system for 25 people. Further information is given in Section 3.4.8. The effect of placing the well at other locations (including the Hanford 200 Area fence line) are also determined.

1.5.2,6 Protection of Surface Water Resources. The thrust of the federal (10 CFR 141) and state requirements (WAC 173-201A) for surface water resources protection is the same. The point of compliance is where the groundwater is predicted to reach the Columbia River. The concentrations of.radionuclides in the groundwater at the point where it enters the Columbia River should meet all of the standards listed in Table 1-1.

The 1.0 mrem (EDE) in a year (one-quarter of the EPA drinking water standard) value is used because it meets the Washington State regulation while minimizing reporting requirements. The Washington State regulation (WAC 173-201A) mandates a dose limit that is the lesser of the EPA drinking water standard and explicit limits contained in the state regulation. For the major radionuclides of interest, the explicit limits (when concerted to dose) are greater than 1.3 mrem in a year. Using $1.0 \mathrm{mrem}$ in a year for the sum of all beta/photon emitters is restrictive.

The time of compliance for the protection of surface water resources is selected as 10,000 years, the same compliance time as for protecting groundwater resources. However, the calculations are carried out to the time of maximum impact, if the peak occurs after 10,000 years.

1.5.2.7 Protection of Air Resources. Air emissions limits were taken from Parts $H$ and $Q$ of the "National Emissions Standards for Hazardous Air Pollutants" (40 CFR 61H and 40 CFR 61Q). These limits are more restrictive than the Washington State requirements (WAC 173-480 and WAC 246-247). Based on these standards, emissions (except radon) are limited to $10 \mathrm{mrem}$ $(E D E)$ in a year with radon emissions limited to $20 \mathrm{pCi} / \mathrm{m}^{2} \mathrm{~s}$.

\subsubsection{Programmatic Requirements}

The LLW Disposal Subproject has also established other requirements. The project mandated that all waste to be disposed of or stored in the facility shall meet NRC Class C concentration limits (10 CFR 61-2).

\subsubsection{Public Involvement}

It is important that Hanford Site stakeholders have an opportunity to affect the performance objectives of this proposed disposal action. A summary of the performance objectives and scenarios (WHC 1994b) was written for stakeholders. The summary was sent to each member and alternate of the Hanford Advisory Board, to selected Hanford Site contractor employees, and to selected members of the DOE's Peer Review Panel and Performance Assessment Task Team.

Feedback was received from the stakeholders and we have responded to their concerns. Copies of the performance objectives document (PAT 1994) were sent to all who requested it. 


\section{HANF-EP-0884 \\ Rev. 1}

All comments received on either the summary or the performance objectives have been documented as an internal file. These comments and corresponding responses are available for review (Murkowski 1995).

A member of the Hanford Advisory Board (Todd Martin) was a member of the external review board (see Appendix F.1) which commented on the interim performance assessment and the performance assessment activity.

\subsection{APPROACH AND MAJOR DATA SOURCES (ASSUMPTIONS)}

Because of the long-time frames involved in this analysis, estimates of impacts are based on computer simulations, rather than on direct observations. The models used in the analyses are very flexible and should be adequate to describe the evolving features of the disposal system. However, because this analysis is performed early in the project's life, many assumptions are made and much data is taken from related Hanford Site projects.

The major sources of information for the base analysis case are

Location: ASSUMED just southwest of PUREX facility in the 200 East Area of the Hanford Site (See Section 3.4.4)

Waste: Immobolized low-activity contents of Hanford single- and double-shell tanks in the 200 East and 200 West Areas of the Hanford Site (See Section 2.3)

Inventory: ASSUMED to be average values calculated from modeling Hanford Site production reactors corrected for off-site transfers, discharges to the ground, separations into high- and low-activity fractions, and off-gas generation. (See Section 3.2)

Long-term waste form performance: ASSUMED to be equal in value to short-term performance required in the request for proposals (See Section 3.4.5)

Disposal facility design: $\quad$ ASSUMED from preconceptual ideas. (Section 3.4.6)

Recharge: Taken from specifications of Hanford Surbace Barrier (first thousand years) and then from analysis of current natural consitions (3.4.7)

Geotechnical: Taken from geotechnical measurements studies of other locations in the Hanford Site 200 East Area (See Sections 3.4.4)

Exposure: $\quad$ Taken from past Hanford Site documents and experience. (See Section 3.4.8) 


\section{HANF-EP-0884}

Rev. 1

Sensitivity cases (See Section 3.5.5) were performed to determine the impact of uncertain data. Among the most important were

- The waste form was explicitly simulated (assuming it was the extensively studied LD6-5412 low-level glass waste form) to determine release rates.

- Recharge rates were varied over rwo orders of magnitude as was their time history.

- Different amounts of key radionuclides were included.

- Different disposal facility designs were studied.

- Exposure parameters were extensively varied.

This performance assessment is just the first of a series of performance assessments which will more accurately estimate the impact of the disposal of immobilized low-activity tank waste. Future performance assessments will be issued as new inofmration and better understanding of the waste form, its inventory, the design of the disposal facility, and site characterization occur.

\subsection{STRUCTURE OF THIS PERFORMANCE ASSESSMENT}

This performance assessment is divided into seven chapters and five appendices. The appendices provide additional detailed information about topics presented in the chapters. The contents of each of the following chapters are summarized in this section.

- Chapter 2 describes the Hanford environment, the waste characteristics, and the waste disposal system.

- Chapter 3 covers the methods used to assess performance of the system, including the radionuclide transport pathways and exposure scenarios. It also discusses the assumptions used in modeling system performance, and outlines the quality assurance procedures.

- Chapter 4 presents and integrates results from the transport and exposure models used to estimate the potential consequences of long-term contaminant release from the disposal vaults.

- Chapter 5 interprets disposal facility performance with respect to the performance objectives defined in Chapter 1.

- Chapter 6 contains brief resumes of contributors to the document. 


\section{HANF-EP-0884}

Rev. 1

- Chapter 7 lists the cited references.

- Appendix A repeats the specifications for immobilization given in the request for proposal (DOE-RL 1996).

- Appendix B displays the dose factors used in the dosimetry calculations.

- Appendix $\mathrm{C}$ describes the computer simulation of the performance of a glass waste form.

- Appendix $D$ describes the computer codes used in moisture flow and contaminant transport simulations.

- Appendix E provides detailed results of the computer simulations.

- Appendix F contains the comments received on the initial release of the Interim Performance Assessment as well as the responses to those comments. 


\section{HANF-EP-0884}

Rev. 1
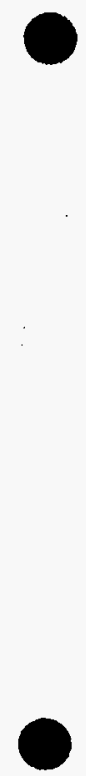

$1-18$ 


\subsection{DISPOSAL FACILITY DESCRIPTION}

\subsection{OVERVIEW}

This chapter explains the expected environment within the region and around the immobilized low-activity tank waste disposal facility, probable waste retrieval and immobilization, and likely design, operating, and closure concepts for the disposal facility. It covers the following topics.

- Hanford Site Characteristics (Section 2.2): regional and local geography, demography (including future land use), climate, geology, hydrology, soils, ecology and biotic conditions, and natural radiation background.

- Waste Characteristics (Section 2.3): current waste storage in underground tanks and plans for retrieving the waste, separating it into high- and low-activity fractions, and immobilizing the low-activity fraction, including packaging and certification.

- Disposal Technology (Section 2.4): the current concepts on disposal units, waste handling and interim storage operations, waste emplacement, disposal unit closure and stabilization, and site closure.

\subsection{HANFORD SITE CHARACTERISTICS}

\subsubsection{Overview}

This section describes the regional and local environment in which the immobilized lowactivity tank waste disposal facility will likely be located. Extensive research has been done on the Hanford Site. However, this section will cover only the characteristics that will be used to model the immobilized low-activity tank waste disposal facility's long-term performance. More complete descriptions will be referenced whenever possible.

\subsubsection{Geography}

The Hanford Site is a $1,450-\mathrm{km}^{2}\left(560-\mathrm{mi}^{2}\right)$ area of semiarid land located in south-central Washington State. The Hanford Site is owned by the U.S. Government and restricted to uses approved by the DOE. Figure 2-1 shows the Hanford Site in relation to the rest of the state. It also identifies the major cities in the region, Seattle, Portland, and Spokane, which are over 160 kilometers (100 miles) from the Hanford Site. 
Figure 2-1. Hanford Site in Washington State.

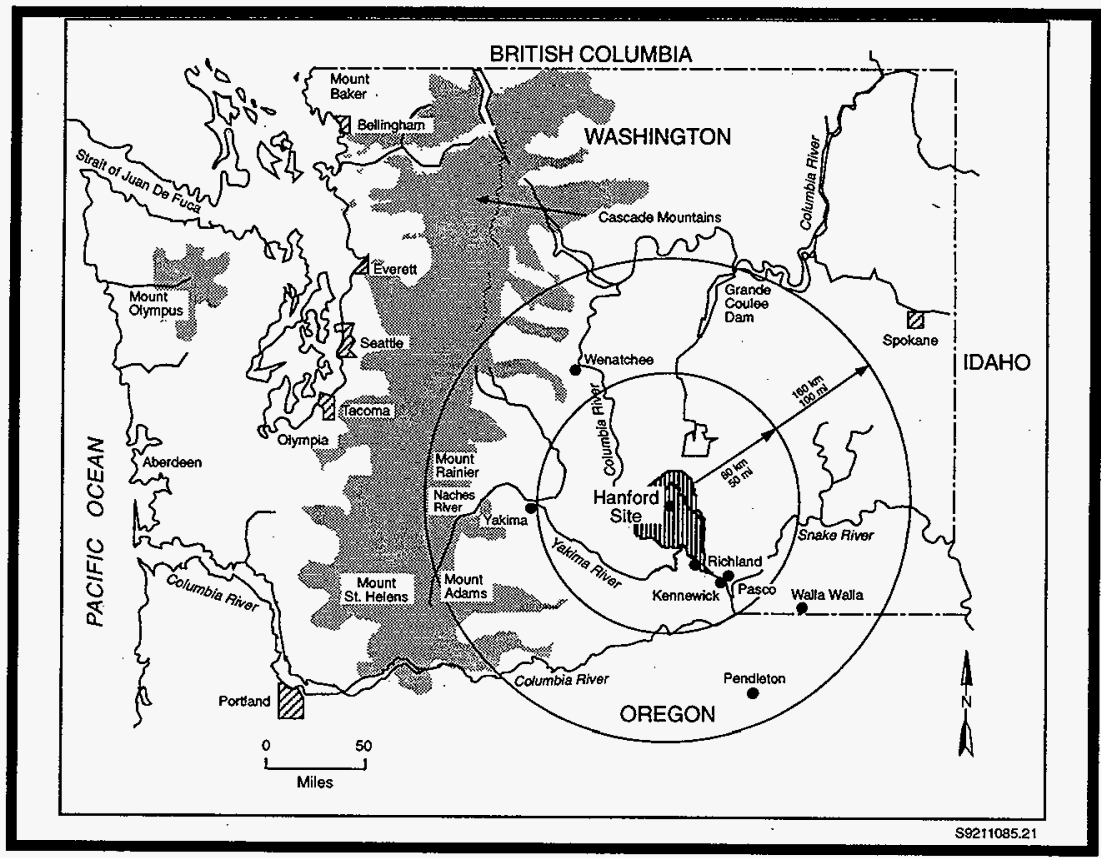

The major features of regional geography are the nearby rivers and mountains. The Columbia River, which forms the eastern boundary of the Hanford Site, is an important source of water and hydroelectric power for the region. Other important rivers near the Hanford Site are the Yakima River to the southwest and the Snake River to the east. The Cascade Mountains, which are about 160 kilometers ( 100 miles) to the west, have an important effect on the climate of the area as discussed in Section 2.2.4.

Figure 2-2 shows the Hanford Site. The DOE is planning to release some of the Hanford Site land for public use. The areas planned for release are the area north of the Columbia River and the area to the southwest of State Highway 240 (the Fitzner/Eberhardt Arid Lands Ecology Reserve). The 200 Areas, where the tank waste is currently located, are in the center of the Hanford Site. Just south of the 200 Areas is land used for commercial low-level radioactive waste disposal (US. Ecology). 
aq 01 s! Xə̣duo $S \& M L$ ә

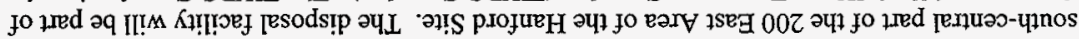

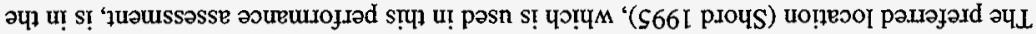

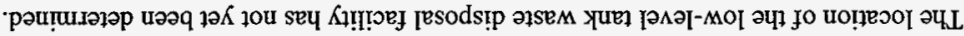

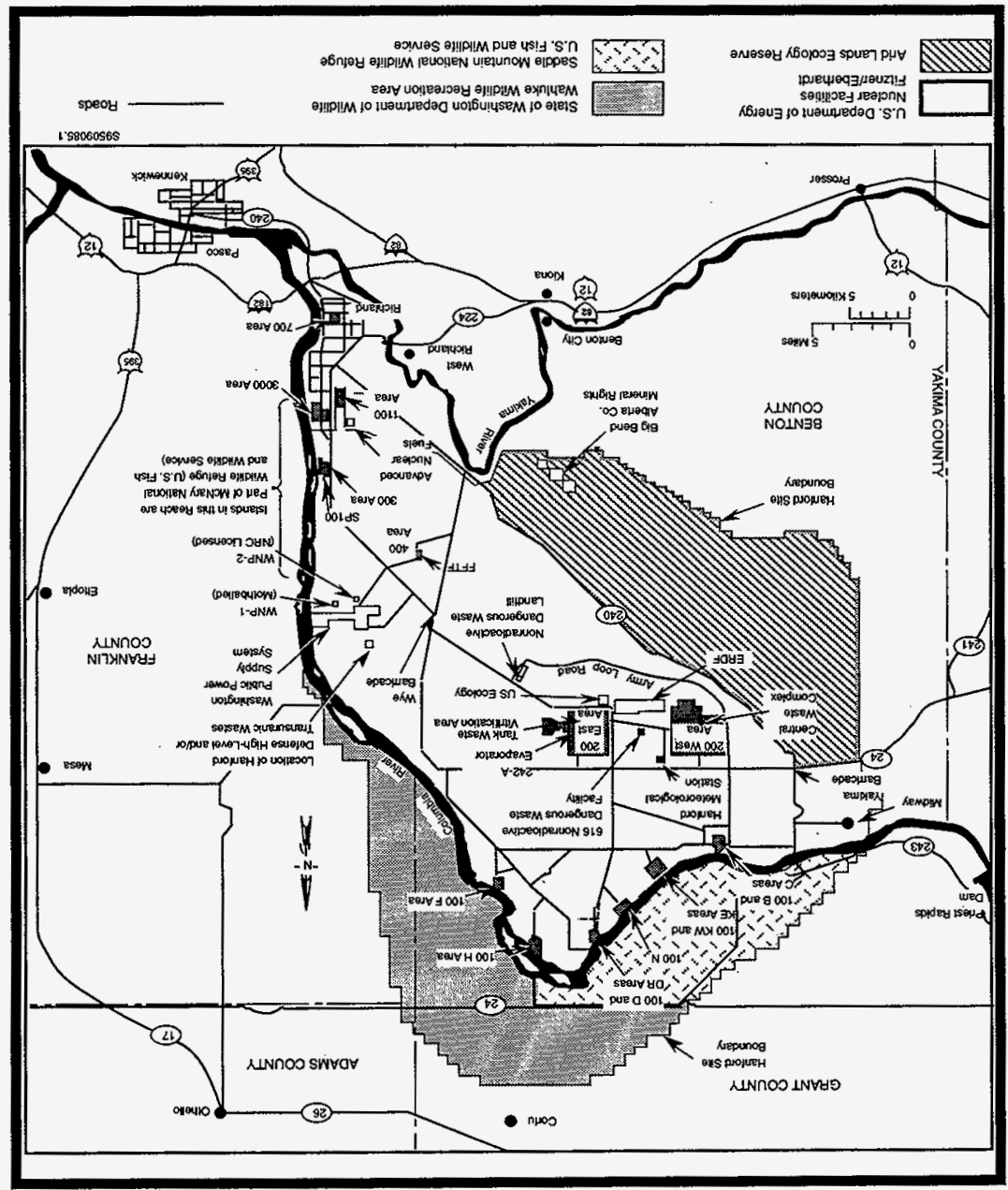

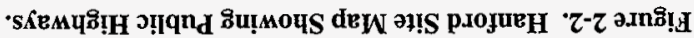




\section{HNF-EP-0884}

Rev. 1

located between existing office structures and the PUREX fuel reprocessing facility. Figure 2-3 shows the proposed TWRS complex area. This location was chosen for the following three reasons:

- The location is near existing tank farms

- Unused land is available

- The location is inside the fence line of the 200 Areas.

However, this location still needs to be approved. The Tank Waste Remediation System does plan to use the four existing empty vaults in the Grout Disposal Facility to store the first $6 \%$ of the immobilized low-activity waste produced (Burbank 1996). Studies are occurring to determine if these vaults would be converted to disposal facilities.

Figure 2-3. Activities in the 200 Areas. The proposed location of the disposal facility is part of the Tank Waste Treatment Complex, located in the south central part of the 200 East Area.

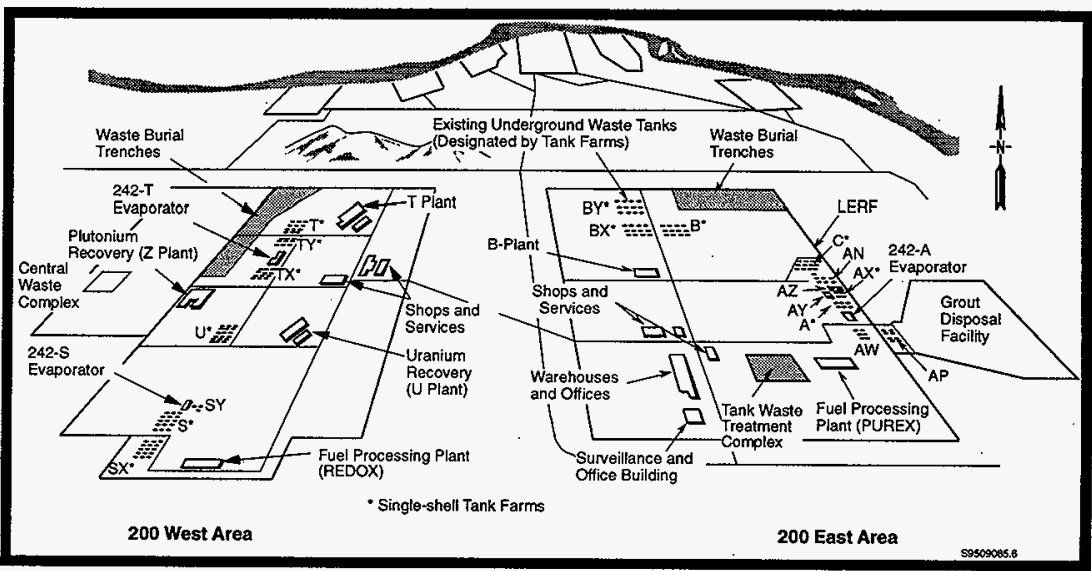

\subsubsection{Demography (Including Land and Water Use)}

2.2.3.1 Overview. Demographic data are used in a performance assessment to help set the scenarios and select the dosimetry parameters. This section describes the current population database, area socioeconomics, past and planned DOE activities, and the results of an investigation of future uses conducted by the Hanford Future Site Uses Working Group. 


\section{HNF-EP-0884}

Rev. 1

2.2.3.2 Population. The major population centers within an 80-kilometer (50-mile) radius of the Hanford Site are illustrated in Figure 2-4, along with populations based on the 1990 U.S. Bureau of Census estimates (DOC 1991). This radius is centered on the Hanford Meteorology Station (HMS), located between the 200 East and 200 West Areas. The Tri-Cities (Richland, Kennewick, and Pasco), southeast of the Site, is the largest population center closest to the Hanford Site. Other major population centers include Yakima and the Yakima Valley towns to the west, Umatilla and Hermiston to the south, and Moses Lake to the north. The cities of Ellensburg and Walla Walla lie just beyond the 80-kilometer (50-mile) radius. Portions of Benton, Franklin, Adams, Grant, Kittitas, Yakima, Klickitat, Walla Walla, Morrow, and Umatilla counties lie within the 80 kilometer radius.

The population estimates for Washington State (OFM 1994) as summarized in Cushing (1995-1) are used. The population in Benton County was approximately 127,000 in 1993. Approximately 35,000 people reside in Richland; 47,000 people reside in Kennewick; and 12,000 people reside in West Richland, Benton City, and Prosser. The approximate population in the unincorporated portions of the county is 32,600 . The estimated population of Franklin County was 43,000 in 1993, with 22,000 people living in Pasco, 3,400 people living in other incorporated areas, and 17,600 people living in unincorporated areas. During 1990, Benton and Franklin Counties accounted for approximately 3 percent of Washington State's population.

Based on estimates made during the 1970 and 1980 census years, the population in the area grew approximately 55 percent (Watson 1984). This population growth and the subsequent decline in 1982 were attributed to the creation and loss of several thousand construction jobs at the Washington Public Power Supply System power reactors. Watson et al. (Watson 1984) projected that the populations within a 16-kilometer $(10$-mile) radius, primarily reflecting the Tri-Cities, would increase by 94 percent between 1980 and 2030 and that the population between 16 and 80 kilometers (10 and 50 miles) would increase by 55 percent.

2.2.3.3 Socioeconomics. The socioeconomics of the area surrounding the Hanford Site are more fully described in Cushing (1995-2). The major employment sectors in the Tri-Cities area since 1970 have been the DOE and the Hanford Site contractors; the Washington Public Power Supply System, which operates a nuclear power plant; agriculture and a large food-processing industry; plus several smaller industrial operations. Other than DOE activities, agriculture and food processing are the dominant industries.

The land use around the Hanford Site varies from urban to rural. Most of the land south of the Hanford Site is urban, including the Tri-Cities, while much of the land to the north and east is irrigated crop land. Most of the irrigation water comes from the Bureau of Reclamation's Columbia Basin Project, which uses the Grand Coulee Dam as the primary water source. The water is transported via canals to the areas north and east of the Columbia River. The land to the west of the Hanford Site is used for a mixture of irrigated agriculture (near the Yakima River) and dry-land farming (at the higher elevations). 
Figure 2-4. Population Centers Within an 80-kilometer Radius of the Hanford Site. Populations Shown Are Based on 1990 Census (DOC 1991).

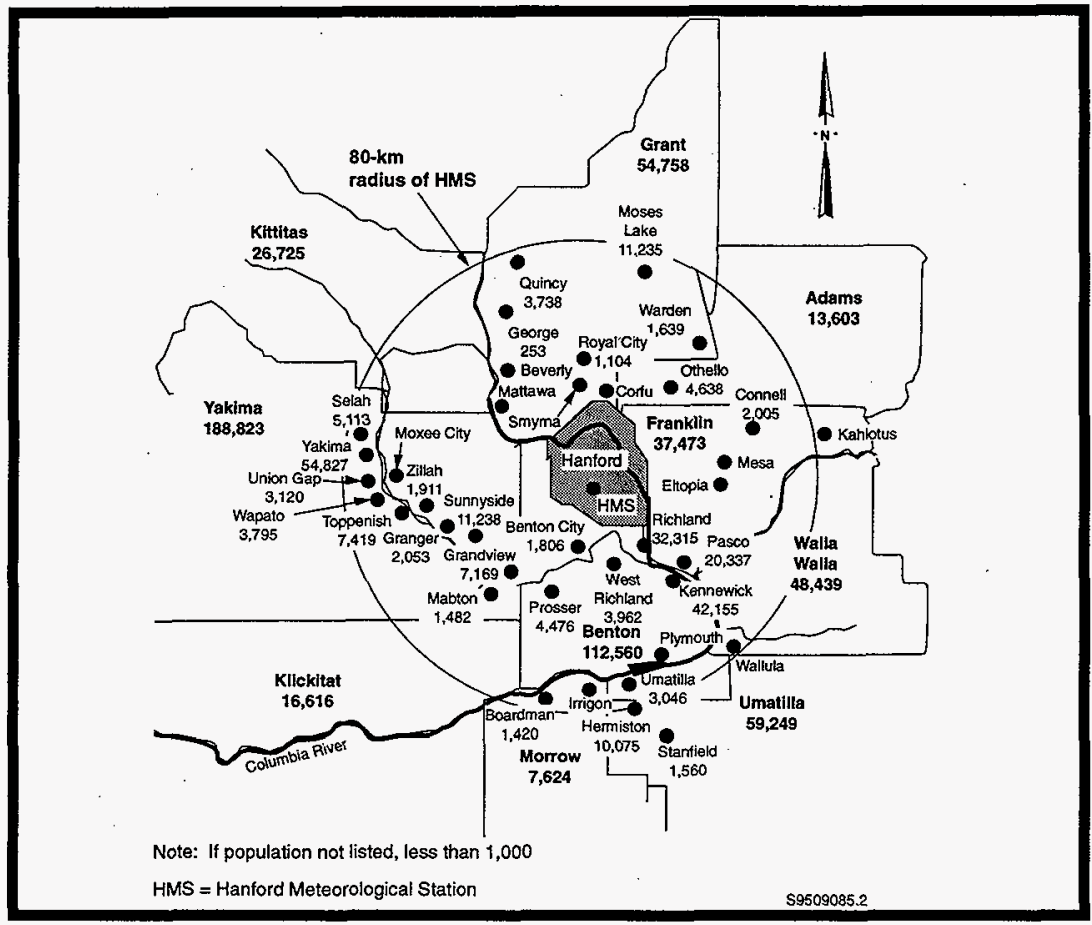

The area rivers are used primarily as sources of irrigation and drinking water but also for recreation. The National Parks Service has suggested that the free-flowing portion of the Columbia River along the Hanford Site boundary (known as the Hanford Reach) be designated as a recreational river under the Wild and Scenic River system. A record of decision is pending with Congressional action expected.

The major land use on the Hanford Site is the result of DOE's nuclear activities, which are more fully described in Section 2.2.3.4. No major mining operations exist in the Hanford Site area other than some local gravel processing. Oil and gas exploration has occurred; however, no economically viable accumulations were found. 


\section{HNF-EP-0884 \\ Rev. 1}

2.2.3.4 Past and Future DOE Activities at the Hanford Site. In 1943, the U.S. Army Corps of Engineers created the Hanford Site from small farming areas along the Columbia River and land ceded by local Indian Tribes to locate facilities for producing nuclear weapon materials for fighting World War II. Since then, the major activities on the Hanford Site have been controlled by the DOE and its predecessors, the Atomic Energy Commission (1945-1975) and the Energy and Research Development Administration (1975-6). Current major programs at the Hanford Site are dedicated to waste management, environmental restoration, and research and development.

The DOE nuclear facilities occupy about 6 percent of the Site's total available area. The major operating areas, as shown in Figure 2-2, are identified by numbers: 100 Areas, 200 Areas, 300 Area, and 400 Area. The activities in these areas are described in the following paragraphs.

The 100 Areas, directly bordering the Columbia River (Figure 2-2), contain nine graphite-moderated plutonium production reactors, eight of which were shut down by the early 1970 's. The ninth is the N Reactor, the first dual-purpose reactor built in the United States. N Reactor began operating in 1963 and ran until it was shut down in 1986.

Fuel reprocessing, plutonium and uranium separation, plutonium finishing, and waste management, including treatment, storage, and disposal activities, were conducted in the 200 Areas. Some waste from research and development activities and fuel fabrication activities in the 300 Area, reactor operation programs conducted in the 100 Areas, and the Fast Flux Test Facility (FFTF) in the 400 Area is sent to the 200 Areas for storage and disposal. Waste management activities are scheduled to continue until the mid 21 st century.

Waste management facilities are located in the 200 Areas which are surrounded by security fencing (Figure 2-2.) The following major facilities are located in the 200 Areas (see Figure 2-3):

- Burial trenches

- Eighteen underground storage tank farms (the A, AN, AP, AW, AX, AY, AZ, B, BX, BY, C, S, SX, SY, T, TX, TY, and U.

- Very large fuel processing and recovery facilities $(B, T, U$, and $Z$ Plants and the REDOX and PUREX facilities)

- Tank waste water evaporator facilities (242-A, $-S$, and $-T)$

- Office and warehouse buildings.

Many of these facilities are inactive. A building (The Canister Storage Building) is being built just west of B-plant which will stored spent nuclear fuel and the immobilized high-level tank waste until a federal geological repository is ready to receive such waste. 


\section{HNF-EP-0884}

Rev. 1

Between and just south of the 200 East and West Areas is the Environmental Remediation Disposal Facility (ERDF, Figure 2-2). This trench system will hold most of the contaminated soil and materials from facility decontamination and decommissioning and Hanford Site remediation.

Some sites near the 200 Areas have been leased for disposal of commercial low-level radioactive waste. A $3.9-\mathrm{km}^{2}\left(1.5-\mathrm{mi}^{2}\right)$ parcel located between the 200 West and East Areas is leased to Washington State. A portion of this land is subleased to U.S. Ecology, Inc., a private company, for the disposal of commercially generated low-level radioactive waste.

The Fast Flux Test Facility (FFTF) is located in the 400 Area. This facility contains a liquid-metal cooled fast reactor previously used for testing breeder reactor fuels, materials, and components. The FFTF operated until 1992 and is now shut down.

A 4.4- $\mathrm{km}^{2}\left(1.7-\mathrm{mi}^{2}\right)$ parcel northeast of the 400 Area is leased to the Washington Public Power Supply System for commercial nuclear power reactors. The Washington Nuclear Plant (WNP-2), a boiling-water reactor, is currently the only operating nuclear reactor on the Hanford Site. Construction of WNP-1 and WNP-4 will not be completed; both reactors were to be pressurized-water reactors.

The 300 Area had been dedicated to fabricating fuel for the $\mathrm{N}$ Reactor and other reactors on the Hanford Site. Now, the 300 Area is used for research programs performed in laboratories constructed over the last 30 years.

Besides the DOE activities already mentioned, the main future DOE activities will deal with site remediation. The largest addition will be the TWRS Complex, which will include the proposed disposal facility and may consist of more than one physical area. The TWRS Complex will be used to treat and store the waste now in the underground storage tanks in the 200 Area. It will also be used to dispose of the low-activity fraction of that waste.

2.2.3.5 Future Hanford Use. In 1992, DOE, EPA, and the Washington State Department of Ecology gathered a group of Hanford stakeholders to study future land-use of the Hanford Site. This Hanford Future Site Uses Working Group issued a summary (HFSUWG 1992a) and a detailed report (HFSUWG 1992b) of its findings.

HFSUWG (1992a-1) contains the following statement about near-term use of the 200 Areas, called the Central Plateau in the report.

"The presence of many different types of radionuclides and hazardous constituents in various forms and combinations throughout the site poses a key challenge to the Hanford cleanup. To facilitate cleanup of the rest of the site, wastes from throughout the Hanford site should be concentrated in the Central Plateau...Waste storage, treatment, and disposal activities in the Central Plateau should be concentrated within this area as well, whenever feasible, to minimize the amount of land devoted to, or contaminated by, waste management activities. This principle of minimizing land used for waste management should specifically 


\section{HNF-EP-0884}

Rev. 1

be considered in imminent near-term decisions about utilizing additional uncontaminated Central Plateau lands for permanent disposal of grout."

The report continues on the subject of future use options (HFSUWG 1992a-2),

"In general, the Working Group desires that the overall cleanup criteria for the Central Plateau should enable general usage of the land and groundwater for other than waste management activities in the horizon of 100 years from the decommissioning of waste management facilities and closure of waste disposal areas."

Based on conversations of the working group, no definition of "general use" could be agreed on. For the "foreseeable future" the working group developed options involving waste treatment, storage, and disposal of DOE low-level radioactive waste. The differences among the options are whether offsite waste (radioactive and/or hazardous) would be allowed to be disposed of on the Hanford Site.

Finally (HFSUWG 1992a-3),

"The working group identified a single cleanup scenario for the Central Plateau. This scenario assumes that future uses of the surface, subsurface and groundwater in and immediately surrounding the 200 West and 200 East Areas would be exclusive... Surrounding the exclusive area would be a temporary surface and subsurface exclusive buffer zone composed of at least the rest of the Central Plateau...As the risks from the waste management activities decrease, it is expected that the buffer zone would shrink commensurately."

The projected land use for this performance assessment is described in Section 3.3.3.2. It is consistent with the recommendations of the Working Group and with DOE's plans.

For nearer term land use planning, as part of the Washington State Growth Management Act of 1991, Benton County is identifying land uses for the Hanford Site. This plan has the 200 Areas treated as industrial areas surrounded by "critical areas." By state law, "critical areas" are defined as land to be protected from use because of wildlife habitat, geologic, or environmental conditions. The only areas found suitable for development are as follows:

- To the northwest of the 200 West Area (a minimum of 6 kilometers [ 4 miles]), in an area known as the McGee ranch, where farming would be allowed

- to the east of the 200 East Area (a minimum of 5 kilometers [ 3 miles]) where research and development activities would be allowed.

However, any formal land use planning is not expected to be accurate in the time frame of this analysis (hundreds to hundreds of thousands of years). 


\section{HNF-EP-0884}

Rev. 1

\subsubsection{Climate and Meteorology}

2.2.4.1 Overview. Local and regional climate patterns and projections must be considered when evaluating the amount of water entering the disposal system. Some of the water will enter the disposal facility, react with the waste form, then carry away contaminants. Weather also affects the potential for flooding. Both total precipitation and seasonal frequency are important. Potential long-term climatic conditions must be projected to evaluate future climate changes that might cause higher precipitation rates or glaciation.

The climate of the Pasco Basin (where the Hanford Site is located) can be classified as midlatitude semiarid or midlatitude desert, depending on the climatological classification system being used. Summers are warm and dry with abundant sunshine. Large diurnal temperature variations are common, resulting from intense solar heating and nighttime cooling. . Daytime high temperature in June, July, and August can exceed $40^{\circ} \mathrm{C}\left(104^{\circ} \mathrm{F}\right)$. Winters are cool with occasional precipitation that makes up about 44 percent of the yearly total. During the winter, outbreaks of cold air associated with modified arctic air masses can reach the area and cause temperatures to drop below $-18{ }^{\circ} \mathrm{C}\left(0^{\circ} \mathrm{F}\right)$. Overcast skies and fog do occur during the fall and winter months.

The Cascade Mountain Range greatly affect the temperature, wind, and precipitation in the region. Air masses that reach the Pasco Basin are changed as they pass over the region's relatively complex topography. The mountains limit the Pacific Ocean's maritime influence, making the climate of Eastern Washington drier with greater temperature extremes than the coast. In addition to the rain shadow effect, the Cascades are a source of cold air drainage, which has a considerable effect on the Site's wind regime.

This rest of this section summarizes the modern climate patterns in the Hanford Site area, the regional climate patterns of the recent past, and the possible future changes.

2.2.4.2 Current Data. Climatological data are available from the Hanford Meteorological Station (HMS), located between the 200 East and 200 West Areas at about 215 meters ( 705 feet) elevation. Data have been collected at this location since 1945. Temperature and precipitation data also are available from nearby locations for the period from 1912 through 1943. Data from the HMS are representative of the general climatic conditions for the region and describe the specific climate of the.200 Areas. Summaries have been published by Hoitinik (1994) and Stone (1983).

The average monthly temperature at the $\mathrm{HMS}$ is $12{ }^{\circ} \mathrm{C}\left(54^{\circ} \mathrm{F}\right)$. The unusually cool nights that occur result from cool gravity winds originating from the Cascade Mountains. Seasonal temperature extremes are greater at the Hanford Site than they would be without the Cascade Mountains. The Pasco Basin has milder winters than sites at the same latitude on the Great Plains because mountain ranges to the north and east shield the area from many of the arctic surges that descend from Canada. Half of all winters are free of temperatures of $-18^{\circ} \mathrm{C}$ $\left(0^{\circ} \mathrm{F}\right)$ or lower. 


\section{HNF-EP-0884}

Rev. 1

Precipitation has been measured at the HMS since 1945. Average annual precipitation at the HMS is $16 \mathrm{~cm}$ (6.3 in.). The precipitation during November, December, and January accounts for 44 percent of this total, while precipitation from July through September accounts for only 13 percent. On the average, only twice a year do 24 -hour amounts of precipitation measure $1.3 \mathrm{~cm}(0.5 \mathrm{in}$.) or more. Rainfall intensities of $1.3 \mathrm{~cm} / \mathrm{h}(0.5 \mathrm{in} . / \mathrm{h})$ persisting for 1 hour are expected once every 10 years. Occurrences of 24-hour amounts of precipitation of $5.1 \mathrm{~cm}$ ( 2 in.) or more have been recorded only twice from 1946 through 1980. One of these was the record storm of October 1-2, 1957, in which rainfall totaled $2.7 \mathrm{~cm}$ (1.08 in.) in 3 hours, $4.3 \mathrm{~cm}$ (1.68 in.) in 6 hours, and $4.8 \mathrm{~cm}(1.88 \mathrm{in}$.$) in 12$ hours.

About 38 percent of all precipitation that occurs during December through February is in the form of snow. Winter monthly average snowfall ranges from $0.8 \mathrm{~cm}(0.3 \mathrm{in}$.) in March to $13.5 \mathrm{~cm}$ (5.3 in.) in January. Only one winter in four is expected to accumulate as much as $15 \mathrm{~cm}$ (5.9 in.) of snow on the ground. During these winters, four days, on average, have $15.2 \mathrm{~cm}$ (6.0 in.) or more of snow on the ground. However, the 1964-1965 winter had 35 days with snow on the ground, 32 of which were consecutive. That winter also provided one of the deepest accumulations, with $31 \mathrm{~cm}$ (12 in.) of snow occurring in December 1964. The record accumulation of snow is $62.2 \mathrm{~cm}$ (24.5 in.) in February 1916.

Prevailing wind directions on the Hanford Central Plateau are from the northwest in all months of the year. Secondary maxima occur for southwesterly winds. Monthly average wind speeds are lowest during the winter, averaging about $10 \mathrm{~km} / \mathrm{h}(6 \mathrm{mi} / \mathrm{h})$. The winds are highest during the summer, averaging $15 \mathrm{~km} / \mathrm{h}(9 \mathrm{mi} / \mathrm{h})$. Wind speeds that are well above average are usually associated with southwesterly winds. However, the summertime drainage winds are generally northwesterly and frequently reach $50 \mathrm{~km} / \mathrm{h}(30 \mathrm{mi} / \mathrm{h})$.

This climate profile suggests opportunities for moisture infiltration or recharge (See Section 2.2.6.5 for a discussion of natural recharge rates). This infiltration is centered around the frequency of precipitation events during the winter months when evaporation is less and plant uptake and transpiration are at a minimum.

2.2.4.3 Historical Data. Historical climate data can provide insights into how future and current climate patterns may differ. Information exists on climate for the past few centuries and, in less detail, for the last 10,000 years.

Cropper and Fritts (Cropper 1986) derived a 360-year regional reconstruction of seasonal and annual variations in temperature and precipitation from statistical relationships between meteorological records from Columbia Basin stations and tree-ring data from western North America. They calibrated the relationship between Columbia Basin weather records and a network of 65 tree-ring chronologies. The results suggest that the average temperature of the Columbia Basin for the past 3 centuries was slightly higher by $0.09^{\circ} \mathrm{C}\left(0.16^{\circ} \mathrm{F}\right)$ and more variable ( 4 percent higher standard deviation) than in the 20th century. The increase was primarily attributed to warmer winters. This reconstruction also suggests that the past 3 centuries were wetter on the average by $0.8 \mathrm{~cm}(0.3 \mathrm{in}$.), primarily in the autumn. Furthermore, droughts were apparently more frequent starting in the second half of the 17 th century and lasted longer than droughts of the 20 th century. 


\section{HNF-EP-0884}

\section{Rev. 1}

Gramulich (1987) also used multiple regression models to reconstruct precipitation in the Pacific Northwest. The results indicate that the average precipitation of the 18th and 19th centuries did not differ from the average precipitation of the 20 th century.

Chatters (1991) and Chatters and Hoover (Chatters 1992) summarized proxy evidence for climatic change in the Columbia Basin for the past 10,000 to 13,000 years. They identify an environment of about $\sim 13,000$ years ago that was kept cool and dry by masses of ice and glacial meltwater, supporting a mosaic of isolated plant and animal communities. This was followed between 10,000 and 8,500 years ago by a period of warmer than modern summers, colder than modern winters and low, but spring-dominant, precipitation. This climate supported extensive grasslands and their associated fauna. By 8,000 years ago, summers and winters were both relatively warm, and precipitation was at least 33 percent below current levels. This climate pattern resulted in reduced stream flows, with late spring flow maxima, and extensive development of shrub-steppe vegetation throughout most of the region. Between 4,500 and 3,900 years ago, the climate went through a period of transition to wetter and cooler conditions. Rivers flooded frequently and forests expanded into steppe zones. From 3,900 to 2,400 years ago the climate was cool in the summer and cold in the winter, with winter-dominant precipitation at least 30 percent above current levels. Warmer, drier conditions returned between 2,400 and 2,000 years ago, reducing vegetation density and renewing flooding.

2.2.4.4 Long-Range Forecasts. Future long-range forecasts of climate are uncertain. Climatologists universally accept that global climates have undergone significant variation in the past and that such natural variations are expected to continue into the future. Berger et al. (1991) reviewed 7 models of different complexity developed to predict the global climate for the next 10,000 to 100,000 years. All the models are in relatively good agreement. Without manmade disturbances, the long-term cooling trend that began some 6,000 years ago is expected to continue for the next 5,000 years. This trend should be followed by a stabilization at about 15,000 years, a cold interval centered at approximately 25,000 years, and finally a major glaciation at about 55,000 years. Although man-made distributions (such as the green-house effect) may occur, the main effects are to delay the onset of these trends.

\subsubsection{Climate Summary. The analyses of present and future climate conditions at the} Hanford Site and in the surrounding region suggest that climatic conditions similar to current conditions will prevail for at least 10,000 years and probably considerably beyond. However, considering the uncertainty inherent in any climate analysis, wetter climate conditions and associated higher recharge or infiltration also will be considered. It is generally accepted that, at about 50,000 years or beyond, major glaciation will occur, followed by possible flooding similar to that near the end of the last glacial stage. Although considerable uncertainty is associated with future glaciation, some simulations in this performance assessment will examine human health impacts associated with a resident population following flooding and redeposition after 50,000 years. 


\section{HNF-EP-0884}

Rev. 1

\subsubsection{Regional Geology}

2,2.5.1 Overview. Knowledge of the thickness and lateral distribution of the sediments and other geologic characteristics is required for the following reasons:

- To define a conceptual model for contaminant transport from the disposal facility through the vadose zone (the zone between the surface and the groundwater which is not saturated with water) and from the unconfined aquifer (the upper most groundwater layer) to the human environment

- To define hydraulic parameters

- To interpret modeling results.

The geology of the Hanford Site includes thick sequences of water-derived sediments varying in texture from cobbles and coarse gravels to fine silts and clays. These sediments overlay thick basalt flows. The top sequence (surface soil) has been modified by wind. An unconfined aquifer exists in the lower part of the sedimentary sequence overlaying the uppermost basalt flow. This relatively thin aquifer is considered the primary contaminant pathway for evaluating exposure scenarios. The aquifer intercepts infiltration from the vadose (unsaturated) zone above it, providing a pathway for water and contaminant transport to the Columbia River.

The geological and physical settings of the Hanford Site have been extensively characterized during past activities. This section summarizes the physical geology and environmental setting of the Hanford Site and of the proposed disposal site. Emphasis is on the sedimentary sequence which is the pathway to the groundwater. More detailed discussions of the geology of the northwest region and the Hanford Site are found in DOE (1987-1), DOE (1988b), Myers (1979), Myers (1981), Reidel (1989), and Delaney (1991). The related subject of hydrology is summarized in Section 2.2.6.

2.2.5.2 Topography and Physiography. The proposed disposal facility is on the Hanford Central Plateau, a Pleistocene flood bar most commonly referred to as the 200 Areas Plateau, near the center of the Hanford Site. The Hanford Central Plateau is approximately 198 meters ( 650 feet) to 229 meters ( 750 feet) above mean sea level. The plateau decreases in elevation to the north, northwest, and east toward the Columbia River. The plateau escarpments have elevation changes of 15 to 30 meters (50 to 100 feet).

The Hanford Site is situated within the Pasco Basin of south-central Washington State (Figure 2-5). The Pasco Basin is one of many topographic depressions located within the Columbia Intermontane Province (Figure 2-6), a broad basin located between the Cascade Range and the Rocky Mountains. The Columbia Intermontane Province is the product of Miocene continental flood, basalt volcanism, and regional deformation that occurred 6 to 17.5 million years ago. The Pasco Basin is bounded on the north by the Saddle Mountains; on the west by Umtanum Ridge, Yakima Ridge, and the Rattlesnake Hills; on the south by the Horse Heaven Hills; and on the east by the Palouse Slope (Figure 2-5). 
HNF-EP-0884

Rev. 1

Figure 2-5. Geologic Structures of the Pasco Basin and the Hanford Site.

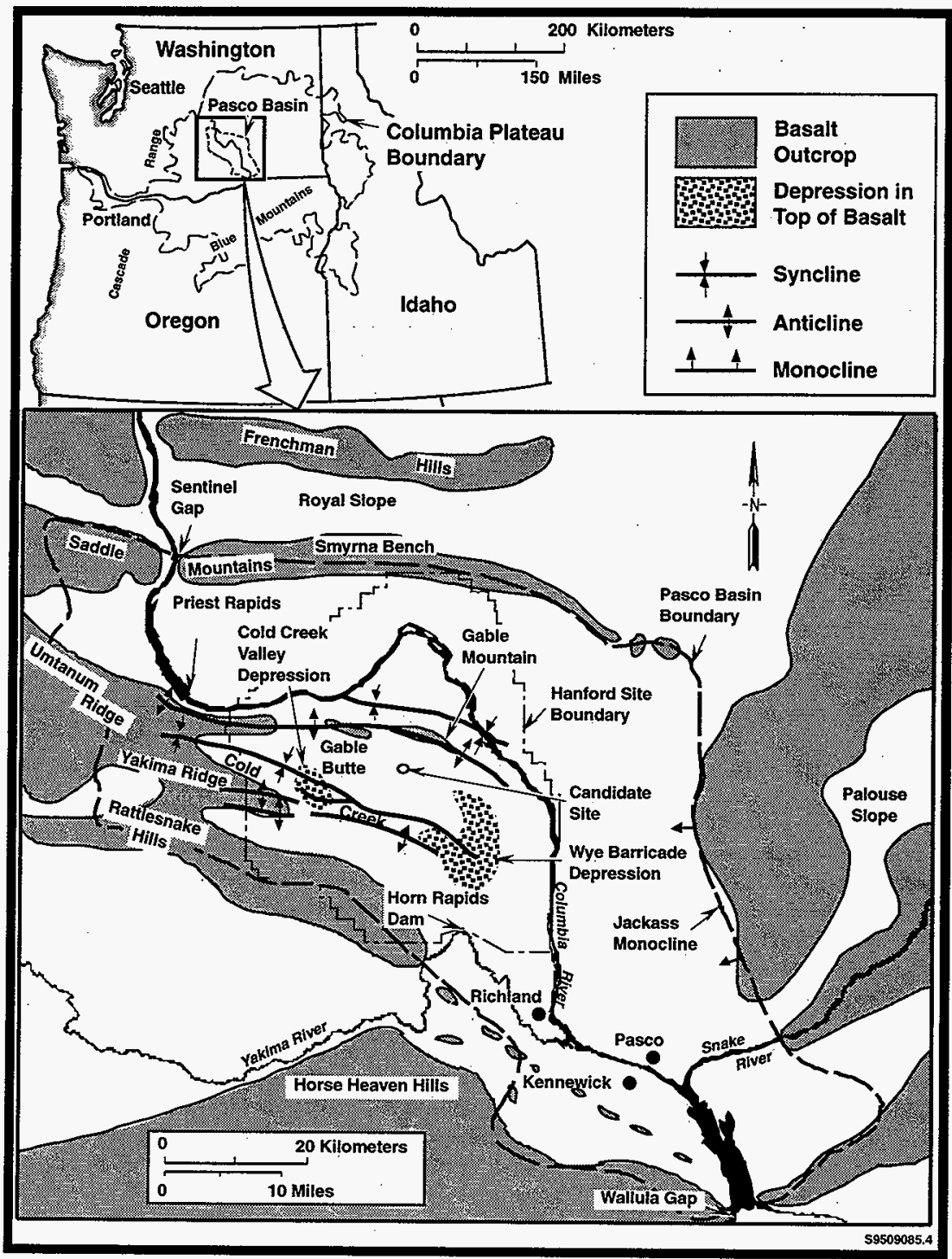


Figure 2-6. Divisions of the Intermontane Physiographic and Adjacent Snake River Plains Provinces.

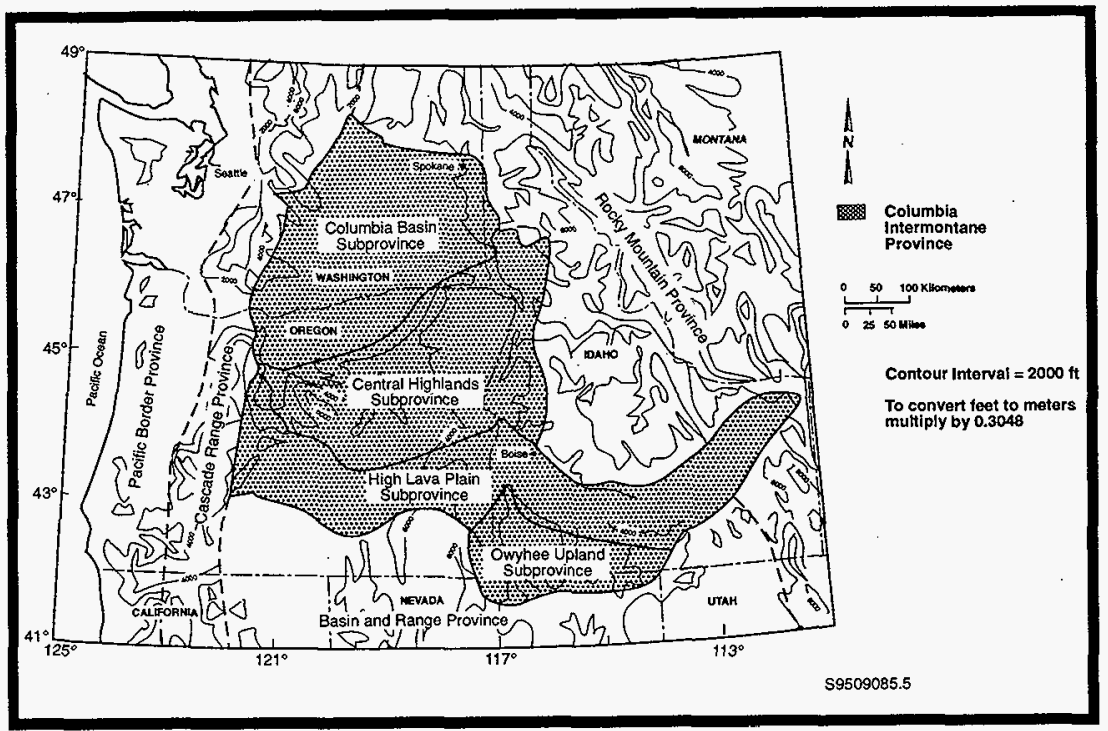

The physical geography of the Hanford Site is dominated by the low-relief plains of the Pasco Basin and anticlinal ridges of the Yakima Folds physiographic region (Figure 2-7). The surface topography of the Hanford Site is the result of the following events:

Uplift of anticlinal ridges
Pleistocene cataclysmic flooding
Holocene eolian activity.

Uplift of the ridges began in the Miocene epoch (starting about 17 million years ago) and continues to the present. This uplift is occurring on geologic time scales (i.e., over tens of millions of years). The uplift is not incorporated into our conceptual model of the immobilized low-activity tank waste disposal facility, which addresses a time scale of tens of thousands of years.

Glacier-related flooding has had a major impact on the physical geography. Cataclysmic flooding occurred when ice dams in western Montana and northern Idaho were breached, allowing large volumes of water to spill across eastern and central Washington. The last major flood occurred about 13,000 years ago, during the late Pleistocene Epoch. Interconnected flood channels; giant current ripples, and giant flood bars are among the landforms created by the 


\section{HNF-EP-0884}

\section{Rev. 1}

Figure 2-7. Landforms of the Pasco Basin and the Hanford Site.

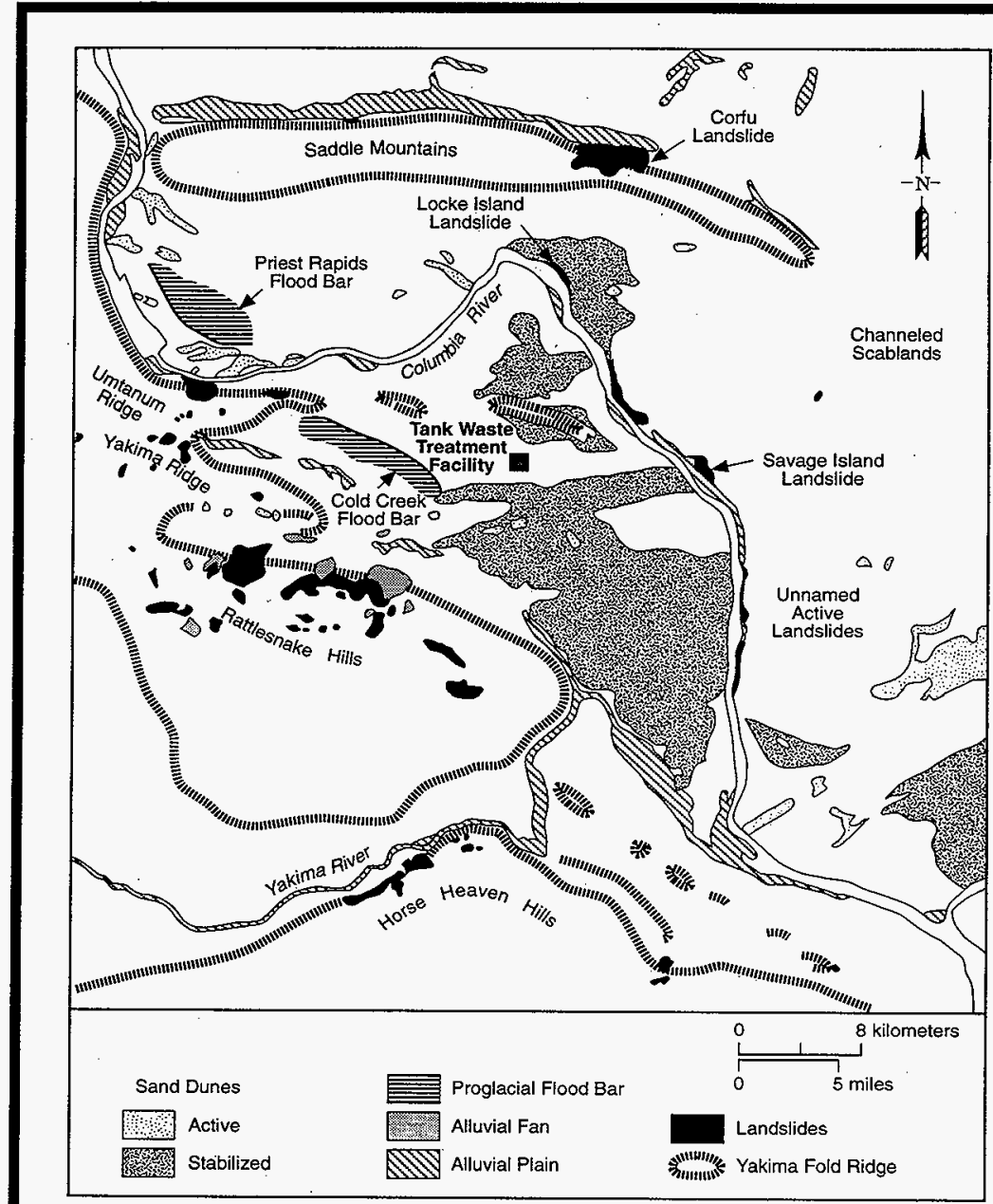

59211085.43 
floods. These formations resulted in heterogeneous and discontinuous characteristics for sediments ranging in size from silts to coarse gravels. These sediments yield a wide range of vadose zone hydraulic properties.

Landslides have had a limited effect on physical geography. Previous landslide activity in the area is generally limited to the White Bluffs area east of the Hanford Site and the Rattlesnake Hills south of the Site. No landslide activity is observed in the Hanford Central Plateau.

During the Holocene Epoch (the last 11,000 years), winds have locally reworked the flood sediments. The winds deposited dune sands in the lower elevation and loess (very fine wind-blown silts) around the margins of the Pasco Basin. Generally, sand dunes have been stabilized by anchoring vegetation. However, they have been reactivated where vegetation has been disturbed. Most sand dunes on the Hanford Site are located southeast of the 200 East Area and are stabilized by vegetation (Figure 2-7).

The location of the Hanford Site in an intermontane basin helps maintain a semiarid climate with low recharge. Most topographical surface features, such as sand dunes and landslides, that could disturb the near-surface hydraulic characteristics affecting recharge are not found at the proposed location of the immobilized low-activity tank waste disposal facility. Moreover, sand dunes are indicators of past, cumulative wind directions. Their location approximately downwind of the proposed disposal facility site suggests that future dune formation over the facility is not likely.

\subsubsection{Stratigraphy}

2.2.5.3.1 Overview. The stratigraphy or geologic layering is not extremely complex in the Hanford region. Late Miocene to Pleistocene suprabasalt sediments ( 2 to 5 million years old) and miocene-aged basalt (16 to 17 million years old) of the Columbia River Basalt Group mostly lie beneath the Hanford Site. Miocene-aged basalt is exposed at some locations, including Gable Mountain and Gable Butte. The basalts and sediments thicken into the Pasco Basin and generally reach maximum thicknesses in the Cold Creek syncline, which is southwest of the proposed site for the disposal facility. Cenozoic ( 25 to 65 million years old) sedimentary and volcaniclastic rocks underlying the basalts are not exposed at the surface near the Hanford Site.

Figure 2-8 delineates the general stratigraphy of the suprabasalt sedimentation that makes up the vadose zone sediments beneath the proposed location of the disposal facility. This figure illustrates the degree of heterogeneity and discontinuity in the sediments. The sedimentation is composed largely of Ringold Formation and Hanford formation sediments, with the Hanford formation above the Ringold Formation. At the proposed disposal facility site, the Hanford formation makes up most of the vadose zone.

The suprabasalt sedimentary sequence at the Hanford Site is about 230 meters ( 750 feet) thick in the west central Cold Creek syncline. This sedimentary sequence pinches out against 
Rev. 1

Figure 2-8. Generalized Stratigraphy of the Suprabasalt Sediments Beneath the Hanford Site.

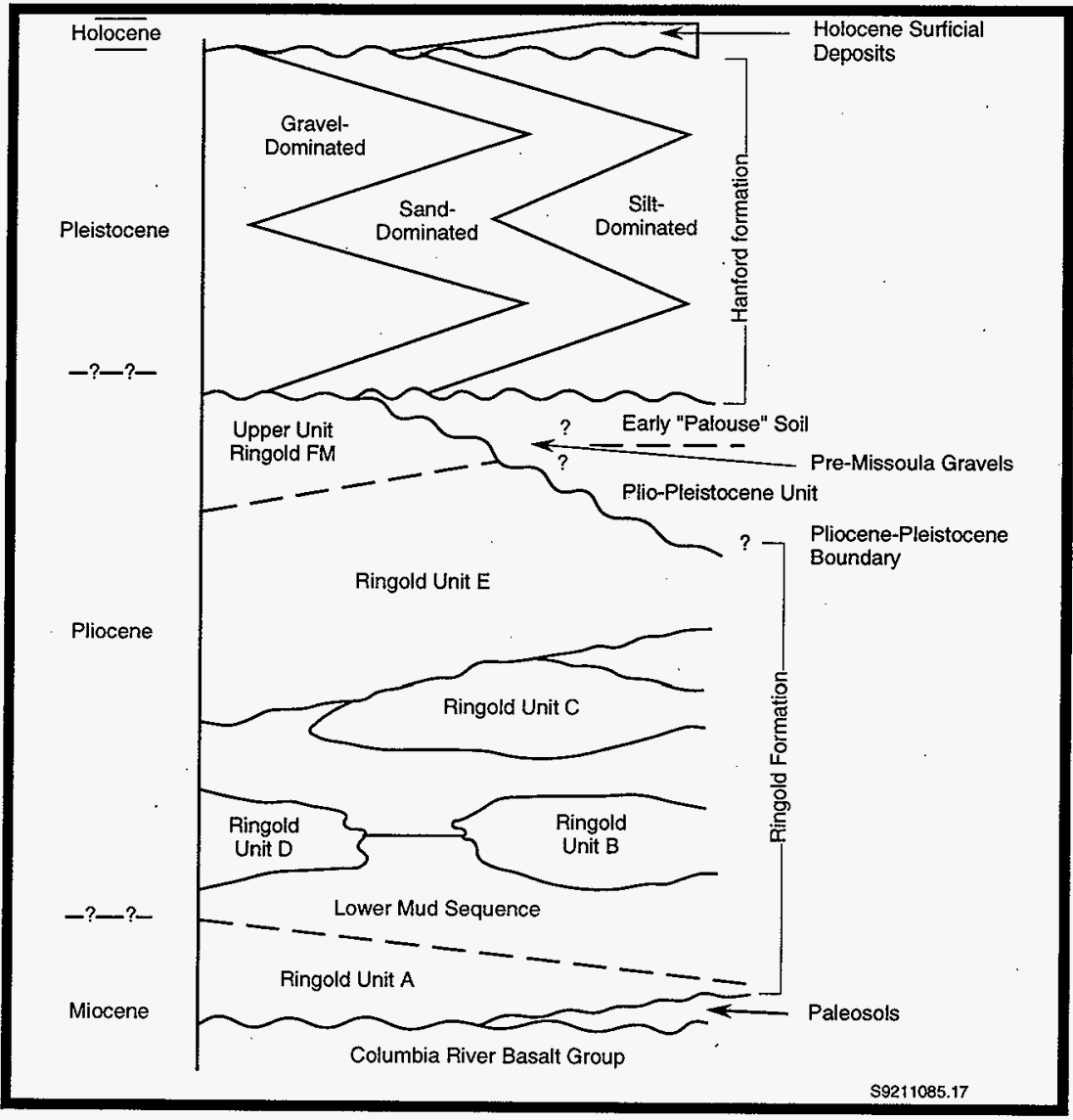

the Saddle Mountains anticline, Gable Mountain/Umtanum Ridge anticline, Yakima Ridge anticline, and Rattlesnake Hills anticline. The suprabasalt sediments are dominated by laterally extensive deposits assigned to the late Miocene- to Pliocene-aged Ringold Formation and the Pleistocene-aged Hanford formation (Figure 2-8). Locally occurring strata assigned to the informally defined Plio-Pleistocene unit, early "Palouse" soil, and pre-Missoula gravels compose the remainder of the sequence. 


\section{HNF-EP-0884}

Rev. 1

The following sections describe the geology of the Ringold and Hanford formations sediments in some detail. These sediments are the basis for determining vadose zone hydraulic and geochemical properties for contaminant transport modeling.

2.2.5.3.2 Ringold Formation. The Ringold Formation varies in thickness throughout the Hanford Site. It is up to 183 meters ( 600 feet) thick in the deepest part of the Cold Creek syncline south of the 200 West Area and 170 meters (560 feet) thick in the western Wabluke syncline near the 100 B Area. It pinches out against the Gable Mountain, Yakima Ridge, Saddle Mountains, and Rattlesnake Mountain anticlines (Figure 2-5). It is mostly absent in the northern and northeastern parts of the 200 East Area and adjacent areas to the north near West Pond.

The Ringold Formation is assigned to a late Miocene to Pliocene age (Fecht 1987, DOE 1988b) and consists of clay, silt, compacted mud, fine- to coarse-grained sand, and granular to cobble gravel. In general, it tends to be finer-grained, or siltier, in the upper parts just below the Hanford formation.

The strata of the Ringold Formation are generally divided as follows (Newcomb 1958; Newcomb 1972; Myers 1979; Bjornstad 1984; DOE 1988b):

- The gravel, sand, and paleosols of the basal unit

- The clay and silt of the lower unit

- The gravel of the middle unit

- The mud and lesser sand of the upper unit

- The basaltic detritus in localized areas.

Ringold strata also have been divided on the basis of facies types (Tallman 1981) and fining upward sequences (PSPL 1982). Recent studies of the Ringold Formation (Lindsey 1989 and 1991) divided the formation on the basis of sediment facies (individual stratigraphic bodies) associations and their distribution. Facies associations in the Ringold Formation (defined on the basis of lithology, petrology, and stratification) include fluvial gravel, fluvial sand, overbank deposits, lacustrine deposits, and basaltic gravel.

2.2.5.3.3 Hanford Formation. The Hanford formation (an informal designation) is up to 64 meters ( 210 feet) thick in the Cold Creek bar near the 200 areas. It is absent on ridges approximately 360 meters ( 1,180 feet) above sea level.

The Hanford formation was deposited by the catastrophic ice-age flooding that ended about 13,000 years ago. The formation consists of pebble-to-boulder sized gravel, fine- to coarse-grained sand, and silt. It can be divided into two main facies: coarse-grained or gravelly deposits and fine-grained or sandy and silty deposits. The Hanford formation is also commonly divided into two informal members: the Pasco gravels and the Touchet Beds (Myers 1979, Tallman 1981, Fecht 1987, DOE 1988b). The Pasco gravels correspond to the gravelly facies, and the Touchet beds to the sandy and silty facies.

The gravelly facies consists of coarse-grained sand and granule-to-boulder sized gravel. These gravels often lack matrix material and have an open framework appearance. The gravelly 


\section{HNF-EP-0884 \\ Rev. 1}

facies dominates the Hanford formation in the 100 Areas north of Gable Mountain, the northern part of the 200 East Area, and the eastern part of the Hanford Site, including the 300 Area. In the 200 East and 200 West Areas, the facies association generally becomes finer to the south. The gravelly facies was deposited by high-energy flood waters in flood bars and along channelways such as the Ringold Coulee, east of the Hanford Site, and Gable Mountain channel, north of the Central Plateau.

The sand and silt facies consists of silt and fine- to coarse-grained sand that commonly display normally graded rhythmites a few centimeters to several tens of centimeters thick in outcrop (Myers 1979, DOE 1988b). This facies is found throughout the central, southern, and western Cold Creek syncline within and south of the 200 Areas. These sediments were deposited under slackwater conditions and in backflooded areas (DOE 1988b).

Clastic dikes are vertical features occasionally seen in the Hanford formation. In clastic dikes a vertical hexagonal structure of very-fine grained sand is surrounded by coarser Hanford formation materials. The importance of these features will be investigated in future studies.

2.2.5.3.4 Surficial Deposits. Holocene surficial deposits consist of silt, sand, and gravel that form a thin ( $<4.9$ meters, [16 feet]) veneer atop much of the Hanford Site. These sediments were deposited by wind and flood processes.

\subsubsection{Seismic}

2.2.5.4.1 Overview. Seismic events can accelerate the degradation of the disposal facility and of the waste form.

The Hanford Site lies in the Pasco Basin near the eastern limit of the Yakima Foldbelt. The Site is underlain by basalt of the Columbia River Basalt Group, which is covered by up to 213 meters ( 700 feet) of relatively stiff sediments. It is in an area of low-magnitude seismicity and is under north-south compressional stress, which is reflected in the deformation of the Yakima folds. The following sources are major contributors to the seismic hazard in and around the Hanford Site:

- Fault sources related to the Yakima folds

- Shallow basalt sources that account for the observed seismicity within the Columbia River Basalt Group and not associated with the Yakima Folds

- Crystalline basement source region

- Cascadia Subduction Zone earthquakes.

The largest historical earthquake in the Columbia Plateau occurred in 1936 near MiltonFreewater, Oregon, approximately 90 kilometers (54 miles) east of the site. The earthquake had a magnitude of 5.75 and was followed by a number of aftershocks. The ground motion from this event is estimated to have been less than $0.03 \mathrm{~g}$ at the Hanford Site. 


\section{HNF-EP-0884}

Rev. 1

A seismic monitoring network has been operated in and around the site since 1969. The network, operated by DOE, can locate all earthquakes of magnitude 1.5 and larger on or near the Hanford Site, and magnitude 2.0 and larger throughout south-central and south-eastern Washington State. The largest recorded earthquake on the Hanford Site was a magnitude 3.8 near Coyote Rapids in 1971 and was felt in the $100 \mathrm{~N}$ Area.

2.2.5.4.2 Seismic Hazard Assessment. This section explains the earthquake ground motions that the facility is expected to experience during the performance period. Elements of the disposal facility that serve as barriers in the overall performance must continue to perform at some level throughout the performance period. Deformation and or cracking from earthquake ground motion is one of the major drivers of physical degradation of the engineered system.

A probabilistic seismic hazard analysis was recently completed for the Hanford Site (Geomatrix 1996). Previous seismic hazard analyses were done for Washington Public Power Supply System's (Supply System) WNP-1/4 and WNP/2, which also are located on the Hanford Site (Power et al. 1981). Woodward Clyde Consultants (WCC 1989) later applied the Supply System study to the Hanford Site areas under DOE control. The mean seismic hazard curves for the 200 West, 200 East, and 400 Areas are shown in Figure 2.9. The 200 West horizontal ground motion values are shown for the selected time period in Table 2-1. (See Geomatrix [1996] for details including response spectra).

Table 2-1. Approximate Probability of Exceeding Given Ground Motions During Selected Time Periods.

\begin{tabular}{||c|c|c|c|c|c||}
\hline $\begin{array}{c}\text { Ground } \\
\text { Motion } \\
(\mathrm{g})\end{array}$ & $\begin{array}{c}\text { Return } \\
\text { Period } \\
\text { (Years) }\end{array}$ & $\begin{array}{c}\text { Annual Probability } \\
\text { of Exceedence } \\
(\mathrm{p})\end{array}$ & $\begin{array}{c}\text { Exceedence } \\
\text { Probability (EP) } \\
\text { over 50 years }\end{array}$ & $\begin{array}{c}\text { EP over } \\
1,000 \\
\text { years }\end{array}$ & $\begin{array}{c}\text { EP over } \\
10,000 \\
\text { years }\end{array}$ \\
\hline 0.19 & $1,000$. & $1 \times 10^{-3}$ & $5 . \%$ & $63 \%$ & $100 \%$ \\
\hline 0.26 & $2,000 .^{\mathrm{b}}$ & $5 \times 10^{-4}$ & $2 . \%$ & $39 \%$ & $99 \%$ \\
\hline 0.37 & $5,000$. & $2 \times 10^{-4}$ & $1 . \%$ & $18 \%$ & $86 \%$ \\
\hline 0.48 & $10,000$. & $1 \times 10^{-4}$ & $0.5 \%$ & $10 \%$ & $63 \%$ \\
\hline
\end{tabular}

\footnotetext{
${ }^{a} \mathrm{EP}=1-(1-\mathrm{p})^{\mathrm{n}} \quad$ where

$p=$ the annual probability of exceedence,

$\mathrm{n}=$ the performance life, and

$\mathrm{EP}=$ the probability of exceedence over the performance life.

b Performance Category 3, DOE Order 5480.28.
} 
Rev. 1

Figure 2-9. Comparison of Seismic Hazard for Various Regions of the Hanford Site.

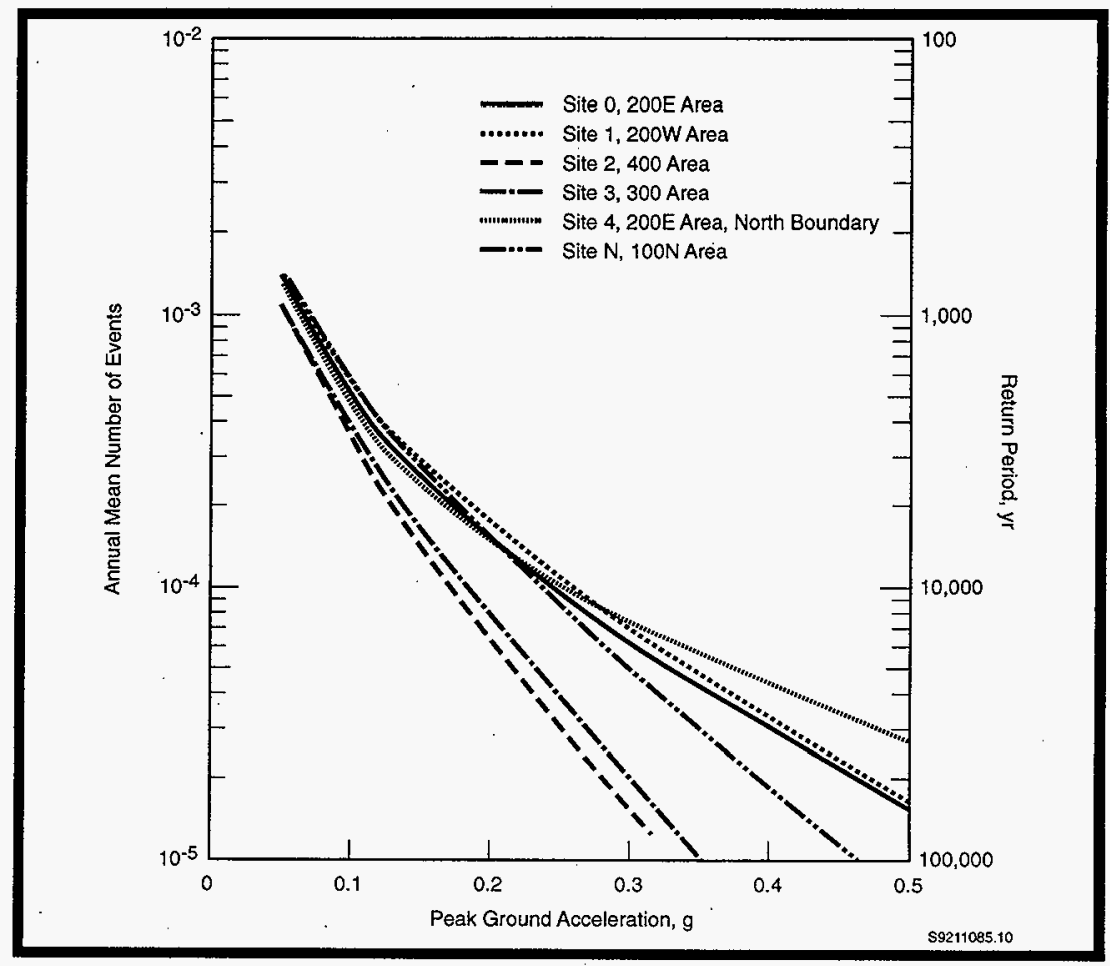

\subsubsection{Regional Hydrology (Both Surface and Groundwater)}

2.2.6.1 Overview. This section describes the concept of recharge rate for the surface and subsurface hydrology of the Hanford Site region and the proposed site for the disposal facility. The surface hydrology is important in determining possible surface pathways for dissolved or suspended contaminants, as well as for identifying sources of infiltration. The groundwater hydrology helps determine possible flow paths for contaminants released from the disposal facility and provides a basis for determining vadose zone thickness.

2.2.6.2 Surface Hydrology. The hydrology of the Pasco Basin (Figure 2-10) is characterized by a number of surface sources and aquifers. Surface drainage enters the Pasco Basin from several other basins, including the Yakima River Basin, the Horse Heaven Basin, the Walla Walla River Basin, the Palouse/Snake Basin, and the Big Bend Basin. Within the Pasco Basin, 
Figure 2-10. Hydrologic Basins Designated for the Washington State Portion of the Columbia Plateau (DOE 1988b).

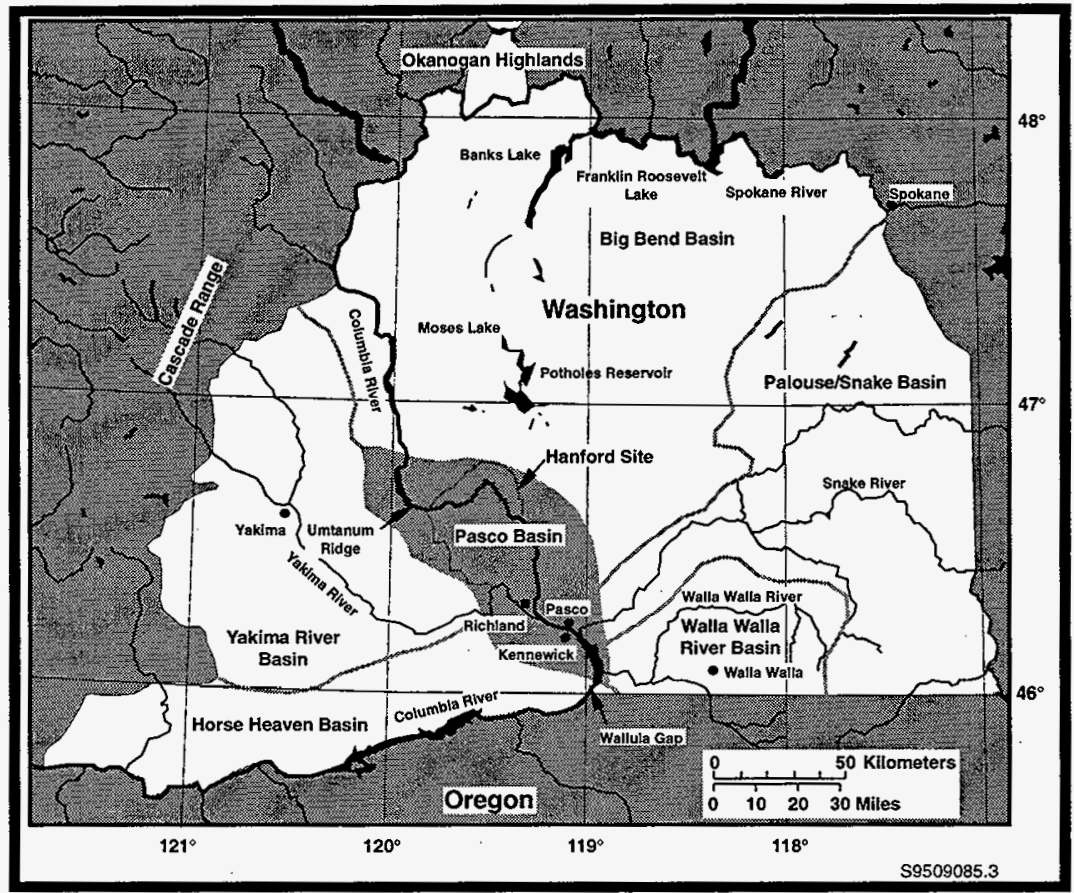

major tributaries, the Yakima, Snake, and Walla Walla Rivers, join the Columbia River. Two intermittent streams, Cold Creek and Dry Creek, cut through the Hanford Site. Water drains through these pathways during wetter winter and spring months. No perennial streams originate within the Pasco Basin.

The total estimated precipitation over the basin averages $16.0 \mathrm{~cm} / \mathrm{y}(6.3 \mathrm{in} . / \mathrm{y})$ (Section 2.2.4.2). Mean annual runoff from the basin is estimated to be less than $3.1 \times 10^{7} \mathrm{~m}^{3 / y}\left(2.5 \times 10^{4}\right.$ acre $\mathrm{ft} / \mathrm{y}$ ), or approximately 3 percent of the total precipitation. The remaining precipitation is assumed to be lost through evapotranspiration, with a small component (perhaps a few percent) contributing to the recharging of the groundwater (DOE 1988b).

The Hanford Site has one pond, West Lake, and various water disposal ponds. West Lake, located 2.7 kilometers ( 1.7 miles) north of the 200 East Area, is a shallow pond with an average depth of about 1 meter ( 3 feet) and a surface area of 4 hectares $(10$ acres). While 


\section{HNF-EP-0884}

Rev. 1

described as a natural lake, the source of recharge to the lake is groundwater that is locally mounded because of infiltration from 200 Area operations. The pond is a topographic depression that intersects the artificially elevated water table (DOE-RL 1993b-1). 200 Area disposal activities are scheduled to halt within a few decades. When this happens, the water table will drop and West Lake will become an intermittent seasonal pond (DOE-RL 1993c). Waste water ponds, cribs, and ditches associated with nuclear fuel processing and waste disposal activities, although currently present on the Hanford Site (Figure 2-11), will not be an important source of water in the future.

Figure 2-11. Location of Water Disposal Ponds on the Hanford Site.

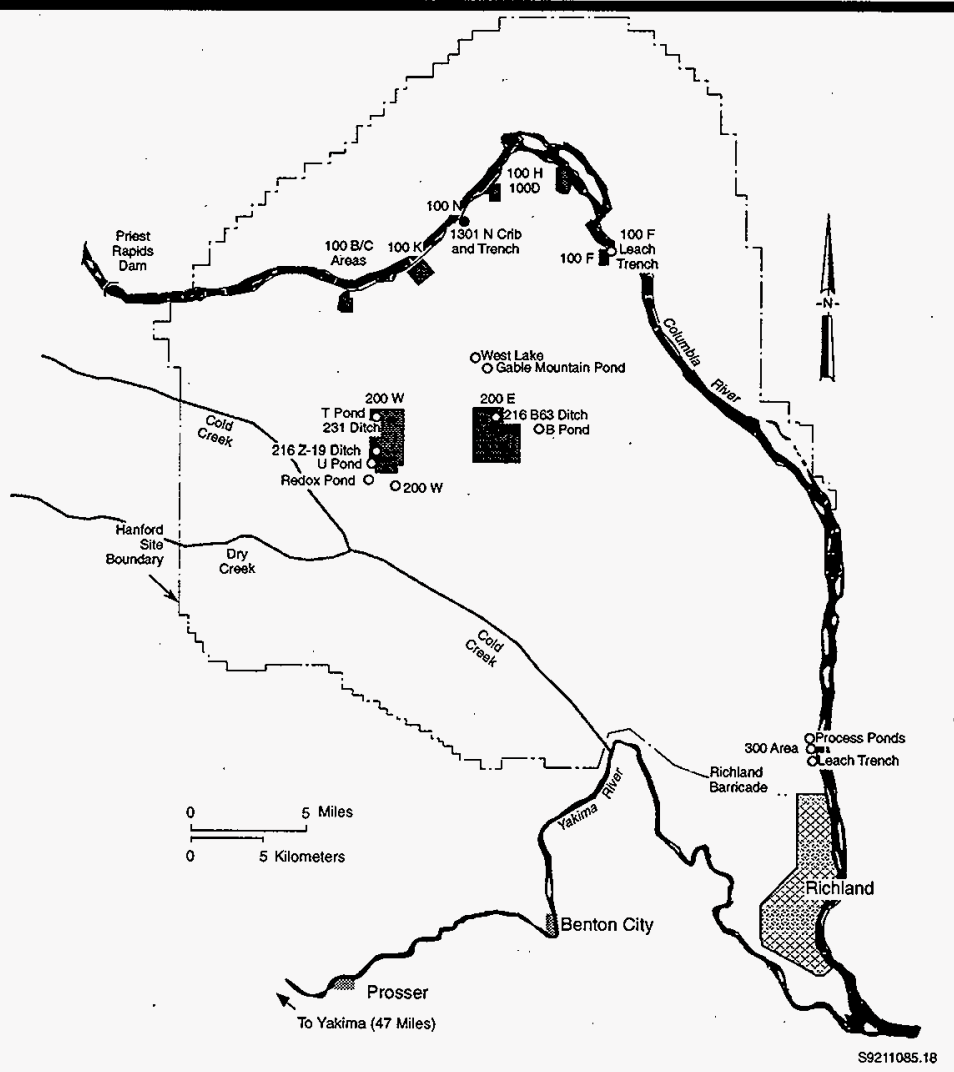




\section{HNF-EP-0884}

Rev. 1

No surface streams are near the proposed disposal facility, but current disposal ponds have an artificial influence on net contributions to the water table. These disposal ponds and related facilities are not expected to exist after current operations end, so their long-term influence is not considered in this performance assessment.

The surface drainage characteristics of the Hanford Site and regional area indicate that the Columbia River and its tributaries are the major surface drainage pathways. The Columbia River is the dominant pathway. The large volume of flow in the Columbia River (typically 1,000 to $3,000 \mathrm{~m}^{3} / \mathrm{s}$ [Woodruff 1992]) through the Pasco Basin and downstream permits considerable dilution of any contaminants that reach the river.

Routine water-quality monitoring of the Columbia River is conducted by DOE for both radiological and nonradiological parameters. The Pacific Northwest National Laboratory (PNNL) has been reporting the water quality data since 1973. The Washington State Department of Ecology (Ecology 1992) has issued a Class A (excellent) quality designation for Columbia River water from Grand Coulee Dam, through the Pasco Basin, to McNary Dam. This designation requires that all industrial uses of this water be compatible with other uses, including drinking, wildlife habitat, and recreation. The Columbia River water is characterized by a low suspended load, a low nutrient content, and an absence of microbial contaminants (Woodruff 1992).

2.2.6.3 Flooding. Cushing (1995-3) describes flooding potentials at the Hanford Site. Except for catastrophic glacie- fiooding, which is not expected for tens of thousands of years, no floods are expected to affect the Hanford Central Plateau.

The flows for the three largest probable Columbia River flood scenarios range from 17,000 to $600,000 \mathrm{~m}^{3} / \mathrm{s}\left(600,000\right.$ to 21 million $\left.\mathrm{ft}^{3} / \mathrm{s}\right)$. The probable maximum flood on the Columbia River (DOE 1986b), based on natural conditions, has been calculated to be $40,000 \mathrm{~m}^{3} / \mathrm{s}$ (1.4 million $\mathrm{ft}^{3} / \mathrm{s}$ ). This is greater than the 500 -year flood. A landslide resulting in Columbia River blockage, followed by flooding could yield a maximum flow of $17,000 \mathrm{~m} / \mathrm{s}$ $\left(600,000 \mathrm{ft}^{3} / \mathrm{s}\right)$. The U.S. Army Corps of Engineers estimated that a 50 percent breach in the Grand Coulee Dam, the largest dam in the region, would yield flows of $600,000 \mathrm{~m} / \mathrm{s}$ ( 21 million $\mathrm{ft}^{3} / \mathrm{s}$ ). None of these flow rates are large enough to cause the waters of the Columbia River to reach the Hanford Central Plateau.

A flood risk analysis of Cold Creek (west of the 200 West Area) was conducted to characterize a basaltic repository for high-level radioactive waste (Skaggs 1981). Based on this evaluation, the probable maximum flood would be 8 kilometers $(5$ miles) to the west of the TWRS Treatment Complex and its closest approach would be about 6 kilometers ( 3.6 miles) to the south.

2.2.6.4 Groundwater Hydrology. The groundwater pathway is considered the most likely pathway for contaminants released from the immobilized low-activity tank waste disposal facility for the following reasons: 


\section{HNF-EP-0884}

Rev. 1

- Low precipitation in the Pasco Basin

- Lack of surface transport pathways near the disposal facility

- Subsurface location of the disposal facility

- Near-surface lysimeter measurements showing downward movement of water

Samples showing the existence of radioactive contaminant plumes in the groundwater due to past Hanford operations.

To evaluate this pathway, information is required about the types of aquifers present, depths to the water table, regional flow paths, and the net recharge rate.

The hydrology of the Pasco Basin is characterized by a multiaquifer system. This system consists of four hydrologic units corresponding to the upper three formations of the Columbia River Basalt Group (Grande Ronde Basalt, Wanapum Basalt, and Saddle Mountains Basalt) and the overlying suprabasalt sediments (the Hanford formation and Ringold Formation). The basalt aquifers consist of the tholeiitic flood basalts of the Columbia River Basalt Group and relatively minor amounts of intercalated sediments of the Ellensburg formation. Confined zones in the basalt aquifers are present in the sedimentary interbeds and/or interflow zones that occur between dense basalt flows. The main water-bearing portions of the interflow zones are networks of interconnecting vesicles and fractures in the flow tops and flow bottoms (DOE 1988b).

The uppermost aquifer system consists of fluvial, lacustrine, and glaciofluvial sediments. Within the Pasco Basin; this aquifer is regionally unconfined and is contained primarily within the Ringold Formation and the Hanford formation. The main body of the unconfined aquifer usually occurs within the Ringold Formation. The water table in the southwestern Pasco Basin is generally within Ringold fluvial gravels. In the northern and eastern Pasco Basin, the water table is generally within the Hanford formation. Hydraulic conductivities in the Hanford formation are usually greater than in the gravel facies of the Ringold Formation (Graham 1981). However, fine-grained deposits in the Ringold Formation form locally confining layers for Ringold fluvial gravels.

The base of the uppermost aquifer system is defined as the top of the uppermost basalt flow. This aquifer system is bounded laterally by anticlinal basalt ridges and is about 152 meters (500 feet) thick near the center of the Pasco Basin. Within the Hanford Site, this uppermost aquifer system lies at depths ranging from less than 0.3 meter ( 1 feet) below ground surface near West Lake and the Columbia and Yakima Rivers, to greater than 107 meters (350 feet) in the central portion of the Cold Creek syncline.

Because the uppermost unconfined aquifer is considered the primary pathway for possible contaminant transport from the immobilized low-activity tank waste disposal facility, it has special importance in this performance assessment. The conceptual model of the unconfined aquifer is discussed in Chapter 3.0. Modeling results are given in Chapter 4.0. 


\section{HNF-EP-0884}

Rev. 1

Before the liquid waste disposal systems, such as B Pond, began operating, and before the onset of large regional irrigation projects, the groundwater table for the Hanford Site could be represented by a 1944 water table map (Figure 2-12). This water map includes limited irrigation near the former towns of White Bluff and Hanford but not the irrigation now common in Cold and Dry Creeks. The 1944 water table contours suggest that groundwater flow is easterly toward the Columbia River with a relatively uniform hydraulic gradient (approximately $1.5 \mathrm{~m} / \mathrm{km}$ [5 ft/mi]). Regional groundwater flow was generally toward the east-northeast, although flow north of Gable Mountain was more to the north.

Figure 2-12. Hindcast Water Table Map of the Hanford Site, January 1944 (ERDA 1975).

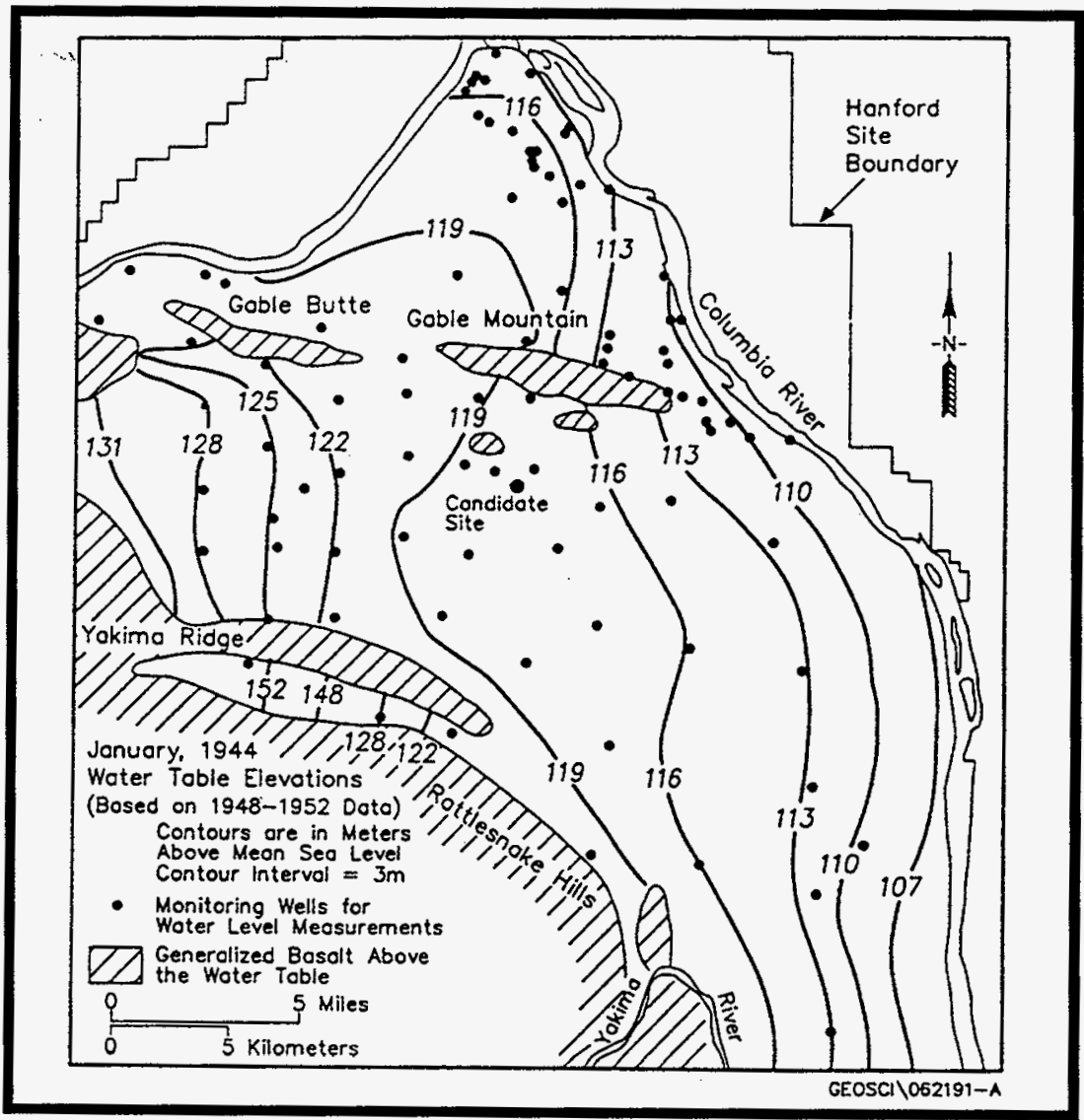




\section{HNF-EP-0884}

Rev. 1

Effluent disposal at the Hanford Site has altered hydraulic gradients and flow directions of the uppermost aquifer system, particularly near the 200 Areas. Figure 2-13 shows the current water table map influenced by effluent disposal actions. Regional irrigation projects had a minor influence on the changes shown in Figure 2-13. Groundwater flow is still nominally easterly toward the Columbia River, but mounding occurs in the 200 East Area near B Pond. Groundwater flow north of Gable Mountain now trends in a more northeasterly direction as a result of mounding near reactors and northerly flow through Gable Gap between Gable Mountain and Gable Butte. South of Gable Mountain, flow is interrupted locally by the groundwater mounds in the 200 Areas. Some groundwater from the 200 Areas flows to the north between Gable Mountain and Gable Butte. For the time periods considered in this performance assessment, effluent disposal operations will have stopped.

Figure 2-13. Hanford Site Water Table Map, June 1989 (Smith 1990).

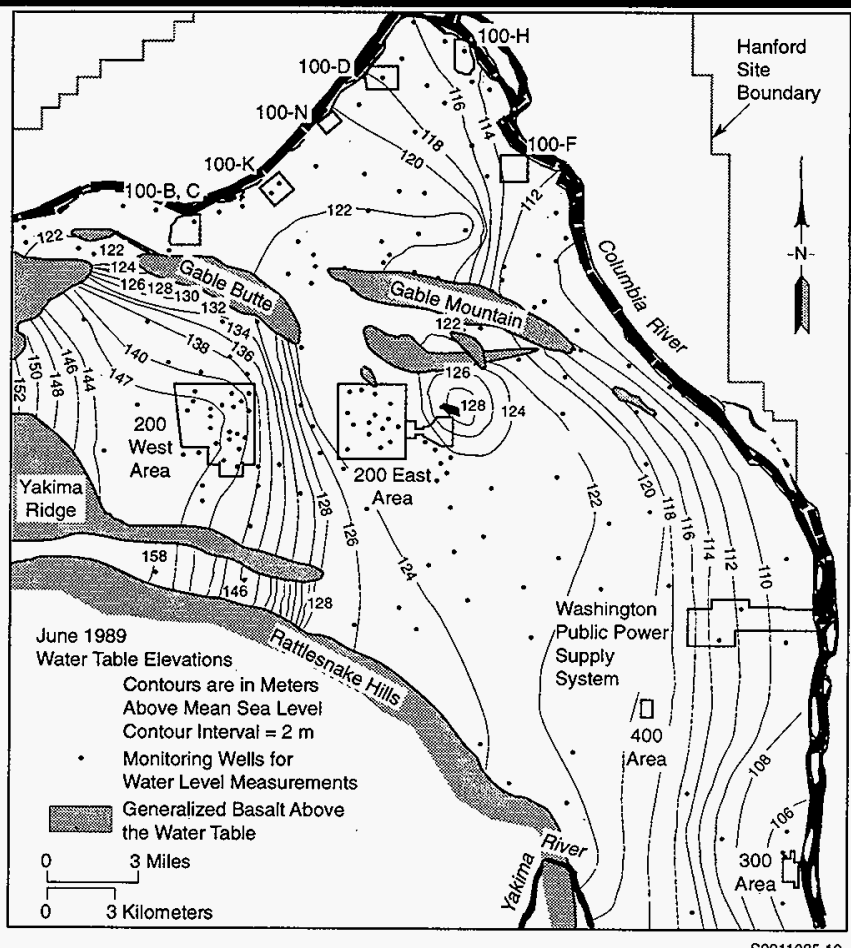




\section{HNF-EP-0884 \\ Rev, 1}

2.2.6.5 Natural Recharge Rates. Recharge is the amount of total precipitation that infiltrates into the unsaturated zone (vadose zone) after runoff, evaporation, and transpiration by plants have occurred. Recharge from rain and snow melt is a major hydrologic variable affecting contaminant transport from the immobilized low-activity tank waste disposal facility. Estimates used for the infiltration rate in the modeling are discussed in Section 3.4.7.

Studies conducted over the last 25 years at the Hanford Site (summarized below), indicate that long-term recharge can vary greatly depending on factors such as climate, vegetation, land use, and soil texture. As noted in Section 2.2.4, most of the precipitation at Hanford falls in the winter and spring and this amount of precipitation is very small. Because of the dry conditions at Hanford, most of the the precipitation is stored in near-surface soils until used by plants or until evaporated during the hot summer months. Natural plants have adapted to use all the water in the near-surface zone. Because of the large storage capacity of the nearsurface soils, water exits downward from this near-surface zone quite rarely (just a few days per decades). Such events typically occur following the rapid melting of a snow pack.

Most recharge rate data at Hanford have been measured directly using a combination of drainage and weighing lysimeters (Rockhold 1995, Gee 1992). These lysimeters are long vertical tubes (some are 5 meters in length) in the ground filled with various type of soils and covered with various types of vegetation. At the bottom of the lysimeters the water which passed through the tube of soil is collected and measured (by volume or weight). From such measurements, the rate at which moisture escapes the near-surface part of the vadose zone can be determined. Because no mechanisms are known to exist which act as traps for the moisture, the measured rate from the lysimeters is considered a good approximation to the recharge rate for the conditions (soil, vegetation, and precipitation) tested by the lysimeter.

The recharge rate has been shown to depend on a variety of conditions. The recharge rate depends on the seasonal distribution of precipitation, with maximum recharge events occurring following the wettest winter periods. The effect of a variety of surface soils, vegetation, and climate conditions on recharge have been studied. Under normal conditions, the recharge rate is highest in coarse-textured soils without vegetation and is at the measurement threshold in fine-textured soil with or without vegetation. Coarse soil surfaces that are either vegetated with shallow-rooted species or are bare exhibit recharge on the order of 50 percent of the precipitation.

Routson and Johnson (Routson 1990) reviewed water infiltration data from a 13-year observation period for a closed-bottom lysimeter located in the 200 East Area and ${ }^{13}{ }^{13} \mathrm{Cs}$ profile data from a solid-waste burial ground trench in the 200 West Area. The recharge rate of the closed-bottom lysimeter was estimated to be $0.0 \pm 2.0 \mathrm{~mm} / \mathrm{y}(0.0 \pm 0.08 \mathrm{in} . / \mathrm{y})$ based on the 13-year record. Gee (1992) reviewed all published lysimeter studies for the Hanford Site. They noted that the main determiners for recharge was the texture of the soil and the amount and type of vegetation on the soil.

The very limited data from environmental tracer techniques are generally consistent with data from the lysimeters. The tracer data indicate that (undisturbed) vegetated sites have experienced as little as 0.01 to $0.1 \mathrm{~mm} / \mathrm{y}(0.0004$ to $0.004 \mathrm{in} . / \mathrm{y})$ of recharge and up to 


\section{HNF-EP-0884 \\ Rev. 1}

3. to $4 . \mathrm{mm} / \mathrm{y}$ ( 0.1 to $0.2 \mathrm{in.} / \mathrm{y}$ ) (Prych 1995). However, the tracer techniques, while powerful, are not applicable to disturbed (or engineered) sites. Also, these techniques have been unable to measure significant rates of recharge at sites with coarse soils and shallow-rooted vegetation, because of deep percolation of natural tracers at these sites.

In addition to studies using lysimeter and tracer techniques, a number of studies have been conducted to estimate recharge on a regional scale. For example, Bauer and Vaccaro (Bauer 1990) estimated groundwater recharge for the Hanford Site as part of their study of recharge affecting the Columbia Plateau regional aquifer. Using estimates of soil type and land use and a water balance model, they estimated recharge rates for most of the Site (including the immobilized low-activity tank waste disposal facility site) ranging from 0 to $12.7 \mathrm{~mm} / \mathrm{y}$ ( 0 to 0.5 in./y). In contrast, in the vicinity of sand dunes in the middle of the Hanford Site, they estimated rates as high as $51 . \mathrm{mm} / \mathrm{y}(2.0 \mathrm{in.} / \mathrm{y})$.

More recently, Fayer and Walters (Fayer 1995c) estimated recharge rates based on measurements (of drainage, water contents, tracers) and numerical modeling. Estimates from these methods were assigned to specific soil-vegetation combinations and distributed across the Hanford Site using a soil map and a vegetation/land use map. The long-term average rates varied from $2.6 \mathrm{~mm} / \mathrm{y}(0.1 \mathrm{in} . / \mathrm{y})$ for several soil and vegetation combinations in the 200 Areas (including the immobilized low-activity tank waste disposal facility site) to $127 . \mathrm{mm} / \mathrm{y}(5.0 \mathrm{in} / \mathrm{y})$ for basalt outcrop with no vegetation at the crest of the Rattlesnake Mountain (Fayer 1995c).

Because of the high degree of variability and importance of recharge to the performance assessment, additional work is planned to estimate recharge rates through a combination of computer simulations, lysimeter measurements, and tracer methods (PAG 1995a). These efforts will consider the comments made by outside experts (Honeyman 1995).

\subsubsection{Geology and Hydrology of the Proposed Immobilized Low-activity Tank Waste Disposal Facility Location}

2.2.7.1 Overview. The geology and hydrology of the 200 East Area have been the subjects of much study and reports over the past several decades (Myers 1979, Myers 1981, Gephart 1979, Tallman 1979, Graham 1981, Routson 1990). The most recent work on the 200 East Area is by Lindsey (1992) and by Connely (1992a).

The 200 East Area lies on the Cold Creek bar, a geomorphic remnant of the cataclysmic floods of the Pleistocene. As the flood waters raced across the lowlands of the Pasco Basin, they lost energy and began leaving behind deposits of gravels. The Hanford Central Plateau is one of the most prominent of such deposits. The plateau lies just south of one of the major channelways across the Hanford Site that forms the topographic lowland south of Gable Mountain.

The principal source of geologic and hydrologic information for the 200 East Area is boreholes. Numerous boreholes have been drilled in the 200 East Area for groundwater monitoring and waste management studies. However, because few boreholes have been drilled 


\section{HNF-EP-0884 \\ Rev. 1}

in the area near the TWRS Treatment Complex, data are limited. Most boreholes in the 200 East Area have been drilled using the cable-tool method. Some boreholes were drilled using rotary and wire-line coring methods. Geologic logs based on these boreholes are constructed by examining chips and cuttings, which limits information on all but the broadest stratigraphic units. Chip samples, which are typically taken at 1.5-meter (5-feet) intervals, are routinely archived at the Hanford Geotechnical Sample Library.

To better determine the site-specific properties of the vadose zone and the unconfined aquifer, three new boreholes are planned (PAG 1995-2). Continuous intact core samples are planned. The need for these boreholes and the integrated characterization plan designed around them are described by Reidel et al (Reidel 1995).

2.2.7.2 Geological Structural Framework. The preferred location of the immobilized lowactivity tank waste disposal facility is south of the Gable Mountain segment of the Umtanum Ridge anticline and north of the Cold Creek syncline (Figure 2-5). The proposed disposal facility lies about 3 kilometers ( 2 miles) north of the axis of the Cold Creek syncline, which controls the structural grain of the basalt bedrock and Ringold Formation. The basalt surface and Ringold Formation trend roughly southeast-northwest, parallel to the major geologic structures of the Hanford Site. As a result, the Ringold Formation and the underlying Columbia River Basalt Group gently dip to the south off the Umtanum Ridge anticline into the Cold Creek syncline.

Geologic mapping at the Hanford Site has not identified any faults near the proposed disposal facility location (DOE 1988b). The closest faults are along the Umtanum Ridge-Gable Mountain structure to the north and the May Junction fault to the east. Both faults are about 7.2 kilometers ( 4.5 miles) from the disposal site.

2.2.7.3 Stratigraphy Under Proposed Disposal Site. Borehole 299-E24-7 lies in the northeast corner of the proposed disposal site and 299-E24-18 is located east of the site. The proposed disposal site stratigraphy is estimated from the logs of these boreholes (Figure 2-14). The stratigraphy encountered in the boreholes is summarized in Figure 2-8. Section 2.2.5.3 describes the general stratigraphic units and lithology shown in Figure 2-14. The following sections give details on the stratigraphic units at the proposed disposal site.

2.2.7.3.1 Ringold Formation. The Ringold Formation at the proposed disposal site is about 30 to 38 meters ( 100 to 125 feet) thick and is dominated by the gravel sequences. The Ringold Formation begins at about 100 meters ( 330 feet) drilled depth and continues to the top of the Columbia River Basalt Group at about 137 meters ( 450 feet).

The primary sediments at the Hanford Site are the Ringold gravel units A and E. Ringold unit $\mathrm{A}$ is probably the predominant unit. Both units are a consolidated sandy gravel to muddy sandy gravel. Without an intervening mud unit, the two cannot be easily distinguished from each other.

The Ringold lower mud unit is interpreted to pinch out to the east of the proposed disposal facility or just under it. The lower mud unit is absent in borehole 299-E24-7, but might 
Figure 2-14. Stratigraphic Units and Lithology at the Proposed Location of the Tank Waste Remediation System Immobilized Low-activity Tank Waste Disposal Facility.

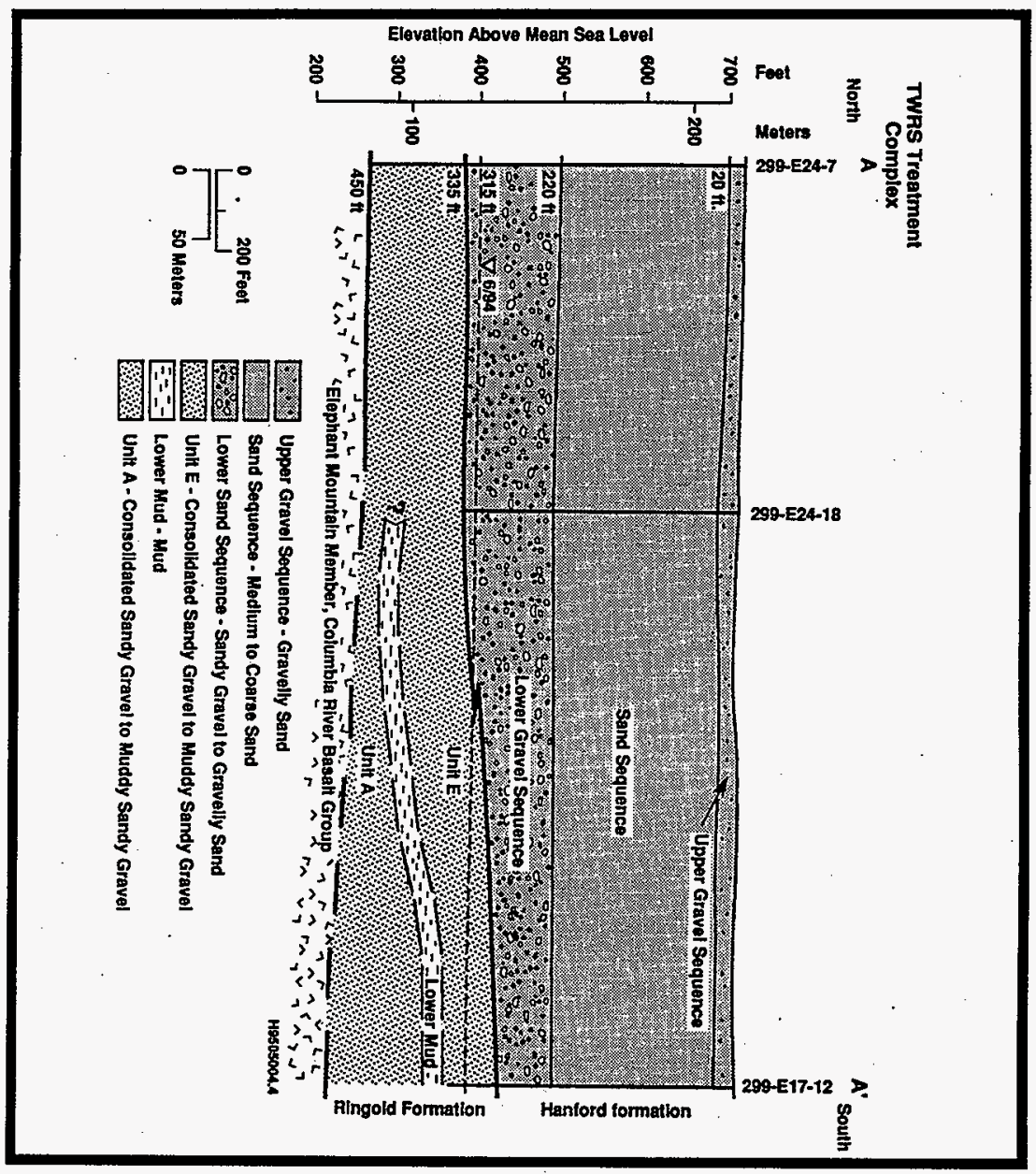

be present farther south under the site. With the lower mud unit absent, gravel unit $\mathrm{E}$ directly overlies gravel unit A. The two units cannot be differentiated in borehole 299-E24-7. Studies in the 200 East Area (e.g., Tallman 1979) show that the lower mud must pinch out somewhere between the eastern boundary of 200 East Area and the proposed disposal facility site. 


\section{HNF-EP-0884}

Rev. 1

2.2.7.3.2 Hanford Formation. At the proposed disposal location, the Hanford formation is about 90 to 105 meters ( 300 to 345 feet) thick and consists predominantly of sands and gravelly sands. The sandy sequence is interpreted to lie between a slightly gravelly sand and a lower sandy gravel to gravelly sand. The Hanford formation thickens both to the north and south of the disposal facility site.

The lower gravel to gravelly sand unit averages about 35 meters ( 115 feet) thick and probably thins to the east on an irregular Ringold surface. Currently, the water table is probably in this lower gravel sequence. The Hanford formation sandy sequence is about 60 meters (200 feet) thick and is the dominant facies in the proposed disposal facility area. The upper 6 meters (20 feet) is composed of an irregularly distributed gravelly sand sequence.

2.2.7.3.3 Holocene Deposits. The southern 200 meters ( 656 feet) of the disposal facility site are covered with a stabilized dune sand that is as much as 8 meters ( 26 feet) high. Mature sagebrush covers much of the proposed disposal facility site and in particular the sand dunes. The age of the sagebrush indicates that the dune field has been stable since before the Hanford Site was established in the 1940's. Because of the relative flat nature of the surface, landslides are not expected to be significant.

\subsubsection{Soils}

Hajek (1966) lists and describes the 15 different soil types on the Hanford Site, varying from sand to silty and sandy loam. The following soils are found in the south central part of the 200 East Area:

- Burbank Loamy Sand: dark-colored, coarse-texture soil underlain by gravel. Surface soil is usually about 40 centimeters ( 16 inches) thick but can be 76 centimeters ( 30 inches) thick. Gravel content of subsoil ranges from 20 to 80 percent.

- Ephrata Sandy Loam: surface is dark colored and subsoil is dark grayish-brown medium-texture soil underlain by gravelly material, which may continue for many feet.

- Rupert Sand: brown-to-grayish brown coarse sand grading to dark grayishbrown at about 90 centimeters

(35 inches). Developed under grass, sagebrush, and hopsage in coarse sandy alluvial deposits that were mantled by wind-blown sand.

\subsubsection{Ecology and Biotic Conditions}

This section summarizes the ecology of the Hanford Site, emphasizing plant and animal activities that may affect exposure pathways. The primary impact would be through root penetration and animal burrowing through barriers into the disposal facility. Secondarily, the 


\section{HNF-EP-0884}

\section{Rev. 1}

types of plants and animals and their density can affect net groundwater recharge, which is greatly influenced by surface vegetation and burrowing. Cushing (1995-4) details both the terrestrial and aquatic ecology of the Hanford Site and presents extensive listings of plant and animal species. This section will consider only terrestrial ecological effects because the proposed immobilized low-activity tank waste disposal facility site is not located near significant aquatic ecological systems.

The Hanford Site consists of mostly undeveloped land. Only about 6 percent of the site is occupied by chemical processing facilities, nuclear reactors that no longer operate, and supporting facilities. Most of the Hanford Site has not experienced tillage or agricultural grazing since the early 1940 's.

The Hanford Site is botanically characterized as a shrub-steppe environment. This environment contains numerous plant and animal species adapted to the region's semiarid climate. Because of the aridity and low water-holding capacity of the soils, the productivity of both plants and animals is relatively low.

The dominant plants on the Hanford Site have changed over time. In the early 1800 's, before settlement and agricultural activities, the dominant plants were big sagebrush and perennial bunchgrass. Agriculture opened the area to invasion by alien plants, predominantly cheatgrass. Today, cheatgrass dominates fields and rangeland that were cultivated 50 years ago. The dominant plants on the Hanford Central Plateau are big sagebrush, rabbitbrush, cheatgrass, and Sandberg's bluegrass, with cheatgrass providing half the total plant cover. Root penetration to depths of over several meters has not been demonstrated in the 200 Areas. Rabbitbrush roots have been found at a depth of 2.4 meters ( 8 feet) near the 200 Areas.

A variety of birds and mammals inhabit the Hanford Site. The most abundant nesting birds of the shrub-steppe at the Hanford Site are the horned lark and western meadowlark. Significant populations of chukar and gray partridge also inhabit the Site. Mourning doves also nest throughout the Hanford Site. The most abundant mammals of the Hanford Site are mice, ground squirrels, gophers, voles, and cottontail rabbits. Larger animals include mule deer and elk. The coyote is the principal mammalian predator on the Hanford Site.

\subsubsection{Regional Background Contamination and Hanford Site Monitoring}

2.2.10.1 Overview. The Hanford Site has an extensive monitoring program. Studies have been directed at determining background levels of possible contaminants in the soil (DOE-RL 1994b and DOE-RL 1995b) and in the groundwater (Johnson 1993). Also, reports are issued annually covering general environmental conditions (Dirkes 1996) and groundwater monitoring (Dresel 1994).

2.2.10.2 Soil Background Levels. Low concentrations of ${ }^{23} \mathrm{U}$ and ${ }^{137} \mathrm{Cs}$ were measured in samples of soil and vegetation during 1994 (Dirkes 1996-1). The levels were similar to those measured in previous years. No discernible increase in concentration could be attributed to current Hanford Site operations. DOE-RL $1995 \mathrm{~b}$ summarizes all the measurements taken to 


\section{HNE-EP-0884 \\ Rev. 1}

determine radionuclide background levels at the Hanford Site. Table 2-2 displays the average of the measurements.

Table 2-2. Activity of Radionuclides in Hanford Sitewide Background Data Set (The table is reproduced from DOE-RL 1995b).

\begin{tabular}{||l|l|l|l|l|l||}
\hline Nuclide & $\begin{array}{l}\text { Activity } \\
(\mathrm{pCi} / \mathrm{g})\end{array}$ & Nuclide & $\begin{array}{l}\text { Activity } \\
(\mathrm{pCi} / \mathrm{g})\end{array}$ & Nuclide & $\begin{array}{l}\text { Activity } \\
(\mathrm{pCi} / \mathrm{g})\end{array}$ \\
\hline${ }^{40} \mathrm{~K}$ & 15.4 & ${ }^{60} \mathrm{Co}$ & 0.00132 & ${ }^{90} \mathrm{Sr}$ & 0.0806 \\
\hline${ }^{137} \mathrm{Cs}$ & 0.417 & ${ }^{154} \mathrm{Eu}$ & 0.0083 & ${ }^{155} \mathrm{Eu}$ & 0.0234 \\
\hline${ }^{226} \mathrm{Ra}^{\mathrm{a}}$ & 0.686 & ${ }^{232} \mathrm{Th}+\mathrm{D}$ & 0.687 & ${ }^{235} \mathrm{U}+\mathrm{D}$ & 0.0271 \\
\hline${ }^{238} \mathrm{U}+\mathrm{D}$ & 0.675 & ${ }^{238} \mathrm{Pu}$ & 0.00158 & ${ }^{239 / 240} \mathrm{Pu}$ & 0.00935 \\
\hline
\end{tabular}

" $+\mathrm{D}$ " indicates that daughters are included

a ${ }^{226} \mathrm{Ra}$ is part of ${ }^{238} \mathrm{U}$ decay chain and is included in that entry.

2.2.10.3 Groundwater Background Levels. Sample results from environmental monitoring can vary depending on local operations, so a regional baseline study was conducted using these and other site wide monitoring results (Johnson 1993). Groundwater background levels are shown in Table 2-3, along with tentative threshold levels.

Table 2-3. Provisional Background Values for Hanford Site Groundwater. ${ }^{\text {a }}$

\begin{tabular}{|l|c|c|}
\hline \multicolumn{1}{|c|}{ Constituent (Concentration) } & PNL Results ${ }^{\mathrm{b}}$ & $\begin{array}{c}\text { Provisional Threshold } \\
\text { Values }\end{array}$ \\
\hline \hline Aluminum (ppb) & $<2$ & $<200$ \\
\hline Ammonium (ppb) & $<50$ & $<120$ \\
\hline Arsenic (ppb) & $3.9 \pm 2.4$ & 10 \\
\hline Barium (ppb) & $42 \pm 20$ & 68.5 \\
\hline Beryllium (ppb) & $<0.3$ & $<5$ \\
\hline Bismuth (ppb) & $<0.02$ & $<5$ \\
\hline Boron (ppb) & $<50$ & $<100$ \\
\hline Cadmium (ppb) & $<0.2$ & $<10$ \\
\hline Calcium (ppb) & $40,400 \pm 10,300$ & 63,600 \\
\hline Chloride (ppb) & $10,300 \pm 6,500$ & NC \\
\hline Chromium (ppb) & $4 \pm 2$ & $<30$ \\
\hline
\end{tabular}


HNF-EP-0884

Rev. 1

\begin{tabular}{|c|c|c|}
\hline Constituent (Concentration) & PNL Results ${ }^{b}$ & $\begin{array}{c}\text { Provisional Threshold } \\
\text { Values }\end{array}$ \\
\hline Copper (ppb) & $<1$ & $<30$ \\
\hline Fluoride (ppb) & $370 \pm 100$ & $1,340,775^{\mathrm{c}}$ \\
\hline Iron-Mid (ppb) & NA & 291 \\
\hline Lead (ppb) & $<0.5$ & $<5$ \\
\hline Magnesium (ppb) & $11,800 \pm 3,400$ & 16,480 \\
\hline Manganese (ppb) & $7 \pm 5$ & NC \\
\hline Mercury (ppb) & $<0.1$ & $<0.1$ \\
\hline Nickel (ppb) & $<4$ & $<30$ \\
\hline Nitrate $(\mathrm{ppb})$ & NA & 12,400 \\
\hline Phosphate (ppb) & $<1,000$ & $<1,000$ \\
\hline Potassium (ppb) & $4,950 \pm 1,240$ & 7,975 \\
\hline Selenium (ppb) & $<2$ & $<5$ \\
\hline Silver (ppb) & $<10$ & $<10$. \\
\hline Silicon (ppb) & NA & 26,500 \\
\hline Sodium (ppb) & $18,260 \pm 10,150$ & 33,500 \\
\hline Strontium (ppb) & $236 \pm 102$ & 264.1 \\
\hline Sulfate $(\mathrm{ppb})$ & $34,300 \pm 16,900$ & 90,500 \\
\hline Uranium $(\mathrm{pCi} / \ell)$ & $1.7 \pm 0.8$ & 3.43 \\
\hline Vanadium (ppb) & $17 \pm 9$ & 15 \\
\hline Zinc (ppb) & $6 \pm 2$ & $\mathrm{NC}$ \\
\hline Field Alkalinity(ppb) & NA & 215,000 \\
\hline Lab Alkalinity (ppb) & $123,000 \pm 21,000$ & 210,000 \\
\hline Field pH & NA & $(6.90,8.24)$ \\
\hline Lab pH & $7.64 \pm 0.16$ & $(7.25,8: 25)$ \\
\hline Total Organic Carbon (ppb) & $586 \pm 347$ & $2,610,1,610^{c}$ \\
\hline Field Conductivity $(\mu \mathrm{mho} / \mathrm{cm})$ & $\mathrm{NA}$ & 539 \\
\hline Lab Conductivity $(\mu \mathrm{mho} / \mathrm{cm})$ & $380 \pm 82$ & 530 \\
\hline
\end{tabular}


HNF-EP-0884

Rev. 1

\begin{tabular}{|l|c|c|}
\hline \multicolumn{1}{|c|}{ Constituent (Concentration) } & PNL Results $^{\mathrm{b}}$ & $\begin{array}{c}\text { Provisional Threshold } \\
\text { Values }\end{array}$ \\
\hline \hline TOX, LDL $(\mathrm{ppb})$ & NA & $60.8,37.6^{\mathrm{c}}$ \\
\hline Total Carbon $(\mathrm{ppb})$ & NA & 50,100 \\
\hline Gross Alpha $(\mathrm{pCi} / \ell)$ & $2.5 \pm 1.4$ & $63,5.79^{\mathrm{c}}$ \\
\hline Gross Beta $(\mathrm{pCi} / \ell)$ & $19 \pm 12$ & $35.5,12.62^{\mathrm{c}}$ \\
\hline Radium $(\mathrm{pCi} / \ell$ & $<0.2$ & 0.23 \\
\hline
\end{tabular}

a From Tables 5-9 and 5-11 of DOE-RL 1992.

b Results shown are mean \pm one standard deviation, unless only an upper limit is given.

c Potential outlier observation(s) were removed.

$\mathrm{NA}=$ not available.

$\mathrm{NC}=$ not calculated.

2.2.10.4 Radiation Background Levels. Various natural and human-produced sources contribute to radiation doses. These sources include natural terrestrial and cosmic background radiation, medical treatment and $x$-rays, natural internal body radioactivity, and inhalation of naturally occurring radon. Figure 2-15 shows the national average dose from each of these sources to an individual. Of the contributions shown in Figure 2-15, natural background contributes 300 mrem to the estimated per capita annual dose to individuals living near the Hanford Site. Human-produced sources contribute an additional $65 \mathrm{mrem}$. In contrast, annual Hanford Site environmental reports such as Dirkes and Hanf (Dirkes 1996-2) estimate that the maximum annual dose to an individual from Hanford Site operations in 1994 was about 0.05 mrem. This value is similar to values seen in the last 4 years.

Other non-DOE industrial sources of public radiation exposure exist at or near the Hanford Site. These include the low-level radioactive waste burial site operated by U.S. Ecology, the nuclear generating station operated by the Supply System, the nuclear fuel production plant operated by Siemans Nuclear Power Corporation, the low-level waste compacting facility operated by Allied Technology Corporation, and a decontamination facility operated by Pacific Nuclear Services. Based on information gathered from these companies, Dirkes and Hanf (Dirkes 1996-2) conservatively determined that the total 1994 annual dose for the hypothetical maximally exposed individual from those activities was also 0.05 mrem. 
Figure 2-15. Averages for Natural and Human-Produced Sources of Radiation (NCRP 1987).

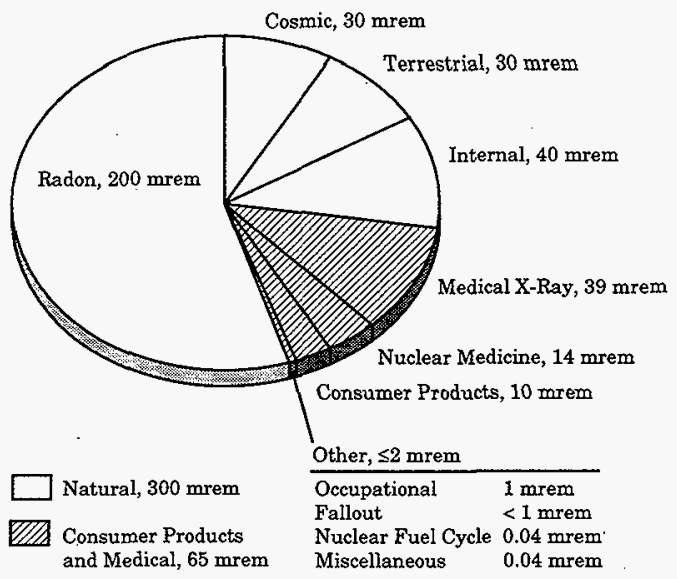

\subsection{WASTE CHARACTERISTICS}

\subsubsection{Overview}

The source of the waste material to be incorporated into a solidified waste form is the waste currently stored in the Hanford Site's single- and double-shell tanks.

Processes used to recover plutonium and uranium from irradiated fuel and radionuclides from tank waste plus miscellaneous sources (e.g., laboratory waste and reactor decontamination solutions) generated over $209,000 \mathrm{~m}^{3}$ (55.3 Mgal) [Hanlon 1996-1] of waste at the Hanford Site. This waste is currently stored in 177 underground tanks in the 200 Areas. The consistency of the tank waste ranges from dilute aqueous solutions to thick paste to hard rock.

The TWRS Record of Decision (DOE 1997) states that the waste will be retrieved from the tanks and then chemically separated to form the high-and low-activity radioactive waste streams. The high-activity radioactive waste stream will contain most of the radionuclides. This waste stream will be vitrified, and the product stored until it can be transferred to a licensed high-level waste repository. The low-activity radioactive waste stream contains the bulk of the non-radioactive chemicals, and is predominantly made up of the soluble components of the waste in the tanks. This waste stream will be solidified in a glass or other form that meets the 


\section{HNF-EP-0884 \\ Rev. 1}

DOE specifications (DOE-RL 1996, reproduced in Appendix A). It is proposed to dispose of the immobilized low-activity waste form on site in a manner that allows the waste to be retrievable for at least 50 years, although this time period has not been officially adopted.

This overall strategy for the Hanford Tank Waste Remediation System is shown in Figure 2-16 (DOE-RL 1995a-1).

\subsubsection{Underground Tank Storage}

To store the liquid high-level radioactive waste generated by Hanford Site operations since 1944, 149 single-shell tanks and 28 double-shell underground tanks were built. The tanks are grouped into 18 tank farms.

Four basic chemical processing operations generated the radioactive waste solutions. These operations were the Bismuth Phosphate process, the REDOX process, the PUREX process, and the Tributyl Phosphate process. The first three processes recovered plutonium from irradiated reactor fuels. The last process recovered uranium waste generated in the bismuth phosphate process. Other specialized campaigns recovered ${ }^{137} \mathrm{Cs}$, ${ }^{90} \mathrm{Sr}$, and other special nuclear materials. To make it less corrosive, the aqueous waste was made alkaline for storage in the underground tanks. Anderson (1990) provides a history of the liquid waste generation and its subsequent handling and storage in the tank farms.

The single-shell tanks, built between 1943 and 1964, are made of reinforced concrete with carbon steel liners (Figure 2-17). Their nominal capacities range from $208 \mathrm{~m}^{3}(55,000$ gal) to $3,785 \mathrm{~m}^{3}$ ( $1 \mathrm{Mgal}$ ). No new waste has been added to any of these tanks since 1980 . Most of the pumpable liquids have been transferred to double-shell tanks for safer storage. The remaining waste is in the following forms:

- Insoluble sludge with interstitial liquids

- Crystalline, water-soluble solids with interstitial liquids (salt cake)

- Supernatant liquids.

Sixty-seven single-shell tanks have leaked or are suspected to have leaked approximately 3,785 $\mathrm{m}^{3}$ (1 Mgal) of waste (Hanlon 1996-2).

The double-shell tanks, first used in 1971, consist of a carbon steel primary tank, an annular space, and a secondary steel tank encased in reinforced concrete (Figure 2-18). Each double-shell tank has a capacity of $4,310 \mathrm{~m}^{3}(1.14 \mathrm{Mgal})$

Most of the tank waste has undergone one or more treatment steps (for example, neutralization, precipitation, decantation, or evaporation). The neutralized waste contains sodium nitrate and nitrite, sodium hydroxide, sodium aluminate, sodium phosphate, various insoluble hydroxides and phosphates, significant quantities of organic materials, and 
Figure 2-16. Strategy for the Hanford Tank Waste Remediation System (from DOERL 1995a-1).

\section{Hanford Tank Waste Remediation System Strategy}

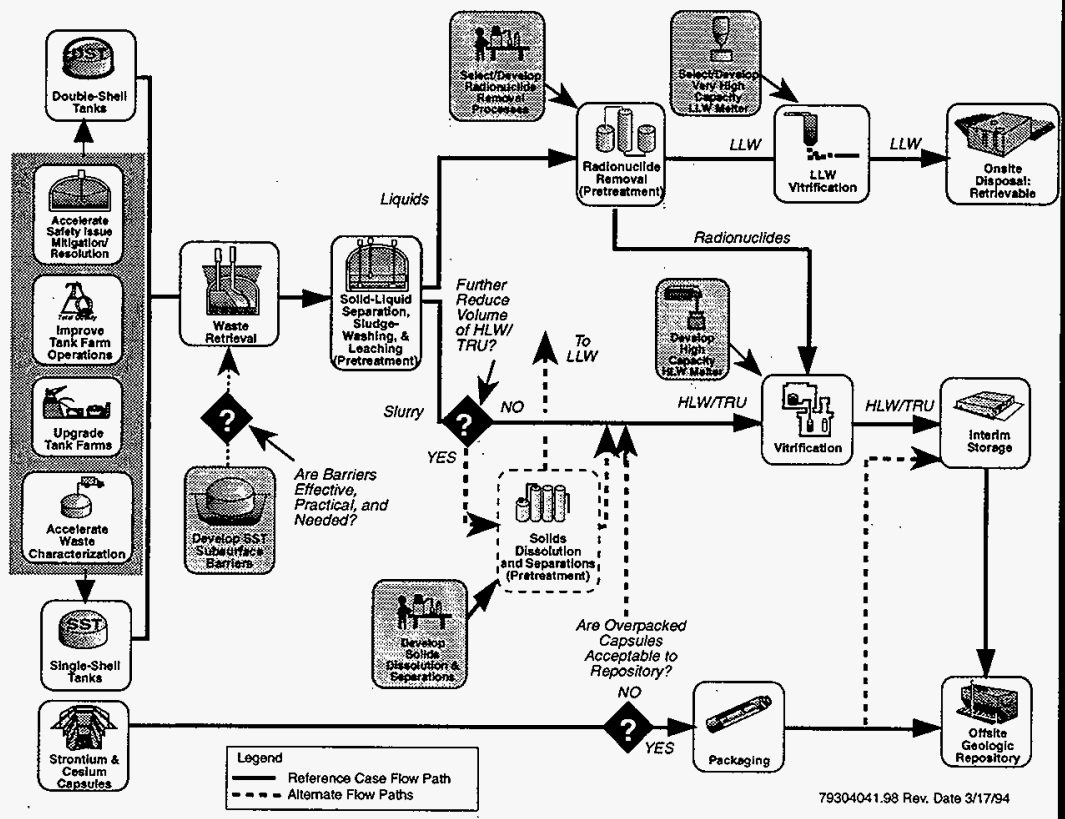

approximately $250 \mathrm{MCi}$ of many different radionuclides. The main effect of the treatment steps other than neutralization was to alter the water content of the waste. 


\section{Rev. 1}

Figure 2-17. Single-Shell Tank. For clarity, feed lines, risers, and instrumentation are not shown.

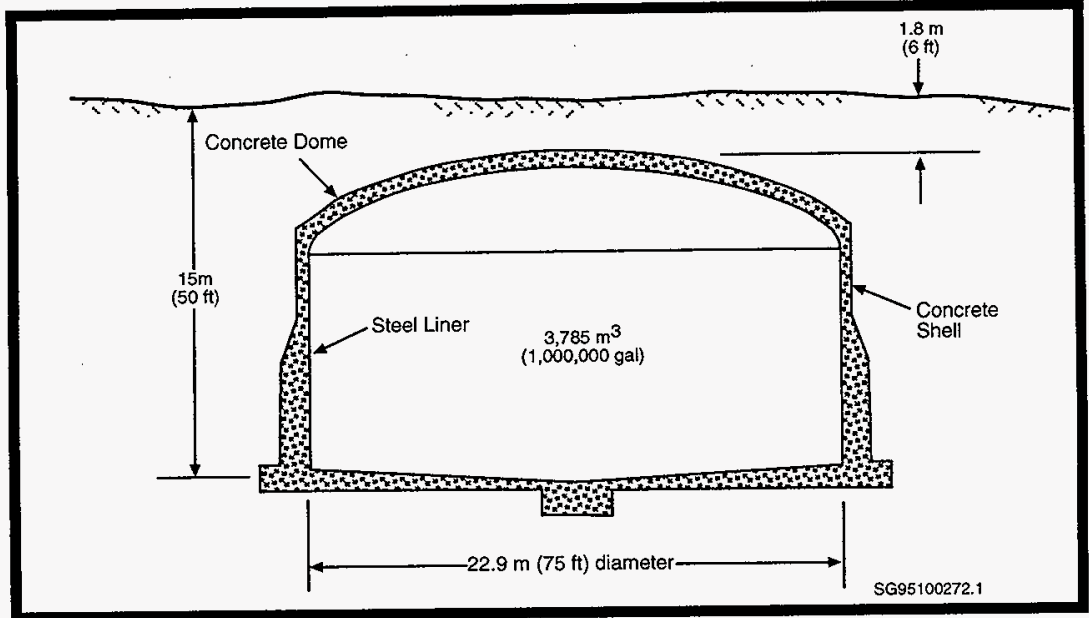

Figure 2-18. Double-Shell Tank.

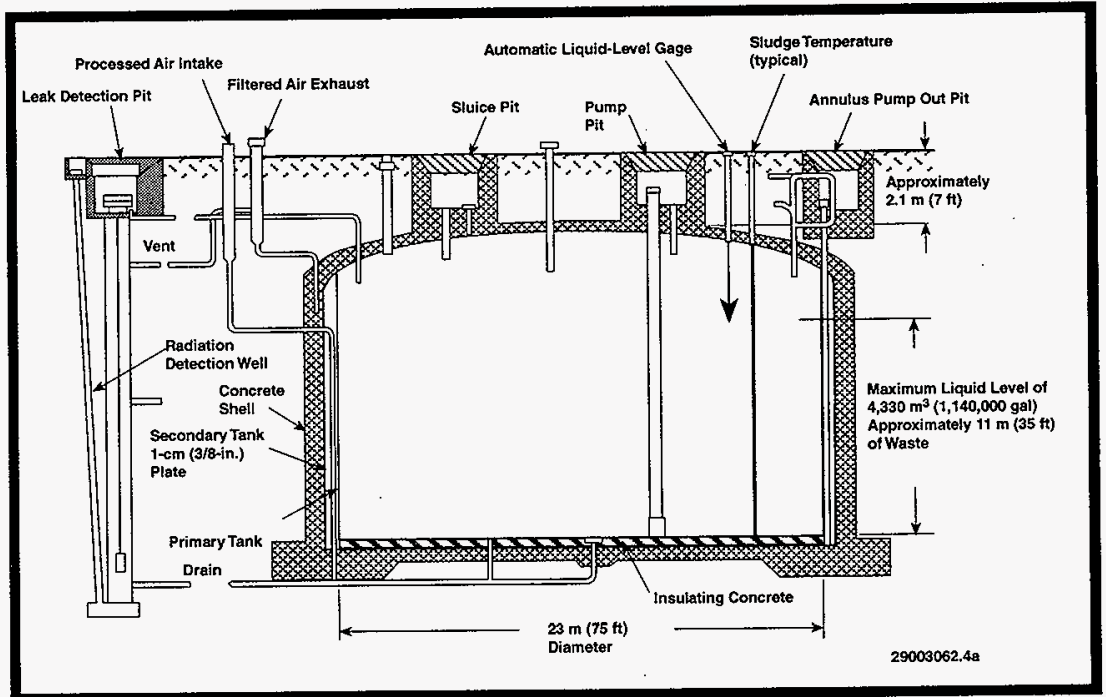




\subsubsection{Tank Waste Retrieval}

According to the Tri-Party Agreement (Ecology 1996-3), as much waste as is technically possible must be removed from the tanks. Unless limited by waste retrieval technology, the single-shell tank waste residues must not exceed $360 \mathrm{ft}^{3}\left(\sim 10 \mathrm{~m}^{3}\right)$ in each 100 -series tank, which can hold $208 \mathrm{~m}^{3}(55,000$ gallons) of waste. For the 200 -series tanks, which have volumes above $2,000 \mathrm{~m}^{3}\left(530,000\right.$ gallons), the limit is $30 \mathrm{ft}^{3}\left(\sim 1 \mathrm{~m}^{3}\right)$. On a tank-by-tank basis, the DOE can request the EPA and Ecology to approve a higher residue limit.

\subsubsection{Separations}

The purpose of the separations step is to separate the retrieved tank waste into the following two radioactive waste streams:

- A low-activity stream containing the bulk of the non-radioactive material and limited amounts of radionuclides. [This waste will be buried in the 200 Areas on the Hanford Site]

- A much smaller high-activity stream containing most of the radionuclides. [This waste will be immobilized and then stored until a licensed federal high-level repository is ready to receive the waste.]

By following this strategy, the Department of Energy minimizes the costs for the disposal of the waste (especially concerning the costs of using the proposed high-level repository) while still protecting the environment and public health and safety.

TWRS plans to use the following three-step approach to accomplish this task during the first period of privatization (2002 through $\sim 2010$ ).

1. Separate the soluble components from the insoluble components by means of intank "sludge washing" followed by settle-decant of the supernate.

2. Treat the soluble fraction to provide a feed to the low-activity waste immobilization facility that is in accordance with the U.S. Nuclear Regulatory Commission's "incidental waste" classification for Hanford Site waste (Berneo 1993). Berneo 1993 requires

- The waste has been processed (or will further be processed) to remove key radionuclides to the maximum extent possible that is technically and economically practical.

- The waste will be incorporated in a solid physical form at a concentration level that does not exceed the applicable concentration limits for Class $\mathrm{C}$ 


\section{HNF-EP-0884}

Rev. 1

low-level waste as set out in 10 CFR Part 61 (10 CFR 61-2).

- The waste is to be managed, pursuant to the Atomic Energy Act (AEA 1954), so that safety requirements comparable to the performance objectives set out in 10 CFR Part $61(10$ CFR 61 - 3) are satisfied.

3. Wash the insoluble fraction in-tank and then use enhanced in-tank sludge washing (alkaline leaching) to remove more soluble non-radioactive material from the feed going to the high-level waste vitrification facility. Any additional separations required will be performed in the proposed high-level waste separations facility.

The second period of privatization may differ in details, but equivalent separations are expected.

The NRC staff (Paperiello 1997) have indicated that such a separations activity along with an assessment consistent with NRC standards would allow the NRC to treat the lowactivity waste as "incidental waste."

\subsubsection{Immobilization of the Low-Activity Waste}

After separation, the waste will be immobilized as a glass waste form. Only some external properties (size, shape), including the maximum contaminant release rate, have been set (DOE-RL 1996). None of the secondary waste streams from immobilization are expected to go into the proposed immobilized low-activity tank waste disposal facility.

\subsubsection{Privatization}

The DOE is proceeding to privatize the immobilization functions of the TWRS. Under privatization, DOE would supply material retrieved from the tanks to private companies. DOE would then receive back the high-level waste, the low-activity solidified waste, and various other waste streams. Specifications for the separation and immobilization of the first 6 to 13 percent of the retrieved waste are included in Appendix 2-A.

\subsubsection{Packaging and Certification}

The physical, chemical, and radiological properties of the waste at the time of disposal have not been completely determined. The waste form is expected to be contained in metal containers having external dimensions of 1.8 by 1.2 by 1.2 meters (about 6 by 4 by 4 feet) (DOE-RL 1996).

The TWRS Privatization contracts describe the product acceptance process in the requirements for the "Products and Secondary Wastes Plan" to be prepared by the Private Contractors during Phase 1A and implemented during Phase 1B. A product acceptance strategy has been prepared (Westsik 1997). Implementing the strategy requires a product acceptance 


\section{HNF-EP-0884}

Rev. 1

process which includes development and maintenance of product specifications, Private Contractor qualification testing and evaluation prior to production, DOE verification testing prior to production, Private Contractor certification testing and reporting during production, and DOE acceptance testing according to a Product Acceptance procedure during production and operation of the storage/disposal facility.

\subsection{DISPOSAL TECHNOLOGY}

\subsubsection{Overview}

The design process for the disposal facilities is just beginning. In the absence of a design, two disposal facility concepts were developed for the interim performance assessment. Both concepts are based on a vault disposal concept developed for estimating costs for a disposal options configuration study (Mitchell 1995). The vault concept was enhanced by adding physical barriers to the amount of water entering the vault and a chemical barrier to reduce glass corrosion (Eiholzer 1995). The concepts were based on the assumption that the waste would be in glass form. The difference between the two facility concepts is the approach taken to incorporate the enhancements. Figures 2-19 and 2-20 show the two concepts, labeled Concepts 1 and 2, respectively.

The following sections outline the current concepts and thinking for disposal technology for the immobilized low-activity tank waste disposal facility. The disposal units, waste handling and interim storage operations, waste emplacement, disposal unit closure and stabilization, and site closure are addressed. For some of the areas covered, planning work has not started. In other areas, the only ideas available now are related to the vault concept given in Mitchell 1995.

\subsubsection{Disposal Units}

The vault bay is the basic unit for both disposal facility concepts. The overall concrete facility is divided into several sections called vault bays. Each vault bay is 38 by 19.5 by 9 meters high ( 125 by 64 by 29.5 feet). The number of vault bays depends on the size of the immobilized low-activity waste containers and the spacing between containers. The vault bays have concrete walls, floors, and ceilings. Six vault bays form a vault row.

Concept 1 consists of 10 adjacent vault rows, all of which are covered by continuous water barriers and a water-conditioning layer (Figure 2-19). The uppermost barrier is the surface barrier which is designed to minimize intrusion and recharge. Beneath the surface barrier, a sand-gravel capillary break will divert any moisture that may come through the surface barrier away from the vault. These two barriers implement the goal of minimizing the amount of water that enters the vault. 
HNF-EP-0884

Rev. 1

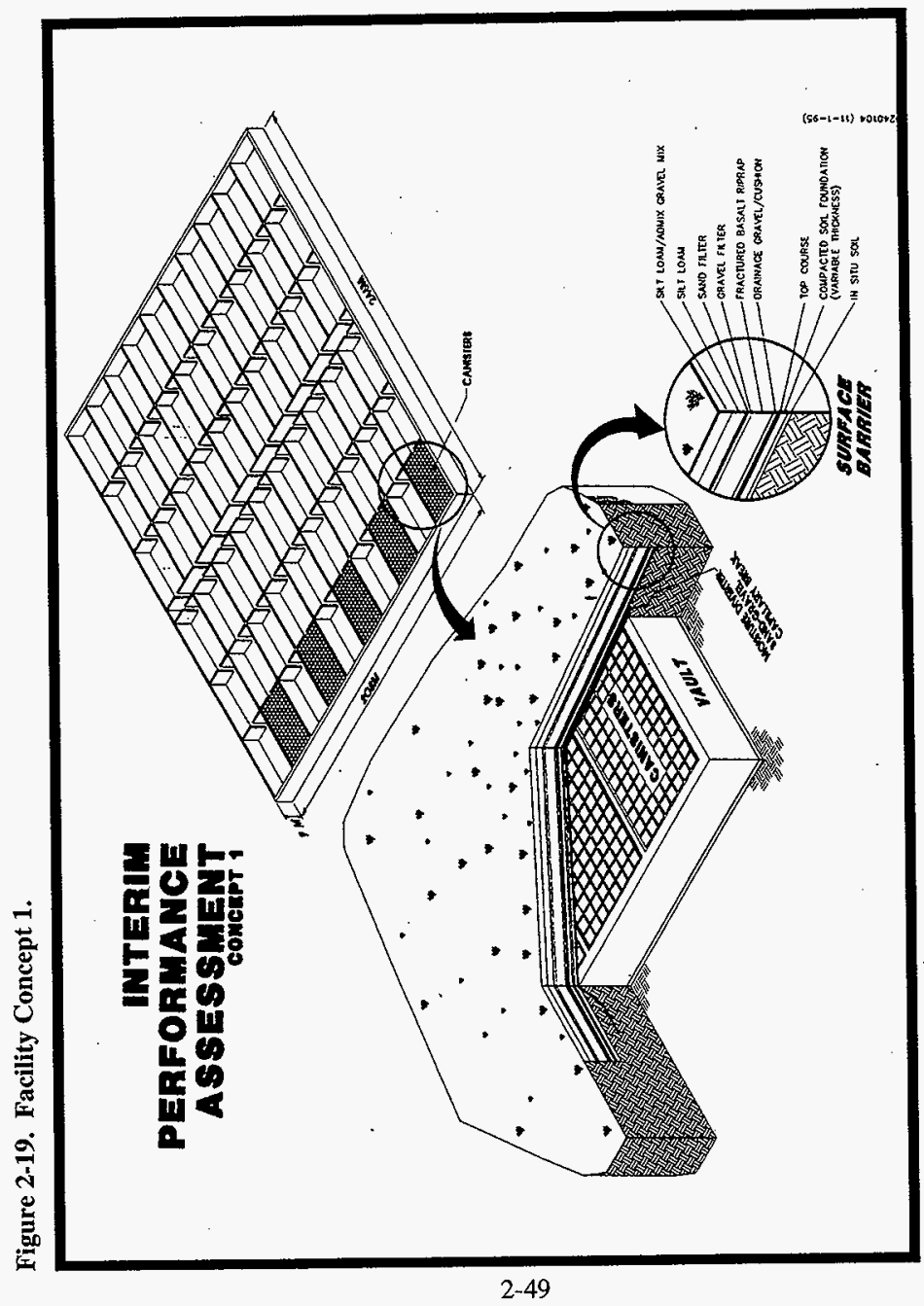


HNF-EP-0884

Rev. 1

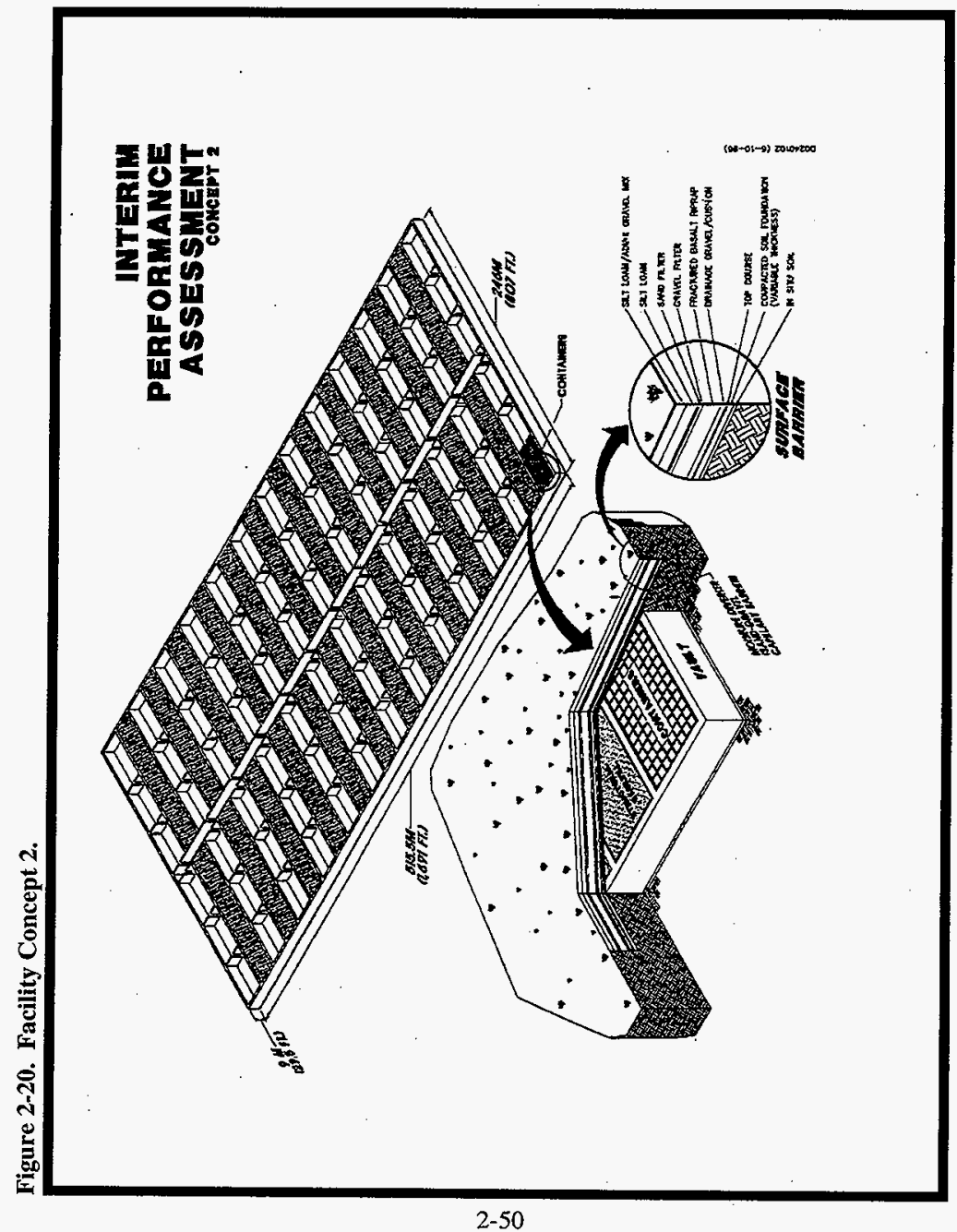


Figure 2-21. Facility Concept 2, Cross Section of Concept.

\section{INTERIM PERFORIMANGE ASSESSTIENT}

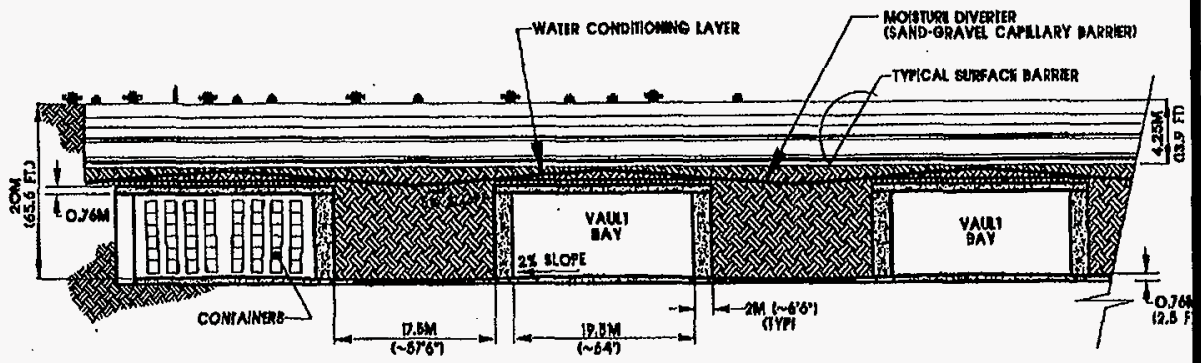

$\operatorname{mrnan}$ 


\section{HNF-EP-0884 \\ Rev. 1}

Beneath the capillary break there may be a water-conditioning layer of crushed glass. This layer would increase the silica content of any moisture that penetrates the first two barriers. It has been well documented in water saturated tests with a wide variety of glass compositions that corrosion rates are much lower in water that is near saturation with respect to amorphous silica. However, as yet, there is no theoretical or direct laboratory evidence that such preconditioning will be effective in reducing glass corrosion rates under low moisture conditions, as are expected in the disposal vault.

Concept 2 consists of 13 vault rows each having its own capillary break and waterconditioning layer (Figures 2-20 and 2-21). The rows containing waste containers are separated by rows of backfilled soil. The reason for alternating rows of vault bays and rows of soil was to reduce the width of the capillary break. The stability of the long capillary break in Concept 1 is a concern. The soil between vault rows allows each capillary break to drain into soil instead of another vault bay. Each row containing immobilized low-activity waste containers is covered by a water-conditioning layer similar to the one described for Concept 1 . The entire engineered region of Concept 2 is capped with a surface barrier.

\subsubsection{Waste Handling and Interim Storage Operations}

Currently, conceptual plans for waste handling or storage are beginning to be studied. How the waste containers will be handled and transported to interim storage will depend on the size of the containers and the proximity of the storage area to the waste immobilization processing area. The proposed privatization effort will determine or influence these factors.

\subsubsection{Waste Emplacement}

Mitchell (1995) provides an idea on how the waste packages might be placed in the disposal facility. This concept was developed for the vault facility described in Mitchell (1995) and used as the basis for disposal facility Concepts 1 and 2 . The filled containers would be brought into the disposal facility and moved within the facility remotely. A cart on a track would bring the waste container into the facility. A remotely operated crane in the facility would remove the waste container from the cart and place the container in one of the vault bays. This emplacement method did not consider the placement of backfilled soil between the containers because filler material was not considered in Mitchell (1995).

Both Concepts 1 and 2 include backfilled soil around and on top of the waste containers in the facility. The soil was included in these concepts for the following three reasons:

- Structural support. The initial Mitchell 1995 design had void space between the immobilized low-activity waste containers and between the containers and the ceiling. The soil would help prevent significant subsidence of the physical barriers when the concrete components of the system fail and collapse into the void space. 


\section{HNF-EP-0884}

Rev. 1

- To wick moisture away from the waste containers.

- To provide radiation shielding for the facility workers.

\subsubsection{Disposal Unit Closure and Stabilization}

Plans for the disposal unit closure and stabilization have not been developed yet. For this analysis, the unit is assumed to be closed so that the amount of water inside the disposal unit is minimized.

\subsubsection{Disposal Site Closure}

Disposal site closure is presumed to consist of applying the surface barrier and placing passive controls on the surface. The surface barrier envisioned is based on the Hanford Barrier (Myers 1994). The intent of the surface barrier is to use evaporation and plant transpiration to minimize the influx of precipitation into the disposal system. The surface barrier includes a sand/gravel layer to work as another capillary break and a layer of basalt riprap to deter burrowing animals, plant root intrusion, and inadvertent intruders.

The original Hanford Barrier included an asphalt layer to help prevent moisture for going toward the vault. This layer has been eliminated for the current disposal concepts for two reasons. First, another capillary break is being used for the second defense to prevent moisture for reaching the vault. Second, the asphalt layer is organic. Organic mixtures are being avoided because they may enhance colloid transport.

Passive controls are assumed to be used to deter inadvertent intrusion. However, the type of passive controls have not yet been selected. 
HNF-EP-0884

Rev. 1

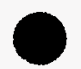

$2-50$ 


\subsection{ANALYSIS OF PERFORMANCE}

\subsection{OVERVIEW}

This chapter defines the models, computer codes, and input data used to analyze the long-term performance of the proposed disposal facility. The information from Chapter 2 is translated into a conceptual physical model, then into a numerical model. The data as well as the conceptual and numerical models are described and justified to the extent practicable. Stronger justification is expected in the preliminary and final performance assessments. For this assessment, the justification is mostly based on engineering judgment; for the preliminary and final assessments it will be based on experimental evidence that is specific to the site, waste form, and facility design as well as from additional expert judgement.

The strategy for this assessment was to define and perform an analysis of a base analysis case and sensitivity cases bracketing the base analysis case. The base analysis case was developed using best estimates of the environmental, the waste form, and the disposal facility parameters and how they will change with time. Following the recommendations of the Peer Review Panel (Case 1989), assumptions were intended to be "conservative but reasonable."

Most of the information in this chapter comes from previously released documents related to the interim performance assessment. Most of the data are from Data Packages for the Hanford Low-Level Tank Waste Interim Performance Assessment (Mann 1995a). The base analysis case was defined in Definition of the Base Analysis Case of the Interim Performance Assessment (Mann 1995b), which also contains a list of sensitivity cases.

This chapter shows in the following manner how the physical systems presented in Chapter 2 are translated into the numerical models which produce the results presented in Chapter 4.

1. The source term radionuclide inventories are described (Section 3.2).

2. The pathways and scenarios analyzed are explained (Section 3.3).

3. The assumptions (Section 3.4) and methodology (Section 3.5) used in the analyses, including the actual data used are presented.

4. The quality assurance measures used in the project are described (Section 3.6). 


\section{HNF-EP-0884}

Rev. 1

\subsection{SOURCE TERMS}

\subsubsection{Relevant Isotopes}

The anticipated tank waste inventories were prescreened (Schmittroth 1995a) to determine which radionuclides are potential problems for the inadvertent intruder and groundwater pathway scenarios. This presceening effort included the calculation of the quantity of all isotopes produced during materials production at Hanford (see Section 3.2.3.2), a simple one-dimensional steady state calculation of the transport of such isotopes through Hanford's vadose zone (both with accepted Hanford-relevant $K_{d} s$ as well as $K_{d}=0$ ), the conversion of groundwater concentrations to drinking water doses (see Section 3.3.6), and the calculation of inadvertent intrusion using the homesteader scenario (see Section 3.3.3.4.3). The study indicated that the following radionuclides are the potentially most important ones for each scenario:

- $\quad{ }^{90} \mathrm{Sr},{ }^{99} \mathrm{Tc},{ }^{137} \mathrm{Cs},{ }^{126} \mathrm{Sn},{ }^{227} \mathrm{Ac},{ }^{239} \mathrm{Pu}$, and ${ }^{241} \mathrm{Am}$ for the inadvertent intruder scenario

- $\quad{ }^{79} \mathrm{Se},{ }^{93} \mathrm{Nb}^{\mathrm{m}}$ (from ${ }^{93} \mathrm{Zr}$ and ${ }^{93} \mathrm{Mo}$ ), ${ }^{99} \mathrm{Tc},{ }^{129} \mathrm{I}$, and uranium isotopes and their daughters for the groundwater scenario

- Uranium, plutonium, neptunium, and americium isotopes and their daughters for the groundwater scenario in which geochemical retardation effects are ignored.

For this analysis, the top 10 contributors from the inadvertent intruder scenario, the top 12 contributors from the groundwater scenario, and the top 14 contributors from the unretarded groundwater scenario were used. These 28 isotopes contribute over $99 \%$ of the dose for the scenarios.

Previous Hanford Site performance assessments (Wood 1994 and Wood 1996) have shown that ${ }^{3} \mathrm{H},{ }^{14} \mathrm{C}$, and ${ }^{226} \mathrm{Rn}$ (from the decay of ${ }^{234} \mathrm{U}$ and ${ }^{238} \mathrm{U}$ ) are the main radionuclides of concern. Since radionuclides in Hanford Site surface waters come from groundwater, radionuclides important for surface water protection are taken from the groundwater selection analysis.

\subsubsection{Inventory Values}

The inventory for this study is from Schmittroth $1995 \mathrm{~b}$ except where noted. Inventory values were not taken from the Grout Performance Assessment (Kincaid 1995), because those estimates were only the waste from double-shell tanks and because those estimates have been superseded. As the TWRS Characterization Program proceeds, new and better estimates are expected and will be used in the preliminary and final performance assessments.

Table 3-1 gives the inventories for the year 2010 for those radionuclides as being the most important for this performance assessment (see Section 3.2.1). The year 2010 is halfway through the treatment, immobilization, and disposal operations. Except for a few radionuclides (for example, ${ }^{90} \mathrm{Sr}$ and ${ }^{137} \mathrm{Cs}$ ), the inventory for radionuclides of concern do not change 


\section{HNF-EP-0884}

Rev. 1

significantly during the period of treatment. The column labeled "Percent to LLW from Tanks" provides the current estimate of the fractional amount of material that will go into the waste form. This estimate comes primarily from the Process Design Group of the Disposal Engineering Section of the Westinghouse Hanford Company (Attachment 1 of Schmittroth 1995b). However, noted changes in Table 3-I are from Petersen 1995. Inventories for years other than 2010 and for all the radionuclides are given in Schmittroth 1995b. The following paragraphs summarize how the inventory was developed.

Table 3-1. Inventories for Interim Performance Assessment." -Inventory is decayed to 2010.

\begin{tabular}{|c|c|c|}
\hline Radionuclide & $\begin{array}{l}\text { Percent to LLW from } \\
\text { Tanks }^{\mathrm{b}}\end{array}$ & $\begin{array}{c}\text { Inventory in LLW } \\
\text { Decayed to } 2010 \\
\text { (Curies) }\end{array}$ \\
\hline${ }^{3} \mathrm{H}$ & 100 & $8.94 E+4$ \\
\hline${ }^{14} \mathrm{C}$ & 1 & $7.73 \mathrm{E}+0$ \\
\hline${ }^{79} \mathrm{Se}$ & $100^{c}$ & $1.03 \mathrm{E}+3$ \\
\hline${ }^{90} \mathrm{Sr}$ & $3^{d}$ & $1.61 \mathrm{E}+6^{\mathrm{e}}$ \\
\hline${ }^{93} \mathrm{Zr}$ & $1^{f}$ & $4.87 \mathrm{E}+1$ \\
\hline${ }^{93} \mathrm{Nb}^{\mathrm{m}}$ & $1^{f}$ & $4.20 \mathrm{E}+1$ \\
\hline${ }^{99} \mathrm{Tc}$ & 82 & $2.23 E+4$ \\
\hline${ }^{126} \mathrm{Sn}$ & $100^{c}$ & $1.58 \mathrm{E}+3$ \\
\hline${ }^{129} \mathrm{I}$ & $10^{i}$ & $6.62 \mathrm{E}+0$ \\
\hline${ }^{137} \mathrm{Cs}$ & $1^{8}$ & $4.51 \mathrm{E}+5^{e}$ \\
\hline${ }^{\mathrm{t} s 1} \mathrm{Sm}$ & $1^{f}$ & $3.16 \mathrm{E}+4$ \\
\hline${ }^{226} \mathrm{Ra}$ & $50^{\mathrm{fih}}$ & $2.35 \mathrm{E}-3$ \\
\hline${ }^{228} \mathrm{Ra}$ & $50^{\text {f, h }}$ & $1.38 \mathrm{E}+0$ \\
\hline${ }^{227} \mathrm{Ac}$ & $1^{\mathrm{fhh}}$ & $1.08 \mathrm{E}+0$ \\
\hline${ }^{229} \mathrm{Th}$ & $1^{f, h}$ & $9.79 \mathrm{E}-3$ \\
\hline${ }^{232} \mathrm{Th}$ & $1^{\mathrm{fnh}}$ & $2.68 \mathrm{E}-2$ \\
\hline${ }^{231} \mathrm{~Pa}$ & $100^{\text {ch h }}$ & $1.45 E+2$ \\
\hline${ }^{233} \mathrm{U}$ & 6 & $2.58 \mathrm{E}+1$ \\
\hline${ }^{234} \mathrm{U}$ & 6 & $1.80 \mathrm{E}+1$ \\
\hline
\end{tabular}


HNF-EP-0884

Rev. 1

\begin{tabular}{|c|c|c|}
\hline Radionuclide & $\begin{array}{l}\text { Percent to } L L W \text { from } \\
\text { Tanks }^{b}\end{array}$ & $\begin{array}{c}\text { Inventory in LLW } \\
\text { Decayed to } 2010 \\
\text { (Curies) }\end{array}$ \\
\hline${ }^{235} U$ & 6 & $7.36 \mathrm{E}-1$ \\
\hline${ }^{236} \mathrm{U}$ & 6 & $4.47 \mathrm{E}-1$ \\
\hline${ }^{238} \mathrm{U}$ & 6 & $1.78 \mathrm{E}+1$ \\
\hline${ }^{237} \mathrm{~Np}$ & 5 & $3.74 \mathrm{E}+0$ \\
\hline${ }^{239} \mathrm{Pu}$ & 6 & $2.23 E+3$ \\
\hline${ }^{240} \mathrm{Pu}$ & 6 & $4.31 \mathrm{E}+2$ \\
\hline${ }^{241} \mathrm{Am}$ & 8 & $4.25 E+3$ \\
\hline${ }^{243} \mathrm{Am}$ & 8 & $2.70 \mathrm{E}+0$ \\
\hline${ }^{245} \mathrm{Cm}$ & $100^{c}$ & $1.03 \mathrm{E}-1$ \\
\hline \multicolumn{3}{|c|}{$\begin{array}{l}\text { a Data are taken from Schmittroth } 1995 \mathrm{~b} \text { except as indicated by superscript " } \mathrm{f} \text { ". } \\
\text { " The fraction of tank waste going into the waste form was taken from Shelton } 1995 \text {. } \\
\text { " Because of the absence of. defensible data, no credit is taken for a reduction in the amount } \\
\text { going to the low-level fraction. } \\
\text { d } 23 \text { percent of }{ }^{90} \mathrm{Sr} \text { produced went into capsules rather than tanks. } \\
\text { ' The daughters }\left({ }^{90} \mathrm{Y} \text { and }{ }^{137} \mathrm{Ba}^{\mathrm{m}} \text { ) are in secular equilibrium with their parents and their }\right. \\
\text { inventories are not included. } \\
\text { f These values are based on the more recent work of Petersen (1995). Schmittroth } 1995 \mathrm{~b} \text { used } \\
\text { values of } 100 \text { percent because of the lack of data. } \\
{ }^{8} 45 \text { percent of }{ }^{137} \mathrm{Cs} \text { produced went into capsules rather than tanks. } \\
\text { "} \text { Also a decay product of other actinides. } \\
\text { 'Assumed in order to track significance. Most of }{ }^{129} \mathrm{I} \text { is assumed to be trapped in off-gas } \\
\text { stream and disposed elsewhere. }\end{array}$} \\
\hline
\end{tabular}

\subsubsection{General Description of the Development of Estimated Immobilized Low-Activity Waste Radionuclide Inventory}

3.2.3.1 Introduction. Tank-by-tank inventories of the radionuclides are generally not currently well known. However, reactor production records and nuclear fuel reprocessing records are reliable enough to establish accurate total tank waste inventory values for most of the fission products and uranium. The inventory of actinide nuclides is more uncertain because actinide production is sensitive to the time dependence of the neutron function and to processing transfers and losses. The estimated loss of fission products (particularly technetium and iodine) during processing or from tank leaks or discharges was used in adjusting the inventories. 


\section{HNE-EP-0884}

Rev. 1

Schmittroth et al. (Schmittroth 1995b) developed an inventory for this interim performance assessment. This inventory is based on the production of various radionuclides and the losses of the same radionuclides from processing and other factors. The process started by calculating radionuclide production values with the ORIGEN2 code (Croff 1980). (The detailed ORIGEN2 model is documented in Schmittroth 1995b.) Then, the calculated production values were corrected for known losses. Next, the reduction factors (splits) from the separated waste to an assumed glass waste form (Shelton 1995) are incorporated. Sections 3.2.3.2 through 3.2.3.5 summarize this strategy. Schmittroth (1995b) gives the details.

\subsubsection{Calculated Radionuclide Production. The irradiation histories of Hanford's} production reactors are modeled as two conceptual reactors. The ORIGEN2 computer code (Croff 1980) is used for this modeling. One conceptual reactor is representative of all the singlepass irradiations. The other conceptual reactor explicitly models the $\mathrm{N}$ reactor, the last production reactor at the Hanford Site. In both cases, detailed fuel types and irradiation histories are simplified, but stili accurate. For example, although some enriched fuel was used in the single-pass irradiations, it was assumed that all the single-pass fuel was natural uranium. Likewise, although $\mathrm{N}$ reactor produced some weapons-grade plutonium, a bumup of 2,000 $\mathrm{MWd} / \mathrm{MTU}$, more typical of fuels-grade production, was used for the entire operating history. The consequences of these assumptions are more fully reported in Schmittroth $1995 \mathrm{~b}$.

Schmittroth et al. (1995b) modified an earlier radionuclide production calculation to obtain the current inventory. Two thorium campaigns were added to the model to account for ${ }^{233} \mathrm{U}$ production. $\mathrm{N}$ reactor fuel discharged to the $\mathrm{K}$ Basins was deleted from the production history because this fuel will not be processed. Cross section modifications were also included. The ${ }^{238} U(n, 2 n)$ cross section was adjusted to better account for ${ }^{237} \mathrm{~Np}$ production. The thorium capture cross section was changed to account for ${ }^{23} \mathrm{U}$ production.

The uncertainties of the ORIGEN2 results vary for different nuclides. For some, including the important fission products ${ }^{99} \mathrm{Tc},{ }^{90} \mathrm{Sr}$, and ${ }^{137} \mathrm{Cs}$, and ${ }^{129} \mathrm{I}$, these uncertainties are expected to be less than 10 percent. The results in these cases depend primarily on fissionproduct yields and the production reactor operating histories. Both these areas are well known. The inventories of ${ }^{238} \mathrm{U}$ and ${ }^{239} \mathrm{Pu}$ before reprocessing are also well- known. However, reprocessing efficiencies and other losses introduce significant uncertainties in the estimated tank waste inventories for these isotopes. Nevertheless, these uncertainties are less than a factor of 2 and based on conservative reprocessing efficiencies; i.e., losses to waste were overestimated. Uncertainties for uranium, neptunium, and plutonium may also be significant. Calculations for ${ }^{3} \mathrm{H}$ and ${ }^{14} \mathrm{C}$ require special care, and current results are only rough estimates.

3.2.3.3 Hanford Production Processing and Storage. Recovery fractions from the processing of material from the Hanford Site production reactors were included in the ORIGEN2 model. These fractions were deducted from the reprocessed waste. The assumed uranium recovery value from reprocessing was 0.99 to give a more conservative (larger) value for the amount of uranium waste. While efficiencies were higher for much of the reprocessing history, considerable uncertainty is associated with early operations. In the early operations, the uranium was discarded, then later extracted in $U$ plant recovery operations. 
The separation fractions for technetium and neptunium were also large. Evidence is good that 20 percent or more of the technetium produced was lost to the waste stream, mainly co-processed with the $\mathrm{UO}_{3}$ and sent off site. Small amounts of technetium were lost to the environment as well. For most of the Hanford processing history, about 70 percent of the neptunium was recovered. Support for these values is provided in Section 4 of Schmittroth (1995b).

3.2.3.4 Separation and Vitrification Losses. The fractions of radionuclides that go to the lowlevel waste depend on evolving evaluations concerning the separation processes that will be used. The amount of separation is uncertain because the separationprocess has not-yet been determined. Preliminary values were recently updated (Shelton 1995) with mainly minor changes from the 1994 estimate (Boldt 1994). The most significant change was an increase from 60 to 82 percent for the fraction of technetium that becomes part of the low-level glass waste. The estimate of the fraction of uranium going to the low-level waste stream (6 percent) was unchanged. However, a somewhat higher value is possible. All the tin was assumed to follow the low-level waste, although there is some indication that the amount may be less than 100 percent. In recognition of the potential importance of ${ }^{12} \mathrm{q}$, the fraction going to the low-level waste was given as 10 percent in a 1994 memo (Boldt 1994). In the most recent memo (Shelton 1995), this value was reduced to zero reflecting the expected volatilization of iodine in the melter. To ensure that ${ }^{129} \mathrm{I}$ continues to be monitored in the interim performance assessment, the earlier value of 10 percent was maintained. Table 3-1 shows the specific values for separation fractions used in the present analyses.

Much of the total cesium and strontium produced in the reactors was separated in earlier chemical processing campaigns at the Hanford Site. This separated inventory, which currently resides in capsules, is not included in this low-level waste inventory. This assumption is consistent with the revised Tri-Party Agreement (Ecology 1996-2), which assumes that cesium and strontium in capsules will be disposed of as high-level waste.

Following separation of the tank waste, immobilization of the low-level waste stream is expected to volatilize some species, notably iodine, cesium, and potentially technetium. The present plan is to trap the volatile radionuclides and to dispose of them in a separate facility.

Note that the above discussion does not include any information from the private vendors awarded the contracts (BNFL and Lockheed Martin Advanced Environmental Services). That information is expected to be available in May 1998. Their separation plans may be different from that given in Shelton 1995. Future performance assessments will be based on published information from the private vendors.

3.2.3.5 Modeling of Decay Chains. In general, the ORIGEN2 model represents the complete production history as well as the reprocessing operations and losses. Thus, the ORIGEN2 results provide total radionuclide inventories for both the single-shell and double-shell tanks. For the most part, recovery fractions and losses expected during separation of the tank waste going to the low-level waste stream are treated separately. An exception was made for the uranium recovery fraction, assumed to be 6 percent, that was explicitly included in the ORIGEN2 calculation. The long half-lives associated with uranium and its daughters make it 


\section{HNF-EP-0884}

\section{Rev. 1}

necessary to explicitly follow the decay chains after the separation split.

\subsubsection{Tank-to-Tank Variations}

Only the estimate for the total inventory is used for the interim performance assessment. Presently, a good estimate of tank-to-tank variations is not available. Large differences in concentrations are known to exist among the tanks. For example, ${ }^{99} \mathrm{Tc}$ concentrations vary from less than $0.01 \mu \mathrm{Ci} / \mathrm{ml}$ to $1 \mu \mathrm{Ci} / \mathrm{m} \ell$ with a mean of about $0.09 \mu \mathrm{Ci} / \mathrm{ml}$ (Schmittroth $1995 \mathrm{~b}$ ). Because waste from various tanks is expected to be mixed, the extremes will not be this severe. However, accurate variations cannot be estimated now because the mixing sequence is not known. Variations in the amount of other radionuclides are also expected but at the present are not well known.

\subsubsection{Release Rate from Waste Form}

The radionuclide source term used in the transport calculations is not only based on the inventory discussed but also on the release rate of the radionuclides. The release rate is a function of the waste form, the disposal facility design, and the resulting chemical environment.

For an accurate determination of the source term, the chemical and physical models for contaminant release from the waste form must be explicitly modeled. However, because the waste form has not yet been determined and only specifications for its short-term release rate are known (DOE-RL 1996), simplified models are used in this analysis. More complete computer simulations of waste form corrosion and contaminant release are planned similar to the simulations found in some of the sensitivity studies.

The scenario for radionuclide release is described in Section 3.3.4 (Contaminant Release Scenario). The release rates of radionuclides from the waste form actually used in the calculations are described in Section 3.4.5.4 (Waste Form Radionuclide Release Rate).

\subsection{Pathways and Scenarios}

\subsubsection{Overview}

This section discusses the selection criteria, the pathways considered and not considered, and the exposure pathways considered and not considered. Special emphasis is given to the justification of the choices made. In this discussion pathways refer to the various environmental paths (for example, groundwater) by which contaminants move in order to go from the waste form to the human environment. Scenarios are the environmental and human-made events (for example, human intrusion or irrigation) which influence how contaminants move or affect humans. 


\section{HNF-EP-0884}

Rev. 1

\subsubsection{Selection Criteria}

The selection of relevant pathways and scenarios for these analyses was mainly based on pathways and scenarios used in earlier Hanford Site long-term environmental analysis documents. Previous long-term environmental analyses have included performance assessments written to satisfy the requirements of DOE Order $5820.2 \mathrm{a}$ as well as environmental impact statements. As noted in Section 1.2.1, four Hanford Site performance assessments for the disposal of low-level waste have already been done (Kincaid 1995, Wood 1994b, Wood 1995, and Wood 1996). The most important environmental impact statements (EIS) have been the Hanford Defense Waste EIS (DOE 1987) and the Tank Waste Remediation System EIS (DOE 1996b). These documents have been fairly consistent in their choice of pathways and scenarios.

After reviewing the relevant documents, reviews, and guidance, pathways and scenarios were selected for this interim performance assessment (PAT 1995b). Selection was based on the relevance of the pathway or scenarios to the current disposal action and performance objectives. Sections 3.3.3 and 3.3.4 contain summaries of the selections and justifications.

\subsubsection{Pathways}

3.3.3.1 Introduction. The selection of pathways for this performance assessment is covered more fully in Scenarios of the TWRS Low-Level Waste Disposal Program (WHC 1995). Possible scenarios were suggested by analyzing the performance objectives from Chapter 1 and determining which pathways could lead to a level of exposure that could equal or exceed the specified performance objective. Postulated land use was also studied to determine possible additional pathways. Finally, likely natural events were identified (such as catastrophic glacial age flooding).

In previous Hanford Site performance assessments (Wood 1994b, Kincaid 1995, Wood 1995, Wood 1996), the dominant pathway was through groundwater. Infiltration of moisture from precipitation entered the engineered system, where the moisture may cause release of the contaminants (for example in a water-glass interaction) or may simply carry away already released contaminants. The moisture and released contaminants travel downward through the vadose zone until the contaminants reach the unconfined aquifer where humans can encounter the radioisotopes through recovery of the groundwater resource for uses in residential and agricultural settings. From previous analyses (Rawlins 1994, Mann 1995b) supporting the Hanford Low-Level Tank Waste Program, this pathway again is expected to be dominant.

The rest of this discussion on pathways is divided into four subsections. First, the future land use of the Central Plateau is discussed. Based on the future land use, the second subsection gives land-use-driven scenarios. Then the inadvertent intruder scenarios are discussed. These intruder scenarios provide additional pathways to consider. Finally possible natural event scenarios are identified.

3.3.3.2 Future Land Use. In 1992 the Hanford Future Site Uses Working Group (HFSUWG) was charged to determine potential future uses of the various parts of the Hanford Site. This 


\section{HNF-EP-0884}

Rev. 1

group consisted of local, state, and federal officials, representatives of affected Indian tribes, and people from agriculture and labor, as well as members of environmental and other special interest groups. Their summary report (HFSUWG 1992a-2) states

"In general, the Working Group desires that the overall cleanup criteria for the Central Plateau should enable general usage of the land and groundwater for other than waste management activities in the horizon of 100 years from the decommissioning of waste management facilities and closure of the disposal areas."

The following four general land uses can be envisioned for the Central Plateau over the time of interest to a performance assessment.

Industrial/commercial
- $\quad$ Dry-land farming
Irigated farming
Natural.

The present land use is heavy industrial. If this use is maintained, records of past activities (particularly the disposal of nuclear materials) are likely to be kept. In addition, in an industrial area, liquid discharges to the ground would be highly regulated and be kept small.

Like the Central Plateau, the Horse Heaven Hills (which are south of the Hanford Site) are near, but at a significantly higher elevation than, the Columbia River. Although the amount of irrigation is increasing at certain locations, relatively little irrigation occurs in the Horse Heaven Hills because of the relatively high energy cost (hence economic cost) of bringing water to the surface. Dry-land farming continues to be the main use for the land of the Horse Heaven Hills.

East of the Central Plateau, across the Columbia River, irrigated farming is extremely common. The water, however, does not come from the nearby stretches of the Columbia River. The water comes from the Columbia Basin Project, which derives its water from the Grand Coulee Dam, over 322 kilometers (200 miles) upstream of the Hanford Site. The water is gravity-fed to the farms. The regional geography makes such a water delivery system unlikely for the Central Plateau.

Finally, west of the Central Plateau is the Fitzner/ Eberhardt Arid Lands Ecology Reserve, a nature preserve area.

For the base analysis case, the assumptions used related to how land would be used in the future where that knowledge of the disposal activities has been retained and that water discharges to the ground are minimized. These assumptions are consistent with the assumptions of HFSUWG, the DOE, and the local planning authorities which are all using a short term (50100 year) planning horizon. 


\section{HNF-EP-0884}

Rev. 1

\subsubsection{Land-Use-Driven Scenarios}

3.3.3.3.1 Introduction. The pathways described here assume that some controls remain in place to prevent public intrusion into the disposal site. That is, the barriers and markers that are to be left will be effective in preventing open use of the land over the disposal site. The land surrounding the marked area, however, could be farmed and could contain wells.

Based on previous analyses at the Hanford Site, the main exposure pathway is expected to be the contamination of the underground aquifer leading to various exposure scenarios. Other pathways include the upward diffusion through the engineered system into the air. The scenario for contaminant release from the engineered system is given Section 3.3.4. Exposure scenarios are described in Section 3.3.6.

3.3.3.3.2 Unconfined Aquifer Contamination. Contamination of the unconfined aquifer is caused by water (natural or human-caused penetrating through the ground surface layer, interacting with the engineered structure (including the waste), and then transporting contaminants down through the unsaturated sediments to the unconfined aquifer.

The main effects of land use on the analyses presented in this performance assessment are as follows:

The amount of water penetrating through the ground surface layer above the disposal facility

The direction and magnitude of flow of the unconfined aquifer from regional irrigation

The amount of well water pumped to the surface.

Because the site of the disposal facility is assumed to be known to the surrounding population, it was assumed that the surface immediately above the disposal facility will not be used. Thus the only source of water would be natural rain or snowfall. The infiltration rate, the rate at which water actually penetrates through the surface layer and enters the sand-gravel capillary barrier, is described in Section 3.4.7 and is expected to be small (less than $5 \mathrm{~mm} / \mathrm{year}$ ).

The second major consequence of land use is on the flow of groundwater in the unconfined aquifer. Analysis (ERDA 1975) of groundwater flow before the start of Hanford Site operations shows a predominantly west-to-east flow (Figure 2-12). Current calculations for post-Hanford operation conditions predict a similar flow (Figure 3-1). These groundwater calculations form an important part in this analysis and are described below (the model in Section 3.5.3.4, the data in Section 3.5.4.4, and the results in Section 4.3.3). However, the creation of ponds and the large amount of water discharged to the ground have altered the groundwater flow (Dirkes 1995) (Figure 2-13). The use of irrigation on the Central Plateau that will also affect groundwater must be considered. No irrigation was assumed for the base analysis case because the energy requirements for irrigation in the Central Plateau are significantly higher than for other nearby regions. However, irrigation on the plateau was 
considered in sensitivity cases to see the effects of selected irrigation on the regional flow of the groundwater in the unconfined aquifer. Irrigation on the 200 Areas was considered unlikely as this area will be dedicated to waste disposal and hence irrigation would be considered an inadvertent intrusion. Each of the following sensitivity cases was considered separately:

- Irrigated farming in the area north of the 200 Areas

- Irrigated farming in the area west of the 200 Areas.

- Irrigated farming in all areas on the plateau except the 200 West Area, the 200 East Area, and the region between these two areas

The last major effect is the amount of water being taken from a well. At the location of the proposed disposal facility, there is a very limited amount of water available in the unconfined aquifer. Because the amount of water is so limited, either only a small amount would be pumped from the unconfined aquifer or the well would extend much deeper and tap the confined aquifer instead of the unconfined aquifer. Thus, minimum distortion of the groundwater flow field in the unconfined aquifer was assumed for the base analysis case. Sensitivity cases were considered, however, to determine the effect of the amount of pumping on the groundwater flowfield and hence on the calculated doses.

3.3.3.3.3 Surface Water. The major surface water in the region is the Columbia River. Here the main impact of land-use is possible irrigation of land near the river. The Columbia River is a more likely source of water than the unconfined aquifer for farm land near the river because of the low elevation and nearness to the river. However, as part of the Washington State Growth Management Act, Benton County is planning to use the land downgradient from the Central Plateau for research and development purposes or for uses not affecting the groundwater.

For the base analysis case, the assumption was that no irrigation would occur downgradient from the plateau.

3.3.3.3.4 Air Resources. Gases and vapors could travel upward from the facility through the soil to the ground surface. This pathway is maximized with minimum downward water movement. No water flow is considered in the calculations for the protection of air resources.

\subsubsection{Inadvertent Intruder Scenarios}

3.3.3.4.1 Introduction. The pathways described here assume that no memory of the disposal facility remains. Two principal cases of intruders were considered:

The disposal facility is compromised by irrigation for commercial farming. A large amount of water enters the disposal facility, causing increased contaminant release from the facility and increased transport to the unconfined aquifer. 
Rev. 1

Figure 3-1. Predicted Groundwater Flowlines for Post Hanford Conditions.

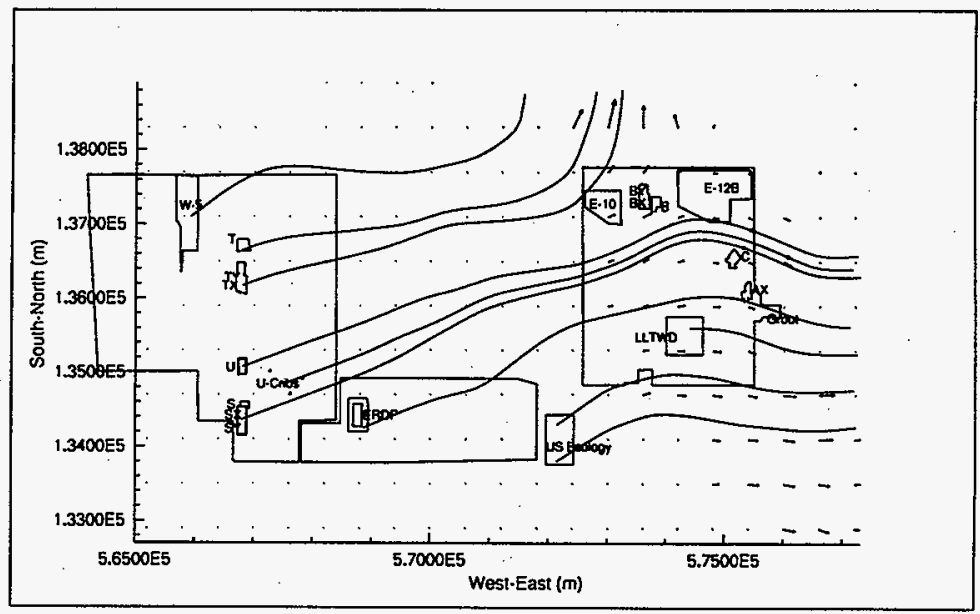

- An inadvertent intruder digs or drills into the disposal site and brings some of the waste to the surface, receiving an acute dose. Another intruder tills the waste into the soil and grows vegetables, receiving a continuous dose while engaged in various activities.

3.3.3.4.2 Irrigated Farming on the Disposal Site. This pathway is basically the same as the base analysis case. The difference is that instead of a small amount of water naturally infiltrating the disposal facility, a much larger amount of water enters the disposal facility. The larger amount of water may increase the contaminant release rate from the engineered facility. The increased amount of water certainly speeds the transport of the contaminants through the vadose zone into the unconfined aquifer.

3.3.3.4.3 Inadvertent Breach of Disposal Facility. Three intruder scenarios that involve bringing waste from the disposal facility to the surface are usually considered in a performance assessment.

1. Excavating for a basement or building foundation

2. Drilling for groundwater or minerals

3. Living where waste has been exhumed and scattered over the surface.

Scenario 1 is not considered credible because the top of the waste is over 10 meters ( 32.8 


\section{HNF-EP-0884 \\ Rev. 1}

feet) below the surface. Neither basements for home residence nor foundations for commercial structures are likely to extend this far below surface level. This scenario was not evaluated in these analyses.

Scenario 2, the construction of small water wells, is quite possible. The driller scenario begins with the assumption that some time after the disposal practices have ended a well is drilled through the waste. Drilling at the disposal site is unintentional, and the waste is not recognized as a potential hazard, even though it is assumed to be in the form of glass chunks. The waste, along with uncontaminated soil taken from the well, is spread over a work area near the well. The dose to the worker is the sum of the contributions from inhalation of resuspended dust, ingestion of trace amounts of soil, and external exposure at the center of a slab of contaminated soil.

The remaining scenario considers a family planting a garden using the material taken from the well. Each individual of concern receives dose by direct exposure to the radiation field in the garden, by inhaling resuspended dust, by ingesting trace amounts of soil, and by consuming garden produce.

Values for the parameters important for these intruder scenarios are given in Section

3.3.3.5 Natural Event Scenarios. The main natural events to be expected are as follows:

- Wind erosion of the surface above the disposal facility

- Earthquakes

- Flooding caused by post-glacial events.

Wind erosion and earthquakes are considered as drivers for changes in the engineered structure as a function of time. They are described in Section 3.4.6.7. Massive regional flooding has occurred many times during the past 50,000 years (see Section 2.2.5.2). The flood in the scenario (caused by the release of water during glacial retreat from a receding ice dam) removes 30 or more meters of ground (including the disposal units). In this scenario, the waste is uniformly redeposited over the Hanford Site. Seasonal flooding or flooding caused by collapsed dams would not affect the disposal site (see Section 2.2.6.3).

\subsubsection{Contaminant Release Scenario}

The actual waste form that will contain the contaminant is not yet known. Before the final request for proposal (RFP) for the privatization effort was released (DOE-RL 1996), the reference waste form was silicate glass. Until the phase $1 \mathrm{~b}$ privatization contract is awarded (expected in May 1998), the waste form will be uncertain, although a glass waste form will be used.

The following subsections discuss different aspects of contaminant release. Section 3.3.4.1 gives a general overall description of the contaminant release scenario. Section 3.3.4.2 


\section{HNF-EP-0884}

Rev. 1

focuses on what occurs during the water/waste form interaction if the waste form is a silicate glass. This more detailed scenario was developed in the acknowledgment of the maturity of silicate glass waste forms. The scenario is based on experience with silicate glass.

The contaminant release rate used in the base analysis case calculations is described in Section 3.4.5.4.

3.3.4.1 General Description. The contaminant release scenario is based on a water/waste form interaction. Initially, the disposal facility design (Section 2.4) delays moisture from entering the vault bays. Eventually, water enters the vault bays and moves downward to the waste packages. Once at a waste package, the water first interacts with the container, aiding its corrosion. Once the container is breached, water is assumed to reach the waste form. The water starts interacting with and breaking down the waste form. The waste form then releases the contaminants into the available water. The release rate will depend on the material, temperature, and the local chemical environment. Then available water transports the contaminant from the waste package and through the disposal facility. If the vault bay contains a getter material that sorbs the contaminant, the contaminant takes longer to move through the disposal facility. Finally, the moisture and contaminants migrate to the vadose zone through cracks in the bottom of the disposal facility.

3.3.4.2 Contaminant Release Based on Glass Corrosion. If the waste form is a silicate glass, glass corrosion processes would control the initial release of the contaminants. Studies have shown (Cunnane 1994) that silicate glasses corrode in three stages.

The first stage occurs under dilute solution conditions. Under these conditions, the water does not contain significant concentrations of many elements released from the glass. The glass reacts at a characteristic initial rate (known as the "forward rate") that depends only on glass composition, temperature, and solution $\mathrm{pH}$. During this time the water/glass reaction releases components of the glass into the water.

The second stage occurs as the concentration of elements released from the glass in the contacting water increases. The rate of glass corrosion continually slows as the solution becomes more concentrated with glass components. The reaction may reach a point where the glass corrosion rate cannot be distinguished from zero. This rate has been called the saturation rate where apparent saturation occurs with respect to the glass phase. The solution is not saturated in a thermodynamic sense because glass is metastable. The solution is saturated in a kinetic sense in that the corrosion rate approaches a very low constant value.

The third stage of glass corrosion may occur if secondary mineral phases begin to precipitate from the "saturated" fluid. Precipitation of many of these mineral phases will cause the solution to become undersaturated with respect to the glass. This undersaturation affects the glass corrosion rate. Mass transfer between the solution and the mineral secondary phases will maintain undersaturation. The resulting glass corrosion rate will depend on the specific chemistry of the secondary mineral phases that are formed. Depending on the secondary mineral phase formed, glass corrosion could remain near the low rate attained during the second stage or could accelerate to a rate near the forward rate. The mineral phases that consume silicon from 


\section{HNF-EP-0884 \\ Rev. 1}

the solution could accelerate the corrosion rate to near the forward rate.

The glass corrosion process releases contaminants into the moisture in contact with the glass. However, the contaminant release rate is not necessarily proportional to the glass corrosion rate. Rather each contaminant is subject to a variety of chemical reactions that can significantly alter the concentration of the contaminants in the moisture that eventually exits the disposal vault. These reactions include oxidation/reduction, dissolution/precipitation, and adsorption. Experiments and numerical analysis are proceeding to better understand the actual contaminant release. Testing is continuing on selected silicate glasses while testing on waste forms chosen by the TWRS privatization effort will start as soon as possible.

\subsubsection{Contaminant Transport}

3.3.5.1 Overview. Previous analyses (Kincaid 1995, Mann 1995b, Wood 1994b, Wood 1995, Wood 1996) have shown that contaminants are transported mainly by their movement in the aqueous phase. Contaminant movement can occur by moving with the water and by diffusing through water. Other mechanisms involved vapor phase transport of the gaseous contaminations or massive movements caused by catastrophic events such as glacial-age flooding. Sections 3.3.5.2 through 3.3.5.5 describe how contaminant transport mechanism were modeled. Appendix D contains the equations actually used in the models.

3.3.5.2 Moisture Movement. Two distinct moisture content regimes are present during contaminant transport: (1) the unconfined aquifer and (2) the vadose zone. In the unconfined aquifer, all the pore space of the porous sediment matrix is filled with water; that is the matrix is water saturated. In the vadose zone, the pore space is only partially filled with water; that is, the vadose zone is unsaturated.

Water flow through a saturated porous medium, such as the unconfined aquifer, is governed by the empirical relationship known as Darcy's Law (Freeze 1979) and by the conservation of mass. Darcy's law defines the discharge of water through a cross section of a porous medium. However, in contamination transport, the average velocity of water flowing through the medium is needed. This is because contaminants that are not geochemically retarded move with the water. The average velocity of the pore water is determined by dividing the discharge or Darcy velocity of the water by the water-filled porosity of the medium. Total porosity is defined as the ratio of void space to total volume.

In an unsaturated medium, the pores are not completely filled with water. For such a medium, moisture content is defined as the ratio of water filled void space to the total volume and the average velocity of the pore water is determined by dividing the Darcy velocity by the moisture content. Additional effects (capillary forces, the dependence of hydraulic conductivity on moisture content, etc.) must be considered when analyzing an unsaturated medium. Richards equation (Richards 1931) becomes the governing equation (see Appendix D).

The important parameters in these equations are the following: 


\section{HNF-EP-0884}

Rev. 1

- Matric potential (or pressure head) as a function of moisture content (water retention function)

- Hydraulic conductivity as a function of moisture content (relative permeability function)

- The source or sink of moisture.

Under extremely dry conditions, water vapor diffusion may be important. Water vapor diffuses through porous media along vapor pressure gradients. The presence of water-soluble components (for example, in the waste form) acts to depress the water vapor potential and causes the water vapor to diffuse from the surrounding soils. This water could then condense at the location of the water-soluble material and leach contamination from that surface. Important factors in this process are the level of water vapor pressure depression and the effective diffusion coefficient of water vapor.

3.3.5.3 Advective, Dispersive, and Diffusive Transport. The equation for the advective, dispersive, and diffusive transport of contaminants can be viewed as a mass balance on a differential volume.

The parameters important in this equation are

- The pore water velocity

- The dispersion coefficient

- The effective porosity of the soil layer

- The retardation factor that depends on the soil's density and wetted porosity and chemical distribution coefficient

- The effective diffusion coefficient

- The half-life for decay.

An increase in the retardation factor increases the time for the contaminant to reach the aquifer. In the absence of an advective component, the diffusion process could bring water soluble contaminants to the land surface via diffusion in a continuous liquid pathway.

Because of the very dry conditions in Hanford soils and expected in the disposal facility, diffusive transport may be more important than advective movement in some conditions. Because of the large storage capacity of the surface soils, the effect of large transient rainstorms is confined to the top few feet of soil.

3.3.5.4 Vapor Transport. Some contaminants may move upward from the disposal facility to the surface in the vapor phase. Such movement is governed by Fick's law. 


\section{HNF-EP-0884}

Rev. 1

3.3.5.5 Solid Transport. If another glacial-age catastrophic flood (such as the previous Missoula floods) occurs, the contaminants will be widely dispersed. For this case, the entire inventory is assumed to be mixed with soil to a depth of 20 meters ( 66 feet) \{the depth of the disposal facility] over the Hanford Site south of the Columbia River [an area of $906 \mathrm{~km}^{2}(350$ $\mathrm{mi}^{2}$ ). Past glacial-age catastrophic floods have deposited soils over a far greater area (even to the extent of carrying most of the soil all the way to the Pacific Ocean) and mixed the soil to greater depths. The all-pathways scenario (described in Section 3.3.6) is then used to estimate the dose.

\subsubsection{Exposure Scenarios}

Two major exposure scenarios are considered: drinking contaminated water and living on a small farm. The details of these scenarios and the justification for all the parameters used in them are in Rittmann (1995). Values for the parameters in these scenarios are discussed in Section 3.4.8 and are given in Appendix B.

The simplest case is exposure to contaminated drinking water pumped from a well. This well is assumed to be no closer to the disposal facility than 100 meters ( 328 feet) and to be located to provide the maximal exposure. This location is the one recommended by the Performance Assessment Task Team (Wood 1994a) and required by the RL implementation directive (DOE-RL 1993) for DOE Order 5820.2A (DOE 1988b). The two major exposure parameters in this scenario are the amount of water consumed and the suite of dose conversion factors used.

The more complex scenario has a person not only drinking the well water, but also using it to irrigate a small farm. Exposure comes from drinking contaminated water, ingesting contaminated food, ingesting and inhaling contaminated soil, and from direct irradiation from the contaminated soil. The total exposure results in the all-pathways dose.

\subsection{VALUES/ASSUMPTIONS}

\subsubsection{Overview}

This section provides and justifies the conceptual models and data for those models that were used in the analyses. The section covers the selection criteria and key assumptions for the conceptual models; describes the models and their associated data, the waste form, release rate, disposal facility, and moisture and moisture infiltration rate. The dosimetry parameters are also discussed. The models actually used in the computer simulations were derived from these conceptual models and are described in Section 3.5. 


\section{HNF-EP-0884}

\section{Rev. 1}

\subsubsection{Selection Criteria}

The following criteria are used to select among the alternatives:

- The ability to justify the choice.

- The availability of experimental evidence

- The use of best calculational methods.

The overriding criterion was the ability to justify the data and calculational methods selected. Justification required that all data, assumptions, and processes were questioned for applicability. Does each selection realistically portray probable situations? The justification process quickly identifies errors, misunderstandings, and false assumptions that can be corrected: This process provides insight into the true requirements for methods and the true need for data.

Whenever possible, direct experimental evidence is the basis for selecting data or approaches for the conceptual models. However, in most cases, collecting direct experimental evidence is not possible. Sometimes collecting all the evidence could take too long such as observing the behavior of glass for 10,000 years. Sometimes the amount of data is too large to obtain such as determining hydrologic parameters for the entire vadose zone.

When direct experimental evidence is limited, the available data are used to support analytical simplifications. This approach has two major examples. The first is extrapolating laboratory-measured data to field conditions, as in the case of hydrologic parameters. The second is measuring various effects of the total process to form a complete picture, as was done to determine the infiltration rate. The infiltration rate was determined by combining short-term lysimetry with mid-and long-term tracer and moisture measurements.

Because this analysis is being performed before key decisions on waste form, location, and disposal facility design have been made, relatively little direct experimental data are available to directly support this interim performance assessment. However, significant amounts of experimental data should be available to support the preliminary and final performance assessments. The statements of work (PAG 1994 and PAG 1995) outline the experiments that will be performed in geology, hydrology, glass performance, other material performance, and infiltration rate.

Analytic and calculational studies must be performed to provide data for processes, such as glass corrosion, that will be evolving over thousands of years. Analytical and computational tools were selected with the intention of using them to provide the most insight and accurate simulations of these processes.

\subsubsection{Key Assumptions}

Most of the data needed for a performance assessment have not yet been obtained. 


\section{HNF-EP-0884}

\section{Rev. 1}

However, enough is known about the proposed disposal action that necessary assumptions can be made. The key assumptions are as follows:

- Location (which dictates geology, stratigraphy, infiltration rate, and associated parameters)

- Waste form (which influences the release rate of contaminants)

- Inventory

- Disposal facility design.

As noted in Section 2.2.2, a preferred location for the disposal action has been recommended by the technical staff (Shord 1995). For this interim performance assessment, the preferred location was assumed to be the site of this disposal action. However, as part of this work a sensitivity study is performed on a site east of the recommended site to determine the impact if part of the waste is disposed in existing TWRS disposal facilities. Only limited characterization has been performed at either site. However, the central plateau area in which the preferred site rests has been well characterized. Therefore, rather good assumptions can be made about parameters that describe the proposed disposal site. Extensive characterization of the disposal site is planned (Reidel 1995).

As noted in Section 2.3.5, the waste form has not been determined. However, the final specifications for the waste form are included in the RFP for privatization (DOE-RL 1996) and included in the resulting contracts. The original waste stabilization program focused on silicate glass. Because of the knowledge and experience base that has been established for silicate glass, many believe that it will be the waste form. In any event, the selected waste form is likely to have release properties similar to those of silicate glass to meet performance criteria. This assumption is based on the requested release rates given in the specifications for the waste form (DOE-RL 1996). For the base analysis case of this interim performance assessment, the release rates for all elements from the waste form were assumed to be that given in the privatization specifications for all elements other than Tc. This means that the release rate assumed for $\mathrm{Tc}$ in the base analysis case is five times higher than allowed in the RL specifications for the waste form. No other credit was taken. For some sensitivity cases, computer simulations of contaminant release rates under disposal conditions for a silicate glass were performed. When the actual waste form is defined, short- and long-term experiments and analyses are planned for understanding the release behavior as a function of time and environmental conditions.

The actual composition of the waste form (both radioactive and nonradioactive) is not known. For these analyses, only the mean composition based on the estimated total radionuclide inventory was used. As retrieval scenarios are better defined and individual tank contents become better known, composition variations in the waste form will be determined. These variations will then be used in the analyses.

Finally, only conceptual ideas exist for the facility design (See Section 2.4). Important features have been identified and preliminary investigations have been done (Mann 1995b). 


\section{HNF-EP-0884}

Rev. 1

Thus, certain design features can be included with some confidence. Much more work remains to be done as the conceptual design ideas are translated into preliminary and then final designs: An important part of such work will be experimental and analytical studies of how the various features behave over time.

\subsubsection{Site}

3.4.4.1 Introduction. This section translates the geology, hydrogeology, and geochemistry described in Chapter 2 into a conceptual model and values that can be used in the analyses supporting this interim performance assessment. The location and stratigraphy of the disposal site are discussed first. Next, the hydrologic and geochemical properties of the vadose zone are addressed. Finally, the properties of the unconfined aquifer are examined.

3.4.4.2 Location and Stratigraphy. As noted in Section 2.2.2, the location of the disposal facility has not been determined. However, a preferred location in the south central part of the 200 East Area has been recommended by the technical staff (Shord 1995). The main strata at this location are the Hanford formation and the Ringold Formation.

The Hanford formation beneath the disposal area consists of three layers. The upper 6 meters ( 20 feet) is the Upper Gravel Sequence. The next 60 meters (197 feet) consists of the Sand Sequence. The bottom, the Lower Gravel Sequence, is 25 to 40 meters ( 82 to 131 feet) thick. For modeling purposes (Table 3-2) a mean thickness of this bottom sequence was taken as 35 meters ( 115 feet) making the Hanford formation 101 meters ( 331 feet) thick in the model.

Table 3-2. Stratigraphy Used for the Base Analysis Case. (Reidel 1995)

\begin{tabular}{||l|l||}
\hline \multicolumn{1}{|c|}{ Formation } & \multicolumn{1}{c|}{ Thickness/Location } \\
\hline \hline Hanford formation & starts at surface \\
Upper Gravel Sequence & 6 meters ( 20 feet) (on surface) \\
Sand Sequence & 60 meters $(197$ feet) \\
Lower Gravel Sequence & 35 meters (115 feet) (bottom) \\
\hline Ringold Formation & starts just below Hanford formation, 101 meters \\
Unit E & below the surface \\
& 30 meters ( 98 feet) \\
\hline Unconfined aquifer & 103 meters (338 feet) below surface, 118 meters (387 \\
& feet) above mean sea level \\
\hline
\end{tabular}

Below the Hanford formation lies the Ringold Formation. Only Unit $\mathrm{E}$ is of concern for these analyses. Unit $\mathrm{E}$ is consolidated sandy gravel to muddy sandy gravel 30 meters (98 feet) thick. 


\section{HNF-EP-0884 \\ Rev. 1}

The large discharge of water from Hanford Site operations has significantly affected the level and flow of the unconfined aquifer. However, DOE has agreed to severely limit such discharges; and at the time of this analysis there will be no discharges. Based on calculations using the Environmental Restoration Contractor (ERC) Hanford Sitewide groundwater model (Law 1996), the present location of the aquifer at the disposal site is 96 meters ( 315 feet) below the surface level or 125 meters ( 410 feet) above mean sea level which is in good agreement with measurements. Computer simulations were used to define the level of the unconfined aquifer after Hanford Site operations cease. Current estimates of the post-Hanford water table (Law 1996) suggest this level as 103 meters ( 338 feet) below the surface level or 118 meters (387 feet) above the mean sea level. This level was used for the base analysis case. The post-Hanford unconfined aquifer is expected to be in the Ringold Formation.

Two sensitivity cases were produced to determine the importance of the hydrologic parameters of each layer. All of the analysis in this performance assessment assumes that the hydrologic parameters do not vary within a formation. Thus by changing the thicknesses of the formations, different hydrologic properties are used in the simulations. The first sensitivity case considers that all, rather than most, of the Hanford formation consists of the Sandy Sequence. The second sensitivity case assumes that the Lower Gravel Sequence starts at 50 meters (164 feet) below the surface rather than at 66 meters ( 216 feet).

Two sensitivity cases will be studied to determine the importance of which formation contains the unconfined aquifer. In one sensitivity case, the top of the unconfined aquifer is at 1997 position, 96 meters ( 315 feet) below the surface (that is, the top of the aquifer is 7 meters above the position of the base analysis case). In the other case, the top of the aquifer is lowered from the base analysis case by the same amount as it was raised in the first sensitivity case. Thus for the second sensitivity case the top of the aquifer is at 110 meters ( 361 feet) below the surface. In both cases the bottom of the aquifer remains at the same elevation below the surface.

3.4.4.3 Vadose Zone Hydrologic Parameters. Vadose zone hydrologic parameters (volumetric moisture content and hydraulic conductivity) for these analyses come from laboratory analyses of samples from the various strata found near the disposal site. Samples were taken from seven locations near the disposal site (Figure 3-2). Corrections were made for the gravel content and for primary drainage. This resulted in moisture retention data. A detailed discussion of the data and methods used to derive them can be found in the work of Khaleel and Freeman (Khaleel 1995). The following paragraphs summarize the methods and data.

The moisture retention data can be described in an empirical relationship following the methods of van Genuchten (1980). The moisture retention function is

$$
\theta(\psi)=\theta_{\mathrm{r}}+\left[\theta_{\mathrm{s}}-\theta_{\mathrm{r}}\right]^{*}\left\{1+[\alpha \psi]^{\mathrm{n}}\right\}^{-\mathrm{m}}
$$

where $\theta(\psi)$ is the volumetric moisture content [dimensionless]

$\Psi \quad$ is the matric potential or pressure head [ $l]$

$\theta_{\mathrm{r}} \quad$ is the residual moisture content [dimensionless]

$\theta_{\mathrm{s}} \quad$ is the saturated moisture content [dimensionless]

$\alpha \quad$ is a fitting parameter $\left(\ell^{-1}\right)$ 
HNF-EP-0884

Rev. 1

$\mathrm{n} \quad$ is a fitting parameter [dimensionless]

$m$ is $1-1 / n$.

Figure 3-2. Hydrologic-Conductivity Sample Locations.

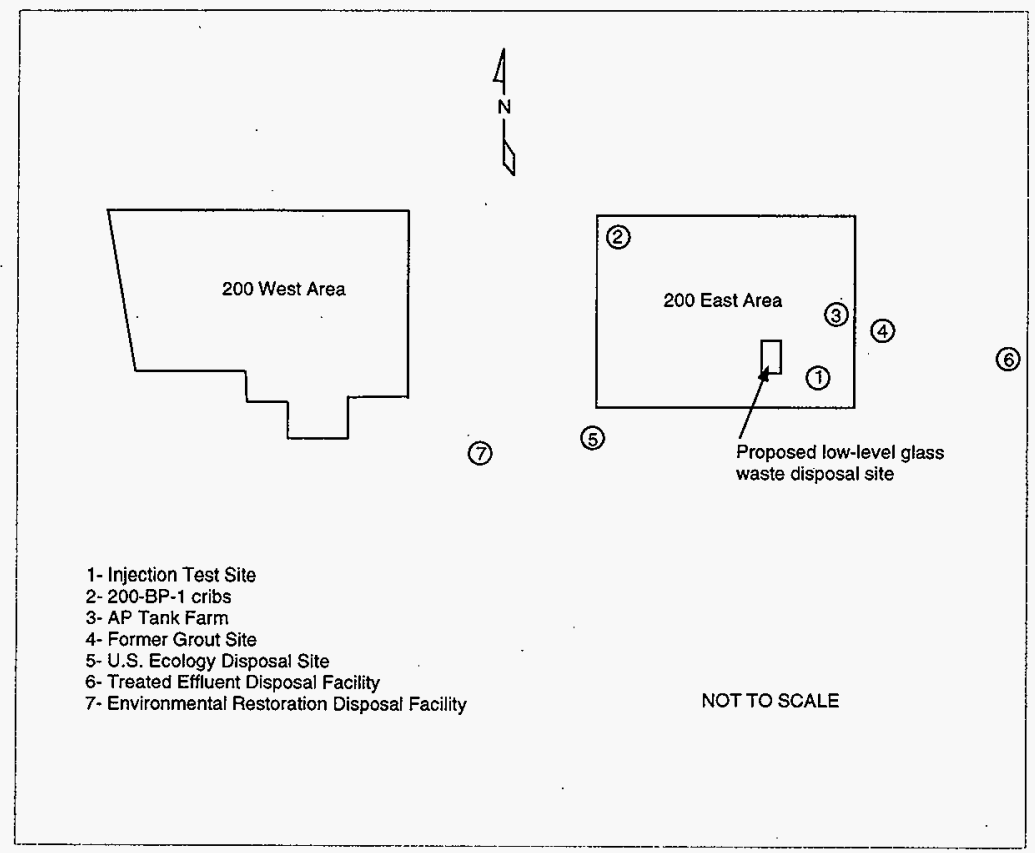

Using the Mualam (1976) model and the above form for moisture retention, the hydraulic conductivity is

$$
\mathrm{K}\left(\mathrm{S}_{\mathrm{e}}\right)=\mathrm{K}_{s} * \mathrm{~S}_{\mathrm{e}}{ }^{\mathrm{f}} *\left\{1-\left[1-\mathrm{S}_{\mathrm{e}}{ }^{1 / m}\right]^{m}\right)^{2}
$$

where $K\left(S_{e}\right)$ is the unsaturated hydraulic conductivity [length/time]

$$
\begin{array}{ll}
\mathrm{K}_{\mathrm{s}} & \text { is the saturated hydraulic conductivity }[\mathrm{V} / \mathrm{t}] \\
\mathrm{S}_{\mathrm{e}} & \text { is effective saturation }=\left(\theta-\theta_{\mathrm{r}}\right) /\left(\theta_{\mathrm{s}}-\theta_{\mathrm{r}}\right)
\end{array}
$$

$\ell \quad$ is the pore-connectivity parameter, estimated by Mualam to be about 0.5 for many soils. In this work, $\ell$ is taken to be 0.5 (a dimensionless quantity). 


\section{HNF-EP-0884}

Rev. 1

The RETC code (van Genuchten 1991) was used to determined values for $\theta_{\nabla} \theta_{,} \alpha$, and $\mathrm{n}$. Values for $\mathrm{K}_{\mathrm{s}}$ were determined by fitting laboratory data to a log-normal distribution. The resulting values are shown in Table 3-3.

Table 3-3. Values for Hydrologic Parameters for the Vadose Zone for the Base Analysis Case. $^{a}$

\begin{tabular}{|c|c|c|c|c|c|c|}
\hline \multirow[t]{2}{*}{ Material } & \multirow{2}{*}{$\begin{array}{l}\text { Number of } \\
\text { Samples }\end{array}$} & \multicolumn{4}{|c|}{ van Genuchten Curve Fitting Parameters for Moisture Retention } & \multirow{2}{*}{$\begin{array}{c}\text { Saturated } \\
\text { Hydraulic } \\
\text { Conductivity } \\
(\mathrm{cm} / \mathrm{s})\end{array}$} \\
\hline & & $\begin{array}{c}\Theta_{\mathrm{s}}^{\mathrm{b} d} \\
\left(\mathrm{~cm}^{3} / \mathrm{cm}^{3}\right) \\
\end{array}$ & $\begin{array}{c}\Theta_{\mathrm{r}}^{\mathrm{cd}} \\
\left(\mathrm{cm}^{3} / \mathrm{cm}^{3}\right) \\
\end{array}$ & $\begin{array}{c}\alpha^{\alpha} \\
\left(\mathrm{cm}^{-1}\right) \\
\end{array}$ & $\mathrm{n}^{\mathrm{d}}$ & \\
\hline $\begin{array}{l}\text { Hanford } \\
\text { sands }\end{array}$ & 60 & 0.3578 & 0.0246 & 0.1566 & 2.1768 & $1.17 \times 10^{-2}$ \\
\hline $\begin{array}{c}\text { Hanford } \\
\text { gravel }\end{array}$ & 8 & 0.1312 & 0.0126 & 0.0125 & 1.530 & $1.32 \times 10^{-3}$ \\
\hline $\begin{array}{l}\text { Ringold } \\
\text { Formation }\end{array}$ & 15 & 0.1342 & 0.0220 & 0.0122 & 1.5865 & $8.74 \times 10^{-5}$ \\
\hline \multicolumn{7}{|c|}{ 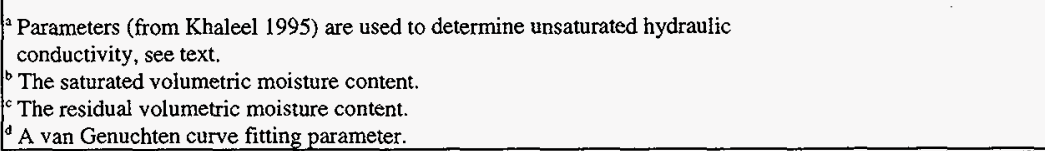 } \\
\hline
\end{tabular}

The grout performance assessment (Kincaid 1995-2) relied on the work of Rockhold et al. (Rockhold 1993) to determine the unsaturated hydraulic conductivity in the vadose zone. Their procedure was similar to the Khaleel and Freeman approach. However, their data set was slightly smaller and did not include samples from near the proposed disposal site. The samples used by Rockhold et al. were mainly from the Grout Disposal Facility with some samples from the AP tank farm, the U.S. Ecology Site, and the 200-BP-1 site. The residual moisture content $\left(\theta_{\mathrm{r}}=0.0234 \mathrm{~cm}^{3} / \mathrm{cm}^{3}\right)$ that Rockhold et al. determined for their

57 samples from the sandy sequence of the Hanford formation is very similar to that found by Khaleel and Freeman $\left(\Theta_{\mathrm{r}}=\right.$ $0.0246 \mathrm{~cm}^{3} / \mathrm{cm}^{3}$ ). The residual moisture contents found by Rockhold et al. for the Hanford formation lower gravel sequence (14 samples yielding $\theta_{r}=0.0213 \mathrm{~cm}^{3} / \mathrm{cm}^{3}$ ) and the Ringold Formation ( 5 samples yielding $\theta_{\mathrm{r}}=0.0283 \mathrm{~cm}^{3} / \mathrm{cm}^{3}$ ) are slightly higher than the values from the Khaleel and Freeman analysis $\left(\Theta_{\mathrm{r}}=0.0126\right.$ and $0.0220 \mathrm{~cm}^{3} / \mathrm{cm}^{3}$, respectively). In general, the two analyses are in close agreement.

The hydraulic properties for construction materials are taken from the work of Rockhold et al. (Rockhold 1993). The values are displayed in Table 3-4. Hydrologic parameters for sand (which is used in the sand-gravel capillary barrier and in sensitivity cases) are assumed to be the same as for the sandy sequence of the Hanford formation. The hydrologic parameters for the water conditioning layer are assumed to be the same as for gravel. 
HNF-EP-0884

Rev. 1

Table 3-4. Values for Hydrologic Parameters for Construction Materials for the Base Analysis Case $^{a}$

\begin{tabular}{|c|c|c|c|c|c|}
\hline \multirow[b]{2}{*}{ Material } & \multicolumn{4}{|c|}{$\begin{array}{l}\text { van Genuchten Curve Fitting Parameters for Moisture } \\
\text { Retention }\end{array}$} & \multirow{2}{*}{$\begin{array}{l}\text { Saturated Hydraulic } \\
\text { Conductivity } \\
(\mathrm{cm} / \mathrm{s})\end{array}$} \\
\hline & $\left(\begin{array}{c}\Theta_{\mathrm{s}}^{\text {b.d }} \\
\left(\mathrm{cm}^{3} / \mathrm{cm}^{3}\right)\end{array}\right.$ & $\begin{array}{c}\Theta_{\mathrm{r}}^{\mathrm{cd}} \\
\left(\mathrm{cm}^{3} / \mathrm{cm}^{3}\right)\end{array}$ & $\begin{array}{c}\alpha^{\mathrm{d}} \\
\left(\mathrm{cm}^{-1}\right)\end{array}$ & $n^{d}$ & \\
\hline Back-filled soil & 0.3710 & 0.0450 & 0.0683 & 2.080 & $3.00 \times 10^{-2}$ \\
\hline Gravel & 0.5180 & 0.0140 & 3.5366 & 2.661 & 1.85 \\
\hline Portland Concrete & 0.2258 & 0.0000 & $7.6 \times 10^{-6}$ & 1.393 & $3.75 \times 10^{-10}$ \\
\hline \multicolumn{6}{|c|}{$\begin{array}{l}\text { Parameters (from Rockhold 1993) are used to determine unsaturated hydraulic } \\
\text { conductivity, see text. } \\
\text { b The saturated volumetric moisture content. } \\
\text { 'The residual volumetric moisture content. } \\
\text { d A van Genuchten curve fitting parameter. }\end{array}$} \\
\hline
\end{tabular}

For the calculations, the particle density of the soil was taken to be $2.72 \mathrm{~g} / \mathrm{cm}^{3}$. The dispersion coefficient of the contaminations was taken to be $0.1 *$ travel length in the direction of travel. The dispersion in the vadose zone in the horizontal direction was taken to be one tenth of the value in the direction of travel. For aquifer transport, the dispersion in the horizontal direction (not in the direction of flow) was also taken to be $0.1 \%$ travel length in the direction of flow and in the vertical direction $0.01 \%$ travel length.

The value of the diffusion coefficient in unsaturated sediments of the vadose zone is taken from the grout performance assessment (Kincaid 1995-3), using the model of Kemper and van Schaik (1966).

$$
\mathrm{D}=1.25 \times 10^{-7} \exp (-10 \theta) \mathrm{cm}^{2} / \mathrm{s},
$$

where $\theta$ is the volumetric moisture content of the sediment.

To estimate the release of radon from the soil, radon's diffusivity must be estimated. Harris et al. (1992) summarized the measurements of gaseous diffusion performance on concrete materials. They concluded that, for dry materials, diffusivities ranged from $10^{-5}$ to $10^{-3} \mathrm{~cm} / \mathrm{s}$ $\left(10^{-6}\right.$ to $\left.10^{-4} \mathrm{in} .{ }^{2} / \mathrm{s}\right)$. The presence of moisture reduces the diffusivity value. Therefore, for these analyses, a value (corresponding to dry conditions) of $1.0 \times 10^{-3} \mathrm{~cm}^{2} / \mathrm{s}\left(1.6 \times 10^{-4} \mathrm{in}^{2} / \mathrm{s}\right)$ was used. A value 10 times larger, based on diffusion in air corrected for moisture and tortuosity, was used in the Hanford Solid Waste Performance Assessments (Wood 1994b and Wood 1996).

Sensitivity cases center around altering the presumed strata and hence their hydrologic properties. The strata changes (sensitivity) investigated in this interim performance assessment are given in Section 3.4.4.2. 


\section{HNF-EP-0884}

Rev. 1

3.4.4.4 Vadose Zone Geochemical Retardation Factors. Chemical interactions with the soil in the vadose zone can greatly slow the transport of contaminants. The amount of slowing is described by a multiplicative factor known as the geochemical retardation factor. Geochemical retardation factors for these analyses are based on extensive laboratory work performed at the Hanford Site. This work is summarized in Kaplan (1995a and 1995b).

Geochemical retardation in unsaturated conditions is predicted to be

$$
R_{f}=1+\rho K_{d} / \theta
$$

where $R_{i}$ is the geochemical retardation factor (dimensionless)

$\rho \quad$ is the bulk density of the material $\left(\mathrm{M} / \mathrm{L}^{3}\right)$

$\mathrm{K}_{\mathrm{d}} \quad$ is the chemical distribution coefficient $\left(\mathrm{L}^{3} / \mathrm{M}\right)$.

$\theta \quad$ is the volumetric moisture content (dimensionless).

A derivation from the general contaminant transport equation is given in Appendix $\mathrm{D}$, Section D.2.3. The chemical distribution coefficient $\left(\mathrm{K}_{\alpha}\right)$ is measured in the laboratory by comparing the amount of material entrapped in or on the soil matrix compared to the amount in the water phase.

The chemical distribution coefficients used in these analyses are based on the reports of Kaplan 1995a and Kaplan 1995b. In particular, Kaplan (1995a) investigates in detail best estimate $K_{d}$ values for the most important contaminants for our disposal conditions. For other contaminants, the "low $\mathrm{K}_{\mathrm{d}}$ " values for neutral-to-high $\mathrm{pH}$, low salt, low organic, and oxic solutions from Table 6.1 of Kaplan $1995 \mathrm{~b}$ are the bases for the values used. The values are based on experiments using saturated Hanford soils (mainly the sandy sequence). Until planned experiments are completed, the chemical distribution coefficients are assumed independent of moisture and geologic layer.

For convenience in modeling, a subset of $\mathrm{K}_{\mathrm{d}}$ values were used in these analyses. The computer code PORFLOW (see Section 3.5.2.3) treats the chemical distribution coefficients as point-estimate values, not as probability functions. The code calculates the contaminant transport for only $4 \mathrm{~K}_{\mathrm{d}}$ values during a simulation.

Therfore, the actual $\mathrm{K}_{d}$ values were reduced to one of eight values. Five of the values chosen are based on the $K_{d}$ values of the most important elements in these analyses. These elements (and the corresponding $K_{d}$ values) are technetium and selenium $\left(K_{d}=0\right.$ for both), uranium $\left(\mathrm{K}_{\mathrm{d}}=0.6 \mathrm{~m} / \mathrm{g}\right)$, iodine $\left(\mathrm{K}_{\mathrm{d}}=3 \mathrm{~m} / \mathrm{g}\right)$, carbon $\left(\mathrm{K}_{\mathrm{d}}=6 \mathrm{~m} / \mathrm{g}\right)$, and neptunium $\left(\mathrm{K}_{\mathrm{d}}=15\right.$ $\mathrm{m} / \mathrm{g}$ ). Two higher $\mathbf{K}_{\mathrm{d}}$ values, 40 and $100 \mathrm{~m} / \mathrm{g}$, were chosen to represent more retarded elements. Elements with such high $\mathrm{K}_{\mathrm{d}}$ values have very little significance for vadose zone transport within the Hanford Site soils. These higher values used for the chemical distribution coefficients for the less important elements in the computer simulations were selected to be conservative. These values are lower than the recommended values. Table 3-5 shows the recommended values and the values actually used in these analyses. 
HNF-EP-0884

Rev. 1

Table 3-5. Chemical Distribution Coefficients $\left(K_{\partial}\right)$ for the Base Analysis Case ${ }^{a}$

\begin{tabular}{|c|c|c|c|c|c|}
\hline Element & $\mathrm{K}_{\mathrm{d}}(\mathrm{m} \ell / \mathrm{g})$ & Element & $\mathrm{K}_{\mathrm{d}}(\mathrm{m} / \mathrm{g})$ & Element & $\mathrm{K}_{d}(\mathrm{~m} / \mathrm{g})$ \\
\hline Ac & $67->40$ & Am & $67->40$ & C & 6 \\
\hline $\mathrm{Ce}$ & 100 & $\mathrm{Cm}$ & $106->100$ & $\mathrm{Co}$ & $1200 \rightarrow 100$ \\
\hline $\mathrm{Cs}$ & $540->100$ & $\mathrm{Eu}$ & 100 & $\mathrm{I}$ & $3^{b}$ \\
\hline $\mathrm{Nb}$ & $50 \rightarrow 40$ & $\mathrm{Ni}$ & $50->40$ & $\mathrm{~Np}$ & $15^{\mathrm{b}}$ \\
\hline $\mathrm{Pa}$ & $10->6$ & $\mathrm{~Pb}$ & $13000 \rightarrow 100$ & $\mathrm{Pu}$ & $80->40$ \\
\hline $\mathrm{Ra}$ & $24 \rightarrow 15$ & $\mathrm{Se}$ & $0^{b}$ & Sn & 100 \\
\hline $\mathrm{Sr}$ & $5 \rightarrow 3$ & $\mathrm{Tc}$ & $0^{b}$ & $\mathrm{Th}$ & 40 \\
\hline $\mathrm{U}$ & $0.6^{\mathrm{b}}$ & $\mathrm{Zr}$ & $90->40$ & others & 0 \\
\hline
\end{tabular}

${ }^{2}$ The number to the left of the arrow is the best estimate of the $K_{d}$ value, the number to the right of the arrow is a conservative estimate to minimize the number of computer simulations since the code only uses $4 \mathrm{~K}_{\mathrm{d}}$ values at a time.

${ }^{b}$ Data taken from Kaplan (1995a), others from Kaplan (1995b).

Because radionuclides spend significantly shorter time in the unconfined aquifer than in the vadose zone, no credit for increased travel time in the unconfined aquifer due to geochemical retardation was taken.

Sensitivity cases were used to judge the effects of different $K_{d}$ values. Two cases used different values for $K_{d}$ for uranium than are used in the base analysis case. One case used a $K_{d}$ value of zero for uranium. This was the conservative value used in earlier environmental assessments. The other used a $\mathrm{K}_{d}$ value of $100 \mathrm{~m} / \mathrm{g}$ for uranium in concrete (Krupka 1995) and $K_{d}$ value of 0 for uranium everywhere else in the system. Another sensitivity case used $K_{d}=0.1$ $\mathrm{m} \ell / \mathrm{g}$ for technetium and selenium.

3.4.4.5 Unconfined Aquifer Properties. No data are available on the hydraulic parameters for the immediate vicinity of the proposed disposal site. The hydraulic parameters to be used are from the Environmental Restoration Contractor (ERC) sitewide model of the Hanford unconfined aquifer (Law 1996). This model was created for the DOE's remedial restoration effort at the Hanford Site. Table 3-6 gives the hydraulic parameters immediately around the disposal site and their values used for these analyses. Measured data are planned for the preliminary performance assessment.

For calculations involving a larger region of the Hanford Site, the ERC Hanford Sitewide Groundwater Model was used. This model contains 18 hydrogeologic material types. The material identification numbers for the upper and lower layers are shown in Figures 3-3 and 3-4, respectively. The hydrologic parameters are displayed in Table 3-7. Hydraulic conductivities 
HNF-EP-0884

Rev, 1

for the 200 East and West Areas were obtained from Connelly et al. (1992a and 1992b) while those for other areas were obtained from Thorne and Newcomer (1992). Because almost all the aquifer tests used to infer data contained in these compilations were single well tests, no information is available for estimating the storage parameters. The aquifer test results were interpolated from point measurements to areal values with the application of the software program EarthVision ${ }^{1}$.

Table 3-6. Hydraulic Parameters for Unconfined Aquifer Immediately Around the Disposal Site (Law 1996)

\begin{tabular}{||c|c|}
\hline \multicolumn{1}{|c|}{ Parameter } & Value \\
\hline $\begin{array}{l}\text { Saturated hydraulic conductivity }(\mathrm{cm} / \mathrm{s}) \\
\text { Ringold Formation } \\
\text { Hanford formation }\end{array}$ & $\begin{array}{l}0.095 \\
3.6\end{array}$ \\
\hline Effective porosity & 0.1 \\
\hline Ringold aquifer thickness $(\mathrm{m})$ & 20. \\
\hline
\end{tabular}

EarthVision is a registered trademark of Dynamic Graphics, Inc. 


\section{HNF-EP-0884}

Rev. 1

Table 3-7. Element Material-Zone Flow Properties. (Law 1996)

\begin{tabular}{|c|c|c|c|}
\hline \multirow[t]{2}{*}{ Zone } & $\begin{array}{c}\text { Horizontal } \\
\text { Saturated Conductivity }(\mathrm{cm} / \mathrm{s})\end{array}$ & \multirow[t]{2}{*}{ Storage } & \multirow[t]{2}{*}{ Effective Porosity } \\
\hline & $\begin{array}{c}\mathrm{K}_{\mathrm{xx}}=\mathrm{K}_{\mathrm{yy}} \\
\mathrm{K}_{\mathrm{zz}}=0.1 * \mathrm{~K}_{\mathrm{xx}} \\
\end{array}$ & & \\
\hline 1 & $2.53 \mathrm{e}-3$ & $1.0 \mathrm{e}-4$ & 0.10 \\
\hline 2 & $6.03 e-3$ & $1.0 \mathrm{e}-4$ & 0.25 \\
\hline 3 & $1.59 \mathrm{e}-2$ & $1.0 \mathrm{e}-4$ & 0.10 \\
\hline 4 & $2.06 \mathrm{e}-2$ & $1.0 \mathrm{e}-4$ & 0.10 \\
\hline 5 & $4.44 \mathrm{e}-2$ & $1.0 \mathrm{e}-4$ & 0.25 \\
\hline 6 & $2.29 \mathrm{e}-1$ & $1.0 \mathrm{e}-4$ & 0.25 \\
\hline 7 & $8.25 \mathrm{e}-2$ & $1.0 \mathrm{e}-4$ & 0.10 \\
\hline 8 & $9.52 \mathrm{e}-2$ & $1.0 \mathrm{e}-4$ & 0.25 \\
\hline 9 & $1.37 \mathrm{e}-1$ & $1.0 \mathrm{e}-4$ & 0.25 \\
\hline 10 & $1.75 \mathrm{e}-1$ & $1.0 \mathrm{e}-4$ & 0.25 \\
\hline 11 & $2.44 \mathrm{e}-1$ & $1.0 e-4$ & 0.25 \\
\hline 12 & $2.85 \mathrm{e}-1$ & $1.0 \mathrm{e}-4$ & 0.25 \\
\hline 13 & $4.44 \mathrm{e}-1$ & $1.0 \mathrm{e}-4$ & 0.25 \\
\hline 14 & $9.52 \mathrm{e}-1$ & $1.0 \mathrm{e}-4$ & 0.25 \\
\hline 15 & 2.38 & $1.0 \mathrm{e}-4$ & 0.25 \\
\hline 16 & 3.59 & $1.0 \mathrm{e}-4$ & 0.25 \\
\hline 17 & 5.81 & $1.0 \mathrm{e}-4$ & 0.25 \\
\hline 18 & 6.76 & $1.0 \mathrm{e}-4$ & 0.25 \\
\hline
\end{tabular}


HNF-EP-0884

Rev. 1
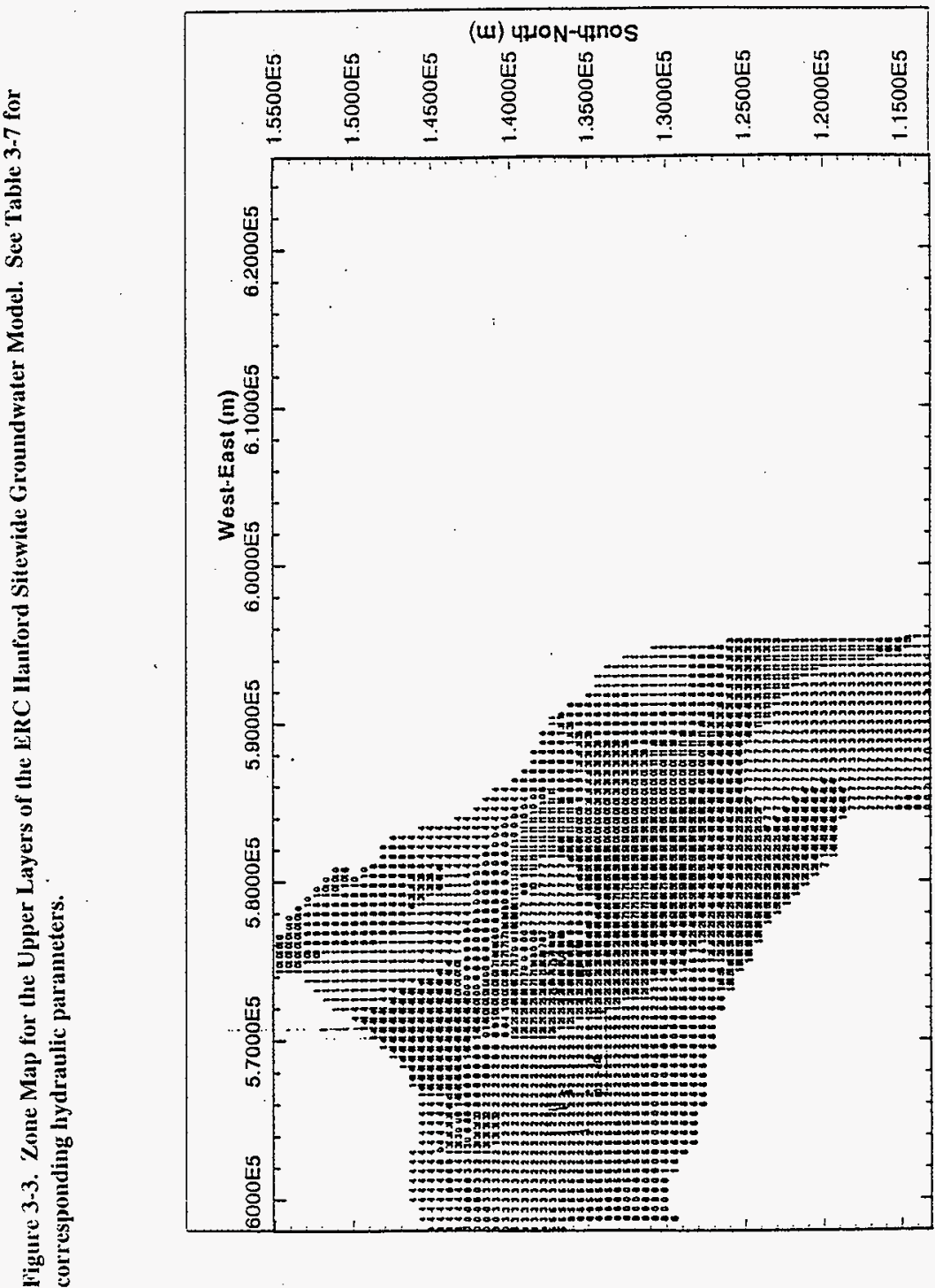


\section{(W) 4HON-4nNOS}

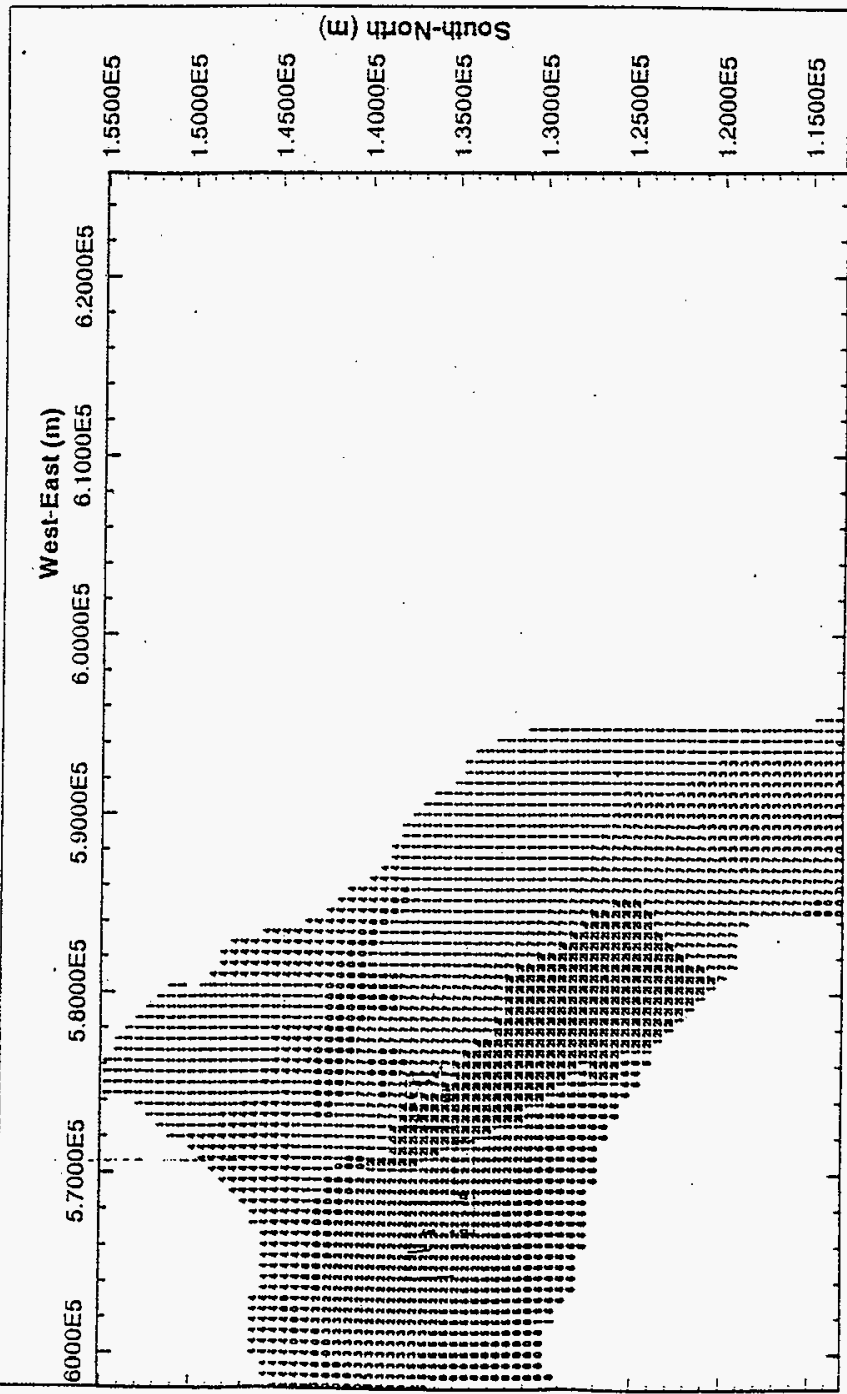

5 


\section{HNF-EP-0884 \\ Rev. 1}

\subsubsection{Waste Package}

3.4.5.1 Introduction. This section describes the conceptual model for the waste package, which consists of the container and the waste form. The contents of the waste package are currently unknown because an effort is under way to privatize the immobilized waste function of (TWRS) (Section 2.3.5). Sections 3.4.5.2 through 3.4.5.5 describe what is known about the waste package components. This description includes the release rate from the waste form. Alternative waste forms and release rates that were used in sensitivity cases are also discussed.

3.4.5.2 Container. The final TWRS privatization Request for Proposal (RFP) (DOE-RL 1996) outlines the type of container that would be acceptable. The aspects of the container that affect the performance assessment are summarized here. The container would be an unspecified metal. The nominal outside dimensions of the package are 1.8 by 1.2 by 1.2 meters (about 6 by 4 by 4 feet). The thickness depends on the type of metal used. It must be thick enough to meet the shielding requirement for a maximum contact dose rate of $1 \mathrm{rem} / \mathrm{hr}$. The stacking height of containers was assumed to be 7.2 meters ( 23.6 feet), which is 6 containers high, consistent with the RFP. Filler material is to be added to reduced void space to less than $1 \%$ of the original container volume.

The conceptual model for the performance and degradation of the waste package ignores the presence of the container. The RFP (DOE-RL 1996) only specifies that the container be made out of metal. Thus the content and durability of the container is not yet known. For these analyses, the container material was assumed to have no effect on hydraulics, chemical retardation, or waste form performance. Once the container has been selected, testing on the container material and container-waste form interactions will be planned to determine the effect of the container degradation on waste form performance.

3.4.5.3 Waste Form. The TWRS privatization RFP (DOE-RL 1996) does not specify a waste form. The waste form will be based on maximum package volume related to gram-mole of waste sodium content and on release rates. For the base analysis case, the waste form is not defined. Only a release rate is prescribed (Section 3.4.5.4). The shape of the waste form is assumed to be nearly cubical. The inventory is also assumed to be evenly distributed among the waste packages produced. Because the waste form (combined with the local chemical consitions [amount of water presence, $\mathrm{pH}$, etc.]) will control the release rate of the radionuclide contaminants, related sensitivity cases are described in the next section.

\subsubsection{Waste Form Radionuclide Release Rate. Although neither the final TWRS} privatization RFP (DOE-RL 1996) nor the resulting contracts specify a waste form, the request and contracts do specify initial (the first 7 days) fractional radionuclide release rates. The initial fractional radionuclide release rate from the waste form averaged over all the containers shall not be greater than:

$$
\begin{aligned}
& \text { - } \quad 1.4 \mathrm{E}-13\left(\mathrm{~s}^{-1}\right)[4.4 \mathrm{ppm} / \mathrm{y}] \text { for }{ }^{79} \mathrm{Se},{ }^{129} \mathrm{I},{ }^{237} \mathrm{~Np} \text {, and uranium isotopes } \\
& \text { - } \quad 2.8 \mathrm{E}-14\left(\mathrm{~s}^{-1}\right)[0.88 \mathrm{ppm} / \mathrm{y}] \text { for }{ }^{99} \mathrm{Tc} .
\end{aligned}
$$




\section{HNF-EP-0884}

\section{Rev. 1}

For the hypothetical waste form used in the base analysis case, the time dependence of the radionuclide release rate was calculated using the non-technetium initial fractional release rate (that is, $4.4 \mathrm{ppm} / \mathrm{y}$ ) and the following assumptions:

1. The waste form corrosion rate is constant in time and does not vary with location in the vault.

2. The radionuclide release rate is proportional to the waste form corrosion rate and the inventory density at the surface.

3. The waste form corrosion rate is proportional to the instantaneous surface area.

4. The radionuclides are uniformly spatially distributed in each waste form.

5. Each linear dimension of the waste form decreases at a constant rate.

6. The waste form has similar lengths in each dimension (for example, a sphere or a cube).

Assumption 2 is perhaps the most questionable assumption. Waste form corrosion rates and, more importantly, contaminant release rates are strong nonlinear functions of the local physical and chemical environment. It is certain that these properties will vary as a function of time and space in the disposal facility. However, to account for these effects in computer simulations requires detailed physical and chemical process models for waste form corrosion. Because the waste form and other details of the disposal facility design have not yet been specified, assumption 2 was used as an enabling assumption. Computer simulations of the physical and chemical processes for the corrosion and contaminant release for a silicate waste form are performed as sensitivity cases.

Using these assumptions, the time-dependent release rate is derived as follows. See Mann (1995b) for details. The first four assumptions yield:

$$
R R R(t)=C * S(t) * I(t) / V(t)
$$

where:
$\operatorname{RRR}(\mathrm{t})$
is the radionuclide release rate $[\mathrm{Ci} / \mathrm{t}]$
$\mathrm{t}$ is the time [t]
C
is the corrosion rate [ $\mathrm{R} / \mathrm{t}]$, taken to be independent of time and chosen so
that the non-Tc rate given in the request for proposal is meet
$S(t) \quad$ is the surface area of the waste form $\left[\ell^{2}\right]$
I is the inventory in the waste form [Ci]
$\mathrm{V}(\mathrm{t}) \quad$ is the volume of the waste form. $\left[\ell^{3}\right]$ 


\section{HNF-EP-0884 \\ Rev. 1}

$$
\mathrm{I}(\mathrm{t}) / \mathrm{V}(\mathrm{t})=\mathrm{I}(0) / \mathrm{V}(0)
$$

Then

$$
R R R(t)=C * S(t) * I(0) / V(0)
$$

The shape of the waste form and Assumption 5 determine the rate at which the surface area decreases. For the base analysis case, the waste form was assumed to be nearly cubical. The surface area then becomes:

$$
\begin{aligned}
\mathrm{S}(\mathrm{t}) & =\mathrm{K} 1 * \mathrm{x}(\mathrm{t})^{2}=\mathrm{K} 1 *[\mathrm{~K} 2 *(\mathrm{~T}-\mathrm{t})]^{2} \\
& =\mathrm{K} 3 *(\mathrm{~T}-\mathrm{t})^{2}
\end{aligned}
$$

where,
$x$
is the time-dependent length $[\ell]$
$\mathrm{T} \quad$ is the time for all the radionuclides to be released from the waste form $[\mathrm{t}]$
$\mathrm{K} 1, \mathrm{~K} 2, \mathrm{~K} 3$ are constants [various units].

The radionuclide release rate for a cubical waste form then becomes

$$
\begin{aligned}
\operatorname{RRR}(\mathrm{t}) & =\mathrm{C} * \mathrm{~K} 3 *(\mathrm{~T}-\mathrm{t})^{2} * \mathrm{I}(0) / \mathrm{V}(0) \\
& =\mathrm{K} 4 *(\mathrm{~T}-\mathrm{t})^{2} * \mathrm{I}(0) .
\end{aligned}
$$

The constant $\mathrm{K} 4$ is determined by the integral over time of the radionuclide release rate from 0 to $T$. The result of the integral is the total inventory, $I(0)$. Thus,

$$
\mathrm{K} 4=3 / \mathrm{T}^{3} \text {. }
$$

The radionuclide release rate becomes:

$$
R R R(t)=3 * I(0) *(T-t)^{2} / T^{3}
$$

The value of $T$ can be determined at $t=0$. At $t=0, R R R(0) / A(0)$ is the initial fractional radionuclide release rate [FRRR(0)]. This rate is given in the RFP. Thus, the time for the waste form to release all the radionuclides is:

$$
\mathrm{T}=3 / \operatorname{FRRR}(0) .
$$

The last two equations were used in the base analysis case for the time-dependent radionuclide release rate from the waste form. Table 3-8 displays their simplified form. 

Case

Relative Radionuclide Release Rate from the Waste Form (ppm/year) =

$3 *[\mathrm{~T} \text { - time }(\mathrm{years})]^{2} / \mathrm{T}^{3}$, where $\mathrm{T}=6.8 \times 10^{5}$ years

Calculations (McGrail 1994) show that the temperature rise from decay in the waste form in the disposal facility is less than $7^{\circ} \mathrm{C}$. The soil above the disposal facility will provide a thermal shield. Thus although the glass corrosion rate is temperature-dependent, the release rate is assumed not to change because of temperature effects.

Several sensitivity calculations on contaminant release were performed because the release rate is important to the performance assessment. Some of the sensitivity cases are variations of the RFP specifications. Others involve a mechanistic estimation of the release rate as a function of space and time based on experimental data. Still others investigate the effects of different release rates caused by relatively small pieces of waste form.

Two sensitivity cases focused on variations of the RFP specifications. The base analysis case was based on a waste form that releases all radionuclides at a rate proportional to the inventory. However, the RFP specifies that the rate for technetium release be a factor of 5 slower based on initial inventories. Such a reduction can occur if the technetium is trapped or if 80 percent of the technetium is removed during waste seperation. One sensitivity case based on the RFP analyzes the effect of trapping the technetium. The case of removing 80 percent of technetium from the inventory is treated as an inventory sensitivity case (Section 3.2.5). The other variation on the RFP was to assume that the waste form shape is not nearly cubical, but plate-like. This leads to a constant non-technetium release rate of $4.4 \mathrm{ppm}$ per year for 227,000 years.

The base analysis case is built on a contract specification. Some sensitivity cases were built on how the waste form is expected to behave. In these cases, the waste form was assumed to be silicate glass. This waste form was the leading candidate before privatization and is the only waste form for which the RFP provides an acceptable performance test. The waste form probably will be a silicate glass. The release rate for these sensitivity cases results from the model discussed in Section 3.3.4.2 and implemented in the AREST-CT computer code (Section 3.5.2.2).

3.4.5.5 Getter or Filler Material. The TWRS privatization RFP (DOE-RL 1996) states that the container may not have void space greater than 1 percent of the volume. This means that a getter or filler material may be part of the waste form. A getter material is a material that chemically combines or traps selected radionuclides. This "trapping" restricts the radionuclides movement downward. Because the form of the waste package is not known, the base analysis case assumed that the waste container was completely filled with the stabilized waste form. No getter or special filler materials are used, only backfill soil is between the waste containers. 


\section{HNF-EP-0884}

Rev. 1

\subsubsection{Waste Disposal Facility}

3.4.6.1 Introduction. The disposal facility concepts summarized in Section 2.4 and given in Eiholzer (1995) are used for the conceptual model. Concept 1 (see Figure 2-19) was used for the base analysis case. Specific aspects of Concept 2 (see Figures 2-20 and 2-21) were used for sensitivity studies. These concepts were used because the actual disposal facility has not been designed, but these concepts are thought to feature the components thought likely to be in the final design.

Sections 3.4.6.2 through 3.4.6.6 cover the specific key components of the disposal concepts. These components are the surface barrier, the capillary barrier, the water conditioning layer, and the vault layout. Values used for each component and any related sensitivity studies are discussed. Section 3.4.6.7 covers the degradation of the man-made portion of the disposal facility.

3.4.6.2 Surface Barrier. The surface barrier is the uppermost component of the waste disposal facility. The surface barrier is designed to store water from precipitation long enough for most of the water to evaporate or transpire through plants in the Hanford Site's arid climate. The surface barrier in the disposal facility concepts is expected to be a Hanford-type surface barrier (Myers 1994) without the asphalt layer. The top of the surface barrier will be flush with the soil surface, which is 221 meters ( 725 feet) above sea level. The barrier covers the entire disposal facility. The barrier extends 1 meter ( 3.3 feet) beyond the outside edge of the over all facility and 8.75 meters (28.7 feet) beyond each vault row for Concepts 1 and 2, respectively. This is the distance that the sand-gravel capillary barrier (next subsection) extends beyond the edge.

The surface barrier is not explicitly modeled in the computer simulations. Rather, the rate of moisture moving through the surface barrier (or the degraded barrier) and passing into the soil beneath it is considered the top boundary condition for the computer simulation. The value for this rate of moisture movement (known as the infiltration rate) is discussed in Section 3.4.7.

3.4.6.3 Sand-Gravel Capillary Barrier. The disposal facility concepts include a sand-gravel capillary barrier beneath the surface barrier. The capillary barrier is designed to divert water away from the disposal vaults. The barrier is a pyramid with 1 meter ( 3.3 feet) of sand on top of gravel (Figure 2-21). The pyramids for Facility Concepts 1 and 2 have $\sim 2^{\circ}$ and $\sim 5^{\circ}$ slopes, respectively. The pyramids are 4 and 2 meters (about 14 and 6.5 feet) high for Concepts 1 and 2 , respectively. The barriers will extend laterally beyond the vaults to mirror the surface barrier. Based on University of Washington experiments for the grout program (Kramer 1989), the sand is not expected to migrate into the gravel even under seismic shaking.

Disposal Facility Concept 1 includes a 1-meter (3.3-feet)-thick gravel wall along the outside vertical concrete walls. This gravel wall is a side capillary barrier which encourages the moisture to remain in the soil and not pass through the gravel into the disposal facility. Mann (1995d) indicates that a gravel wall will improve the moisture movement around the facility.

Three sensitivity cases looked at the effects of the capillary barrier. The first case

$$
3-35
$$




\section{HNF-EP-0884}

Rev. 1

included the large capillary barrier over the top of the vault, but no side capillary barrier The second case did not contain any sand-gravel capillary barriers. The last case looked at the influence of the size of the capillary barrier. In this case, the effects of the capillary barrier for Concept 2 were compared to the effects of the capillary barrier for Concept 1. The widths of the capillary barriers for Concepts 1 and 2 are 208 and 41 meters (682 and 134.5 feet), respectively.

\subsubsection{Water Conditioning Layer. Each disposal facility concept includes a water} conditioning layer. This layer, which is above the roof of the concrete disposal vaults, is designed to add silicon to any moisture that reaches the layer. If the waste form is a glass, silicon enriched moisture could slow down glass corrosion. For the conceptual model, this water conditioning layer ( 1 meter [ 3.3 feet] thick.) was considered only as back-filled soil. The efficiency of such a water conditioning layer to change the chemical environment inside the disposal vault will be investigated in future analyses.

3.4.6.5 Vault. The concrete structure containing the waste packages is generically called the vault.

As described in Section 2.4.2, the basic unit of the vault is the vault bay. A vault bay consists of four walls, a roof, and a floor (sometimes call a pad) made from concrete. For the conceptual design the concrete structure is assumed to be made from Portland cement. While steel structural reinforcement of the walls is likely to be used in the design, the impacts of the presence of steel were not included in this study because an actual design is not available. The bottom of the vault bay floor is 20.75 meters ( 68 feet) below grade ( 200 meters [656 feet] above mean sea level). The dimensions of the vault bay are given in Table 3-9.

Six vault bays placed end to end make a vault row. For Concept 1 , the vault rows are next to each other, sharing a common wall. For Concept 2, the vault rows are separated by a row width of soil. Such a row of dirt would allow greater radiation protection for workers and a more robust sand-gravel capillary barrier would use more land and cost more. Section 2.4.2 describes and shows the vault layouts. These are summarized in Table 3-10 and displayed in Figures 2-19 (Concept 1) and 2-20 (Concept 2).

Section 3.5.5.6 describes the sensitivity cases analyzed. These cases focused on the different impacts of design features, including vault layout and orientation as well as the effectiveness of various facility components.

3.4.6.6 Filler Material. The disposal facility concepts include filler material between and above the stacks of waste packages inside the vault bays.

The type of filler material has not been chosen. Its main function is to fill the voids between containers and hence minimize subsidence. A secondary purpose can be to act as a higher conductivity path for moisture flow than the waste form packages. By performing such a role, less moisture would be available for waste form dissolution. 
HNF-EP-0884

Rev. 1

Table 3-9. Dimension of a Vault Bay for Base Analysis Case ${ }^{\mathrm{a}}$

\begin{tabular}{|l|l|l|l|l||}
\hline $\begin{array}{l}\text { Part of Vault } \\
\text { Bay }\end{array}$ & \multicolumn{1}{|c|}{ height } & \multicolumn{1}{|c|}{ length } & \multicolumn{1}{c|}{ width } & \multicolumn{1}{|c|}{ thickness } \\
\hline roof (ceiling) & -- & $\begin{array}{l}40 \mathrm{~m} \\
(131 \mathrm{ft})\end{array}$ & $\begin{array}{l}21.5 \mathrm{~m} \\
(70.5 \mathrm{ft})\end{array}$ & $\begin{array}{l}0.76 \mathrm{~m} \\
(2.5 \mathrm{ft})\end{array}$ \\
\hline internal walls & $\begin{array}{l}9 \mathrm{~m} \\
(29.5 \mathrm{ft})\end{array}$ & $\begin{array}{l}\text { dependent on floor } \\
\text { length or width }\end{array}$ & -- & $\begin{array}{l}1 \mathrm{~m} \\
(3.3 \mathrm{ft})\end{array}$ \\
\hline $\begin{array}{l}\text { external walls } \\
\text { (walls next to } \\
\text { soil) }\end{array}$ & $\begin{array}{l}9 \mathrm{~m} \\
(29.5 \mathrm{ft})\end{array}$ & $\begin{array}{l}\text { dependent on floor } \\
\text { length or width }\end{array}$ & -- & $\begin{array}{l}2 \mathrm{~m} \\
(6.6 \mathrm{ft})\end{array}$ \\
\hline floor (pad) & -- & $\begin{array}{l}40 \mathrm{~m} \\
(131 \mathrm{ft})\end{array}$ & $\begin{array}{l}21.5 \mathrm{~m} \\
(70.5 \mathrm{ft})\end{array}$ & $\begin{array}{l}0.76 \mathrm{~m} \\
(2.5 \mathrm{ft})\end{array}$ \\
\hline
\end{tabular}

${ }^{\mathrm{a}}$ Data from Eiholzer (1995). Figures of the facility concepts are in Section 2.4.2.

Table 3-10. Vault Layout for Base Analysis Case ${ }^{\text {a }}$

1. Six (6) vault bays are laid out forming a vault row so that short sides are next to each other, resulting in a length of 246 meters ( 807 feet). A vault row is oriented in the east-west direction.

2. Concept 1 (base analysis case)

a. Ten (10) vault rows are placed parallel to each other, having a common internal wall. Total width is 208 meters ( $682 \mathrm{ft}$ ), resulting in an area of $51,000 \mathrm{~m}^{2}$ (12.6 acres). (Eiholzer 1996)

3. Concept 2 (sensitivity)

a. Thirteen (13) vauit rows are placed parallel to each other. (Eiholzer 1996)

b. Vault rows are separated by 17.5 meters $(57.4 \mathrm{ft})$, with walls on long side being exterior walls. Separations filled with compacted backfill soil created during excavation. The facility (vault rows plus separations) is 515.5 meters $(1,691.3 \mathrm{ft})$ wide, resulting in an area of $127,000 \mathrm{~m} 2$ ( 31 acres).

${ }^{2}$ Data from Eiholzer (1995) expect where noted. Section 2.4.2 contains figures (2-19 through 221) on the facility concepts.

The amount of filler material will depend on the stacking arrangement and number of waste packages. Because the actual arrangement is not known, an arrangement was developed for each concept. Figure 3-5 shows the spacing of the waste packages in the vault bays for Concepts 1 and 2, respectively (Eiholzer 1996). The arrangement for Concept 1 was used for the base analysis case. The arrangement for Concept 2 was used as a sensitivity case. The sensitivity case that used the arrangement for Concept 2 determined the effect of a lower radionuclide concentration throughout the disposal facility. The arrangements differ for each concept to examine if the spacing between waste containers affects the overall environmental outcome. 
Figure 3-5. Waste Package Spacing for Disposal Facility Concepts 1 and 2 (from Eiholzer 1996).

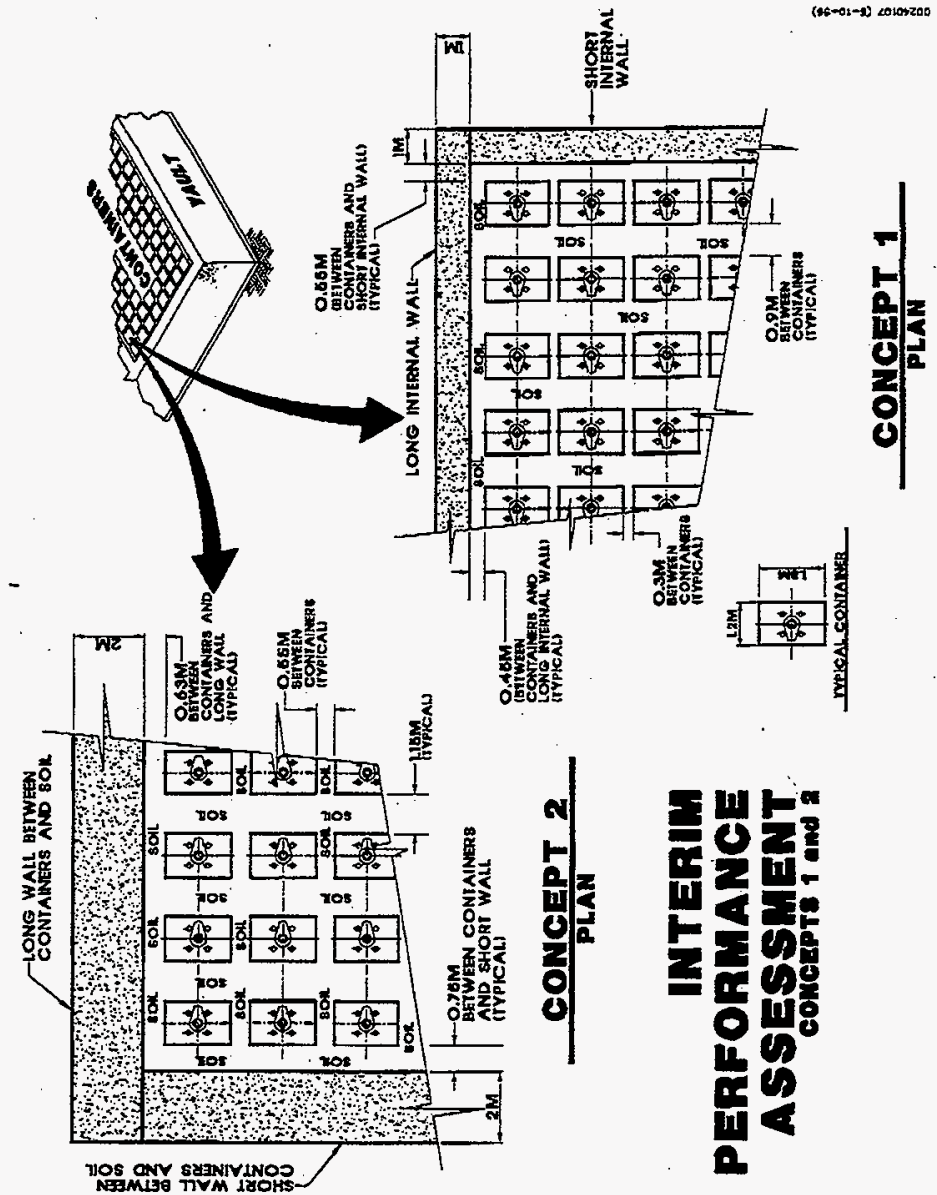




\section{HNF-EP-0884}

\section{Rev. 1}

3.4.6.7 Existing TWRS Disposal Facilities Sensitivity Study. Using the four existing TWRS disposal vaults as part of the disposal action is being considered. These vaults, described in Performance Assessment of Grouted Double-Shell Tank Waste Disposal at Hanford (Kincaid 1995-4), are located about one kilometer east of the proposed disposal site. They could hold about 6 percent of the projected waste volume. Because the vaults are so close to the preferred location, the geology and associated data are very similar. The design for the grout vaults is similar to the presumed facility design, except that the grout vaults have 0.5 to 1.0 meter of asphalt surrounding the concrete structure. No credit is taken for this asphalt, even though, as shown by Kincaid 1995, the asphalt greatly slowed the release of moisture and contaminants from the disposal facility.

3.4.6.8 Degradation of the Waste Disposal Facility. The disposal facility will degrade with time These analyses are based on the assumption that natural materials such as sand and gravel will not degrade, but that manufactured materials such as concrete and glass will. This section discusses components of the waste disposal facility and how they may degrade.

The Hanford surface barrier has a design life of at least 1,000 years (Myers 1994), with deterioration thought to come mainly from the effects of wind and animal intrusion. Although the actual lifetime of the surface barrier is not known, 1,000 years was used for these analyses. The infiltration rate through the barrier will change at the end of the lifetime of the barrier (Section 3.4.7). Because the top of the Hanford-type surface barrier is at ground level, erosion should not pose the problem that it would if the barrier were above ground. Also, the facility's location is not in an area of sand dune formation (Section 2.2.5.2).

Because the capillary barrier is constructed of natural materials, it is assumed not to change from material degradation. Studies (Kramer 1989) have shown that the mixing of the sand and gravel should not significantly affect performance. However, the capillary barrier could fail if much subsidence occurs within the disposal facility. Large drops or gaps in the barrier would cause a discontinuity and possible functional failure. However, calculations (Mann 1995b) indicate that large subsidence is required for the capillary barrier to fail. The subsidence aspect of the capillary barrier was examined in a sensitivity study.

The waste packages will degrade over time from the water-waste form interaction described in Section 3.4.5.4. The effect of the degradation of the waste containers is ignored in these 10,000-year analyses because these materials will degrade so quickly in comparison that the container is assumed to have never existed. The possible effect of changed waste form release rates caused by chemical interactions of the waste form and container await the specifications for these materials.

All concrete structures are considered to be degraded at 500 years. Five hundred years was chosen because of a Nuclear Regulatory Commission staff's draft branch technical position (NRC 1997) recommending that no credit be taken for engineered physical components after at most 500 years. It is expected that future analysis will show that because of the design specifications and conditions on the Hanford Site that the design life of the concrete structures in the disposal facility will be longer than 500 years. 


\section{HNF-EP-0884}

Rev. 1

Earthquakes could accelerate the facility's degradation, particularly that of the concrete structures: However, earthquake analyses will not be performed for these analyses because not enough is known about the design of the disposal facility. As the facility design develops, the influence of earthquakes will be incorporated in future low-level tank waste performance assessments.

Besides the influence of subsidence on the capillary barrier, the following sensitivity cases related to facility degradation were investigated:

- All the concrete was considered degraded at closure. This case indicates how important the concrete structure is to the disposal system.

- The concrete structure degrades at 2,000 years. This case examined the "bathtub" effect that occurs when water collects in the bottom of the disposal facility for a long time and is then immediately released.

\subsubsection{Infiltration Rate}

The infiltration rate is the rate at which water leaves the near-surface zone (the zone affected by plant development, animal intrusion, and evaporation) and enters the sand-gravel capillary barrier. For the first 1,000 years, the near-surface zone is the Hanford-type barrier. That part of the infiltration rate not diverted by the sand-gravel capillary barrier provides the moisture that drives the corrosion of the waste form and carries the contaminants from the facility. This moisture and (starting at some depth into the vadose zone) the diverted water carry the contaminants into the aquifer. Table 3-11 displays the infiltration rates for the base analysis case.

Table 3-11. Infiltration Rates for Base Analysis Case. (Rockhold 1995)

\begin{tabular}{|c|l|}
\hline \hline Parameter & \multicolumn{1}{|c|}{ Recharge Rate Value } \\
\hline \hline At the Disposal Facility & \\
First 1,000 years & $0.5 \mathrm{~mm} / \mathrm{y}(0.02 \mathrm{in} . / \mathrm{y})$ \\
Thereafter & $3.0 \mathrm{~mm} / \mathrm{y}(0.12 \mathrm{in} / \mathrm{y})$ \\
\hline
\end{tabular}

Normally, the infiltration rate is assumed to be equal to the recharge rate, the rate at which water enters the aquifer. This assumption is based on the separate assumption that little water is stored or converted in the vadose zone. Because of the equality of values, recharge rate and infiltration rate are often used interchangeably in performance assessments. In future performance assessments, the removal of water from the system during the corrosion processes will be explicitly included. 


\section{HNF-EP-0884 \\ Rev. 1}

Rockhold et al. (Rockhold 1995) estimated the short-term and long-term recharge rates for the proposed disposal site. The short-term recharge rate $(0.5 \mathrm{~mm} / \mathrm{y}$ [0.02 in./y]) was based on the design specifications of the Hanford surface barrier (Myers 1994 and described in Section $3.4 .6 .2)$. The long-term recharge rate $(3 \mathrm{~mm} / \mathrm{y}[0.12 \mathrm{in} / \mathrm{y}])$ was based on the data for the disposal site from Fayer and Walters (Fayer 1995a). Fayer and Walters estimated recharge rates at locations throughout the Hanford Site based on vegetation cover and soil type. Site-specific measurements will be performed once the location of the disposal facility is decided.

Because the specifications for the surface barrier cite 1,000 years for the design life, the base analysis case used the infiltration rate of $0.5 \mathrm{~mm} / \mathrm{y}$ for the first 1,000 years. Then the infiltration rate was immediately increased to $3 \mathrm{~mm} / \mathrm{y}$. The infiltration through the surface barrier is not expected to increase this quickly. However, analyses on the behavior of the Hanford Surface Barrier beyond 1,000 years on which to base a slower rate of increase do not exist. The infiltration rate outside the region of the surface barrier for the first 1,000 years is expected to be the natural rate $(3 \mathrm{~mm} / \mathrm{y})$. However, this effect is ignored because the barrier covers most of the surface area important for contaminant transport.

The following three sensitivity cases, based on natural conditions were selected to bracket the selected infiltration rates for the disposal facility:

- The first does not consider the surface barrier. The $3 \mathrm{~mm} / \mathrm{y}$ recharge rate was used throughout the calculation.

- The second used the rate that was used in the grout performance assessment (Kincaid 1995). For the grout performance assessment, the surface barrier was assumed to be effective forever. However the recharge rate used in the grout performance assessment was slightly higher, $1 \mathrm{~mm} / \mathrm{y}(0.04 \mathrm{in} . / \mathrm{y})$ than used in the barrier specifications and hence in this analysis.

- The third used a very low recharge rate. The recharge rate of $0.1 \mathrm{~mm} / \mathrm{y}(0.004$ in./y) was used. Preliminary tracer measurements indicate that if sagebrush persists at the disposal site, this recharge rate may be appropriate.

The infiltration rate used for the land-use sensitivity cases given in Sections 3.3.3.3.2 and 3.3.3.4.2 was $100 \mathrm{~mm} / \mathrm{y}$ (3.9 in./y) to simulate irrigated farming.

\subsubsection{Exposure Parameters}

3.4.8.1 Overview. Data are needed to convert radionuclide concentrations into human dose equivalent. The first step is to decide which of several internal and external dose conversion libraries to use. The next step is to calculate dose conversion factors based on the various exposure scenario pathways (Sections 3.3 .3 and 3.3.6). Finally, significant data need to be determined for the inadvertent intrusion scenarios. The values for all the exposure parameters are those recommended in Rittmann 1995. 


\section{HNF-EP-0884}

Rev. 1

3.4.8.2 Internal and External Dose Conversion Factors. Both the Department of Energy and the Environmental Protection Agency have published libraries of values to be used in converting radionuclide concentrations into human dose equivalent. In addition, the Hanford Site has developed its own library. This section describes the choice of libraries used for internal and external dose conversion.

The internal dose conversion factors specify the effective dose equivalent (EDE) from a unit intake (ingested or inhaled). These dose factors reflect the committed dose over a period of 50 years. This period was established by the International Commission for Radiological Protection (ICRP 1977) for determining internal dose and relating it to whole body exposure.

The three internal dose conversion libraries considered for this performance assessment were the ones developed by the DOE (DOE 1988d), the EPA (EPA 1988), and the Hanford Site. The Hanford Site values were based on the GENII computer code system (Napier 1988), which was last revised in 1993 (Rittmann 1993). In most cases, the three libraries have similar values. However, for technetium, a key radionuclide the values greatly differ. The GENII value for ${ }^{99} \mathrm{Tc}$ is 70 percent higher than the DOE value. The EPA value is 12 percent higher than the DOE value. The DOE library (DOE 1988d) was chosen for this performance assessment because of its widespread use in other DOE performance assessments.

External dose conversion factors give the expected dose equivalent to an individual standing in the center of a large contaminated area. The three sources of external dose factors used at the Hanford Site are from the DOE (DOE 1988c) and EPA (EPA 1993), and from the revised values based on GENII (Rittmann 1993). The values in the external dose factors libraries differ more than the values in the internal dose factors libraries. The DOE external dose factors library assumes that all radionuclides are at the surface and that no soil mixing has occurred. Thus, the values of the DOE library lead to larger dose estimates. The GENII and EPA models are similar to each other, but the EPA implementation uses a Monte Carlo approach while GENII uses a deterministic approach. For the key radionuclides important in external exposure, ${ }^{126} \mathrm{Sn}$ and ${ }^{137} \mathrm{Cs}$, the DOE dose factor is about four times larger than the EPA value. The GENII value is about 20 percent larger than the EPA value. Because of its modern database and methods, the EPA library was used in these analyses for external doses.

Although not the intent, the effect of these choices is to choose libraries with the lowest dose factors for the important radionuclides. Sensitivity cases were performed using each of the dose factor libraries.

3.4.8.3 Drinking Water and All-Pathways Dose Conversion Factors. Parameters other than the dose conversion factors are important in converting radionuclide concentrations into doses. This section covers the values needed for the drinking water exposure pathway and the allpathways scenario, the two exposure scenarios considered in this performance assessment.

Water taken from a well is not just taken at the point of maximum contaminant concentration in the ground water, but rather over an interval. Based on the grout performance assessment (Kincaid 1995-8], a well screen depth of 4.6 meters is used. Hand calculations shown that in the 100 meters of travel in the ground water, the contaminants will experience 


\section{HNF-EP-0884}

Rev. 1

little vertical dispersion. Thus the screen depth is assumed to contain all of the contaminants contained in the entire height of the groundwater at the well location.

Pumping water up from the unconfined aquifer can distort the groundwater flow at high pumping rates and hence lower the concentration of radionuclides in the well water. A minimal pumping rate of 10 liters/day (10.6 quarts/day) [ 2 liters/day ( 2.1 quarts/day) per person for a family of 5] is assumed. To maximize the exposure at the 200 East Area boundary and make the calculations simpler, the position of the vaults is assumed to be in the northeast quarter of the disposal area.

For the drinking water scenario, the dosimetry parameter needed is the amount of water consumed. The value commonly used in performance assessments, 2 liters/day, is the value used in these analyses. This value is 35 percent higher than the 1.48 liters/day ( $1.56 \mathrm{qt} /$ day) measured for the western United States by the EPA (Yang 1986). The resulting drinking water dose factors used for this performance assessment are displayed in Table B-1 in Appendix B.

As its name implies, the all-pathways scenario is more inclusive. This scenario includes drinking water, ingesting and inhaling soil, ingesting food, and receiving external radiation. Rittmann (1995) provides a complete description of all the parameters and the justification for the selected values. The resulting dose factors are displayed in Table B-2 in Appendix B. The following paragraphs summarize these pathways and the values used in this performance assessment.

Soil is taken into the body by ingestion and by inhalation. Soil ingestion is assumed to occur through hand-mouth contact, licking the lips, and similar motions at the rate of 100 milligrams per day ( 0.0035 ounce/day) (EPA 1989a). Soil inhalation is based on the methods found in NUREG/CR-5512 (Kennedy 1992) and results in $2.3 \mathrm{mg} /$ day $(0.00008 \mathrm{oz} /$ day) being inhaled.

Food ingestion exposure is based on the EPA's Exposure Factors Handbook (EPA 1989a), daily consumption factors for the western United States (Yang 1986), and animal, dairy, and plant intake rates (Kennedy 1992). However, water consumption is taken as 2 liters per day. For this calculation it is assumed that half of the person's meat is raised on irrigated fodder and 25 percent of the person's vegetables come from the garden.

Finally, the individual is exposed daily to radiation emitted by the contaminated soil. For these analyses, the time for external exposure was assumed to be 4,120 hours per year (Rittmann 1995).

The all-pathways dose factors found in Table B-2 are nearly the same as the drinking water dose factors found in Table B-1. The drinking water pathway is the largest contributor for most nuclides. Table B-2 shows the ratios between the all-pathways dose factors and the drinking water dose factors.

3.4.8.4 Inadvertent Intruder Parameters. Selecting values for parameters important in inadvertent intruder scenarios is very difficult. Such intrusion is postulated to be in the future so 


\section{HNF-EP-0884}

\section{Rev. 1}

that the nature of the intrusion is ill-defined. Moreover, uncertainty abounds about the proper values to be used in a given scenario. This performance assessment looks at the driller and homesteader scenarios (Section 3.3.3.4).

For the driller scenario the most important parameters are the amount of waste taken from the site, the size of the area over which the waste is spread, and the physical integrity of the waste.

The amount of waste material taken from the disposal site is assumed to be the stack height of the waste (7.2 meters [23.6 feet] from Section 3.4.5.2) times the area of the bore hole for the well. For this performance assessment, the diameter of the well is assumed to be 0.3 meter ( 1 foot). Although consistent with the diameters used in earlier Hanford Site performance assessments, this value is larger than the range of diameters (10.2 to 25.4 centimeters [4 to 10 inches]) commonly found in local communities. In future performance assessments, an estimate of the well diameter based on actual experience will be used.

The area over which the waste is spread is initially $100 \mathrm{~m}^{2}$ (about $1,100 \mathrm{ft}^{2}$ ). This value has been historically used in Hanford performance assessments.

The integrity of the waste form becomes important in determining the amount of radionuclides available for inhalation or uptake by plants and animals. For the base case analysis, 90 percent of the radionuclides exhumed is assumed to stay within the waste form. The importance of this assumption was investigated by sensitivity cases.

The worker at the well drilling site is exposed for 5 days ( 8 hours per day). The dose to the worker is the sum of the contributions from inhalation of resuspended dust $\left(0.1 \mathrm{mg} / \mathrm{m}^{3}\right)$, ingestion of trace amounts of soil (100 mg/day), and external exposure at the center of a slab of contaminated soil for 40 hours. The dose factors for this drilling scenario can be found in Table B-3 in Appendix B.

The most important parameters in the second phase of the inadvertent intruder scenario, the homesteader scenario, are the volume of waste exhumed, the area over which it is spread, and the integrity of the waste form. For this scenario, the depth over which the waste is mixed with the soil and the parameters from the all-pathways scenario are also important.

The same amount of waste is exhumed as in the driller scenario, but now the waste is assumed to be spread over a larger area. The area over which the waste is spread is assumed to be $500 \mathrm{~m}^{2}(0.124 \mathrm{acre})$. In all earlier Hanford Site performance assessments, the garden area has been $2,500 \mathrm{~m}^{2}\left(0.62\right.$ acre). The $500-\mathrm{m}^{2}$ garden was chosen for this performance assessment because the size represents an area large enough to supply a significant portion of a person's vegetable and fruit diet. Household gardens in the vicinity of the Hanford Site range in size from $10 \mathrm{~m}^{2}$ to $1,000 \mathrm{~m}^{2}\left(107 \mathrm{ft}^{2}\right.$ to 0.25 acre) (Napier 1984).

The value taken for the depth of the soil mixing is $15 \mathrm{~cm}$ (5.9 in.). This value has been used in other onsite performance assessments and is typical for root systems of garden vegetables. 


\section{HNF-EP-0884}

Rev. 1

The values for other parameters for this scenario are taken from the driller scenario (immediately above) and from the all-pathways exposure scenario (Section 3.4.8.3). The resulting dose factors are displayed in Table B-4 in Appendix B.

3.4.8.5 Other Scenarios. Two other scenarios (integrated dose estimate and the glacial-age catastrophic flood) have additional parameters. For the cases where integrated doses are calculated, populations of 25 for a public drinking water system ( 40 CFR 141) and 5,000,000 for the number of people living on the Columbia River (Kincaid 1995-5) were used. The flow rate in the Columbia River was taken to be $1000 \mathrm{~m} / \mathrm{s}$ (the lower end of typical values, $1,000-3,000$ $\mathrm{m}^{3} / \mathrm{s}$, cited by Woodruff 1992). For the catastrophic flood scenario, the waste is conservatively assumed to be redeposited uniformly to a depth of 20 meters ( 65.6 feet, the depth of the bottom of the disposal facility) over an area equivalent to the Hanford Site $\left(1,450 \mathrm{~km}^{2}[560 \mathrm{mi}\}\right)$.

It is realized that the exposure parameters chosen for the base analysis case may not be appropriate for Native American communities. Future performance assessments will treat these communities.

3.4.8.6 Half-lives. The half-lives and decay chain branching ratios are taken from Radioactive Decay Data Tables (Kocher 1981). The half-lives and other decay data used in this analysis are presented in Table 3-12. Normally these data have very small uncertainties. However, for two key nuclides in this study $\left({ }^{79} \mathrm{Se}\right.$ and $\left.{ }^{126} \mathrm{Sn}\right)$, the half-lives are based on a single measurement from the 1940's. Unpublished data from the Pacific Northwest National Laboratory (PNNL) (Jenquin 1995) indicates that the calculated values of reactor fuel yield in terms of curies/gram of fuel are a factor of 7 higher than measured values for ${ }^{79} \mathrm{Se}$ and a factor of 4.5 higher for ${ }^{126} \mathrm{Sn}$. Because the fission yield is well known and burnout cross sections are insignificant, these more recent results indicate that the half-life values for ${ }^{79} \mathrm{Se}$ and ${ }^{126} \mathrm{Sn}$ given in most standard references are about a factor of five too small. An increase in the half-lives would imply a decrease in the inventories (expressed in Curies) used in this analysis.

Table 3-12. Halflife and Other Decay Information

\begin{tabular}{||l|c|c|c|l||}
\hline Parent & Half-live (y) & $\begin{array}{c}\text { Next Long-Lived } \\
\text { Daughter }\end{array}$ & $\begin{array}{c}\text { Number of } \\
\text { Alpha Emitters }\end{array}$ & $\begin{array}{c}\text { Branching } \\
\text { Ratio }\end{array}$ \\
\hline \hline${ }^{3} \mathrm{H}$ & 12.28 & & 0 & 1.0 \\
\hline${ }^{10} \mathrm{Be}$ & $1.60 \times 10^{6}$ & & 0 & 1.0 \\
\hline${ }^{14} \mathrm{C}$ & 5,730 & & 0 & 1.0 \\
\hline${ }^{22} \mathrm{Na}$ & 2.602 & & 0 & 1.0 \\
\hline${ }^{36} \mathrm{Cl}$ & 301,000 & & 0 & 1.0 \\
\hline${ }^{40} \mathrm{~K}$ & $1.277 \times 10^{9}$ & & 0 & 1.0 \\
\hline${ }^{54} \mathrm{Mn}$ & 0.856 & & 0 & 1.0 \\
\hline
\end{tabular}




\section{HNF-EP-0884}

Rev. 1

\begin{tabular}{|c|c|c|c|c|}
\hline Parent & Half-live (y) & $\begin{array}{c}\text { Next Long-Lived } \\
\text { Daughter }\end{array}$ & $\begin{array}{c}\text { Number of } \\
\text { Alpha Emitters }\end{array}$ & $\begin{array}{c}\text { Branching } \\
\text { Ratio }\end{array}$ \\
\hline${ }^{55} \mathrm{Fe}$ & 2.7 & & 0 & 1.0 \\
\hline${ }^{60} \mathrm{Co}$ & 5.271 & & 0 & 1.0 \\
\hline${ }^{59} \mathrm{Ni}$ & 75,000 . & & 0 & 1.0 \\
\hline${ }^{63} \mathrm{Ni}$ & 100.1 & & 0 & 1.0 \\
\hline${ }^{79} \mathrm{Se}$ & 65,000 . & & 0 & 1.0 \\
\hline${ }^{87} \mathrm{Rb}$ & $4.73 \times 10^{10}$ & & 0 & 1.0 \\
\hline${ }^{90} \mathrm{Sr}$ & 28.6 & & 0 & 1.0 \\
\hline${ }^{93} \mathrm{Zr}$ & $1.53 \times 10^{6}$ & ${ }^{93} \mathrm{Nb}^{\mathrm{m}}$ & 0 & 1.0 \\
\hline${ }^{93} \mathrm{Nb}^{\mathrm{m}}$ & 14.6 & & 0 & 1.0 \\
\hline${ }^{94} \mathrm{Nb}$ & 20,300 . & & 0 & 1.0 \\
\hline${ }^{93} \mathrm{Mo}$ & 3,500 . & & 0 & 1.0 \\
\hline${ }^{99} \mathrm{Tc}$ & 213,000 . & & 0 & 1.0 \\
\hline${ }^{106} \mathrm{Ru}$ & 1.01 & & 0 & 1.0 \\
\hline${ }^{107} \mathrm{Pd}$ & $6.50 \times 10^{6}$ & & 0 & 1.0 \\
\hline${ }^{108} \mathrm{Ag}^{\mathrm{m}}$ & 127. & & 0 & 1.0 \\
\hline${ }^{109} \mathrm{Cd}$ & 1.2704 & & 0 & 1.0 \\
\hline${ }^{113} \mathrm{Cd}^{\mathrm{m}}$ & 13.7 & & 0 & 1.0 \\
\hline${ }^{115} \mathrm{In}$ & $4.6 \times 10^{15}$ & & 0 & 1.0 \\
\hline${ }^{121} \mathrm{Sn}^{\mathrm{m}}$ & 55. & & 0 & 1.0 \\
\hline${ }^{126} \mathrm{Sn}$ & 100,000 . & & 0 & 1.0 \\
\hline${ }^{125} \mathrm{Sb}$ & 2.77 & & 0 & 1.0 \\
\hline${ }^{129} \mathrm{I}$ & $1.57 \times 10^{7}$ & & 0 & 1.0 \\
\hline${ }^{134} \mathrm{Cs}$ & 2.062 & & 0 & 1.0 \\
\hline${ }^{135} \mathrm{Cs}$ & $2.30 \times 10^{6}$ & & 0 & 1.0 \\
\hline${ }^{137} \mathrm{Cs}$ & 30.17 & & 0 & 1.0 \\
\hline${ }^{133} \mathrm{Ba}$ & 10.5 & & 0 & 1.0 \\
\hline${ }^{147} \mathrm{Pm}$ & 2.6234 & & 0 & 1.0 \\
\hline
\end{tabular}


HNF-EP-0884

Rev. 1

\begin{tabular}{|c|c|c|c|c|}
\hline Parent & Half-live (y) & $\begin{array}{c}\text { Next Long-Lived } \\
\text { Daughter } \\
\end{array}$ & $\begin{array}{c}\text { Number of } \\
\text { Alpha Emitters } \\
\end{array}$ & $\begin{array}{c}\text { Branching } \\
\text { Ratio } \\
\end{array}$ \\
\hline${ }^{147} \mathrm{Sm}$ & $1.06 \times 10^{11}$ & & 1 & 1.0 \\
\hline${ }^{151} \mathrm{Sm}$ & 90. & & 0 & 1.0 \\
\hline${ }^{150} \mathrm{Eu}$ & 36. & & 0 & 1.0 \\
\hline${ }^{152} \mathrm{Eu}$ & 13.6 & & 0 & 1.0 \\
\hline${ }^{154} \mathrm{Eu}$ & 8.8 & & 0 & 1.0 \\
\hline${ }^{155} \mathrm{Eu}$ & 4.96 & & 0 & 1.0 \\
\hline${ }^{152} \mathrm{Gd}$ & $1.10 \times 10^{14}$ & & 1 & 1.0 \\
\hline${ }^{106} \mathrm{Ho}^{\mathrm{m}}$ & $1,200$. & & 0 & 1.0 \\
\hline${ }^{187} \mathrm{Re}$ & $4.7 \times 10^{10}$ & & 0 & 1.0 \\
\hline${ }^{204} \mathrm{Tl}$ & 3.779 & & 0 & 1.0 \\
\hline${ }^{210} \mathrm{~Pb}$ & 22.26 & & 1 & 1.0 \\
\hline${ }^{226} \mathrm{Ra}$ & 1,600 . & ${ }^{210} \mathrm{~Pb}$ & 4 & 1.0 \\
\hline${ }^{228} \mathrm{Ra}$ & 5.75 & ${ }^{228} \mathrm{Th}$ & 0 & 1.0 \\
\hline${ }^{227} \mathrm{AC}$ & 21.773 & & 5 & 1.0 \\
\hline${ }^{228} \mathrm{Th}$ & 1.9132 & ${ }^{208} \mathrm{~Pb}$ & 5 & 1.0 \\
\hline${ }^{229} \mathrm{Th}$ & 7340. & & 5 & 1.0 \\
\hline${ }^{230} \mathrm{Th}$ & 77000. & ${ }^{226} \mathrm{Ra}$ & 1 & 1.0 \\
\hline${ }^{232} \mathrm{Th}$ & $1.405 \times 10^{10}$ & ${ }^{228} \mathrm{Ra}$ & 1 & 1.0 \\
\hline${ }^{231} \mathrm{~Pa}$ & 32,764 . & ${ }^{227} \mathrm{Ac}$ & 1 & 1.0 \\
\hline${ }^{232} \mathrm{U}$ & 72. & ${ }^{228} \mathrm{Th}$ & 1 & 1.0 \\
\hline${ }^{233} \mathrm{U}$ & 159200. & ${ }^{229} \mathrm{Th}$ & 1 & 1.0 \\
\hline${ }^{234} \mathrm{U}$ & 244,500 . & ${ }^{230} \mathrm{Th}$ & 1 & 1.0 \\
\hline${ }^{235} \mathrm{U}$ & $7.038 \times 10^{8}$ & ${ }^{231} \mathrm{~Pa}$ & 1 & 1.0 \\
\hline${ }^{236} \mathrm{U}$ & $2.34 \times 10^{7}$ & ${ }^{232} \mathrm{U}$ & 1 & 1.0 \\
\hline${ }^{238} \mathrm{U}$ & $4.468 \times 10^{9}$ & ${ }^{234} \mathrm{U}$ & 1 & 1.0 \\
\hline${ }^{237} \mathrm{~Np}$ & $2.14 \times 10^{6}$ & ${ }^{233} \mathrm{U}$ & 1 & 1.0 \\
\hline${ }^{236} \mathrm{Pu}$ & 2.851 & ${ }^{232} \mathrm{U}$ & 1 & 1.0 \\
\hline
\end{tabular}


HNF-EP-0884

Rev. 1

\begin{tabular}{||l|c|c|c|l||}
\hline \hline Parent & Half-live (y) & $\begin{array}{c}\text { Next Long-Lived } \\
\text { Daughter }\end{array}$ & $\begin{array}{c}\text { Number of } \\
\text { Alpha Emitters }\end{array}$ & $\begin{array}{c}\text { Branching } \\
\text { Ratio }\end{array}$ \\
\hline \hline${ }^{238} \mathrm{Pu}$ & 87.75 & ${ }^{234} \mathrm{U}$ & 1 & 1.0 \\
\hline${ }^{239} \mathrm{Pu}$ & $24,131$. & ${ }^{235} \mathrm{U}$ & 1 & 1.0 \\
\hline${ }^{240} \mathrm{Pu}$ & $6,569$. & ${ }^{236} \mathrm{U}$ & 1 & 1.0 \\
\hline${ }^{241} \mathrm{Pu}$ & 14.4 & ${ }^{241} \mathrm{Am}$ & 0 & 1.0 \\
\hline${ }^{242} \mathrm{Pu}$ & $375,800$. & ${ }^{238} \mathrm{U}$ & 1 & 1.0 \\
\hline${ }^{244} \mathrm{Pu}$ & $8.26 \times 10^{7}$ & ${ }^{240} \mathrm{Pu}$ & 1 & 1.0 \\
\hline${ }^{241} \mathrm{Am}$ & 432.2 & ${ }^{237} \mathrm{~Np}$ & 1 & 1.0 \\
\hline${ }^{242} \mathrm{Am}{ }^{\mathrm{m}}$ & 152. & ${ }^{238} \mathrm{Pu}$ & 1 & $0.82782^{\mathrm{a}}$ \\
\hline${ }^{243} \mathrm{Am}$ & $7,380$. & ${ }^{239} \mathrm{Pu}$ & 1 & 1.0 \\
\hline${ }^{243} \mathrm{Cm}$ & 28.5 & ${ }^{239} \mathrm{Pu}$ & 1 & 1.0 \\
\hline${ }^{244} \mathrm{Cm}$ & 18.11 & ${ }^{240} \mathrm{Pu}$ & 1 & 1.0 \\
\hline${ }^{245} \mathrm{Cm}$ & $8,500$. & ${ }^{241} \mathrm{Pu}$ & 1 & 1.0 \\
\hline${ }^{246} \mathrm{Cm}$ & $4,750$. & ${ }^{242} \mathrm{Pu}$ & 1 & 1.0 \\
\hline${ }^{247} \mathrm{Cm}$ & $1.56 \times 10^{7}$ & ${ }^{243} \mathrm{Am}$ & 1 & $0.9174^{b}$ \\
\hline${ }^{248} \mathrm{Cm}$ & $339,000$. & ${ }^{244} \mathrm{Pu}$ & & 1 \\
\hline
\end{tabular}

${ }^{2}$ Remainder goes to ${ }^{242} \mathrm{Cm}$

${ }^{b}$ Remainder undergoes spontaneous fission

\subsection{Performance Analysis Methodology}

This section describes how the performance of the system was determined. That is, this section explains how the data and conceptual models presented in Sections 3.2 through 3.4 are transiated into a numerical model suitable for computer simulation. First the strategy of the computer simulation is introduced. Then the computer code selection criteria are summarized. The codes used are then described with their selection justified. Next the description of how the disposal facility concepts and the natural system are translated into computer models is presented. Finally the parameters used in the computer simulations are given.

Calculations of relatively simple equations (for example, gaseous diffusion or glacial-age catastrophic flood consequences) were done by hand. These equations will be treated in Chapter 4 , where the results are discussed. 


\section{HNF-EP-0884}

Rev. 1

\subsubsection{Integration}

3.5.1.1 Strategy. Previous long-term environmental assessments at the Hanford Site have consistently shown that the groundwater pathway is the most important. This pathway also requires the most calculations. The conceptual model used for this and earlier Hanford Site performance assessments takes eight steps:

1. The water leaves the very near-surface soil region at the infiltration rate.

2. The water moves toward the waste form, most of which is diverted by any intact capillary barrier.

3. The water that is not diverted is chemically modified by the local environment, interacts with the waste form, accumulates contaminants, and again is chemically modified by the local environment.

4. The water (possibly a reduced amount) leaves the disposal facility carrying contaminants with it. Some contaminants may interact with the material in the disposal facility, slowing the release of the contaminants to the surrounding natural environment.

5. The water moves through the undisturbed, unsaturated zone (vadose zone) below the disposal facility down to the unconfined aquifer. The contaminants also are transported through the vadose zone, again possibly undergoing some geochemical sorption.

6. The water and contaminants move and mix with the water in the unconfined aquifer until they are extracted from the aquifer and brought to the surface or until they reach the Columbia River.

7. Contaminants are normally extracted by being carried to the surface with groundwater being pumped through a well.

8. The radionuclide contaminants then result in human exposure through a variety of pathways (ingestion, inhalation, and external radiation).

These eight steps are shown in Figure 3-6 as a flow chart.

The results for each step are computed separately and used in the next step so that computations can be made more easily. Such an approach is taken to maximize computational efficiency. Some of the computer simulations take 100 hours of computer time; some take a few minutes. Each is a highly specialized calculation. However, the overall model is always considered at each step and consistent data are used throughout. 
HNF-EP-0884

Rev. 1

Figure 3-6. Eight Sequential Steps for the Groundwater Pathway

1) Water starts downward journey from the near-surface region.

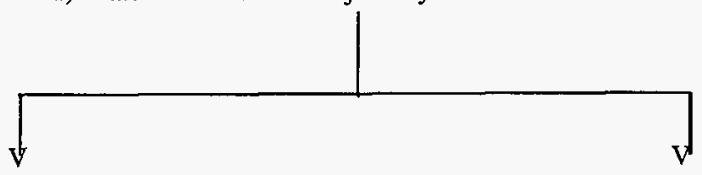

2) Most water diverted by the sand-gravel capillary barrier.

3) Water is chemically modified, interacts with waste form, and accumulates contaminants.

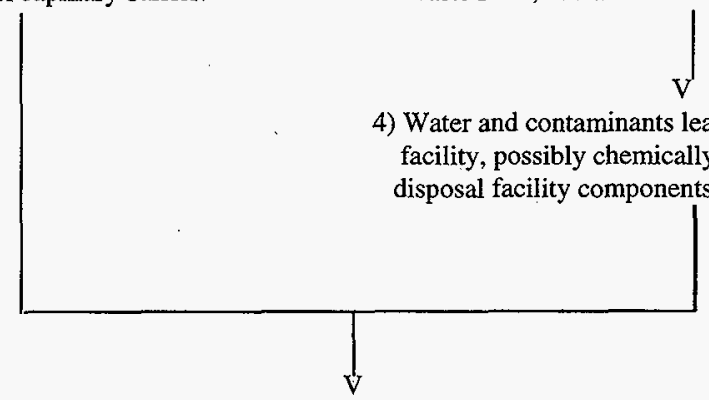

5) Water and contaminants move down through the vadose zone.<smiles>[Tl]</smiles>

6) The contaminants move downgradient in the unconfined aquifer, mixing with the groundwater, diluting the contaminant concentration.<smiles>[AlH][V]</smiles>

7) Water and contaminants are pumped to surface.<smiles>C=[IH]</smiles>

8) Humans receive exposure from contaminants.

The strategy for the current computations is to define a base analysis case, then develop sensitivity cases derived from that base analysis case. In some instances the sensitivity cases are built on an alternative case (such as the one describing disposal facility Concept 2). The results for the base analysis case and the sensitivity cases are presented in Chapter 4. Chapter 5 combines the results of the computer simulations, the results of simpler calculations, and the results of other analyses to integrate and interpret how the contaminants will affect the environment in the long term.

3.5.1.2 Base Analysis Case. The base analysis case provides the best estimate of how the system may evolve given the information available. The base analysis case is not necessarily the way that the system will behave. As more information concerning the waste form, the disposal 


\section{HNF-EP-0884 \\ Rev. 1}

facility design, and disposal site location are gathered, it is expected that the definition of the base analysis case will evolve. The approach used in the base analysis case is conservative, but reasonable. This approach is required by the DOE's Peer Review Panel.

The major features of the base analysis case are as follows:

- The location of the facility is as recommended by Shord (1995)

- The future land-use is as a protected area, without artificial recharge (for example, no irrigated farming occurs)

- The design of the disposal facility is based on Concept 1 (Section 3.4.6)

- The long-term contaminant release rate from the waste form for all elements is that given in the TWRS Privitization specifications (DOE 1996a) for the shortterm release rate for all elements other than Tc. This means that the Tc release rate in the base analysis case is 5 times higher than the $\mathrm{Tc}$ release rate given in the RFP.

- The data for the natural system are those collected and interpreted for this performance assessment (Section 3.4.4).

Mann (1995b) describes the base analysis case in detail. The details of the models and related data for the base analysis case are presented in Sections 3.5.3 and 3.5.4, respectively.

\subsubsection{Computer Codes}

This section discusses the computer codes used for this performance assessment and justifies their technical adequacy. The general selection criteria used to select the major computer codes are first summarized. Succeeding subsections describe each major computer code used and the reason for their selection.

3.5.2.1 General Selection Criteria for Computer Codes. The large computer codes used for this assessment were selected based on meeting general code selection criteria and functional criteria related to the simulation being done. Large computer codes were needed for computing in the following two functional areas:

- Calculation of the contaminant release rate from glass (used only for sensitivity cases in this analysis) and

- Calculation of water flow and contaminant transport.

The codes considered had to first meet the general code selection criteria. 


\section{HNF-EP-0884}

Rev. 1

The general code selection criteria were based on government code selection documents and the experience of others. The waste management code selection criteria of the DOE (Case 1988) and of the NRC (Kozak 1989) were used to develop these selection criteria. The criteria were also shaped by the experience gained from other DOE performance assessments (WSRC 1992, Kincaid 1995-6) and on codes selected for earlier Hanford Site risk assessments (DOE-RL 1991a). The general required selection criteria included the following:

- Having the appropriate scientific framework

- Having documentation covering the underlying theory, use, and verification

- Being under configuration control.

General desirable criteria included the following:

- Suitable hardware requirements

- Suitable complexity

- Flexible interfaces with other codes

- A bias against proprietary codes

- Familiarity of the users with the code.

Mann 1995c details the development of the general selection criteria and the complete criteria.

The actual codes selected also had to meet criteria related to the function being simulated. Sections 3.5.5.2 through 3.5.2.6 summarize the codes chosen and the reasons for their selection. References to specific functional criteria will be given in their sections or related appendices.

\subsubsection{AREST-CT}

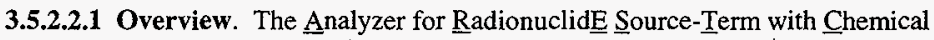
Transport (AREST-CT) code is the source-term code used for some of the sensitivity cases in the interim performance assessment. The base analysis case and many of the sensitivity cases assume the release rate are based on the rates specified in the request for proposal for the waste form (DOE-RL 1996) which was not derived from a simulation of how a waste form would perform. AREST-CT calculates the time-dependent flux of radionuclides released from the waste form. AREST-CT contains two important factors that allow the code to simulate the processes in the disposal facility. First, the code is based on basic principles of physics, chemistry, and thermodynamics which provides the best estimate of contaminant release over the spatial and long time periods of interest. Second, the model for the disposal facility can be coupled with a model for

radionuclide release, thus providing the ability to couple the effects of facility design with waste form performance.

Using chemical reaction rates (including the glass corrosion rates) and moisture values in 


\section{HNF-EP-0884 \\ Rev. 1}

the vaults from PORFLOW (Section 3.5.2.3), AREST-CT provides the source term for the vadose zone calculations. AREST-CT calculates the following:

- The degradation of the waste form with corresponding release of radionuclides

- The chemical reactions that depend on time and space (including the formation of secondary mineral phases and the consumption of water)

- The transport of the water and contaminants through a vertical slice of the disposal facility.

3.5.2.2.2 Selection. AREST-CT was selected because it best meets the criteria and requirements for the disposal system release model (McGrail 1994) and the general code requirements (Mann 1995c). Ten source codes were considered (See Appendix C.3). Whereas some of the codes were comparable to AREST-CT in their ability to describe the physical processes important for the near-field, their ability to describe chemical process was significantly inferior. Similiarly, the codes whose strength was in their ability to model chemical processes were weak in their ability to model the physical processes. AREST-CT also scored high in numerical methods and functionality.

3.5.2.2.3 Code Description. AREST-CT calculates the total mass flux of radionuclides leaving the disposal facility by solving a coupled set of equations. The set describes the radionuclide release from the waste form and the mass transport from the waste form through the disposal facility, constrained by chemical reactions. This coupled set of equations is commonly known as the reaction-transport equation. The value for radionuclide release from the waste form is taken from either an assumed constant release rate or a simulation using a mechanistic glass corrosion model. More detailed documentation of the design or models used in the AREST-CT code is found in Engel (1995) and Engel (1995a), respectively.

The governing equations are given in Appendix C.2.

3.5.2.2.4 Code History. The AREST-CT code was developed at PNNL to analyze the engineered barrier system of a subsurface disposal site for storing nuclear waste. The engineered barrier system is the constructed or human-altered components of the disposal system. In this case, it is the disposal facility design starting with the water conditioning layer.

The code was originally developed to support the engineered-system performance analyses for the proposed high-level waste repository at Yucca Mountain, Nevada. Specific capabilities that address the low-level waste disposal action have been included in AREST-CT.

3.5.2.2.5 Verification. A two-part verification test of AREST-CT, Version 1, was done to ensure that modules of the program were correctly implemented and worked together (Chen 1995). A summary is given here; more details are given in Appendix C.4.

First, specific portions or modules of AREST-CT were unit tested to verify that the modules performed correctly. Individual code modules were evaluated against hand 
calculations, analytical solutions, or other existing numerical codes. Each module was unit tested before being incorporated into AREST-CT. All modules were considered acceptable for current use.

Second, the entire integrated computer code was tested. At the time of verification, no analytical solutions existed for the reaction-transport problems designed for AREST-CT. The code was benchmarked against simulation results from other similar reaction-transport codes.

A one-dimensional idealization of a low-level-waste engineering system was run as a benchmark test case. The system consisted of 7 solids and 12 aqueous species. Two types of reactions were considered, equilibrium aqueous reactions and solid dissolution/precipitation reactions. The results of the test showed that AREST-CT simulations were of similar quality to the other codes. More details are given in Chen (1995).

Additional testing and verification will be conducted as the AREST-CT code develops. Future testing will include integration testing for mechanisms of radioactive decay and decay chain in-growth, and for two-dimenisional simulation. Plans for code development call for coupling with a multiphase flow solver so that it can model infiltration velocity changes with time-dependent porosity and permeability changes that result from solid dissolution/precipitation reactions and from the consumption of water that occurs during the hydrolysis of the glass waste form. Now, the program uses the water velocity from the separate moisture flow code.

\subsubsection{PORFLOW.}

3.5.2.3.1 Overview. The PORFLOW code (ACRi 1994) was used to calculate the transport of contaminants from the waste packages in the disposal facility to the unconfined aquifer. PORFLOW was also used to calculate the effect of possible disposal facility components on the amount of water that goes into the vaulted area then to the vadose zone.

PORFLOW interfaces with the two other major codes, AREST-CT (Section 3.5.3.2) and VAM3D-CG (Section 3.5.2.4), used in the analyses. PORFLOW supplies AREST-CT with the moisture movement velocities into the vault, which drives the glass corrosion process. ARESTCT supplies PORFLOW with the contaminant source term at the bottom of the waste disposal facility. PORFLOW

supplies VAM3D-CG, the code used for the unconfined aquifer, with the amount of moisture and contaminants entering the aquifer.

3.5.2.3.2 Selection. The process used to select PORFLOW (Piepho 1995) is summarized here. PORFLOW was given first consideration for use as a flow and transport code because it was used in the Performance Assessment of Grouted Double-Shell Tank Waste Disposal at Hanford (Kincaid 1995) and in earlier analyses of this disposal action (Rawlins 1994 and Mann 1995b). The capabilities of PORFLOW were compared to the capabilities of the VAM3D-CG (Huyakorn 1994) and TRACR3D (Birdsell 1991) codes. All three codes met the flow and transport code requirements for this performance assessment (Mann 1995c). 


\section{HNF-EP-0884}

Rev. 1

Other codes, such as CFEST (Gupta 1987), MODFLOW (McDonald 1988), and SLAEMS (Strack 1989), were considered. However, they are aquifer codes and hence can not be used for vadose zone transport. Code selection documents from the Yucca Mountain Project (Reeves 1994) and the Savannah River Saltstone effort (WSRC 1992) were also consulted for alternative codes.

PORFLOW was selected to simulate flow and transport in the vadose zone for the following reasons:

- It met all the requirements established for this performance assessment

- It had desired features that the other codes lacked

- It was used in the earlier phases of this project

- The analysts were familiar with PORFLOW

As Section 3.5.2.4.2 describes, VAM3D-CG was used for the unconfined aquifer șimulations because it is used in the Hanford sitewide groundwater model.

Versions of the PORFLOW and VAM3D-CG codes available in 1990 were approved by Hanford regulators to support Waste Management and Environmental Remediation activities (DOE-RL 1991a and 1991b).

3.5.2.3.3 Code Description. PORFLOW (ACRi 1994) calculates multi-phase fluid flow, heat transfer, and mass transport in unsaturated and saturated porous or fractured media. The code can simulate transient or steady state problems in Cartesian or cylindrical geometry in two or three dimensions. The material, i.e., soil or concrete, that PORFLOW models can be either uniform or a mixture. The material can contain distinct elements such as discrete fractures or boreholes within a porous matrix.

In this interim performance assessment, PORFLOW is used to simulate the following (See Appendix D.2 for the governing equations):

- The moisture content distribution from the bottom of the surface barrier into and through the vault region

- The contaminant concentration distribution from the vault area down into the unconfined aquifer.

For the first simulation, the source rate of the moisture is the infiltration rate given in Section 3.4.7. PORFLOW tracks the moisture front through and around the sand-gravel capillary barrier, through the water conditioning layer, through the concrete structure, and into the vault bay with containers and filler material. PORFLOW simulates the moisture content distribution at the surface of the waste package. This distribution is an input used by ARESTCT. 


\section{HNF-EP-0884 \\ Rev. 1}

Tracking the contaminants from the vault region down into the unconfined aquifer is a more complicated task. Again PORFLOW uses the infiltration rate from Section 3.4.7 and the various features of the disposal facility to establish moisture movement. For this problem, the vadose zone region below the disposal facility is also considered. The moisture content distribution within the vadose zone is predicted. Then PORFLOW tracks the movement of the radioactive contaminants down into the groundwater. The contaminants are assumed to be released from the surface of the waste package at the rate established in Section 3.4.5.4. Each PORFLOW run follows four sets of radionuclides, each set corresponding to a different $\mathrm{K}_{\mathrm{d}}$ value (Section 3.4.4.4). All the geologic layers (Section 3.4.4.2) with their different properties (Section 3.4.4.3) are treated in the same run.

3.5.2.3.4 Verification and Benchmarking. PORFLOW Version 2.394gr, used in this analysis, has been extensively verified and benchmarked (Piepho 1994). Verification and benchmarking efforts were based on the following:

- Comparing the results of the Version 2.394gr with earlier versions of PORFLOW

- Reproducing the results of analytical solutions from verification problems

- Comparing the results with other codes used to solve complex problems.

Additional details are given in Appendix D.4.1

3.5.2.3.6 Field Testing. As this document is being written PORFLOW is being used to simulate the Sisson/Lu Injection Experiment and previous leaks from Tank T-106. The Sisson/Lu experiment (Sisson 1984) injected a known amount of water and radioactive tracers into a well just east of the proposed disposal site. The methods, tools, and boreholes have been recently reevaluated (Fayer 1995c). The leak from Tank T-106 is the best characterized of the Hanford Site tank leaks.

\subsubsection{VAM3D-CG}

3.5.2.4.1 Overview. VAM3D-CG (Variably Saturated Analysis Model in $\underline{3}$-Dimensions with Preconditioned Conjugate Gradient Matrix Solvers) (Huyakorn 1994) was used to calculate flow and contaminant transport in the unconfined aquifer from unit moisture flow and contaminant amounts at the bottom of the vadose zone.

3.5.2.4.2 Selection. Although PORFLOW was selected to be the flow and transport code in both the vadose zone and the unconfined aquifer (Piepho 1995), VAM3D-CG was the code actually used to calculate results in the aquifer. VAM3D-CG was chosen because of the need for a model to treat not just the area near the disposal facility but the entire Hanford Site. Although PORFLOW could perform such calculations, the model for the Hanford Site groundwater system had already been developed for the VAM3D-CG code (Law 1996) and successfully used in other Hanford Site performance assessments (Wood 1994b and Wood 1996). 


\section{HNF-EP-0884 \\ Rev. 1}

Recommendation 94-2 of the Defense Nuclear Facilities Safety Board (DNFSB 1994) stressed the importance of calculating the environmental impact of all previous DOE actions on the points of compliance. This means that at the point where performance objectives must be met, the actions of all disposal and ground discharges besides the current proposed action must be included in the evaluation. Fortunately, the ERC Hanford Sitewide Groundwater Model (Law 1996) based on VAM3D-CG had been developed. Although other groundwater models of the Hanford Site (for example, Wurstner 1995) exist, this model has had boundary conditions optimized for future land uses.

VAM3D-CG was selected for the Hanford Sitewide Groundwater Model (Law 1996) for the following reasons:

- The solution algorithms were robust

- The original developer, an internationally known expert, was available

- The VAM3D-CG code is capable of dealing with partially and fully saturated flow, thus efficiently simulating a fluctuating free water surface

- The VAM3D-CG code supports the use of special grid shapes (transitional elements) for detailed simulation of small areas, thereby making computations more efficient

- The version of the VAM3D-CG code available in 1990 was approved by Hanford Site regulators to support Waste Management and Environmental Remediation activities (DOE-RL 1991a and DOE-RL 1991b).

The VAM3D-CG code is preferred over the PORFLOW code for Hanford sitewide groundwater modeling applications because it offers a curvilinear grid. A curvilinear grid can be set up to follow layering or other characteristic patterns. For example, the thickness of the aquifer at the Hanford Site varies from over 100 meters (328 feet) to a few meters. A curvilinear grid was set up for the varying aquifer thickness, which allows faster input data preparations and faster code execution. The rectangular grid representations for varying formation thicknesses can lead to erroneous results when coarse grids are used or to prohibitively large matrices and computational times when fine grids are used.

3.5.2.4.3 Code Description. VAM3D-CG (Huyakorn 1994) calculates saturatedunsaturated groundwater flow and solute transport with variable water table positions and highly non-linear soil moisture conditions. The code can simulate transient or steady state problems in one, two, or three dimensions using a finite element model. Special grid elements (in the shape of hexahedrals) are used to define discrete volumes with irregular geometry. The size of these elements can vary. Many "fine" elements can be used in places where the geometry varies quickly. Such finer elements allow a better description of regions in which the values of parameters and variables are rapidly changing. An orthogonal curvilinear grid can also be used to represent flow domains. 


\section{HNF-EP-0884 \\ Rev. 1}

In this interim performance assessment, VAM3D-CG was used to forecast the contaminant movement in the groundwater. VAM3D-CG used the values for the hydrologic parameters from the ERC Hanford Sitewide Groundwater Model (Section 3.4.4.5). A normalized contaminant source term was used for the amount of contaminant entering the unconfined aquifer. Water flow and contaminant transport patterns were then distorted by stress of pumping the water in the well. Thus VAM3D-CG calculated the contaminant concentration in the well relative to the normalized contaminant source term.

3.5.2.4.5 Verification and Benchmarking. Versions 2.4b (Lu 1994) and 3.1 (Lu 1995) of VAM3D-CG were tested in the following manner:

- Results of the installed version were compared to those published by the vendor (Huyakorn 1993)

- These versions were benchmarked against the results from PORFLO-3 Version 1.2 (Sagar 1990) for Hanford Site-relevant problems.

More details are given in Appendix D.4.2.

3.5.2.4.6 Calibration and Validation. Calibration and validation tests were run for both Versions 2.4b and 3.1. The calibration/validation effort for Version 2.4b (Lu 1993) used data from the Hanford Injection Test experiment (Sisson 1984). The calibration/validation effort for Version 3.1 used data from the reevaluation of the Hanford Injection Test Experiment and from new experiments (Fayer 1995b). The Hanford Sitewide Groundwater Flow and Transport Calibration Report (Law 1996)

describes in detail the various comparisons made with Hanford Site data.

3.5.2.5 INTEG. INTEG (Mann 1996) calculates a specific impact (whether dose rate or concentration level) based on the inventory, vadose zone transport, aquifer transport, and the dosimetry factors. The dose rate calculated depends on the type of dosimetry factor (i.e., allpathways, drinking water). The program solves the following equation for each year under consideration.

$$
\text { Response }=\sum_{i} \frac{I_{i}(t) \Gamma_{i}(t) w_{i} D_{i}}{r A}
$$

where

$\mathrm{I}_{\mathrm{i}} \quad$ is the amount (or inventory) of radionuclide $\mathrm{i}(\mathrm{Ci})$. The time-dependent value is calculated by INTEG based on the initial inventory and on decay and the ingrowth from other radionuclides.

$\Gamma_{\mathrm{i}} \quad$ is the flux of contaminants at the bottom of the vadose zone normalized to an unit inventory for radionuclide $\mathrm{i}(\{\mathrm{Ci} / \mathrm{y}\} / \mathrm{Ci})$. The time-dependent value is calculated by PORFLOW.

$w_{i} \quad$ is the ratio of the concentration of radionuclide $i$ at the well location to the contaminant concentration at the bottom of the vadose zone (Dimensionless). 


\section{HNF-EP-0884 \\ Rev. 1}

This quantity was called the well intercept factor in earlier Hanford performance assessments. The peak value as calculated by VAM3D-CG is used.

$D_{i} \quad$ is the dose rate factor $\left(m r e m / y ~ p e r ~ C i / m^{3}\right)$. The values are taken from the tables in Appendix $B . D_{i}$ is unity when the response that is calculated in a concentration.

r is the recharge rate $(\mathrm{m} / \mathrm{y})$. The value at 10,000 years is used at all times.

A is the area over which the contaminant flux enters the aquifer $\left(\mathrm{m}^{2}\right)$. The value used is the area of the disposal facility being modelled.

The program is modeled after GRTPA (Rittmann 1993), which served a similar function in earlier work (Rawlins 1994 and Mann 1995b). INTEG allows greater freedom in specifying data used in the integration. The code has been benchmarked against the results of GRTPA (Mann 1996).

3.5.2.6 Spreadsheets. Commercial spreadsheets were used in determining inadvertent intrusion doses. The Quattro ${ }^{2}$

Pro spreadsheet was used for developing the spreadsheet cells, while the Wingz ${ }^{3}$ spreadsheet was used for the actual runs. The spreadsheet calculations were compared with answers from the GENII computer program (Rittmann 1994). The verification of the spreadsheet formulas was done as part of the review by the Hanford Environmental Dose Oversight Panel (HEDOP) (Rhoads 1996).

\subsubsection{Computer Models}

3.5.3.1 Overview. This section describes the numerical models used in the PORFLOW and VAM3D-CG computer simulations. Because the AREST-CT simulations of contaminant release rate are only used in sensitivity studies, the discussion of its numerical models is given only in Appendix C.

For both the vadose zone and groundwater calculations, two slightly different models are used. These models are described in the following sections. Each case has a computational complex model that describes the effect of many interacting features. These are the disposal facility models for the vadose zone calculations and the sitewide models for the groundwater calculations, respectively. Each case also has a much simpler calculational model that comprises the major features of the more complex models, but allows quicker runs. These simpler models are the unit cell model for the vadose zone calculations and the pumping model for the groundwater calculations. The base analysis case was run using all the models. Most of the sensitivity cases were run using the simpler models.

Quattro is a registered trademark of Corel Corporation

Wingz is a trademark of Investment Intelligence Systems Incorporated 
3.5.3.2 Disposal Facility Model. This two-dimensional model, shown in Figure 3-7, treats an entire vault row (see Section 3.4.6) consisting of ten vault bays by assuming centerline symmetry. See Piepho 1996 for more details. The model includes the sand-gravel capillary barrier, the water conditioning layer, the vault row, the waste packages, the filler material, and the vadose zone. The surface barrier is not treated. The water flux at the bottom of the surface barrier is considered a boundary condition. Source terms for contaminant release are considered to be at the surfaces of the waste containers.

Figure 3-7. Zone Map for Disposal Facility Model

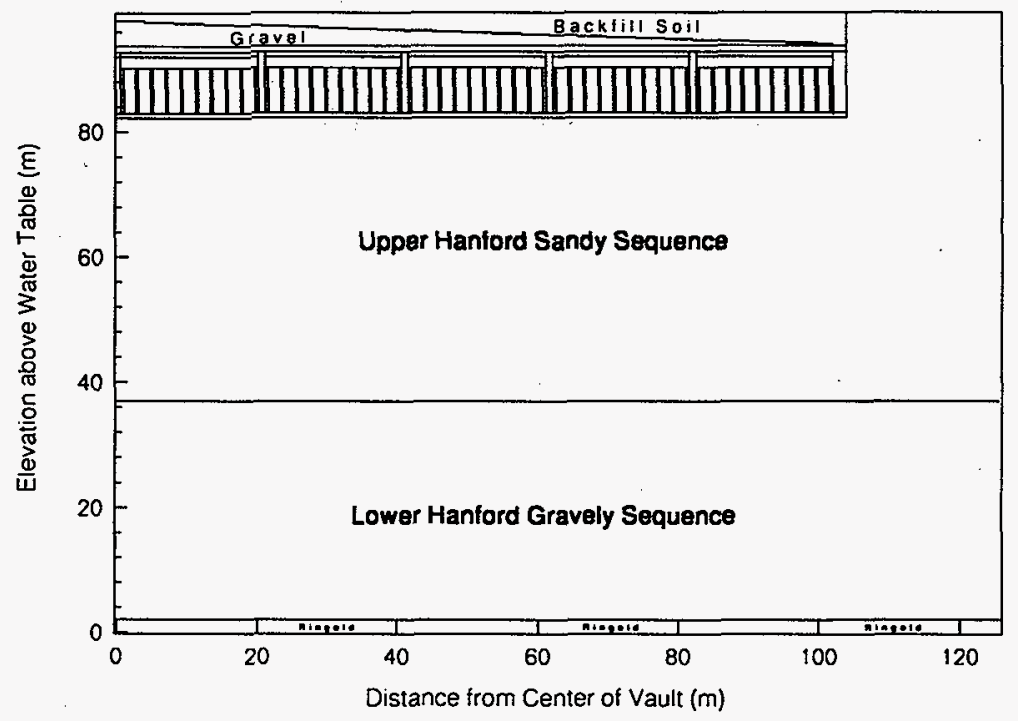

Appendix D.6.1 has the input file for the base analysis case. A two-dimensional model (165 columns with 133 layers) is used. The sand-gravel capillary barrier is modelled with 28 layers, the water conditioning layer with 3 , the vault roof, walls, and floor with 3 . In each of the five vault bays modelled, there are 9 sets of waste containers (each container being modelled by a $2 \times 9$ grid) separated by a $1 \times 9$ grid for the filler material. The vadose zone was modeled using 46 layers for the sandy sequence, 36 for the gravel sequence, and the bottom 4 modeled for the unconfined aquifer. Symmetry is assumed about the center of the disposal facility with the last 10 columns separating adjacent vaults.

Earlier versions of this model were used in determining the effect of various disposal facility design options on long-term environmental performance (Mann 1995b). 


\section{HNF-EP-0884 \\ Rev. 1}

The diffusion coefficient specified in Section 3.4.4.3 is based on the Kemper diffusion model (Kemper 1966). However, if the Kemper model is used in PORFLOW, then dispersion cannot be calculated. Therefore the Scheidegger (1961) model was used and the parameters adjusted to obtain the same diffusion value for the moisture contents expected in the problem.

3.5.3.3 Unit Cell Model. The Unit Cell Model calculations focused on the calculations of sensitivity cases. Thus the model is very much simpler than the disposal facility model just discussed. This two-dimensional model treats a thin vertical slice one container (1.8 meter) wide and six containers high of the disposal facility model. The sand-gravel capilliary barrier and the concrete roof are not modeled. Kline 1996 gives full details.

Figure 3-8 displays the geometry. The top of the model is the filler material atop the waste containers. The model continues with the waste containers and lateral filler material and with a degraded concrete floor. The vadose zone is below the engineered system with the unconfined aquifer at the very bottom of the model.

The grid spacing is 10 by 50 , resulting in Peclet numbers near unity. Nonuniform spacing that includes more detail in the disposal facility is used to minimize the number of nodes. The contaminant source terms $\left(6.82 \times 10^{-7} \mathrm{y}^{-1} \mathrm{~m}^{-3}\right)$ are given as a volumetric source within the waste containers. Both vertical sides of the model are assumed to be reflective. The boundary condition at the top is the specified infiltration rate. The boundary condition at the water table is fully saturated.

An earlier use of this model (Kline 1995b) showed very good agreement with full disposal models (Mann 1995b).

3.5.3.4 Sitewide Model. The aquifer was analyzed using the ERC Hanford Sitewide Groundwater Model (Law 1996). A horizontal finite-element grid size of $600 \mathrm{~m}$ by 600 meters (1,962.5 by $1,962.5$ feet) was selected. Element heights varied depending on the thickness of the aquifer and the thickness of the high-conductivity Hanford formation. The model grid consists of 6 layers each with 2,474 elements and 2,611 nodes. Vertical discretization was performed using six layers. The top three are in the Hanford formation, and the bottom three are in the underlying Ringold Formation.

Boundary conditions reflect an arid environment with a few streams and rivers as water sources. Inflow along Cold Creek and Dry Creek are prescribed as hydraulic head conditions for model calibrations under 1979 conditions. For these calculations influx representing the recharge from the Cold Creek and Dry Creek was used as flux boundary conditions, replacing the fixed head condition. Influx from the Yakima River is treated as a prescribed head. The recharge from the front of Rattlesnake Mountain or from precipitation is not included in the present model. The model treats the Columbia River as a boundary that is held constant in time but variable in distance along the river, with numerical values obtained by five river stage ganges over a 1-year period (1992-3). The data are undocumented, but were collected using the protocol described by Campell (1994). No flow is allowed into basalt outcrops or into the bottom of the modei (corresponding to the top of the underlying basalt unit or to the lower mud unit of the Ringold Formation). 


\section{HNF-EP-0884}

Rev. 1

As noted in Section 3.5.2.4.4, versions of this Hanford sitewide groundwater model have been used for earlier Hanford Site performance assessments.

Figure 3-8. Zone Map for Unit Cell Model. $\mathrm{P}=$ head, $\mathrm{C}=$ concentration, aq = infiltration rate, and $x$ and $z$ are spatial directions.

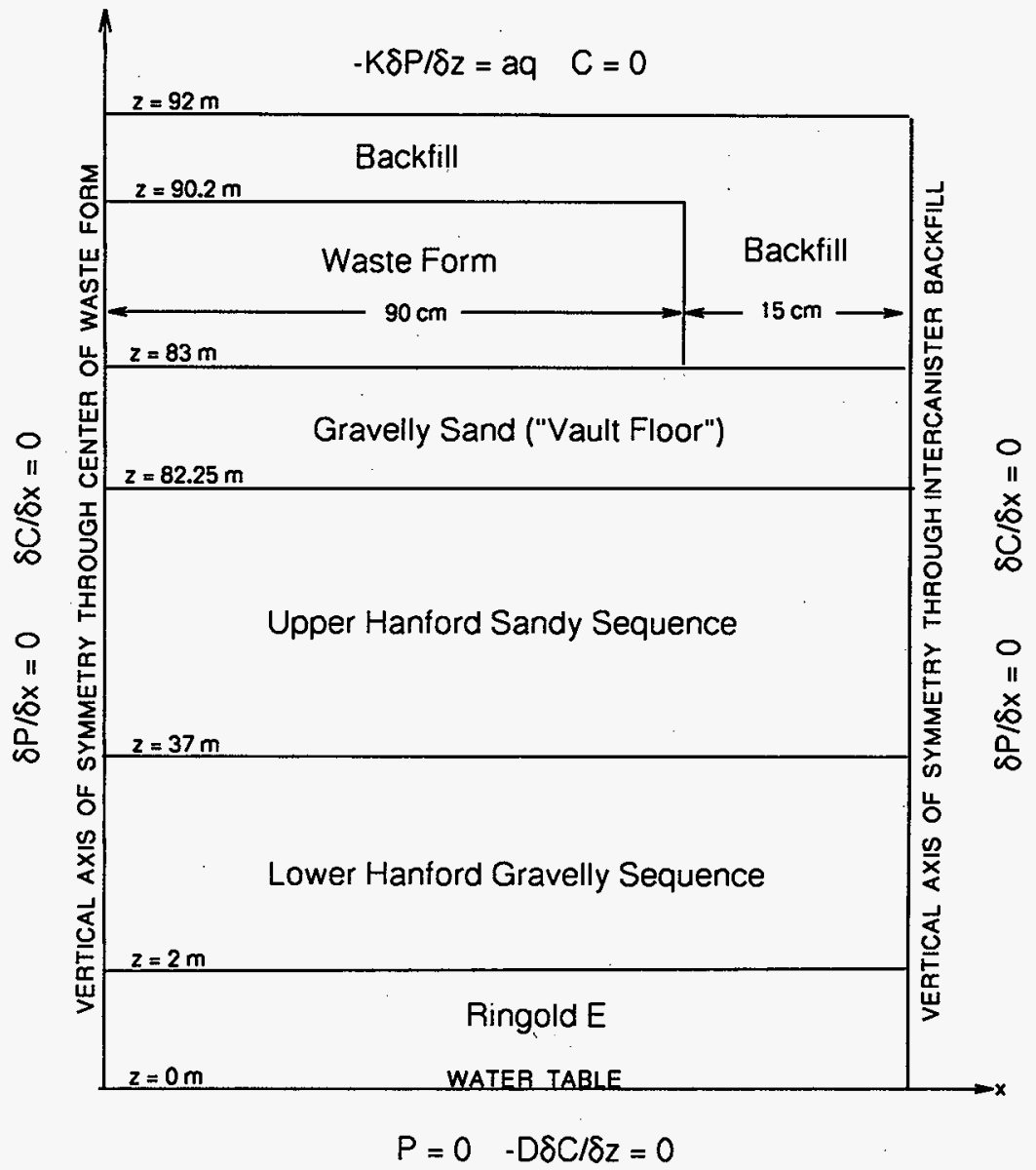


Figure 3-9. Zone Map for Pumping Model (Material types 7 and 12 from Table 3-7 are used).

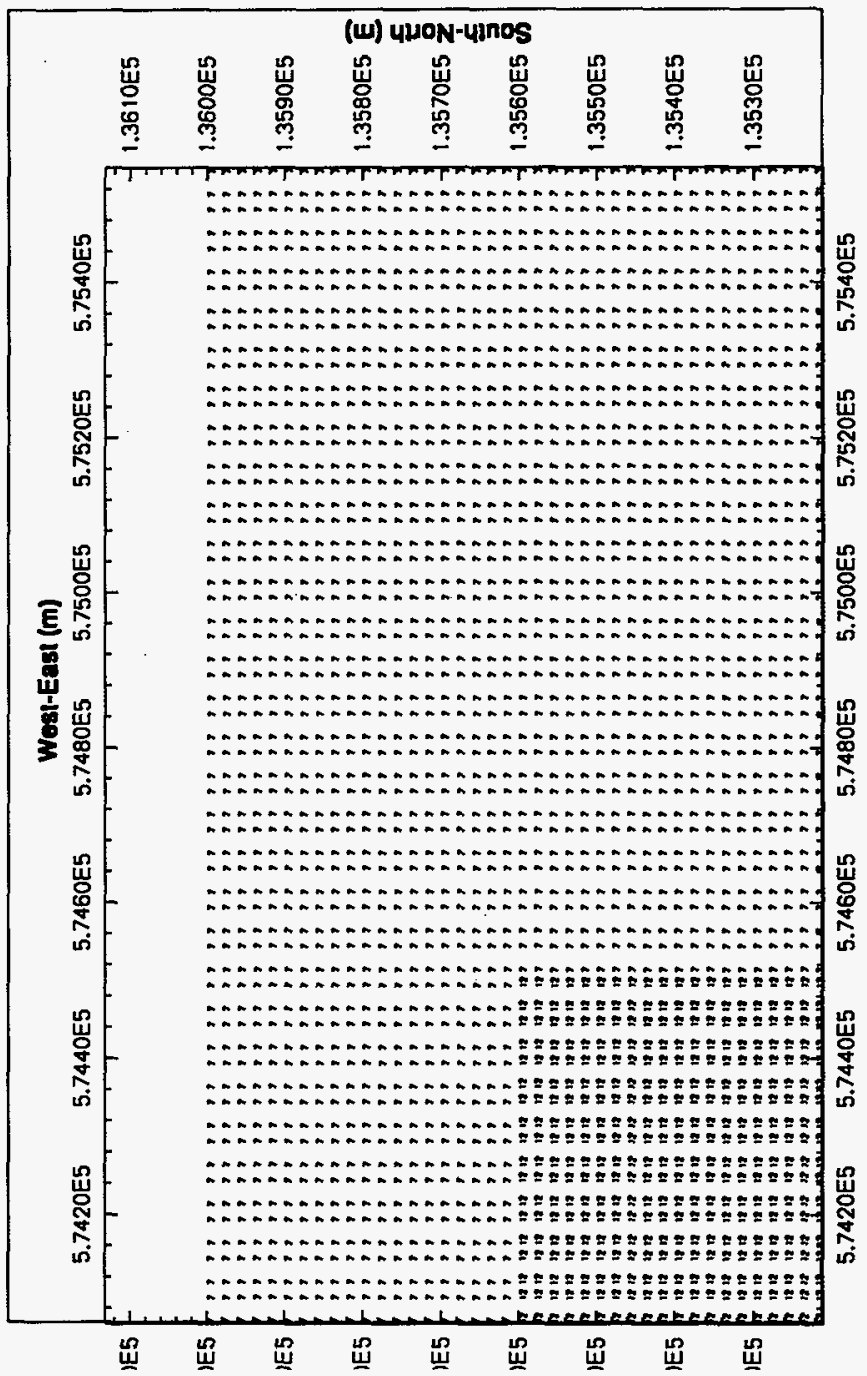




\section{HNF-EP-0884}

Rev. $\mathrm{i}$

3.5.3.5 Pumping Model. This model is similar to the ERC Hanford Sitewide Groundwater Model, but on a smaller scale. This model calculates the effect of various pumping rates at the well on the groundwater flow. The element size is 25 by 20 meters ( 82 by 66 feet) and consists of four layers (Figure 3-9). Each layer has 2,400 elements and 2,501 nodes. The bottom of the model is flat, using an average value for the top of the basalt zone. Values of the hydraulic head from the sitewide model were used as boundary conditions.

\subsubsection{Input Data}

3.5.4.1 Overview. This section specifies the data actually used in the computer models for the base analysis case. The intent is to follow the data given in Sections 3.2,3.3, and 3.4 as closely as possible. Data used in the sensitivity cases are given in Section 3.5.5.

Input files for each computer model related to the base analysis case are given in Appendices C.5 and D.5.

3.5.4.2 Contaminant Release Modeling. The contaminant release rate from the waste package is based on the request for proposal and on a time dependence derived in Section 3.4.5.

3.5.4.3 Vadose Zone Modeling. The same input data are used for both the disposal facility and unit cell models. The input data used by both models for the base analysis case are summarized in Table 3-13. The actual input files for the base analysis case calculations are presented in Appendix D.5.

3.5.4.4 Aquifer Modeling. The aquifer models are based on a Hanford Site groundwater model (Law 1996). The hydrologic parameter data for the base analysis case are from Table 3-7

(Section 3.4.4.5). For the pump model, only material types 7 and 12 of the 18 types shown in Figures 3-3 and 3-4 were used.

The data set for the site model was calibrated/validated in three ways. The 1979 Hanford Site water tables were simulated using the known Hanford Site-related artificial recharges and assuming steady-state conditions. Second, the difference between the 1993 water table and the 1979 water table was calculated using a transient simulation. Finally, the movement of tritium plumes from 1979 to 1993 was simulated in a transient contaminant transport calculation. In all cases (Law 1996), good agreement was found between measured and simulated values.

3.5.4.5 Integration of Results. In addition to data already discussed, the input data for INTEG were taken from the output of the vadose zone and the aquifer models. Inventories were taken from Section 3.2.3. Dose conversion factors were taken from Section 3.3.6. 


\section{HNF-EP-0884}

\section{Rev. 1}

Table 3-13. Base Analysis Case Input Data for the Disposal Facility and Unit Cell Models.

\begin{tabular}{|c|c|c|}
\hline \multicolumn{3}{|l|}{ Soil Layering } \\
\hline $\begin{array}{l}\text { Hanford formation } \\
\text { Upper Gravel Sequence } \\
\text { Sand Sequence } \\
\text { Lower Gravel Sequence }\end{array}$ & $\begin{array}{l}6 \text { meters }(20 \mathrm{ft}) \text { (on surface) } \\
60 \text { meters }(197 \mathrm{ft}) \\
35 \text { meters }(98 \mathrm{ft}) \text { (bottom) }\end{array}$ & Section 3.4 .4 .2 \\
\hline $\begin{array}{l}\text { Ringold Formation } \\
\text { Unit E }\end{array}$ & 30 meters ( $98 \mathrm{ft}$ ), below Hanford formation & Section $3: 4.4 .2$ \\
\hline \multicolumn{3}{|l|}{ Hydrologic Parameters } \\
\hline \multicolumn{3}{|l|}{ Infiltration Rate } \\
\hline $\begin{array}{l}\text { At the Disposal Facility } \\
\text { First } 1000 \text { years } \\
\text { After } 1000 \text { years }\end{array}$ & $\begin{array}{l}0.5 \mathrm{~mm} / \mathrm{y}(0.02 \mathrm{in} . / \mathrm{y}) \\
3.0 \mathrm{~mm} / \mathrm{y}(0.12 \mathrm{in} . / \mathrm{y})\end{array}$ & Section 3.4 .7 \\
\hline
\end{tabular}


HNF-EP-0884

Rev. 1

\begin{tabular}{|c|c|c|}
\hline Parameter & Value & $\begin{array}{l}\text { Section with } \\
\text { Justification for Using } \\
\text { Value } \\
\end{array}$ \\
\hline \multicolumn{3}{|l|}{ Geochemical Parameters } \\
\hline $\begin{array}{l}\text { Chemical Distribution Coefficients }\left(\mathrm{K}_{\downarrow}\right) \\
\mathrm{Se}, \mathrm{Tc}, \text { Others } \\
\mathrm{U} \\
\mathrm{Sr}, \mathrm{I} \\
\mathrm{Pa}, \mathrm{C} \\
\mathrm{Ra}, \mathrm{Np} \\
\mathrm{Ac}, \mathrm{Nb}, \mathrm{Am}, \mathrm{Ni}, \mathrm{Zr}, \mathrm{Pu}, \mathrm{Th} \\
\mathrm{Ce}, \mathrm{Cs}, \mathrm{Cm}, \mathrm{Eu}, \mathrm{Pb}, \mathrm{Co}, \mathrm{Sn}\end{array}$ & $\begin{array}{l}0.0 \mathrm{~m} / / \mathrm{g} \\
0.6 \mathrm{~m} / \mathrm{g} \\
3.0 \mathrm{ml} / \mathrm{g} \\
6.0 \mathrm{~m} \ell / \mathrm{g} \\
15 . \mathrm{m} / \mathrm{g} \\
40 . \mathrm{m} \ell / \mathrm{g} \\
100 \mathrm{~m} / \mathrm{g}\end{array}$ & Section 3.4.4.4 \\
\hline \multicolumn{3}{|l|}{ Contaminant Release Rate } \\
\hline $\begin{array}{l}\text { Relative Radionuclide } \\
\text { Release Rate }\end{array}$ & $\begin{array}{l}\text { Calculated release based on initial release rate and } \\
\text { time-dependent surface area. See reference section. }\end{array}$ & $\begin{array}{l}\text { Section 3.4.5.4 } \\
\text { (Values given in Table 3- } \\
\text { 8) } \\
\end{array}$ \\
\hline \multicolumn{3}{|l|}{ Disposal Facility Degradation } \\
\hline Concrete & degraded at 500 years & Section 3.4.6.7 \\
\hline Natural materials & $\begin{array}{l}\text { properties do not degrade, but system performance } \\
\text { changes bewcause of rearrange of materials }\end{array}$ & Section 3.4.6.7 \\
\hline
\end{tabular}




\section{HNF-EP-0884 \\ Rev. 1}

3.5.4.6 Inadvertent Intrusion. The base analysis case evaluates the two relevant parts of the inadvertent intrusion scenario: drilling for groundwater or minerals and homesteading where waste has been exhumed and spread around the surface. The input data values related to the scenarios were taken from Section 3.3.3.4.3. These values are summarized in Table 3-14. The dose conversion factors used were taken from Section 3.4 .8 .

Table 3-14. Important Input Parameters for the Base Analysis Case Inadvertent Intrusion Analysis.

\begin{tabular}{||l|l|l||}
\hline Parameter & Value & Section with Justification \\
\hline Diameter of well drilled & $0.3 \mathrm{~m}(12 \mathrm{in})$. & Section 3.3.3.4.3 \\
\hline Garden size & $\begin{array}{l}\text { acute exposure: } \\
100 \mathrm{~m}^{2}\left(1,071 \mathrm{ft}^{2}\right) \\
\text { chronic exposure: } \\
500 \mathrm{~m}^{2}\left(5,374 \mathrm{ft}^{2}\right)\end{array}$ & Section 3.3.3.4.3 \\
\hline Waste Form Size & $\begin{array}{l}\text { Calculated by linear release } \\
\text { rate based on initial release } \\
\text { rate and time }\end{array}$ & Section 3.4.5.4 \\
\hline
\end{tabular}

\subsubsection{Sensitivity Cases}

3.5.5.1 Overview. Sensitivity cases were run to determine the effect of various assumptions and data values. For most sensitivity cases, only one parameter or one set of parameters differs from the base analysis case or another sensitivity case. Thus, the change, if any, in the final answer will indicate the effect of that parameter on the overall answer. Table 3-15 summarizes the sensitivity cases. Sections 3.5.5.2 through 3.5.5.12 discuss the sensitivity cases and explain why each case was run. 
HNF-EP-0884

Rev. 1

Table 3-15. List of Sensitivity Cases. Except for intrusion scenarios, the performance measures calculated were the drinking water dose and the all-pathways dose. For the intrusion scenarios, the acute and continous doses were calculated.

\begin{tabular}{|c|c|c|}
\hline $\begin{array}{l}\text { Discussion } \\
\text { Section }\end{array}$ & $\begin{array}{c}\text { Sensitivity Case } \\
\text { (Unless Noted All Cases Treat Groundwater Scenario) }\end{array}$ & $\begin{array}{l}\text { Results } \\
\text { Presented in } \\
\text { Section }\end{array}$ \\
\hline \multicolumn{3}{|c|}{ Scenario } \\
\hline 3.5 .5 .2 & $\begin{array}{l}\text { Assume different parameters for intrusion scenario: Cases include garden size }=2,500 \mathrm{~m}^{2}[26,910 \mathrm{ft}] \mathrm{rather} \\
\text { than } 500 \mathrm{~m}^{2}\left(5,382 \mathrm{ft}^{2}\right) \text { and diameter of the well }=0.2 \mathrm{~m}(8 \mathrm{in}) \text { rather than } 0.3 \mathrm{~m}(12 \mathrm{in} .) \text {. }\end{array}$ & 4.2 .3 \\
\hline 3.5.5.2 & $\begin{array}{l}\text { Irrigated farming over the disposal facility, implying an infiltration rate of } 100 \mathrm{~mm} / \mathrm{y}(3.9 \mathrm{in} / \mathrm{y}) \text { forever, } \\
\text { rather than base analysis case of } 0.5 \mathrm{~mm} / \mathrm{y}(0.02 \text { in./y) for first } 1,000 \text { years and } 3.0 \mathrm{~mm} / \mathrm{y}(0.12 \mathrm{in} . / \mathrm{y}) \\
\text { thereafter. }\end{array}$ & 4.7.4.3 \\
\hline 3.5 .5 .2 & $\begin{array}{l}\text { Assume irrigation occurs on Hanford Plateau. Cases studied are irrigation in all areas except } 200 \text { Areas and } \\
\text { region between } 200 \text { East and } 200 \text { West Areas, irrigation only north of } 200 \text { Areas, and irrigation only west of } \\
200 \text { Areas. In base analysis case, no irrigation is assumed. }\end{array}$ & 4.8.3.3 \\
\hline 3.5.5.2 & Assume industry in 200 Areas (recharge reduced in 200 Areas by a factor of 2). & 4.8.3.3 \\
\hline 3.5.5.2 & 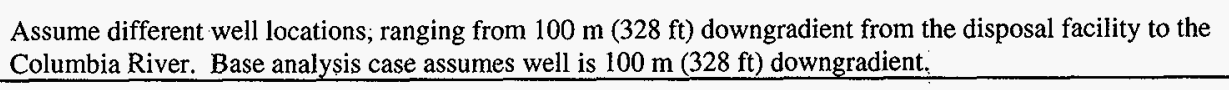 & 4.8 .3 .5 \\
\hline 3.5.5.2 & $\begin{array}{l}\text { Assume different pumping rates at the well } \\
\left(10 \mathrm{~m}^{3} / \mathrm{d}[2,640 \mathrm{gal} / \mathrm{day}], 50 \mathrm{~m}^{3} / \mathrm{d}[13,200 \mathrm{gal} / \mathrm{d}], 100 \mathrm{~m}^{3} / \mathrm{d}[26,400 \mathrm{gal} / \mathrm{d}], \text { and } 150 \mathrm{~m}^{3} / \mathrm{d}[39,600 \mathrm{gal} / \mathrm{d}]\right) \\
\text { instead of the rate of } 0.01 \mathrm{~m}^{3} / \mathrm{d}[10 \mathrm{l} / \mathrm{d}=2.6 \mathrm{gal} / \mathrm{day}] \text { used in the base analysis case. }\end{array}$ & 4.8.3.6 \\
\hline 3.5.5.2 & Treat natural events, such as glacial-age flooding. & 4.11 \\
\hline
\end{tabular}




\section{HNF-EP-0884}

Rev. 1

\begin{tabular}{|c|c|c|}
\hline $\begin{array}{l}\text { Discussion } \\
\text { Section }\end{array}$ & $\begin{array}{c}\text { Sensitivity Case } \\
\text { (Unless Noted All Cases Treat Groundwater Scenario) }\end{array}$ & $\begin{array}{c}\text { Results } \\
\text { Presented in } \\
\text { Section } \\
\end{array}$ \\
\hline \multicolumn{3}{|c|}{ Inventory } \\
\hline 3.5 .5 .3 & $\begin{array}{l}\text { Changes in inventory caused by TWRS Privatization Effort. Cases assumes that only } 20 \% \text { of the }{ }^{99} \mathrm{Tc} \\
\text { inventory of the base analysis case is disposed in facility. }\end{array}$ & 4.8 .2 \\
\hline 3.5 .5 .3 & Arbitrary changes in inventory to determine sensitivity (I, Se, U). & 4.8 .2 \\
\hline \multicolumn{3}{|c|}{ Recharge } \\
\hline 3.5 .5 .4 & $\begin{array}{l}\text { Recharge rate }=3.0 \mathrm{~mm} / \mathrm{y}(0.12 \mathrm{in} . / \mathrm{y}) \text { forever. The base analysis case used } 0.5 \mathrm{~mm} / \mathrm{y}(0.042 \mathrm{in} . / \mathrm{y}) \text { for the first } \\
1,000 \text { years, and } 3.0 \mathrm{~mm} / \mathrm{y} \text { thereafter. }\end{array}$ & 4.7 .4 .2 \\
\hline 3.5 .5 .4 & Recharge rate $=1.0 \mathrm{~mm} / \mathrm{y}(0.04 \mathrm{in} . / \mathrm{y})$ forever. & 4.7 .4 .2 \\
\hline 3.5 .5 .4 & Recharge rate $=0.1 \mathrm{~mm} / \mathrm{y}(0.004 \mathrm{in} . / \mathrm{y})$ forever. & 4.7 .4 .2 \\
\hline \multicolumn{3}{|c|}{ Geology } \\
\hline 3.5 .5 .5 & $\begin{array}{l}\text { Top of unconfined aquifer is at } 96 \mathrm{~m}(315 \mathrm{ft}) \text { below the surface. In the base analysis case, the top of the } \\
\text { aquifer is at } 103 \mathrm{~m}(338 \mathrm{ft}) \text { below the surface. }\end{array}$ & 4.7 .2 .3 \\
\hline 3.5 .5 .5 & Top of unconfined aquifer is at $110 \mathrm{~m}(360 \mathrm{ft})$ below the surface. & 4.7 .2 .3 \\
\hline
\end{tabular}


HNF-EP-0884

Rev. 1

\begin{tabular}{|c|c|c|}
\hline $\begin{array}{l}\text { Discussion } \\
\text { Section }\end{array}$ & $\begin{array}{l}\text { Sensitivity Case } \\
\text { (Unless Noted All Cases Treat Groundwater Scenario) }\end{array}$ & $\begin{array}{c}\text { Results } \\
\text { Presented in } \\
\text { Section } \\
\end{array}$ \\
\hline \multicolumn{3}{|c|}{ Facility } \\
\hline 3.5 .5 .6 & $\begin{array}{l}\text { Reduce radionuclide density in disposal facility by a factor of } 2 \text { by increasing the number of vault rows by a } \\
\text { factor of } 2 \text {. }\end{array}$ & 4.6 .2 .2 \\
\hline 3.5 .5 .6 & Rotate the disposal facility $90^{\circ}$. Long side now being north-south. & 4.6 .2 .3 \\
\hline 3.5 .5 .6 & Shorter sand-gravel capillary barrier (Concept 2 layout). Base analysis case used Concept 1 layout. & 4.6 .2 .4 \\
\hline 3.5 .5 .6 & Sand-gravel capillary barrier in facility design replaced with back-filled soil. & 4.6 .3 .2 \\
\hline 3.5 .5 .6 & Side sand-gravel capillary barrier in facility design replaced with back-filled soil. & 4.6 .3 .3 \\
\hline 3.5 .5 .6 & Sand used as filler material inside the disposal facility instead of back-filled soil. & 4.6 .3 .4 \\
\hline \multicolumn{3}{|c|}{ Degradation } \\
\hline 3.5.5.7 & $\begin{array}{l}\text { Concrete floors, walls, and ceiling degrade at } 2,000 \text { years in order to test "bath tub effect". Base analysis case } \\
\text { has all concrete degrading at } 500 \text { years. }\end{array}$ & 4.6 .4 \\
\hline 3.5.5.7 & $\begin{array}{l}\text { Degraded sand-gravel capillary barrier. (The degradation point is at } 2 / 3 * 1 \text { from the apex of the barrier where } 1 \\
\text { is half the width of the barrier.) }\end{array}$ & 4.6 .4 \\
\hline \multicolumn{3}{|c|}{ Hydrologic Parameters } \\
\hline 3.5.5.8 & $\begin{array}{l}\text { Change hydrologic parameters in vadose zone so that the entire zone has parameters corresponding to the } \\
\text { Hanford formation sandy sequence instead of the varying sequences. }\end{array}$ & 4.7 .2 .3 \\
\hline 3.5.5.8 & $\begin{array}{l}\text { Change hydrologic parameters in vadose zone so that the bottom half of the zone has parameters } \\
\text { corresponding to the Hanford formation gravelly sand sequence instead of the Ringold Formation. }\end{array}$ & 4.7 .2 .3 \\
\hline
\end{tabular}


HNF-EP-0884

Rev. 1

\begin{tabular}{|c|c|c|}
\hline $\begin{array}{l}\text { Discussion } \\
\text { Section }\end{array}$ & $\begin{array}{l}\text { Sensitivity Case } \\
\text { (Unless Noted All Cases Treat Groundwater Scenario) }\end{array}$ & $\begin{array}{c}\text { Results } \\
\text { Presented.in } \\
\text { Section } \\
\end{array}$ \\
\hline 3.5 .5 .8 & Change diffusion constant for the vadose zone to $1.00 \times 10^{-6} \mathrm{~cm} / \mathrm{sec}$ from $1.25 \times 10^{-7} \mathrm{~cm} / \mathrm{sec}$. & 4.7 .2 .3 \\
\hline \multicolumn{3}{|c|}{ Waste Form } \\
\hline 3.5 .5 .9 & Waste form is a thin plate, implying a time-independent radionuclide release rate. & 4.4 .3 .2 \\
\hline 3.5 .5 .9 & $\begin{array}{l}{ }^{99} \mathrm{Tc} \text { release rate reduced by a factor of } 5 \text { from the base analysis case. Thus the Tc release rate is that given in } \\
\text { the RFP. }\end{array}$ & 4.4.3.3 \\
\hline 3.5 .5 .9 & All $K_{d}=0$ elements release rate reduced by factor of 5 . & 4.4 .3 .3 \\
\hline 3.5 .5 .9 & Release rate for all elements reduced by factor of 5 . & 4.4.3.3 \\
\hline 3.5 .5 .9 & $\begin{array}{l}\text { Contaminant release rate from glass (in the form of marbles) as calculated by mechanistic models, including } \\
\text { sodium ion exchange. Contaminants transported to floor of vault. }\end{array}$ & 4.4 .3 .4 \\
\hline 3.5.5.9 & $\begin{array}{l}{ }^{99} \mathrm{Tc} \text { release from glass marbles determined by mechanistic models, but with sodium ion exchange. } \\
\text { Contaminants transported to floor of vault. }\end{array}$ & 4.4 .3 .4 \\
\hline 3.5 .5 .9 & $\begin{array}{l}{ }^{99} \mathrm{Tc} \text { release from glass marbles determined by mechanistic model, with sodium ion exchange. Contaminants } \\
\text { transported to floor of vault with pore velocity of } 10 \mathrm{~cm} / \mathrm{y} \text {. }\end{array}$ & 4.4.3.4 \\
\hline \multicolumn{3}{|c|}{ Geochemical } \\
\hline 3.5.5.10 & For uranium: $\mathrm{K}_{d}=0$ instead of $0.6 \mathrm{~m} \ell / \mathrm{g}$ as was used in the base analysis case. & 4.7 .3 \\
\hline 3.5.5.10 & For uranium: $\mathrm{K}_{\mathrm{d}}=0$ in vadose zone and $\mathrm{K}_{\mathrm{d}}=100 \mathrm{~m} / \mathrm{g}$ in concrete. & 4.7 .3 \\
\hline 3.5 .5 .10 & For major elements (Se and $\mathrm{Tc}$ ): $\mathrm{K}_{d}=0.1 \mathrm{m \ell} / \mathrm{g}$ instead of 0 . & 4.7 .3 \\
\hline
\end{tabular}


HNF-EP-0884

Rev. 1

\begin{tabular}{|c|c|c|}
\hline $\begin{array}{l}\text { Discussion } \\
\text { Section }\end{array}$ & $\begin{array}{l}\text { Sensitivity Case } \\
\text { (Unless Noted All Cases Treat Groundwater Scenario) }\end{array}$ & $\begin{array}{c}\text { Results } \\
\text { Presented in } \\
\text { Section }\end{array}$ \\
\hline \multicolumn{3}{|c|}{ Exposure } \\
\hline 3.5 .5 .11 & $\begin{array}{l}\text { Different dose factor sets. The dose factor libraries from DOE, EPA, and GENII computer analyses were } \\
\text { used instead of taking internal dose factors from DOE and external dose factors from EPA. }\end{array}$ & 4.8 .4 \\
\hline 3.5.5.11 & Use different ingestion, inhalation, and time of exposure values from base analysis case. & 4.8 .4 \\
\hline \multicolumn{3}{|c|}{ Location of Facility } \\
\hline 3.5 .5 .11 & $\begin{array}{l}\text { Location of facility at existing TWRS disposal (grout) vaults which are east of the PUREX Facility, rather } \\
\text { than at the proposed location which is west of PUREX. }\end{array}$ & 4.8 .5 \\
\hline \multicolumn{3}{|c|}{ Calculations } \\
\hline 3.5 .5 .13 & Halved dispersion of base analysis case for vadose zone contaminant transport. & 4.7 .2 .3 \\
\hline 3.5 .5 .13 & Twice dispersion of base analysis case for vadose zone contaminant transport. & 4.7 .2 .3 \\
\hline 3.5.5.13 & Twice number of grid points from base analysis case for vadose zone flow and transport. & 4.8 .6 \\
\hline 3.5 .5 .13 & $\begin{array}{l}\text { Initial volumetric moisture content in the disposal facility = residual moisture content of material, rather than } \\
10 \% \text { as in the base analysis case. }\end{array}$ & 4.8 .6 \\
\hline 3.5.5.13 & Initial volumetric moisture content in disposal facility $=20 \%$. & 4.8 .6 \\
\hline
\end{tabular}




\section{HNF-EP-0884 \\ Rev. 1}

3.5.5.2 Scenario-Dependent Sensitivity Cases. The scenario-dependent sensitivity cases are selected analyses to determine the extent to which results related to a scenario depend on selected values or assumptions. Several scenario-dependent cases were developed (Table 3-15). Land-use, drinking water, inadvertent intruder, and catastrophic natural scenarios were considered (Section 3.3).

Predicting land use at the Hanford Site for the next 10,000 years is impossible. Natural conditions were assumed for the base analysis case (Section 3.3.3.2). For land-use sensitivity cases, the effect of various land uses were calculated. The following uses were examined:

- Irrigated farming on top of the disposal facility with an infiltration rate of 100 $\mathrm{mm} / \mathrm{y}(3.9 \mathrm{in} / \mathrm{y})$. Such irrigation is considered as an inadvertent intrusion. However, in this analysis such irrigation is calculated as part of the groundwater scenario.

- Irrigated farming in other parts of the Hanford Central Plateau with recharge rates of $100 \mathrm{~mm} / \mathrm{y}(3.9 \mathrm{in} . / \mathrm{y})$. Such irrigation will distort the groundwater flow and change the water table height.

- Industrial use of the 200 Area, which is assumed to decrease the infiltration rate over the entire 200 Area by a factor of 2 , since water would be collected and then discharged at a point off the 200 area plateau.

The real value for the infiltration rate for irrigated farming is unknown. However, the value of $100 \mathrm{~mm} / \mathrm{y}(3.9 \mathrm{in} . \mathrm{y})$ is the lower value used in the Hanford grout performance assessment (Kincaid 1995) (the other value was $250 \mathrm{~mm} / \mathrm{year}$ ) and twice that used in the Hanford solid waste performance assessments (Wood 1994b and Wood 1996). These sensitivity cases treat only the effect of infiltration on the unconfined aquifer; the effect of different vadose zone distance is examined separately (See Section 3.5.5.5)

The drinking water scenario is based on the pumping rate and the location of the well. Minimal pumping $\left(0.01 \mathrm{~m}^{3} / \mathrm{day}=10\right.$ liters/day [ 2.6 gallons/day], corresponding to a family of five using the well only to obtain drinking water) is assumed for the base analysis case. As pumping is increased, water is taken from a wider area, resulting eventually in drawing in water that is uncontaminated. Pumping rates of 10 to $150 \mathrm{~m}^{3} /$ day $(2,640$ to 39,600 gallons/day) were used to determine the effect of the pumping rate on the overall drinking water dose.

In the base analysis case, the well is assumed to be 100 meters ( 328 feet) downgradient from the disposal facility. To determine the effect of the position of the well, the well was located as near as 50 meters (164 feet) and at various other distances (including the 200 Area fence line) along flow lines down to the Columbia River.

For the intrusion scenario, the parameters are quite uncertain. For one sensitivity case, the well diameter was decreased from 0.3 meters ( 12 inches) to 0.2 meters ( 8 inches). In another sensitivity case, the garden area was increased from $500 \mathrm{~m}^{2}$ to $2,500 \mathrm{~m}^{2}(0.124$ acre to 0.618 acre). The values used in the sensitivity cases were the values used in the base case of the grout 


\section{HNF-EP-0884}

\section{Rev. 1}

performance assessment (Kincaid 1995).

Finally, the effects of catastrophic natural events were evaluated. The base analysis case does not evaluate a catastrophic natural event. Neither seasonal flooding nor even the collapse of the region's largest dam would cause water to reach the disposal facility. However, a catastrophic ice-age flood similar to those that have occurred in the past, would affect the disposal facility and is analyzed.

3.5.5.3 Inventory-Dependent Sensitivity Cases. The inventory of radionuclides that will be in the waste form is uncertain. The inventory in the waste form depends on the amount and type of waste presently being stored in the Hanford Site tanks, the process used to separate tank waste into low-activity and high-activity waste streams, and the method of immobilization. At present, the separation process that the private vendors will use is unknown, as are the details of the method of immobilization. These sensitivity cases are designed to evaluate the effect of different amounts of key radioisotopes.

One sensitivity case was based on a possible strategy for reducing technetium release rates. In the request for proposal, the total ${ }^{99} \mathrm{Tc}$ release rate is specified at a level 5 times lower than that for other radionuclides. One strategy for achieving this reduced release rate is to reduce the amount of technetium by 80 percent. Such a sensitivity case was run.

The degree to which iodine will be volatilized in the immobilization operation (and hence not be in the final waste form) is unknown. For the base analysis case, it was assumed that 90 percent of the iodine will be volatilized. A sensitivity case of 50 percent of the iodine being volatilized was performed.

In the supporting document (WHC 1996) for the DOE petition to the NRC for the separated waste to be considered as non-high-level waste, various uncertainty bands are given. The amount of Cs separation may be different from what is assumed in the base analysis case. A sensitivity case increasing the amount of ${ }^{137} \mathrm{Cs}$ from $0.451 \mathrm{MCi}$ to $5.0 \mathrm{MCi}$ was performed.

3.5.5.4 Infiltration-Dependent Sensitivity Cases. The infiltration rate is one of the most important parameters of the calculation (Section 3.4.7). Besides the sensitivity case of $100 \mathrm{~mm} / \mathrm{y}$ (3.9 in./y) mentioned in Section 3.5.5.2, three additional cases involving different recharge rates were run. The base analysis case used $0.5 \mathrm{~mm} / \mathrm{y}(0.02 \mathrm{in} . / \mathrm{y})$ for the first 1,000 years, followed by a rate of $3.0 \mathrm{~mm} / \mathrm{y}(0.12 \mathrm{in} . / \mathrm{y})$. The first sensitivity case models the case of extremely low recharge $(0.1 \mathrm{~mm} / \mathrm{y})[0.004 \mathrm{in} . / \mathrm{y}]$. The second case uses the same rate as the Hanford Grout Performance Assessment (Kincaid 1995), (1.0 mm/y) [0.04 in./y], allowing comparisons to be made with that analysis. The final case used a recharge rate of $(3.0 \mathrm{~mm} / \mathrm{y})$ [0.12 in./y]. This case shows the effectiveness of the surface barrier, because the difference between this sensitivity case and the base analysis case is the recharge rate for the first 1,000 years. The recharge rate in the latter case was based on the presence of the surface barrier.

3.5.5.5 Geology-Dependent Sensitivity Cases. An understanding of the geologic strata is the starting point for the vadose zone simulations. Most of the sensitivity studies that are partially derived from geologic considerations are described in Sections 3.5.5.8 and 3.5.5.10. The 


\section{HNF-EP-0884 \\ Rev. 1}

sensitivity cases considered in this section deal with the location of the top of the unconfined aquifer. The effects of contaminant transport in both the vadose zone and in the unconfined aquifer were calculated.

Two sensitivity cases were developed that place the top of the unconfined aquifer above and below the position given in the base analysis case, 103 meters ( 338 feet) below the surface. One case located the top of the aquifer at 96 meters ( 315 feet) below the surface, its present location. This location is in the Hanford formation; the base analysis case had the aquifer in the Ringold Formation. This is an indirect way to study the influence of the hydrologic parameters.

The other sensitivity case located the top of the aquifer at 110 meters ( 360 feet) below the surface. This was deeper than the location used in the base analysis case by the same amount as the previous case was above the value of the base analysis case. The deeper location results in a larger vadose zone, resulting in longer contaminant travel time through the vadose zone.

3.5.5.6 Facility-Dependent Sensitivity Cases. The design of the disposal facility has not yet started, so the model used in the base analysis case has significant uncertainties. Several sensitivity cases were studied to determine the importance of various design features.

Three sensitivity cases deal with the sand-gravel capillary barrier proposed for the top and sides of the disposal facility. The first case has no capillary barrier at all. The second case has the barrier only at the top of the facility. The third case used the Concept 2 layout (Section 3.4.6.3), which has a much shorter barrier.

Another case replaces the soil between the stacks of containers with sand to examine the effect of the hydrologic properties of the filler material. The hydrologic properties determine the "wicking" action of material.

Two additional sensitivity cases deal with the geometry of the disposal facility. In one case, the facility is rotated to determine the effect of facility orientation on contaminant concentration in the well compared to contaminant concentration at the bottom of the vadose zone. The second case doubles the area of the facility, while keeping the total inventory of radionuclides constant. This simulates a decrease in radionuclide density, which could result from lower waste loadings, different spacing between the containers, or other reasons.

3.5.5.7 Facility Degradation-Dependent Sensitivity Cases. Four sensitivity cases test the importance of assumptions made about facility degradation for the base analysis case. These assumptions were that natural materials do not degrade but that man-made materials, such as concrete, degrade at 500 years (Section 3.4.6.7).

Two cases deal with the degradation of the concrete walls, floors, and ceilings. In the first case, the concrete degrades to gravelly sand at the time of closure. No credit is taken for concrete as a physical barrier. The second case determines the effect of the concrete structure trapping water and then releasing it all at once. This so-called "bathtub effect" is modelled by having the concrete ceiling and the upper parts of the concrete walls degrade at 500 years but the concrete floor degrades at 2,000 years, 


\section{HNF-EP-0884}

Rev. 1

A group of sensitivity cases focuses on the effects of a degrading sand-gravel capillary barrier. The degradation of the capillary barrier is modeled by having the capillary barrier subside at a point $2 / 3$ down the length of the barrier. The cases run were based on different amounts of subsidence.

3.5.5.8 Hydrologic Parameter-Dependent Sensitivity Cases. Hydrologic properties are expected to vary spatially. To determine the importance of different hydrologic parameters, large changes in these parameters were made in the vadose zone calculation. For the base analysis case, the Hanford formation was assumed to have the hydrologic properties of gravelly sand for the top 6 percent, sand for the middle 60 percent, and gravelly sand for the bottom portion. The first sensitivity case assumes that the entire formation has the properties of sand. The second assumes that the hydrologic properties correspond to gravelly sand for the top 6 percent, sand for the next 44 percent, and gravelly sand for the bottom 50 percent.

A separate sensitivity case looked at the importance of diffusion. The diffusion constant was changed from $1.27 \times 10^{-7} \mathrm{~cm}^{2} / \mathrm{s}$ to $1 \times 10^{-6} \mathrm{~cm}^{2} / \mathrm{s}$.

3.5.5.9 Waste Form-Dependent Sensitivity Cases. Waste form-dependent sensitivity cases were made to relate the effects assumptions about the waste form have on the overall source term component of the analysis. For the base analysis case, the contaminant release rate was based on the initial fractional radionuclide release rate (Section 3.4.5.4) given for elements other than Tc in the TWRS privatization specification (DOE-RL 1996). Also, because the waste form was unspecified, it was assumed to be a large cube that fits in the container. The related sensitivity cases focus on changes in the contaminant release rate and the waste form.

Two main sensitivity cases dealt with alternative interpretations of the waste form performance in the request for proposal (DOE-RL 1996). The first assumed the release rates were independent of time. This is equivalent to assuming that corrosion is only important in one dimension (for example if the waste form were a series of plates) or that the surface to volume ratio stays constant as a function of time. Because of the decrease in size of a waste form unit, the surface to volume ratio would normally decrease as size decreases unless cracking becomes important. The second sensitivity case assumes that, for some reason (for example, precipitation into a stable compound or incorporation into an altered glass phase), the release rate for technetium was a factor of five less than for the other elements. The effect of a reduced release rate for all elements or for just $\mathrm{K}_{\bar{\sigma}}=0$ elements was also calculated.

The final sensitivity cases used a mechanistic approach to determine the contaminant release rate, rather than using the specifications in the RFP. The AREST-CT computer code (Section 3.5.2.2) simulated the corrosion of LD6-5412 glass, the release of contaminants into the water, the formation of secondary mineral phases, and then the transport of contaminants out of the waste package. For these calculations (see Appendix $\mathrm{C}$ for details), spheres 1 centimeter in diameter surrounded by a sand matrix were used. The glass made up 70 percent of the volume. Such assumptions led to a surface area that is 27 times larger than the surface area of a nonfractured monolithic $1.2 \times 1.2 \times 1.8$ meter cube. An average pore velocity of $1 \mathrm{~cm} / \mathrm{y}$ was used for the transport calculations. Two additional sensitivity cases were performed around this sensitivity case. The first case assumed that the only reaction involving glass was the glass 


\section{HNF-EP-0884 \\ Rev. 1}

corrosion reaction (and that the sodium in the glass was not preferentially leached out). The second additional case involved a pore velocity of $10 \mathrm{~cm} / \mathrm{y}$. The results of these calculations (which yield time- and spatial-dependent release rates) are presented in Section 4.4.2.

3.5.5.10 Geochemical-Dependent Sensitivity Cases. The values for chemical distribution coefficients, $K_{d}$ can vary with environmental conditions (Kaplan 1995a). This means that as a contaminant moves from the disposal facility environment to the vadose zone, the $K_{d}$ value for the contaminant will change. However, in the base analysis case, the $\mathrm{K}_{\mathrm{d}}$ values were assumed not to vary as the contaminants move through the disposal system and the vadose zone. To determine the sensitivity to different $K_{d}$ values, a series of sensitivity cases for the most important elements was defined.

Two cases involve the $K_{d}$ for uranium. The first used a reduced value for the $K_{d}$ value for uranium. The value was reduced from $0.6 \mathrm{ml} / \mathrm{g}$ to 0 throughout the system. A uranium $\mathrm{K}_{\mathrm{d}}$ value of 0 has been used in other Hanford Site performance assessments (Wood 1994b, Kincaid 1995 , Wood 1995, and Wood 1996). The other case used 0 as the $K_{d}$ value of uranium everywhere except in concrete, where the $\mathrm{K}_{d}$ value was $100 \mathrm{~m} / \mathrm{g}$ (Krupka 1995).

The best present knowledge for the chemical distribution coefficients for technetium and selenium is that these elements do not sorb on sediments present on the Hanford Site. This is why the $K_{d}$ value used in the base analysis case for each element was 0 . However, a sensitivity case using $0.1 \mathrm{ml} / \mathrm{g}$ was created to quantify the effect of a small amount of retardation to determine the value of on-going experiments to determine non-zero $\mathrm{K}_{d}$ values for very mobile contaminants.

3.5.5.11 Exposure Parameter-Dependent Cases. Many dosimetry parameters have been proposed. To determine the sensitivity to the parameters chosen for the base analysis case, different parameter sets were used in sensitivity cases. Separate sensitivity runs were made with the dose factor sets from the DOE, EPA, and GENII computer analyses. 'The dose factor values are given in Rittmann (1995). In addition, the sensitivity to ingestion rates, inhalation rates, and time of exposure was calculated.

3.5.5.12 Location of the Facility. The base analysis case assumed that a single disposal facility would exist in the south central part of the 200 East Area. However, some of the immobilized waste could be placed in the existing vaults at the eastern edge of the 200 East Area, which were built to hold grouted waste from the double-shell tanks. Sensitivity studies were made to determine the long-term impacts from placing part of the waste in these vaults.

3.5.5.13 Calculational Assumption-Dependent Sensitivity Cases. The previous sections addressed uncertainties related to data about natural and man-made materials. However, uncertainties based on the calculational methods used must be addressed. Sensitivity cases were defined to address steady-state versus transient calculations, the effect of the number of grid points, the effect of dispersion, and the effect of initial moisture content.

In any computer representation, a finite number of spatial elements must represent an infinite number of points. A sensitivity case using double the number of grid points shows the 


\section{HNF-EP-0884}

Rev. 1

effect of grid size and spacing.

Dispersion of contaminants, especially on the large scales represented in these analyses, is quite uncertain. A series of dispersion values was used to determine the sensitivity of the calculations to this parameter.

Finally, the initial moisture content in the disposal facility was varied to determined the importance of this initial condition. The base analysis case used 10-percent moisture content as the initial value. One sensitivity case used the residual moisture content $\left(\Theta_{\mathrm{r}}\right.$ from Section 3.4.4.3) as the initial moisture content for each soil type. The other sensitivity case used a value of 20 percent, twice that used in the base analysis case.

\subsection{Quality Assurance}

\subsubsection{Overview}

This section describes the quality assurance activities associated with the performance assessment activity. Three separate areas are covered: 1) experimental data collection, 2) computer code use, and 3 ) analyses. The following sections are arranged according to which organization performing the activity.

\subsubsection{Pacific Northwest National Laboratory (PNNL).}

The work for the performance assessment activity conducted by PNNL was performed according to the appropriate portions of PNNL's Quality Assurance (QA) Program Plan. This program conforms to NQA-1, Quality Assurance Standard Requirements for Nuclear Facilities (ANSI/ASME 1989), as interpreted in Parts 1 and 3 of PNNL's Quality Assurance Manual (PNL 1994). Part 3 of this manual is a set of administrative procedures that define how the various requirements of NQA-1 are implemented. The administrative procedures define controls, policies, and established methods for managing and conducting all aspects of work that affect quality. For experimental studies at PNNL supporting this performance assessment, all phases of the work were performed according to the QA program.

Computer codes used for the performance assessment are documented, tested, and reviewed following the software control procedures established as part of the overall QA program. These software control procedures have been structured to address requirements of NQA-1, Basic Requirements 3, and Supplement 3S-1, Supplemental Requirements for Design Control. The procedures cover all aspects of code development and use.

A key aspect of the QA program involves technical and peer reviews of procedures, test plans, data, calculations, and test results. The reviews range from verifying that calculations or data reduction have been performed correctly to evaluating test methodology as described in a proposed test plan. 


\section{HNF-EP-0884 \\ Rev. 1}

No audits were performed for the interim performance assessment. However, comprehensive audits are expected for the preliminary and final performance assessments.

Records generated from all activities are indexed and managed according to QA program requirements. Record holding facilities are used for long-term records retention and storage.

\subsubsection{Project Hanford Management Contractors}

Most of the effort for the performance assessment was performed when the Westinghouse Hanford Company (WHC) was responsible for Hanford Site tank waste. The quality assurance activities at WHC are similar to those at PNNL. The disposal project does not yet have a QA plan, so the requirements of the Hanford Site Grout Facilities Quality Assurance Program Plan (Wood 1992) are being used temporarily. Further requirements are established in WHC's Quality Assurance Manual (WHC 1992); the requirements are indexed corresponding to NQA-1.

For this performance assessment, Basic Item 19 of the WHC Quality Assurance Program (software quality assurance) was implemented by using the document Software Practices (WHC 1993) and Section 2.1 of Standard Engineering Practices (WHC 1994a). All codes used in these analyses are under configuration control and have been verified.

\subsubsection{Other Contractors}

Other organizations, such as Argonne National Laboratory and D.B. Stevens, Inc., worked on this activity. Their work was performed under either the PNNL or WHC QA plan.

\subsubsection{Hanford Environmental Dose Overview Panel}

The Richland Operations Office of DOE established the Hanford Environmental Dose Oversight Panel (Schreckhise 1993) to

- Ensure that appropriate radiological and nonradiological environmental and health dose assessment methods are used at the Hanford Site

- Ensure that all Hanford Site-related environmental and health dose assessments are technically consistent

- Foster communications among Hanford Site contractors regarding environmental and health dose assessments.

All dose calculations used in this performance assessment have been reviewed and approved for publication by a HEDOP reviewer (Rhoads). 


\section{HNF-EP-0884}

Rev. 1

\subsubsection{Technical Reviews of Supporting Efforts}

External technical reviews by outside experts are being held on specialized topics because of the large amount of technical data used in performance assessments. The purpose of these reviews is to ensure that the proper methods, techniques, and resources are used in obtaining the data.

The only review held so far concerned the recharge rate (Honeyman 1995). The panel consisted of Mr. William E. Kennedy, Dr. Fred M. Phillips, Dr. Bridget Scanlon, Dr. Martinus Th. van Genuchten, and Dr. Peter J. Wierenga. They concluded that the recharge research performed at the Hanford Site over the past several decades was adequate for the preliminary performance assessment. However, additional effort would add credibility to the final performance assessment.

Additional focused panel reviews are expected to occur in the future for the preliminary and final performance assessments.

\subsubsection{Review of the Performance Assessment}

Various individuals and organizations have commented on the first version of the interim performance assessment. Their comments (as well as the responses to those comments) are displayed in Appendix F.

An external advisory board (Professor Lynn Gelhar, Dr. Louis Kovach, Todd Martin, Dr. Bill Prindle, and Dr. Elmer Wilhite with George Williamson serving as secretary) was especially formed to review the performance assessment activity and, in particular, this performance assessment. The qualifications of this board are given in Appendix A of Appendix F.1.3. Their report is shown in Appendix F.1.3, while the responses to their comments are in Appendix F.1.4.

Others who provided comments were Phil Lamont and Doug Hildebrand of the Richland Operations Office of the Department of Energy, the staff of the Nuclear Regulatory Commission, the U.S. Department of the Navy, and four Hanford employees (Dewey Burbank, Dr. Kathleen Rhoads, Jeffrey Voogd, and Joseph Westsik). 


\section{HNF-EP-0884 \\ Rev. 1}

\section{RESULTS OF ANALYSES}

\subsection{OVERVIEW}

This chapter presents the results of the analyses described in Chapter 3. Further it discusses the data and methods affecting those results. The emphasis of this chapter is not on the computational results per se, but rather on understanding the suite of analyses. Thus many of the numerical results will be found in Appendix E, "Detailed Results".

This chapter is divided into four parts, organized by scenario:

1. The results from the inadvertent intruder scenarios (Section 4.2 )

2. The results from the groundwater scenarios, including the impact on surface water (Sections $4.3-4.10$ )

3 The results from the releases to air (Section 4.11)

4. The results of catastrophic events (Section 4.12).

For each scenario, the all-pathway dose is calculated, as appropriate.

\subsection{RESULTS FOR INADVERTENT INTRUDER SCENARIO}

\subsubsection{Overview}

Based on the discussion presented in section 3.3.3.4, only two scenarios are considered:

1. A person drills through the disposal facility in the process of creating a well to obtain water

2. A homesteader lives on the land contaminated by the drill tailings.

As noted in section 1.5.2.4, the time of compliance is 500 years after closure. Results will be presented, however, for the time period of 100 years after closure to 1000 years after closure. The performance objective for the driller scenario is 500 mrem (EDE) for a one-time exposure, while for the homesteader scenario the performance objective is $100 \mathrm{mrem}$ (EDE) per year for a continuous exposure.

The time of closure is taken to be 2020, although the final closure of all the vaults is not expected until 2028 . 


\subsubsection{Driller Scenario}

This scenario is described in section $3.3 .3 .4 ;$ the parameters used are presented in section 3.4.8.3. This scenario is less restrictive than the homesteader scenario, which is described in section 4.2.3. Therefore, only a brief summary of the driller scenario will be presented.

The results for the driller scenario are presented in Table 4-1 and displayed in Figure 4-1. The effect of waste form dissolution can be seen In Table 4-1 for the long-lived radionuclides. For these radionuclides (for example, ${ }^{99} \mathrm{Tc}$ ), the estimated dose increases as a function of time because more of the radionuclides are available for ingestion.

Figure 4-1. Inadvertent Intruder Results for the Driller Scenario - Base Analysis Case. The D in the legend represents "daughters."

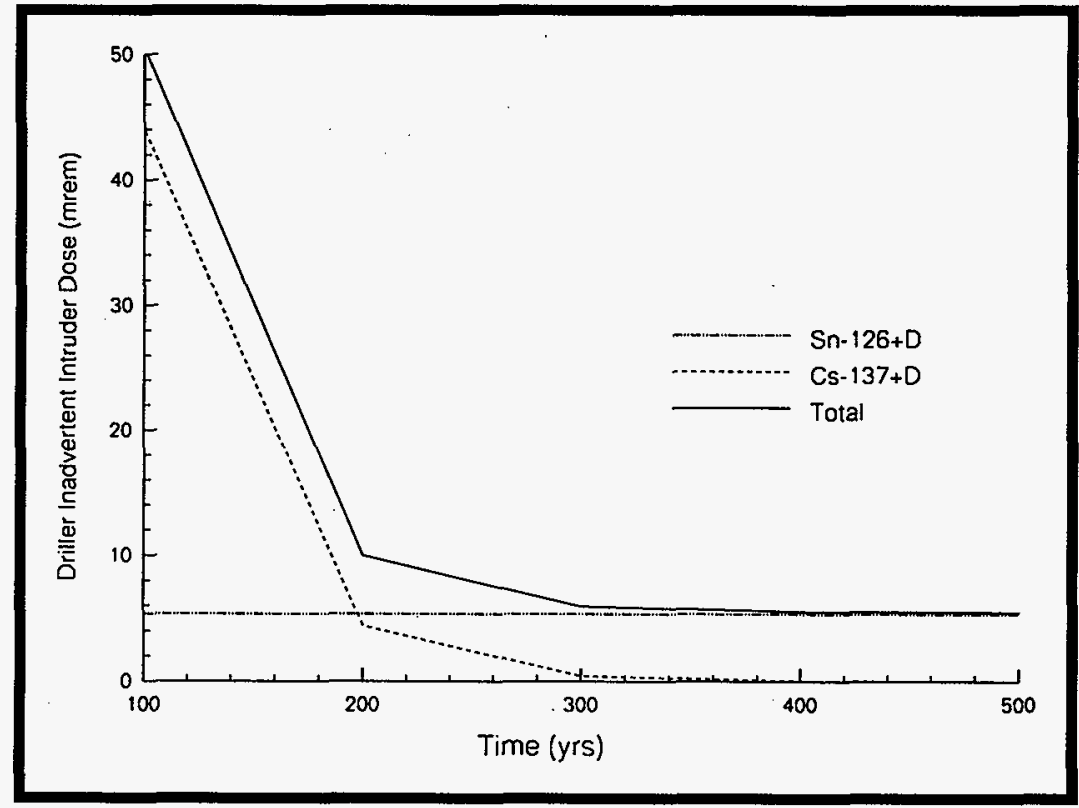

At all times calculated, the predicted dose is at least one order of magnitude less than $500 \mathrm{mrem}$, the performance objective at 500 years. The main radionuclide contributing to the dose initially is ${ }^{137} \mathrm{Cs}$. After about 180 years, ${ }^{126} \mathrm{Sn}$ becomes the most important nuclide. 


\section{HNF-EP- 0884}

Rev. 1

Table 4-1. Driller Intruder Dose (mrem) at Various Intrusion Times (years)a

\begin{tabular}{|c|c|c|c|c|c|c|c|c|}
\hline Nuclide & 100 & 200 & 300 & 400 & 500 & 600 & 800 & 1000 \\
\hline $\mathrm{C}-14$ & $3.36 \mathrm{E}-08$ & $3.39 E-08$ & $3.41 \mathrm{E}-08$ & $3.44 E-08$ & $3.46 \mathrm{E}-08$ & $3.49 E-08$ & $3.53 \mathrm{E}-08$ & $3.57 \mathrm{E}-08$ \\
\hline $\mathrm{Se}-79$ & $6.50 \mathrm{E}-06$ & $6.86 \mathrm{E}-06$ & $7.21 \mathrm{E}-06$ & $7.57 \mathrm{E}-06$ & $7.93 E-06$ & $8.28 \mathrm{E}-06$ & $8.98 \mathrm{E}-06$ & $9.68 \mathrm{E}-06$ \\
\hline $5 x-90+D$ & $1.06 \mathrm{E}+00$ & $9.38 E-02$ & $8.32 \mathrm{E}-03$ & $7.38 \mathrm{E}-04$ & $6.54 \mathrm{E}-05$ & $5.80 \mathrm{E}-06$ & $4.56 \mathrm{E}-08$ & $3.59 \mathrm{E}-10$ \\
\hline Zr-93 & $1.62 \mathrm{E}-06$ & 1. $65 E-06$ & $1.66 \mathrm{E}-06$ & $1.67 E-06$ & 1. $68 E-06$ & $1.69 \mathrm{E}-06$ & $1.71 \mathrm{E}-06$ & $1.74 \mathrm{E}-06$ \\
\hline $\mathrm{Nb}-93 \mathrm{~m}$ & 1. $22 \mathrm{E}-08$ & $1.06 E-10$ & $9.16 \mathrm{E}-13$ & $7.95 E-15$ & $6.91 \mathrm{E}-17$ & $5.99 E-19$ & $4.52 \mathrm{E}-23$ & $3.41 \mathrm{E}-27$ \\
\hline $\mathrm{TC}-99$ & $8.97 \mathrm{E}-04$ & $8.98 \mathrm{E}-04$ & $8.99 \mathrm{E}-04$ & $9.00 E-04$ & $9.01 \mathrm{E}-04$ & $9.02 \mathrm{E}-04$ & $9.04 E-04$ & $9.06 \mathrm{E}-04$ \\
\hline$S n-126+D$ & $5.35 \mathrm{E}+00$ & $5.35 \mathrm{E}+00$ & $5.34 \mathrm{E}+00$ & $5.34 \mathrm{E}+00$ & $5.33 E+00$ & $5.33 E+00$ & $5.32 \mathrm{E}+00$ & $5.32 \mathrm{w}+00$ \\
\hline$I-129$ & $2.75 E-05$ & $2.76 \mathrm{E}-05$ & $2.77 \mathrm{E}-05$ & $2.78 E-05$ & $2.79 E-05$ & $2.79 \mathrm{E}-05$ & $2.81 \mathrm{E}-05$ & $2.82 \mathrm{E}-05$ \\
\hline $\mathrm{Cs}-134$ & $1.36 \mathrm{E}-20$ & $3.43 E-35$ & $8.64 \mathrm{E}-50$ & $2.17 \mathrm{E}-64$ & $5.48 E-79$ & 1. $38 E-93$ & $8.74 \mathrm{E}-123$ & $5.54 \mathrm{E}-152$ \\
\hline$C s-137+D$ & $4.395+01$ & $4.41 \mathrm{E}+00$ & 4. $44 \mathrm{E}-01$ & $4.46 \mathrm{E}-02$ & $4.48 E-03$ & $4.50 E-04$ & $4.55 \mathrm{E}-06$ & $4.60 E-08$ \\
\hline$S m-151$ & 5. $00 \mathrm{E}-06$ & $2.49 \mathrm{E}-06$ & $1.24 \mathrm{E}-06$ & $6.10 \mathrm{E}-07$ & $3.00 \mathrm{E}-07$ & $1.47 \mathrm{E}-07$ & $3.50 \mathrm{E}-08$ & $8.24 E-09$ \\
\hline$R a-226+D$ & $6.81 \mathrm{E}-06$ & $6.52 \mathrm{E}-06$ & $6.24 E-06$ & $5.98 \mathrm{E}-06$ & $5.73 E-06$ & $5.48 \mathrm{E}-06$ & $5.03 E-06$ & $4.61 E-06$ \\
\hline $\mathrm{Ra}-228+\mathrm{D}$ & $4.47 \mathrm{E}-08$ & $2.60 \mathrm{E}-13$ & 1. $51 \mathrm{E}-18$ & $8.81 E-24$ & $5.12 \mathrm{E}-29$ & $2.98 E-34$ & $1.01 \mathrm{E}-44$ & $3.41 E-55$ \\
\hline$A C-227+D$ & $2.73 E-05$ & $1.14 E-06$ & 4. $74 E-08$ & $1.98 E-09$ & $8.24 \mathrm{E}-11$ & $3.43 E-12$ & $5.95 \mathrm{E}-15$ & $1.03 E-17$ \\
\hline $\mathrm{Th}-229+\mathrm{D}$ & $4.59 E-06$ & $4.56 \mathrm{E}-06$ & $4.53 \mathrm{E}-06$ & $4.49 E-06$ & $4.46 \mathrm{E}-06$ & $4.43 E-06$ & $4.36 \mathrm{E}-06$ & $4.30 E-06$ \\
\hline$T h-232$ & 1. $14 \mathrm{E}-04$ & $1.14 \mathrm{E}-04$ & $1.14 \mathrm{E}-04$ & $1.14 E-04$ & $1.14 \mathrm{E}-04$ & $1.14 E-04$ & $1.14 \mathrm{E}-04$ & $1.14 \mathrm{E}-04$ \\
\hline $\mathrm{Pa}-231$ & $9.32 \mathrm{E}-02$ & $9.72 \mathrm{E}-02$ & $9.78 \mathrm{E}-02$ & $9.82 \mathrm{E}-02$ & $9.86 \mathrm{E}-02$ & $9.90 E-02$ & $9.98 E-02$ & $1.01 E-01$ \\
\hline $\mathrm{u}-233$ & 1. $28 \mathrm{E}-04$ & $2.44 E-04$ & $3.59 \mathrm{E}-04$ & $4.73 \mathrm{E}-04$ & $5.87 \mathrm{E}-04$ & $7.01 \mathrm{E}-04$ & $9.25 \mathrm{E}-04$ & $1.15 E-03$ \\
\hline$U-234$ & $3.47 \mathrm{E}-06$ & 4. $64 E-0.6$ & $5.82 \mathrm{E}-06$ & $7.00 \mathrm{E}-06$ & $8.18 E-06$ & $9.38 E-06$ & $1.18 \mathrm{E}-05$ & $1.42 \mathrm{E}-05$ \\
\hline
\end{tabular}




\section{HNF-EP-0884}

Rev. 1

\begin{tabular}{|c|c|c|c|c|c|c|c|c|}
\hline Nuclide & 100 & 200 & 300 & 400 & 500 & 600 & 800 & 1000 \\
\hline $\mathrm{U}-235+\mathrm{D}$ & $1.75 \mathrm{E}-04$ & $1.76 \mathrm{E}-04$ & $1.77 \mathrm{E}-04$ & $1.78 \mathrm{E}-04$ & $1.79 \mathrm{E}-04$ & $1.80 \mathrm{E}-04$ & 1. $82 E-04$ & $1.85 E-04$ \\
\hline $\mathrm{U}-236$ & $5.71 \mathrm{E}-08$ & $8.37 E-08$ & $1.10 \mathrm{E}-07$ & $1.37 E-07$ & $1.63 E-07$ & $1.90 \mathrm{E}-07$ & $2.43 \mathrm{E}-07$ & $2.95 E-07$ \\
\hline $\mathrm{U}-238+\mathrm{D}$ & $6.77 \mathrm{E}-04$ & $6.78 \mathrm{E}-04$ & $6.79 E-04$ & $6.80 E-04$ & $6.81 \mathrm{E}-04$ & $6.82 \mathrm{E}-04$ & $6.84 E-04$ & $6.86 \mathrm{E}-04$ \\
\hline$N p-237+D$ & 1. $25 E-03$ & 1. $25 \mathrm{E}-03$ & $1.25 \mathrm{E}-03$ & $1.25 \mathrm{E}-03$ & $1.26 \mathrm{E}-03$ & 1. $26 \mathrm{E}-03$ & 1. $26 \mathrm{E}-03$ & 1. $26 \mathrm{E}-03$ \\
\hline $\mathrm{Pu}-239$ & 1. $07 \mathrm{E}-03$ & $1.93 E-03$ & $2.78 E-03$ & $3.63 E-03$ & $4.48 \mathrm{E}-03$ & $5.31 \mathrm{E}-03$ & $6.97 \mathrm{E}-03$ & $8.61 \mathrm{E}-03$ \\
\hline $\mathrm{Pu}-240$ & $1.86 \mathrm{E}-04$ & $3.49 \mathrm{E}-04$ & $5.07 \mathrm{E}-04$ & $6.63 \mathbf{E}-04$ & $8.15 \mathrm{E}-04$ & $9.63 \mathrm{E}-04$ & 1. $25 E-03$ & $1.52 \mathrm{E}-03$ \\
\hline$A m-241$ & $5.22 \mathrm{E}-02$ & $4.58 E-02$ & $4.01 \mathrm{E}-02$ & $3.51 \mathrm{E}-02$ & $3.07 \mathrm{E}-02$ & $2.68 \mathrm{E}-02$ & $2.05 E-02$ & 1. $56 \mathrm{E}-02$ \\
\hline Am-243+D & $7.47 \mathrm{E}-04$ & $7.41 \mathrm{E}-04$ & $7.35 \mathrm{E}-04$ & $7.30 \mathrm{E}-04$ & $7.24 \mathrm{E}-04$ & $7.18 \mathrm{E}-04$ & $7.07 \mathrm{E}-04$ & $6.96 \mathrm{E}-04$ \\
\hline $\mathrm{Cm}-245$ & $1.12 \mathrm{E}-05$ & $1.14 \mathrm{E}-05$ & $1.15 \mathrm{E}-05$ & $1.16 \mathrm{E}-05$ & 1. $17 \mathrm{E}-05$ & 1. $18 \mathrm{E}-05$ & $1.19 \mathrm{E}-05$ & $1.20 \mathrm{E}-05$ \\
\hline Total & 50.46 & 10.00 & 5.94 & 5.53 & 5.48 & 5.47 & 5.46 & 5.45 \\
\hline
\end{tabular}

values in bold indicate highest contributor to dose

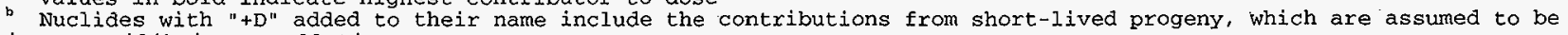
in equilibrium at all times 
None of the sensitivity cases affect the conclusion that the driller scenario meets the performance objective. Even increasing the ${ }^{137} \mathrm{Cs}$ content to $5 \mathrm{MCi}$ (WHC 1996) only results in increasing the predicted total driller dose to $493 \mathrm{mrem}$ at 100 years and has no significant effect after 300 years. Changing other parameters (inventory of other radionuclides, waste density, size of the well, area over which the waste form is spread, the integrity of the waste form) modified the predicted exposures by at most a factor of two.

\subsubsection{Homesteader Scenario}

4.2.3.1 Results. This scenario is described in section 3.3.3.4; the parameters used are presented in Sections 3.4.8.3 and 3.4.8.4. The waste is assumed to be 7.2 meters ( 24 feet) thick and uniformly distributed in the disposal facility (i.e. the waste is averaged over the volume of the container and the filler material). This averaging method is consistent with the assuming that the placement of the well is random over the disposal vault. The well is 0.30 meters (12 inches) in diameter. Thus, the drilling operation brings 0.509 cubic meters of waste to the surface. This waste is spread over an area of $500 \mathrm{~m}^{2}$ (5382 $\mathrm{ft}^{2}$ ) and mixed by tilling to a depth of 0.15 meters ( 5.9 inches). since the garden volume is $75 \mathrm{~m}^{3}\left(2649 \mathrm{ft}^{3}\right)$, the waste is diluted by a factor of 133. For dose factor generation, if the waste has an unit concentration of $1 \mathrm{ci} / \mathrm{m}^{3}$, then the final concentration in the garden soil is $4.52 \mu \mathrm{Ci} / \mathrm{kg}$.

The predicted doses for a hypothetical homesteader are presented in Table $4-2$ and displayed in Figure 4-2. As in the driller scenario, estimated doses for long-lived radionuclides increase as a function of time because more of the waste is available for ingestion and inhalation as the waste form degrades.

The main radionuclide contributing to the dose initially is
${ }^{137} \mathrm{Cs}$. After 190 years, ${ }^{126} \mathrm{Sn}$ becomes the most important radionuclide. Because the radionuclides are assumed to be trapped in the glass and hence unavailable for ingestion or inhalation, the dominant dose pathway is external radiation. Using the many (mostly conservative assumptions) of the base analysis case, the predicted dose is 27.5 mrem in a year, over a factor of 3 lower than the performance objective of $100 \mathrm{mrem} / \mathrm{y}$ at 500 years. The estimated dose exceeds $100 \mathrm{mrem} / \mathrm{y}$ for times less than 150 years after closure of the facility. The major parameters driving these results are the following: 
Figure 4-2. Inadvertent Intruder Results for the Homesteader Scenario - Base Analysis Case. The D in the legend represents "daughters."

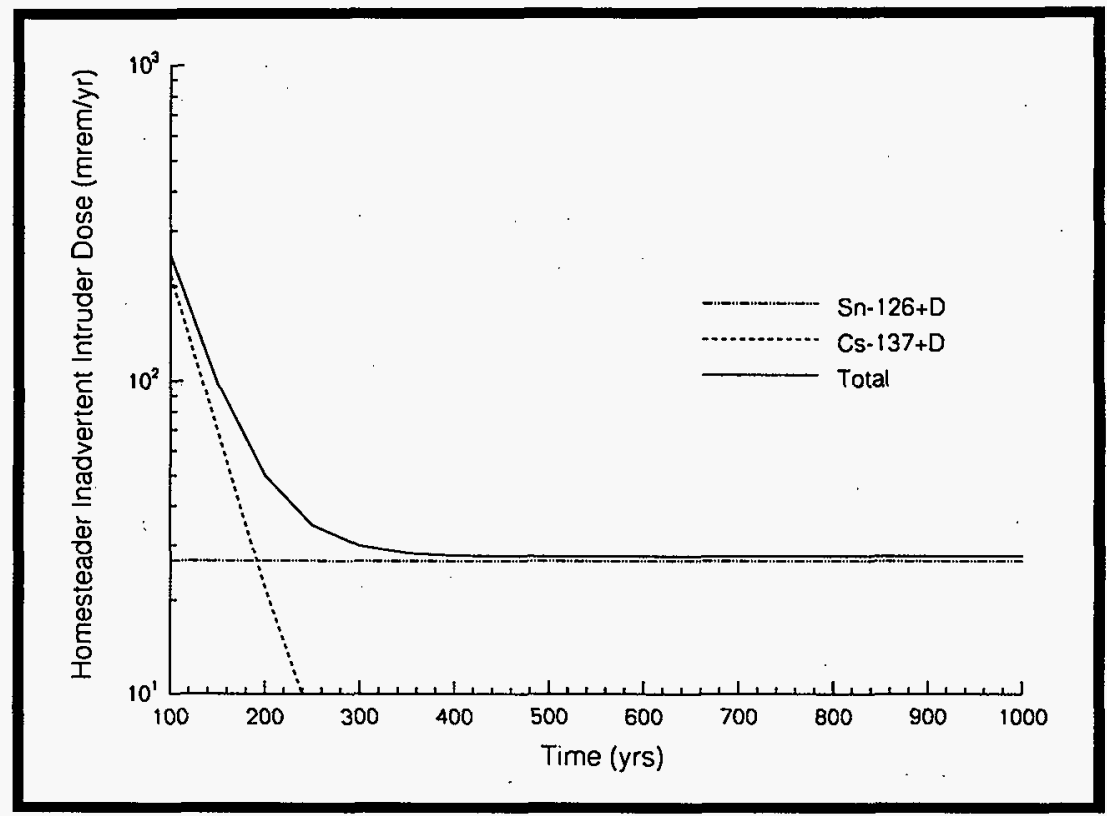

- The initial inventory of ${ }^{137} \mathrm{Cs}$

- The initial inventory of ${ }^{126} \mathrm{Sn}$

- The assumption that the glass does not shatter into extremely small fines after the drilling episode

- The area over which the waste is spread on the surface

- The size of the hole drilled

- The areal density of the waste inside of the disposal facility.

The sensitivity of the results to these and other parameters is discussed in sections 4.2.3.2 through 4.2 .3 .8 . 
HNF-EP- 0884

Rev. 1

Table 4-2. Homesteader Intruder Dose (mrem in a year) at various Intrusion Times (years)"

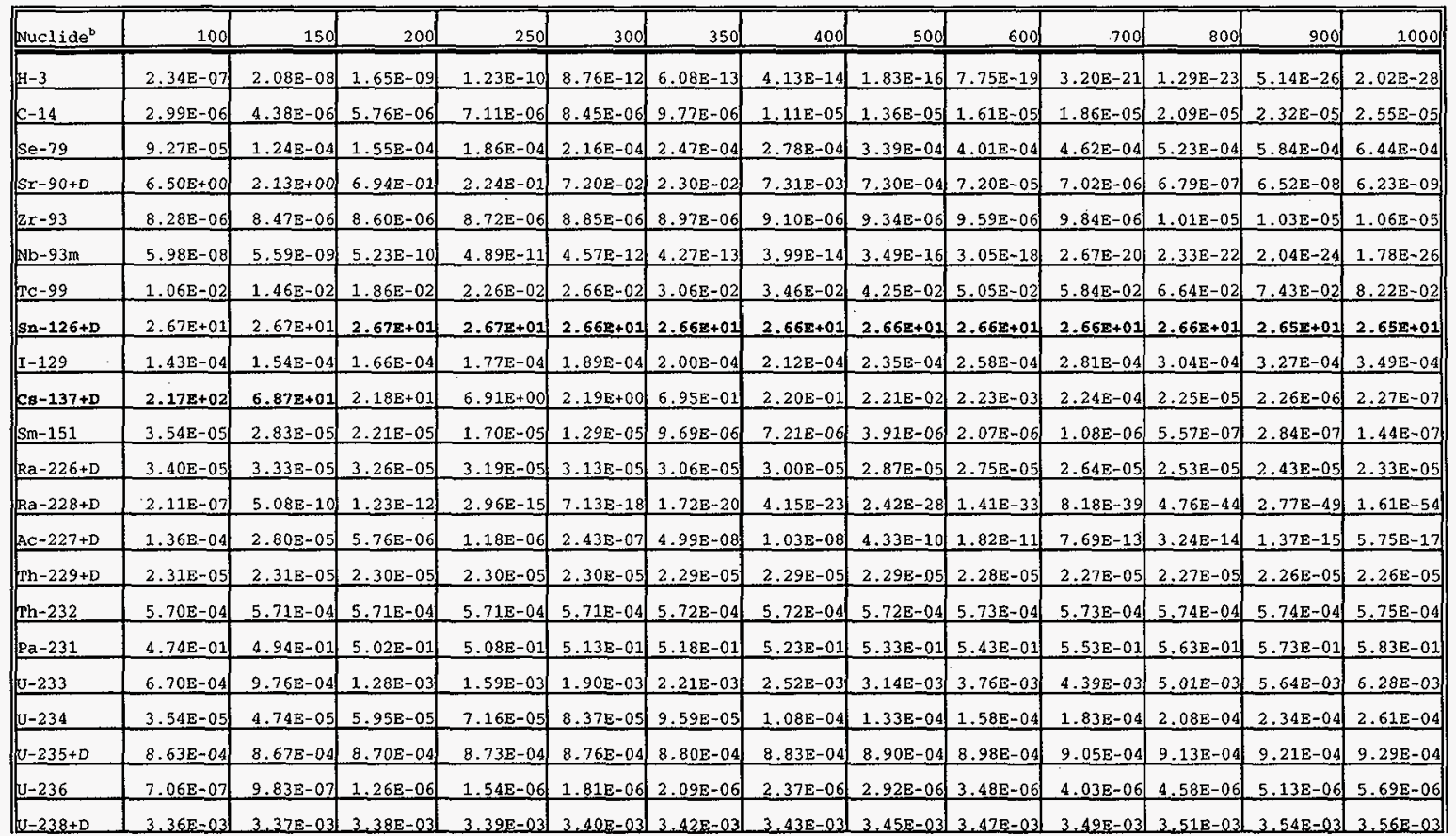




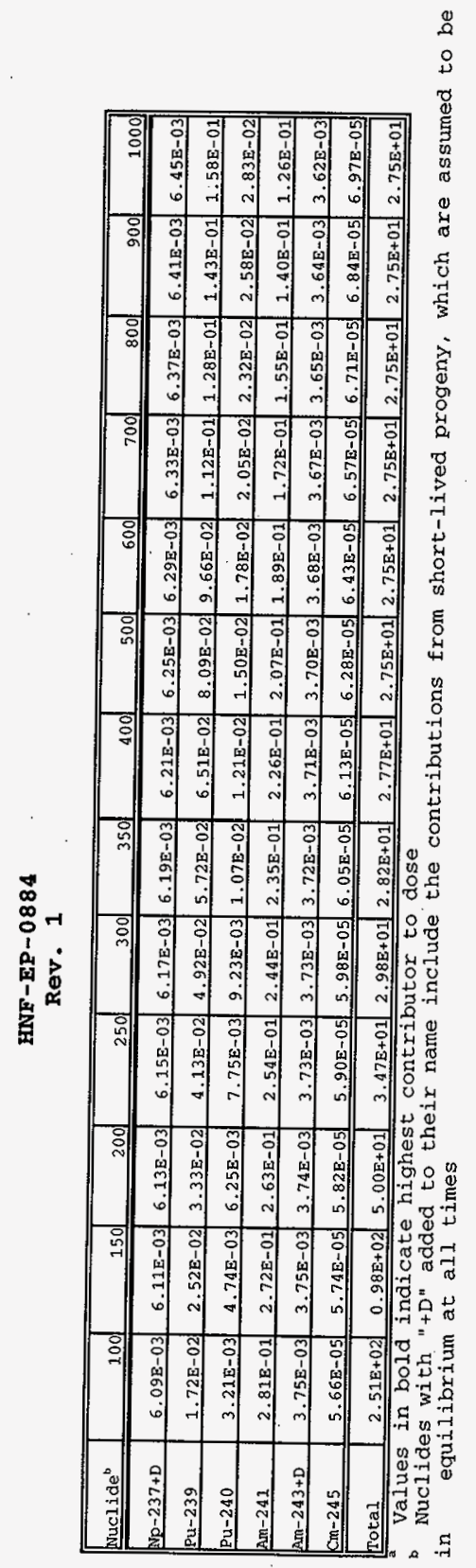


4.2.3.2 ${ }^{137} \mathrm{Cs}$. At 100 years after closure, ${ }^{137} \mathrm{Cs}$ contributes over 88 percent of the predicted dose. Thus if the amount of ${ }^{137} \mathrm{Cs}$ is changed, the change in the predicted dose at 100 years follows the change in ${ }^{137} \mathrm{Cs}$. However, the amount of ${ }^{137} \mathrm{Cs}$ will not affect the predicted dose at the time of compliance (500 years after closure), because of its short half-life ( 30 years). The predicted dose due to ${ }^{137} \mathrm{Cs}$ decreases about an order of magnitude for every 100 years, thus the predicted dose due to ${ }^{137} \mathrm{Cs}$ at 500 years is $10^{-4}$ of the value at 100 years.

As part of the effort to determine the radioactive classification of the material taken from the single shell tanks (whether it is high-level waste or incidental waste after it has been treated).(WHC 1996), an inventory as high as $5 \mathrm{MCi}$ of ${ }^{137} \mathrm{Cs}$ in the disposal facility has been proposed. This change by a factor of 11, implies the predicted dose of 9.8 rem 100 years after closure.

The predicted dose from ${ }^{137} \mathrm{Cs}$ falls below that from ${ }^{126} \mathrm{Sn}$ at about 200 years.

4.2.3.3 ${ }^{126} \mathrm{Sn}$. Similarly the dose at 500 years (the compliance time) is so dominated by ${ }^{126} \mathrm{Sn}$ (over 95 percent of the dose), that the change in the predicted dose is proportional to the change in the initial inventory of ${ }^{126} \mathrm{Sn}$. Because of the long half-life of ${ }^{126} \mathrm{Sn}(100,000$ years), the predicted dose is relatively insensitive to the amount of time since closure.

It should be noted that the amount of ${ }^{126} \mathrm{Sn}$ to be placed in the waste form is highly uncertain. For these calculations (as was explained in section 3.2 .3 ), all of the ${ }^{126} \mathrm{Sn}$ from the Hanford Site production reactors is assumed to go into the waste form. No credit is taken in this analysis for any separation that may have been done during the initial processing of the fuel or in the pretreatment of the waste following their retrieval from the Hanford Site tanks. Future efforts will use less conservative assumptions.

4.2.3.4 Stability of waste Form. It is assumed that the waste form will not completely shatter into fine grains that could then be either ingested or inhaled. Rather, the waste form would retain most of its radionuclides. Sensitivity cases assuming that 10 and 100 percent of the radionuclides are available for ingestion or inhalation show that the predicted dose is relatively insensitive to this assumption. Figure 4-3 displays the ratio of the case assuming 10 percent of the waste available for ingestion to the case where none of the waste is available as well as the ratio for the case of 100 percent availability to the case of 0 percent availability. Both ratios are displayed as a function of time since closure. 


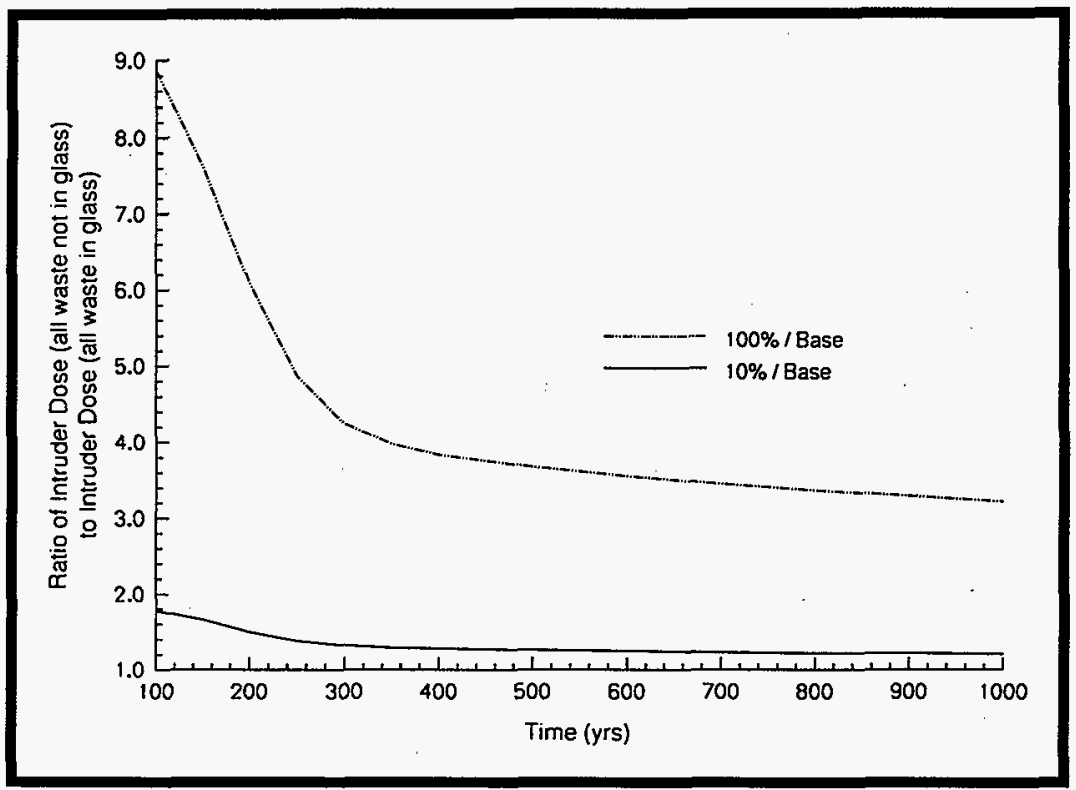

Figure 4-4 shows the radionuclides predicted to contribute to the dose at 100 years and at 500 years for the base analysis case where the amount of glass available is the amount of glass that has dissolved (< 1 percent) and for 100 percent availability. It can be seen that at 100 years, ${ }^{90} \mathrm{Sr}$ becomes significant when ingestion is allowed. However, ${ }^{137} \mathrm{Cs}$ still contributes over two-thirds of the predicted dose. At 500 years, even with ingestion, ${ }^{126} \mathrm{Sn}$ still contributes two-thirds of the predicted dose. However, ${ }^{99} \mathrm{Tc},{ }^{231} \mathrm{~Pa},{ }^{239} \mathrm{Pu}$, and ${ }^{241} \mathrm{Am}$ contribute noticeable amounts when ingestion is possible. In no case is inhalation a major exposure path.

4.2.3.5 Area of Homesteader Garden. The predicted dose depends on the area of the homesteader garden and the time during which the homesteader spends in the garden. The homesteader receives dose from external radiation when he is in the garden or dose from internal exposure when he ingests produce from the garden. A homesteader is assumed to remain in a smaller garden a shorter amount of time. 
Figure 4-4. Contribution of Major Radionuclides for the Base Analysis Case and When Ingestion is Allowed.

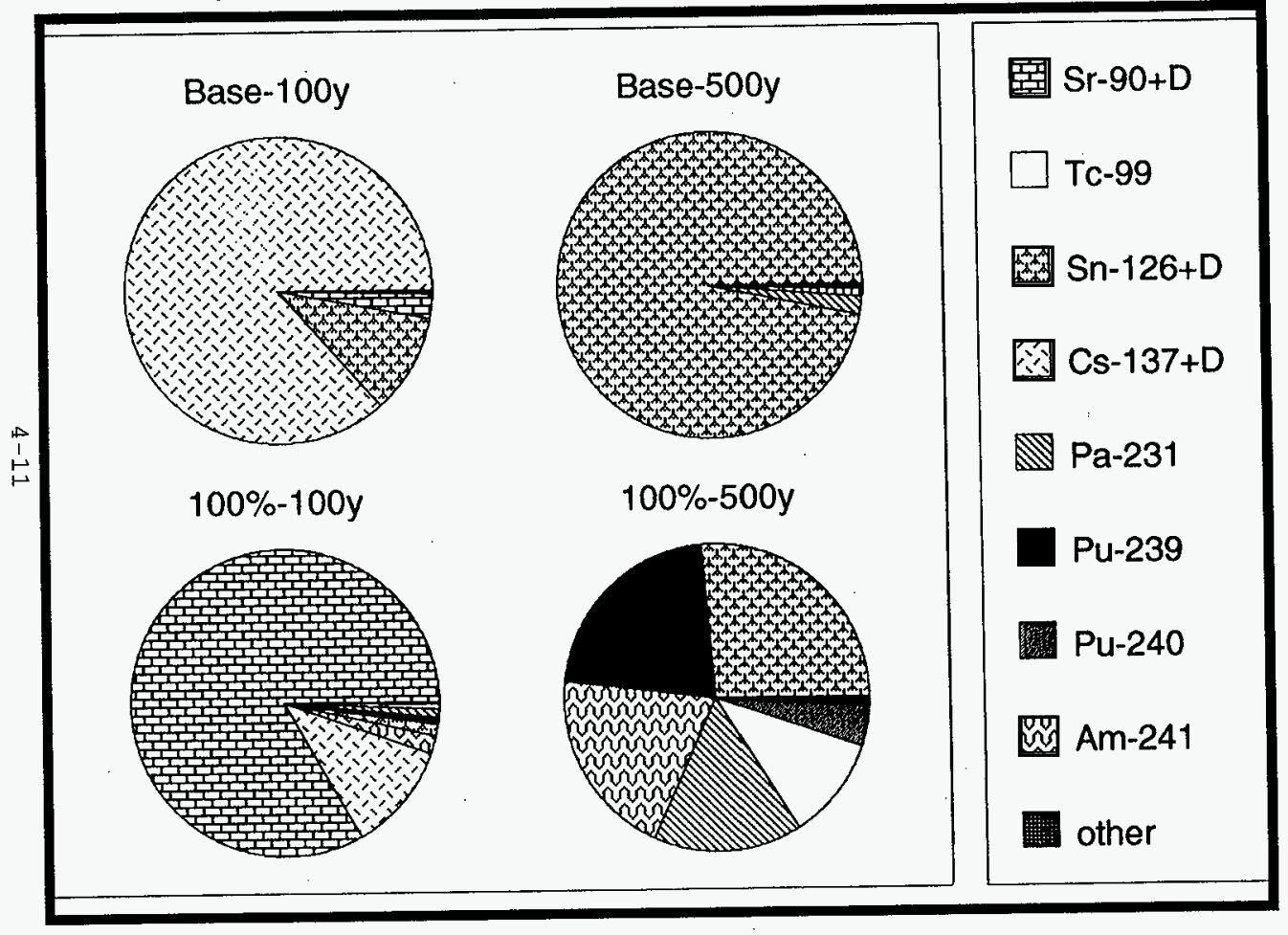




\section{FWNE-EP-0884 \\ Rev. 1}

The base analysis case assumes a much smaller area 1500 square meters) than previous Hanford performance assessments (2500 square meters). The change in garden size proportionally changes the soil concentration and internal doses, but only slightly changes the external dose. The larger garden has soil concentrations that are a factor of five smaller than the soil concentration in the small garden. The same relationship is found with the internal doses. However, the external doses from the larger garden are only 10 to 25 percent less than the external dose from the smaller garden. Thus, relative to the larger garden, the smaller garden gives only a $10 \%$ increase in the predicted dose for ${ }^{126} \mathrm{Sn}$ and only a $24 \%$ increase for ${ }^{137} \mathrm{Cs}$. For those radionuclides where ingestion is the main exposure pathway (for example ${ }^{90} \mathrm{Sr},{ }^{99} \mathrm{Tc}, \mathrm{Pu}$ isotopes, ${ }^{241} \mathrm{Am}$ ), then the ratio of the predicted dose is, in fact, nearly inversely proportional to the ratio of the garden areas. The ratio of effective dose rates for each radionuclide for the $500 \mathrm{~m}^{2}(5,382$ $\left.\mathrm{ft}^{2}\right)$ garden to the $2,500 \mathrm{~m}^{2}\left(26,910 \mathrm{ft}^{2}\right)$ is shown in Table $\mathrm{B}-5$ in Appendix B.

4.2.3.6 Size of the Hole Drilled. The predicted dose is proportional to the amount of waste brought up from the disposal facility. For the base analysis case, the hole was conservatively estimated as 0.3 meters (12 inches). However, a more likely maximum diameter is 0.2 meters ( 8 inches). Such a smaller diameter hole would bring up only $42 \%$ of the waste when compared to the 0.3 meter (12 inch) hole. Thus the predicted dose is reduced by $42 \%$.

4.2.3.7 Areal Density of the Waste. Because the predicted dose depends linearly on the amount of waste material brought to the surface, the predicted dose depends on the waste concentration. As noted in section 4.2.3.1, the waste is assumed to be averaged over both the container and the filler material. However,

because the hole is assumed to go through the entire height of the disposal facility, the vertical dimension becomes

unimportant. Thus, it is not the normal volumetric density but the areal density (the volumetric density times the height) that is important.

The areal density can differ from the base analysis case for a number of reasons. The area of the disposal facility could differ because of any of the following:

A different design of the disposal facility (for example, the use of a dirt spacers between vault rows)

- Different amounts of waste material to filler material in a vault

Different assumption of the total height of waste, causing a change in the area occupied by the waste itself 


\section{FNF-EP-0884 \\ Rev, 1}

- Different waste loading (because of sodium content or other reasons).

If Concept 2 (Section 3.4.6.5) is used for the design of the disposal facility, then the area of the disposal facility increases by a factor of 2.5 and the predicted dose decreases by $60 \%$. If the sodium loading of the waste form decreases from $20 \%$ to $15 \%$, then the area increases by four-thirds (1.333) (assuming no change in facility height) and the predicted dose decreases by 25 응.

4.2.3.8 Other Factors. Other factors are less important in determining the predicted dose. Such factors include the use of dose conversion factors and estimates of the amount of radionuclides other than ${ }^{126} \mathrm{Sn}$ and ${ }^{137} \mathrm{Cs}$.

The dose conversion factors important to the homesteader scenario are the external dose conversion factors. The factors used in the base analysis case are the ones from the EPA (EPA 1993). For ${ }^{126} \mathrm{Sn}$, the DOE external dose conversion factor (DOE $1988 \mathrm{C}$ ) is a factor of 4.45 larger than the EPA factor. The DOE value is larger because it assumes all the radionuclides are on the surface of the soil and hence there is no shielding of the photon radiation. The EPA factor, on the other hand, is based on the more realistic assumption of mixing (over a 15 centimeter layer). Previous Hanford performance assessments have used dose factors based on GENII (Napier 1988) which uses models similar to that of the EPA. For ${ }^{126} \mathrm{Sn}$, the external dose conversion factor is 20 percent higher than the EPA value. For ${ }^{137} \mathrm{Cs}$, the ratios of the external dose conversion factors are similar to those for ${ }^{126} \mathrm{Sn}$.

Because of the dominance of ${ }^{126} \mathrm{Sn}$ and ${ }^{137} \mathrm{Cs}$ in the dose calculations, changes in the amount of other radionuclides is relatively unimportant. Because of different processing strategies, the amount of ${ }^{90} \mathrm{Sr}$ might be as much as twice the amount assumed in the base analysis case (3.4 MCi versus 1.6 MCi) (WHC 1996). Even using the maximum amount of ${ }^{90} \mathrm{Sr}$ would increase the total predicted dose at 100 years by less than $0.3 \%$ because ${ }^{90} \mathrm{Sr}$ does not significantly contribute to the estimated dose unless it is ingested. Changes in the amount of other isotopes are predicted to be less significant to the intruder dose.

\subsubsection{Summary}

The estimated exposures of the driller scenario easily meet the performance objectives by two orders of magnitude. The estimated exposures for the homesteader scenario are a factor of three lower than performance objectives.

Conservative values were taken for most of the parameters. Further analysis is expected to show that the diameter of the 


\section{FINF-EP-0884 \\ Rev. 1}

borehole should be smaller, that the area over which it is spread will be larger, and that the amount of ${ }^{126} \mathrm{Sn}$ (the dominant isotope) will be smaller. Each of these will lead to smaller estimated doses. Also, once experiments on the half-life of ${ }^{126} \mathrm{Sn}$ are documented, it is likely the value taken for its half-life will increase over the value used in this analysis, leading to lower estimated inventory values (when expressed in $\mathrm{C} i$ ) and hence lower estimated dose values.

This analysis assumed that the inventory in the Hanford Site tanks was uniformly spread among the vaults. Because the amount of ${ }^{126} \mathrm{Sn}$ is likely to vary among the tanks, the estimated maximum exposure will be higher than calculated here. Such a calculation awaits a better definition of the contents of each tank and a strategy for mixing tank contents during the retrieval and separations processes. Given the conservatism of the rest of the calculations and the gap between the estimated doses and the performance objectives, it is likely that the maximum exposure will also easily meet the performance objective.

\subsection{RESULTS OF GROUNDWATER SCENARIOS - BASE ANALYSIS CASE}

\subsubsection{Overview}

This section presents the results of the analyses for the base analysis groundwater contamination case. The groundwater analysis is by far the most complex of the various scenarios. This section provides the results for the base analysis case. Later sections in this chaptex provide the sensitivity analyses:

$\begin{array}{lll}- & \text { Section } 4.4 & \text { (Base Case Sensitivity) } \\ \text { - Section } 4.5 & \text { (Waste Form Sensitivity) } \\ \text { - Section } 4.6 \text { (Facility Design Sensitivity) } \\ \text { - Section } 4.7 \text { (Contaminant Transport Sensitivity) } \\ \text { - Section } 4.8 \text { (Other Factors). }\end{array}$

Section 4.9 describes the effect of other Hanford site actions on the groundwater affected by this study. Section 4.10 puts into context the information given in sections 4.3 through 4.9 .

The various parts of section 3.3 described the scenarios considered in the groundwater scenario. Section 3.4 presented the values used for the parameters.

Each analysis case depends on three key calculations:

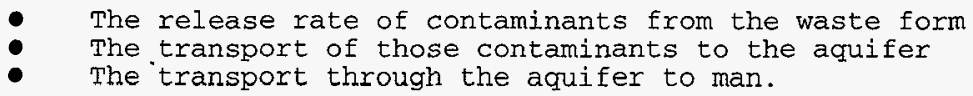

For the base analysis case, the release rate of contaminants from 
the waste form is derived from the TWRS Privatization specifications (DOE-RL 1996). This section presents numerical simulation results for the transport of the contaminants through the vadose zone, the transport through the unconfined aquifer, and the integration of those simulation results.

\subsubsection{Vadose Zone Transport}

4.3.2.1 Overview. Once the contaminants are released from the waste form and the disposal facility, they slowly move downward through the unsaturated soil (the "vadose zone") beneath the disposal facility. At the Hanford site this zone is characterized by very low moisture content.

To separate the effects of inventory contained in the waste form from the travel in the vadose zone, vadose zone calculations were performed for a waste form containing an unit inventory. The results of the vadose zone transport calculations are thus a contaminant flux through the vadose zone to the groundwater normalized to an unit amount of inventory for that radionuclide. Since the calculations integrate over the area of the disposal facility, the units of the normalized flux become $\mathrm{yr}^{-1}$.

Because the radionuclide release from the waste form extends over many hundreds of thousands of years, the normalized contaminant flux at the bottom of the vadose zone appears to be a step function with a fairly sharp rise (see Figure 4-5). Such a curve can be characterized by three numbers:

- The maximum value

- The time at which the curve reaches half the maximum value

- The first time at which the curve has a non-zero value (taken here as $10^{-6}$ times the maximum value).

These three values, along with the value for the compliance time of 10,000 years will be tabulated for each calculation. When a graphical comparison of different calculations yields insight, figures will also be displayed. Appendix E contains tables and figures that provide more information.

This type of shape results from the length of time during which contaminants are released from the disposal facility being very much longer than the travel time for those contaminants in the vadose zone. Thus the temporal shape of the contaminant flux at the bottom of the vadose zone is determined from the time dependence of the release from the waste form (or waste disposal facility) rather than from the time dependence of vadose zone transport. Appendix E.1 contains a mathematical justification of this effect. This "step" shape is different from the quickly rising, slowly decaying peaked shapes often seen in performance 
Figure 4-5. General Characteristics of Vadose Zone Transport. The normalized contaminant flux to the aquifer is shown for the simulation of Concept 2, constant release rate from waste form, full facility model.

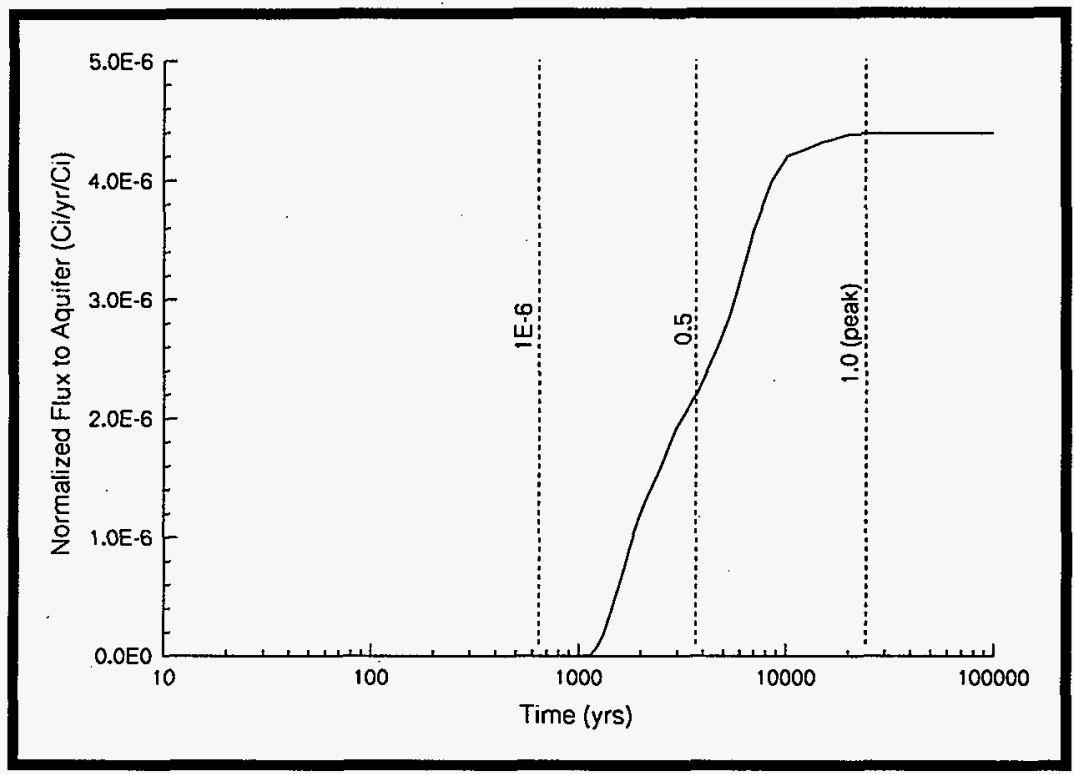

assessments. The shape of the rise of the "step" function is mainly governed by the same parameters (dispersion, travel time, and travel distance) that provide the width of typical vadose calculations.

4.3.2.2 Comments on Computer simulations. As noted in chapter 3. two separate sets of analyses were performed for contaminant transport in the vadose zone. The results from the full facility model are documented in Piepho (1996). The results from the Unit Cell Model are documented in Kline (1996).

Because of the large size of the disposal facility and the significant depth of the vadose zone, the model for vadose zone transport is quite complex. Because of the large number of spatial nodes and the small time steps needed, the model strains computer resources. For the base analysis case, $4 \mathbf{k}_{\alpha}$ bins were solved for over 70,000 time steps at 22,000 nodes. This run took about 100 hours on an IBM RS 6000 Model 580 UNIX computer. For the cases modeling concept 2 , where far fewer nodes are used, runs were made on a Pentium-based processor and took 10 hours. 


\section{FRNF-EP-0884 \\ Rev. 1}

Simulations of the Unit Cell Model, which used fewer nodes still, were run on the UNIX computer and took about 1 hour.

The mass balance errors for concept 1 simulations (the largest ones experienced in the modeling) are shown in Table 4-3. Simulations for concept 2 and the Unit cell Model yielded fractional mass balance errors of less than 1 percent for all times. In addition, for the simulations of concept 1 cases having a reduced release rate, the solution became unstable after 50,000 years. In such cases, values for times greater than 50,000 years were replaced by the maximum value at 50,000 years. This instability is thought to be due to terminating the transient flow calculation before an equilibrium flow condition was reached. The value at 50,000 years is near the rate of contaminant release from the waste form and is a good approximation for later times.

\section{Table 4-3. Fractional Mass Balance Error as a Function of Time for Modeling Concept 1 simulations (Base Analysis Case).}

\begin{tabular}{|c|c|}
\hline Time (years) & Fractional Mass Balance Error ( 8$)$ \\
\hline 21,500 & 0.5 \\
\hline 37,500 & 2.1 \\
\hline 53,500 & 3.5 \\
\hline
\end{tabular}

The Unit Cell Model calculations focused on the calculations of sensitivity cases. Thus to simplify the model and to conserve computer resources, the model did not include a hydraulic diverter above the vaults. Because of the assumed instantaneous step change in infiltration rate at 1,000 years and the step change in properties of the man-made materials at 2,000 years, a pulse of contaminants occurs shortly after 2,000 years. Only unretarded contaminants $\left(K_{d}=0.0\right)$ showed this effect. Since the $\mathrm{K}_{d}=0.1 \mathrm{ml} / \mathrm{g}$ group had nearly the same time dependence as the $\mathrm{K}_{\mathrm{a}}=0.0$ group (except for this pulse), all dose calculations reported for the Unit cell Model use the $\mathrm{K}_{\mathrm{d}}=0.1 \mathrm{ml} / \mathrm{g}$ results for the unretarded group.

4.3.2.3 Base Analysis Case simulation overview. This section describes the simulation of the moisture flow and contaminant transport in the vadose zone for the base analysis case. The following paragraphs discuss the simulated moisture content distribution within the disposal facility and the vadose zone as a function of time, the simulated flow paths within the vadose zone, and the contaminant transport within the vadose zone and the unconfined aquifer. 


\subsubsection{Base Analysis Case Simulation of Moisture Flow in} Vadose zone. Contaminant transport depends strongly on the moisture content and flow in the vadose zone. Figure 4-6 shows the moisture content and a few flow lines at 1,000 years for the entire vadose zone. Figure 4-7 shows that information in more detail around the edge of the disposal facility. Figures 4-8 and 4-9 show similar information at 4,000 years (the time at which steady state flow occurs).

The effectiveness of the sand-gravel capillary barrier is clearly seen in the figures. The flow lines go around the hydraulic diverter, leaving a moisture shadow underneath. At 500 years, the moisture content [volume water $_{\text {/ volume }}$ soil] beneath the facility is $0.035 \mathrm{~cm}^{3} / \mathrm{cm}^{3}$. In the path of the diverted flow, the moisture content increases to $0.050 \mathrm{~cm}^{3} / \mathrm{cm}^{3}$, then declines to $0.042 \mathrm{~cm}^{3} / \mathrm{cm}^{3}$ moving away from the facility. Most of the shadowing effect disappears by the time the moisture reaches the bottom of the sandy sequence of the Hanford formation.

At 500 years, the simulation shows no indication of significant flow through the barrier. The moisture content in the backfill soil separating the canisters is $0.050 \mathrm{~cm}^{3} / \mathrm{cm}^{3}$ at the top of the canisters, increasing to only $0.053 \mathrm{~cm}^{3} / \mathrm{cm}^{3}$ at the bottom. These results remain almost constant (the relative change being less then 3 percent) moving horizontally outward from the center of the facility.

At longer times, the shadow remains intact but is not quite as extensive. At 4,000 years, the moisture content directly beneath the facility has increased slightly (to $0.038 \mathrm{~cm}^{3} / \mathrm{cm}^{3}$ at the edge of the facility). More significantly the large flow around the barrier has increased the moisture content just outside of the facility to $0.078 \mathrm{~cm}^{3} / \mathrm{cm}^{3}$. The moisture content of the soil most distant from the facility also increases (to $0.050 \mathrm{~cm}^{3} / \mathrm{cm}^{3}$, reflecting the $3 \mathrm{~mm} / \mathrm{y}$ recharge that occurs beginning at 1,000 years caused by the presumed return of the surface soil and vegetation to natural conditions.

At these longer times, the computer simulation shows somewhat poorer performance of the hydraulic diverter. Isolated sets of nodes show higher moisture contents $(0.016$ to 0.028 $\left.\mathrm{cm}^{3} / \mathrm{cm}^{3}\right)$ than the remainder of the nodes $\left(0.014 \mathrm{~cm}^{3} / \mathrm{cm}^{3}\right)$. However, the moisture content of the filler material between the canisters still remains at about $0.05 \mathrm{~cm}^{3} / \mathrm{cm}^{3}$ with the bottom of the filler material again being slightly moister than the top. 
Figure 4-6. Moisture Content and Flow Lines for the Base Analysis Case at 1,000 Years. The moisture content is given as saturation which is volumetric moisture content divided by the porosity of the material. The waste forms are shown as $100 \%$ saturated to improve readability.

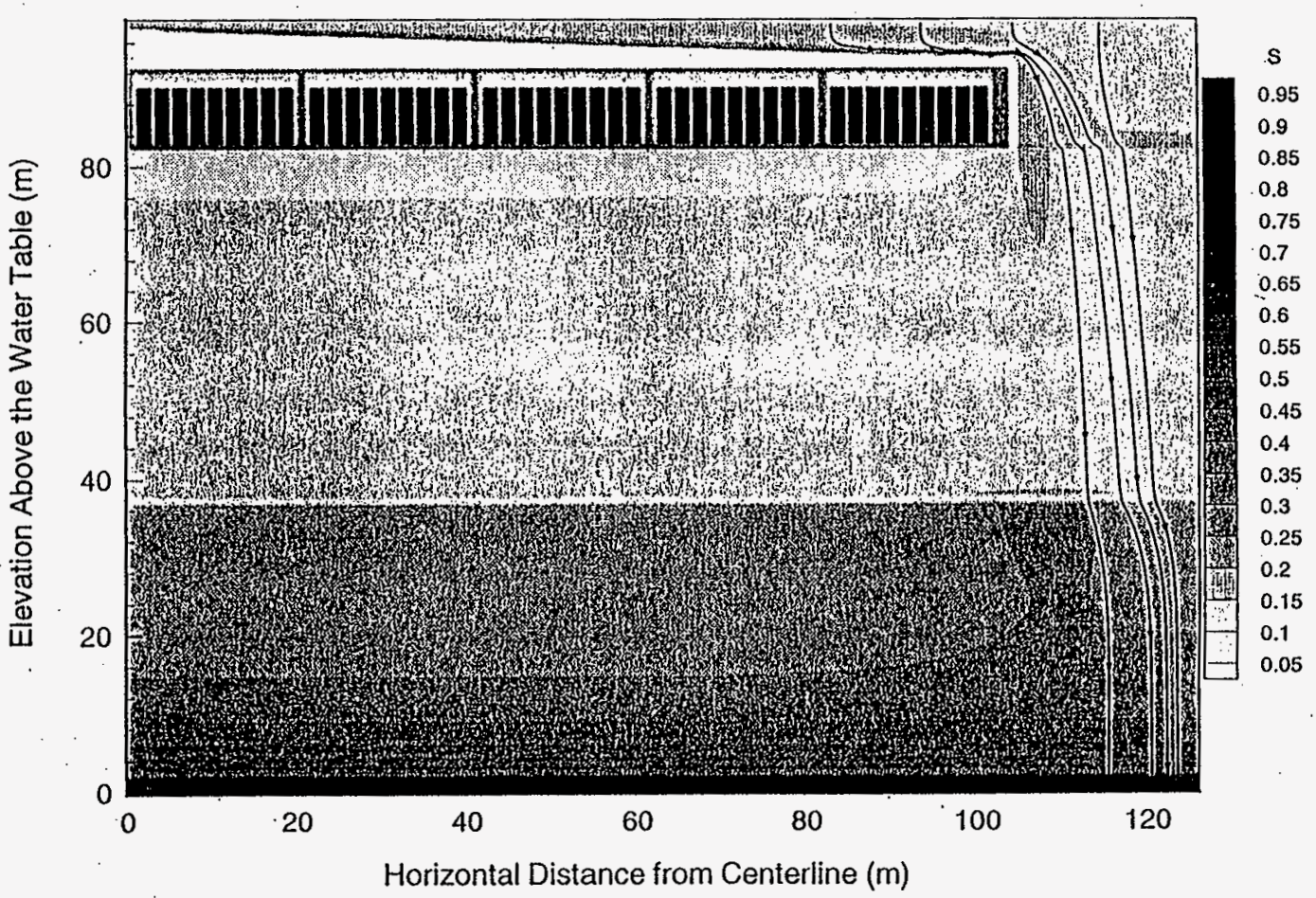

Horizontal Distance from Centerline (m) 
Figure 4-7. Moisture Content and Flow Iines at 1,000 Years with Emphasis on the Edge of the Disposal Facility.

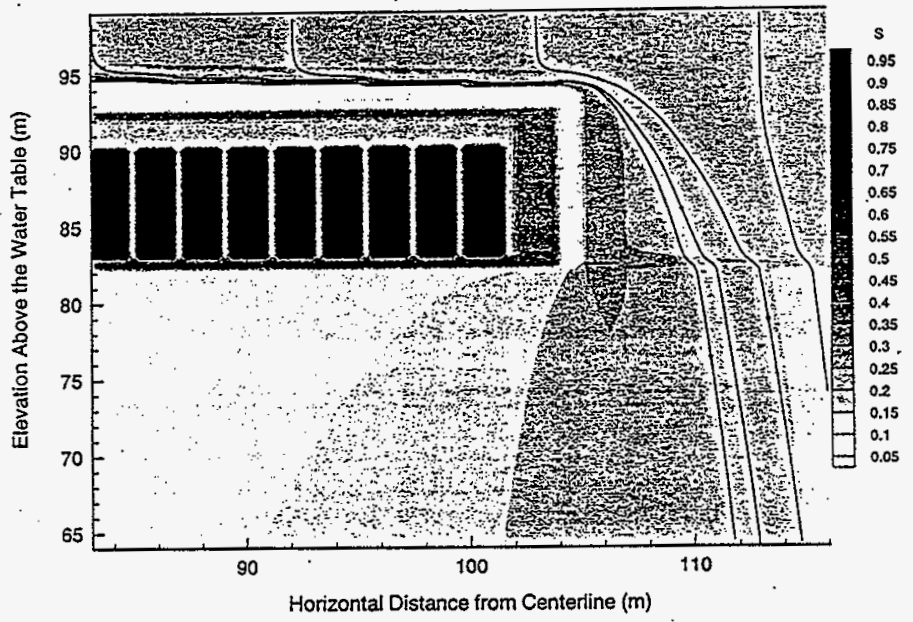

Figure 4-8. Moisture Content and Flow Iines at 4,000 Years (Steady state) with Emphasis on the Edge of the Disposal Facility

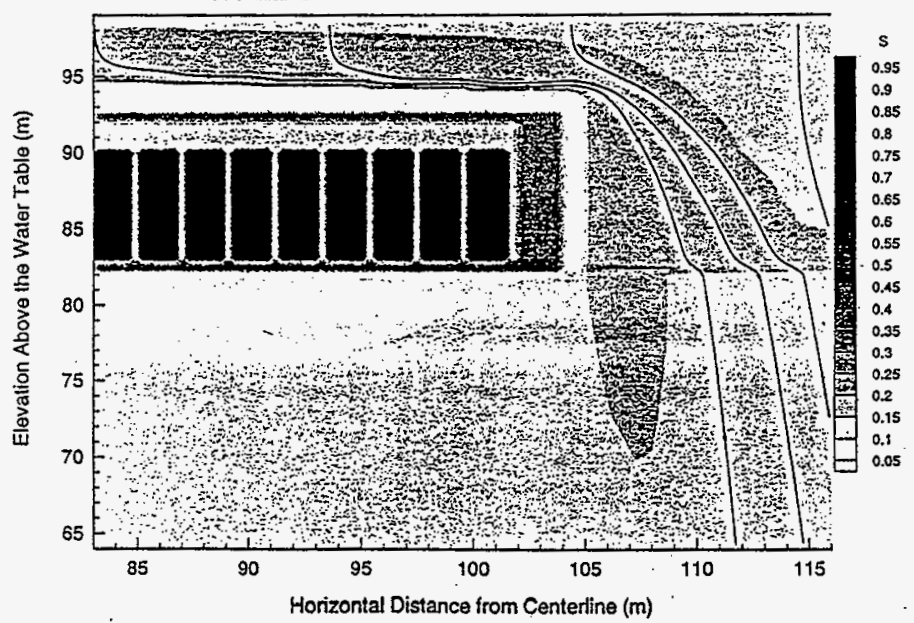


Figure 4-9. Moisture Content and Flow Lines for the Base Analysis Case at 4,000 Years (Steady state). The moisture content is given as saturation which is volumetric moisture content divided by the porosity of the material. The waste forms are shown as $100 \%$ saturated to improve readability.

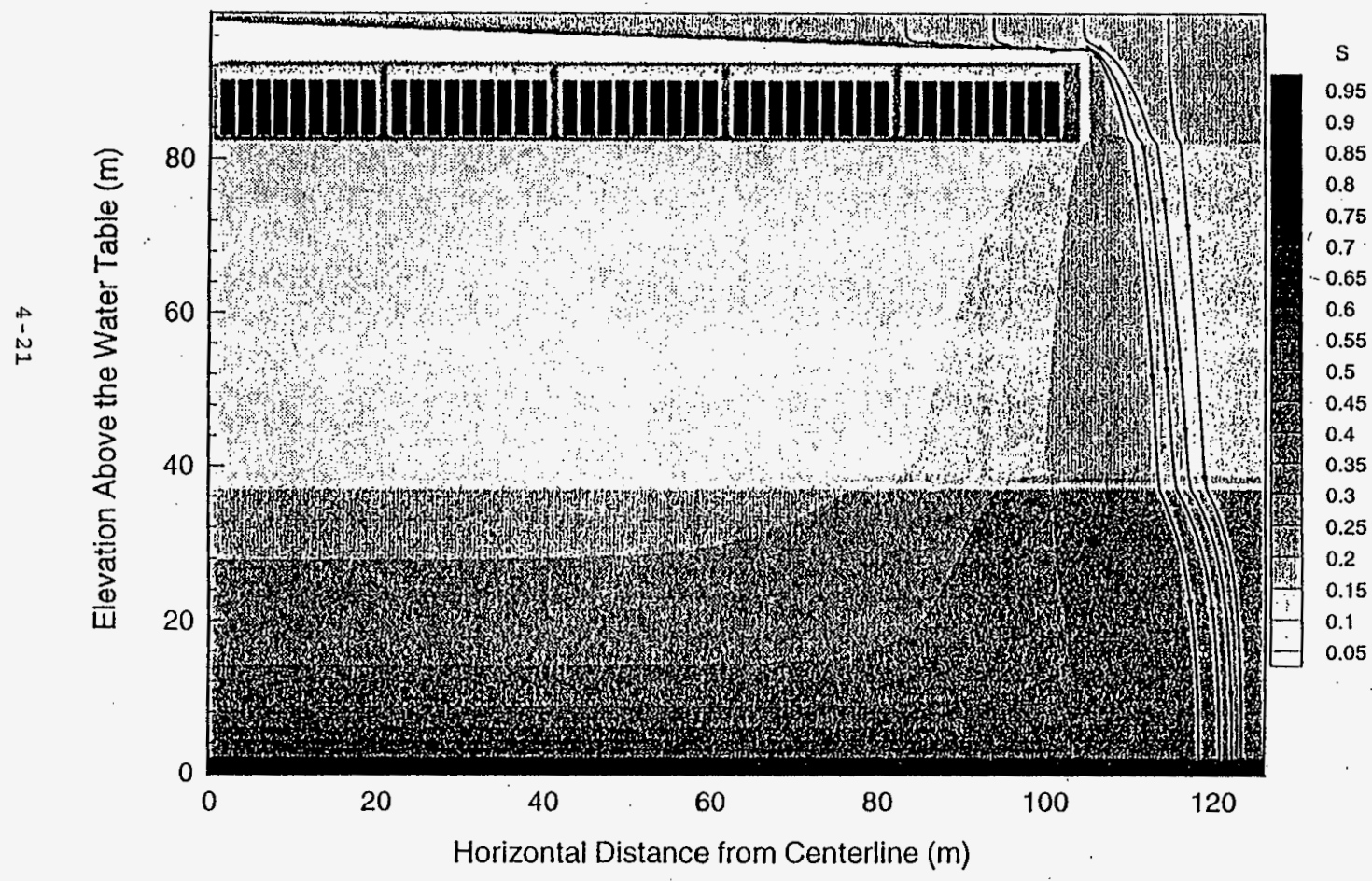




\section{HINF-EP-0 884 \\ Rev. 1}

4.3.2.5 Base Analysis Case simulation of Contaminant Transport in Vadose zone. Normalized contaminant fluxes to the aquifer [that is, contaminant fluxes normalized to 1 Curie of inventory] were calculated using PORFIOW for 7 different $K_{d}$ values $\left(K_{d}=0\right.$, $0.1,0.6,3.0,15,40 .$, and $100 . \mathrm{m} / \mathrm{g})$ for times up to 100,000 years. The functions are normalized to 1 unit of contaminant in the waste form.

Figure 4-10 shows the normalized contaminant flux to the aquifer for $K_{a}=0,0.1$, and $0.6 \mathrm{~m} / \mathrm{g}$. Table $4-4$ shows the major parameters describing the normalized contaminant flux for each $\mathrm{K}_{\mathrm{d}}$ group calculated.

At 10,000 years, only the first $3 \mathrm{~K}_{\mathrm{d}}$ groups are significant, having normalized flux values greater than $10^{-6}$ per year. In fact, the calculations indicate that those radionuclides with $\mathrm{K}_{d}$ $=100 . \mathrm{ml} / \mathrm{g}$ do not even reach the aquifer in 10,000 years.

Because of the large value used for dispersion, an extremely small amount of the $\mathrm{K}_{\mathrm{d}}=0$ group reaches the aquifer before 500 years.

Figure 4-10. Normalized Contaminant Flux to the Aquifer for $\mathrm{K}_{\mathrm{a}}=0,0.1$, and $0.6 \mathrm{ml} / \mathrm{g}$ - Base Analysis Case.

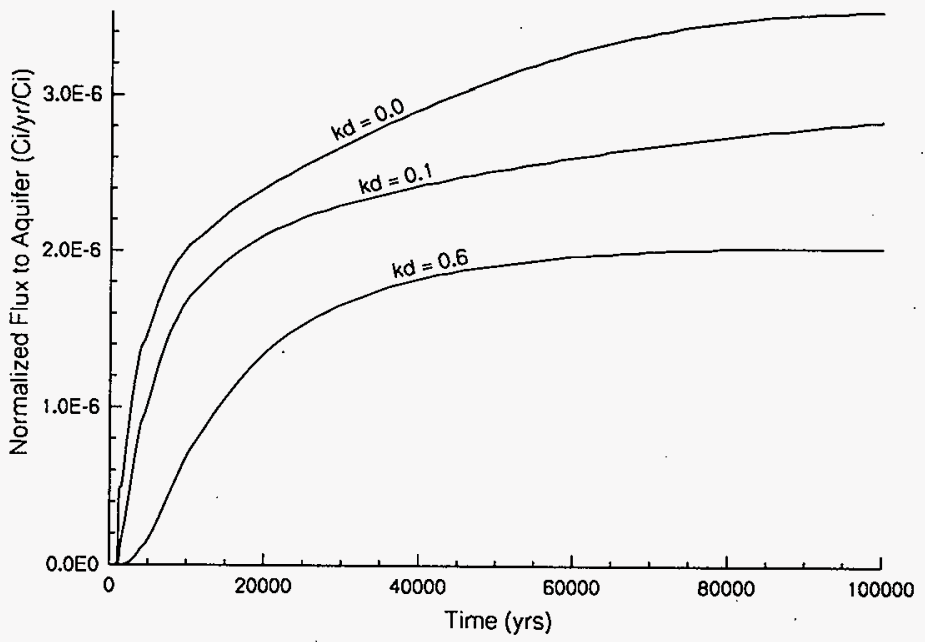


Rev. 1

Table 4-4. Major Parameters Describing the Normalized Contaminant Flux to the Aguifer for the Base Analysis Case. Decay is included later in the analysis.

\begin{tabular}{|c|c|c|c|c|c|}
\hline$\underset{(m l / g)}{K_{d}}$ & $\begin{array}{l}\text { Value at } \\
10 \mathrm{~K} \text { Years } \\
\text { (Ci/y/Ci) }\end{array}$ & $\begin{array}{c}\text { Peak } \\
\text { Value }{ }^{(a)} \text { in } \\
\text { First } 100 \mathrm{~K} \\
\text { Years } \\
(\mathrm{Ci} / \mathrm{y} / \mathrm{Ci}) \\
\end{array}$ & $\begin{array}{c}\text { Time of } \\
\text { True Peak } \\
\text { Value } \\
\text { (y) }\end{array}$ & $\begin{array}{c}\text { Time of } \\
0.5 * \text { True } \\
\text { Peak } \\
\text { value } \\
(y) \\
\end{array}$ & $\begin{array}{c}\text { Time of } \\
10^{-6} \star \text { True } \\
\text { Peak } \\
\text { value } \\
\text { (y) }\end{array}$ \\
\hline 0. & 2.04 e- 6 & $3.53 e-6$ & $>100,000$ & 12,000 & 450 \\
\hline 0.1 & 1.71 e- 6 & $2.84 \mathrm{e}-6$ & $>100,000$ & 12,000 & 650 \\
\hline 0.6 & $0.72 e-6$ & $2.02 e-6$ & $\geq 100,000$ & $>100,000$ & 1,300 \\
\hline 3. & $1.3 e-09$ & $1.37 e^{-6}$ & $\geq 100,000$ & $>100,000$ & 3,400 \\
\hline 15. & $9.3 e-15$ & 0.20 e- 6 & $>100,000$ & $>100,000$ & 17,000 \\
\hline 40. & $2.4 \mathrm{e}-23$ & 4.0 e-09 & $\geq 100,000$ & $>100,000$ & 44,000 \\
\hline 100. & 0.0 & $2.1 e-12$ & $\geq 100,000$ & $>100,000$ & $>100,000$ \\
\hline
\end{tabular}

The value given is for the peak value in the first 100,000 years.

b Unless a peak value was obtained in the first 100,000 years, the true peak value was taken as $4 \times 10^{-6} \mathrm{Ci} / \mathrm{Y} / \mathrm{Ci}$.

For none of the $K_{d}$ groups does the normalized flux to the unconfined aquifer reach its maximum before the computer simulations end at 100,000 years. However, the $k_{d}=0$ group is expected to be very near its peak (based on the shape of the curve in Figure $4-10$ and the contaminant release rate). Because the contaminant flux to the aquifer is expected to stay high (due to the slow release of contaminants from the waste form), calculations to longer times are needed to demonstrate the character of the full release and the magnitude of peak concentration and dose. The normalized flux to the aquifer can be approximately estimated based on the $\mathrm{K}_{\mathrm{d}}=0$ group. By assuming that the release rate continues indefinitely and that the waste form release controls the temporal shape of the normalized flux, the normalized flux to the aquifer $(\Gamma)$ can be approximated by

$$
\Gamma\left(K_{d}, \quad t \cdot\left[1+\alpha K_{d}\right]\right)=\Gamma\left(K_{d}=0, t\right),
$$

where $\alpha$ is a fitting parameter related to vadose zone thickness and moisture content. By comparing the time of occurrence for $\Gamma$ $=10^{-6}$ per year for $\mathrm{K}_{\mathrm{d}}=0$ and $\mathrm{K}_{\mathrm{d}}=3 \mathrm{ml} / \mathrm{g}, \alpha$ is found to be 6.6 $\mathrm{g} / \mathrm{ml}$. Larger values are found in the Unit Cell Model $(\sim 35 \mathrm{~g} / \mathrm{ml})$ where the effect of the moisture shadow of the facility is absent. A comparison between the two methods is shown in Appendix E.2.2. Using equation 1, normalized fluxes were estimated out to 66 million years assuming that the flux never decreases from its maximum value. The value of 67 million years 


\section{EINF-EP- 0884}

Rev. 1

results the endpoint of the explicit calculation $(100,00 \mathrm{y}), \alpha$ $(6.6 \mathrm{~g} / \mathrm{ml})$, and the maximum $\mathrm{K}_{\mathrm{d}}$ value $(100 \mathrm{ml} / \mathrm{g})$.

This is a conservative assumption, because the flux for groups with small $k_{d}$ values will show decreases in the range of a few million years as the release rate from the waste form goes to zero in this time frame.

\subsubsection{Aquifer Transport}

These results are based on applying the Hanford site wide groundwater model as described in section 3.5.3.4. Two models were used, one with high spatial resolution near the disposal site and one with a lower resolution describing the flow and transport all the way down to the Columbia River. A fuller description is given in Lu 1996 which assumed a recharge rate of $1 \mathrm{~mm} / \mathrm{y}$. The results of Lu 1996 have been modified to reflect actual recharge rates (normally $3 \mathrm{~mm} / \mathrm{y}$ ) by multiplying the results of $\mathrm{Lu}(199.6)$ by the recharge rate.

The results for the close-in model are shown in Figures 4-11 and 4-12. Figure 4-11 shows the concentration ratio contours (concentration at the well relative to the concentration in the vadose zone underneath the disposal facility) 120 years after the flux starts to entex the aquifer at the aquifer's surface. The plume is basically west to east with a slight northerly bias as suggested by the groundwater flows depicted in Figure 3-1. At 100 meters downgradient, the width of the plume is predicted to be about 25 meters (full width at the half maximum value), increasing only slightly (about 30 meters) 900 meters downgradient. Figure 4-12 shows the time history of the concentration ratio at the well 100 meters down gradient from the disposal facility and at the 200 Area fence (about 900 meters downgradient). At the well 100 meters downgradient, the concentration ratio reaches a steady state value $\left(5.31 \times 10^{-3}\right)$ after 30 years. At a well 900 meters downgradient (the 200 East Area boundary, a steady state value $\left(4.08 \times 10^{-3}\right)$ is reached after about 60 years. The steady state values are summarized in Table 4-5.

The flow paths for the distant well sites are displayed in Figure 4-13. The relative contamination levels for 400 years after the contaminants enter the aquifer are shown in Figure 4-14. Time histories for the eight wells shown in Figure 4-16 are displayed in Figure 4-15. Although there is some compression of the flow lines, dispersion of the contaminants is much more important. The concentration ratio for a point near the river is less than $2 \times 10^{-4}$ for a unit concentration entering the aquifer beneath the disposal site and it takes about 400 years to reach the Columbia River. The steady-state concentration ratios are summarized in Table 4-5. 


\section{FINF-EP-0884 \\ Rev. 1}

Figure 4-11. Concentration Ratios 120 Years after Contaminants Enter Aquifer. Larger square in lower left hand quarter is the disposal site. Smaller square in upper right quarter of the larger square is the location of modeled vaults. (Lu 1996). Assumes concentration of $1 \mathrm{ci} / \mathrm{m}^{3}$ in the vadose zone and a recharge rate of $1 \mathrm{~mm} / \mathrm{y}$. Since the actual recharge rate is 3 $\mathrm{mm} / y$, actual concentrations will be 3 times higher than shown.

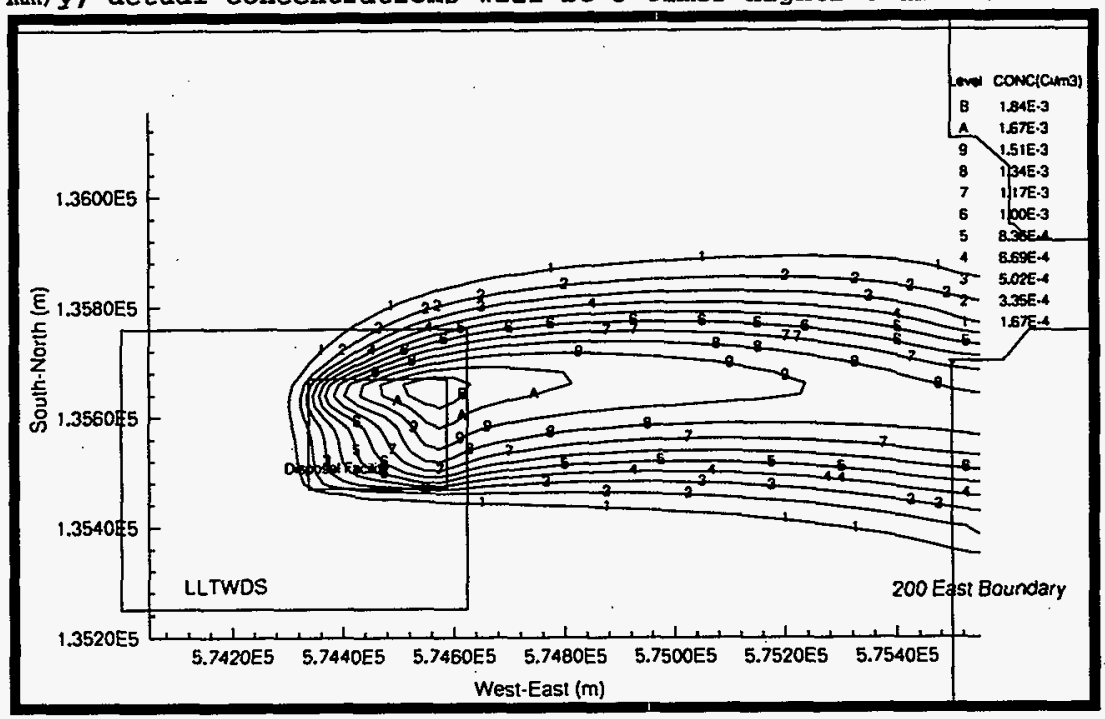

The consistency of the two aquifer models can be judged by comparing the results of the models at the 200 East Area Boundary (about 900 meters downgradient from the disposal facility). The near model gives $4.08 \times 10^{-3}$, while the geometric interpolation of wells W1 ( $\sim 750$ meters downgradient) and W2 ( 1200 meters downgradient) give $4.17 \times 10^{-3}$.

Large-scale Hanford groundwater modeling for conditions far in the future is just beginning to undergo extensive review. Some discrepancies are to be expected. For example, a study to evaluate the potential for transport of nickel radioisotopes from the 218-E-12B Burial Ground (Rhoads et al. 1994) postulated unsaturated sediments beneath this site located in the northern part of the 200 East Area (as contrasted to the 5 meters predicted in this analysis). The postulation was based on twodimensional CFEST (Gupta 1987) simulations under an assumption of a low recharge condition and supported by the measurements of adjacent wells. However, the desaturation condition should be limited to the vicinity of the 218-E-12B Burial Ground, because of the basalt structure being much nearer the surface at the burial ground. 
Figure 4-12. Concentration Ratios as a Function of Time at Points of Maximum Concentration 100 Meters Downgradient and at the 200 East Boundary (about 900 Meters Downgradient). (Iu 1996)

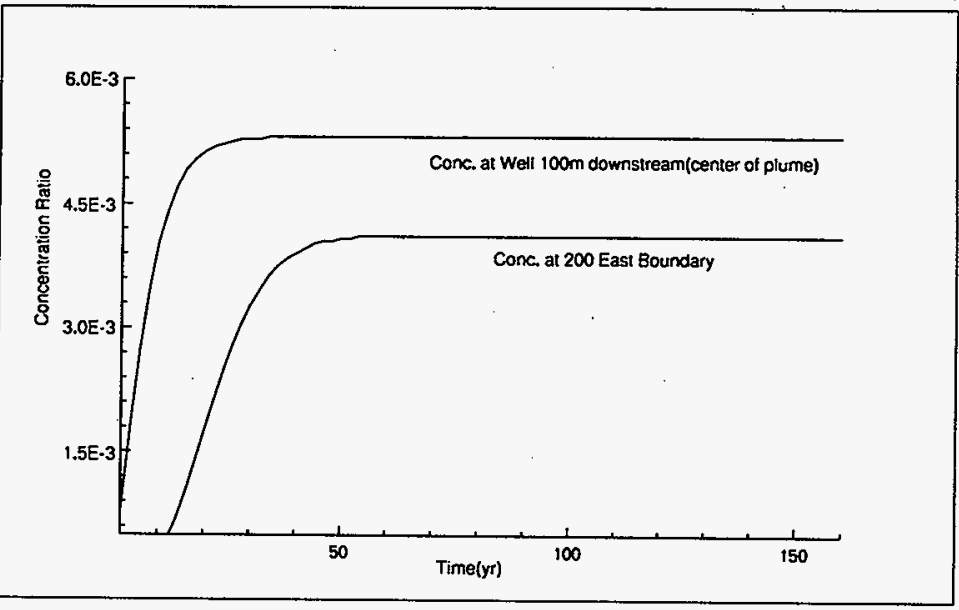

Table 4-5. Concentration Ratios at Hypothetical Wells Relative to Unit Concentration Entering Aquifer Under Disposal Facility

\begin{tabular}{|c|c|c|}
\hline Wel1 Number & Distance (meters) & Concentration Ratio \\
\hline-- & 100. & $5.31 \times 10^{-3}$ \\
\hline$h 1$ & $\sim 750$. & $4.89 \times 10^{-3}$ \\
\hline-- & $\begin{array}{r}200 \text { East Area Boundary } \\
(\sim 900 \text { meters })\end{array}$ & $4.08 \times 10^{-3}$ \\
\hline h2 & $\sim 1,200$ & $3.27 \times 10^{-3}$ \\
\hline h3 & $-1,750$ & $2.07 \times 10^{-3}$ \\
\hline h4 & $\sim 2,500$ & $1.79 \times 10^{-3}$ \\
\hline h5 & $-6,000$ & $4.77 \times 10^{-4}$ \\
\hline h6 & $\sim 12,000$ & $2.91 \times 10^{-4}$ \\
\hline h7 & $\sim 15,000$ & $2.54 \times 10^{-4}$ \\
\hline $\mathrm{h} 8$ & $-20,000$ & $1.86 \times 10^{-4}$ \\
\hline
\end{tabular}


HNF-EP-0884

Rev. 1

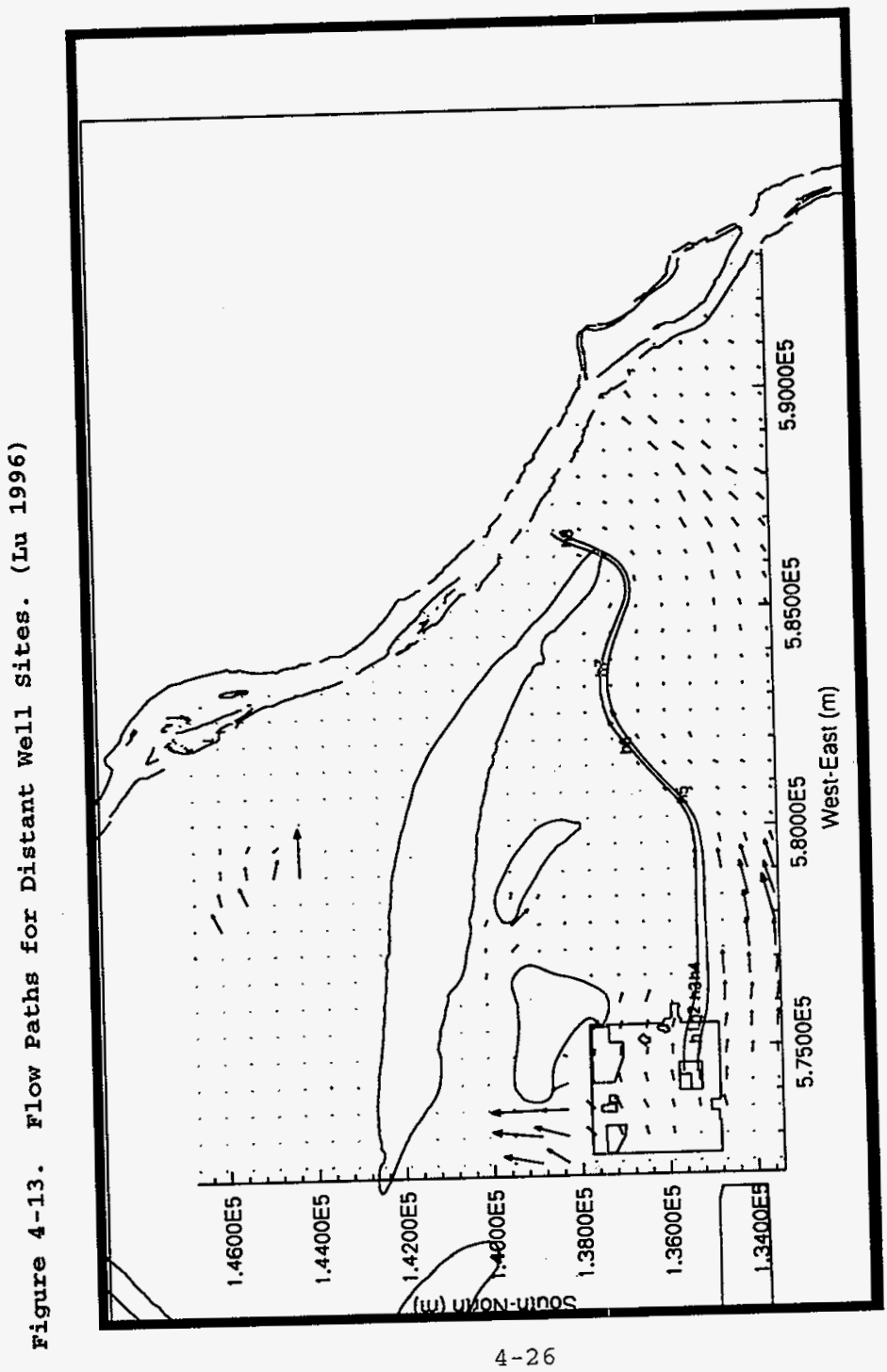


Figure 4-14. Concentration Ratio Contours 400 Years after the Contaminants Enter the Aquifer. ( $\mathrm{Lu}$ 1996) Assumes concentration of $1 \mathrm{Ci} / \mathrm{m}^{3}$ in the vadose zone and a recharge rate of $1 \mathrm{~mm} / Y$. Since actual recharge is $3 \mathrm{~mm} / Y$, actual concentrations will be 3 times higher than shown.

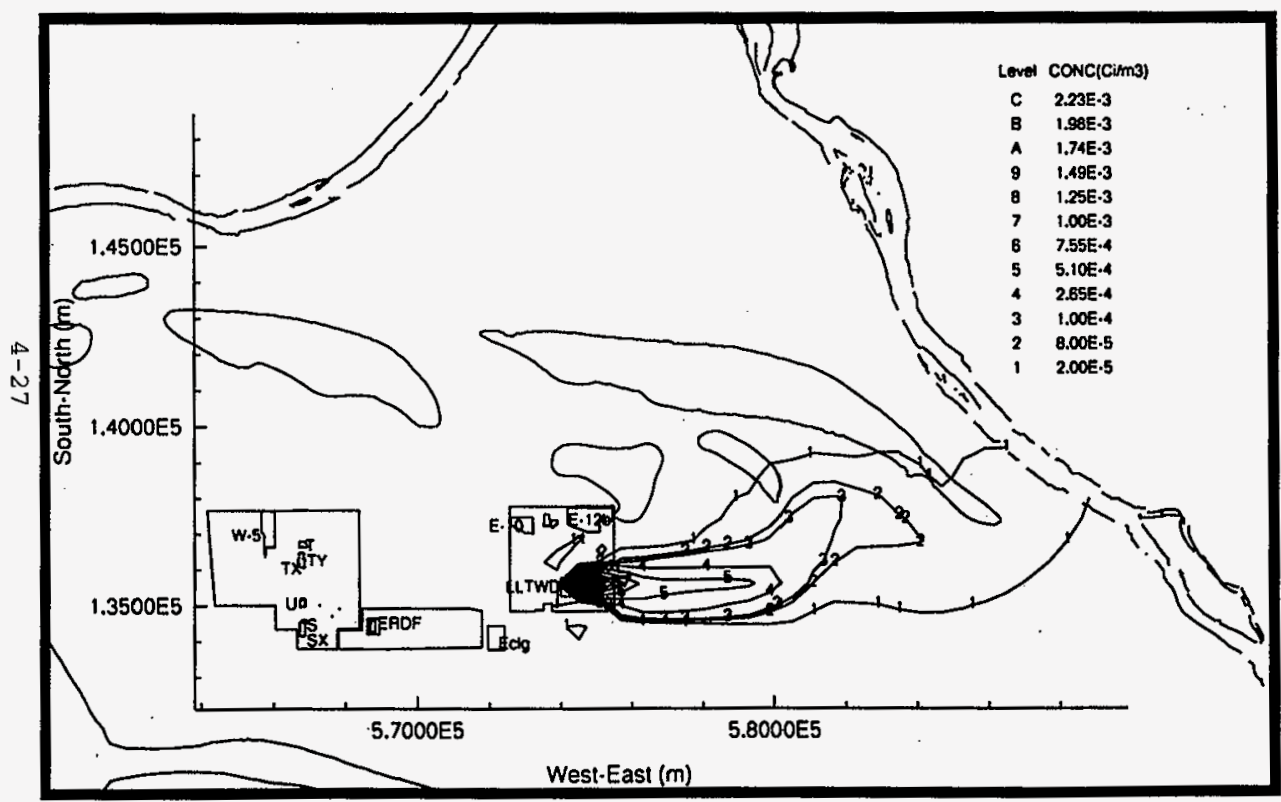


HINF-EP-0 884

Rev. 1

Figure 4-15. Concentration Ratio Histories at Downstream Hypothetical Wells. (Iu 1996) Locations hl through h8 are shown in Figure 4-13 and defined in Table 4-5.
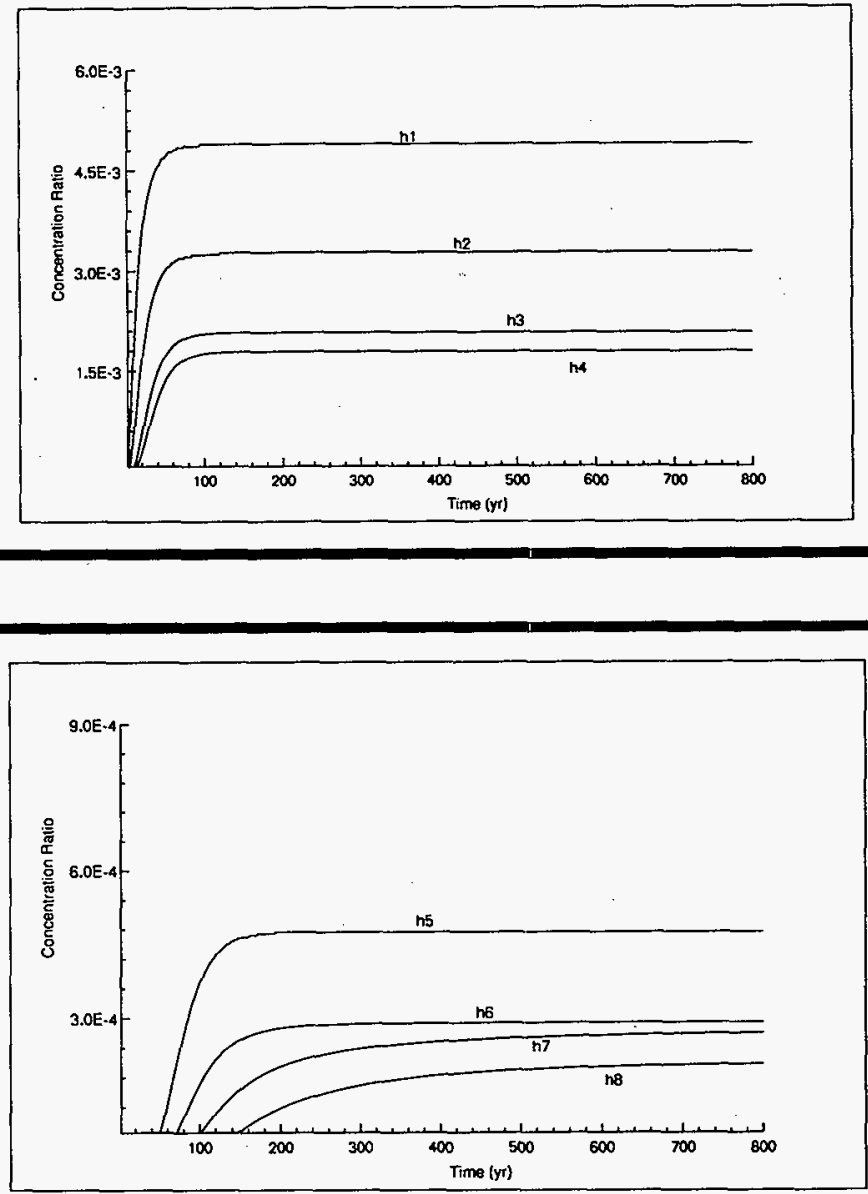


\section{FNNF-EP-0884 \\ Rev. 1}

\subsubsection{Integration}

This section describes the result of combining the results of the vadose zone transport (section 4.3 .2 ), the results of the aquifer transport (Section 4.3 .3 ), the amounts of the radionuclides (section 3.2.2), and the exposure parameters (Section 3.4.8).

The computer program PORCON (described in Mann 1996) was used to combine the results of the PORFLOW runs. Thus one file would contain all $K_{d}$ bins even though PORFLOW was limited to 4 bins per run. The program INTEG (described in section 3.5.2.5) then combines the results of the transport simulations (vadose zone and aquifer) with inventory and exposure parameters to calculate the dose and radionuclide concentration at a well.

Concept 1 is the facility design used for the base analysis case. This section describes in detail the impacts of simulation results for this case. The impacts are estimated for water drawn from a well 100 meters downgradient of the disposal facility. from a well just before the groundwater mixes with the columbia River, and from the Columbia River itself.

As shown in Table 4-6, the impacts estimated at a well 100 meters downgradient from the disposal facility are less than the performance objectives set in section 1.5. The beta/photon and total drinking water doses as a function of time are displayed in Figure 4-16.. Also shown in Figure 4-16 are the doses from ${ }^{99} \mathrm{TC}$ and ${ }^{79} \mathrm{Se}$, the two biggest contributors to the dose. Table 4-7 shows the major contributors to the beta/photon dose at 10,000 years. Figure 4-17 shows the alpha-emitting radionuclide concentration as a function of time at the same well. Table 4-8 shows the major contributors to the alphaemitting radionuclide concentration at 10,000 years. Figure 4-18 and Table 4-9 show the all-pathways dose and major contributors to that dose, respectively.

Doses and radionuclide concentrations were also calculated just before the radionuclides enter the columbia River. Because the travel time in the unconfined aquifer is so short, the main difference between the impact 100 meters downgradient and the impact at the Columbia River $(\sim 20,000$ meters) is that more mixing occurs in the unconfined aquifer. Table 4-10 shows the estimated dose and radionuclide concentrations.

For all the impacts considered, the value of the impact is still rising at 10,000 years. As noted in section 4.3.2.5, detailed computer simulations were carried out for each $\mathrm{K}_{\mathrm{d}}$ group for 100,000 years, while approximations were used out to $100,000,000$ years. Table 4-11 presents the estimated maxima. 


\section{HANF-EP-0884 \\ Rev. 1}

Table 4-6. Estimated Impact From Base Analysis Case at a Well 100 Meters Downgradient from the Disposal Facility at 10,000 years.

\begin{tabular}{||l|c|c|}
\hline Type of Impact & Value & $\begin{array}{c}\text { Performance } \\
\text { objective }\end{array}$ \\
\hline $\begin{array}{l}\text { Dose from Beta/Photon Emitting } \\
\text { Radionuclides (mrem in a year) }\end{array}$ & 2.0 & 4.0 \\
\hline All-Pathways Dose (mrem in a year) & 6.4 & 25. \\
\hline $\begin{array}{l}\text { Concentration of Alpha-Emitting } \\
\text { Radionuclides (pCi/l) }\end{array}$ & 1.65 & 15. \\
\hline $\begin{array}{l}\text { Radium Concentration (pCi/l) } \\
\text { Uranium Concentration (pCi/l) }\end{array}$ & 1.65 & 3.001 \\
\hline
\end{tabular}

Figure 4-16. Drinking Water Doses for the Base Analysis Case at a Well 100 Meters Downgradient.

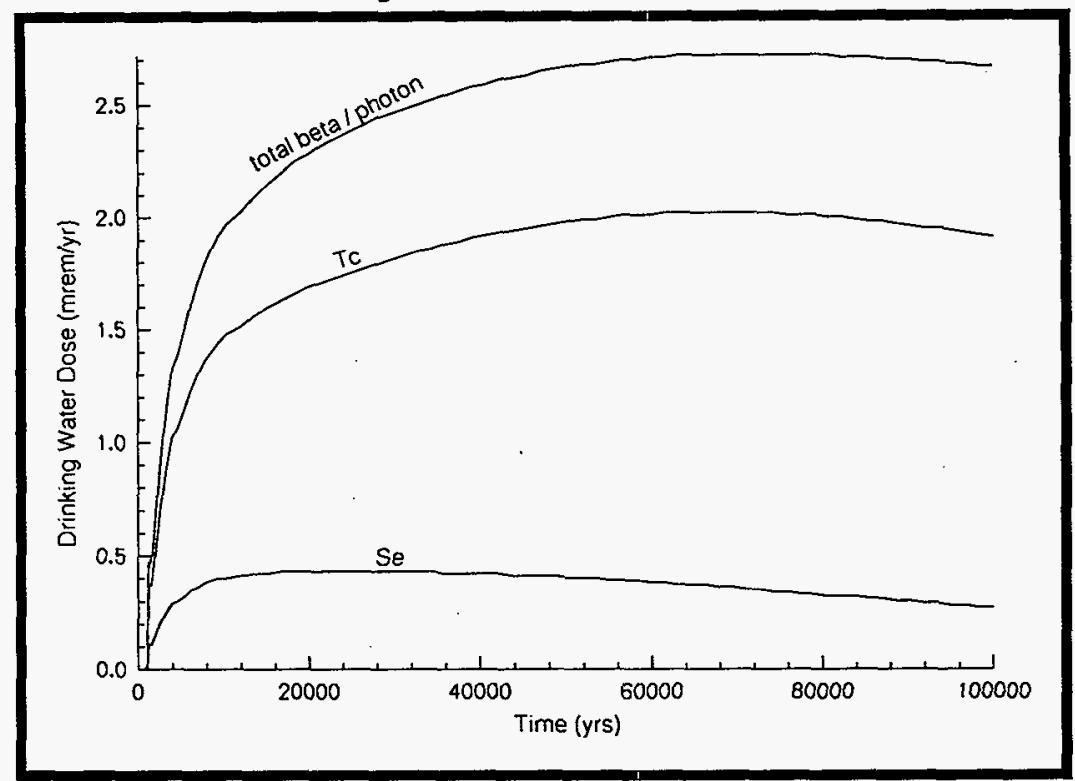




\section{HNE-EP- 0884 \\ Rev. 1}

Table 4-7. Major Contributors at 10,000 Years to the Estimated Beta/Photon Drinking Water Dose at a Well 100 Meters Downgradient from the Disposal Facility for the Base Analysis Case.

\begin{tabular}{|l|c|c|}
\hline Radionuclide & Dose (mrem/year) & Concentration (pCi/l) \\
\hline \hline${ }^{99} \mathrm{TC}$ & 1.48 & 1560. \\
\hline${ }^{79} \mathrm{Se}$ & 0.40 & 67. \\
\hline others ${ }^{\mathrm{a}}$ & 0.09 & 2. \\
\hline total & 1.97 & 1630. \\
\hline
\end{tabular}

Mainly beta-emitting daughters of uranium.

Figure 4-17. Alpha-Emitting Radionuclide Concentrations for the Base Analysis Case at a Well 100 Meters Downgradient from the Disposal Facility.

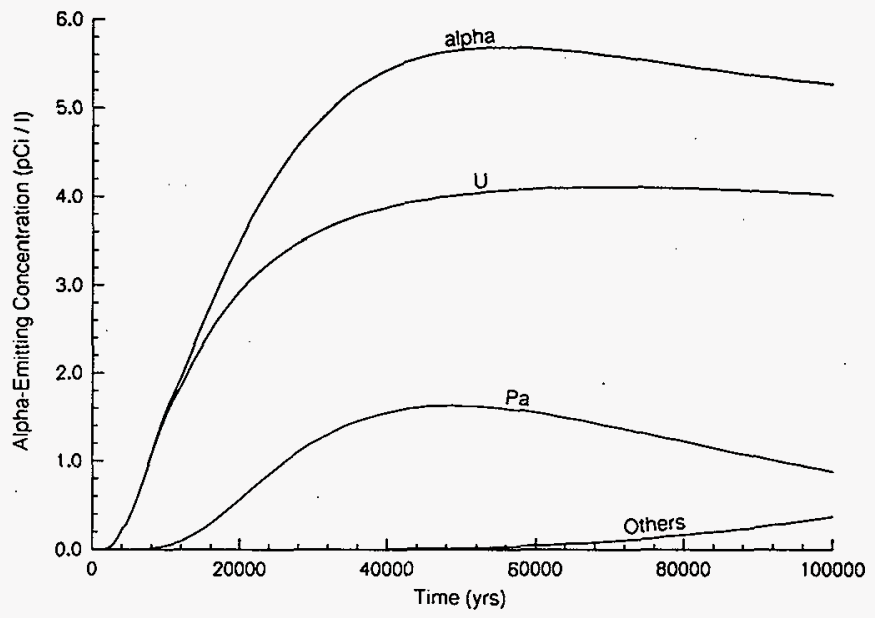

The last calculation for the base analysis case is the calculation of the integrated dose. Two cases are presented: a public drinking water system supplying 25 people located near the disposal facility and a population of 5 million drinking water from the columbia River after the contaminants are mixed with the river. Although not realistic, it is assumed that all the water consumed by the 5 million people comes from the well that intersects the groundwater just before the groundwater reaches the Columbia River. Even so, the estimated integrated dose of 
Rev. 1

0.05 person-rem/y and slightly less than 5 person-rem/y, respectively are far below the performance objective of 500 person-rem/y.

Table 4-8. Major Contributors at 10,000 Years to the AlphaEmitting Radionuclide Concentration at a Well 100 Meters Downgradient of the Disposal Facility for the Base Analysis Case.

\begin{tabular}{||c|c|c|}
\hline \hline Radionuclide & Dose (mrem/year) & Concentration (pCi/l) \\
\hline \hline${ }^{226} \mathrm{Ra}$ & 0.00 & $4 . \times 10^{-12}$ \\
\hline${ }^{228} \mathrm{Ra}$ & 0.00 & $9 . \times 10^{-12}$ \\
\hline${ }^{231} \mathrm{~Pa}$ & 0.42 & 0.053 \\
\hline${ }^{232} \mathrm{U}$ & 0.01 & 0.013 \\
\hline${ }^{233} \mathrm{U}$ & 0.12 & 0.64 \\
\hline${ }^{234} \mathrm{U}$ & 0.08 & 0.47 \\
\hline${ }^{235} \mathrm{U}$ & 0.00 & 0.019 \\
\hline${ }^{236} \mathrm{U}$ & 0.00 & 0.014 \\
\hline${ }^{238} \mathrm{U}$ & 0.08 & 0.46 \\
\hline others & $<0.01$ & $<0.01$ \\
\hline total & 0.71 & 1.65 \\
\hline
\end{tabular}

Table 4-9. Major Contributors at 10,000 Years to the AllPathways Dose at a Well 100 Meters Downgradient of the Disposal Facility for the Base Aralysis Case.

\begin{tabular}{|l|c|}
\hline Radionuclide & $\begin{array}{c}\text { Dose } \\
\text { (mrem/year) }\end{array}$ \\
\hline${ }^{99} \mathrm{TC}$ & 4.86 \\
\hline${ }^{79} \mathrm{Se}$ & 0.73 \\
\hline${ }^{231} \mathrm{~Pa}$ & 0.46 \\
\hline${ }^{233} \mathrm{U}$ & 0.14 \\
\hline${ }^{234} \mathrm{U}$ & 0.10 \\
\hline${ }^{238} \mathrm{U}$ & 0.09 \\
\hline others & $<0.03$ \\
\hline total & 6.4 \\
\hline
\end{tabular}


Figure 4-18. All-Pathways Doses for the Base Analysis Case at a We11 100 Meters Downgradient.

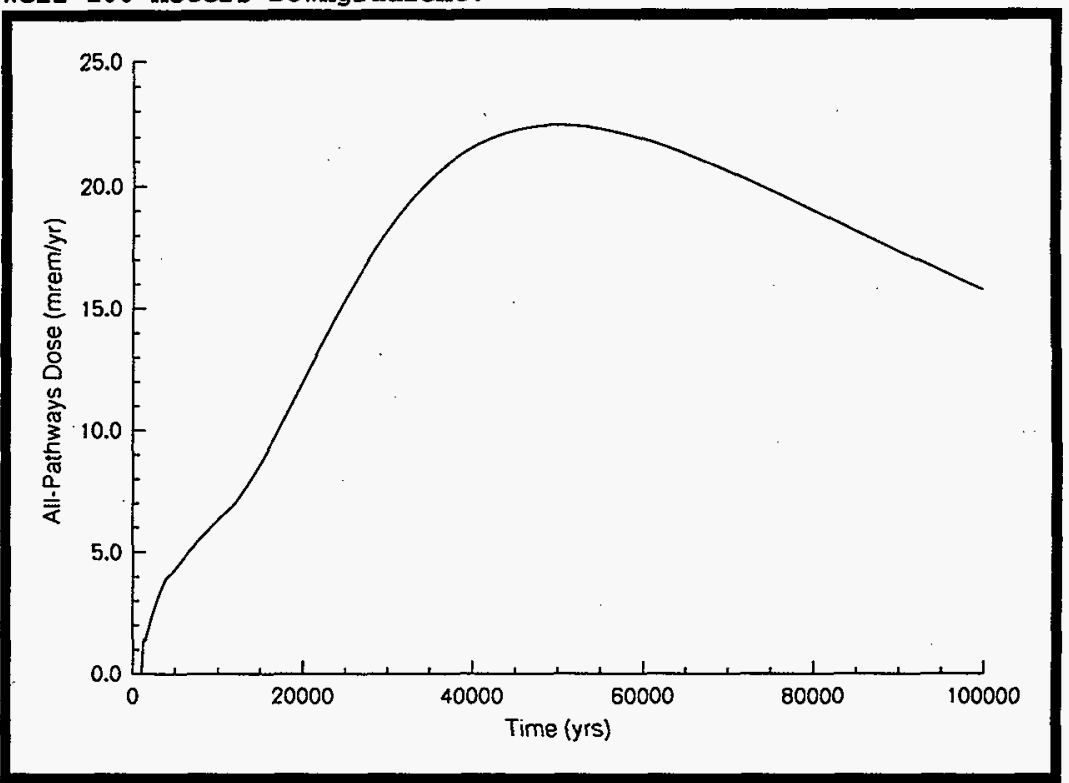

Table 4-10. Estimated Impact From Base Analysis Case from Groundwater Just Before Mixing with the Columbia River at 10,000 Years.

\begin{tabular}{||l|c|c|}
\hline \hline Type of Impact & Value & $\begin{array}{c}\text { Performance } \\
\text { objective }\end{array}$ \\
\hline $\begin{array}{l}\text { Dose from Beta/Photon Emitting } \\
\text { Radionuclides (mrem in a year) }\end{array}$ & 0.069 & 1.0 \\
\hline All-Pathways Dose (mrem in a year) & 0.22 & 25. \\
\hline $\begin{array}{l}\text { Concentration of Alpha-Emitting } \\
\text { Radionuclides (pCi/l) }\end{array}$ & 0.058 & 15. \\
\hline Radium Concentration (pCi/l) & $2 . \times 10^{-11}$ & 3. \\
\hline Uranium Concentration (pCi/l) & 0.056 &.-- \\
\hline
\end{tabular}




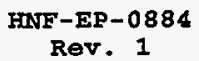

Table 4-11. Estimated Maximun Impact From Base Analysis Case Using the Groundwater Scenario.

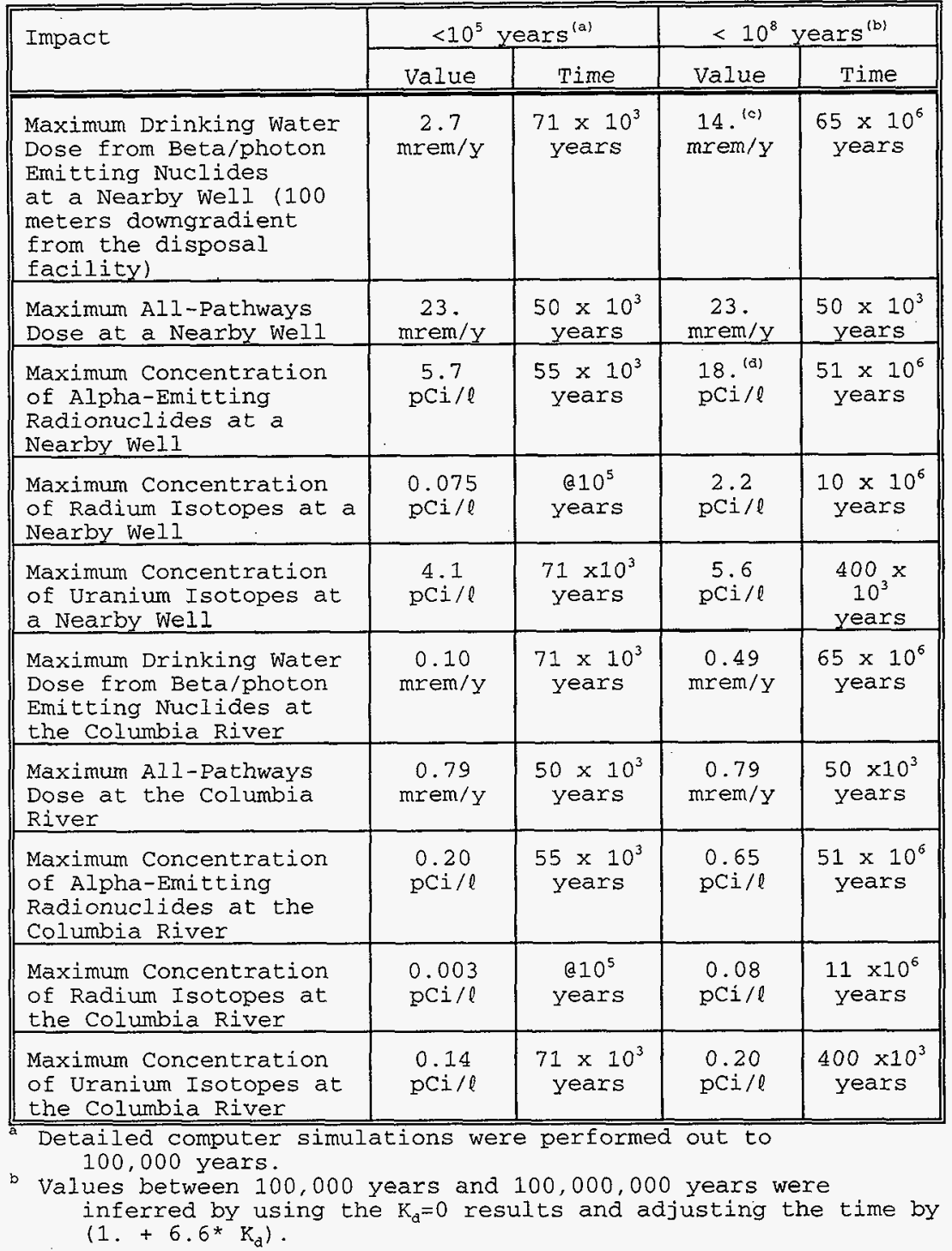


c The drinking water dose from beta/photon emitters at a well 100 meters downgradient is estimated to exceed $4 \mathrm{mrem} / \mathrm{year}$ at about 750,000 years.

d The alpha-emitting radionuclide concentration at a well

100 meters downgradient is estimated to exceed $15 \mathrm{pCi} / \mathrm{l}$ at 2.5 million years.

\subsection{RESULTS OF GROUNDWATER SCENARIOS - BASE SENSITIVITY CASES}

\subsubsection{Overview.}

Beside the base analysis case, sensitivity cases were built around two other cases. The first case involved using the full facility model of concept 2. The second involved using the Unit Cell Model for vadose zone transport and the geometry of Concept 1 for aquifer transport. This additional cases were chosen to highlight the differences between Concept 1 and Concept 2 and to reduce computer resource requirements, respectively.

This section provides the results from these two base sensitivity case runs.

\subsubsection{Concept 2 .}

4.4.2.1 overview. Because concept 2 forms the basis for many sensitivity runs, the estimated impacts are described here. The data and models used for this case (known as the concept 2 base sensitivity case) are the same as for the base analysis case except that the concept 2 design is used. The reasons for the differences between these results and those for the base analysis case (Concept 1) are explained in Section 4.6.2.4.

\subsubsection{Vadose zone Transport simulation of the Concept 2 Main Analysis Case. Figure 4-19 displays the normalized flux to the aquifer for the three fastest groups ( $\mathrm{K}_{\mathrm{d}}=0,0.1$, and $0.6 \mathrm{ml} / \mathrm{g}$ ). Table 4-12 presents the relevant parameters for each of the $\mathrm{K}_{\mathrm{d}}$ groups. Since the mean horizontal path from the side walls to the waste is much shorter for the concept 2 design (about 8 meters) than for the concept 1 design (about 70 meters), the moisture content in the disposal facility and below the disposal facility is higher for the Concept 2 design than for the base analysis case. Because of this higher moisture content, the hydraulic conductivity is higher and hence the contaminants reach the aquifer more quickly using the concept 2 facility design.}

4.4.2.3 Integration of Vadose Zone and Other Data. Table 4-13 provides the estimated impacts at a well 100 meters downgradient at 10,000 years using Concept 2. Table 4-14 provides the estimated maximum impacts at the same well. The estimated impacts at the Columbia River are the same as for concept 1 (Tables $4-10$ and $4-11$ ). 
Rev. 1

Figure 4-19. Normalized Contaminant Flux to the Unconfined Aquifer for $\mathrm{k}_{\mathrm{d}}=0 ., 0.1$, and $0.6 \mathrm{ml} / \mathrm{g}$ for Concept 2 (Full Facility Model).

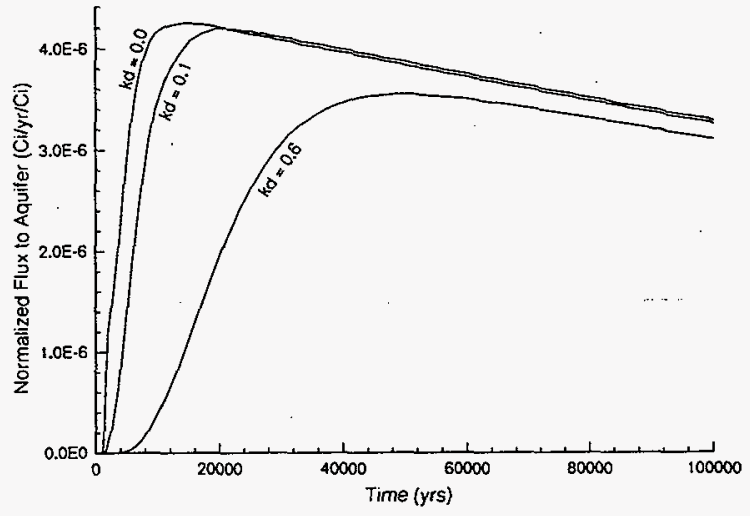

Table 4-12. Major Parameters Describing the Normalized Contaminant Flux to the Aquifer for Concept 2. (Full Facility Model).

\begin{tabular}{|c|c|c|c|c|c|}
\hline $\begin{array}{c}K_{\mathrm{d}} \\
(\mathrm{ml} / \mathrm{g})\end{array}$ & $\begin{array}{l}\text { Value at } \\
\text { lok Years } \\
\text { (Ci/y/Ci) }\end{array}$ & $\begin{array}{c}\text { Peak Value } \\
\text { in First } \\
100 \mathrm{~K} \\
\text { Yéars } \\
\text { (Ci/y/Ci) } \\
\end{array}$ & $\begin{array}{c}\text { Time of } \\
\text { True Peak } \\
\text { Value } \\
(y)\end{array}$ & $\begin{array}{c}\text { Time of } \\
0.5 * \text { True } \\
\text { Peak } \\
\text { Value } \\
(y) \\
\end{array}$ & $\begin{array}{c}\text { Time of } \\
10^{-6} * \text { True } \\
\text { Peak } \\
\text { Value } \\
(y) \\
\end{array}$ \\
\hline 0 . & $4.22 e^{-6}$ & $4.25 e^{-6}$ & 13,000 & 3,600 & 500 \\
\hline 0.1 & $3.69 e-6$ & $4.19 e^{-6}$ & 21,000 & 6,600 & 900 \\
\hline 0.6 & $0.53 e-6$ & $3.10 e^{-6}$ & $>100,000$ & 22,000 & 2,000 \\
\hline 3.0 & $4.6 e-11$ & $2.80 e^{-6}$ & $>100,000$ & $>100,000$ & 8,000 \\
\hline 15. & $5.6 e-22$ & $2.1 \quad e-8$ & $>100,000$ & $>100,000$ & 38,000 \\
\hline 40 & $6.9 e-23$ & $3.2 e-12$ & $>100,000$ & $>100,000$ & $>100,000$ \\
\hline 100. & $2.6 e-24$ & $9.6 e-20$ & $>100,000$ & $>100,000$ & $>100,000$ \\
\hline
\end{tabular}

The value given is for the peak value in the first 100,000 years.

b Unless an actual peak was obtained in the first 100,000 years, the true peak value was taken as $4 \times 10^{-6} \mathrm{Ci} / \mathrm{y} / \mathrm{Ci}$. 
Table 4-13. Estimated Impact Using Concept 2 Geometry at a Well 100 Meters Downgradient from the Disposal Facility at 10,000 Years. (Full Facility Model)

\begin{tabular}{|l|lc||}
\hline \hline Type of Impact & \multicolumn{2}{|c|}{ Value } \\
\hline \hline Dose from Beta/Photon Emitting Radionuclides & 1.11 & $\mathrm{mrem} / \mathrm{y}$ \\
\hline All-Pathways Dose & 3.3 & $\mathrm{mrem} / \mathrm{y}$ \\
\hline $\begin{array}{l}\text { Concentration of Alpha-Emitting } \\
\text { Radionuclides }\end{array}$ & $0.27 \mathrm{pCi} / \ell$ \\
\hline Radium Concentration & $<1 . \times 10^{-10} \mathrm{pCi} / \ell$ \\
\hline \begin{tabular}{l} 
Uranium Concentration \\
\hline
\end{tabular}
\end{tabular}

Table 4-14. Estimated Maximum Impact Using Concept 2 Geometry at 100 Meters Downgradient from the Disposal Facility. (Ful1 Facility Model)

\begin{tabular}{|c|c|c|c|c|}
\hline \multirow[t]{2}{*}{ Impact } & \multicolumn{2}{|c|}{$<10^{5}$ years $^{(a)}$} & \multicolumn{2}{|c|}{$\leq 10^{\dot{\varepsilon}}$ years $^{(b)}$} \\
\hline & Value & Time & Value & Time \\
\hline $\begin{array}{l}\text { Maximum Drinking Water } \\
\text { Dose from Beta/photon } \\
\text { Emitting Nuclides } \\
\text { at a Nearby Well }\end{array}$ & $\begin{array}{c}1.12 \\
\mathrm{mrem} / \mathrm{y}\end{array}$ & $\begin{array}{l}15 \times 10^{3} \\
\text { years }\end{array}$ & $\begin{array}{l}5.0 .^{(\mathrm{c})} \\
\mathrm{mrem} / \mathrm{y}\end{array}$ & $\begin{array}{c}13 \times 10^{6} \\
\text { years }\end{array}$ \\
\hline $\begin{array}{l}\text { Maximum All-Pathways } \\
\text { Dose at a Nearby Well }\end{array}$ & $\begin{array}{c}7.9 \\
\text { mrem/y }\end{array}$ & $\begin{array}{c}72 \times 10^{3} \\
\text { years }\end{array}$ & $\begin{array}{c}7.9 \\
m r e m / y \\
\end{array}$ & $\begin{array}{c}72 \times 10^{3} \\
\text { years }\end{array}$ \\
\hline $\begin{array}{l}\text { Maximum Concentration } \\
\text { of Alpha-Emitting } \\
\text { Radionuclides at a } \\
\text { Nearby well }\end{array}$ & $\begin{array}{l}2.6 \\
\mathrm{pCi} i \mathrm{l}\end{array}$ & $\begin{array}{l}62 \times 10^{3} \\
\text { years }\end{array}$ & $\begin{array}{c}6.9 \\
\mathrm{pCi} / \ell\end{array}$ & $\begin{array}{l}3 \times 10^{6} \\
\text { years }\end{array}$ \\
\hline $\begin{array}{l}\text { Maximum Concentration } \\
\text { of Radium Isotopes at a } \\
\text { Nearby Well }\end{array}$ & $\begin{array}{l}0.002 \\
\mathrm{pCi} / \ell\end{array}$ & $\begin{array}{l}\text { @ } 10^{5} \\
\text { years }\end{array}$ & $\begin{array}{c}0.78 \\
\mathrm{pCi} / \mathrm{l}\end{array}$ & $\begin{array}{l}3 \times 10^{6} \\
\text { years }\end{array}$ \\
\hline $\begin{array}{l}\text { Maximum Concentration } \\
\text { of Uranium Isotopes at } \\
\text { a Nearby Well }\end{array}$ & $\begin{array}{c}2.1 \\
\mathrm{pCi} / \ell\end{array}$ & $\begin{array}{l}47 \times 10^{3} \\
\text { years }\end{array}$ & 2.1 & $\begin{array}{c}47 \times 10^{3} \\
\text { years }\end{array}$ \\
\hline
\end{tabular}

Detailed computer simulations were performed out to 100,000 years.

b Values between 100,000 years and 100,000,000 years were inferred by using the $K_{\alpha}=0$ results and adjusting the time by $\left(1 .+6.6 * K_{d}\right)$.

- The drinking water dose from beta/photon emitters at a well 100 meters downgradient is estimated to exceed 4 mrem/year at about 3 million years. 


\section{HNF - EP -0884 \\ Rev. 1}

\subsubsection{Unit Cell Model.}

4.4.3.1 Overview. Because the Unit Cell Model is used in many of the sensitivity runs, the calculated impacts are described here. The Unit cell Model takes a canister-wide slice of the Concept 1 facility concept, but without the sand-gravel capillary barrier (See Section 3.5.3.3 and Figure 3-8). The case presented here (known as the Unit cell Model base sensitivity case) retains the values used in the base analysis case. The reasons for the differences between these results and those for the base analysis case (Concept 1) is presented in section 4.6.3.2.

\subsubsection{Vadose zone Transport Simulation of the Unit Cell Model}

Main Analysis Case. Table 4-15 summarizes the calculated

normalized fluxes to the unconfined aquifer. Figure 4-20

displays those fluxes as a function of time. Figure 4-21 presents the normalized fluxes from the disposal facility to the vadose zone. Major features include a constant flux (due to the constant release rate) and a faster rise (due to the absence of a hydraulic diverter) than for the full facility models. A more complete description is given in KIine (1996).

As mentioned in section 4.3 .2 .2 , the $K_{d}=0$ case shows a spike at early times due to changing the infiltration rate at 1,000 years. Thus in the results discussed below, the $\mathrm{K}_{\mathrm{d}}=0.1 \mathrm{~m} / \mathrm{g}$ (which do not show the spike) are used.

Table 4-15. Major Parameters Describing the Normalized Contaminant Flux to the Aouifer Using the Unit Cell Model.

\begin{tabular}{|c|c|c|c|c|c|}
\hline $\begin{array}{c}\mathrm{K}_{\mathrm{d}} \\
(\mathrm{ml} / \mathrm{g})\end{array}$ & $\begin{array}{l}\text { Value at } \\
10 \mathrm{~K} \text { Years } \\
(\mathrm{Ci} / \mathrm{Y} / \mathrm{Ci})\end{array}$ & $\begin{array}{c}\text { Peak } \\
\text { Value } \\
\text { (Ci/y/Ci) }\end{array}$ & $\begin{array}{c}\text { Time of } \\
\text { Peak } \\
\text { Value } \\
(y)\end{array}$ & $\begin{array}{c}\text { Time of } \\
0.5 * \text { True } \\
\text { Peak } \\
\text { value } \\
(y) \\
\end{array}$ & $\begin{array}{c}\text { Time of } \\
10^{-6} \text { True }^{2} \\
\text { peak } \\
\text { value } \\
(\mathrm{y}) \\
\end{array}$ \\
\hline 0. & 4.37 e- 6 & $6.9 \mathrm{e}-6^{\circ}$ & 2,150 & 1,200 & 170 \\
\hline 0.1 & $4.37 e-6$ & $4.42 \mathrm{e}-6$ & 17,000 & 3,000 & 350 \\
\hline 0.6 & $2.65 e-6$ & 4.42 e- 6 & 39,000 & 9,100 & 1,500 \\
\hline 3. & 2.01 e-9 & $4.35 \mathrm{e}-6$ & $>100,000$ & 39,000 & 6,200 \\
\hline 6. & $1.6 \mathrm{e}-12$ & $3.26 e-6$ & $>100,000$ & 76,000 & 11,000 \\
\hline 15 & $1.4 \mathrm{e}-18$ & $3.27 \mathrm{e}-7$ & $\geq 100,000$ & $>100,000$ & $>100,000$ \\
\hline 40. & 0. & $2.9 e-10$ & $>100,000$ & $>100,000$ & $>100,000$ \\
\hline 100. & 0. & $2.4 e^{-15}$ & $>100,000$ & $>100,000$ & $>100,000$ \\
\hline
\end{tabular}

The value given is for the peak value in the first 100,000 years.

- Unless a peak value was obtained in the first 100,000 years, the true peak value was taken as $4 \times 10^{-6} \mathrm{Ci} / \mathrm{y} / \mathrm{Ci}$.

- Value results from changing properties at 2,000 years. 


\section{HNF-EP-0884 \\ Rev. 1}

Figure 4-20. Normalized Contaminant Flux to the Unconfined Aquifer for $\mathrm{K}_{\mathrm{d}}=0,0.1,0.6$, and 3 . ml/g using the Unit Cell Model.

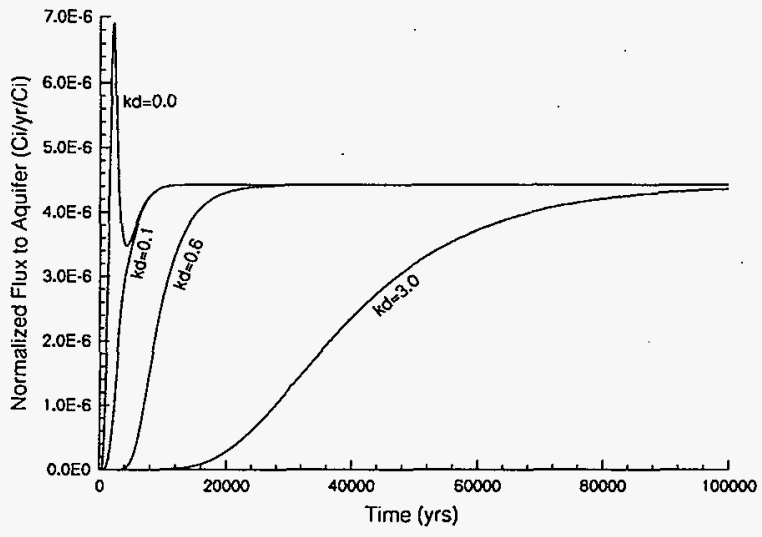

Figure 4-21. Normalized Contaminant Flux from the Disposal Facility to the Vadose zone using the unit cell Model

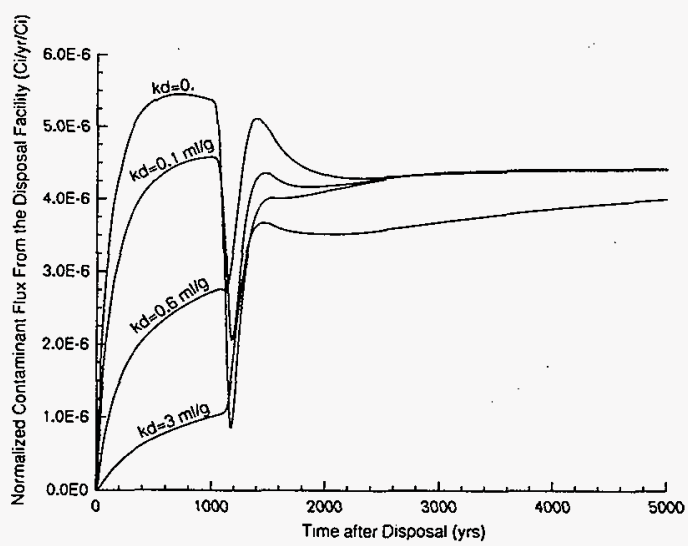




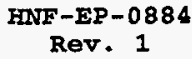

4.4.3.3 Integration of Vadose Zone Calculations and Other Data. Table 4-16 provides the estimated impacts at a well 100 meters downgradient at 10,000 years using the Unit Cell Model for the vadose zone calculations and the concept 1 geometry for the aquifer calculations. Table 4-17 provides the estimated maximum impacts at the same well.

Table 4-16. Estimated Impact at 10,000 Years from Groundwater at a Well 100 Meters Downgradient Using the Unit Cell Model and Concept 1 Geometry. The Unit Cell Model does not have a hydraulic diverter.

\begin{tabular}{|l|c|}
\hline Type of Impact & Value \\
\hline \hline $\begin{array}{l}\text { Dose from Beta/Photon Emitting Radionuclides } \\
\text { All-Pathways Dose }\end{array}$ & $4.4 \mathrm{mrem} / \mathrm{y}$ \\
\hline $\begin{array}{l}\text { Concentration of Alpha-Emitting } \\
\text { Radionuclides }\end{array}$ & $13.9 \mathrm{mrem} / \mathrm{y}$ \\
\hline Radium Concentration & $5.9 \mathrm{pc} / \mathrm{l}$ \\
\hline \begin{tabular}{l} 
Uranium Concentration \\
\hline
\end{tabular} & $5.9 \mathrm{pCi} / \mathrm{l}$ \\
\hline
\end{tabular}

Table 4-17. Estimated Maximum Impact from Groundwater at a Well 100 Meters Downgradient Using the Unit Cell Model for Concept 1 Design. The Unit cell Model does not have a hydraulic diverter.

\begin{tabular}{|c|c|c|}
\hline \multirow[t]{2}{*}{ Impact } & \multicolumn{2}{|c|}{$<10^{5}$ years $^{(a)}$} \\
\hline & Value & Time \\
\hline $\begin{array}{l}\text { Maximum Drinking water Dose from } \\
\text { Beta/photon Emitting Nuclides at a Nearby } \\
\text { Well }\end{array}$ & $\begin{array}{l}4 \cdot 5^{(b)} \\
\mathrm{mrem} / \mathrm{y}\end{array}$ & $\begin{array}{l}15 \times 10^{3} \\
\text { years }\end{array}$ \\
\hline Maximum All-Pathways Dose at a Nearby well & $\begin{array}{l}63 \cdot{ }^{(c)} \\
\mathrm{mrem} / \mathrm{y}\end{array}$ & $\begin{array}{l}50 \times 10^{3} \\
\text { years }\end{array}$ \\
\hline $\begin{array}{l}\text { Maximum Concentration of Alpha-Emitting } \\
\text { Radionuclides at a Nearby Well }\end{array}$ & $\begin{array}{c}15 \cdot 0^{(d)} \\
p C \dot{i} / \ell\end{array}$ & $\begin{array}{l}49 \times 10^{3} \\
\text { years }\end{array}$ \\
\hline $\begin{array}{l}\text { Maximum Concentration of Radium Isotopes } \\
\text { at a Nearby well }\end{array}$ & $\begin{array}{r}0.12 \\
\mathrm{pCi} / \mathrm{l} \\
\end{array}$ & $\begin{array}{l}e 10^{5} \\
\text { years }\end{array}$ \\
\hline $\begin{array}{l}\text { Maximum Concentration of Uranium Isotopes } \\
\text { at a Nearby well }\end{array}$ & $\begin{array}{l}9.5 \\
\mathrm{pCi} / \mathrm{l}\end{array}$ & $\begin{array}{c}25 \times 10^{3} \\
\text { years }\end{array}$ \\
\hline
\end{tabular}

Detailed computer simulations were performed out to 100,000 years.

b The beta/photon drinking water dose is estimated to exceed 4 mrem in a year at 7,200 years.

c The all-pathways dose is estimated to exceed 25 mrem/year at 22,000 years.

- The concentration of alpha-emitting radionuclides is estimated to exceed 15 mrem in a year at 46,000 years. 


\section{FNNE-EP-0884 \\ Rev. I}

\subsection{RESULTS OF GROUNDWATER SCENARIOS - WASTE FORM SENSITIVITY CASES}

\subsubsection{Overview}

The performance of the waste form is one of the most important inputs to this performance assessment, yet it is one of the least well-known parameters. For the base analysis case, the initial release of contaminants is assumed to happen at the same rate as the dissolution of the waste form for the non-technetium inventory as specified in the RFP for low-level tank waste immobilization (DOE-RI 1996). Subsequent release rates are established by using the same release rate per unit surface area and the available surface area. This section discusses the sensitivity of using different interpretations of the RFP as well as using more mechanistic approaches to determine glass performance.

\subsubsection{Contaminant Release Rates from Waste Form}

Although the contaminant release rate from the RFP forms the basis of the base analysis case, sensitivity runs were performed $u$ sing a mechanistic model for glass corrosion and contaminant release. The AREST-CT computer code (Section 3.5.2.2 and Appendix C) simulated the dissolution of LD6-5412 glass, the release of contaminants from the glass, and the transport of those contaminants through the bottom of the disposal vaults. These simulations are discussed in Appendix $\mathrm{E}$.

Because of financial limitations and current limitations of the model, certain effects were not modeled in this analysis but will be modeled in the future performance assessments. For example, water consumed during glass dissolution is not removed from the system in this analysis. Such water consumption is relatively unimportant for glass shapes a meter in size but can be important for shapes a centimeter in size. This analysis assumes that the surface area of the glass is proportional to the square of the effective radius of the glass and hence decreases as the glass dissolves. Processes which could increase the surface area (such as cracking subsequent to cooling) are not considered.

The simulations performed for this analysis show that the ion exchange of sodium for hydrogen in the glass waste form

$$
(\mathrm{Glass}-0.4208 \mathrm{Na})+0.4208 \mathrm{H}^{+}=(\mathrm{Glass}-0.4208 \mathrm{H})+0.4208 \mathrm{Na}^{+}
$$

is very important at the low temperatures expected in the disposal vault. Because of this ion exchange reaction, the computed $\mathrm{pH}$ in the glass/water interface rises to over 12 . Since the glass LD6-5412 is much less stable at these high pH levels, the dissolution rate is significant (see Figure 4-22.). Using water-saturated, low-temperature, batch tests with LD6-5412 glass, the sodium ion-exchange reaction was identified only as a 


\section{HINF-EP-0884 \\ Rev. 1}

minor secondary reaction that contributed to an enhanced rate of sodium release as compared with other major glass components, including boron and silicon. However, in an unsaturated environment where little water is present, the importance of this reaction mechanism was first revealed through computer simulations that properly couple chemical reactions and transport.

Figure 4-22. Glass Dissolution Rate as a Function of Time and Space in the Disposal Vault.

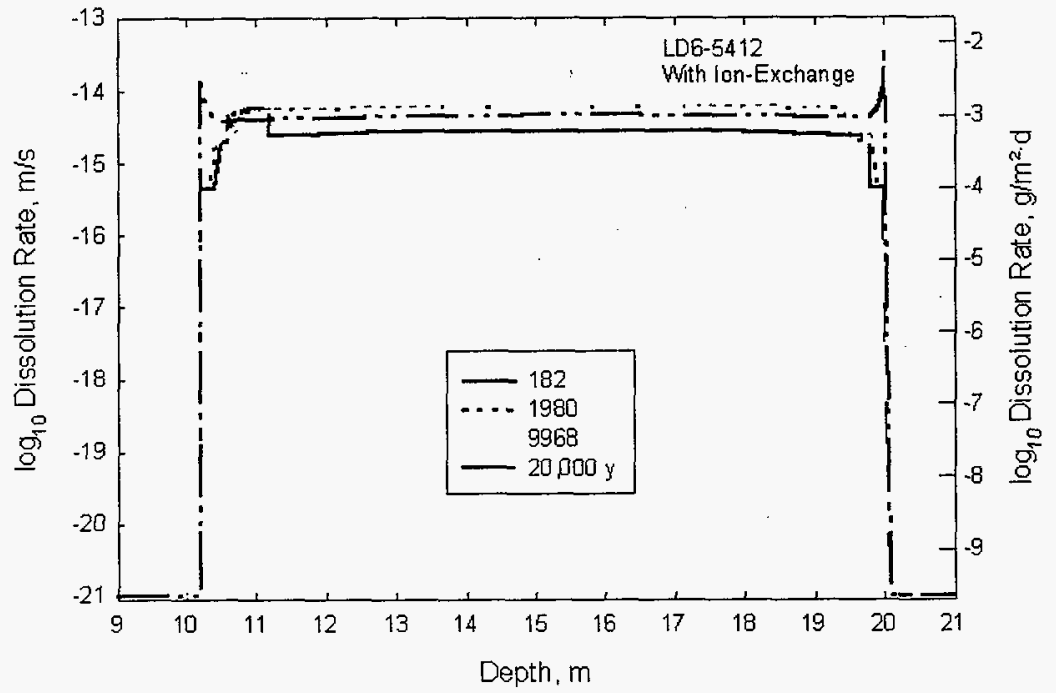

The AREST-CT computer code was also used to transport the contaminants through the vault floor once they were released from the glass. The maximum release rate through the vault floor is shown in Table 4-18: Figure 4-23 displays the time dependence of the release rate through the floor. These calculations assume that the concrete floor has degraded and has the hydraulic parameters of gravel. Note that all of the calculated release rates are smaller than those specified in the RFP (DOE-RI 1996).

To determine the actual importance of the ion exchange reaction, the $\mathrm{Tc}$ release rate was recalculated with the ion exchange reaction absent from the simulation. Without the sodium ion exchange reaction, the pH peaks at only about 10.5. Such a 


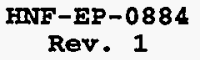

Table 4-18. Maximum Release Rate through Vault Floor as Calculated by AREST-CT.

\begin{tabular}{||l|c|}
\hline Element & Release Rate (ppm/y) \\
\hline \hline Base Analysis Case & 4.4 \\
\hline Selenium & 0.78 \\
\hline Technetium: & \\
full simulation & 0.50 \\
no sodium ion exchange & 0.02 \\
high pore velocity & 1.4 \\
\hline Iodine & 0.50 \\
\hline Uranium. & 0.64 \\
\hline Plutonium & 0.50 \\
\hline
\end{tabular}

Figure 4-23. Estimated Release Rates through the Vault Floox.

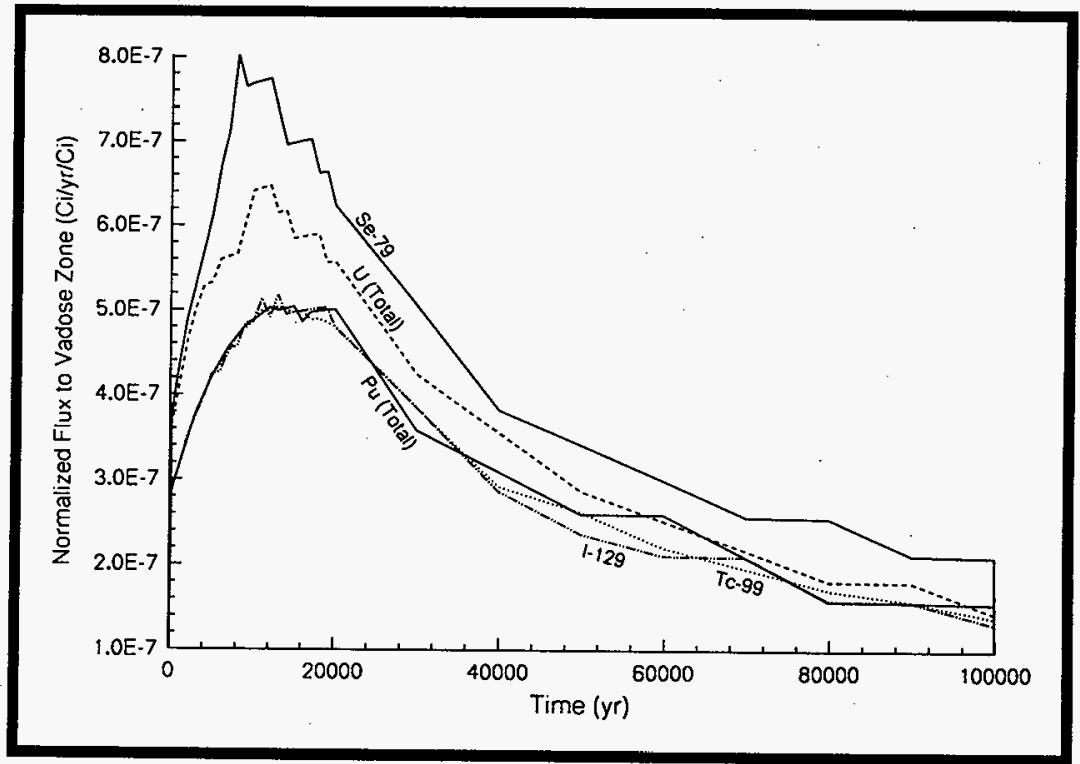


Rev. 1

lower pH reduces the glass corrosion rate by about a factor of 30, resulting in a glass corrosion rate that is three or four orders of magnitude lower than the forward rate of reaction for LD6-5412. The maximum release rate is shown in Table 4-18 and the time dependence of the release rate through the floor is displayed in Figure 4-24.

Figure 4-24. Normalized TC Fluxes Through the Vault Floor for Various Assumptions. The Unit Cell Model Base Sensitivity Case Assumed the Sodium Ion-Exchange Reaction Occurred and the Pore velocity was $1.0 \mathrm{~cm} / \mathrm{y}$.

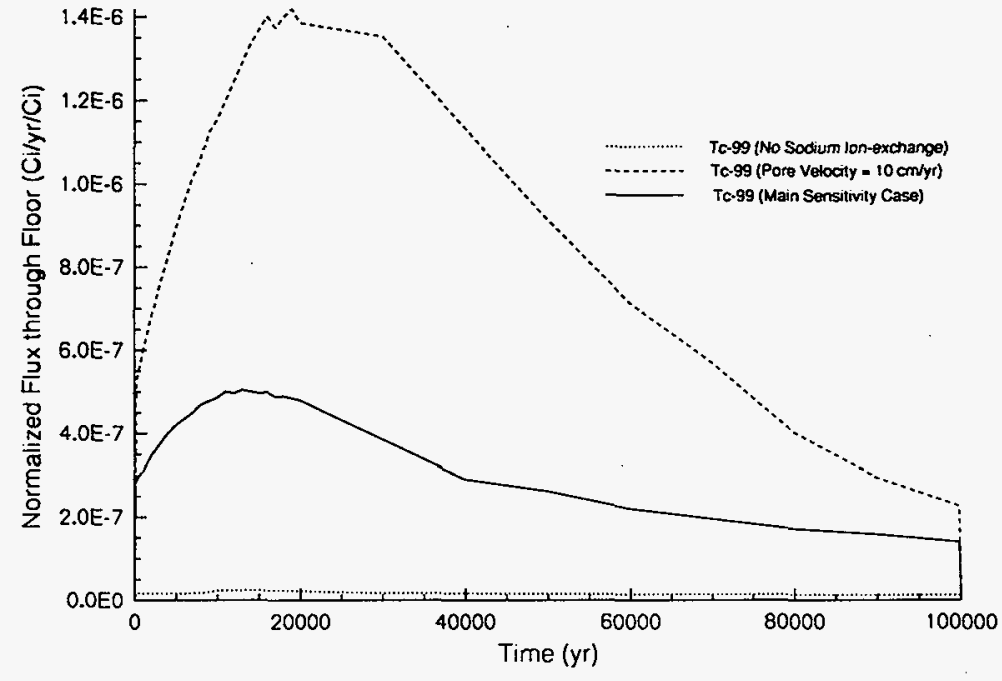

Finally, the AREST-CT calculation simulated a case with more water available in the vault system, resulting in an pore velocity of $10.0 \mathrm{~cm} / \mathrm{y}$ rather than $1.0 \mathrm{~cm} / \mathrm{y}$. The technetium release rate increased by a factor of 3 as seen in Table 4-18 and Figure 4-24.

\subsubsection{Impact on Exposure Calculations}

4.5.3.1 Overview. This section describes the sensitivity of the estimated impacts to various assumptions made concerning the waste form. Included in the discussion are the effects caused by the treatment of the time dependence of the release rate, to the special treatment of technetium in the RFP, and to the release rates calculated by the mechanistic model. 
Rev. 1

4.5.3.2 Constant Mass Release. The base analysis case assumes that the rate of waste form dissolution (and hence of contaminant release) is proportional to the amount of surface area of the waste form. Thus the base analysis case has a declining amount of contaminants being released as a function of time. A sensitivity case was run to determine the effect of constant contaminant release at a rate of $4.4 \mathrm{ppm}$. This is equivalent to assuming that the waste form has the shape of a thin plate. Figure 4-25 displays the normalized flux to the aquifer for the $\mathrm{K}_{\mathrm{d}}=0$ group for the Concept 2 base sensitivity case and for the case of constant contaminant release using concept 2 . Table $4-19$ presents the parameters for the curves of the various $\mathrm{K}_{\mathrm{d}}$ groups. The results for the two cases are very similar for the first 10, 000 years. They diverge thereafter as the results for the constant release case go to the expected value of $4.4 \times 10^{-6}$, while the results of the case with release proportional to surface area decline. The results for the constant release case go to the expected value, thus supporting the values calculated using the time-dependent release rate.

Figure 4-25. Normalized Flux to the Aquifer for $\mathrm{k}_{\mathrm{d}}=0$ for Concept 2 simulations Using Constant Contaminant Release and Using Contaminant Release Proportional to Surface Area (Full Facility Model).

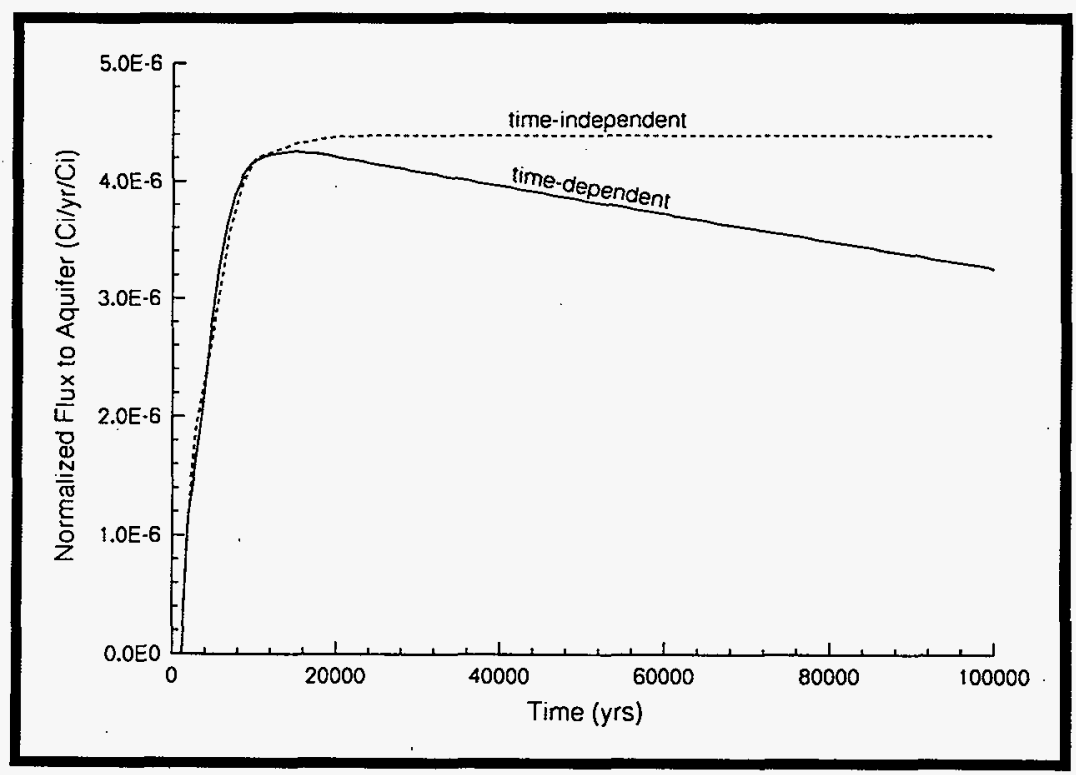




\section{HNNF-EP-0884}

Rev. 1

Table 4-19. Major Parameters Describing the Normalized Contaminant Flux to the Aquifer for Concept 2 Using Constant Contaminant Release (Full Facility Model).

\begin{tabular}{|c|c|c|c|c|c|}
\hline $\begin{array}{c}K_{d} \\
(\mathrm{ml} / g)\end{array}$ & $\begin{array}{c}\text { Value at } \\
10 \mathrm{~K} \text { Years } \\
(1 / \mathrm{y})\end{array}$ & $\begin{array}{c}\text { Peak } \\
\text { Value } \\
(1 / \mathrm{y})\end{array}$ & $\begin{array}{c}\text { Time of } \\
\text { Peak } \\
\text { Value } \\
(\mathrm{y})\end{array}$ & $\begin{array}{c}\text { Time of } \\
0.5 * \text { Peak } \\
\text { Value(a) } \\
(\mathrm{y})\end{array}$ & $\begin{array}{c}\text { Time of } \\
10^{-6} \star \text { Peak } \\
\text { Value } \\
(\mathrm{y})\end{array}$ \\
\hline \hline 0. & $4.21 \times 10^{-6}$ & $4.39 \times 10^{-6}$ & 35,000 & 3,700 & 650 \\
\hline 0.1 & $3.46 \times 10^{-6}$ & $4.35 \times 10^{-6}$ & 50,000 & 6,900 & 1,150 \\
\hline 0.6 & $0.42 \times 10^{-6}$ & $3.95 \times 10^{-6}$ & $>100,000$ & $22,000^{(b)}$ & $2,100^{(b)}$ \\
\hline
\end{tabular}

The value given is for the peak value in the first

100,000 years. It is expected that true peak value is about $4 . \times 10^{-5}$.

b Time of $K$ * true peak value is about that listed.

Because the normalized fluxes are so close for the constant release and for the time-varying release, the estimated impacts differ very little except at long times (>50,000 years).

4.5.3.3 Reduced Release Rate for Technetium. The RFP for tank waste immobilization (DOE-RL 1996) specified a lower release rate for technetium (by a factor of 5) than for the other radionuclides. This lower rate could be achieved by reducing the amount of technetium in the waste (and returning technetium to DOE) or by having a better performing waste form. For this section, it is assumed that the waste form has a release rate that is five times better than the base analysis case. The results are similar to the base analysis case and to the Concept 2 base sensitivity case for the first 100,000 years except the normalized flux to the aquifer is a factor of five lower.

Table 4-20 provides the effects of better performing waste forms, assuming that only technetium is affected and assuming that all $\mathrm{K}_{\mathrm{d}}=0$ radionuclides are affected. The doses do not decrease by a factor of five from the base analysis case because other radionuclides become important. For example, if the improved factor of five performance only affects technetium, then ${ }^{79} \mathrm{Se}$ is calculated to be the most important radionuclide. The beta/photon drinking water dose at 10,000 years being 50 percent from ${ }^{79} \mathrm{Se}$ and 47 percent from ${ }^{99} \mathrm{TC}$. Alternatively, when the performance is improved for all the $k_{d}=0$ radionuclides, then the impact of the $k_{d}=0.6 \mathrm{ml} / \mathrm{g}$ radioisotopes (mainly uranium and its daughters) is enough to provide one-third of the dose. 
FNF - EP-0884

Rev. 1

Table 4-20. Sensitivity of Impacts Caused by Different Interpretations of Waste Immobilization Request for Proposal.

\begin{tabular}{|c|c|c|c|}
\hline Case & Time & $\begin{array}{l}\text { Beta/Photon } \\
\text { Drinking } \\
\text { Water Dose } \\
\text { (mrem/y) } \\
\end{array}$ & $\begin{array}{c}\text { All- } \\
\text { Pathways } \\
\text { Dose } \\
\text { (mrem/y) } \\
\end{array}$ \\
\hline \multirow[t]{2}{*}{ Base Analysis Case } & $10 \mathrm{~K} \mathrm{y}$ & 2.0 & 6.4 \\
\hline & $\max$ & $2.7 @ 71 \mathrm{~K}$ & 23. @ $50 \mathrm{~K}$ \\
\hline \multirow{2}{*}{$\begin{array}{c}\text { Tc has } 5 \text { times smaller } \\
\text { release rate }\end{array}$} & $10 k y$ & 0.87 & 2.8 \\
\hline & $\max$ & $1.20 @ 100 \mathrm{~K}$ & 18. \& $49 \mathrm{~K}$ \\
\hline \multirow{2}{*}{$\begin{array}{l}\text { All } \mathrm{K}_{\mathrm{a}}=0 \text { radionuclides } \\
\text { have } 5 \text { times smaller } \\
\text { release rates }\end{array}$} & $10 \mathrm{~K} Y$ & 0.57 & 2.3 \\
\hline & $\max$ & 0.99 a $100 \mathrm{~K}$ & 17. e $49 \mathrm{~K}$ \\
\hline \multirow{2}{*}{$\begin{array}{l}\text { All radionuclides have } 5 \\
\text { times smaller release } \\
\text { rates }\end{array}$} & $10 \mathrm{~K} \mathrm{y}$ & 0.40 & 1.3 \\
\hline & $\max$ & $0.54 @ 71 \mathrm{~K}$ & $4.6 @ 50 \mathrm{~K}$ \\
\hline \multirow{2}{*}{$\begin{array}{c}\text { Concept } 2 \text { base sensitivity } \\
\text { case }\end{array}$} & $10 \mathrm{~K} \mathrm{y}$ & 1.11 & 3.3 \\
\hline & $\max$ & 1.12 e $15 \mathrm{~K}$ & $7.9 @ 72 \mathrm{~K}$ \\
\hline \multirow{2}{*}{$\begin{array}{c}\text { Tc has } 5 \text { times smaller } \\
\text { release rate }\end{array}$} & $10 \mathrm{~K} \mathrm{y}$ & 0.42 & 1.05 \\
\hline & $\max$ & $1.34 @ 99 \mathrm{~K}$ & $8.9 @ 99 \mathrm{~K}$ \\
\hline \multirow{2}{*}{$\begin{array}{l}\text { All } \mathrm{K}_{\mathrm{d}}=0 \text { radionuclides } \\
\text { have } 5 \text { times smaller } \\
\text { release rates }\end{array}$} & $10 \mathrm{~K} \mathrm{y}$ & 0.24 & 0.72 \\
\hline & $\max$ & $1.43 @ 99 \mathrm{~K}$ & $9.0 @ 99 \mathrm{~K}$ \\
\hline \multirow{2}{*}{$\begin{array}{l}\text { All radionuclides have } 5 \\
\text { times smaller release } \\
\text { rates }\end{array}$} & $10 \mathrm{~K} \mathrm{Y}$ & 0.22 & 0.66 \\
\hline & $\max$ & $0.23 @ 15 \mathrm{~K}$ & $1.6 @ 72 \mathrm{~K}$ \\
\hline \multirow{2}{*}{$\begin{array}{c}\text { Release rate constant at } 4.4 \\
\mathrm{ppm} / \mathrm{y}\end{array}$} & $10^{\mathrm{K} \mathrm{y}}$ & 1.11 & 3.3 \\
\hline & $\max$ & $1.15 @ 25 \mathrm{~K}$ & $8.4 @ 74 \mathrm{~K}$ \\
\hline
\end{tabular}

4.5.3.4 Mechanistic Approaches to Waste Form Performance. Silicate glass is a leading candidate for the waste form. As described in section 4.5.2, the AREST-CT code was used to estimate the release of contaminants from the waste form and the transport of those contaminants through the vault floor. This section presents the results of the Unit Cell Model following those contaminants through the vadose zone and the unconfined aquifer to the well. Table 4-21 displays the estimated impacts using the calculated glass release rates as a source term. Figure 4-26 shows the estimated beta/photon drinking water dose when sodium ion exchange is included and excluded. 


\section{FINF-EP-0884 \\ Rev. 1}

Table 4-21. Estimated Impacts When Using Calculated Glass Release Rates at a Well 100 Meters Downgradient from a Concept 1 Facility (Unit Cell Model).

\begin{tabular}{|l|c|c|c|}
\hline Case & $\begin{array}{c}\text { Beta/Photon } \\
\text { Drinking } \\
\text { Water Dose } \\
\text { (mrem/y) }\end{array}$ & $\begin{array}{c}\text { Alpha-Emitting } \\
\text { Radionuclide } \\
\text { Concentration } \\
\text { (pci/l) }\end{array}$ & $\begin{array}{c}\text { All- } \\
\text { Pathways } \\
\text { Dose } \\
\text { (mrem/y) }\end{array}$ \\
\hline Base Sensitivity Case & 4.4 & 5.9 & 13.4 \\
\hline $\begin{array}{l}\text { Glass Mechanistic } \\
\text { Model (with sodium } \\
\text { ion exchange) }\end{array}$ & 0.53 & 0.63 & 1.5 \\
\hline $\begin{array}{l}\text { Glass Mechanistic } \\
\text { Model without sodium } \\
\text { ion exchange - Tc } \\
\text { only }\end{array}$ & 0.20 & 0.63 & 0.5 \\
\hline $\begin{array}{l}\text { Glass Mechanistic } \\
\text { Model } \\
\text { high pore velocity } \\
\text { Tc only }\end{array}$ & 0.97 & 0.63 & 3.0 \\
\hline
\end{tabular}

Figure 4-26. Beta/Photon Drinking Water Dose When Using Glass Release as a Source Term for a Well 100 Meters Downgradient of a Concept 1 Facility (Unit Cell Model).

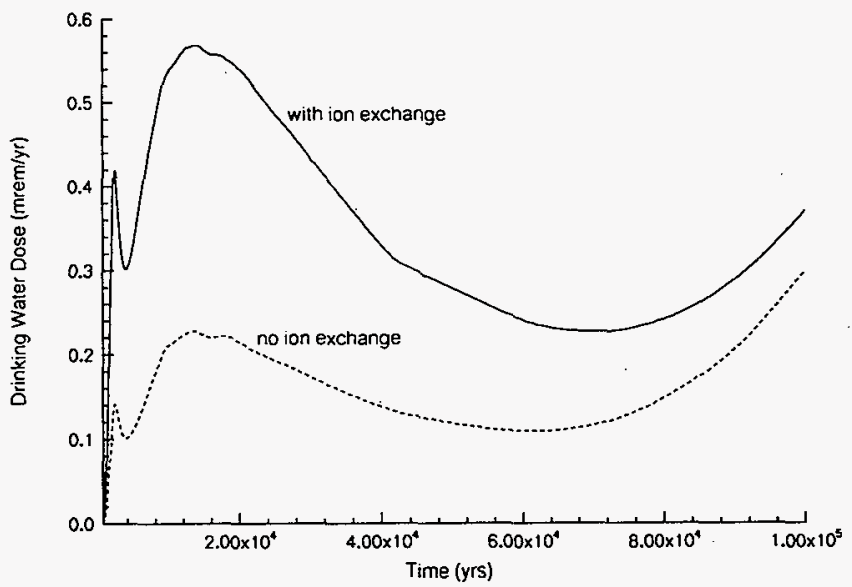


Because the release rate for each element is reduced by about a factor of 8 (Table 4-18), the impacts are reduced by about the same factor. ${ }^{79} \mathrm{Se}$ is a bit more important

(contributing $\sim 30$ percent to the beta/photon drinking water dose in this case as contrasted to $\sim 20$ percent for the base analysis case) when a mechanistic model is used than when all elements have the same release rate, because it has a slightly higher calculated release rate than technetium.

As noted in section 4.5.2, sodium ion exchange has an important effect, significantly increasing the $\mathrm{pH}$ level and hence the glass corrosion rate. If the effect of sodium ion exchange is excluded for the technetium calculations, then the effects are even less. The $\mathrm{pH}$ of the system stays in the 8 and 9 region, resulting in much slower glass dissolution. However, the peak release rate is achieved sooner since without the sodium exchange reaction, less time is needed to reach the peak $\mathrm{pH}$ (and hence peak release rate) level.

For the calculations shown in Table 4-21 and Figure 4-26, only the release rate for technetium is reduced. Thus the estimated impacts are the result of the elements other than technetium (primarily selenium and uranium). If all elements are affected in a manner similar to technetium, then the effects would drop by a factor of about 40 from the base analysis case.

These sets of calculations involve contaminant transport as well as release. However, AREST-CT was only used to model the interior of the vault, so its model is incomplete. As a sensitivity case, the pore velocity (that is, the infiltration rate divided by the porosity) was increased to $10.0 \mathrm{~cm} / \mathrm{y}$ (from $1.0 \mathrm{~cm} / \mathrm{Y})$. The resulting release rate through the floor increases by only a factor of only 2.7 .

\subsection{RESULTS OF GROUNDWATER SCENARIOS - DISPOSAL FACILITY SENSITIVITY CASES}

\subsubsection{Overview}

At present no designs for the disposal facility have been developed. Concepts 1 and 2 are simply preconceptual ideas that reflect possible facility components, shapes, and sizes. For this performance assessment, the effect of vault layout and degradation, as well as other effects were investigated.

\subsubsection{Vault Layout}

4.6.2.1 Overview. Sections 4.6.2.2 through 4.6.2.4 report the results for assuming different layouts of the vaults. Included are increasing the number of rows of Concept 1 , rotating Concept 1 by $90^{\circ}$, and by inserting soil between the vault rows (Concept 2). 
4.6.2.2 Number of vault Rows. The number of canisters that will be produced is uncertain because the vendors have to optimize a number of factors. The number of rows is not expected to be significantly less than the base analysis case, but could be more depending on the choice of sodium loading and waste loading in the glass. Doubling the number of rows results in reducing the aquifer mixing factor (the well/vadose-zone concentration ratio) by $30 \%$ and increasing the area by 2 . Thus the estimated dose and concentrations decrease by. 65 percent.

4.6.2.3 Orientation. Because the shape of Concept 1 is nearly square (208 meters by 246 meters), rotating the facility $90^{\circ}$ has little effect. The calculations show a 2 percent increase in the well/vadose-zone concentration ratio (and impacts). This is because the initial orientation of Concept 1 had the long side nearly perpendicular to the groundwater flow path. A larger effect would be seen if concept 2 were rotated by $90^{\circ}$, because Concept 2 is less square in shape (246 meters by 515 meters).

However, as will be seen in Section 4.8.3.4, irrigation in other parts of the Hanford Central Plateau could change the direction slightly of groundwater flow. Thus, although the orientation of the vaults would affect the estimated doses, the exact effect is difficult to determine. The present orientation results in among the highest estimated impacts.

4.6.2.4. Concept 2. The major difference between the concept 1 and Concept 2 facility design concepts is that in concept 2 the vault rows are separated from each other by soil (Figures 2-20 and 2-21), while in Concept 1 the vault rows shared walls. This difference leads to two major effects and some minor ones. The major effects are in opposite directions, an increased release rate from the facility for concept 2 and a decrease in groundwater concentration because the site area is larger. This section discusses these major effects caused by the differences in Concepts 1 and 2 , the minor effects and the effects produced by the concept 2 vault layout.

In both concepts 1 and 2 , the hydraulic barrier above the waste is predicted to divert most of the water around the disposal facility (Figures 4-6 through 4-9). The moisture content of the filler material is predicted to be the same for either concept 1 or 2, but the two concepts differ in the magnitude of rain shadow beneath the disposal facility. Directly beneath the center of the facility, the moisture content increases from $0.035 \mathrm{~cm}^{3} / \mathrm{cm}^{3}$ in Concept 1 to $0.038 \mathrm{~cm}^{3} / \mathrm{cm}^{3}$ in Concept 2. At the edge of the facility, the increase is from $0.036 \mathrm{~cm}^{3} / \mathrm{cm}^{3}$ (Concept 1) to $0.041 \mathrm{~cm}^{3} / \mathrm{cm}^{3}$ (Concept 2). A similar increase is seen as one progresses down the vadose zone.

Figure 4-27 displays the normalized flux entering the aquifer for the unretarded group of chemicals $\left(K_{d}=0\right)$ for Concepts 1 and 2. Although the normalized fluxes approach the same peak 
Rev. 1

Figure 1-27. Normalized Flux to the Aquifer for $k_{d}=0$ Elements from Concepts 1 and Concept 2. The Effects of Increased Area and a Smallex Aquifer Mixing Factor, However, Result in a Smaller Dose at 10,000 Years from Concept 2. (Full Facility Models)

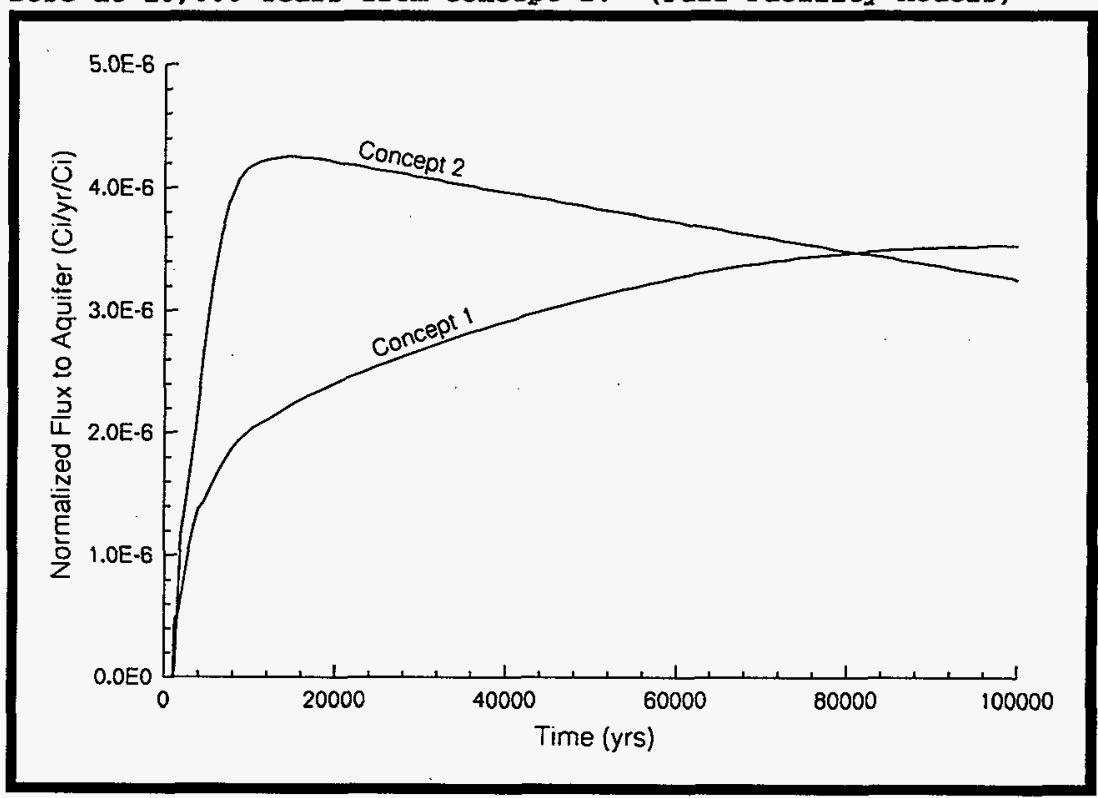

value (the rate at which contaminant is released from the waste form), the contaminants reach the aquifer much more quickly in Concept 2 (the flux reaches half its height in $-3,600$ years in Concept 2 versus $\sim 10,000$ years in concept 1). This faster travel time is caused by the higher hydraulic conductivity in the concept 2 case resulting from the increased moisture content found for that case.

However, the waste is more dispersed in Concept 2 than in concept 1 . Thus the flux entering the aquifer mixes with a larger volume of water. Modeling each row as a separate source, the aquifer mixing factor (or concentration ratio) is reduced to 0.00381 for Concept 2 (versus 0.00531 for Concept 1). This yields a higher mixing factor $(0.00381$ versus 0.00309$)$ than would be indicated by just the increase in area, because the vadose zone fluxes are peaked over each row rather than uniform over the entire area of the disposal facility. Because of lateral spreading in the vadose zone, which is not taken into account using the Unit Cell Model, the actual aquifer mixing factor will be between. 0.00381 and 0.00309 . 


\section{HINE $-\mathrm{EP}-0884$ \\ Rev. 1}

Minor differences in effects caused by Concepts 1 and 2 relate to the effectiveness of the hydraulic barriers. The hydraulic barrier over concept 1 is much longer and has a much shallower slope. The relative performance of such a shallower slope was not investigated separately in these analyses. Concept 1 also has a larger amount of water moving by the side walls. The effect of this on degradation of the barrier or side walls was also not investigated.

Finally, the release rate of the contaminants was assumed to be independent of the moisture, but the corrosion rate of glass (and presumably other waste forms) does depend on the amount of water present. Because the interior of the concept 2 facility is expected to have somewhat more moisture, the contaminant release rate should change.

\subsubsection{Facility Design Options}

4.6.3.1 Overview. Because only a preconceptual idea exists for the facility design, relatively few sensitivity cases were run on vault components. The components examined were the sand-gravel capillary hydraulic barrier above the disposal vault, a similar barrier on the sides of the vault and the type of filler material between the canisters. The effect of other possible components is discussed in Section 4.6 .4 .

4.6.3.2 Hydraulic Diverter. Both the Concept 1 and 2 facilities have a sloping barrier above the disposal vaults and a barrier along the vault rows, the purpose of which is to divert moisture away from the waste form. This diverter, also known as a sandgravel capillary barrier, works on the principal that the overlying sand is forced to become very nearly saturated before the water in the sand will drain into the gravel. Being near saturation (while not being at or above the air entry potential of the gravel), the relatively high unsaturated hydraulic conductivity of the sand layer when combined with its sloping configuration, offers the moisture an easier route downward by allowing it to move laterally until its comes to the edge of the capillary barrier and then downward through the vadose zone profile. The coarse gravel component of the barrier exhibits relatively large open pores which are not wet by the moisture until the overlying sand layer reaches the air entry potential of the gravel.

The Unit cell Model calculations did not model this diverter, so a comparison of the base analysis case (Concept 1) and the Unit Cell Model base sensitivity case for the Unit Cell Model provides an indication of the usefulness of the barrier. The beta/photon drinking water dose for Concept 1 increases by a factor of 2.2 with the alpha-emitting radionuclide concentration increasing a factor of 3.5. See Table 4-22. 
Rev. 1

Table 4-22. Effect of Facility Design Options on Estimated Impacts at 10,000 Years

\begin{tabular}{|c|c|c|c|}
\hline $\begin{array}{l}\text { Disposal Facility } \\
\text { Feature }\end{array}$ & $\begin{array}{l}\text { Beta/photon } \\
\text { Drinking } \\
\text { Water Dose } \\
\text { (mrem/y) }\end{array}$ & $\begin{array}{l}\text { Alpha-emitting } \\
\text { Radionuclide } \\
\text { Concentration } \\
(\mathrm{pCi} / \ell)\end{array}$ & $\begin{array}{c}\text { All-Pathways } \\
\text { Dose } \\
\text { (mrem/y) }\end{array}$ \\
\hline \multicolumn{4}{|c|}{ Concept 1 Geometry } \\
\hline $\begin{array}{l}\text { Full Facility } \\
\text { Model with } \\
\text { hydraulic barrier } \\
\text { (Base Analysis } \\
\text { Case) }\end{array}$ & 2.0 & 1.7 & 6.4 \\
\hline $\begin{array}{l}\text { Unit cell Model } \\
\text { which has no } \\
\text { hydraulic barrier }\end{array}$ & 4.4 & 5.9 & 13.4 \\
\hline $\begin{array}{l}\text { Unit Cell Model. } \\
\text { Material between } \\
\text { canisters is sand }\end{array}$ & 4.4 & 5.6 & 13.3 \\
\hline \multicolumn{4}{|c|}{ Concept 2 Geometry } \\
\hline $\begin{array}{l}\text { Full Facility } \\
\text { Model with } \\
\text { hydraulic barrier }\end{array}$ & 1.11 & 0.27 & 3.3 \\
\hline $\begin{array}{l}\text { Unit Cell Model } \\
\text { which has no } \\
\text { hydraulic barrier }\end{array}$ & 1.23 & 1.66 & 3.8 \\
\hline $\begin{array}{l}\text { Full Facility } \\
\text { Model but without } \\
\text { side gravel walls }\end{array}$ & 1.16 & 0.72 & 3.5 \\
\hline
\end{tabular}

The cause for this increase is that, when no diverter is present over the vault area, the sediments immediately below the vault area are more moist (Figure 4-28.). Hence the contaminants are more easily flushed from the vault zone and the vadose zone when there is no hydraulic diverter. This is reflected in the travel times which are much faster in the Unit Cell Model $(\sim 1,300$ years for the unretarded group) than in the concept 1 Full

Facility Model $(-10,000$ years $)$.

For concept 2, the effect of the hydraulic diverter is small for the beta/photon drinking dose (the effect being about 10 percent). However, the effect of the diverter on the concentration of alpha-emitting radionuclides becomes larger (increasing to a factor of 6.1). The beta/photon dose does not significantly increase because the unretarded group for concept 2 is already near its maximum value, the travel time being about 
Rev. 1

Figure 4-28. Moisture Values of Unit Cell Model for steady state. The moisture content is given as saturation which is volumetric moisture content divided by the porosity of the material. The display on the right shows the top 15 meters.

\section{Unit Cell Model}

Steady State Saturation Distribution

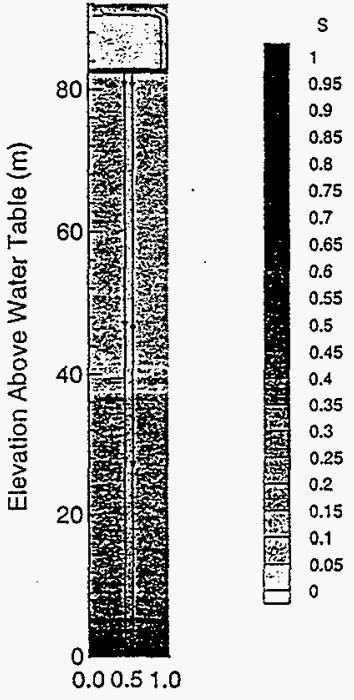

Distance from Center of Canister $(m)$

\section{Unit Cell Model}

Steady State Saturation Distribution

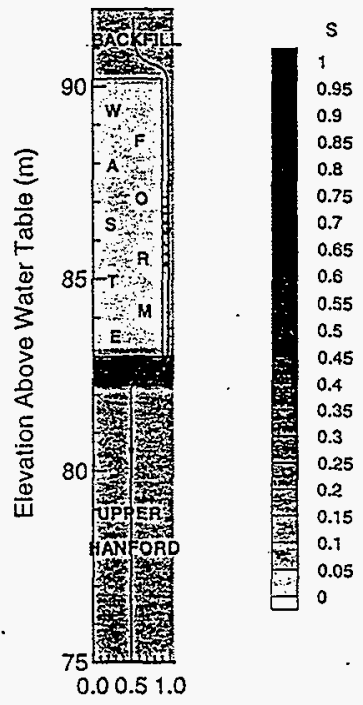

Distance from Center of Canister $(\mathrm{m})$

3,500 years. However, the effect of speeding the uranium group is significant (travel time for Concept 2 Full Facility Model is about 20,000 years, for the unit Cell Model about 10,000 years).

The changes in the alpha-emitting radionuclide concentration are greater than the changes in the beta/photon drinking water cose when there is no hydraulic diverter. The flux of the unretarded group (selenium and technetium) is nearly at its maximum value even with a hydraulic barrier. However, with a hydraulic diverter the $k_{a}=0.6 \mathrm{~m} / \mathrm{g}$ group (uranium) the flux is far below its maximum value. Thus for a design without a hydrauiic diverter for which the flux of both groups reach their maximum value, the effect is larger for the uranium group and hence for the impact concerning alpha-emitters. 


\section{FANE-EP-0884 \\ Rev. 1}

4.6.3.3 Side Hydraulic Diverter. Calculations were performed with a hydraulic diverter on top but not on the sides. The presence of the side hydraulic diverter for concept 2 has about a 5 percent effect on performance for the beta/photon drinking water dose and about a 50 percent effect for the alpha-emitting radionuclide concentration. The cause of the performance change is the same for the top hydraulic barrier, but the effect is less because the moisture has to move horizontally rather than downward.

The effect of a side hydraulic diverter was not calculated for Concept 1 . However, because of its extended lateral dimensions, the effect of such a side hydraulic diverter should not be significant.

4.6.3.4 Filler Material. The base analysis case uses the hydraulic properties for the filler material between the canisters in the vaults. If hydraulic properties of sand are used instead, the effects do not change significantly. The travel times are 2 percent longer causing some decrease in the alpha-emitting radionuclide concentration.

\subsubsection{Degradation}

Relatively little analysis has been performed on degradation of the disposal facility because of the conceptual nature of the facility design and because much of the facility is presumed to be made of natural materials. However, the effect of the concrete floor remaining intact, trapping water, and then failing has been investigated. The effect of having the hydraulic barrier above the waste fail in one location was also investigated.

The effect of trapping water in concrete for 2,000 years, then having the floor fail releasing the water was investigated for both Concepts 1 and 2 . There was less than a 3 percent difference in the normalized flux at the aquifer for the different $K_{\alpha}$ groups studied, with most groups having differences less than 1 percent. Hence little difference $(<1$ percent) showed up in the estimated impacts.

A failure in the hydraulic barrier was postulated in the Concept 2 design about two-thirds of the way down the barrier. Again there is relatively little differences in the normalized flux $(<5$ percent) at the aquifer and in the dose.

Some additional simulations were made as part of an earlier study (Mann 1995d) to determine the sensitivity of design choices. According to these calculations, the barrier still diverted water as long as the sand formed a continuous path and did not for some reason subside completely into the gravel. 
Rev. I

\subsection{RESULTS FOR GROUNDWATER SCENARIOS - TRANSPORT SENSITIVITY CASES}

\subsubsection{Overview}

A number of sensitivity cases were run to determine the effect of using different values for the hydraulic parameters, the geochemical parameters, and the infiltration rate. Each of these parameters affect the rate at which the contaminants enter the unconfined aquifer.

\subsubsection{Hydraulic Parameters}

4.7.2.1 Overview. Hydraulic parameters are important in two distinct areas of the model: the disposal facility and the vadose zone.

4.7.2.2 Disposal Facility Hydraulic Properties. As noted, the disposal facility has not yet been designed. Sensitivity cases were run for the hydraulic and diffusion properties of the filler material between the canisters.

As noted in section 4.6.3.4, a sensitivity run substituted the hydraulic properties of sand for back-filled soil. No significant change to the estimated impacts was noted.

The present philosophy concerning the design of the disposal facility is to keep the waste form and surrounding filler material as dry as possible to minimize waste form corrosion and transport of the released materials. In such a low-moisture facility, the transport of contaminants may be dominated more by diffusion (movement of contaminants in water) than by advection (movement of contaminations with water flow).

The simulations of Concepts 1 and 2 in the base analysis case used the Scheidegger diffusion model (see Section 3.5.3.2). As discussed in that section, the effective diffusion term could be lower. A sensitivity case with an effective value 20 times lower results in a much lower calculation of contaminant flux and, hence, dose. Figure 4-29 displays the normalized unretarded contaminant flux to the aquifer as a function of time for the two diffusion cases for Concept 1. Table 4-23 shows the estimated beta/photon drinking water dose for the two diffusion cases for both Concept 1 and 2 . The relative change for other estimated impacts is similar. Concept 2 shows a much smaller effect because the path out of the facility is shorter in Concept 2 and because filler material is more moist and hence more advection occurs in Concept 2 . 
Figure 4-29. Estimated Unretarded Contaminant Flux to Aguifer for Concept 1 for Different Diffusion Coefficients (Full Facility Model).

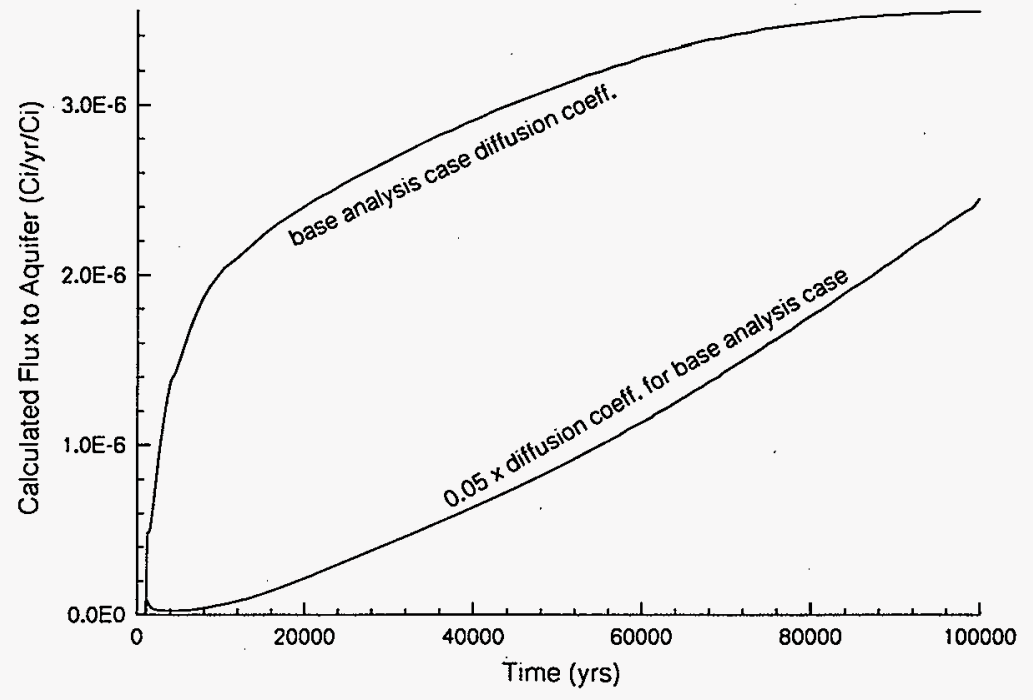

Table 4-23. Estimated Beta/Photon Drinking Water Dose at 10,000 years at a Well 100 Meters Downgradient for Different Diffusion Coefficients.

\begin{tabular}{||l|l|c||}
\hline \multirow{2}{*}{ Concept } & Diffusion Coefficient & $\begin{array}{r}\text { Beta/Photon Dose at } \\
10,000 \text { Years (mrem/y) }\end{array}$ \\
\hline \multirow{2}{*}{1} & Base Analysis Case & 1.97 \\
\cline { 2 - 4 } 2 & $0.05 *$ Base Analysis Case & 0.06 \\
\hline \multirow{2}{*}{2} & Base Analysis Case & 1.11 \\
\cline { 2 - 4 } & $0.05 *$ Base Analysis Case & 0.20 \\
\hline
\end{tabular}

4.7.2.3 Vadose zone Hydraulic Properties. The effects on dose rates of both vadose zone hydraulic properties (moisture retention and unsaturated conductivity relationships) and dispersion coefficients were investigated in the sensitivity studies. 


\section{FINF-EP-0884 \\ Rev. 1}

Because the hydraulic properties are so strongly correlated with stratigraphy, changing the positions of the strata in the vadose zone model changed the hydraulic properties of the simulation. The base analysis case assumed that the first 6 meters were from the upper gravel sequence, the next 60 meters were from the sandy sequence, and the bottom 35 meters were from the lower gravel sequence. The results of using different strata (and, hence, different moisture retention and conductivity curves) are show in Table 4-24. Figure 4-30 shows the normalized unretarded contaminant flux entering the unconfined aquifer.

Table 4-24. Estimated Impact at 10,000 Years Assuming Different strata (and hence Hydraulic Properties).

\begin{tabular}{|c|c|c|c|}
\hline strata & $\begin{array}{c}\text { Beta/Photon } \\
\text { Drinking } \\
\text { water Dose } \\
\text { (mrem/y) }\end{array}$ & $\begin{array}{c}\text { Alpha-Emitting } \\
\text { Radionuclide } \\
\text { Concentration } \\
\text { (pci/l) } \\
\end{array}$ & $\begin{array}{c}\text { All- } \\
\text { Pathways } \\
\text { Dose } \\
\text { (mrem/y) }\end{array}$ \\
\hline $\begin{array}{l}\text { Base Analysis case } \\
\text { Vadose zone = } \\
6 \mathrm{~m} \text { gravel sequence } \\
60 \mathrm{~m} \text { sandy sequence } \\
35 \mathrm{~m} \text { gravel sequence }\end{array}$ & 2.0 & 1.7 & 6.4 \\
\hline $\begin{array}{c}\text { Unit Cell Model (no } \\
\text { hydraulic barrier) } \\
\text { Vadose zone = same as } \\
\text { base analysis case }\end{array}$ & 4.4 & 5.9 & 13.4 \\
\hline $\begin{array}{l}\text { Unit Cell Model } \\
\text { Vadose zone = } \\
101 \mathrm{~m} \text { sandy sequence }\end{array}$ & 4.6 & 9.9 & 18.8 \\
\hline $\begin{array}{l}\text { Unit cell Model } \\
\text { Vadose zone= } \\
6 \mathrm{~m} \text { gravel sequence } \\
45 \mathrm{~m} \text { sandy sequence } \\
50 \mathrm{~m} \text { gravel sequence }\end{array}$ & 4.1 & 4.2 & 12.5 \\
\hline
\end{tabular}

If the hydraulic parameters of the sandy sequence are used throughout the vadose zone, then the bottom 35 meters are a bit less moist and the contaminants travel faster $(\sim 2,500$ years versus $\sim 5,000$ years for the unretarded group, and $\sim 5,400$ years versus $-9,100$ years for the uranium group). This does not result in much of a change in the beta/photon drinking water dose since selenium and technetium are on the plateau of the flux curve. However, the changes place the uranium isotopes also on the plateau of the flux curve, resulting in a 50 percent increase in the estimated alpha-emitting radionuclide concentration. Note, however, that the travel times for the uranium group for concept 1 ( 100,000 years) and for concept $2(\sim 20,000$ years) are much 


\section{HNF-EP-0 0884}

Rev. 1

longer than for the Unit Cell Model. A full facility model simulation would show less of a change in alpha-emitting radionuclide concentration (or the all-pathway dose) than the unit cell model simulation. Using the full facility simulation, the steepest part of the contaminant curve would not happen beyond 10,000 years. Even with a 50 percent increase predicted by the Unit Cell Model, the results for neither Concept 1 nor 2 would exceed the performance objectives.

The second sensitivity case increased the thickness of the lower gravel sequence at the expense of the sandy sequence. The predicted impacts declined ( 20 percent for alpha-emitting radionuclide concentration), but not significantly. The reason for the asymmetry is that, in the Unit Cell Model, the unretarded group still reaches the unconfined aquifer before 10,000 years for both the Unit Cell Model base sensitivity case and for the increased-gravel-layer case, and in neither case is the impact of the uranium group dominant.

Figure 4-30. Normalized Unretarded Contaminant Flux Entering the Unconfined Aquifer for Three Different Sets of Hydraulic Properties in the vadose zone (Unit Cell Model).

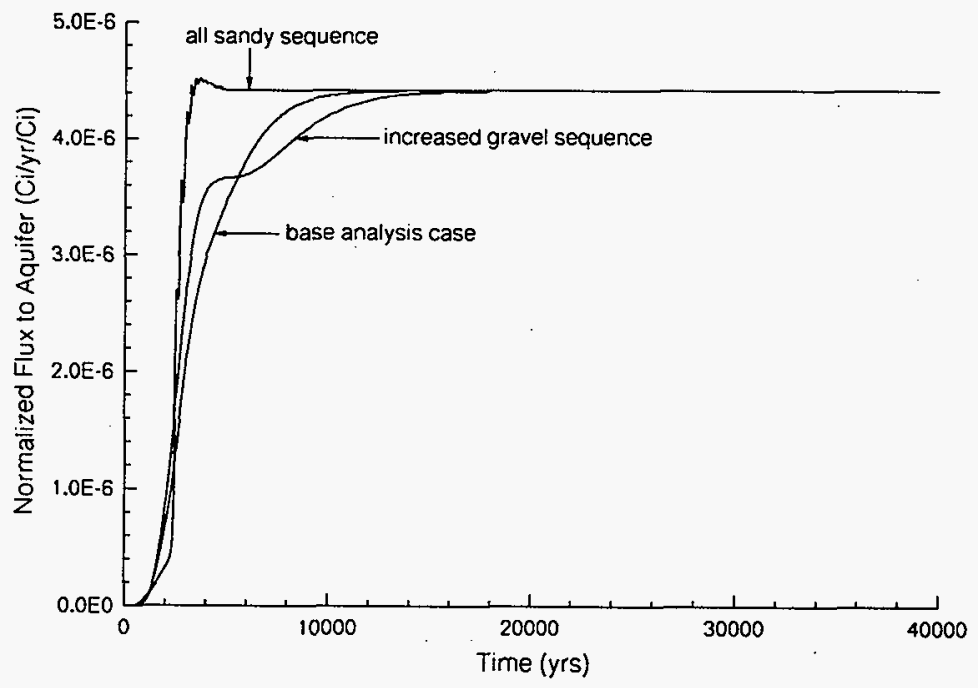


The position of the water table also affects the amount of uranium $\left(\mathrm{K}_{d}=0.6 \mathrm{~m} / \mathrm{g}\right)$ flux reaching the aquifer at 10,000 years as seen in Table 4-25. The flux of the unretarded group (selenium and technetium) is near its maximum and does not change. However, with the travel time estimated by the Unit cell Model being close to 10,000 years, changes in the water table position do matter. As noted, however, if a full facility model is used, the sensitivity disappears because the travel time is significantly longer than 10,000 years.

Table 4-25. Normalized Contaminant Flux Reaching the Unconfined Aquifer at 10,000 years as a Function of Water Table Position.

\begin{tabular}{||c|c|c|c|c||}
\hline \multirow{2}{*}{$\begin{array}{l}\text { Depth to Water } \\
\text { Table (m) }\end{array}$} & \multicolumn{2}{|c|}{$\mathrm{K}_{0}=0$} & \multicolumn{2}{|c|}{$\mathrm{K}_{a}=0.6 \mathrm{ml} / \mathrm{g}$} \\
\cline { 2 - 5 } & $\begin{array}{c}\text { Flux at } \\
10,000 \mathrm{Y} \\
(1 / \mathrm{y})\end{array}$ & $\begin{array}{c}\text { Travel } \\
\text { Time } \\
(\mathrm{y})\end{array}$ & $\begin{array}{c}\text { Flux at } \\
10,000 \mathrm{Y} \\
(1 / \mathrm{y})\end{array}$ & $\begin{array}{c}\text { Travel } \\
\text { Time } \\
(\mathrm{y})\end{array}$ \\
\hline 96 & $4.38 \mathrm{e}-6$ & 2,600 & $3.42 \mathrm{e}-6$ & 7,500 \\
\hline 101 & $4.37 \mathrm{e}-6$ & 3,000 & $2.65 \mathrm{e}-6$ & 9,100 \\
\hline 110 & $4.29 \mathrm{e}-6$ & 3,300 & $1.99 \mathrm{e}-6$ & 10,600 \\
\hline
\end{tabular}

The dispersion coefficient describes the spreading of the contaminants as they move with the flow. Sensitivity cases were run for the full facility model for concept 2 with twice the value for the dispersion coefficient used in the base analysis case and with one-half of the value used in the base analysis case. The difference in the calculated unretarded $\left(k_{d}=0\right)$ flux in both magnitude and time of arrival is only a few percent. However, for the uranium group $\left(\mathrm{K}_{a}=0.6 \mathrm{ml} / \mathrm{g}\right)$, the fluxes change by 25 percent at 10,000 years, reflecting the wider spreading with higher dispersion values. As expected, the calculations show that the center of the contaminant flux and the peak value are unaffected. Thus, changing the dispersion coefficient results in very little change in either the beta/photon dose or al1-pathways dose at 10,000 years or for peak doses, but there is a larger percentage change ( 10 percent) for the alpha-emitting radionuclide concentration at 10,000 years. A similar effect is seen for the Unit Cell Model as shown in Table 4-26. The travel time does not change much, but the slope of the curve changes significantly, becoming much more sharp as the dispersion coefficient is lowered. 


\section{FINE - EP -0884 \\ Rev. 1}

Table 4-26. Effect of Dispexsion on $k_{a}=0.6 \mathrm{ml} / \mathrm{g}$ Normalized Contaminant Fluxes to the Aquifer, Unit Cell Model.

\begin{tabular}{||c|c|c|c|}
\hline $\begin{array}{c}\text { Dispersion } \\
\text { Coefficient }\end{array}$ & $\begin{array}{c}\text { Flux value at } \\
10,000 \text { years } \\
\left(y^{-1}\right)\end{array}$ & $\begin{array}{c}\text { Time When } \\
0.5 * \text { Peak } \\
\text { Value Occurs } \\
(y)\end{array}$ & $\begin{array}{c}\text { Time When } \\
10^{-6} \text { Peak } \\
\text { Value Occurs } \\
(y)\end{array}$ \\
\hline $\begin{array}{c}0.1 \text { * Base } \\
\text { Analysis Case }\end{array}$ & $2.54 \times 10^{-6}$ & 9,600 & 4,000 \\
\hline $\begin{array}{c}0.5 * \text { Base } \\
\text { Analysis Case }\end{array}$ & $2.51 \times 10^{-6}$ & 9,400 & 2,800 \\
\hline $\begin{array}{c}\text { Base Analysis Case } \\
2.0 * \text { Base } \\
\text { Analysis Case }\end{array}$ & $2.65 \times 10^{-6}$ & 9,100 & 1,500 \\
\hline
\end{tabular}

\subsubsection{Geochemical}

Retardation of contaminant transport greatly limits the number of isotopes that are important in the groundwater scenario. The cases described in this section investigate the sensitivity of the calculations to the geochemical parameters. Table 4-27 summarizes the effects on the beta/photon dose, the alpha-emitting radionuclide concentration, and the all-pathways dose at 10,000 years at a well 100 meters downgradient.

Previous Hanford Site performance assessments (Wood 1994b, Kincaid 1995, wood 1995, and wood 1996) have assumed a conservative value for the uranium $\mathrm{K}_{\mathrm{a}}$ of 0 . Using such a value greatly increases the movement of uranium and its daughters. Thus, the alpha-emitting radionuclide concentration at 10,000 years increases significantly (by a factor of 2 for concept 1 and by a factor of 3 for concept 2). The beta/photon dose increases by 10 percent because of the presence of beta emitters in the decay chain. However, the estimated results are still below the performance objectives.

Uranium is known to strongly absorb in concrete, having a chemical distribution coefficient $\left(\mathrm{K}_{\mathrm{d}}\right)$ value of $100 \mathrm{ml} / \mathrm{g}$. Using this value in the floor of the Unit Cell Model increases the travel time for the uranium group by a factor of 4 (from 9,100 years to 39,000 years) and reduces the alpha-emitting radionuclide concentration at 10,000 years by a factor of 3 from the case of assuming the $K_{d}$ of uranium is 0 and a factor of 2 from the case of assuming the value is $0.6 \mathrm{ml} / \mathrm{g}$.

The base analysis case assumes that selenium and technetium move through the vadose zone without retardation. Major experiments on Hanford site soils support this conclusion. However, to determine the sensitivity to the value of $\mathrm{K}_{\mathrm{d}}$ chosen, 
Rev. 1

a sensitivity case with a slightly higher value $(0.1 \mathrm{ml} / \mathrm{g})$ was evaluated. Only a 15 percent decrease was noted at 10,000 years in the beta/photon arinking water and the all-pathways dose.

If a material could be found that would chemical trap technetium (and selenium), then the performance of the disposal facility would be significantly improved. Assuming that the $k_{d}$ for technetium was $100 \mathrm{ml} / \mathrm{g}$ in the floor results in a 60 percent reduction in the beta/photon dose at 10,000 years. If both selenium and technetium could be trapped, then the dose falls by 75 percent. It should be emphasized that such a material has not yet been found.

Table 4-27. Effect of Geochemical Parameters on Impacts at a Well 100 Meters Downgradient at 10,000 Years.

\begin{tabular}{|c|c|c|c|}
\hline Geochemical Effect & $\begin{array}{c}\text { Beta/Photon } \\
\text { Dose } \\
\text { (mrem/y) }\end{array}$ & $\begin{array}{c}\text { Alpha-Emitting } \\
\text { Radionuclide } \\
\text { Concentration } \\
\text { (pCi/l) }\end{array}$ & $\begin{array}{l}\text { All- } \\
\text { Pathways } \\
\text { Dose } \\
\text { (mrem/y) }\end{array}$ \\
\hline \multicolumn{4}{|c|}{ Concept 1 - Full Facility Model } \\
\hline Base Analysis Case & 1.97 & 1.65 & 6.4 \\
\hline $\mathrm{K}_{d}$ for Uranium $=0$ & 2.1 & 4.6 & 7.1 \\
\hline $\begin{array}{l}\mathrm{K}_{\mathrm{d}} \text { for } \mathrm{se} \text { and } \mathrm{Tc}= \\
0.1 \mathrm{m \ell} / \mathrm{g}\end{array}$ & 1.66 & 1.65 & 5.5 \\
\hline \multicolumn{4}{|c|}{ Concept 2 - Full Facility Model } \\
\hline Base Sensitivity Case & 1.11 & 0.27 & 3.3 \\
\hline $\mathrm{K}_{\theta}$ for uranium $=0$ & 1.23 & 2.6 & 3.8 \\
\hline $\begin{array}{l}\mathrm{K}_{\mathrm{d}} \text { for } \mathrm{se} \text { and } \mathrm{TC}= \\
0.1 \mathrm{~m} \ell / \mathrm{g}\end{array}$ & 0.94 & 0.27 & 2.8 \\
\hline \multicolumn{4}{|c|}{ Unit Cell Model - Concept 1 Geometry } \\
\hline Base Sensitivity Case & 4.4 & 5.9 & 13.4 \\
\hline $\mathrm{K}_{\alpha}$ for uranium $=0$ & 4.6 & 9.7 & 14.3 \\
\hline $\begin{array}{l}\mathrm{K}_{\mathrm{d}} \text { for uranium } \\
\text { concrete }=100 \mathrm{ml} / \mathrm{g} \\
\text { vadose zone }=0\end{array}$ & 4.2 & 1.6 & 12.6 \\
\hline $\begin{array}{l}\mathrm{K}_{\mathrm{a}} \text { for technetium } \\
\text { concrete }=100 \mathrm{ml} / \mathrm{g} \\
\text { vadose zone }=0\end{array}$ & 1.72 & 6.3 & 3.4 \\
\hline $\begin{array}{l}\mathrm{K}_{d} \text { for } \mathrm{Se} \text { and } \mathrm{Tc} \\
\text { concrete }=100 \mathrm{ml} / \mathrm{g} \\
\text { vadose zone }=0\end{array}$ & 0.98 & 6.3 & 4.7 \\
\hline
\end{tabular}




\subsubsection{Infiltration Rate}

4.7.4.1 Overview. In most performance assessments, the infiltration has a large effect in either increasing (for higher infiltration rates) or decreasing (for lower infiltration rates) the impact relative to the base analysis case. For this performance assessment where the release time is long, the sensitivity to infiltration rate is more one sided. For the base analysis case, the flux entering the unconfined aquifer is very near its maximum (that is, the flux is rising but very near the top of the plateau). Increasing the infiltration rate from the base analysis case moves the start of the plateau to early times and hence raises the value. However, since the value for the base analysis case is already near the value at the top of the plateau, the value due higher infiltration rates is not significantly greater. However, decreasing the infiltration rate moves the start of the plateau to much later times, thus causing the 10,000 year point to be significantly lower on the impacts curve. Thus lower infiltration rates can greatly reduce the impacts at 10,000 years. However, the peak impact (at the top of the plateau) remains the same.

An important assumption of this analysis is that the contaminant release rate is independent of the moisture flux through the facility. As noted in section 4.5.2, mechanistic simulations of contaminant release show an increase in release in release as the infiltration is increased. Moreover, since water is needed to corrode glass, at very low infiltration rates the glass dissolution rate may also be affected. This effects will be studied in future assessments as the waste form and facility design are determined.

4.7.4.2 Low Infiltration Rates. The base analysis case assumed that the infiltration rate would be $1 \mathrm{~mm} / \mathrm{y}$ for the first 1,000 years. The surface barrier is assumed to instantaneously degrade, resulting in a natural recharge rate of $3 \mathrm{~mm} / \mathrm{y}$ thereafter. A series of sensitivity cases investigated the result of other low infiltration rates. Table 4-28 presents a summary. Figure 4-31 shows the normalized contaminant flux at the unconfined aquifer as a function of time for various infiltration rates. Figure 4-32 shows the fluxes for the uranium group.

Assuming a steady state infiltration rate of $3 \mathrm{~mm} / \mathrm{y}$ raised the impacts slightly. The calculated travel times for the unretarded group decreased to $\sim 2,400$ years from the Unit cell Model base sensitivity case of $\sim 3,000$ years (Concept 1 being $\sim 10,000$ years and concept $2 \sim 4,000$ years). The travel time for the uranium group $\left(K_{\mathrm{d}}=0.6 \mathrm{ml} / \mathrm{g}\right)$ also decreases to 8,600 years from 9,100 years. Thus both the unretarded contaminants and the next group of contaminants are on the plateau and not much change is seen when at 10,000 years using the Unit cell Model for a surface barrier with a 1,000-year life. 
Rev. 1

Table 4-28. Effect of Infiltration Rates on Estimated Impacts at 10,000 Years for a Well 100 Meters Dowagradient from the Facility.

\begin{tabular}{|c|c|c|c|}
\hline Recharge case & $\begin{array}{c}\text { Beta/Photon } \\
\text { Drinking } \\
\text { Water Dose } \\
\text { (mrem/y) }\end{array}$ & $\begin{array}{c}\text { Alpha-Emitting } \\
\text { Radionuclide } \\
\text { Concentration } \\
\text { (pCi/l) }\end{array}$ & $\begin{array}{c}\text { Al1-Pathways } \\
\text { Dose } \\
\text { (mrem/y) }\end{array}$ \\
\hline \multicolumn{4}{|c|}{ Concept 1 Geometry - Unit Cell Model } \\
\hline $\begin{array}{l}0.5 \mathrm{~mm} / \mathrm{y} \text { for } 1000 \\
\text { years, } 3 . \mathrm{mm} / \mathrm{y} \\
\text { thereafter }\end{array}$ & 4.4 & 5.9 & .13 .4 \\
\hline $100 \mathrm{~mm} / \mathrm{y}$ (steady) & 5.0 & 31. & 194.0 \\
\hline $3.0 \mathrm{~mm} / \mathrm{y}$ (steady) & 4.4 & 5.9 & 13.4 \\
\hline $1.0 \mathrm{~mm} / \mathrm{y}$ (steady) & 3.5 & 0.19 & 10.3 \\
\hline $0.1 \mathrm{~mm} / \mathrm{y}$ (steady) & $<0.001$ & $<0.001$ & 0.001 \\
\hline \multicolumn{4}{|c|}{ Concept 2 - Full Facility Model } \\
\hline $\begin{array}{l}0.5 \mathrm{~mm} / \mathrm{y} \text { for } 1000 \\
\text { years, } 3 . \mathrm{mm} / \mathrm{y} \\
\text { thereafter }\end{array}$ & 1.11 & 0.27 & 3.3 \\
\hline $1.00 \mathrm{~mm} / \mathrm{y}$ & 1.37 & 2.0 & 3.2 \\
\hline
\end{tabular}

Figure 4-31. Normalized Contaminant Fluxes at the Unconfined Aguifer for Unretarded Contaminants for Various Infiltration Rates. (Unit Cell Model). Note that the curves approach the 4.4 ppm/year release rate from the waste form.

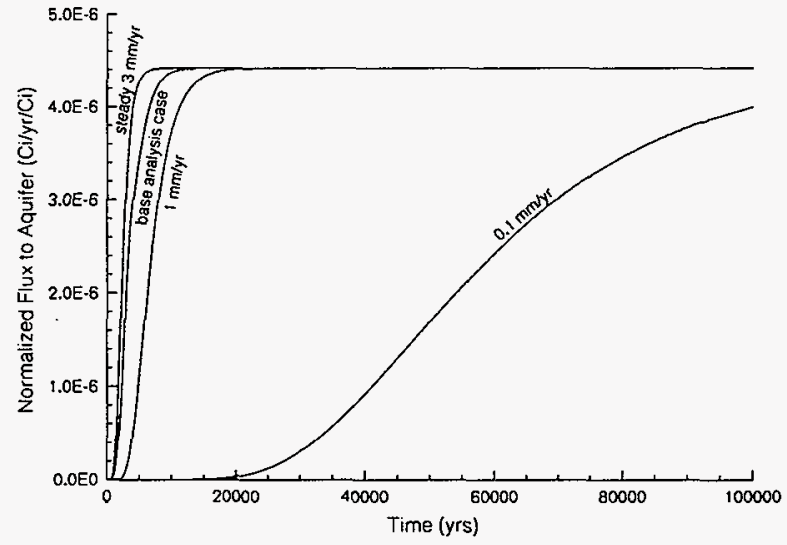


Rev. 1

Figure 4-32. Normalized Contaminant Fluxes at the Unconfined Aquifer for $k_{a}=0.6 \mathrm{ml} / \mathrm{g}$ Contaminants for Various Infiltration Rates. (Unit Cell Model)

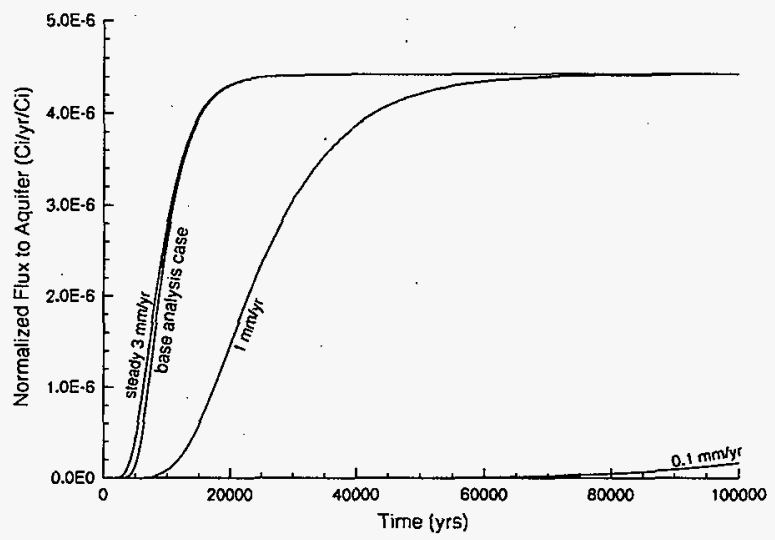

If the surface barrier has a much longer life, then the infiltration rate does not exceed $1 \mathrm{~mm} / \mathrm{y}$. The estimated beta/photon drinking water dose using the Unit Cell Model at 10,000 years decreases by 20 percent while the alpha-emitting radionuclide concentration declines by a factor of 4 . The beta/photon dose does not decline by much because the travel time for unretarded elements like selenium and technetium $(\sim 6,500$ years) is still small compared to 10,000 years. However, the travel time for the uranium group increases to $\sim 24,000$ years, yielding a significant decrease. If a hydraulic break is present (that is, using the results for concept 1 or 2 ), then the unretarded groups would also show significant decreases. The travel times for unretarded elements for a constant $1-\mathrm{mm} /$ year infiltration rate would increase to $-30,000$ years for concept 1 and $-11,000$ years for Concept 2 .

If the infiltration rate is even less $(0.1 \mathrm{~mm} / \mathrm{y})$, then the travel times become so long $\left(-25,000\right.$ years for $K_{d}=0$ and over 100,000 years for $\mathrm{K}_{\mathrm{d}}=0.6 \mathrm{ml} / \mathrm{g}$ ) that at 10,000 years no significant impacts are seen.

4.7.4.3 High Infiltration Rates. If the infiltration rate should increase, the contaminants move much more quickly to the aquifer. Figure $4-33$ shows the calculated normalized contaminant fluxes to the aquifer for the concept 2 base sensitivity case and for the case of $100 \mathrm{~mm} / \mathrm{y}$ infiltration rate. The peak value is somewhat higher $\left(4.8 \times 10^{-6} \mathrm{y}^{-1}\right.$ for the case of $100 \mathrm{~mm} / \mathrm{y}$ versus $4.2 \times 10^{-6} y^{-1}$ for the base analysis case) because the release 
Figure 4-33. Normalized Unretarded Contaminant Fluxes at the Unconfined Aquifer Using the Concept 2 Geometry For Infiltration Rates of 3 and $100 \mathrm{~mm} / y$. (Unit Cell Model)

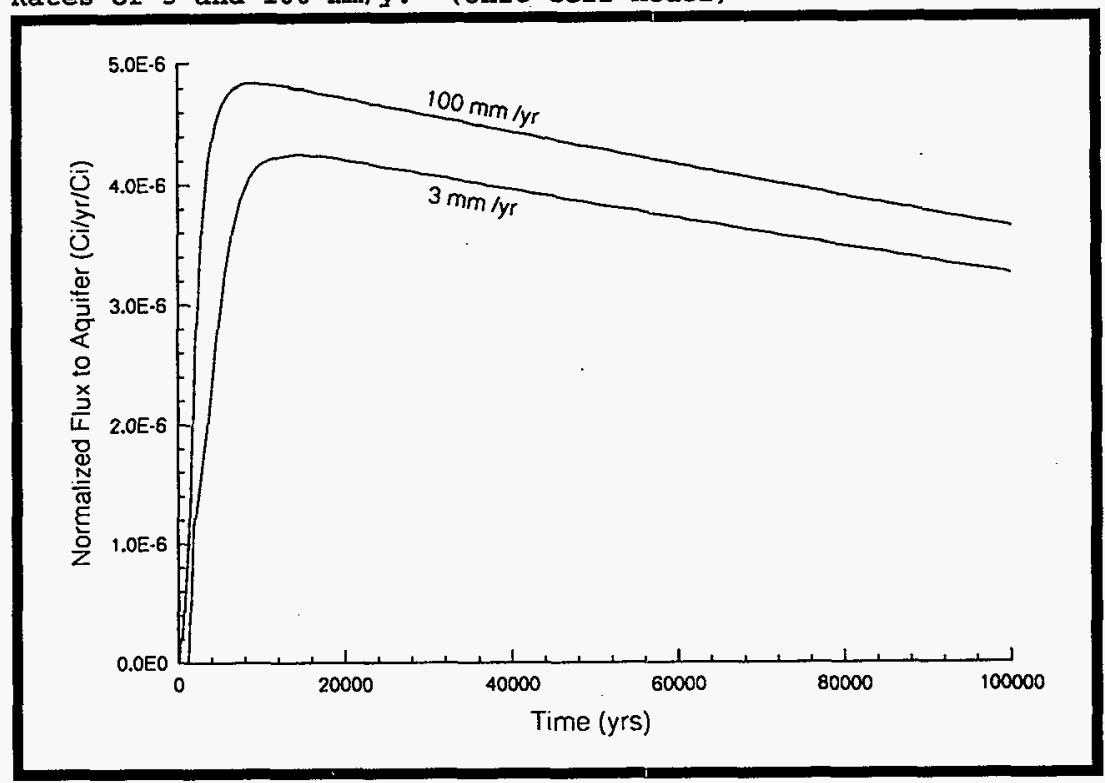

rate is higher at shorter times. However, because the contaminant flux is limited by the release rate from the waste form, the major effect of the high recharge rate is that the contaminants reach the aquifer sooner. The timing of the arrival is such that it is still long compared to the half-Iives of ${ }^{137} \mathrm{Cs}$ and ${ }^{90} \mathrm{Sr}$, so these nuclides still do not contribute to the dose. However, at 10,000 years the contaminant flux for the uranium group $\left(\mathrm{K}_{\mathrm{d}}=0.6 \mathrm{ml} / \mathrm{g}\right)$ is nearer its peak, so the relative contribution by uranium isotopes and their daughters to the allpathways dose is higher than for the base analysis case.

Table 4-28 presents the impacts. The estimated beta/photon drinking water dose at 10,000 years does. increase, but only by about 20 percent. More importantly, the peak moves to 9,300 years. The alpha-emitting radionuclide concentration for the high infiltration case increases significantly from $0.92 \mathrm{pCi} / \mathrm{l}$ to $2.7 \mathrm{pCi} / \mathrm{l}$, which is still well below the performance objective of $15 \mathrm{pci} / \mathrm{l}$. Such a large increase is caused by the uranium isotopes arriving at the well inside of 10,000 years. The magnitude of the increase in the al1-pathways peak is similar to that of the beta/photon drinking water dose. 


\section{FNNF-EP-0884 \\ Rev. 1}

The importance of the hydraulic diverter is seen when comparing the Unit Cell Model results (no diverter) to the Concept 2 case). Without a diverter and with a $100-\mathrm{mm} / \mathrm{y}$ infiltration rate, the alpha-emitting radionuclide concentration and al1-pathways dose increase by factors of 30 and 40 respectively. The reason is that the soil beneath the disposal facility stays relatively dry (moisture content $=0.041 \mathrm{~cm}^{3} / \mathrm{cm}^{3}$ ) even for an infiltration rate of $100 \mathrm{~mm} / \mathrm{y}$ with a hydraulic diverter while it becomes almost saturated (43 percent saturation, implying a moisture content of $0.15 \mathrm{~cm}^{3} / \mathrm{cm}^{3}$ ) without a diverter.

\subsection{RESULTS OF GROUNDWATER SCENARIOS - OTHER SENSITIVITY CASES}

\subsubsection{Overview}

This section describes the sensitivity to the amount of radionuclides in the waste (inventory), to the land use assumed, to the library of dosimetry parameters chosen, to the location of the facility, and to various calculational assumptions.

\subsubsection{Inventory}

As noted in section 4.3.4, ${ }^{99} \mathrm{TC},{ }^{79} \mathrm{Se}$, and uranium isotopes with their daughters are the largest contributors by far. This section describes the effect of changing the inventories of these materials.

The RFP requires that the release rate of ${ }^{99} \mathrm{Tc}$ be $0.88 \mathrm{ppm}$ (of the amount of ${ }^{99} \mathrm{TC}$ supplied to the vendor) per year. This release rate, which is five times more restrictive than for other isotopes, can be met by separating out up to 80 percent of the ${ }^{99} \mathrm{TC}$ and returning it to DOE for immobilization into high-level immobilized waste. Table 4-29 displays the results of assuming that the vendor does return 80 percent of the ${ }^{99} \mathrm{TC}$ to the DOE and puts the remaining 20 percent into the low-level immobilized waste. The calculated results are very similar to those for the case (Section 4.5.3.2) where all the technetium is in the waste form, but where technetium is assumed to have a release rate five times lower than other materials. The beta/photon emitter dose at 10,000 years is nearly the same $10.82 \mathrm{mrem} /$ year for reduced inventory versus $0.90 \mathrm{mrem} /$ year for the reduced release rate). The 211-pathways dose at 10,000 years is the same for the two cases. The doses do not decline in proportion to the ${ }^{99} \mathrm{TC}$ inventory, because as the ${ }^{99} \mathrm{Tc}$ inventory is decreased, ${ }^{79} \mathrm{Se}$ becomes more important. If the ${ }^{99} \mathrm{TC}$ inventory is reduced by a factor of 5 , ${ }^{99} \mathrm{TC}$ would be responsible for less than half of the estimated beta/photon drinking water or all-pathways dose. 
Table 4-29. Effect of Inventory Changes on Estimated Results at 10,000 Years at a Well 100 Meters Downgradient from the Facility. (Concept 1 - Full Facility Model)

\begin{tabular}{|l|c|c|c|}
\hline $\begin{array}{l}\text { Inventory } \\
\text { Assumption }\end{array}$ & $\begin{array}{c}\text { Beta/Photon } \\
\text { Drinking } \\
\text { Waster Dose } \\
\text { (mrem/y) }\end{array}$ & $\begin{array}{c}\text { Alpha-Emitting } \\
\text { Radionuclide } \\
\text { Concentration } \\
\text { (pci/l) }\end{array}$ & $\begin{array}{c}\text { All-Pathways } \\
\text { Dose } \\
\text { (mrem/y) }\end{array}$ \\
\hline $\begin{array}{l}\text { Base Analysis } \\
\text { Case }\end{array}$ & 1.97 & 1.65 & 6.4 \\
\hline $\begin{array}{l}\text { Technetium at } \\
\text { oo of } \\
\text { original } \\
\text { inventory }\end{array}$ & 0.79 & 1.65 & 2.5 \\
\hline $\begin{array}{l}\text { Selenium at } \\
\text { twice original } \\
\text { inventory }\end{array}$ & 2.4 & 1.65 & 7.1 \\
\hline $\begin{array}{l}\text { Iodine at 5 } \\
\text { times the } \\
\text { original } \\
\text { inventory }\end{array}$ & 1.97 & 1.65 & 6.4 \\
\hline $\begin{array}{l}\text { Uranium at } \\
\text { twice original } \\
\text { inventory }\end{array}$ & 2.05 & 3.2 & 6.8 \\
\hline
\end{tabular}

Uncertainties for selenium and uranium inventories have not been established. Also the exact amount of iodine that will escape from the melter and be trapped by filters is not yet known. Impacts of increasing the inventory of these elements by a factor of 2 for selenium and uranium and 5 for iodine are shown in Table 4-29.

Doubling the selenium inventory produces a 20 percent increase in the beta/photon drinking water dose and a 10 percent increase in the all-pathways dose. A five-fold increase in iodine has no calculated effect. Doubling the uranium inventory while keeping the same isotopic ratios increases the alphaemitting radionuclide concentration by almost a factor of 2 and the all-pathways dose by 25 percent.

Short-life isotopes like ${ }^{137} \mathrm{Cs}$ and ${ }^{90} \mathrm{Sr}$ decayed away before they reach the groundwater. Thus even though the exact amount of these isotopes awaits NRC determination, these isotopes will not contribute to postulated doses for the groundwater pathway. 
Rev. 1

\subsubsection{Land Use}

4.8.3.1 Overview. Land use mainly affects the travel of contaminants in the unconfined aquifer. Land uses that could affect the infiltration rate are described in section 4.7.4.3. Land uses that result in intrusion into the disposal facility itself are described in section 4.2.2. This section describes land uses that affect the properties of the groundwater system beneath the Hanford Site. For more details, see Lu (1996).

4.8.3.2 Irrigation at the Disposal Facility. Even though lands on the Hanford Central plateau are not expected to be irrigated, lands near the Hanford Site are presently being irrigated. As described in section 4.7.4.3, infiltration rates of $100 \mathrm{~mm} / \mathrm{y}$ were used to describe the effects of possible irrigation at the disposal site.

4.8.3.3 Irrigation on the Hanford Central plateau. Surrounding the Hanford Site, there are large areas under irrigation. Because radioactive plumes are present in the groundwater, irrigation is not expected to occur on the present Hanford site, even after the land is released by the federal government. However, sensitivity cases based on irrigating large plots of land were simulated nonetheless. In all cases an infiltration rate of $100 \mathrm{~mm} / \mathrm{y}$ was used.

The first case assumed that all the area immediately north of the Hanford 200 Areas would be irrigated. At the disposal site, the groundwater table would rise 2 meters, the direction of water flow would change to the southeast, but the increase in water flux in this 2 meter interval would be significant because the interval is in a high permeability zone (the Hanford formation). Thus, the concentration ratio (and hence impacts) decreases by 42 percent.

The second case assumes that all the area immediately to the west of the 200 west Area would be irrigated. This would result in groundwater mounding just west of the 200 west Area (extending slightly into the 200 west Area). The result at the disposal site would be a small rise in the water table, but this higher water level would reside in the high permeability zone and hence would experience greater dilution. For this case, the concentration ratio and hence impacts would be reduced to 80 percent of the value of the base analysis case.

The third and last irrigation case assumed that all the areas north, west, and south of the 200 Areas would be irrigated, but not the area between 200 West and 200 East Areas. Because of the large area south of the 200 Areas, the water table would rise significantly (about 8 meters at the disposal site) and the direction of flow would be northerly over almost all of the 200 Areas. The calculated concentration ratio and hence the impacts would drop by a factor of 5 . 


\section{HNE -EP- 0884 \\ Rev. 1}

Because of the uncertainty in the recharge rate, another sensitivity case was run with the recharge rate over the 200 Areas being reduced by a factor of 2 . No change was calculated for the aquifer mixing factor and hence no changes in the estimated impacts resulted. This result is to be expected because the source of water for the unconfined aquifer lies significantly west of the 200 Areas with the infiltration of water from the 200 Areas making a very small contribution to the aquifer.

In summary, irrigation increases the amount of water in the unconfined aquifer. Because the bottom of the unconfined aquifer is fixed, added water forces an increase in the thickness of the aquifer which in most cases will result in part of the unconfined aquifer being in the more conductivity Hanford formation. The end result is a decrease in the calculated well/vadose-zone concentration ratio and hence the impacts according to the portion of the aquifer residing in the high permeability zone. However, as noted, because of land use restrictions, such irrigation is not expected to occur.

4.8.3.4. Level of the Water Table. For the base analysis case, the location of the top of the unconfined aquifer (the water table) is deeper than the current location because discharges at the Hanford site of liquid effluents to the ground will have stopped. Thus the level of the water table is expected to decline with time until it reaches a pre-Hanford-operations level. However, the amount of contaminant mixing in the groundwater is very sensitive to the level of the water table because the predicted level is near the interface of two geologic formations that have very different hydraulic properties. Therefore, sensitivity cases were run using the pumping model: one raised the water table 7 meters (to its current location) and the other lowered it by 7 meters.

If the level of the water table is raised 7 meters, then the upper portions of the groundwater lie within the Hanford formation, whose hydraulic conductivity is 37 times that of the base analysis case. Two effects are observed, the aquifer mixing factor (well/vadose-zone concentration ratio) is reduced by $85 \%$ to $2.64 \times 10^{-4}$ and the flow from the disposal site to the 200 East Area fence is east to southeast rather than almost due east, as in the base analysis case. Thus, if the level of the water table is raised 7 meters, all impacts will be about an order of magnitude lower than calculated for the base analysis case.

If the level of the water table is lowered 7 meters, then the main effect is that the thickness of the unconfined aquifer is reduced from 28 meters to 21 meters. Just as in the base analysis case, all of the unconfined aquifer is in the Ringold Formation. Lowering the water table results in a smaller amount of water with which the contaminants can mix, resulting in a wel1/vadose-zone concentration ratio (and estimated impacts) about 40 percent higher than the base analysis case. 


\section{HNE-EP-0884 \\ Rev. 1}

4.8.3.5. Position of the Well. As discussed in Section 4.3.3, the transport within the aquifer was calculated for various well positions. The calculated dose or alpha-emitting radionuclide concentration is proportional to the relative concentrations in Table 4-7. As expected, as the distance from the disposal

facility increases, the estimated impact declines. The estimated impact at a well at the 200 Area fence line is only 77 percent of the value at a well 100 meters downgradient of the disposal facility, assuming that the disposal facility is west of the PUREX facility.

4.8.3.6. Pumping at the well. The amount of pumping at the well can distort the groundwater flow field and change the predicted dose. Table 4-30 provides the effect of various pumping rates at a well 100 meters downgradient from the disposal facility normalized to a pumping rate of $0.01 \mathrm{~m}^{3}$ per day. This pumping rate corresponds to 10 liters per day. Thus the base analysis case of a well supplying drinking water to 25 people would correspond to a pumping rate of $0.25 \mathrm{~m}^{3}$ per day. Such a small pumping rate has little impact on the groundwater flow patterns and hence has piratically no effect (< 0.1 percent) on the predicted dose rates. Much larger pumping rates would lower the predicted dose as more uncontaminated water would be used.

Table 4-30. Effect of Pumping Rates on Aguifer Mixing Ratio at a Well 100 Meters Downgradient of Facility

\begin{tabular}{||l|l|l|l|l|l||}
\hline \multirow{2}{*}{} & \multicolumn{5}{|c|}{ Pumping Rate $\left(\mathrm{m}^{3} /\right.$ day) } \\
\cline { 2 - 6 } & 0.01 & 10. & 50. & 100. & 150. \\
\hline \hline $\begin{array}{l}100 \text { meter } \\
\text { downgradient we11 }\end{array}$ & 1.00 & 0.95 & 0.75 & 0.57 & 0.45 \\
\hline
\end{tabular}

\subsubsection{Dosimetry Parameters}

For the base analysis case (Section 3.4.8.2), the selection of dose factors was based on using the best data, rather than using a common source. The internal dose factors were taken from the DOE and the external dose factors from the EPA. other choices could be made. Table 4-31 shows the estimated doses at a well 100 meters downgradient at 10,000 years. The changes are relatively small for a variety of database choices with none of the results exceeding performance objectives.

Assumptions concerning ingestion rates, inhalation rates, and times of exposure only affect the all-pathways dose. Most of the all-pathway dose comes from drinking water ( 53 percent) or from ingesting vegetable percent ( 34 percent). Therefore, the estimated all-pathways dose is relatively insensitive to inhalation rates and times of exposure. The calculation is only 


\section{FNF-EP-0884 \\ Rev. 1}

moderately sensitive to ingestion rates or uptake factors (with technetium uptake factors being the most important).

Table 4-3I. Effect of Different Dose Factor Libraries on the Beta/Photon Drinking Water Dose and All-Pathways Dose at a Well 100 Meters Down Gradient at 10,000 Years.

\begin{tabular}{||l|c|c|}
\hline Source & $\begin{array}{c}\text { Beta/Photon } \\
\text { Dose } \\
(\mathrm{mrem} / \mathrm{y})\end{array}$ & $\begin{array}{c}\text { All-Pathways } \\
\text { Dose } \\
(\mathrm{mrem} / \mathrm{y})\end{array}$ \\
\hline Base Analysis Case & 1.97 & 6.4 \\
\hline Department of Energy & $\begin{array}{c}1.97 \\
(0 \%)\end{array}$ & $\begin{array}{c}6.4 \\
(0 \%)\end{array}$ \\
\hline Environmental Protection Agency & $\begin{array}{c}2.2 \\
(10 \%)\end{array}$ & $\begin{array}{c}7.0 \\
(9 \%)\end{array}$ \\
\hline $\begin{array}{l}\text { GENII (Hanford Environmental } \\
\text { Computer Code) }\end{array}$ & $\begin{array}{c}3.0 \\
(52 \%)\end{array}$ & $\begin{array}{c}9.9 \\
(55 \%)\end{array}$ \\
\hline
\end{tabular}

Numbers in parenthesis are percentage increases from base analysis case

\subsubsection{Location of the Facility}

This performance assessment assumes that the location of the disposal facility is just southwest of the PUREX site. However, it is possible (Burbank 1996) that some of the waste may be disposed of in the Grout Facility Area, which is just east of the PUREX site. Because the two sites are so close (about a kilometer apart) and the geology does not vary significant, both vadose zone and aquifer transport are expected to be similar. The vadose zone transport runs discussed in section 4.7 .2 show a weak dependence on the geologic layers (less than 10 percent).

A calculation of aquifer transport at the Grout Facility showed the same well/vadose-zone concentration factor as for the base analysis case. The more important effect is that the grout facility is right next to the 200 East Area fence. Thus there is about 25 percent less mixing before the contaminants hit the fence line than in the base analysis case.

\subsubsection{Calculational Assumptions}

A number of sensitivity runs using the Unit Cell Model were made to test calculational assumptions. These included increasing the number of nodes in the model, changing the initial amount of moisture in the construction materials, and rotating the canister so that the long side ( 1.8 meters) was being modeled rather than the short (1.2 meters). None of the results differed significantly from the Unit Cell Model base sensitivity analysis case (see Table 4-32). 


\section{HNF-EP-0884 \\ Rev. 1}

Table 4-32. Test of Unit Cell Calculational Assumptions: Normalized Flux Entering Unconfined Aquifer $\left(K_{d}=0.1 \mathrm{ml} / \mathrm{g}\right)$.

\begin{tabular}{|c|c|c|c|c|}
\hline Case & $\begin{array}{c}\text { Value at } \\
10 \mathrm{~K} \mathrm{Y} \\
(1 / \mathrm{y})\end{array}$ & $\begin{array}{c}\text { Peak } \\
\text { Value } \\
(1 / y) \\
\end{array}$ & $\begin{array}{c}\text { Time of } \\
\text { Peak Value } \\
\text { (y) }\end{array}$ & $\begin{array}{c}\text { Time of } 0.5^{*} \\
\text { Peak Value } \\
(\mathrm{y})\end{array}$ \\
\hline $\begin{array}{l}\text { Base Sensitivity } \\
\text { Case }\end{array}$ & $4.37 e-6$ & $4.42 e-6$ & 17,000 & 3,140 \\
\hline $\begin{array}{l}\text { Double number of } \\
\text { horizontal nodes }\end{array}$ & $4.37 e-6$ & $4.42 e-6$ & 17,000 & 3,150 \\
\hline $\begin{array}{l}\text { Initial moisture } \\
=0.2 \text { in } \\
\text { construction } \\
\text { materials }\end{array}$ & $4.37 e-6$ & $4.42 e-6$ & 17,000 & 3,100 \\
\hline $\begin{array}{l}\text { Initial moisture } \\
=\text { residual level } \\
\text { in construction } \\
\text { materials }\end{array}$ & $4.37 e-6$ & $4.42 e-6$ & 17,000 & 3,100 \\
\hline $\begin{array}{l}\text { Rotate canister } \\
\text { orientation by } \\
90^{\circ}\end{array}$ & $4.37 e-6$ & $4.42 e-6$ & 17,000 & 3,150 \\
\hline
\end{tabular}

\subsubsection{Neglected Processes and Conditions.}

The major processes involved in contaminant transport have been modeled. However, the following processes also should be discussed:

- Preferential flow through the vadose zone

- Upward diffusion of contaminants

- Upward migration by capillary action

- Consumption of water in glass dissolution process.

Clastic dikes are very localized vertical geologic features of the Hanford plateau that exhibit enhanced flow under saturated conditions. Future work will characterize the hydraulic properties of these features and determine the effect (if any) of these features at the site of the disposal facility.

Upward diffusion and upward migration only become important with extremely low infiltration rates. Both processes produce a characteristic time, $T$, which depends on the soil diffusivity, $D$, and on the length to be traversed, L,

$$
\mathrm{T}=\mathrm{L}^{2} / \mathrm{D} \text {. }
$$

For the case of upward diffusion, the equation can be derived from Fick's law (see section 4.11). For the case of capillary 


\section{FNNE-EP-0884 \\ Rev. 1}

rise, the equation can be derived by neglecting the gravity term in the flow equation. Using a length of 6 meters (the total thickness of the sand-gravel capillary barrier, waterconditioning layer, and the vault roof) and a soil diffusivity of $1.25 \times 10^{-7} \mathrm{~cm}^{2} / \mathrm{s}$ (from section 3.4 .4 .3 ), the characteristic time is almost 100,000 years.

Moreover, as noted in section 3.4.5.4, water must be present to dissolve the glass. Because the aquifer is so far below the disposal facility, capillary action could not bring water up from the waste. Thus the only source for the quantity of water needed to dissolve a significant amount of the waste form is from infiltration. Therefore, under extremely dry conditions, there would be no mobile contaminants to move.

\subsection{IMPACT OF OTHER HANFORD ACTIONS ON GROUNDWATER}

The Defense Nuclear Facilities Safety Board recommended (DNFSB 1994) that, in the evaluation of the impact of the disposal of radioactive waste, DOE consider not just the impact from the disposal action under consideration but also all other government actions that might affect those impacts. The analysis presented here will be brief because the location of the disposal facility has not yet been determined. A more complete study is being conducted at Hanford and will be published separately (scheduled for December 1977).

The main pathway that is affected in such an integrated analysis is the groundwater pathway. Inadvertent intruder scenarios and releases to the air are controlled at the source point. As will be seen in section 4.12 , the impacts of catastrophic events on disposed waste are not significant.

Assuming that the disposal facility is placed just southwest of the PUREX facility, the previous Hanford site actions that would affect groundwater downgradient of the disposal facility are those activities that are upgradient of the facility. From Figure 3-1, those actions are the operations at the S, SX, SY, and U Tank Farms and the disposal of waste at the Environmental Remediation Disposal Facility and at the commercial low-level waste disposal site (operated by U.S. Ecology).

Using the aquifer model described in section 3.5.3.4, mixing effects were calculated (appendix of $L u$ 1996) for the transport of contaminants from these potential sources to a well 100 meters downgradient of the disposal facility. The mixing factors are displayed in Table 4-33. Because of the distance from the sources, the mixing factors are significantly less than from the low-level tank waste disposal site. 
Rev. 1

Table 4-33. Mixing Factors from other sources for a Well 100 Meters Downgradient of the Low-Level Tank Waste Disposal site.

\begin{tabular}{||l|l|l|l|l|l||}
\hline & \multicolumn{5}{|c|}{ Upstream Sources } \\
\cline { 2 - 6 } & $\begin{array}{c}\text { Low-Leve1 } \\
\text { Tank } \\
\text { Waste } \\
\text { Site }\end{array}$ & ERDF Site & $\begin{array}{c}\text { S, SX, SY } \\
\text { Tank Farm }\end{array}$ & $\begin{array}{c}\text { U Tank } \\
\text { Farm }\end{array}$ & $\begin{array}{c}\text { Commercial } \\
\text { LIW } \\
\text { Disposal } \\
\text { Site }\end{array}$ \\
\hline $\begin{array}{l}\text { Mixing } \\
\text { Factor }\end{array}$ & $1.77 \times 10^{-3}$ & $3.01 \times 10^{-4}$ & $2.08 \times 10^{-4}$ & $1.25 \times 10^{-4}$ & $8.91 \times 10^{-5}$ \\
\hline $\begin{array}{l}\text { Fraction } \\
\text { of Base } \\
\begin{array}{l}\text { Analysis } \\
\text { Case }\end{array}\end{array}$ & 1.00 & 0.17 & 0.12 & 0.07 & 0.05 \\
\hline \hline
\end{tabular}

Both the Department of Energy (DOE 1988b) and the Nuclear Regulatory Commission (10 CFR 61-4) mandate that at the edge of the disposal facility a member of the general public can receive an exposure of no more than 25 mrem in a year. Thus assuming that the other sources have their maximum impact and ignoring any time factors which might reduce the effect of the overlap, the other sources could add no more than 10.3 mrem in a year. Adding this to the amount estimated in section 4.3.4.2, yields a total dose of less than 19 mrem in a year for the first 10,000 years. Moving the point of compliance to the 200 East Area fence will reduce the estimated compliance dose, but by less than

25 percent.

\subsection{SUMMARY OF GROUNDWATER SCENARIO}

\subsubsection{Overview}

Tables 4-8 and 4-12 show that the performance objectives for the groundwater scenario are met for the base analysis case. Table 4-14 shows using Concept 2, the performance objectives are again met. However, for both concepts 1 and 2 , the estimated doses from beta/photon emitters at a well 100 meters downgradient from the facility $(2.0$ and 1.1 mrem in a year, respectively) are only a factor of 2 to 4 lower than the performance objective of 4 mrem in a year. Also the beta/photon doses are estimated to exceed 4 mrem. in a year at a time far in the future $(\sim 750,000$ years for Concept 1 and 3 million years for concept 2$)$.

This section discusses the main causes for these results and provides a feeling for the robustness of the estimates. The next section presents the most important factors for the maximum value, while section 4.10 .3 extends the discussion to the value at 10,000 years. 


\section{FANF - EP - 0884 \\ Rev. 1}

\subsubsection{Maximum Impact of the Groundwater Scenario}

4.10.2.1 overview. Although the performance objectives are for a time period up to 10,000 years, the maximum impact is of interest for three reasons:

- The maximum value allows a determination of whether the disposal action has a significant impact at any time

- A comparison of the impact at the time of compliance to the maximum impact allows a determination of how sensitive the result is to choice of conceptual model and model parameters

- An examination of the time history of doses allows an identification of models and model parameters which have the greatest overall impact.

Therefore, this section describes the value of the maximum impact and those few parameters which determine that value.

4.10.2.2 Value of Maximum Impact. Table 4-34 shows the maximum impact at 10,000 years for concept 1 assuming instantaneous transport through the vadose zone and a time-independent waste form release rate of 4.4 parts per million per year for all radionuclides. The corresponding values for concept 2 would be 40 percent lower. Using the values in Table $4-34$, it can be seen that only a very few contaminants would be important even if the vadose zone did not retard their movement. For the beta/photon drinking water dose, ${ }^{99} \mathrm{TC},{ }^{126} \mathrm{Sn}$, and the daughters of the uranium isotopes are the most important contaminants. ${ }^{79} \mathrm{Se}$, neptunium and its daughters, and americium and its daughters are the next most important. For the alpha-emitting radionuclide concentration, the most important radiocontaminants are the uranium and plutonium isotopes (and their daughters). For the all-pathways dose, the above radiocontaminants plus the americium isotopes (and daughters) are of the greatest concern. However, americium, plutonium, and tin are expected to be very highly retarded (having $K_{a}$ values $z 40 \mathrm{~m} / \mathrm{g}$ ), resulting in travel times of millions of years, and hence, significant decay, making their impacts insignificant.

Therefore, the main radiocontaminants of interest are ${ }^{99} \mathrm{TC}$, the uranium isotopes (and their daughters), and other $K_{d}=0$ contaminants (primarily ${ }^{79} \mathrm{Se}$ ). Thus at 10,000 years, assuming Concept 1, a waste form release rate of $4.4 \mathrm{ppm} / \mathrm{y}$, and no effect of the vadose zone, the impacts from technetium, uranium, and selenium are

beta/photon drinking water dose $<12.7$ mrem in a year alpha-emitting radionuclide concentration $<25$. pCi/l all-pathways dose $\quad<27.4 \mathrm{mrem}$ in a year. 


\section{FINF-EP-0884}

Rev. 1

Although these values are above the performance objectives, they are at most a factor of 3.5 above and are a worst case, neglecting the important known effects of facility design and vadose zone transport. Including these effects drops the estimated doses below the performance objectives as already shown in section 4.3 .

Table 4-34. Maximum Contribution from Contaminants at 10,000 Years at a Well 100 Meters Downgradient from the Facility, Assuming INSTANTANEOUS Vadose Zone Transport, a Constant Waste Form Release Rate of $4.4 \mathrm{ppm} / \mathrm{y}$, and Concept 1 .

\begin{tabular}{|c|c|c|c|c|}
\hline Gantaminants & $\begin{array}{c}\mathrm{K}_{\mathrm{d}} \text { in } \\
\text { base } \\
\text { case } \\
(\mathrm{m} / \mathrm{g}) \\
\end{array}$ & $\begin{array}{c}\text { Beta/Photon } \\
\text { Drinking } \\
\text { water Dose } \\
\text { (mrem/y) } \\
\end{array}$ & $\begin{array}{c}\text { Alpha-Emitting } \\
\text { Radionuclide } \\
\text { Concentration } \\
(\mathrm{pCi} / \mathrm{l}) \\
\end{array}$ & $\begin{array}{c}\text { All- } \\
\text { Pathways } \\
\text { Dose } \\
\text { (mrem/y) } \\
\end{array}$ \\
\hline $\begin{array}{l}\text { Performance } \\
\text { Objective }\end{array}$ & --- & 4.0 & 15 . & 25 . \\
\hline${ }^{79} \mathrm{Se}$ & 0.0 & 0.87 & 0. & 1.6 \\
\hline${ }^{93} \mathrm{Zr}+{ }^{93} \mathrm{Nb}^{\mathrm{m}}$ & 40. & 0.012 & 0. & 0.034 \\
\hline${ }^{99} \mathrm{TC}$ & 0.0 & 3.2 & 0. & 10.5 \\
\hline${ }^{126} \mathrm{Sn}$ & 100. & 3.1 & 0. & 12.1 \\
\hline${ }^{129} \mathrm{I}$ & 3.0 & 0.21 & 0. & 0.42 \\
\hline $\begin{array}{l}\text { Thorium and } \\
\text { daughters }\end{array}$ & 40 . & $0.008^{c}$ & $0.028^{c}$ & $0.018^{c}$ \\
\hline $\begin{array}{l}\text { Uranium and } \\
\text { daughters }\end{array}$ & 0.6 & 8.6 & 23.2 & 11.3 \\
\hline $\begin{array}{l}\text { Neptunium and } \\
\text { daughters }\end{array}$ & 15. & 1.67 & 0.65 & 1.83 \\
\hline $\begin{array}{l}\text { Plutonium and } \\
\text { daughters }\end{array}$ & 40 . & 0.013 & $282 .{ }^{\mid c\}}$ & $966 .^{\text {(c) }}$ \\
\hline $\begin{array}{l}\text { Americium and } \\
\text { daughters }\end{array}$ & 40. & $1.03^{(a)}$ & $4.2^{(e)}$ & $15.0^{(e)}$ \\
\hline $\begin{array}{l}\text { Curium and } \\
\text { daughters }\end{array}$ & 100 . & $0.001^{\text {(a) }}$ & $0.018^{(f)}$ & $0.06^{(f)}$ \\
\hline \multicolumn{5}{|c|}{$\begin{array}{l}{ }^{14} \mathrm{C},{ }^{90} \mathrm{Sr},{ }^{137} \mathrm{Cs}, \text { and }{ }^{151} \mathrm{Sm} \text { have doses less than } 0.001 \mathrm{mrem} / \mathrm{y} . \\
{ }^{226} \mathrm{Ra} .\end{array}$} \\
\hline
\end{tabular}




\section{HNF-EP-0884 \\ Rev. 1}

\subsubsection{Important Parameters Determining Maximum Impact.}

Because the contaminant transport rather than waste from release sets the time scale in most performance assessments, the maximum response in those analyses depends on many variables. The total amount of contaminant reaching a point is fixed, and the peak response is inversely proportional to the width of the transport curve. In this analysis, the release rate of the waste form sets the time scale. The response mirrors the release rate and the maximum depends only on a few variables.

These few parameters can be found by using the equation described in section 3.5.2.5

$$
\text { Response }=\sum_{i} \frac{I_{i} \Gamma_{i} W D_{i}}{r A}
$$

and noting that for the small amount of recharge characteristic of the Hanford site that the aquifer mixing factor $w$ can be written as

$$
w(r)=w\left(r_{0}\right) \frac{r}{r_{0}} \frac{A}{A_{0}}=w_{0} \frac{r}{r_{0}} \frac{A}{A_{0}}=w_{0} r A
$$

and that for very-long-lived nuclides released very slowly from the waste form that

$$
\Gamma_{i}(t) \Rightarrow R_{i}\left(t-t_{0}\right)
$$

resulting in

$$
\text { Response } \Rightarrow \frac{w\left(r_{0}\right)}{r_{0} A_{0}} \sum_{i} I_{i} R_{i} D_{i}
$$

where

$I_{i}=$ the inventory of contaminant $i$

$\Gamma_{i}=$ the flux of contaminants at the bottom of the vadose zone

$w=$ the ratio of contaminant concentration at the well to the concentration at the bottom of the vadose zone

$D_{i}=$ the dosimetry factor relating response to concentration of contaminant $i$

$r=$ is the recharge rate

$A_{0}=$ reference area over which the contaminants leave the vadose zone (taken to be the area of the disposal facility)

$r_{0}=$ reference recharge rate (taken as $1 \mathrm{~mm} / \mathrm{y}$ )

$\mathrm{R}_{\mathrm{i}}=$ the release rate of contaminant $i$ from the waste form at a time corrected for the vadose zone travel time $t_{0}$.

The second equation follows that for small recharge rates the concentration of contaminants in water in the vadose zone is proportional to the recharge and area but that the concentration 


\section{FNNE-EP-0884 \\ Rev. 1}

of contaminant in water in the well depends only on the much larger amount of groundwater. The third equation reflects that the time dependence of the problem is driven by the slow release of the waste form rather than the travel in the vadose zone. For convenience, the effect of retardation on the aquifer mixing factor $w$ is neglected, and one value is used for all elements.

The maximum response depends on the inventory, the waste form release rate, the dosimetry factor for each long-lived contaminant, and a quantity that reflects the mixing in the unconfined aquifer. Each of these terms has an uncertainty associated with it.

The inventory of each major radionuclide taken as an upper limit is reasonably well known. As the result of the pretreatment and the immobilization processes, the amount of radionuclides may drop.

The waste form release rate used in this study comes from the RFP. This rate is defined at short times in the RFP and was extended to longer times using a simple model. As noted in Section 4.5.2 which describes a mechanistic approach to estimate release rate, the release rate could be significantly different in magnitude and shape. However, how the vendors will proceed will not be known until early 1998.

Different sets of dosimetry factors exist and the results show some sensitivity to them. However, the sensitivity is minor.

The mixing of the contaminants in the groundwater depends on the flow rate and dispersion in the unconfined aquifer. Although. some uncertainty (factor of $\sim 2$ ) exists about what the flow rate will be thousands of years in the future, the values used in this study are probably near the low end.

Uncertainty remains in the calculated maximum, but this uncertainty mainly reflects a lack of knowledge of processes that will be selected in the next few years. Better information on the inventories and the flow of the unconfined aquifer will also help to increase our confidence.

\subsubsection{Impact of the Groundwater Scenario at 10,000 Years}

4.10.3.1 overview. The time of compliance is for the first 10,000 years. Therefore the values of the calculated responses during this time are the most important. Section 4.3.4 describes the analysis for the base analysis case. This section will describe the general understanding of the calculated results for the first 10,000 years.

Unlike the maximum value, the value of an impact at 10,000 years depends on most of the input variables. However, the 
variables can be grouped by the manner in which they affect the results:

- The parameters affecting travel time

- The parameters affecting how quickly the estimated impact raises from small values to the maximum value

- the parameters affecting how the estimated impact decreases after the maximum value is reached.

4.10.3.2 Travel Time. Travel time is very important because it allows many radionuclides to decay before reaching the compliance point. It also allows the grouping of radionuclides into groups for easier analysis. For times significantly greater than the travel time for a group, the value of the response for that group is at its maximum and depends only on a few variables. For times much less than the travel time, that group contributes very little compared to groups that have already reached the maximum value. The exception is for the unretarded group, which is the first group to reach the unconfined aquifer. For times around the travel time, the response for the group is not only significant but changes quickly. The sensitivity cases have shown that the major parameters affecting the travel time are as follows:

- The vault layout (Section 4.6.2)

- The hydraulic diverter (Section 4.6.3.2)

- The hydraulic parameters of the disposal facility and of the vadose zone (Section 4.7 .2 )

- The infiltration rate (Section 4.7.4)

- The transport and hydraulic diffusion parameter in the fillex material between canisters (Section 4.7.2.2)

- the geochemical $K_{\alpha}$ values within the disposal system and in the natural environment (Section 4.7.3).

The first four parameters affect the moisture content in the disposal facility or in the vadose zone.

The vault layout is important because the vaults cast a moisture shadow if the design contains a hydraulic diverter. Water tends to.go down rather than horizontally, so that once the water is laterally displaced, relatively dry sediments exists beneath the engineered disposal system. The larger the engineered disposal system, the larger the shadow. The unretarded travel time is calculated to be four times longer when all the vaults are a single unit than when only vault rows are used. Such a longer travel time is caused by the lower hydraulic conductivity which results from the drier soil conditions in the 


\section{HNF-EP-0884 \\ Rev. 1}

moisture shadow.

The hydraulic diverter or, more properly, the sand-gravel capillary barxier creates the moisture shadow. If no diverter is used, then the flow is almost totally vertical. The unretarded travel time for the base analysis case is only 1,100 years without a barxiex but about 10,000 years with one.

The hydraulic parameters establish how moisture flows and how wet (or dry) the soil is for a particular infiltration rate. Assuming various strata and hence different hydraulic properties, the travel time for the uranium isotopes can vary by about 15 percent.

The inside of the disposal facility is expected to be so dry that the movement of contaminants is likely to be by diffusion through the moisture rather than movement with the moisture. Which process is more important will be determined by the parameters describing diffusion and moisture transport inside the facility. In the base analysis case diffusion is more important than advection. If the diffusion parameter is decreased by 20 , the travel time to the aquifer increases by a factor of 6 .

The retardation of contaminant travel by geochemical processes allows most of the most troublesome isotopes to decay before they reach the aquifer. For example, it is calculated to take ${ }^{90} \mathrm{Sr} 5,000$ half-lives to reach the aquifer, ${ }^{137} \mathrm{Cs}$ 150,000 half-1ives, and ${ }^{239} \mathrm{Pu} 75$ half-1ives.

4.10.3.3 Rise of the Response. Not only will the variables described in section 4.10.3.2 affect travel time, but also the amount of contamination spreading, both laterally and temporarily. These effects combine to define the shape of the rise of the response at the water table. For the uranium group, the rise time from $10^{-6}$ of the peak value to half of the peak value ranges from 80 percent of the travel time for the base analysis case to 50 percent when the dispersion coefficient is decreased by an order of magnitude.

\subsubsection{Eall of the Response After the Maximum Value is}

Reached. The fall of the response curve is important because doses from later retarded groups will add to the first maximum value. Without a falloff, the maximum dose would be a sum of the values shown in Table 4-34. In reality, two effects (decay of the isotopes and reduced waste form release rate) greatly reduces the total.

Although the half-lives of the important unretarded radiocontaminants are very long, they are short compared to the travel times for plutonium and americium. For example, the travel time of plutonium is about $8{ }^{99} \mathrm{TC}$ half-lives while the travel time for americium is about 20. Thus ${ }^{99} \mathrm{TC}$, the dominant isotope, at early times is not significant at the times when plutonium and americium contribute. 


\section{FNNF-EP-0884 \\ Rev. 1}

The waste form release rate is expected to decline significantly as time passes. Using either a release rate proportional to surface area or one resulting from the computer simulations from section 4.5.2, shows that the release rate is approximately 25 percent lower (using surface area) or a factor of 4 (using the simulation) lower than the peak value which is reached just after just 100,000 years.

\subsection{RESULTS OF SCENARIOS WITH RELEASES TO THE AIR}

In previous performance assessments, three radionuclides were considered $\left({ }^{3} \mathrm{H},{ }^{14} \mathrm{C}\right.$, and $\left.{ }^{222} \mathrm{Rn}\right)$ as candidates for atmospheric release. Gaseous release from a vitrified waste form is not a very credible scenario because the waste form is assumed to be stable over such a long time. The waste form is assumed to release less than $4.4 \times 10^{-6}$ of its initial inventory per year.

As discussed in section 3.3.5.4, the transport of vapors is governed by Fick's equation, the steady-state solution (Wood 1995) to which is

$$
J=C \sqrt{\lambda D} \exp (-x \sqrt{\lambda / D})
$$

where

$$
\begin{aligned}
& J=\text { the flux at the surface }\left(\mathrm{Ci} \mathrm{m} \mathrm{m}^{-2} \mathrm{y}^{-1}\right) \text {, } \\
& \mathrm{C}=\text { the concentration of the radionuclide in the ground } \\
& \left(\mathrm{Ci} / \mathrm{m}^{3}\right) \text {, } \\
& x=\text { the depth of the source }(m) \text {, } \\
& \lambda=\text { the mean life of the radionuclide }\left(=6.64 \times 10^{-2} \mathrm{Y}^{-1}\right. \text { for } \\
& \left.{ }^{3} \mathrm{H}, 1.2 \times 10^{-4} \mathrm{y}^{-1} \text { for }{ }^{14} \mathrm{C} \text { and } 65.9 \mathrm{y}^{-1} \text { for }{ }^{222} \mathrm{Rn}\right) \text {, and } \\
& D=\text { the diffusion coefficient }\left(=10^{-3} \mathrm{~cm}^{2} / \mathrm{s}=3.14 \mathrm{~m}^{2} / \mathrm{y}\right) \\
& \text { [from section 3.4.4.3]. }
\end{aligned}
$$

The concentration of ${ }^{14} \mathrm{C}$ is simply the inventory $(7.73 \mathrm{Ci})$ times the fractional amount release from the waste form (taken as $4.4 \times 10-6$ in a year) divided by the waste volume $\left(3.2 \times 10^{5} \mathrm{~m}^{3}\right)$. However, the inventory of ${ }^{3} \mathrm{H}$ and ${ }^{222} \mathrm{Rn}$ changes as a function of time because of the short half-life of ${ }^{3} \mathrm{H}$ and the decay of ${ }^{222} \mathrm{Rn}$ 's parents (primarily ${ }^{234} \mathrm{U}$ and ${ }^{238} \mathrm{U}$ ). The inventory for ${ }^{3} \mathrm{H}$ is taken at 500 years after closure and the release fraction as $4.4 \times 10^{-6}$ in a year. The inventory for ${ }^{222} \mathrm{Rn}$ as a function of time is shown in Table 4-35. As expected, the ${ }^{222} \mathrm{Rn}$ inventory starts at the initial activity of its parent, ${ }^{226} \mathrm{Ra}$, and builds until it reaches the activity of ${ }^{238} \mathrm{U}$.

Because the top of the waste form is greater than 10 meters from the surface, the depth of the source will be taken to be 10 meters for these calculations. The calculated releases to the atmosphere axe

$$
{ }^{3} \mathrm{H}(500 \mathrm{y}):
$$

$$
\begin{aligned}
& \text { 7. } 51 \times 10^{-19} \mathrm{Ci} \mathrm{m} \mathrm{m}^{-1}=2.4 \times 10^{-14} \mathrm{pCi} \mathrm{m}^{-2} \mathrm{~s}^{-1} \\
& 1.95 \times 10^{-12} \mathrm{Ci} \mathrm{m}^{-2} \mathrm{y}^{-1}=6.2 \times 10^{-8} \mathrm{pCi} \mathrm{m} \mathrm{s}^{-1}
\end{aligned}
$$


Rev. 1

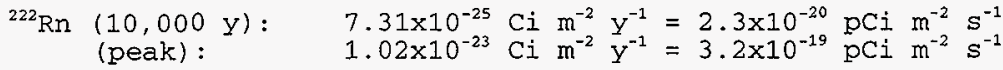

The very small fluxes of ${ }^{222} \mathrm{Rn}$ result from the short half-life of ${ }^{222} \mathrm{Rn}$ and the very deep burial of the waste. Practically all of the radon decays before it can reach the surface.

Table 4-35. Inventory of ${ }^{222} \mathrm{Rn}$ as a Function of Time.

\begin{tabular}{|r|l||l|l|}
\hline Time $(y)$ & Inventory $(\mathrm{Ci})$ & Time $(\mathrm{y})$ & Inventory $(\mathrm{Ci})$ \\
\hline \hline 0. & $2.35 \mathrm{E}-03$ & 1000. & $3.27 \mathrm{E}-02$ \\
\hline 2000. & $1.10 \mathrm{E}-01$ & 3000. & $2.19 \mathrm{E}-01$ \\
\hline 5000. & $4.89 \mathrm{E}-01$ & 7500. & $8.74 \mathrm{E}-01$ \\
\hline 10000. & $1.28 \mathrm{E}+00$ & 20000. & $2.64 \mathrm{E}+00$ \\
\hline 30000. & $3.96 \mathrm{E}+00$ & 50000. & $6.27 \mathrm{E}+00$ \\
\hline 75000. & $8.63 \mathrm{E}+00$ & 100000. & $1.05 \mathrm{E}+01$ \\
\hline 200000. & $1.49 \mathrm{E}+01$ & 300000. & $1.66 \mathrm{E}+01$ \\
\hline 500000. & $1.76 \mathrm{E}+01$ & 750000. & $1.78 \mathrm{E}+01$ \\
\hline 1000000. & $1.78 \mathrm{E}+01$ & & \\
\hline \hline
\end{tabular}

To convert the ${ }^{3} \mathrm{H}$ and ${ }^{14} \mathrm{C}$ flux into a dose, the following equation is used

$$
D=J A(X / Q) \quad B \quad F
$$

where

$$
\begin{aligned}
& D=\quad \text { the annual inhalation dose }
\end{aligned}
$$

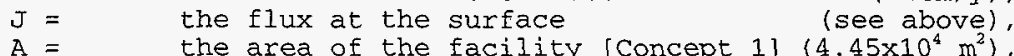

$$
\begin{aligned}
& (\mathrm{X} / \mathrm{Q})=\text { normalized integrated exposure }\left(1.0 \times 10^{-4} \mathrm{~s} / \mathrm{m}^{3}\right) \text {, } \\
& B=\quad \text { inhalation rate }\left(2.67 \times 10^{-4} \mathrm{~m}^{3} / \mathrm{s}\right) \\
& F=\text { dose conversion factor }\left({ }^{3} \mathrm{H}: 9.5 \times 10^{4} \mathrm{mrem} / \mathrm{Ci}\right) \\
& \left({ }^{24} \mathrm{C}: 2.1 \times 10^{6} \mathrm{mrem} / \mathrm{Ci}\right)
\end{aligned}
$$

The values for $(X / Q), B$, and $F$ are taken from the Performance Assessment for the Disposal of Low-Level Waste in the 200 West Area Burial Grounds (Wood $1994 \mathrm{~b}-3$ ). The resulting annual dose is 2. $7 \times 10^{-12}$ mrem at 500 years for ${ }^{3} \mathrm{H}$ and $4.8 \times 10^{-9}$ mrem (steady state) for ${ }^{14} \mathrm{C}$.

Thus the predicted release of ${ }^{3} \mathrm{H},{ }^{14} \mathrm{C}$ and ${ }^{222} \mathrm{Rn}$ are far below the corresponding performance objectives $(10 \mathrm{mrem}$ in a year for ${ }^{3} \mathrm{H}$ and ${ }^{14} \mathrm{C}$ and 20 pCi $\mathrm{m}^{-2} \mathrm{y}^{-2}$ for $\left.{ }^{222} \mathrm{Rn}\right)$.

These calculations for ${ }^{3} \mathrm{H}$ are sensitive to the amount of ${ }^{3} \mathrm{H}$ in the waste form, taken to be 100 percent, and to the time of 


\section{FINF-EP-0884 \\ Rev. 1}

compliance taken as 500 years. Because of the short half-life, ${ }^{3} \mathrm{H}$ should decay long before the waste form releases any of the amount that will actually be in the waste form.

The calculations for ${ }^{14} \mathrm{C}$ are relatively insensitive to the various parameters. However, the amount of ${ }^{14} \mathrm{C}$ might be as high as $100 \mathrm{Ci}$ (WHC 1996), compared with $7.73 \mathrm{Ci}$ of the base analysis case. Using the higher estimate of ${ }^{14} \mathrm{C}$ inventory would raise the predicted dose to $6.3 \times 10^{-8}$ mrem in a year, still much less than the performance objective of $10 \mathrm{mrem}$ in a year.

Because so much of the ${ }^{222} \mathrm{Rn}$ is predicted to decay by the time it reaches the surface, the ${ }^{222} \mathrm{Rn}$ calculation is extremely sensitive to the waste depth and the diffusion coefficient of $\mathrm{Rn}$ in the soil. If the waste is only 5 meters deep rather than the 10 meters assumed or if the diffusion coefficient is $10^{-2} \mathrm{~cm}^{2} / \mathrm{s}$, the value used in the Hanford Burial Grounds Performance Assessment (Wood 1994b-3), then the predicted flux increases by over 10 orders of magnitude. However, the predicted dose is still orders of magnitude less than the performance objective.

\subsection{RESULTS OF CATASTROPHIC EVENTS}

Based on the discussion presented in section 3.3.3, the only scenario considered is that of an ice-age flood that scrapes away all material down to 20 meters (the depth of the disposal facility) and then redeposits the material over the area of the Hanford Site. As noted in section 2.2.4.4, the next such event might be expected in about 50,000 years. Using the farm scenario as the exposure scenario and assuming that all the waste is in a form that can be inhaled or ingested, the predicted dose is estimated to be 0.76 mrem (EDE) in a year. Practically all of the predicted dose (>98 percent) comes from the external exposure of ${ }^{126} \mathrm{Sn}$ and its daughters. If the glacier flood occurs as early as 10,000 years, the predicted dose increases to 1.01 mrem (EDE) in a year. If the flood occurs at 100,000 years, the predicted dose is $0.53 \mathrm{mrem}$ (EDE) in a year. All of these values are much less than the 25 mrem (EDE) in a year maximum established for the first 10,000 years for the all-exposure pathways. If the flood only redistributes the waste over an area equivalent to the 200 Areas $\left(78 \mathrm{~km}^{2}\right)$, the predicted dose at 50,000 years [14 mrem (EDE) in a year] is still less than the all-pathways limit. 
HNF-EP-0884

Rev. 1

$4-86$ 


\section{PERFORMANCE EVALUATION}

\subsection{OVERVIEW}

This chapter compares the estimated impacts from Chapter 4 with the performance objectives established in Chapter 1 . It also discusses items required by DOE guidance for this chapter (changes needed to meet the performance objectives, waste acceptance criteria, and future work that is planned).

\subsection{COMPARISON OF ESTIMATED IMPACTS TO PERFORMANCE OBJECTIVES}

\section{2 .1 Overview}

The comparison of estimated impacts to performance objectives is given for each area of protection cited in section 1.5:

- Protection of the general public
- Protection of the inadvertent intruder
- Protection of groundwater resources
- Protection of surface water resources
Protection of air resources.

\subsubsection{Protection of General Public}

Table 5-1 compares the performance objectives for protecting the general public with the results from the base analysis case. The estimated all-pathways doses are significantly lower than the performance objectives during the first 10,000 years (the time of compliance). The sensitivity cases show that for the allpathways performance objective to be exceeded would require one or more of the following:

- The waste form not meeting the specifications in the RFP for TWRS Privatization (DOE-RL 1996) or not performing at long times as modeled in this analysis

- A high infiltration rate and a disposal facility design without a hydraulic diverter

- A significantly larger inventory.

None of the performance measures (i.e impacts) are estimated to exceed the value of the performance objectives at any time. However, the maximum value of the all-pathways dose $123 \mathrm{mrem}$ in a year estimated to occur at about 50,000 years) is just below the value of the performance objective $(25 \mathrm{mrem}$ in a year). The other two measures (all-pathways including other Hanford Site sources and ALARA) are estimated to remain significantly lower than the performance objectives at ali times. 
Table 5-1. Comparison of Estimated Impacts with Performance Objectives for Protecting the Public. Time of Compliance is 10,000 Years. Point of Compliance is Well 100 Meters Downgradient of the Facility.

\begin{tabular}{||l|c|c||}
\hline Performance Measure & $\begin{array}{c}\text { Performance } \\
\text { objective }\end{array}$ & $\begin{array}{c}\text { Estimated } \\
\text { Impact }\end{array}$ \\
\hline All-pathways [mrem in a year] & 25. & 6.4 \\
\hline $\begin{array}{c}\text { All-pathways, including other Hanford } \\
\text { Sources [mrem in a year] }\end{array}$ & 100. & $<19$. \\
\hline ALARA (all-pathways) [persons-rem/y] & 500. & 5. \\
\hline
\end{tabular}

\subsubsection{Protection of Inadvertent Intruders}

Table 5-2 compares the estimated impacts to the performance objectives for protecting the inadvertent intruder. The time of compliance starts at 500 years after closure. For both acute and continuous exposure, the performance objective is met by at least a factor of three. ${ }^{126} \mathrm{Sn}$ is the most important radionuclide. The estimated dose values for inadvertent intrusion are larger than expected because the well and garden size used in this analysis are conservative. Also, the actual inventory of ${ }^{126} \mathrm{Sn}$ will probably be smaller than used here because much of it will go into the high-level waste fraction. Finally, there are indications that the value for the half-life of ${ }^{126} \mathrm{Sn}$ used in this analysis is too small which results in an overprediction of dose.

Table 5-2. Comparison of Estimated Impacts with Performance objectives for Protecting the Inadvertent Intruder. Time of Compliance starts at 500 years.

\begin{tabular}{|l|c|c||}
\hline Performance Measure & $\begin{array}{c}\text { Performance } \\
\text { Objective }\end{array}$ & $\begin{array}{c}\text { Estimated } \\
\text { Impact }\end{array}$ \\
\hline Acute exposure [mrem] & 500. & 5.5 \\
\hline Continuous exposure [mrem in a year] & 100. & 27.5 \\
\hline
\end{tabular}

\subsubsection{Protection of Groundwater Resources}

Table 5-3 compares the estimated impacts to the performance objectives for protecting the groundwater resources. The time of compliance is 10,000 years and the point of compliance is at a well 100 meters down gradient of the disposal facility. The estimated impact from beta/photon emitters is a factor of two less than the performance objectives and a factor of nine less 


\section{FNVE-EP-0884 \\ Rev. 1}

than the performance objectives for the alpha-emitting radionuclides. The concentration of radium is insignificant. The most important drivers are the inventory of technetium and uranium, the release rate from the waste form, and the amount of mixing in the aquifer. Retardation of uranium isotopes while migrating through the engineered disposal system and natural vadose zone is important in achieving the alpha-emitting radionuclides performance measure.

Table 5-3. Comparison of Estimated Impacts with Performance Objectives for Protecting Groundwater Resources. Time of Compliance is 10,000 Years. Place of Compliance is a well 100 Meters Downgradient of the Facility.

\begin{tabular}{|l|c|c|}
\hline Performance Measure & $\begin{array}{c}\text { Performance } \\
\text { Objective }\end{array}$ & $\begin{array}{c}\text { Estimated } \\
\text { Impact }\end{array}$ \\
\hline Beta/Photon Emitters [mrem in a year] & 4. & 2.0 \\
\hline Alpha-emitting radionuclides [pCi/l] & 15. & 1.7 \\
\hline Ra [pCi/l] & 3. & $<0.001$ \\
\hline
\end{tabular}

\subsubsection{Protection of Surface Water Resources}

Table 5-4 compares of the estimated impacts to the performance objectives for protecting the surface water resources. The time of compliance is 10,000 years and the point of compliance is at a well intercepting the groundwater just before it mixes with the columbia River. The estimated impacts are over an order of magnitude lower than the performance objectives. Because of the large flow of the Columbia River and the tremendous mixing that occurs in a relatively few miles of the river, the predicted impacts from the use of water from the Columbia River would be far lower.

Table 5-4. Comparison of Estimated Impacts with Performance Objectives for protecting Surface Water Resources. Time of Compliance is 10,000 Years. Place of Compliance is a WelI Intercepting the Groundwater Prior to Entering the Columbia River.

\begin{tabular}{|l|c|c|}
\hline Performance Measure & $\begin{array}{c}\text { Performance } \\
\text { objective }\end{array}$ & $\begin{array}{c}\text { Estimated } \\
\text { Impact }\end{array}$ \\
\hline Beta/Photon Emitters [mrem in a year] & 1. & 0.070 \\
\hline Alpha-emitting radionuclides [pCi/l] & 15. & 0.060 \\
\hline Ra [pCi/l] & 3. & $<0.001$ \\
\hline
\end{tabular}




\subsubsection{Protection of Air Resources}

Table 5-5 displays a comparison of the estimated impacts to the performance objectives for protecting air resources. The time of compliance is 10,000 years and the point of compliance is just above the disposal facility. The estimated impacts are over a order of magnitude lower than the performance objectives.

Table 5-5. Comparison of Estimated Impacts with Performance Objectives for Protecting Air Resources. Time of Compliance is 10,000 Years. Place of Compliance is Just Above the Disposal Facility.

\begin{tabular}{||l|c|c|}
\hline Performance Measure & $\begin{array}{c}\text { Performance } \\
\text { objective }\end{array}$ & $\begin{array}{c}\text { Estimated } \\
\text { Impact }\end{array}$ \\
\hline Radon $\left[\mathrm{pCi} \mathrm{m}^{-2} \mathrm{~s}^{-1}\right.$ ] & 20. & $<0.001$ \\
\hline $\begin{array}{l}\text { Other radionuclides }\left({ }^{3} \mathrm{H} \text { and }{ }^{14} \mathrm{C}\right) \\
\text { [mrem in a year] }\end{array}$ & 10. & $<10^{-8}$ \\
\hline
\end{tabular}

\subsubsection{Application to Existing TWRS Disposal Facility}

Some 6 percent of the low-level tank waste may be disposed of in four existing vaults just east of the PUREX facility. This waste may have a higher (at most a factor of 2) concentration of technetium than waste to be processed later. The present structures are similar to those in concept 2, but their long side is shorter than Concept 2, but still long compared to the width. Therefore, the impact of using the four existing vaults would meet the pexformance objectives for protecting the general public, groundwater, surface water, and air resources. Because the inventory of radiocontaminants such as ${ }^{126} \mathrm{Sn}$ in the initial 6 percent of the low-level tank waste is not known, how such a disposal would affect inadvertent intruders is not yet known, but should not differ greatly from the forecast described in Section 5.2 .3 .

The impact from the disposal of the remainder of the waste in alternative facilities should closely follow the analysis presented. The inventory of waste not disposed of in the four existing vaults is nearly the same as the inventory assumed in this analysis.

\subsubsection{Summary}

Most of the estimated effects easily meet the performance objectives set out in section 1.5. However, the estimated allpathways dose, the continuous dose to a inadvertent homesteader, 
Rev. 1

beta/photon drinking water dose, and the concentration of alphaemitting radionuclides in groundwater are less than a factor of 10 lower than the corresponding performance objective. As new information is obtained for the project, it is expected that the estimated impacts will probably decline, thereby increasing the margin of compliance with the performance objectives.

\subsection{CHANGES REQUIRED TO MEET PERFORMANCE OBJECTIVES}

All performance objectives were met in this analysis.

However, this analysis was based on making enabling assumptions concerning disposal facility location and design as well as waste form performance. As the project matures, these enabling assumptions may become faulty. In that case, changes may need to be made in order to achieve the performance objectives.

\subsection{WASTE ACCEPTANCE CRITERIA}

No waste acceptance criteria are being established in this analysis. This analysis does show that the specifications for the waste form contained in the Request for Proposal for tank waste immobilization (DOE-RL 1996) when combined with an acceptable disposal facility design can meet performance objectives established in this document. A waste acceptance activity for the first phase of tank waste immobilization is just starting.

The waste form specifications for the bulk of the lowactivity tank waste will be established in 2005 . The results of the final performance assessment will be used in setting the specifications for that waste. Also the waste acceptance activity will use the results of those analyses.

\subsection{CONTINUED WORK}

\subsubsection{Overview}

As often noted in this report, the type of waste form, the inventory in the waste form, the location of the disposal facility, and the design of the disposal facility have not yet been decided. However, many of the decisions affecting these items will be made in 1997 and 1998. This section describes the overall schedule for the performance assessment activity as well as plans for data collection. 


\section{HNE-ESP-0884 \\ Rev. 1}

\subsubsection{Overall schedule}

Table 5-6 displays the current schedule for the major events in the performance assessment activity. This schedule assumes that two sets of performance assessments will be written, one for waste to be disposed of at an existing TWRS disposal facility and another for an alternative location (probably consisting of new facilities). In addition, a research plan has been laid out to obtain the waste form, geotechnical, and other data that will be needed in the preliminary and final performance assessments.

Table 5-6. Schedule of Major Events in Performance Assessment Activity. Abbreviations are Defined at the End of the Table.

\begin{tabular}{||l|c|}
\hline Event & \multicolumn{1}{|c|}{ Date } \\
\hline \hline Review, Revise, and Reissue of this Document & Sept. 1997 \\
\hline Publish Data Packages for the PPA & April 2000 \\
\hline Send PPA to DOE for comment & March 2001 \\
\hline $\begin{array}{l}\text { Send FPA to WSDOE for comment } \\
\text { (TPA Milestone 90-05T) }\end{array}$ & Dec. 2001 \\
\hline $\begin{array}{l}\text { Publish Data Packages for the FPA } \\
\text { Send FPA to DOE for approval }\end{array}$ & March 2002 \\
\hline Receive approval from Dof & Jan. 2003 \\
\hline
\end{tabular}

\subsubsection{Data Collection Activities}

5.5.3.1 Overview. An extensive data collection activity is planned for the low-level tank waste performance assessment activity. The data to be collected fall into three natural groupings: data related to waste form performance, data related to the transport of contaminants from the waste form to the point of compliance, and other data.

Much data have already been collected. The intent is to issue documents containing all the data to be used in each performance assessment. These documents would be similar to Data Packages for the Hanford Low-Level Tank Waste Interim Performance Assessment (Mann 1995a), which forms the basis of this performance assessment.

5.5.3.2 Waste Form Data. Because of the expected very slow release of contaminants from the waste form, most of the impacts of this disposal action are proportional to the performance of the waste form. At the time of this writing, the waste form to be used has not been decided. However, silicate glass is the most likely candidate. 
Rev. 1

The release of contaminants from a glass waste form in a dry environment over thousands of years is very complex. Many data paths are being pursued. Short-term experiments are being run to determine glass corrosion rates as a function of temperature, pH, and other environmental conditions. Other short-term experiments determine the mineral phases that form after glass corrodes. Still other experiments reveal the rate of corrosion under unsaturated conditions. Finally, long-term (over many years) experiments are being performed.

All this information is being used to formulate, test, and calibrate computer models. These models are being further developed to be more robust and accurate. More chemical processes are being modeled. The intent is to have a computer model that simulates the influx of water to the disposal facility, the corrosion of the glass, the release of the contaminants from the original glass waste form and its secondary mineral phases, and the transport of those contaminants out of the engineered disposal system.

5.5.3.3 Disposal Facility Data. To model the disposal facility, not only is the design needed but also are the hydraulic and transport properties of the waste form and near-field environment. Movement of moisture through cracks in glass and the determination of hydraulic and geochemical properties of the original and degraded materials will be the subject of research. Efforts to support design of moisture barriers (both surface and sand-gravel capillary), getter materials, and water conditioning layers are part of the multi-year plan.

5.5.3.4 Geotechnical Data. Geotechnical data are those data that describe the vadose zone and the unconfined aquifer. The vadose zone and the unconfined aquifer play an important role in the performance assessment because the vadose zone delays the arrival of contaminants and the aquifer supplies additional water in which the contaminants can mix.

In each of the next three years a borehole will be drilled in the locations where the disposal facilities will be sited. The boreholes will not only provide samples for determining other geotechnical information, but will also allow access to the vadose zone for in-situ moisture experiments and to the unconfined aquifer for groundwater testing.

The samples from the boreholes (as well as samples from other locations on the Hanford Central Plateau) will be used to determine the geologic strata underlying the disposal facilities and the hydraulic and geochemical properties of those strata. In addition, the samples will be used to determine chlorine content as a function of depth (and hence infiltration rate over the last 13,000 years).

other analyses will also use and support the determination of geotechnical data needed for the preliminary and final 


\section{FINE-EP-0884 \\ Rev. 1}

performance assessments. For example, the computer simulations of moisture flow in Hanford site. surface sediments will combine the long-term infiltration rates determined by chlorine measurements, with short-term (a few decades) determination of the infiltration rate and with climate, soil, and vegetation studies. Enhanced contaminant transport through colloidal movement or in clastic dikes will also be studied. Studies of the spatial variability of soil hydraulics data and alternate conceptual models will be important for the completion of the preliminary and final performance assessments.

5.5.3.5 Other Data. Large amounts of data are generated outside of the performance assessment activity. These data must be reviewed and examined for relevance and quality. Examples are inventory estimation, facility design data, and dosimetry data. Inventory estimates depend on the amount of radionuclides in the Hanford Site tanks, the type of processing used to separate the low-activity fraction from the high-level waste fraction, and the techniques used to immobilize the low-activity waste fraction. For facility design data, close cooperation will be maintained with the design team to ensure that accurate facility design data are used and to ensure that current performance assessment estimates are factored into design concepts and calculations.

\subsection{CONCLUSION}

This analysis of the long-term effects from the proposed disposal of low-level Hanford site tank waste used the methods and formats required by the Peer Review Panel to satisfy DOE order 5820.2A. Many decisions (choice of location, choice of waste form, choice of facility design) remain to be made.

However, the calculations presented in this analysis show that it is likely that once these decisions are made and the additional data are collected, the performance objectives will be met. 


\subsection{RESUMES OF PREPARES}

NEIL R. BROWN, Project Manager, TWRS-Low Level Waste Immobilization, U.S. Department of Energy, Richland Operations Office (DOE-RL)

B.S. Material Science and Engineering, Rice University

Ph.D. Material Science and Engineering, Northwestern University

Prior to joining DOE, Neil was a post doctoral fellow at the Argonne National Laboratory where he studied corrosion characteristics of waste glass and soil remediation. At DOE, Neil has overseen technology development for the Low-Level Waste Program as well as the development of TWRS Privatization Specifications. Currently Neil is the DOE Contract Officer for BNFL, Inc's effort as part of TWRS privitization. Neil reviewed this document.

YUETING CHEN, Research Scientist, Applied Geology and Geochemistry, Water and Land Resources Department, Pacific Northwest National Laboratory

B.S. Geochemistry, China University of Geosciences

M.S. Geochemistry, China University of Geosciences

Ph.D. Geochemistry, Indiana University

From 1985 to 1989, Dr. Chen worked as a lecturer at the China University of Geosciences. While earning his Ph.D. in geochemistry at Indiana University under Professor Peter Ortoleva, he developed a reactive-transport simulator CIRF.A. Since joining PNNL in 1994, he has been the principal developer of the AREST-CT code. His expertise is in reaction-transport modeling of subsurface systems. He is the co-author of one book and has published and presented over 22 papers. Dr. Chen performed the AREST-CT calculations for this analysis.

MARY P CURRY, Technical Writer/Editor, Lockheed Martin Services, Incorporated.

$$
\text { B.S. Agriculture, Arizona State University }
$$

Mary has written and edited technical material for the aerospace and nuclear industry since 1982 and worked at the Hanford Site since 1991. She is responsible for editing this document. 
CHERYL R. EIHOLZER, formally a Principal Engineer with Westinghouse Hanford Company, now a senior research engineer at the Pacific Northwest National Laboratory.
B.N.E. Nuclear Engineering
Georgia Institute of Technology
M.S. Metallurgical Engineering
University of Illinois, Champaign-Urbana

Cheryl was the main co-author of this document. She also produced the facility concepts used in this assessment and oversaw the material science research conducted for the overall performance assessment effort. She has more than 10 years experience in metallurgical related research and development, technical support, and project coordination for government, foreign, and private industry.

CHARLES T. KINCAID, Staff Scientist, Geosciences Department, Pacific Northwest National Laboratory

B.S. Civil Engineering, Humboldt State College 1970

Ph.D. Engineering (Hydraulics), Utah State University

Dr. Kincaid is the Hanford representative on the DOE Peer Review Panel. He was the technical manager and key contributor to the Performance Assessment of Grouted Double-Shell Tank Waste Disposal at Hanford and is now leading the effort on the Hanford Site Composite Analysis. He has been the Technical Group Leader of the Soil Physics Group and of the Subsurface Transport Group. He was a key contributor in the development of contaminant transport codes and has contributed to various performance assessments. Charlie reviewed this document and advised on its development.

RAZIUDDIN KHALEEL, Consulting Engineer, Nuclear and Environmental Initiatives, Flour Daniel Northwest Company

B.S. Civil Engineering, Bangladesh University of Engineering and Technology

M.S. Water Science and Engineering, Asian University of Technology $\quad 1970$

Ph.D. Soil and Water Engineering, Texas A\&M University

Dr. Khaleel has over 25 years of experience in groundwater hydrology and numerical simulations of subsurface flow and transport. He was a key contributor to the Hanford solid waste performance assessments, particularly in the area of conceptual model development, direction of modeling, and in writing the document. For this document, Raz reviewed the approach, models, and results. 


\section{INNF-EP -0884 \\ Rev. 1}

NIALL W. KLINE, Fellow Software Engineer, Information and Scientific Systems, Lockheed Matrin Services, Incorporated

B.A. Mathematics, Washington State University

M.S. Mathematics, Washington State University

Mr. Kline has been an employee of BCS Richland, Inc. at the Hanford Site since January of 1978. He has nearly 20 years of experience in mathematical modeling and numerical simulation of physical systems. For the past 15 years, Mr. Kline has concentrated on modeling and simulation of isothermal and nonisothermal flow and transport in both groundwater and the vadose zone. For this performance assessment, Niall developed and tested the unit cell model and performed the unit cell simulations of vadose zone flow and transport.

PHILIPE. LAMONT, General Engineer, Department of Energy - Richland Operations Office (DOE-RL)
B.S. Chemical Engineering, Washington State University
M.S. Chemical Engineering, University of Idaho

Mr. LaMont is a Project Director in the DOE-RL Hanford Tank Waste Remediation System Office. He has more than 20 years of experience in nuclear waste management. Mr. LaMont reviewed the interim performance assessment as part of his responsibility for management of projects for storage/disposal of the immobilized waste products from the planned treatment of Hanford tank waste.

ALLEN H. LU, Fellow Scientist, Environmental Modeling Section, Westinghouse Hanford Company (retired).

B.S. Naval Navigation and Engineering, Chinese Naval Academy

M.S. Nuclear Physics, Tsin-Hua University, Taiwan

Ph.D. Nuclear Physics,

Renesselaer Polytechnic Institute

Dr. Lu has been employed at the Hanford Site since 1979. He has worked on a variety of nuclear engineering projects. Most recently, he has been in charge of various modeling studies using the VAM3D-CG flow and transport code. In particular, he was responsible for the source term and modeling for the Hanford solid waste performance assessments. For this document, Allen performed the aquifer calculations. 
Rev. 1

FREDERICK M. MANN, Consulting Scientist, Nuclear and Environmental Initatives, Flour Daniel Northwest Company

B.S. Physics, Stanford University

Ph.D. Physics, California Institute of Technology

Dr. Mann is the team leader for the Tank Waste Performance Assessment Activity, which is charged with preparing this performance assessment. He has worked for over twenty years in the field of nuclear data and the application of that data to large energy facilities. He has advised the Department of Energy and the International Atomic Energy Agency. He was the main author of this document.

B. PETER MCGRAIL, Staff Scientist IV, Applied Geology and Geochemistry, Water and Land Resources Department, Pacific Northwest National Laboratory

B.S. Nuclear Engineering, University of Missouri

M.S. Nuclear Engineering, University of Missouri

Mr. McGrail has over 14 years of experience in fundamental and applied research on immobilization and disposal of hazardous and radioactive wastes. He is a principal investigator on performance assessment projects for high-level waste disposal in Japan and the U.S., and for the Hanford low-level waste disposal project. He is a co-developer of the AREST-CT code, which is used to simulate the release and transport of contaminants modified by both kineticand equilibrium-controlled chemical reactions. He is the principal developer of the Tank Waste Simulator code, which is used to model coupled fluid, heat, and chemical mass transport. processes in underground storage tanks. In addition to his modeling research, Mr. McGrail has also invented several novel experimental techniques to evaluate the kinetics and thermodynamics of waste form-water reactions including a two-phase single-pass flow-through method and the pressurized unsaturated flow (PUF) method. Mr. McGrail has published and presented over 100 papers on all aspects of his waste management research. Mr. McGrail supervised the AREST-CT calculations for this analysis. 
Rev. 1

MEL G. PIEPHO, Senior Specialist, Hydrological/Numerical Modeling Section, Daniel B.

Stephens and Associates, Inc.

B.S. $\quad$ Mathematics and Physics, Butler University 1968

M.S. $\quad$ Physics, Indiana University $\quad 1970$

M.A. Mathematics, Indiana University $\quad 1971$

Ph.D. Physics, Indiana University $\quad 1974$

Dr. Piepho has over twenty years of mathematical modeling, numerical analysis, and computer science experience. For the last ten years, he has concentrated in studies of vadose zone flow and contaminant transport. He supplied the flow and transport calculations for the Hanford Grout performance assessment. For this performance assessment, Mel performed the vadose zone calculations for the facility model.

STEPHEN P. REIDEL, Staff Scientist IV, Applied Geology and Geochemistry, Water and Land Resources Department, Pacific Northwest National Laboratory

B.S. $\quad$ Geology, University of Cincinnati 1970

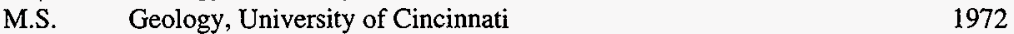

Ph.D. Geology, Washington State University $\quad 1978$

Dr. Reidel has been studying the geology and geohydrology of the Columbia Basin for over 25 years, with nearly 20 years spent at the Hanford Site. At Hanford he has worked in the fields of commercial nuclear waste disposal, groundwater management and protection, waste management, site characterization, and natural phenomena hazards. He is a recognized expert on the geology of the Hanford Site. He is currently an Associate Adjunct Professor at Washington State University and a part time faculty member at Yakima Valley Community College. Steve provided much of the geology for this assessment and reviewed the document.

PAUL D. RITTMANN, Process/Speciality Engineer II, Nuclear and Environmental Initatives, Flour Daniel Northwest Company.

B.A. Physics, University of Wisconsin $\quad 1971$

M.S. $\quad$ Physics, Purdue University 1973

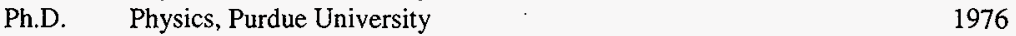

Dr. Rittmann has employed at the Hanford Site since 1980 and has been using environmental transport and dose models since 1983. He is a member of the Hanford Environmental Dose Overview Panel. He was responsible for the dosimetry analyses for the Hanford solid waste performance assessments. For this document, Paul performed supplied the dosimetry data and equations. 
FRANK SCHMITTROTH, Fellow Scientist, Criticality and Shielding, Westinghouse Hanford Company (retired).

B.S. Physics, Oregon State University

B.S. Mathematics, Oregon State University 1962

Ph.D. Physics, Oregon State University

Dr. Schmittroth worked for Westinghouse Hanford Company from 1970 to 1996. Primary activities have supported nuclear data analysis: specifically in the areas of nuclear cross sections, decay heat, and calculations of radionuclide inventories from both fast and thermal reactors. Recent activities have included groundwater modeling (vadose zone and unconfined aquifers), statistical analyses, and Monte Carlo transport calculations of molecular flow. Frank reviewed this document.

ANN M. TALLMAN, Fellow Scientist, Liquid Effluent Services, Westinghouse Hanford Company (retired)

B.S. Chemistry, Ashland University (Ohio)

M.A.T. General Science, Michigan State University

Ph.D. Geology, Michigan State University

Dr. Tallman has nineteen years of experience in geology and geotechnical studies and applications at the Hanford Site. Her work has been applied to site characterization and selection studies and to the design and construction of new facilities. She is the point of contact for the Hanford Site in matters relating to natural phenomena hazards (NPH) and NPH design criteria. Prior to coming to Hanford, she was an assistant professor of geology at Smith College. Ann provided the section on seismic analysis and reviewed the entire document.

Jeffry A Voogd, Program Engineer, Tank Waste Remediation System Storage and Disposal, Lockheed Martin Hanford Company

B.S. Chemical Engineering, University of Washington, 1977

Mr. Voogd has programmatic responsibilities for storage and disposal of Hanford tank waste after treatment by private vendors. This role includes coordination of cost, scope and schedule among activities leading to final disposal of immobilized low activity waste. Prior, he has held positions in engineering management, low activity waste disposal, high level waste vitrification, and fuel reprocessing. These positions included previous assignments with performance assessment, waste disposal system design, waste form performance and waste characterization. 
Rev. 1

GEORGE F. WILLIAMSON, Project Manager, Storage and Disposal Subproject, Westinghouse Hanford Company (retired).

B.S. Metallurgical Engineering, Purdue University

M.S. Engineering, North Carolina State University

Mr. Williamson was the project Manager for this activity until he retired in 1996. George has 30 years of technical and project management experience in the nuclear field associated with the fabrication of nuclear fuels for commercial power reactors and mixed waste treatment and disposal projects for defense wastes. He participated in the early development of the performance assessment for the grouting of Hanford tank wastes. George was the project manager for this activity and reviewed this performance assessment. 
FNE-EP-0884

Rev. 1

$6-8$ 


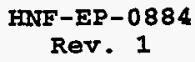

\subsection{REFERENCES}

10 CFR 61, "Licensing Requirements for the Land Disposal of Radioactive Waste," Code of Federal Regulations, Volume 10, Part 61, Section 55, U.S. Nuclear Regulatory Commission, Washington, D.C., December 27, 1982 as amended May 25, 1989.

[1. Section 61.52(a)(2) mandates the protection for inadvertent intrusion for Class $\mathrm{C}$ wastes.]

[2. Section 61.55 describes waste classification. (May 1989)]

[3. Subpart C, sections 61.40 through 61.44 stated the performance objectives.]

[4. Section 61.41 mandates the protection for the general public.]

40 CFR 61H, Subpart H, "National Emission Standards for Emissions of Radionuclides Other than Radon from Department of Energy Facilities," Code of Federal Regulations, Volume 40, Part 61, Subpart H, Section 92, U.S. Environmental Protection Agency, Washington, D.C., December 15, 1989.

40 CFR 61Q, Subpart Q, "National Emission Standards for Radon Emissions from Department of Energy Facilities," Code of Federal Regulations, Volume 40, Part 61, Subpart Q, Section 192, U.S. Environmental Protection Agency, Washington, D.C., December 15, 1989.

40 CFR 141, "National Primary Drinking Water Regulations," Code of Federal Regulations, Volume 40, Part 141, Sections 15 and 16, U.S. Environmental Protection Agency, Washington, D.C., December 24, 1975.

40 CFR 143, "National Secondary Drinking Water Regulations," Code of Federal Regulations, Volume 40, Part 143, U.S. Environmental Protection Agency, Washington, D.C., July $19,1979$.

40 CFR 193, "Radiation Site Cleanup Regulation", proposed Code of Federal Regulations by the U.S. Environmental Protection Agency.

40 CFR 196, "Environmental Radiation Standards for Management and Disposal of Low-Level Waste", proposed Code of Federal Regulations by the U.S. Environmental Protection Agency.

ACRi, 1994a, PORFLOW User's Manual Version 2.50, Analytic and Computational Research, Inc., Bel Air, California, March 1994.

ACRi, 1994b, PORFLOW Validation Version 2.50, Analytic and Computational Research, Inc., Bel Air, California, 1994.

AEA 1954, Atomic Energy Act of 1954, 42 USC 2011 or 2014 et seq. 


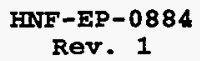

Anderson 1990, J.D. Anderson, A History of the 200 Area Tank Farms, WHC-MR-0132, Westinghouse Hanford Company, Richland, Washington, June 1990.

ANSI/ASME 1989, Quality Assurance Standard Requirements for Nuclear Facilities, ANSI/ASME NQA-1, American National Standards Institute/American Society of Mechanical Engineers, New York City, New York, 1989.

Boldt 1994, A.L. Boldt, "Source Terms", DSI to K.D. Boomer, Westinghouse Hanford Company, Richland, Washington, February, 9, 1994. Attachment 1 in Schmittroth 1995b.

Baca 1984, R.G. Baca, R.C. Arnett, P.M. Clifton, and N.W. Kline, Chapter I-VII of Repository Horizon Identification Report, RHO-BW-ST-28P, Rockwell Hanford Operations, Richland, Washington, 1984.

Bauer 1990, H.H. Bauer and J.J. Vaccaro, Estimates of Ground Water Recharge to the Columbia Plateau Regional Aquifer System; Washington, Oregon and Idaho for Predevelopment and Current Land Use Conditions, WRIR 88-4108, U.S. Geological Survey, Tacoma, Washington.

Berger 1991, A. Berger, H. Gallee, and J.L. Melice, "The Earth's Future Climate at the Astronomical Timescale," In G.M. Goodess and J.P. Palutikof, Future Climate Change and Radioactive Waste Disposal: Proceedings of International Workshop, NSS/R257, U.K. Nirex Radioactive Waste Disposal, Ltd., Harwell, OX11 ORH, United Kingdom, pp. 148-165.

Bernero 1993, "State of Washington and Oregon Denial of Petition for Rule Making", Bernero (Director, Office of Nuclear Materials Safety and Safeguards), 58 FR (Federal Register) 12342, U.S. Nuclear Regulatory Commission, Washington, D.C., March 4, 1993.

Bhuyan 1989, D. Bhuyan, Development of an Alkaline/Surfactant/Polymer Compositional Reservoir Simulator (UT-CHEM), PhD Dissertation, University of Texas, Austin, Texas, 1989.

Birdsell 1991, K.H. Birdsell and B.J. Travis, TRACR3D: A Model of Flow and Transport in Porous Media, LA-11798-M, Los Alamos National Laboratory, Los Alamos, New Mexico, 1991.

Bjornstad 1984, B.N. Bjornstad, Suprabasalt Stratigraphy Within and Adjacent to the Reference Repository Location, SD-BWI-DP-039, Rockwell Hanford Operations, Richland, Washington.

Burbank 1996, D.A. Burbank, Jr., Alternatives Generation and Analysis for Immobilized LowLevel Waste Interim Storage Architecture, WHC-SD-W465-AGA-001, Rev. 0, Westinghouse Hanford Company, September 1996. 


\section{ENNF-EP-0881 \\ Rev. 1}

Campbell 1994, M.D. Campbell, Monitoring Groundwater and River Interaction Along the Hanford Reach of the Columbia River, PNL-9437, Pacific Northwest Laboratory, Richland, Washington, 1994.

Carnahan 1986, C.L. Carnahan, "Simulation of Uranium Transport with Variable Temperature and Oxidation Potential: The Computer Program THCC (Thermo-Hydro-Chemical Coupling)," in Scientific Basis for Nuclear Waste Management X, eds. J.K. Bates and W.B. Seefeldt, Materials Research Society, Pittsburgh, Pennsylvania, 1986.

Case 1988, M.J. Case and M.D. Otis, Guidelines for Radiological Performance Assessments of DOE Low-Level Radioactive Waste Sites, DOE-LLW-62T (Section 4.5.2.5), U.S. Department of Energy, Idaho Operations Office, Idaho Falls, Idaho, July 1988.

Case 1989, M.J. Case, R.L. Dodge, T.G. Frangos, W.R. Hansen, W.E. Kennedy, Jr., D.W. Layton, D.W. Lee, and E.L. Wilhite, Recommended Format and Content for DOE LowLevel Waste Disposal Facility Radiological Performance Assessment Reports, DOE/LLW-81, Radioactive Waste Technical Support Program, Idaho National Engineering Laboratory, Idaho Falls, Idaho, April 1989.

CERCLA, Comprehensive Environmental Response, Compensation, and Liability Act of 1980, 42 U.S. C. 9601 , et seq.

Chatters 1991, J.C. Chatters, "Long-Term Climate Change Effects," L.L. Cadwell (editor), Hanford Site Protective Barrier Development Program: Fiscal Year 1990 Highlights, PNL-7831, Pacific Northwest Laboratory, Richland, Washington, pp. 2.23-3.1, September 1991.

Chatters 1992, J.C. Chatters and K.A. Hoover, "Response of the Columbia River Fluvial System to Holocene Climatic Change," Quaternary Research, Vol. 37, pp. 42-59.

Chen 1994, Y. Chen, CIRF: A General Coupled Reaction-Transport Model and Simulator, PhD dissertation, Indiana University, Bloomington, Indiana, 1994.

Chen 1995, Y. Chen, D.W. Engel, B.P. McGrail, and K.S. Lessor, AREST-CT V1.0 Software Verification, PNL-10692, Pacific Northwest Laboratory, Richland, Washington, July 1995. [Also included as Appendix H in Mann 1995a.]

Chen 1996, Y. Chen, W. Chen, A. Park, J. Mu, and P. Orotleva, "A General Coupled ReactionTransport Model for Solute Transport and Porous Media Alternation with Both Kinetically Controlled and Equilibrium Controlled Chemical Reactions," in preparation, 1996. 


\section{ENNE-EP-0884 \\ Rev. 1}

Cleary 1978, R.W. Cleary and M.J. Ungs, "Two Dimensional Groundwater Transport Strip Source Model No. 4", Analytic Models for Groundwater Pollution and Hydrology Report, 78-WR-15, Water Resources Program, Department of Civil Engineering, Princeton, New Jersey, 1978.

Codell 1982, R.B. Codell, K.T. Key, and G. Whelan, A Collection of Mathematical Models for Dispersion in Surface Water and Groundwater, NUREG-0868, Nuclear Reactor Regulation, Nuclear Regulatory Commission, Washington, D.C., June 1982.

Connelly 1992a, M.P. Connelly, J.V. Borghese, C.D. Delaney, B.H. Ford, J.W. Lindberg, and S.J. Trent, Hydrogeologic Model for the 200 East Ground-Water Aggregate Area, WHCSD-EN-TI-014, Westinghouse Hanford Company, Richland, Washington, April 1992.

Connelly 1992b, M.P. Connelly, J.V. Borghese, C.D. Delaney, B.H. Ford, J.W. Lindberg, and S.J. Trent, Hydrogeologic Model for the 200 West Ground-Water Aggregate Area, WHC-SD-EN-TI-003, Westinghouse Hanford Company, Richland, Washington, April 1992.

Cowan 1996, S.P. Cowan, "Conditional Acceptance of the Hanford 200 West Area Burial Ground Performance Assessment", memorandum to Charles Hansen, U.S. Department of Energy, Washington, D.C., June 27, 1996.

Croft 1980, A.G. Croft, ORIGEN-2 - A Revised and Updated Version of the Oak Ridge Isotope Generation and Depletion Code, ORNL-5621, Oak Ridge National Laboratory, Oak Ridge, Tennessee, 1980.

Cropper 1986, J.P. Cropper and H.C. Fritts, 1986, A 360 Year Temperature and Precipitation Record for the Pasco Basin Derived from Tree Rings, DOE/RL-01830-T46, U.S. Department of Energy, Richland, Washington.

Cunnane 1994, J.C. Cunnane, J.K. Bates, W.L. Ebert, X. Feng, J.J. Mazer, D.J.

Wronkiewicz, J. Sproul, W.L. Bourcier, B.P. McGrail, and M.K. Altenhofen, High-Level Waste Nuclear Waste Glass: A Compendium of Characteristics, DOE-EM-0177, U.S. Department of Energy, Washington, D.C., 1994.

Cushing 1995, C.E. Cushing (editor), Hanford Site National Environmental Policy Act (NEPA) Characterization, PNL-6415, Revision 7, Pacific Northwest Laboratory, Richland, Washington, September 1995.

[1. Section 4.7.3 contains population data]

[2. Section 4.7 contains the discussion on socioeconomics]

[3. Section 4.3.1.5 describes flooding on the Hanford Site]

[4. Section 4.5 contains ecological data] 
Delaney 1991, C.N. Delaney, K.A. Lindsey, and S.P. Reidel, Geology and Hydrology of the Hanford Site: A Standardized Text for Use in WHC Documents and Reports, WHC-SD-ER-TI-003, Revision 0, Westinghouse Hanford Company, Richland, Washington, 1991.

Dirkes 1995, R.L. Dirkes and R.W. Hanf, Hanford Site Environmental Report for Calendar Year 1994, PNL-10774, Pacific Northwest Laboratory, Richland, Washington, June 1995.

[1. Section 5.6 describes soil and vegetation surveillance.]

[2. Section 6.0 describes radiation doses from Hanford operations.]

DNFSB 1994, Defense Nuclear Facility Safety Board Recommendation 94-2, "Conformance with Safety Standards at DOE Low-Level Nuclear Waste and Disposal Sites," 59 Federal Register 47309 (1994).

DOC 1991, 1990 U.S. Census of Population and Housing, State and County Profiles, Washington (Summary Tape 1A for Washington State), Office of Financial Management, U.S. Department of Commerce, Washington, D.C., 1991.

Dodge 1991, R.L. Dodge, W.R. Hansen, W.E. Kennedy, Jr., D.W. Layton, D.W. Lee, S.T. Maheras, S.M. Neuder, E.L. Wilhite, R.U. Curl, K.F. Grant, B.A. Heath, and K.H. Turner, Performance Assessment Review Guide for Low-Level Radioactive Waste Disposal Facilities, DOE/LLW-93, Radioactive Waste Technical Support Program, Idaho National Engineering Laboratory, Idaho Falls, Idaho, October 1991.

DOE 1986a, Environmental Assessment for the Grouting and Near-Surface Disposal of Low-

Level Radioactive Phosphate/Sulfate Wastes from N Reactor Operations, DOE/EA-0312, U.S. Department of Energy, Richland, Washington, December 1986.

DOE 1986b, Environmental Assessment Reference Repository Location, Hanford Site, Washington, DOE/RW-0070, U.S. Department of Energy, Washington, D.C.

DOE 1987, Final Environmental Impact Statement: Disposal of Hanford Defense High-Level, Transuranic and Tank Wastes, DOE/EIS-0113, Vol. 1-5, U.S. Department of Energy, Washington, D.C., December 1987.

[1. Section 4.2 and Appendix O describe the Hanford Site geology.]

DOE 1988a, "Radioactive Waste Management", DOE Order 5820.2A, U.S. Department of Energy, Washington, D.C., September 26, 1988.

[1. Chapter III, section 3 describes the requirement and content of a performance assessment.]

DOE 1988b, Consultation Draft Site Characterization Plan. DOE/RW-0164, Vols. 1-9, Office of Civilian Radioactive Waste Management, U.S. Department of Energy, Washington, D.C. 


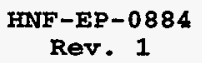

DOE 1988c, External Dose-Rate Conversion Factors for Calculation of Dose to the Public, DOE/EH-0070 (DE88-014297), U.S. Department of Energy, Washington, D.C., July 1988.

DOE 1988d, Internal Dose Conversion Factors for Calculation of Doses to the Public, DOE/EH-0071 (DE88-014297), U.S. Department of Energy, Washington, D.C., July 1988.

DOE 1993, "Radiation Protection of the Public and the Environment", DOE Order 5400.5, U.S. Department of Energy, Washington, D.C., January 7, 1993.

[1. Section 3 of Chapter 1 provides the DOE primary standard of 100 mrem effective dose equivalent to members of the public in a year.]

DOE 1995, Draft Waste Management Programmatic Environmental Impact Statement For Managing Treatment, Storage, and Disposal of Radioactive and Hazardous Waste, DOE/EIS-0200-D, U.S. Department of Energy, Washington, D.C., August 1995. [Pages 34 to 43 of the summary provide information of the low-level waste in the DOE complex. Note that this EIS does not separate the Hanford tank waste into low- and high-level components.]

DOE 1996a, Implementation Plan, Defense Nuclear Facilities Safety Board Recommendation 94-2, Compliance with Safety Standards at Department of Energy Low-Level Nuclear Waste and Disposal Sites, Draft Revision 1, U.S. Department of Energy, Washington, D.C., March 11, 1996.

[The beginning of Section VII, "Radiological Assessment" discusses the use of DOE Order 5400.5 as the basis of the composite approach.]

DOE 1996b, Environmental Impact Statement for the Tank Waste Remediation System, DOE/EIS-0189, U.S. Department of Energy and the Washington State Department of Ecology, Washington, D.C., August 1996.

DOE 1997, Record of Decision for the Tank Waste Remediation System, Hanford Site, Richland, Washington, Federal Register, Volume 62, page 8693, Fenruary 26, 1997.

DOE-RL 1982, Site Characterization Report for the Basalt Waste Isolation Project, DOE/RL 82-3, U.S. Department of Energy, Richland, Washington, March 1982.

DOE-RL 1991a, Description of Codes and Models to Be Used in Risk Assessment, DOE/RL-9144, U.S. Department of Energy, Richland, Washington, 1991.

DOE-RL 1991b, Ground-Water Development Plan in Support of Risk Assessment, DOE/RL-9162, U.S. Department of Energy, Richland, Washington, 1991.

DOE-RL 1992, Annual Report for RCRA Groundwater Monitoring Projects at Hanford Site Facilities for 1991 - Progress Report, DOE/RL-92-03, U.S. Department of Energy, Richland, Washington. 


\section{FNVF-EP-0884 \\ Rev. 1}

DOE-RL 1993a, "Radioactive Waste Management," RLID (Richland Operations Implementing Directive) 5820.2A, U.S. Department of Energy, Richland, Washington, November 23, 1993.

[Chapter III, Section 3a describes the requirements for a performance assessment.]

DOE-RL 1993b, Phase 1 Remedial Investigation Report for 200-BP-I Operable Unit, DOE/RL92-70, U.S. Department of Energy, Richland, Washington.

[1. p. 3-10]

DOE-RL 1993c, 200 East Groundwater Aggregate Area Management Study Report, DOE/RL92-19, U.S. Department of Energy, Richland, Washington.

DOE-RL 1993d, Remedial Investigation and Feasibility Study Report for the Environmental Restoration Facility, DOE/RL-93-99, U.S. Department of Energy, Richland, Washington, October 1994.

DOE-RL 1994a, Phase I Remedial Investigation Report for the 300-FF-5 Operable Unit, DOE/RL 93-21, U.S. Department of Energy, Richland, Washington, January 1994.

DOE-RL 1994b, Hanford Site Background: Part 1, Soil Background for Nonradioactive Analytes, DOE/RL-92-94, Revision 2, 2 volumes, U.S. Department of Energy, Richland, Washington, March 1994.

DOE-RL 1995a, Tank Waste Remediation System Integrated Technology Plan, DOE/RL-92-61, Revision 2, U.S. Department of Energy, Richland, Washington, February 1995. [1. p. 1-6 contains figure for TWRS strategy.]

DOE-RL 1995b, Hanford Site Background: Evaluation of Existing Soil Radionuclide Data, DOE-RL-95-55, Rev. 0, U.S. Department of Energy, Richland, Washington, July 1995.

DOE-RL 1996, Request for Proposals (RFP) No. DE-RP06-96RL13308, letter from J.D. Wagoner to Prospective Offerors, Department of Energy, Richland, Washington, February 20, 1996.

Dresel 1994, P.E. Dresel, S.P. Luttrell, J.C. Evans, W.D. Webber, P.D. Thorne, M.A. Chamness, B.M. Gillespie, B.E. Opitz, J.T. Rieger, and J.K. Merz, Hanford Site Ground-Water Monitoring for 1993, PNL-10082, Pacific Northwest Laboratory, Richland, Washington, September 1994.

Ecology 1992, Water Quality Standards for Waters of the State of Washington, Washington Administrative Code, Chapter 173-201, Washington State Department of Ecology, Olympia, Washington, 1992. 


\section{HNE-EP-0884 \\ Rev. 1}

Ecology 1996, Washington State Department of Ecology, United States Environmental Protection Agency, United States Department of Energy, Hanford Facility Agreement and Consent Order, Sixth Amendment, February 1996. The document is available from any of the parties.

[1. Appendix D lists the activities and associated milestones. Activities 45 (closure of single-shell tanks), 50 (pretreatment processing), and 60 (vitrification of Hanford low-level waste) cover the generation of the waste packages for this performance assessment.]

[2. Activity D lists the activities and associated milestones. Activity 50 deals with pretreatment processing.]

[3. Milestone 45-0 in Appendix D describes retrieval criteria.]

Eiholzer 1995, C.R. Eiholzer, Disposal Facility Data for the Interim Performance Assessment, WHC-SD-RPT-159, Revision 0, Westinghouse Hanford Company, Richland, Washington, May 1995.

Eiholzer 1996, Internal Memo to F.M. Mann, "Changes to Facility Concepts due to Privatization Draft Specifications for Low-Activity Waste Package," January 15, 1996.

Engel 1995, D.W. Engel, B.P. McGrail, J.A. Fort, K.S. Lessor, R.E. Williford, and M.K. Altenhofen, Software Design Description for the AREST-CT Code Development, Pacific Northwest Laboratory, Richland, Washington, 1995.

Engel 1995a, D.W. Engel, B.P. McGrail, D.M. Elwood, W.J. Gray, R.E. Einziger, R.E. Williford, W.E. Nichols, and M.K. Altenhofen, Mathematical Document for the ARESTCT Code Development, Number Pacific Northwest Laboratory, Richland, Washington, 1995.

EPA 1988, Limiting Values of Radionuclide Intake and Air Concentration and Dose Conversation Factors for Inhalation, Submersion, and Ingestion, EPA-520/1-88-020, U.S. Environmental Protection Agency Federal Guidance Report Number 11, U.S. Government Printing Office, Washington, D.C., 1988.

EPA 1989a, Exposure Factors Handbook, EPA/600/8-89/043, U.S. Environmental Protection Agency, Washington, D.C., 1989.

EPA 1989b, Risk Assessment Methodology: Environmental Impact Statement for NESHAPS Radionuclides. Volume I: Background Information Document, EPA/520/1-89/005, U.S. Environmental Protection Agency, Washington, D.C., January 1989.

EPA 1993, External Exposure to Radionuclides in Air, Water, and Soil, EPA-402-R-93-081, U.S. Environmental Protection Agency, Washington, D.C., 1993.

ERDA 1975, Final Environmental Statement Waste Management Operations, Hanford Reservation, Richland, Washington, ERDA 1538, Vol. 1-2, U.S. Energy Research and Development Administration, Washington, D.C., December 1975. 
Eyler 1984, L.L. Eyler and M.J. Budden, Verification and Benchmarking of PORFLO: An Equivalent Porous Continuum Code for Repository Scale Analysis, PNL-5044, Pacific Northwest Laboratory, Richland, Washington, November 1984.

Fayer 1995a, M.J. Fayer and T.B. Walters, Estimated Recharge Rate at the Hanford Site, PNL10285, Pacific Northwest Laboratory, Richland, Washington, March 1995.

Fayer 1995b, M.J. Fayer, R.E. Lewis, R. Engelman, A.L. Pearson, C.J. Murray, J.L. Smoot, R.R. Randall,W.H. Wegener, and A.H. Lu, Re-Evaluation of a Subsurface Injection Experiment for Testing Flow and Transport Models, PNL-10860, Pacific Northwest National Laboratory, Richland, Washington, December 1995.

Fecht 1987, K.R. Fecht, S.P. Reidel, and A.M. Tallman, "Paleodrainage of the Columbia River System on the Columbia Plateau of Washington State--A Summary," Selected Papers on the Geology of Washington, Division of Geology and Earth Resources, Bulletin 77, p. 219-248, edited by J.E. Schuster.

Freeze 1979, R.A. Freeze and J.A. Cherry, Groundwater, Prentice-Hall, Inc. Englewood Cliffs, New Jersey, 1979. [Section 2 discusses the principles of water flow.]

Gee 1992, G.W. Gee, M.J. Fayer, M.L. Rockhold, and M.D. Campbell, "Variations in Recharge at the Hanford Site," Northwest Science 66(4):237-250.

Geomatrix Consultants, Inc. 1996, Probablistic Seismic Hazard Analysis for DOE Hanford Site, Washington, WHC-SD-W236A-TI-002, Revision 1, Westinghouse Hanford Company, Richland, Washington, 1996.

Gephart 1979, R.E. Gephart, R.C. Arnett, R.G. Baca, L.S. Leonhart, and F.A. Spane, Jr., Hydrologic Studies Within the Columbia Plateau, Washington: An Integration of Current Knowledge, RHO-BWI-ST-5, Rockwell Hanford Operations, Richland, Washington. 1979.

Gosman 1969, A.D. Gosman, W.M. Pun, A.K. Runchal, D.B. Spaiding, and M. Wolfstein, Heat and Mass Transfer in Recirculating Flows, Academic Press, New York City, New York, 1969.

Gramulich 1987, L.H. Gramulich, "Precipitation Variation in the Pacific Northwest (1675-1975) as Reconstructed from Tree Rings," Annals of the Association of American Geographers, 77:19-29.

Graham 1981, M.J. Graham, M.D. Hall, S.R. Strait, and W.R. Brown, Hydrology of the Separations Area, RHO-ST-42, Rockwell Hanford Operations, Richland, Washington, July 1981. 
Rev. 1

Gupta 1987, S.K. Gupta, C.R. Cole, C.T. Kincaid, and A. Molti, Coupled Fluid, Energy, and Solute Transport (CFEST) Model: Formulation and User's Manual, BMI/ONWI-660, Battelle Memorial Institute, Columbus, Ohio, October 1987.

Hajek 1966, B.F. Hajek, Soil Survey: Hanford Project in Benton County, Washington, BNWL243, Pacific Northwest Laboratory, Richland, Washington.

Hanlon 1996, B.M. Hanlon, Waste Tank Summary Report for Month Ending November 30 , 1995, WHC-EP-0182-92, Westinghouse Hanford Company, Richland, Washington, February 1996:

[1. Table E-1 summarizes the amount of waste in the tanks.] [2. Appendix A provides the status of the tanks.]

Harris 1992, A.W. Harris, A. Atkinson, and P.A. Claisse, "Transport of Gases in Concrete Barriers," Waste Management, 12:155-178, 1992.

Haworth 1988, A. Haworth, S.M. Sharland, P.W. Tasker, and C.J. Tweed, A Guide to the Coupled Chemical Equilibria and Migration Code CHEQMATE, UK Nirex Ltd. Report NSS/R113, United Kingdom, 1988.

HFSUWG 1992a, The Future for Hanford: Uses and Cleanup, Summary of the Final Report of the Hanford Future Site Uses Working Group, December 1992. This report is available through the Environmental Data Management Center, Westinghouse Hanford Company, Richland, Washington.

[1. Page 9 discusses use the central plateau wisely for waste management.]

[2. Page 23 discusses the future use options of the 200 Areas.]

[3. Page 25 discusses the cleanup scenario.]

HFSUWG 1992b, The Future for Hanford: Uses and Cleanup, the Final Report of the Hanford Future Site Uses Working Group, December 1992. This report is available through the Environmental Data Management Center, Westinghouse Hanford Company, Richland, Washington.

Hoitinik 1994, D.J. Hoitinik and K.W. Burk, Climatological Data Summary 1993 with Historical Data, PNL-9809, Pacific Northwest Laboratory, Richland, Washington, 1994.

Honeyman 1995, letter to Mr. L. Erickson, "Peer Review Comments on Hanford Recharge Workshop: May 22-23, 1995," Letter 9554648, Westinghouse Hanford Company, Richland, Washington, September 1995. [The letter has the full report of the panel as an attachment.]

Huyakorn 1993, P.S. Huyakorn and S. Panday, VAM3DCG - Variably Saturated Analysis Model in Three Dimensions with Preconditioned Conjugate Gradient Matrix Solvers: Version 2.4b, Documentation and User's Guide, Hydrogeologic, Inc, Hernadon, Virginia, 1993. 


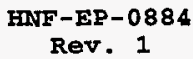

Huyakorn 1994, P.S. Huyakorn and S. Panday, VAM3DCG - Variably Saturated Analysis Model in Three Dimensions with Preconditioned Conjugate Gradient Matrix Solvers:

Documentation and User's Guide, Version 3.l, Hydrogeologic, Inc, Hernadon, Virginia, February 1994.

ICRP 1977, International Commission on Radiological Protection, ICRP Publication 26, Pergamon Press, New York, New York, 1977.

Jenquin 1995, U. Jenquin, "Comments on Se-79 Half-Life ", memo, Pacific Northwest Laboratory, Richland, Washington, December 6, 1995.

Johnson 1993, V.G. Johnson, Groundwater Status Report, WHC-EP-0595, Westinghouse Hanford Company, Richland, Washington, March 1993.

Kaplan 1995a, D.I. Kaplan and R.J. Serne, Distribution Coefficient Values Describing Iodine, Neptunium, Selenium, Technetium, and Uranium Sorption to Hanford Sediments, PNL10379, Sup. 1, Pacific Northwest Laboratory, Richland, Washington, March 1995. [Also included as Appendix Q of Mann 1995a.]

Kaplan 1995b, D.I. Kaplan, R.J. Serne, and M.G. Piepho, Geochemical Factors Affecting Radionuclide Transport Through Near and Far Fields at a Low-Level Waste Disposal Site, PNL-10379, Pacific Northwest Laboratory, Richland, Washington, March 1995. [Also included as Appendix P of Mann 1995a.]

Kemper 1966, W.D. Kemper and J.C. van Schaik, "Diffusion of Salts in Clay-Water Systems", Soil Sci. Am. Proc. 30:534-540, 1966.

Kennedy 1992, W.E. Kennedy and D.L. Strenge, Residual Radioactive Contamination from Decommissioning, Volume 1, NUREG/CR-5512, Pacific Northwest Laboratory, Richland, Washington, October 1992.

Kervevan 1994, C. Kervevan, R. Fabriol, A. Guillen, and J.-P. Sauty, "A Sequential-Parallel Approach for Coupling Chemistry and Transport in Groundwater Quality Modelling," High-Performance Computing and Networking Proceedings, Volume I: Applications, eds W. Gentzch and U. Harms, Springer-Verlag, Berlin, Germany, 1994.

Khaleel 1995, R. Khaleel and E.J. Freeman, A Compilation of Hydrologic Properties for LowLevel Tank Waste Disposal Facility Performance Assessment, WHC-SD-WM-RPT-0165, Revision 0, Westinghouse Hanford Company, Richland, Washington, June 1995. [Also included as Appendix O in Mann 1995a.] 
Rev. 1

Kincaid 1995, C.T. Kincaid, J.W. Shade, G.A. Whyatt, M.G. Piepho, K. Rhoads, J.A. Voogd, J.H. Westsik, Jr., K.A. Blanchard, and B.G. Lauzon, Performance Assessment of Grouted Double-Shell Tank Waste Disposal at Hanford, WHC-SD-WM-EE-004, Revision 1, Westinghouse Hanford Company, Richland, Washington, May 1995.

[1. Section 1.5.1, page 1.15 explains the reason for the selection of 10,000 years as the general time of compliance and of 500 years as the time of inadvertent intruder compliance.]

[2. Sections 3.4 .12 on page 3.69 and 3.4 .13 starting on page 3.70 describe the vadose zone hydrologic parameters.]

[3. Section 3.3.6.6 on page 3.62 describes the effective diffusion constant for the vadose zone.]

[4. Section 2.6 describes the Grout Disposal Facility.]

[5. The population along the Columbia River is found as footnote $f$ to Table 4.2 on page 4.12.]

[6. Appendix G.1 describes code selection.]

[7. Appendix $\mathrm{H}$ describes the benchmarking of PORFLOW $2.394 \mathrm{gr}$ against TRACR3D.]

[8. The footnote to Table 3.20 uses a screen depth of 4.6 meter.]

Kline 1983, N.W. Kline, A.K. Runchal, and R.G. Baca, PORFLO Computer Code: Users Guide, RHO-BW-CR-138P, Rockwell Hanford Operations, Richland, Washington, December 1983.

Kline 1995a, N.W. Kline and R. Khaleel, "Effect of Moisture-Dependent Anisotropy and Enhanced Recharge Around Underground Storage Tanks," Proceedings of the International Conference on Mathematics and Computations, Reactor Physics, and Environmental Analyses, pp. 181-191, American Nuclear Society, Inc., La Grange Park, IL; also WHC-SA-2680-FP, Westinghouse Hanford Company, Richland, Washington, 1995.

Kline 1995b, N.W. Kline, Development of a Unit Cell Model for Interim Performance Assessment of Vitrified Low Level Waste Disposal, WHC-SD-WM-RPT-189, Revision 1, Westinghouse Hanford Company, Richland, Washington, September 1995.

Kline 1996, N.W. Kline, Unit Cell Modeling in Support of the Interim Performance Assessment for Low Level Tank Waste Disposal, WHC-SD-WM-RPT-225, Rev. 0, Westinghouse Hanford Company, Richland, Washington, August 1996.

Kocher 1981, D.C. Kocher, Radioactive Decay Data Tables, DOE/TIC-11026, U.S. Government Printing Office, Washington, D.C. 1981.

Kozak 1989, M.W. Kozak, M.S.Y. Chu, C.P. Harlan, and P.A. Mattingly, Background Information for the Development of a Low-Level Waste Performance Assessment Methodology, NUREG/CR-5453 [SAND89-2509], Volume 4 (Section 2.0), U.S. Nuclear Regulatory Commission, Washington, D.C., 1989. 


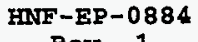

Rev. 1

Kramer 1989, S.L. Kramer and R.D. Holtz, Experimental Investigation of Seismically-Induced Particle Migration, contained in letter from R.D. Holtz to P.L. Brockman, University of Washington, Seattle, Washington, August 1989.

Krupka 1995, K.M. Krupka and R.J. Serne, Performance Assessment of Low-Level Radioactive Waste Disposal Facilities: Effects on Radionuclide Concentrations by Cement/GroundWater Interactions, NUREG/CR-6637, U.S. Nuclear Regulatory Commission, Washington, DC, May 1995.

[Table 5.1 provides $\mathrm{K}_{d}$ values for selected radionuclide elements for concrete environments.]

Law 1996, A. Law, S. Panday, C. Denslow, K. Fetch, A. Knepp, Hanford Sitewide Groundwater Flow and Transport Model Calibration Report, BHI-00608, Rev. 0, Bechtel Hanford Inc., Richland, Washington, April 1996.

Lindsey 1989, K.A. Lindsey and D.R. Gaylord, Sedimentology and Stratigraphy of the MiocenePliocene Ringold Formation, Hanford Site, South-Central Washington, WHC-SA-0740FP, Westinghouse Hanford Company, Richland, Washington, 1989.

Lindsey 1991, K.A. Lindsey, Revised Stratigraphy for the Ringold Formation, Hanford Site, South-central Washington, WHC-SD-EN-EE-004, Revision 0, Westinghouse Hanford Company, Richland, Washington, 1991.

Lindsey 1992, K.A. Lindsey, B.N. Bjornstad, J.W. Lindberg, and K.M. Hoffmann, Geologic Setting of the 200 East Area: An Update, WHC-SD-EN-TI-012, Rev. 0, Westinghouse Hanford Company, Richland, Washington, 1992.

Lowe 1993, S.S. Lowe, W.C. Carlos, J.J. Irwin, R. Khaleel, N.W. Kline, J.D. Ludowise, R.M. Marusich, and P.D. Rittmann, Engineering Study of Tank Leaks Related to Hydraulic Retrieval of Sludge from Tank 241-C-106, WHC-SD-WM-ES-218, Revision 1, Westinghouse Hanford Company, Richland, Washington, June 1993.

Lu 1993, A.H. Lu and R. Khaleel, "Calibration/Validation of VAM3D Model Using Injection Test Data at Hanford," in Vadose Zone Modeling Workshop Proceedings, March 29-30, 1993, R. Khaleel (ed.), p. 99 - 111, WHC-MR-0420, Westinghouse Hanford Company, Richland, Washington, August 1993.

Lu 1994, A.H. Lu and D.W. Langford, Verification and Benchmark Testing of the VAM3D-CG Flow and Transport Code for Use in Performance Assessment at Hanford, WHC-SDER-CSWD-005, Westinghouse Hanford Company, Richland, Washington, July 1994.

Lu 1995, A.H. Lu and D.W. Langford, Verification and Benchmark Testing of Version 3.1 of the VAMBDCG Flow and Transport Computer Code for Use in Performance Assessment at Hanford, WHC-SD-ER-CSWD-007, Westinghouse Hanford Company, Richland, Washington, 1995. 


\section{FWNE-EP-0884 \\ Rev. 1}

Lu 1996, A.H. Lu, Contaminant Transport in the Unconfined Aquifer, Input to the Low Level Tank Waste Interim PA, WHC-SD-WM-RPT-241, Westinghouse Hanford Company, Richland, Washington, June 1996.

Lytle 1995, Headquarters Review of the "Performance Assessment of Grouted Double-Shell Tank Waste at Hanford," memorandum from J.L. Lytle to J. Kinzer, Department of Energy, Washington, D.C., June 1, 1995.

MacKinnon 1994, R.J. MacKinnon, T.M. Sullivan, C.J. Suen, and S.A. Simonson, BLT-EC (Breach, Leach, Transport, and Equilibrium Chemistry), a Finite Element Model for Assessing the Release of Radionuclides from Low-Level Waste Disposal Units:

Background, Theory, and Model, Description, Brookhaven National Laboratory, Upton, New York, 1994.

Magnuson 1990, S.O. Magnuson, K.G. Baca, and A.J. Sondrup, Independent Verification and Benchmark Testing of the PORFLO-3 Computer Code, Version 1.0, EGG-86-9175, EG\&G Idaho, Inc., Idaho Falls, Idaho, 1990.

Mangold 1991, D.C. Mangold and C.F. Tsang, "A Summary of Subsurface Hydrological and Hydrochemical Models" Review of Geophysics, Vol. 29, 51-79, 1991.

Mann 1995a, F.M. Mann, Data Packages for the Hanford Low-Level Tank Waste Interim Performance Assessment, WHC-SD-WM-RPT-166, Revision 0, Westinghouse Hanford Company, Richland, Washington, July 1995.

Mann 1995b, F.M. Mann, C.R. Eiholzer, R. Khaleel, N.W. Kline, A.H. Lu, B.P. McGrail, P.D. Rittmann, and F. Schmittroth, Definition of the Base Analysis Case of the Interim Performance Assessment, WHC-SD-WM-RPT-200, Revision 0, Westinghouse Hanford Company, Richland, Washington, December 1995.

Mann 1995c, F.M. Mann, Computer Code Selection Criteria and Considerations for the Hanford Tank Low-Level Waste Interim Performance Assessment, WHC-SD-WMCSWD-073, Westinghouse Hanford Company, Richland, Washington, March 1995. [Also included as Appendix D in Mann 1995a.]

Mann 1995d, F.M. Mann, C.R. Eiholzer, N.W. Kline, B.P. McGrail, and M.G. Piepho, Impacts of Disposal System Design Options on Low-Level Glass Waste Disposal System Performance, WHC-EP-0810, Revision 1, Westinghouse Hanford Company, Richland, Washington, September 1995.

Mann 1996, F.M. Mann, INTEG: A Program to Calculate Groundwater Contamination and Human Doses, WHC-SD-WM-RPT-219, Westinghouse Hanford Company, Richland, Washington, June 1996. 


\section{HANE-EP -0884}

Rev. 1

McDonald 1988, M.G. McDonald and A.W. Harbaugh, "A Modular Three-Dimensional Finite Difference Groúndwater Flow Model," Techniques of Water Resources Investigations, 06-A1, United States Geological Survey, Washington, D.C., 1988.

McGrail 1994, B.P. McGrail and L.A. Mahoney, Selection of a Computer Code for Hanford Low-Level Waste Engineered-System Performance Assessment, PVTD-C95-04-01E, Revision 1, Pacific Northwest Laboratory, Richland, Washington, December 1994. [Also included as Appendix $\mathrm{G}$ in Mann 1995a]

McGrail 1995, B.P. McGrail and D.K. Peeler, Evaluation of the Single-Pass Flow-Through Test to Support a Low-Activity Waste Specification, PNL-10746, Pacific Northwest Laboratory, Richland, Washington, September 1995.

Mitchell 1995, D.E. Mitchell, Immobilized Low-Level Waste Disposal Options Configuration Study, WHC-SD-WM-TI-686, Revision 0, Westinghouse Hanford Company, Richland, Washington, February 1995.

Mualem 1976, Y. Mualem, "A New Model for Predicting the Hydraulic Conductivity of Unsaturated Porous Media," Water Resources Research, 12 (1976) 513.

Murkowski 1995, letter from R.J. Murkowski to L. Erickson, "Performance Objectives and Scenario for the Glass Low-Level Waste Interim Performance Assessment," Correspondence Number 9550371, Westinghouse Hanford Company, Richland, Washington, January 27, 1995.

Myers 1979, C.W. Myers, S.M. Price, J.A. Caggiano, M.P. Cochran, W.J. Czimer, N.J. Davidson, R.C. Edwards, K.R. Fecht, G.E. Holmes, M.G. Jones, J.R. Kunk, R.D. Landon, R.K. Ledgerwood, J.T. Lillie, P.E. Long, T.H. Mitchell, E.H. Price, S.P. Reidel, and A.M. Tallman, Geologic Studies of the Columbia Plateau: A Status Report, RHO-BWI-ST-4, Rockwell Hanford Operations, Richland, Washington, October 1979.

Myers 1981, C.W. Myers and S.M. Price. "Bedrock Structure of the Cold Creek Syncline Area," in Subsurface Geology of the Cold Creek Syncline, RHO-BWI-ST-14 [see Tallman 1981], Rockwell Hanford Operations, Richland, Washington, July 1981.

Myers 1994, D.R. Myers and D.A. Duranceau, Prototype Hanford Surface Barrier: Design Bases Document, BHI-0007, Bechtel Hanford Company, Richland, Washington, November 1994.

Napier 1984, B.A. Napier, R.A. Peloquin, W.E. Kennedy Jr., and S.M. Neuder, Intruder Dose Pathway Analysis for the Onsite Disposal of Radioactive Wastes: The ONSITE/MAXII Computer Program, NUREG/CR-3620, U.S. Nuclear Regulatory Commission, Washington, DC, 1984. 
Napier 1988, B.A. Napier, R.A. Peloquin, D.L. Strenge, and J.V. Ramsdell, GENII - The Hanford Environmental Radiation Dosimetry Software System, PNL-6584, Pacific Northwest Laboratory, Richland, Washington, December 1988.

NCRP 1987, Ionizing Radiation Exposure of the Population of the United States, Report No. 93, National Council on Radiation Protection, Bethesda, Maryland.

NEPA, National Environmental Policy Act of 1969, 42 U.S.C. 4321 et seq.

Newcomb 1958, R.C. Newcomb, "Ringold Formation of the Pleistocene Age in the Type Locality, the White Bluffs, Washington," American Journal of Science, 33(1):328-340.

Newcomb 1972, R.C. Newcomb, J.R. Strand, and F.J. Frank, Geology and Groundwater Characteristics of the Hanford Reservation of the U.S. Atomic Energy Commission, Washington, Geological Survey Professional Paper 717, U.S. Geological Survey, Washington, D.C. 1972.

NLLWMP 1992, Proceedings of the Department of Energy Performance Assessment Briefing, Denver, Colorado, October 29, 1991, DOE/LLW-138, National Low-Level Waste Management Program, Idaho National Engineering Laboratory, Idaho Falls, Idaho, February 1992.

Noorishad 1987, J. Noorishad, C.L. Carnahan, and J.V. Benson, Development of the NonEquilibrium Reactive Chemical Transport Code CHMTRNS, LBL-22361, Lawrence Berkeley Laboratory, Berkeley, California, 1987.

NRC 1997, Branch Technical Position on a Performance Assessment Methodology for LowLevel Radioactive Waste Disposal Facilities (draft for public comment). NUREG-1573. Low-Level Waste Management Branch, U.S. Nuclear Regulatory Commission, Washington, D.C., May 1997.

[1. Section 3.2.3 describes the time frame for performance assessment analyses.]

[2. Sections 3.2.2 and 3.3.4 discusse the role and timing assumptions for engineered systems.]

[3. Section 3.2.1.2 discusses.site conditions to be used in performance assessment]

OFM 1994, Office of Financial Management, 1994 Population Trend for Washington State, Office of Financial Management, Forecasting Division, Olympia, Washington, 1994.

PAG 1994, Hanford Tank Low-Level Waste Performance Assessment Group, Statements of Work for FY 1995 to 2000, WHC-SD-WM-PAP-062, Revision 0, Westinghouse Hanford Company, Richland, Washington, June 1994. 


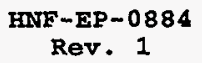

PAG 1995, Hanford Tank Low-Level Waste Performance Assessment Group, Statements of Work for FY 1996 to 2001 for the Hanford Low-Level Tank Waste Performance Assessment Project, WHC-SD-WM-PAP-062, Revision 1, Westinghouse Hanford Company, Richland, Washington, June 1995.

[1. Section 3.1.9 describes plans for recharge rate determination.]

[2. Section 3.1.D describes the integrated borehole activity. Other activities described in the SOW will obtain samples from these boreholes.]

Paperiello 1997, C.J. Paperiello (Director of Office of Nuclear Material Saety and Safeguards), letter dated June 1997 to Jackson Kinzer (Assistant Manager, Office of Tank Waste Remediation Systems) "Classification of Hanford Low-Activity Tank Waste Fraction". \{Letter is given in Appendix F.3.3\}.

PAT 1994, Performance Assessment Team, Performance Objectives of the Tank Waste Remediation Systems Low-Level Waste Disposal Program, WHC-EP-0826, Revision 0, Westinghouse Hanford Company, Richland, Washington, December 1994.

PAT 1995a, Performance Assessment Team, Performance Objectives of the Tank Waste Remediation Systems Low-Level Waste Disposal Program, WHC-EP-0826, Revision 1, Westinghouse Hanford Company, Richland, Washington, January 1995. [Included as Appendix B in Mann 1995a.]

PAT 1995b, Performance Assessment Team, Scenarios of the TWRS Low-Level Waste Disposal Program, WHC-EP-0828, Revision 1, Westinghouse Hanford Company, Richland, Washington, January 1995. [Included as Appendix C in Mann 1995a.]

Petersen 1995; C.A. Petersen, "Radionuclide Solubility," DSI to G.F. Williamson, Westinghouse Hanford Company, Richland, Washington, November 27, 1995.

Piepho 1991, M.G. Piepho and A.K. Runchal, "A Comparison of Three Methods for Solving Flow Equations of Two Immiscible Fluids in Variably Saturated Media," Proceedings of the Third Symposium on Multiphase Transport in Porous Media, American Society of Mechanical Engineers; also WHC-SA-1289-FP, Westinghouse Hanford Company, Richland, Washington, 1991.

Piepho 1994, M.G. Piepho, W.H. Sutherland and P.D. Rittmann, The Grout/Glass Performance Assessment Code System (GPACS) with Verification and Benchmarking, WHC-SD-WMUM-019, Revision 0, Westinghouse Hanford Company, Richland, Washington, December 1994. [Also included as Appendix F in Mann 1995a.]

Piepho 1995, M.G. Piepho, Selection of Flow and Transport Code for the Hanford Low-Level Tank Waste Interim Performance Assessment, WHC-SD-WM-CSWD-074, Revision 0, Westinghouse Hanford Company, Richland, Washington, February 1995. [Also included as Appendix E in Mann 1995a.] 
Rev. 1

Piepho 1996, M.G. Piepho, Low-Level-Vitrification-Waste Performance Assessment Flow and Transport Modelling, DBSA-PNWB-967-42, Daniel B. Stevens \& Associates, Inc., Richland, Washington, May 1996.

PNL 1994, Quality Assurance Plan, PNL-MA-70, Pacific Northwest Laboratory, Richland, Washington, August 1994.

Power 1981, M.S. Power, K.J. Coppersmith, R.R. Youngs, D.P. Schwratz, and F.H. Swam III, Final Safety Analysis Report WNP-2, Amendment N.18, Appendix 2.5K, "Seismic Exposure Analysis for the WNP-2 and WNP-1/4 Site," Washington Public Power Supply System, Richland, Washington.

Prych 1995, E.A. Prych, Estimating Deep Percolation Rates at Selected Locations on the USDOE Hanford Site, WA, Using Two Chloride-Tracer Methods, Open File 94-514, U.S. Geological Survey, Tacoma, Washington, 1995.

PSPL 1982, Skagit/Hanford Nuclear Project, Preliminary Safety Analysis Report,.Vol. 4, App. 20, Amendment 23, Puget Sound Power and Light Company, Bellevue, Washington.

Rawlins 1994, J.A. Rawlins, R.A. Karnesky, R. Khaleel, A.H. Lu, F.M. Mann, B.P. McGrail, W.J. McMahon, M.G. Piepho, P.D. Rittmann, and F. Schmittroth, Impacts of Disposal System Design Options on Low-Level Glass Waste Disposal System Performance, WHCEP-0810, Revision 0, Richland, Washington, September 1994.

RCRA, Resource Conservation and Recovery Act of 1976, 42 U.S.C. 6901, et seq.

Reeves 1994, M. Reeves, N.A. Baker, and J.O. Duguid, Review and Selection of Unsaturated Flow Models, B00000000-01425-2200-00001, Revision 0, INTERA, Inc., Las Vegas, Nevada, 1994.

Reidel 1989, S.P. Reidel and P.R. Hooper, editors, "Volcanism and Tectonism in the Columbia River Flood-Basalt Province," Special Paper 239, Geological Society of America, Boulder, Colorado, p. 386, plate 1, 1989.

Reidel 1993, S.P Reidel., V.G. Johnson and N.W. Kline, Groundwater Impact Assessment for the 216-U-17 Crib, 200 West Area, WHC-EP-0664, Westinghouse Hanford Company, Richland, Washington, June 1993.

Reidel 1995, S.P. Reidel, A.M. Tallman, V.G. Johnson, C.J. Chou, S.M. Narbutovski, and J.P. Kiesler, TWRS Complex Site Characterization Plan, Westinghouse Hanford Company, Richland, Washington, June 1995. 
Rhoads 1994, K. Rhoads, B.N. Bjornstad, R.E. Lewis, S.S. Teel, K.J. Cantrell, R.J. Serne, L.H. Sawyer, J.L. Smoot, J.E. Szecsody, M.S. Wigmosta, and S.K. Wurnster, Estimation of the Release and Migration of Nickel Through Soils and Groundwater at the Hanford Site 218-E-12B Burial Ground, PNL-9791, Pacific Northwest Laboratory, Richland, Washington, 1994.

Rhoads 1996, Kathleen Rhoads, "HEDOP Review of LL Tank Waste PA", memo from K. Rhoads to Fred Mann, Pacific Northwest National Laboratory, Richland, Washington, September 1996.

Richards 1931, L.A. Richards, "Capillary Conduction of Liquids Through Porous Mediums," Physics, 1 (1931) 318.

Rittmann 1993, P.D. Rittmann, GRTPA - A Program to Calculate Human Dose from PORFLOW Output, WHC-SD-WM-UM-018, Westinghouse Hanford Company, Richland, Washington, November 1993.

Rittmann 1994, P.D. Rittmann, Dose Estimation for the Solid Waste Performance Assessment, WHC-SD-WM-TI-616, Westinghouse Hanford Company, Richland, Washington, August 1994.

Rittmann 1995, P.D. Rittmann, Data and Assumptions for Estimates of Radiation Doses for the Glass Low-Level Waste Interim Performance Assessment, WHC-SD-WM-TI-707, Revision 0, Westinghouse Hanford Company, Richland, Washington, June 1995. [Also included as Appendix $R$ in Mann 1995a.]

Rockhold 1993, M.L. Rockhold, M.J. Fayer, and P.R. Heller, Physical and Hydraulic Properties of Sediments and Engineered Materials Associated with Grouted Double-Shell Tank Waste Disposal at Hanford, PNL-8813, Pacific Northwest Laboratory, Richland, Washington, September 1993. [Also Appendix J of Kincaid 1995.]

Rockhold 1995, M.L. Rockhold, M.J. Fayer, C.T. Kincaid, and G.W. Gee, Estimate of the Natural Ground Water Recharge for the Performance Assessment of a Low-Level Waste Disposal Facility at the Hanford Site, PNL-10508, Pacific Northwest Laboratory, Richland, Washington, March 1995. [Also included as Appendix K in Mann 1995a.]

Routson 1990, R.C. Routson and V.G. Johnson, "Recharge Estimates for the Hanford Site 200 Area Plateau," Northwest Science, 64:150-158, 1990.

Runchal 1979, A.K. Runchal and T. Maini, "Regional Groundwater Flow Near a High-Level Radioactive Waste Repository," Engineering Bulletin 50, pp. 11-20, Dames and Moore, 1979.

Runchal 1985, A.K. Runcal, B. Sagar, R.G. Baca, and N.W. Kline, PORFLO - A Continuum Model for Fluid Flow, Heat Transfer, and Mass Transport in Porous Media, RHO-BWCR-150P, Rockwell Hanford Operations, Richland, Washington, 1985. 


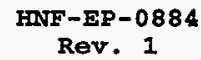

Runchal 1992, A.K. Runchal, B. Sagar and N.W. Kline, PORFLO-3: A Mathematical Model for Fluid Flow, Heat, and Mass Transport in Variably Saturated Geologic Media; Users Manual, Version 1.2, WHC-EP-0385, Westinghouse Hanford Company, Richland, Washington, December 1992.

RWTSP 1994, A Compilation of DOE Performance Assessment Peer Review Panel Review Comments and Recommendations, DOE/LLW-216, Radioactive Waste Technical Support Program, Idaho National Engineering Laboratory, Idaho Falls, Idaho, 1994.

Sagar 1990, B. Sagar and A.K. Runchal, PORFLO-3: A Mathematical Model for Fluid Flow, Heat, and Mass Transport in Variably Saturated Geologic Media; Theory and Numerical Methods, Version 1.0, WHC-EP-0042, Westinghouse Hanford Company, Richland, Washington, March 1990.

Schreckhise 1993, R.G. Schreckhise, K. Rhoads, J.S. Davis, B.A. Napier, and J.V. Ramsdell, Recommended Environmental Dose Calculation Methods and Hanford Specific Parameters, PNL-3777, Rev. 2, Pacific Northwest Laboratory, Richland, Washington, 1993.

Schmittroth 1995a, F.A. Schmittroth and T.H. DeLorenzo, Consequence Ranking of Radionuclides in Hanford Tanks Waste, WHC-SD-WM-RPT-163, Revision 0, Westinghouse Hanford Company, Richland, Washington, September 1995.

Schmittroth 1995b, F.A. Schmittroth, T.H. DeLorenzo, D.W. Wootan, and D.Y. Garbrick, Inventories for Low-Level Tank Waste, WHC-SD-WM-RPT-164, Revision 0, Westinghouse Hanford Company, Richland, Washington, June 1995. [Also included as Appendix J in Mann 1995a.]

Serne 1993, R.J. Serne, "Solid-Waste Leach Characteristics and Contaminant-Sediment Interactions, Volume 1: Batch Leach and Adsorption Tests and Sediment Characterization", PNL-8889, Vol. 1, Pacific Northwest Laboratory, Richland, Washington, 1993.

Shelton, 1995, L.W. Shelton, DSI to F. Schmittroth and A. L. Boldt, Westinghouse Hanford Company, Richland, Washington, May 22, 1995. [Attachment 1 to Schmittroth 1995a.]

Shord 1995, A.L. Shord, Tank Waste Remediation System Complex Site Evaluation Report, WHC-SD-WM-SE-021, Revision 0, Westinghouse Hanford Company, Richland, Washington, May 1995.

Simunek 1993, J. Simunek and D.L. Suarez, UNSATCHEM-2D Code for Simulating Saturated Water Flow, Heat Transport; Carbon Dioxide Production and Transport, and Multicomponent Solute Transport with Major Ion Equilibrium and Kinetic Chemistry, Research Report No. 128, U.S. Salinity Laboratory, Riverside, California, 1993. 
Singleton 1994, K.M. Singleton and K.A. Lindsey, Groundwater Impact Assessment Report for the 216-U-14 Ditch, WHC-EP-0698, Westinghouse Hanford Company, Richland, Washington, January 1994.

Sisson 1984, J.B. Sisson and A.H. Lu, Field Calibration of Computer Models for Applications to Buried Liquid Discharges: A Status Report, RHO-ST-46p, Rockwell Hanford Company, Richland, Washington, August 1984.

Skaggs 1981, R. L. Skaggs and W. H. Walters, Flood Analysis of Cold Creek Near the Hanford Site, RHO-BWI-C-120/PNL-4219, Rockwell Hanford Operations, Richland, Washington, 1981.

Smith 1990, R.M. Smith and W.R. Gorst, RCRA Ground-Water Monitoring Projects for Hanford Facilities: Annual Progress Report for 1989, PNL-7215, Pacific Northwest Laboratory, Richland, Washington, 1990.

Stewart 1987, G.H. Stewart, W.T. Farris, D.G. Huizenga, A.H. McMakin, G.P. Streile, and R.L. Treat, Long-Term Performance Assessment of Grouted Phosphate/Sulfate Waste from $N$ Reactor Operations, PNL-6512, Pacific Northwest Laboratory, Richland, Washington, April 1987.

Stone 1983, W.A. Stone, J.M. Thorp, O.P. Gifford, and D.J. Hoitink, Climatological Summary for the Hanford Area, PNL-4622, Pacific Northwest Laboratory, Richland, Washington, June 1983.

Strack 1989, O.D.L. Strack, Groundwater Mechanics, Prentice-Hall, Englewood Cliffs, New Jersey, 1989.

Tallman 1979, A.M. Tallman, K.R. Fecht, M.C. Marratt, and G.V. Last, Geology of the Separation Areas Hanford Site, South Central Washington, RHO-ST-23, Rockwell Hanford Operations, Richland, Washington, 1979.

Tallman 1981, A.M. Tallman, J.T. Lillie, K.R. Fecht, C.W. Myers, and S.M. Price, "Suprabasalt Sediments of the Cold Creek Syncline Area," Subsurface Geology of the Cold Creek Syncline, RHO-BWI-ST-14, Rockwell Hanford Operations, Richland, Washington, 1981.

Thorne 1992, P.D. Thorne and D.R. Newcomer, Summary and Evaluation of Available Hydraulic Property Data for the Hanford Site Unconfined Aquifer System, PNL-8337, Pacific Northwest Laboratory, Richland, Washington, November 1992.

Travis 1991, B.J. Travis and K.H. Birdsell, TRACR3D: A Model of Flow and Transport in Porous Media, LA-1 1798-M, Los Alamos National Laboratory, Los Alamos, New Mexico, 1991. 


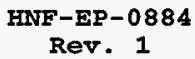

van Genuchten 1980, M.Th. van Genuchten, "A Closed Form Equation for Predicting the Hydraulic Conductivity of Unsaturated Soils," Journal of the American Soil Science Society, $\underline{44}$ (1980) 892.

van Genuchten 1991, M.Th. van Genuchten, F.J. Leij, and S.R. Yates, The RETC Code for Quantifying the Hydraulic Functions of Unsaturated Soils, EPA/000/0-91/000, U.S. Environmental Protection Agency, Washington, D.C. 1991.

WAC 173-200, "Water Quality Standards for Ground Waters of the State of Washington," Washington State Administrative Code, 173-200, Section 170, Washington State Department of Ecology, Olympia, Washington, December 1, 1990.

WAC 173-201A, "Water Quality Standards for Surface Waters of the State of Washington," Washington State Administrative Code 173-201A, Washington State Department of Ecology, Olympia, Washington, December 22, 1992.

WAC 173-480, "Ambient Air Quality Standards and Emission Limits for Radionuclides," Washington State Administrative Code 173-480, Section 040, Washington State Department of Ecology, Olympia, Washington, July 7, 1986.

WAC 246-247, "Radiation Protection - Air Emissions," Washington State Administrative Code 246-247, Section 040, Washington State Department of Ecology, Olympia, Washington, January 31, 1991.

Warrick 1976, A.W. Warrick and D.O. Homer, "Time Dependent Linearized Infiltration: III. Strip and Disc Sources," Science Soc. Amer. Proc. 40, 639-643, 1976.

Watson 1984, E.C. Watson, C.D. Becker, R.E. Fitzner, K.A. Gano, K.L. Imhoff, R.F. McCallum, D.A. Myers, T.L. Page, K.R. Price, J.V. Ramsdell, D.G. Rice, D.L. Schreiber, L.A. Skumatz, D.J. Sommer, J.J. Tawil, R.W. Wallace, and D.G. Watson, Environmental Characterization of Two Potential Locations at Hanford for a New Production Reactor, PNL-5275, Pacific Northwest Laboratory, Richland, Washington, September 1984.

WCC 1989, Evaluation of Seismic Hazard for N-Reactor Facilities, Hanford Reservation, Hanford, Washington, WHC-MR-0023, Prepared for Westinghouse Hanford Company by Woodward-Clyde Consultants, Oakland, California.

Westsik 1997, J.H. Westsik, Jr. and P.L. Miller, "Preliminary Product Acceptance Strategy for ILAW, IHLW, Intermediate Products, and Secondary Wastes," WIT-097-036, Pacific Northwest National Laboratory, Richland, Washington, January 1997.

WHC 1990, Liquid Effluent Study Final Project Report, WHC-EP-0367, Westinghouse Hanford Company, Richland, Washington, August 1990.

WHC 1992, Quality Assurance Manual, WHC-CM-4-2, Westinghouse Hanford Company, Richland, Washington, 1992. 
WHC 1993, Software Practices, WHC-CM-3-10, Westinghouse Hanford Company, Richland, Washington, January 1993.

WHC 1994a, Standard Engineering Practices, WHC-CM-6-1, Westinghouse Hanford Company, Richland, Washington, May 1994.

WHC 1994b, Overview of the Performance Objectives and Scenarios of the TWRS Low-Level Waste Disposal Program, WHC-EP-0827, Revision 0, Westinghouse Hanford Company, Richland, Washington, October 1994.

[Based on comments on Revision 0, Revision 1 was issued in January 1995. Revision 1 is included as Appendix A in Mann 1995a.]

WHC 1995, Scenarios of the TWRS Low-Level Waste Disposal Program, WHC-EP-0828, Revision 1, Westinghouse Hanford Company, Richland, Washington, January 1995. [Also included as Appendix C in Mann 1995a.]

WHC 1996, Technical Basis for Classification of Low-Activity Waste Function from Hanford Site Tanks, WHC-SD-WM-TI-699, Revision 1, Westinghouse Hanford Company, Richland, Washington, July 1996.

Wilhite 1994, Performance Assessment Peer Review Panel Recommendations on the "Performance Assessment of Grouted Double-Shell Tank Waste Disposal at Hanford" WHC-SD-WM-EE-004, Revision O (U), letter from E.L. Wilhite to J.A. Turi, SRT-WED94-01 12, Westinghouse Savannah River Company, Aiken, South Carolina, October 4 , 1994.

Wolery 1992, T.J. Wolery, EQ3NR, A Computer Program for Geochemical Aqueous SpeciationSolubility Calculations:Theoretical Manual, User's Guide, and Related Documentation, UCRL-MA-1 10662-PT-III, Lawrence Livermore Laboratory, Livermore, California, 1992.

Wood 1992, R.F. Wood, Hanford Site Grout Facilities Quality Assurance Plan, WHC-EP-0494, Revision 0, Westinghouse Hanford Company, Richland, Washington, January 1992.

Wood 1994a, D.E. Wood (Chairman), R.U. Curl (Technical Secretary), D.R. Armstrong, J.R. Cook, M.R. Dolenc, D.C. Kochner, K.W. Owens, E.P. Regnier, G.W. Roles, R.R. Seitz, and M.I. Wood, Performance Assessment Task Team Progress Report, DOE/LLW-157, Revision 1, Idaho National Engineering Laboratory, Idaho Falls, Idaho, May, 1994.

Wood, 1994b, M.I. Wood, R. Khaleel, P.D. Rittmann, A.H. Lu, S.H. Finfrock, R.J. Serne, and K.J. Cantrell, Performance Assessment for the Disposal of Low-Level Waste in the 200 West Area Burial Grounds, WHC-EP-0645, Westinghouse Hanford Company, Richland, Washington, November, 1994.

[1. Section 1.6, page 1-8 discusses the time of compliance.]

[2. P. 3-31 provides the discussion of the radon diffusivity coefficient.]

[3. Section 4.3.1 provides the calculation of the release of contaminants to air] 
Rev. 1

Wood 1995, M.I. Wood, R. Khaleel, P.D. Rittmann, A.H. Lu, S.H. Finfrock, and T.H.

DeLorenzo, Environmental Remediation Disposal Facility Performance Assessment, BHI-00169, Revision 00, Bechtel Hanford Company, Richland, Washington, August 1995.

Wood 1996, M.I. Wood, Performance Assessment for the Disposal of Low-Level Waste in the 200 East Area Burial Grounds, WHC-EP-0875, Westinghouse Hanford Company, Richland, Washington, September 1996.

Woodruff 1992, R.K. Woodruff, R.W. Hanf, and R.E. Lundgren, Hanford Site Environmental Report for Calendar Year 1991, PNL-8148, Pacific Northwest Laboratory, Richland, Washington, 1992.

WSRC 1992, Radiological Performance Assessment for the Z-Area Saltstone Disposal Facility, WSRC-RP-92-1360 (Appendix B.10), Westinghouse Savannah River Company, Aiken, South Carolina, December 1992.

Wurstner 1995, S.K. Wurstner, P.D. Thorne, M.A. Chamness, M.D. Freshley, and M.D. Williams, Development of a Three-Dimensional Ground-Water Model of the Hanford Site Unconfined Aquifer System: FY 1995 Status Report, PNL-10886, Pacific Northwest National Laboratory, Richland, Washington, December 1995.

Yang 1986, Y. Yang and C.B. Nelson, "An Estimate of Daily Food Usage Factors for Assessing Radionuclide Intakes in the U.S. Population," Health Physics, $\underline{50}$ (1986) 245.

Yeh 1990, G.T. Yeh and V.S. Tripathi, HYDROGEOCHEM: A Coupled Model of Hydrologic

Transport and Geochemical Equilibria in Reactive Multicomponent Systems, DE91007825, Oak Ridge National Laboratory, Oak Ridge, Tennessee, 1990. 
This document was too large to scan as a whole document; therefore, it is divided into smaller sections.

DOCUMENT NUMBER: HNF-EP-0884

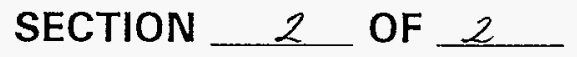

TITLE:

Appenalces A threU $F$

DATE:

$9101 / 97$

REV:

\section{ORIGINATOR: F.MMANN, C.R.EIHOLZER,Y.CHEN, NW.KLINE, \\ CO: A.H. LU, B.P. MC GRAIL, R.D. RITMANN}

REFERENCES:

KEYWORDS:

PROJECTS: TFARM, TWRS 
Rev. 1

\section{APPENDIX A \\ SPECIFICATIONS FOR IMMOBILIZATION \\ (USDOE/RI 1996) \\ [References are given in section 2.2 .1 \\ and not necessarily in Chapter 7.]}

[These spefications have been incorporated into the contracts with British Nuclear Fuels Limited, Inc. (DE-RP06-96RL13308) and with Lockheed Martin Advanced Environmental Systems (DE-RP0696RL13309)

Specification 2: Immobilized Low-Activity Waste

2.1 Scope: This Specification defines the requirements for the Immobilized Low-Activity Waste (ILAW) product, one of the final waste products identified in Section C.4 of this Statement of Work.

\subsection{Requirements:}

\subsubsection{References:}

2.2.1.1 10 CFR 61. Licensing Requirements for Land Disposal of Radioactive Waste, Code of Federal Regulations. U.S. Nuclear Regulatory Commission, Washington, D.C.

2.2.1.2 40 CFR 268. Land Disposal Restrictions. Code of Federal Regulations. U.S. Environmental Protection Agency, Washington, D.C.

2.2.1.3 49 CFR 172.101. Table 2-Radionuclides. Code of Federal Regulations. U.S. Department of Transportation, Washington, D.C.

2.2.1.4 49 CFR 173. Shippers-General Requirements for Shipments and Packaging. Subpart I - Radioactive Materials, Code of Federal Regulations. U.S. Department of Transportation, Washington, D.C.

2.2.1.5 ANSI Standard N14.5. January 16, 1987. American National Standard for Radioactive Materials - Leakage Tests on Packages for Shipment. American National Standards Institute, New York, New York.

2.2.1.6 ANSI/ANS-16.1. April 14, 1986. Measurement of the Leachability of Solidified Low-Level Radioactive Wastes by a Short Term Test Procedure. American National Standards Institute/American Nuclear Society, La Grange Park, Illinois.

2.2.1.7 ANSI/ANS-55.1. July 28, 1992. American National Standard for Solid Radioactive Waste Processing System for Light-Water-Cooled Reactor Plants; Appendix B - Testing for Free Liquids in Solidified Matrices. American National Standards Institute/American Nuclear Society, La Grange Park, Ilinois.

2.2.1.8 ASTM B553-79. May 25, 1979. Standard Test Methods of Electroplated Plastics. American Society for Testing and Materials. Easton, Maryland. 


\section{HWF-EP-0884 \\ Rev. 1}

2.2.1.9 ASTM C39-94. November 15, 1994. Standard Test Method for Compressive Strength of.Cylindrical Concrete Specimens. American Society for Testing and Materials, Easton, Maryland.

2.2.1.10 ASTM C1285-94. October 15, 1994. Standard Test Methods for Determining Chemical Durability of Nuclear Waste Glasses: Product Consistency Test $(P C T)$. American Society for Testing and Materials, Easton, Maryland.

2.2.1.11 ASTM G21-90. October 26, 1990. Standard Practice for Determining Resistance of Synthetic Polymeric Materials to Fungi. American Society for Testing and Materials. Easton, Maryland.

2.2.1.12 ASTM G22-76. November 26, 1976. Standard Practice for Determining Resistance of Plastics to Bacteria. American Society for Testing and Materials, Easton, Maryland.

2.2.1.13 DOE Order 5820.2A. September 26, 1988. Radioactive Waste Management. U.S. Department of Energy, Washington, D.C.

2.2.1.14 NRC. January 1995. Branch Technical Position on Concentration Averaging and Encapsulation. Division of Waste Management, Office of Nuclear Material Safety and Safeguards, U.S. Nuclear Regulatory Commission, Washington, D.C.

2.2.1.15 NRC. January 1991. Technical Position on Waste Form, Rev. 1, Low-Level Waste. Division Management Branch, Office of Nuclear Material Safety and Safeguards, U. S. Nuclear Regulatory Commission, Washington, D.C.

2.2.1.16 NUREG/BR-0204. April 1995. Instructions for Completing NRC's Uniform LowLevel Radioactive Waste Manifest. U.S. Nuclear Regulatory Commission, Washington, D.C.

2.2.1.17 NUREG-1293. Rev. 1. April 1991. Pittiglio, C. L., Jr., and D. Hedges. Quality Assurance Guidance for a Low-Level Radioactive Waste Disposal Facility. Division of Low-Level Waste Management and Decommissioning, Office of Nuclear Material Safety and Safeguards, U.S. Nuclear Regulatory Commission, Washington, D.C.

2.2.1.18 SW-846, Method 9095. Rev. 0. September 1986. Paint Filter Liquids Test. In Test Methods for Evaluating Solid Waste, Volume 1C: Laboratory Manual Physical/Chemical Methods, U.S. Environmental Protection Agency, Office of Solid Waste and Emergency Response, Washington, D.C.

2.2.1.19 WA 7890008967. Rev. 2. August 1995 (as modified). Dangerous Waste Portion of the Resource Conservation and Recovery Act Permit for the Treatment, Storage and Disposal of Dangerous Waste. Hanford Facility, Washington State Department of Ecology, Olympia, Washington.

2.2.1.20 WAC 173-303. 1995. Dangerous Waste Regulations, Washington Administrative Code, as amended. 


\section{HWNE-EP- 0884 \\ Rev. 1}

\subsubsection{Product Requirements:}

2.2.2.1 Package Description: The ILAW products shall be in the form of a package. The constituent parts of each package are: a sealed metal container enclosing a waste form, in which the ILAW product is emplaced; an optional matrix material, which may be used to encapsulate the waste form; and an optional filler material, which may be used to fill void spaces in the container before it is closed.

2.2.2.2 Waste Loading: For every gram-mole of sodium provided to the Contractor in Waste Envelopes A and C, the Contractor may produce up to $100 \mathrm{~cm}^{3}$ of ILAW product (based on the external dimensions of the package). For every gram-mole of sodium in Waste Envelope B, the Contractor may produce up to $250 \mathrm{~cm}^{3}$ of ILAW product (based on the external dimensions of the package).

2.2.2.3 Size and Configuration: The package shall be a rectangular metal container and shall have an external dimension, including all appurtenances, of $1.8 \mathrm{~m}$ (length) $\mathrm{x}$ $1.2 \mathrm{~m}$ (width) $\times 1.2 \mathrm{~m}$ (height) $\pm 0.2 \mathrm{~m}$. Once a package size is selected, the dimension of all packages shall be constant and have a dimensional tolerance of $\pm 0.01 \mathrm{~m}$.

2.2.2.4 Mass: The mass of each package shall not exceed 10,000 kg.

2.2.2.5 Void Space: The head space in the fully loaded package shall not exceed 1 percent of the total internal volume of the container. A non-compactible filler material (screened to 4 mesh size or smaller) may be used to meet this requirement. If the waste form and matrix materials are loaded into the container in a manner that results in void spaces between the emplaced pieces, the filler material shall be used to fill the void spaces. If a filler material is used, it shall be compatible with the other materials in the package.

2.2.2.6 Chemical Composition Documentation: The Contractor shall identify in the Products and Secondary Wastes Plan the chemical composition of the waste form, matrix material, and filler material for each package. The reported composition shall include elements (excluding oxygen) present in concentrations greater than 0.5 percent by weight. Crystalline and noncrystalline phases expected to be present shall be identified and the amount of each phase shall be estimated for the waste form, matrix material, and filler material.

2.2.2.7 Radiological Composition Documentation: The Contractor shall identify the individual package inventory of radionuclides that are significant as defined in NUREG/BR-0204 and 49 CFR 172.101 (Table 2), in the Products and Secondary Wastes Plan. ${ }^{99} \mathrm{Technetium}\left({ }^{99} \mathrm{Tc}\right)$ shall be considered to be significant at concentrations greater than $0.003 \mathrm{Ci} / \mathrm{m}^{3}$ in the ILAW form. The inventories shall be indexed to the year 2000 . The documentation shall be consistent with the Radiological Description format described in NUREG/BR0204. 
2.2.2.8 Radionuclide Concentration Limitations: The radionuclide concentration of the ILAW form shall be less than Class C limits as defined in 10 CFR 61.55 and as described in Branch Technical Position on Concentration Averaging and Encapsulation. In addition, the average concentrations of ${ }^{137} \mathrm{Cesium}\left({ }^{137} \mathrm{Cs}\right)$, ${ }^{90}$ Strontium $\left({ }^{90} \mathrm{Sr}\right)$, and ${ }^{99} \mathrm{Tc}$ shall be limited as follows: ${ }^{137} \mathrm{Cs}<3 \mathrm{Ci} / \mathrm{m}^{3},{ }^{90} \mathrm{Sr}<20$ $\mathrm{Ci} / \mathrm{m}^{3}$ and ${ }^{99} \mathrm{Tc}<0.3 \mathrm{Cj} / \mathrm{m}^{3}$. The average concentrations shall be calculated by adding the inventories of each of the above radionuclides in the packages that have been presented to date for acceptance and dividing by the total volume of waste in these packages.

2.2.2.9 Surface Dose Rate Limitations: The dose rate at any point on the external surface of the package shall not exceed $1,000 \mathrm{mRem} / \mathrm{hr}$.

2.2.2.10 Surface Contamination Limitations: Removable contamination on the external surfaces of the package shall not exceed $367 \mathrm{~Bq} / \mathrm{m}^{2}$ for alpha and $3670 \mathrm{~Bq} / \mathrm{m}^{2}$ for beta-gamma contamination when measured using the method described in 49 CFR 173.443(a).

2.2.2.11 Labeling and Manifesting: Each package shall have a label attached or stamped on the outer surfaces of at least two sides of the container in a readily accessible location. The label shall contain a unique identification (e.g., serial number) which shall be assigned to each package and the corresponding documentation. Labels and markings shall have a predicted service life of 50 years assuming that the packages are stored in a ventilated enclosure at ambient temperatures.

The Contractor shall prepare a shipping manifest for delivery with each shipment of ILAW product. Information on the manifest shall satisfy the requirements in DOE Order 5820.2A, Chapter III, Section 3.d, and NUREG/BR-0204. Any package containing dangerous waste must be labeled and manifested in accordance with WAC 173-303-370 and the Dangerous Waste Portion of the Resource Conservation and Recovery Act Permit for the Treatment, Storage, and Disposal of Dangerous Wastes (Permit No. WA 7890008967).

2.2.2.12 Closure and Sealing: The fully loaded package shall be closed, sealed, and a Tamper Indicating Device applied. The closure system shall be leak tight as defined by ANSI Standard N14.5. The closure system shall be designed to ensure that the seal remains intact for a storage period of 50 years in an ambienttemperature, ventilated enclosure.

2.2.2.13 External Temperature: The temperature of the accessible external surfaces of the package shall not exceed $50^{\circ} \mathrm{C}$ when returned to DOE. This temperature constraint shall assume a shaded, still air environment at an ambient temperature of $38^{\circ} \mathrm{C}$.

2.2.2.14 Free Liquids: The package shall contain no detectable free liquids as prescribed in ANSV/ANS-55.1 or SW-846 Method 9095. 


\section{HNF-EP-0884 \\ Rev. 1}

2.2.2.15 Pyrophoricity or Explosivity: The package contents shall not be pyrophoric, readily capable of detonation, or readily capable of explosive decomposition or reaction (including reaction with water) at normal pressure and temperature. The waste form and any optional matrix and filler materials shall not be ignitable or reactive as defined in WAC 173-303-090(5) and WAC 173-303-090(7).

2.2.2.16 Explosive or Toxic Gases: The package shall not contain or be capable of generating quantities of explosive (e.g., hydrogen) or toxic gases, vapors, or fumes harmful to persons handling the waste.

2.2.2.17 Radionuclide Release Rate: The average fractional release rates for the waste form or waste form/matrix combination shall be the following: For ${ }^{99} \mathrm{Tc}$, the average fractional release rate $\left(\mathrm{R}_{\mathrm{TC}}\right)$ shall be less than $2.8 \mathrm{E}-14\left(\mathrm{~s}^{-1}\right)$; and for, ${ }^{79}$ Selenium $\left({ }^{79} \mathrm{Se}\right),{ }^{129}$ Iodine $\left({ }^{129} \mathrm{I}\right),{ }^{237}$ Neptunium $\left({ }^{237} \mathrm{~Np}\right)$, and uranium isotopes, the average fractional release rate $(R)$ shall be less than $1.4 \mathrm{E}-13\left(\mathrm{~s}^{-}\right)($see Sections 2.2.2.17.1 and 2.2.2.17.2). The basis for fractional release rate determination shall be the radionuclide inventory remaining in the liquid fraction of waste processed following solid separation.

2.2.2.17.1 Silicate Glass Waste Forms: For silicate glass waste forms, compliance with the fractional release rate requirements shall be established by showing that the average value of the product of the glass corrosion rate, the glass surface area to volume ratio, and the fraction of the processed inventory of technetium that is solidified in the glass satisfies the following constraints:

$$
\begin{array}{ll}
\text { Equation TS 2.1 } & R_{T C}=\left(\frac{C_{g}}{D}\right) \times\left(\frac{S_{g}}{V_{g}}\right) \times F<2.8 E-14\left(\mathrm{~s}^{-1}\right) \\
\text { Equation TS 2.2 } & R=\left(\frac{C_{g}}{D}\right) \times\left(\frac{S_{g}}{V_{g}}\right)<1.4 E-13\left(\mathrm{~s}^{-1}\right)
\end{array}
$$

where:

$\mathrm{C}_{\mathrm{g}}$ is the corrosion rate of the glass $\left(\mathrm{kg} /\left(\mathrm{m}^{2}-\mathrm{s}\right)\right)$

$\rho$ is the glass density $\left(\mathrm{kg} / \mathrm{m}^{3}\right)$

$S_{g}$ is the surface area of the glass in the package that is available for corrosion $\left(\mathrm{m}^{2}\right)$

$\mathrm{V}_{\mathrm{g}}$ is the glass volume in the package $\left(\mathrm{m}^{3}\right)$

$F$ is the fraction of the soluble inventory (residual inventory in the solution after solid/liquid separation) of technetium that is solidified in the glass. $\mathrm{F}$ is calculated by dividing the technetium inventory solidified in each package by the average inventory to date of technetium processed per package. F shall be estimated by either sampling and analyzing the feed and glass products or from process knowledge. 


\section{FENE-EP-0884 \\ Rev. 1}

The average values for $R$ and $R_{T C}$ shall be calculated by maintaining a running summation of the $R$ and $R_{T C}$ values of the packages presented to date for acceptance (excluding any that have not been accepted) and dividing by the number of packages accepted to date.

The corrosion rate $\left(\mathrm{C}_{\mathrm{g}}\right)$ shall be the average rate determined to occur at $20^{\circ} \mathrm{C}$ over a period of 7 days when statistical product inventory information of the waste form is tested using the Product Consistency Test (PCT) (ASTM C1285-94). The $20^{\circ} \mathrm{C}$ rates shall be determined as follows:

- The normalized release of sodium, silicon, and boron (if present as a constituent in the glass) shall be measured using a 7-day PCT run at $20^{\circ} \mathrm{C}$ (ASTM C1285-94). Alternatively, the normalized releases may be measured at any temperature in the range of $20^{\circ} \mathrm{C}$ to $90^{\circ} \mathrm{C}$ provided the Contractor develops and applies an empirical correlation to relate the elevated temperature results to those at $20^{\circ} \mathrm{C}$.

- The normalized release of $\mathrm{Si}$ shall be used to calculate the average corrosion rate of the glass $\left(\mathrm{kg} /\left(\mathrm{m}^{2}-\mathrm{s}\right)\right)$ over the 7-day test period. Secondary mineral formation and phase separation shall not affect the PCT.

The surface area to volume ratio $\left(S_{\varepsilon} N_{g}\right)$ of the glass product shall be the average surface area to volume ratio of the products expected based on information obtained from destructive examination of prototypical non-radioactive products produced during product qualification.

2.2.2.17.2 Waste Forms Other Than Silicate Glass: The Contractor shall identify how the fractional release rates, $R_{\mathrm{TC}}$ and $\mathrm{R}$, are to be determined for waste forms and waste form/matrix combinations other than silicate glass if applicable. The Contractor shall be responsible for identifying an appropriate approach and testing method to show that the waste form products proposed will meet or exceed the specified radionuclide release requirements when immersed in deionized water at $20^{\circ} \mathrm{C}$. The approach and testing methods do not necessarily require direct measurement of the radionuclides identified in this specification; measurement of a waste form characteristic (e.g., the corrosion rate for silicate glass waste forms) to which the radionuclide release rate can be related may be more appropriate.

2.2.2.18 Compressive Strength: The Contractor shall determine the mean compressive strength of the waste form (and any optional matrix and filler materials) by testing representative non-radioactive samples. The compressive strength shall be at least 3.45E6 $\mathrm{Pa}$ when tested in accordance with ASTM C39-94 or an equivalent testing method. 
2.2.2.19 Thermal, Radiation, Biodegradation and Immersion Stability: The ILAW product shall be resistant to thermal, radiation, biodegradation and immersion degradation, as described in NRC Technical Position on Waste Form. Resistance to each of these types of degradation shall be established by showing that the mean compressive strength of representative samples shall be equal to or greater than $3.45 \mathrm{E} 06 \mathrm{~Pa}$ and not less than 75 percent of the initial compressive strength after subjecting the samples to the following:

2.2.2.19.1 Thermal degradation: 30 thermal cycles between a high of $60^{\circ} \mathrm{C}$ and a low of $-40^{\circ} \mathrm{C}$ in accordance with the ASTM B553-79 or an equivalent testing method.

2.2.2.19.2 Radiation degradation: Exposure to a minimum radiation dose of I.0E08 rad or to a dose equivalent to the maximum level of exposure expected from self-irradiation during storage, transportation and disposal if this is greater than $1.0 \mathrm{E} 08 \mathrm{rad}$.

2.2.2.19.3 Biodegradation: No evidence of culture growth when representative samples are tested in accordance with ASTM G21-90, ASTM G22-76, or equivalent methods.

2.2.2.19.4 Immersion degradation: Immersion for 90 days under the ANSVANS16.1 testing conditions.

2.2.2.20 Waste Form Leach Testing: The waste form shall have a sodium leachability index greater than 6.0 when tested for 90 days in deionized water using the ANSI/ANS-16.1 procedure.

2.2.2.21 Dangerous Waste Limitations: The ILAW product shall be acceptable for land disposal under the State of Washington Dangerous Waste Regulations, WAC 173-303 and 40 CFR 268. The Contractor shall perform sampling and testing necessary to support designation of the ILAW product for dangerous waste characteristics, dangerous waste criteria and dangerous waste sources as specified in WAC 173-303-070. Information needed to show that the treated waste in the ILAW product is not prohibited from land disposal pursuant to WAC 173-303-140 and 40 CFR 268 shall be provided by the Contractor. Also, information specified in WAC 173-303-072 to pursue an exemption or categorical exclusion from the dangerous waste requirements shall be provided by the Contractor in the Products and Secondary Wastes Plan. The sampling, preparation and testing methods shall conform to the requirements in WAC 173303-110.

2.2.2.22 Compression Testing: Each fully loaded package shall be able to withstand a compression load of $50,000 \mathrm{~kg}$ force. Compliance with this specification shall be established by using the compression test described in 49 CFR 173.465(d). The Contractor shall demonstrate the integrity of the package by showing that the dimensions of the tested packages are within the tolerance range and by showing that the seal remains intact in accordance with Section 2.2.2.12. 


\section{FINE-EP-0884 \\ Rev. 1}

2.2.2.23 Container Material Degradation: The container shall be resistant to degradation by microbial action, moisture, radiation effects, or chemical reactions with the container contents under the expected storage conditions that may reasonably occur during storage (in an ambient-temperature, ventilated enclosure) and handling and disposal operations. The container and handling appurtenances shall be designed to allow safe lifting and movement (in accordance with Section 2.2.3.1) after a storage period of 50 years. The integrity of the container shall not be jeopardized by wind, blowing sand, precipitation, sunlight, or extreme temperatures $\left(+60^{\circ} \mathrm{C},-40^{\circ} \mathrm{C}\right)$.

\subsubsection{Handling Requirements:}

2.2.3.1 Package Handling: The package shall be compatible with forklift and crane lifting and movement. The package shall be equipped with lifting and other handling appurtenances designed to allow safe lifting, movement, and stacking of the packages when fully loaded. The package shall maintain its integrity during handling, transportation, and stacking. The package shall allow for vertical stacking of six packages.

2.3 Inspection and Acceptance: The Products and Secondary Wastes Plan provided as a Part A deliverable in Standard 3, Waste Products and Secondary Wastes, shall define the content and delivery of Contractor documentation required to demonstrate compliance with the requirements of this specification. Product inspection and acceptance requirements will be performed in accordance with Section E, Inspection and Acceptance and NUREG-1293. In addition to Section E requirements for ILAW, the Contractor shall conform to the Contractor Certification Program as described in DOE Order 5820.2A, Chapter 3, Section 3.E.(4). 


\section{HNNF-EP-0884 \\ Rev. 1 \\ APPENDIX B DOSIMETRY DOSE FACTORS}

This appendix provides tables of factors to convert radionuclide concentrations to dose rates. The scenarios are described in section 3.3 .6 and the underlying parameters in Section 3.4.8. Five tables are given:
B-1 Drinking Water Scenario Dose Factors
B-2 Al1-Pathways Dose Factors
B-3 Drilling Scenario Dose Factors
B-4 Intruder Scenario Dose Factors
B-5 Ratio of Intruder Dose Factors for $2500 \mathrm{~m}^{2}$ garden relative to $500 \mathrm{~m}^{2}$ garden.

Table B-1. Drinking Water Scenario Dose Factors ${ }^{a}$

\begin{tabular}{|c|c|c|c|}
\hline Nuclide & $\begin{array}{c}\text { Drinking water } \\
\text { Dose Factor } \\
\text { (mrem/y per pci/l) }\end{array}$ & Nuclide & $\begin{array}{c}\text { Drinking water } \\
\text { Dose Factor } \\
\text { (mrem/y per pCi/l) }\end{array}$ \\
\hline $\mathrm{H}-3$ & 4. $60 \mathrm{E}-05$ & $\mathrm{Eu}-155$ & $9.49 \mathrm{E}-04$ \\
\hline Be-10 & $3.07 \mathrm{E}-03$ & $6 d-152$ & 1. $10 \mathrm{E}-01$ \\
\hline$c-14$ & $1.53 \mathrm{E}-03$ & Ho-166m & $5.69 E-03$ \\
\hline $\mathrm{Na}-22$ & $8.76 \mathrm{E}-03$ & Re-187 & $6.06 \mathrm{E}-06$ \\
\hline $\mathrm{Cl}-36$ & $2.19 E-03$ & $P 1-204$ & $2.34 E-03$ \\
\hline$K-40$ & $1.39 \mathrm{E}-02$ & $\mathrm{~Pb}-210+\mathrm{D}$ & $4.92 \mathrm{E}+00$ \\
\hline$M n-54$ & $1.97 \mathrm{E}-03$ & $\mathrm{Bi}-207$ & $3.58 E-03$ \\
\hline$F e-55$ & $4.23 E-04$ & Po-209 & 1. $46 \mathrm{E}+00$ \\
\hline $\mathrm{Co}-60$ & $1.90 \mathrm{E}-02$ & $\mathrm{Ra}-226+\mathrm{D}$ & $8.04 \mathrm{E}-01$ \\
\hline $\mathrm{Ni}-59$ & $1.46 \mathrm{E}-04$ & $R a-228+D$ & $8.77 \mathrm{E}-01$ \\
\hline $\mathrm{Ni}-63$ & $3.94 \mathrm{E}-04$ & $A c-227+D$ & 1.07E+01 \\
\hline $\mathrm{se}-79$ & $6.06 E-03$ & $\mathrm{Th}-228+\mathrm{D}$ & $5.50 \mathrm{E}-01$ \\
\hline $\mathrm{Rb}-87$ & $3.50 E-03$ & $T h-229+D$ & $2.85 E+00$ \\
\hline$S x-90+D$ & $1.02 E-01$ & $T h-230$ & $3.87 \mathrm{E}-01$ \\
\hline Zr-93 & 1. $17 E-03$ & $\mathrm{Th}-232$ & $2.04 \mathrm{E}+00$ \\
\hline $\mathrm{Nb}-93 \mathrm{~m}$ & $3.87 E-04$ & $\mathrm{~Pa}-231$ & $8.03 E+00$ \\
\hline $\mathrm{Nb}-94$ & $3.72 \mathrm{E}-0.3$ & $\mathrm{U}-232$ & $9.49 E-01$ \\
\hline $\mathrm{MO}-93$ & $9.49 E-04$ & $u-233$ & $1.97 E-01$ \\
\hline $\mathrm{Tc}-99$ & $9.49 \mathrm{E}-04$ & $u-234$ & $1.90 \mathrm{E}-01$ \\
\hline$R u-106+D$ & $1.53 E-02$ & $U-235+D$ & $1.83 E-01$ \\
\hline
\end{tabular}


Rev. 1

\begin{tabular}{|c|c|c|c|}
\hline Nuclide & $\begin{array}{c}\text { Drinking water } \\
\text { Dose Factor } \\
\text { (mrem/y per pci/l) }\end{array}$ & Nuclide & $\begin{array}{c}\text { Drinking water } \\
\text { Dose Factor } \\
\text { (mrem/y per pCi/l) } \\
\end{array}$ \\
\hline $\mathrm{Pd}-107$ & 1. $02 E-04$ & $\mathrm{U}-236$ & 1. $83 \mathrm{E}-01$ \\
\hline $\mathrm{Ag}-108 \mathrm{~m}+\mathrm{D}$ & $5.48 \mathrm{E}-03$ & $U-238+D$ & $1.77 \mathrm{E}-01$ \\
\hline $\mathrm{Cd}-109$ & $8.76 E-03$ & $\mathrm{~Np}-237+\mathrm{D}$ & $2.85 \mathrm{E}+00$ \\
\hline $\mathrm{Cd}-113 \mathrm{~m}$ & $1.10 \mathrm{E}-01$ & Pu-236 & $9.49 \mathrm{E}-01$ \\
\hline$I n-115$ & 1. $02 \mathrm{E}-01$ & $P u-238$ & $2.77 \mathrm{E}+00$ \\
\hline$S n-121 m+D$ & 1. $45 E-03$ & $\mathrm{Pu}-239$ & $3.14 \mathrm{E}+00$ \\
\hline$S n-126+D$ & 1. $34 \mathrm{E}-02$ & $P u-240$ & $3.14 \mathrm{E}+00$ \\
\hline $\mathrm{Sb}-125+\mathrm{D}$ & $2.51 \mathrm{E}-03$ & Pu-241+D & $6.28 \mathrm{E}-02$ \\
\hline$I-129$ & 2. $04 \mathrm{E}-01$ & $P u-242$ & $2.99 \mathrm{E}+00$ \\
\hline $\mathrm{Cs}-134$ & $5.40 \mathrm{E}-02$ & $\mathrm{Pu}-244+\mathrm{D}$ & $2.92 \mathrm{E}+00$ \\
\hline $\mathrm{Cs}-135$ & $5.18 \mathrm{E}-03$ & $\mathrm{Am}-241$ & $3.29 E+00$ \\
\hline $\mathrm{Cs}-137+\mathrm{D}$ & $3.65 E-02$ & $A m-242 m+D$ & $3.13 \mathrm{E}+00$ \\
\hline$B a-133$ & $2.34 \mathrm{E}-03$ & $A m-243+D$ & $3.29 \mathrm{E}+00$ \\
\hline Pm-147 & $6.94 E-04$ & $\mathrm{Cm}-243$ & $2.12 \mathrm{E}+00$ \\
\hline$S m-147$ & $1.31 \mathrm{E}-01^{\circ}$ & $\mathrm{Cm}-244$ & $1.68 \mathrm{E}+00$ \\
\hline $\mathrm{Sm}-151$ & $2.48 E-04$ & $\mathrm{Cm}-245$ & $3.29 \mathrm{E}+00$ \\
\hline$E u-150$ & $4.53 E-03$ & $\mathrm{Cm}-246$ & $3.29 \mathrm{E}+00$ \\
\hline$E u-152$ & $4.38 E-03$ & $\mathrm{Cm}-247+\mathrm{D}$ & $2.99 \mathrm{E}+00$ \\
\hline$E u-154$ & $6.64 E-03$ & $\mathrm{Cm}-248$ & 1.17E+01 \\
\hline
\end{tabular}

Nuclides with "+D" added to the name include the contributions from short-lived progeny, which are assumed to be in equilibrium at all times. 
HNF $-E P-0884$

Rev. 1

Table B-2. All-Pathways Dose Factors" (Well Water)

\begin{tabular}{|c|c|c|c|c|c|}
\hline Nuclide & $\begin{array}{c}\text { All-Pathways } \\
\text { Dose Factor } \\
\text { (mrem/y per } \\
\text { pci/l) }\end{array}$ & $\begin{array}{c}\text { Ratio to } \\
\text { Drinking } \\
\text { Water } \\
\text { Dose Factor }\end{array}$ & Nuclide & $\begin{array}{c}\text { All-Pathways } \\
\text { Dose Factor } \\
\text { (mrem/y per } \\
\text { pCi / l) }\end{array}$ & $\begin{array}{c}\text { Ratio to } \\
\text { Drinking } \\
\text { Water } \\
\text { Dose Factor }\end{array}$ \\
\hline $\mathrm{H}-3$ & $5.30 \mathrm{E}-05$ & 1.15 & Eu-155 & $1.36 \mathrm{E}-03$ & 1.43 \\
\hline$B e-10$ & $3.41 E-03$ & 1.11 & Ga-152 & 1. $28 \mathrm{E}-01$ & 1.17 \\
\hline$c-14$ & $1.79 \mathrm{E}-03$ & 1.17 & $\mathrm{Ho}-166 \mathrm{~m}$ & $1.85 E-02$ & 3.25 \\
\hline $\mathrm{Na}-22$ & $5.71 E-02$ & 6.52 & $R e-187$ & $8.56 \mathrm{E}-06$ & 1.41 \\
\hline $\mathrm{Cl}-36$ & $3.40 E-02$ & 15.5 & $\mathrm{~T} 1-204$ & $4.95 \mathrm{E}-03$ & 2.12 \\
\hline$K-40$ & $3.06 \mathrm{E}-02$ & 2.21 & $\mathrm{~Pb}-210+\mathrm{D}$ & $5.50 \mathrm{E}+00$ & 1.12 \\
\hline$M n-54$ & $6.48 \mathrm{E}-03$ & 3.29 & $B i-207$ & $1.44 \mathrm{E}-02$ & 4.02 \\
\hline$F e-55$ & $6.57 E-04$ & 1.55 & Po-209 & $1.69 \mathrm{E}+00$ & 1.15 \\
\hline $\mathrm{Co}-60$ & $4.84 \mathrm{E}-02$ & 2.55 & $\mathrm{Ra}-226+\mathrm{D}$ & $9.20 \mathrm{E}-01$ & 1.14 \\
\hline $\mathrm{Ni}-59$ & $1.90 \mathrm{E}-04$ & 1.30 & $\mathrm{Ra}-228+\mathrm{D}$ & $9.98 \mathrm{E}-01$ & 1.14 \\
\hline $\mathrm{Ni}-63$ & $5.13 E-04$ & 1.30 & $A C-227+D$ & 1. $16 \mathrm{E}+01$ & 1.09 \\
\hline$s e-79$ & 1. $09 \mathrm{E}-02$ & 1.80 & $T h-228+D$ & $6.08 \mathrm{E}-01$ & 1.11 \\
\hline$R b-87$ & $7.75 E-03$ & 2.21 & $T h-229+D$ & $3.11 E+00$ & 1.09 \\
\hline$S r-90+D$ & 1. $26 E-01$ & 1.24 & Th-230 & 4. $22 \mathrm{E}-01$ & 1.09 \\
\hline $2 x-93$ & 1. $42 E-03$ & 1.21 & $\mathrm{Th}-232$ & $2.23 E+00$ & 1.09 \\
\hline $\mathrm{Nb}-93 \mathrm{~m}$ & $3.15 E-03$ & 8.14 & $\mathrm{~Pa}-231$ & $8.75 E+00$ & 1.09 \\
\hline $\mathrm{Nb}-94$ & 4. $12 E-02$ & 11.1 & $\mathrm{U}-232$ & 1. $09 E+00$ & 1.15 \\
\hline $\mathrm{MO}-93$ & 1. $28 E-03$ & 1.35 & $\mathrm{U}-233$ & $2.26 \mathrm{E}-01$ & 1.15 \\
\hline $\mathrm{TC}-99$ & $3.12 E-03$ & 3.29 & $\mathrm{U}-234$ & $2.18 E-01$ & 1.15 \\
\hline$R u-106+D$ & 1. $85 E-02$ & 1.20 & $U-235+D$ & $2.12 E-01$ & 1.15 \\
\hline $\mathrm{Pd}-107$ & $1.99 \mathrm{E}-04$ & 1.95 & $U-236$ & $2.10 E-01$ & 1.15 \\
\hline $\mathrm{Ag}-108 \mathrm{~m}+\mathrm{D}$ & $2.57 \mathrm{E}-02$ & 4.70 & $U-238+D$ & $2.04 E-01$ & 1.15 \\
\hline$c d-109$ & 1. $04 E-02$ & 1.19 & $\mathrm{~Np}-237+\mathrm{D}$ & $3.11 E+00$ & 1.09 \\
\hline $\mathrm{Cd}-113 \mathrm{~m}$ & $1.30 \mathrm{E}-01$ & 1.19 & $\mathrm{Pu}-236$ & 1. $03 E+00$ & 1.09 \\
\hline In-115 & 1. $31 E-01$ & 1.28 & $\mathrm{Pu}-238$ & $3.02 E+00$ & 1.09 \\
\hline$S n-121 m+D$ & 4. $28 E-03$ & 2.94 & $P u-239$ & $3.42 E+00$ & 1.09 \\
\hline$S n-126+D$ & $5.29 E-02$ & 3.96 & $\mathrm{Pu}-240$ & $3.42 E+00$ & 1.09 \\
\hline $\mathrm{Sb}-125+\mathrm{D}$ & $5.52 E-03$ & 2.20 & $\mathrm{Pu}-241+\mathrm{D}$ & $6.84 E-02$ & 1.09 \\
\hline
\end{tabular}


HINF-EP -0884

Rev. 1

\begin{tabular}{||c|c|c||c|c|c|}
\hline Nuclide & $\begin{array}{c}\text { All-Pathways } \\
\text { Dose Factor } \\
\text { (mrem/y per } \\
\text { pCi/l) }\end{array}$ & $\begin{array}{c}\text { Ratio to } \\
\text { Drinking } \\
\text { Water } \\
\text { Dose Factor }\end{array}$ & Nuclide & $\begin{array}{c}\text { All-Pathways } \\
\text { Dose Factor } \\
\text { (mrem/y per } \\
\text { pCi/l) }\end{array}$ & $\begin{array}{c}\text { Ratio } \\
\text { Drink } \\
\text { Water } \\
\text { Dose Factor }\end{array}$ \\
\hline $\mathrm{I}-129$ & $4.13 \mathrm{E}-01$ & 2.02 & Pu-242 & $3.26 \mathrm{E}+00$ & 1.09 \\
\hline $\mathrm{Cs}-134$ & $1.22 \mathrm{E}-01$ & 2.25 & Pu-244+D & $3.18 \mathrm{E}+00$ & 1.09 \\
\hline $\mathrm{CS}-135$ & $1.09 \mathrm{E}-02$ & 2.09 & Am-241 & $3.58 \mathrm{E}+00$ & 1.09 \\
\hline $\mathrm{Cs}-137+\mathrm{D}$ & $8.02 \mathrm{E}-02$ & 2.20 & $\mathrm{Am}-242 \mathrm{~m}+\mathrm{D}$ & $3.41 \mathrm{E}+00$ & 1.09 \\
\hline $\mathrm{Ba}-133$ & $4.93 \mathrm{E}-03$ & 2.11 & Am-243+D & $3.58 \mathrm{E}+00$ & 1.09 \\
\hline $\mathrm{Pm}-147$ & $8.31 \mathrm{E}-04$ & 1.20 & $\mathrm{Cm}-243$ & $2.31 \mathrm{E}+00$ & 1.09 \\
\hline $\mathrm{Sm}-147$ & $1.58 \mathrm{E}-01$ & 1.20 & $\mathrm{Cm}-244$ & $1.83 \mathrm{E}+00$ & 1.09 \\
\hline $\mathrm{Sm}-151$ & $2.98 \mathrm{E}-04$ & 1.20 & $\mathrm{Cm}-245$ & $3.58 \mathrm{E}+00$ & 1.09 \\
\hline $\mathrm{Eu}-150$ & $1.54 \mathrm{E}-02$ & 3.39 & $\mathrm{Cm}-246$ & $3.58 \mathrm{E}+00$ & 1.09 \\
\hline $\mathrm{Eu}-152$ & $1.28 \mathrm{E}-02$ & 2.93 & $\mathrm{Cm}-247+\mathrm{D}$ & $3.27 \mathrm{E}+00$ & 1.09 \\
\hline $\mathrm{Eu}-154$ & $1.61 \mathrm{E}-02$ & 2.43 & $\mathrm{Cm}-248$ & $1.27 \mathrm{E}+01$ & 1.09 \\
\hline
\end{tabular}

Nuclides with "+D" added to the name include the contributions from short-lived progeny, which are assumed to be in equilibrium at all times. 
ENNF-EP-0884

Rev. 1

Table B-3. Drilling Scenario Dose Factors" (Soil) (Assumes that waste height is $8 \mathrm{~m}$, actual height is $7.2 \mathrm{~m}$ )

\begin{tabular}{|c|c|c|c|}
\hline Nuclide & $\begin{array}{c}\text { Drilling Dose Factor } \\
\left(\mathrm{mrem} / \mathrm{y} \text { per } \mathrm{Ci} / \mathrm{m}^{3}\right)\end{array}$ & Nuclide & $\begin{array}{l}\text { Drilling Dose Factor } \\
\left(\mathrm{mrem} / \mathrm{y} \text { per } \mathrm{Ci} / \mathrm{m}^{3}\right)\end{array}$ \\
\hline $\mathrm{H}-3$ & 3. $63 \mathrm{E}-03$ & $\mathrm{Eu}-155$ & $2.08 E+01$ \\
\hline $\mathrm{Be}-10$ & $2.16 \mathrm{E}-01$ & $\mathrm{Gd}-152$ & 3. $08 \mathrm{E}+01$ \\
\hline$C-14$ & $2.82 \mathrm{E}-02$ & $\mathrm{Ho}-166 \mathrm{~m}$ & 1. $04 \mathrm{E}+03$ \\
\hline $\mathrm{Na}-22$ & 1. $34 E+03$ & $R e-187$ & $1.10 E-04$ \\
\hline $\mathrm{Cl}-36$ & 3. $00 \mathrm{E}-01$ & $\mathrm{Tl}-204$ & $4.98 \mathrm{E}-01$ \\
\hline$K-40$ & $9.75 \mathrm{E}+01$ & $\mathrm{~Pb}-210+\mathrm{D}$ & $8.79 E+01$ \\
\hline$M n-54$ & $5.11 \mathrm{E}+02$ & $\mathrm{Bi}-207$ & $9.24 \mathrm{E}+02$ \\
\hline $\mathrm{Fe}-55$ & $7.60 \mathrm{E}-03$ & Po-209 & 2. $84 \mathrm{E}+01$ \\
\hline $\mathrm{Co}-60$ & $1.54 \mathrm{E}+03$ & $\mathrm{Ra}-226+\mathrm{D}$ & 1. $09 \mathrm{E}+03$ \\
\hline $\mathrm{Ni}-59$ & $2.67 \mathrm{E}-03$ & $\mathrm{Ra}-228+\mathrm{D}$ & $5.84 \mathrm{E}+02$ \\
\hline $\mathrm{Ni}-63$ & $7.15 E-03$ & $A C-227+D$ & 1. $21 \mathrm{E}+03$ \\
\hline se-79 & $1.07 \mathrm{E}-01$ & $T h-228+D$ & $9.90 \mathrm{E}+02$ \\
\hline$R b-87$ & $7.67 \mathrm{E}-02$ & $\mathrm{Th}-229+\mathrm{D}$ & 4. $61 E+02$ \\
\hline Sr $-90+D$ & 4. $42 \mathrm{E}+00$ & $T h-230$ & $4.54 \mathrm{E}+01$ \\
\hline $\mathrm{Zx}-93$ & $5.87 \mathrm{E}-02$ & $T h-232$ & $2.28 \mathrm{E}+02$ \\
\hline $\mathrm{Nb}-93 \mathrm{~m}$ & $2.19 \mathrm{E}-02$ & $\mathrm{~Pa}-231$ & $3.16 \mathrm{E}+02$ \\
\hline $\mathrm{Nb}-94$ & $9.65 E+02$ & $\mathrm{U}-232$ & $9.73 \mathrm{E}+01$ \\
\hline Mo- 93 & $8.70 E-02$ & $\mathrm{U}-233$ & 1. $92 \mathrm{E}+01$ \\
\hline $\mathrm{TC}-99$ & $3.15 \mathrm{E}-02$ & $\mathrm{U}-234$ & 1. $90 \mathrm{E}+01$ \\
\hline $\mathrm{Ru}-106+\mathrm{D}$ & 1. $31 \mathrm{E}+02$ & $\mathrm{U}-235+\mathrm{D}$ & 1. $02 \mathrm{E}+02$ \\
\hline $\mathrm{Pd}-107$ & 3. $33 E-03$ & $\mathrm{U}-236$ & $1.76 \mathrm{E}+01$ \\
\hline $\mathrm{Ag}-108 \mathrm{~m}+\mathrm{D}$ & $9.83 \mathrm{E}+02$ & $\mathrm{U}-238+\mathrm{D}$ & $3.11 \mathrm{E}+01$ \\
\hline $\mathrm{Cd}-109$ & $1.84 \mathrm{E}+00$ & $\mathrm{~Np}-237+\mathrm{D}$ & $2.27 \mathrm{E}+02$ \\
\hline $\mathrm{cd}-113 \mathrm{~m}$ & $2.13 E+00$ & $\mathrm{Pu}-236$ & $3.57 \mathrm{E}+01$ \\
\hline In-115 & $2.21 E+00$ & $P u-238$ & 1. $03 \mathrm{E}+02$ \\
\hline$S n-121 m+D$ & $2.67 \mathrm{E}-01$ & $\mathrm{Pu}-239$ & $1.16 \mathrm{E}+02$ \\
\hline$S n-126+D$ & 1.20E+03 & Pu-240 & $1.16 \mathrm{E}+02$ \\
\hline$S b-125+D$ & $2.52 \mathrm{E}+02$ & $\mathrm{Pu}-241+\mathrm{D}$ & 2. $29 E+00$ \\
\hline$I-129$ & $5.02 E+00$ & Pu-242 & 1. $.09 E+02$ \\
\hline
\end{tabular}


Rev. 1

\begin{tabular}{|l|c||l|c||}
\hline Nuclide & $\begin{array}{c}\text { Drilling Dose Factor } \\
\text { (mrem/y per Ci/m })\end{array}$ & Nuclide & $\begin{array}{c}\text { Drilling Dose Factor } \\
\left(\mathrm{mrem} / \mathrm{y} \text { per } \mathrm{Ci} / \mathrm{m}^{3}\right)\end{array}$ \\
\hline \hline $\mathrm{Cs}-134$ & $9.53 \mathrm{E}+02$ & Pu-244+D & $3.12 \mathrm{E}+02$ \\
\hline $\mathrm{Cs}-135$ & $9.41 \mathrm{E}-02$ & Am-241 & $1.24 \mathrm{E}+02$ \\
\hline $\mathrm{Cs}-137+\mathrm{D}$ & $3.45 \mathrm{E}+02$ & Am-242m+D & $1.23 \mathrm{E}+02$ \\
\hline $\mathrm{Ba}-133$ & $2.10 \mathrm{E}+02$ & $\mathrm{Am}-243+\mathrm{D}$ & $2.19 \mathrm{E}+02$ \\
\hline $\mathrm{Pm}-147$ & $2.17 \mathrm{E}-02$ & $\mathrm{Cm}-243$ & $1.43 \mathrm{E}+02$ \\
\hline $\mathrm{Sm}-147$ & $1.08 \mathrm{E}+01$ & $\mathrm{Cm}-244$ & $6.15 \mathrm{E}+01$ \\
\hline $\mathrm{Sm}-151$ & $7.88 \mathrm{E}-03$ & $\mathrm{Cm}-245$ & $1.60 \mathrm{E}+02$ \\
\hline $\mathrm{Eu}-150$ & $8.90 \mathrm{E}+02$ & $\mathrm{Cm}-246$ & $1.22 \mathrm{E}+02$ \\
\hline $\mathrm{Eu}-152$ & $6.86 \mathrm{E}+02$ & $\mathrm{Cm}-247+\mathrm{D}$ & $3.07 \mathrm{E}+02$ \\
\hline $\mathrm{Eu}-154$ & $7.50 \mathrm{E}+02$ & $\mathrm{Cm}-248$ & $4.30 \mathrm{E}+02$ \\
\hline
\end{tabular}

"Nuclides with "+D" added to the name include the contributions from short-lived progeny, which are assumed to be in equilibrium at all times. 
HNF-EP- 0884

Rev. 1

Table B-4. Intruder Scenario Dose Factors" (Soil) (Assumes waste height is $8 \mathrm{~m}$, actual height is $7.2 \mathrm{~m}$ )

\begin{tabular}{|c|c|c|c|c|c|c|}
\hline \multirow[t]{2}{*}{ Nuclide } & \multirow{2}{*}{$\begin{array}{c}\text { External } \\
\text { (mrem/y per } \\
\mathrm{CI} / \mathrm{m}^{3} \text { ) }\end{array}$} & \multicolumn{4}{|c|}{ Internal $\quad\left(\mathrm{mrem} / \mathrm{Y}\right.$ per $\left.\mathrm{Ci} / \mathrm{m}^{3}\right)$} & \multirow{2}{*}{$\begin{array}{l}\text { Total } \\
\text { (mrem } / y_{1} \text { per } \\
\left.\text { Ci } / \mathrm{m}^{3}\right)\end{array}$} \\
\hline & & Inhalation & $\begin{array}{c}\text { Soil } \\
\text { Ingestion } \\
\end{array}$ & Vegetables & SubTotal & \\
\hline $\mathrm{H}-3$ & 0.0 & $4.00 E-04$ & $5.93 E-04$ & $2.85 \mathrm{E}-01$ & $3.26 \mathrm{E}-01$ & $3.26 \mathrm{E}-01$ \\
\hline $\mathrm{Be}-10$ & $5.43 E-01$ & $1.02 \mathrm{E}+00$ & $7.71 \mathrm{E}-01$ & $1.67 \mathrm{E}+00$ & $3.46 \mathrm{E}+00$ & $4.00 \mathrm{E}+00$ \\
\hline$C-14$ & $6.73 \mathrm{E}-03$ & $5.95 \mathrm{E}-03$ & $3.76 \mathrm{E}-01$ & 1. $63 \mathrm{E}+02$ & 1. $64 \mathrm{E}+02$ & 1. $64 \mathrm{E}+02$ \\
\hline $\mathrm{Na}-22$ & $5.30 \mathrm{E}+03$ & $2.04 \mathrm{E}-02$ & $1.93 \mathrm{E}+00$ & $7.15 \mathrm{E}+01$ & $7.34 E+01$ & $5.37 \mathrm{E}+03$ \\
\hline $\mathrm{C} 1-36$ & $1.07 \mathrm{E}+00$ & $5.32 \mathrm{E}-02$ & $5.05 \mathrm{E}-01$ & $2.23 E+04$ & $2.23 E+04$ & $2.23 E+04$ \\
\hline $\mathrm{K}-40$ & $4.34 \mathrm{E}+02$ & $3.45 \mathrm{E}-02$ & $3.46 \mathrm{E}+00$ & $1.19 \mathrm{E}+03$ & $1.19 \mathrm{E}+03$ & $1.63 E+03$ \\
\hline$M n-54$ & $1.57 E+03$ & $1.27 E-02$ & $3.39 E-01$ & $6.14 \mathrm{E}+01$ & $6.18 \mathrm{E}+01$ & $1.63 E+03$ \\
\hline$F e-55$ & 0.0 & $6.65 \mathrm{E}-03$ & $9.38 \mathrm{E}-02$ & $1.79 \mathrm{E}-01$ & $2.79 \mathrm{E}-01$ & $2.79 \mathrm{E}-01$ \\
\hline $\operatorname{Co}-60$ & $6.49 E+03$ & 4. $07 \mathrm{E}-01$ & $4.46 \mathrm{E}+00$ & $3.59 \mathrm{E}+01$ & $4.08 \mathrm{E}+01$ & $6.53 E+03$ \\
\hline $\mathrm{Ni}-59$ & 0.0 & $3.77 \mathrm{E}-03$ & $3.67 \mathrm{E}-02$ & $9.68 \mathrm{E}-01$ & 1. $01 \mathrm{E}+00$ & $1.01 E+00$ \\
\hline $\mathrm{Ni}-63$ & 0.0 & $8.68 \mathrm{E}-03$ & $9.88 \mathrm{E}-02$ & $2.61 \mathrm{E}+00$ & $2.72 \mathrm{E}+00$ & $2.72 E+00$ \\
\hline $\mathrm{Se}-79$ & $9.53 E-03$ & $2.58 \mathrm{E}-02$ & $1.52 \mathrm{E}+00$ & $2.51 \mathrm{E}+01$ & $2.67 \mathrm{E}+01$ & $2.67 E+01$ \\
\hline$R b-87$ & $7.18 \mathrm{E}-02$ & $9.55 \mathrm{E}-03$ & $8.78 \mathrm{E}-01$ & $3.95 \mathrm{E}+01$ & 4.04E+01 & $4.05 E+01$ \\
\hline$S r-90$ & 1. $16 \mathrm{E}+01$ & $6.74 \mathrm{E}-01$ & $2.51 \mathrm{E}+01$ & $4.11 \mathrm{E}+03$ & $4.14 \mathrm{E}+03$ & $4.15 E+03$ \\
\hline $2 x-93$ & 1. $25 \mathrm{E}-03$ & $9.31 \mathrm{E}-01$ & $2.96 \mathrm{E}-0.1$ & $4.42 \mathrm{E}-01$ & $1.67 \mathrm{E}+00$ & 1. $67 \mathrm{E}+00$ \\
\hline
\end{tabular}


HNF-EP- 0884

Rev. 1

\begin{tabular}{|c|c|c|c|c|c|c|}
\hline \multirow[t]{2}{*}{ Nuclide } & \multirow{2}{*}{$\begin{array}{c}\text { External } \\
\text { (mrem/y per } \\
\text { Ci } / \mathrm{m}^{3} \text { ) }\end{array}$} & \multicolumn{4}{|c|}{ Internal } & \multirow{2}{*}{$\begin{array}{c}\text { Total } \\
\left(\text { mrem } / y^{3} \text { per }\right. \\
\left.\text { Ci } / \mathrm{m}^{3}\right)\end{array}$} \\
\hline & & Inhalation & $\begin{array}{c}\text { Soil } \\
\text { Ingestion }\end{array}$ & Vegetables & SubTotal & \\
\hline $\mathrm{Nb}-93 \mathrm{~m}$ & $5.21 \mathrm{E}-02$ & $7.93 \mathrm{E}-02$ & $9.49 \mathrm{E}-02$ & 4. $20 \mathrm{E}-01$ & $5.95 E-01$ & $6.47 \mathrm{E}-01$ \\
\hline $\mathrm{Nb}-94$ & $4.34 \mathrm{E}+03$ & $9.57 \mathrm{E}-01$ & $9.35 \mathrm{E}-01$ & $4.10 \mathrm{E}+00$ & $5.99 \mathrm{E}+00$ & 4. $34 \mathrm{E}+03$ \\
\hline Mo-93 & $2.99 E-01$ & $8.19 \mathrm{E}-02$ & $2.37 E-01$ & $9.43 \mathrm{E}+00$ & $9.75 \mathrm{E}+00$ & $1.00 \mathrm{E}+01$ \\
\hline $\mathrm{TC}-99$ & $3.80 \mathrm{E}-02$ & 1.29E-02 & 1. $41 \mathrm{E}-01$ & 1. $58 \mathrm{E}+02$ & 1. $58 \mathrm{E}+02$ & 1. $58 \mathrm{E}+02$ \\
\hline $\mathrm{Ru}-106$ & $4.25 \mathrm{E}+02$ & $9.22 \mathrm{E}-01$ & $2.78 E+00$ & $3.65 \mathrm{E}+01$ & $4.02 \mathrm{E}+01$ & 4. $65 E+02$ \\
\hline Pd-107 & 0.0 & $3.76 \mathrm{E}-02$ & $2.56 \mathrm{E}-02$ & $6.88 \mathrm{E}-01$ & $7.51 \mathrm{E}-01$ & 7. $51 \mathrm{E}-01$ \\
\hline $\mathrm{Ag}-108 \mathrm{~m}$ & $4.40 \mathrm{E}+03$ & $5.78 \mathrm{E}-01$ & 1. $37 \mathrm{E}+00$ & $6.51 \mathrm{E}+01$ & $6.71 E+01$ & $4.47 E+03$ \\
\hline Cd-109 & $5.80 \mathrm{E}+00$ & $2.23 \mathrm{E}-01$ & 1. $69 \mathrm{E}+00$ & 1. $82 \mathrm{E}+02$ & 1. $84 \mathrm{E}+02$ & 1. $90 \mathrm{E}+02$ \\
\hline $\mathrm{Cd}-113 \mathrm{~m}$ & $3.18 \mathrm{E}-01$ & $3.95 \mathrm{E}+00$ & $2.67 \mathrm{E}+01$ & $2.63 \mathrm{E}+03$ & $2.66 E+03$ & 2. $66 \mathrm{E}+03$ \\
\hline In-115 & $2.03 E-01$ & $9.87 \mathrm{E}+00$ & $2.57 \mathrm{E}+01$ & $3.72 E+01$ & $7.27 \mathrm{E}+01$ & $7.29 E+01$ \\
\hline $\mathrm{Sn}-121 \mathrm{~m}$ & 1. $07 \mathrm{E}+00$ & $2.67 \mathrm{E}-02$ & 3. $63 \mathrm{E}-01$ & $1.85 \mathrm{E}+00$ & $2.24 \mathrm{E}+00$ & $3.32 E+00$ \\
\hline $\mathrm{Sn}-126$ & $5.41 E+03$ & $2.19 \mathrm{E}-01$ & $3.36 \mathrm{E}+00$ & 1. $71 \mathrm{E}+01$ & $2.07 \mathrm{E}+01$ & $5.43 E+03$ \\
\hline $\mathrm{Sb}-125$ & $9.98 \mathrm{E}+02$ & $2.93 E-02$ & $5.56 \mathrm{E}-01$ & $7.45 \mathrm{E}+00$ & $8.03 E+00$ & 1. $01 \mathrm{E}+03$ \\
\hline$I-129$ & $5.79 \mathrm{E}+00$ & $4.56 \mathrm{E}-01$ & $4.48 \mathrm{E}+01$ & $1.49 \mathrm{E}+03$ & $1.54 \mathrm{E}+03$ & $1.54 \mathrm{E}+03$ \\
\hline $\mathrm{Cs}-134$ & $3.64 \mathrm{E}+03$ & $1.16 \mathrm{E}-01$ & 1. $15 \mathrm{E}+01$ & $3.64 \mathrm{E}+02$ & $3.75 E+02$ & $4.01 \mathrm{E}+03$ \\
\hline $\mathrm{Cs}-135$ & $1.96 \mathrm{E}-02$ & $1.31 \mathrm{E}-02$ & 1. $30 \mathrm{E}+00$ & $3.85 E+01$ & $3.98 \mathrm{E}+01$ & $3.98 \mathrm{E}+01$ \\
\hline $\mathrm{Cs}-137$ & 1. $53 E+03$ & $9.18 \mathrm{E}-02$ & $9.07 \mathrm{E}+00$ & $2.69 \mathrm{E}+02$ & $2.78 \mathrm{E}+02$ & $1.81 E+03$ \\
\hline
\end{tabular}

B- 8 
HNF-EP-0884

Rev. 1

\begin{tabular}{|c|c|c|c|c|c|c|}
\hline \multirow[t]{2}{*}{ Nuclide } & \multirow{2}{*}{$\begin{array}{c}\text { External } \\
\text { (mxem/y per } \\
\left.\mathrm{Ci} / \mathrm{m}^{3}\right)\end{array}$} & \multicolumn{4}{|c|}{ Internal (mrem/y per $\left.\mathrm{ci} / \mathrm{m}^{3}\right)$} & \multirow{2}{*}{$\begin{array}{c}\text { Total } \\
(\mathrm{mrem} / \mathrm{y} \text { per } \\
\left.\mathrm{Ci} / \mathrm{m}^{3}\right)\end{array}$} \\
\hline & & Inhalation & $\begin{array}{c}\text { Soil } \\
\text { Ingestion } \\
\end{array}$ & Vegetables & SubTotal & \\
\hline$B a-133$ & $9.13 E+02$ & 1.93E-02 & $5.67 E-01$ & $6.75 \mathrm{E}+00$ & $7.33 \mathrm{E}+00$ & $9.20 \mathrm{E}+02$ \\
\hline $\mathrm{Pm}-147$ & $2.25 \mathrm{E}-02$ & $8.67 \mathrm{E}-02$ & $1.53 E-01$ & $5.94 \mathrm{E}-01$ & $8.34 \mathrm{E}-01$ & $8.56 \mathrm{E}-01$ \\
\hline $\mathrm{Sm}-147$ & 0.0 & $2.06 \mathrm{E}+02$ & 3. $30 \mathrm{E}+01$ & 1.22E+02 & $3.61 \mathrm{E}+02$ & $3.61 \mathrm{E}+02$ \\
\hline$S m-151$ & $5.03 E-04$ & $8.38 \mathrm{E}-02$ & $6.21 \mathrm{E}-02$ & $2.29 \mathrm{E}-01$ & $3.75 \mathrm{E}-01$ & $3.76 \mathrm{E}-01$ \\
\hline Eu-150 & $3.96 \mathrm{E}+03$ & $7.76 \mathrm{E}-01$ & $1.13 \mathrm{E}+00$ & $4.16 \mathrm{E}+00$ & $6.06 \mathrm{E}+00$ & $3.97 E+03$ \\
\hline$E u-152$ & $3.01 \mathrm{E}+03$ & $6.23 \mathrm{E}-01$ & $1.07 \mathrm{E}+00$ & $3.99 \mathrm{E}+00$ & $5.69 \mathrm{E}+00$ & $3.01 \mathrm{E}+03$ \\
\hline Eu-154 & $3.24 \mathrm{E}+03$ & $7.26 \mathrm{E}-01$ & $1.61 \mathrm{E}+00$ & $6.00 \mathrm{E}+00$ & $8.34 \mathrm{E}+00$ & $3.25 E+03$ \\
\hline Eu-155 & $8.71 \mathrm{E}+01$ & $1.06 \mathrm{E}-01$ & $2.23 \mathrm{E}-01$ & $8.43 \mathrm{E}-01$ & $1.17 \mathrm{E}+00$ & $8.83 E+01$ \\
\hline $\mathrm{Gd}-152$ & 0.0 & $6.97 E+02$ & $2.75 \mathrm{E}+01$ & $1.01 \mathrm{E}+02$ & $8,25 E+02$ & $8.25 E+02$ \\
\hline Ho- $166 \mathrm{~m}$ & $4.69 \mathrm{E}+03$ & $2.09 E+00$ & 1. $43 \mathrm{E}+00$ & $5.26 E+00$ & $8.78 \mathrm{E}+00$ & $4.70 \mathrm{E}+03$ \\
\hline Re-187 & 0.0 & 1. $41 E-04$ & $1.51 \mathrm{E}-03$ & 3. $44 \mathrm{E}-01$ & $3.46 \mathrm{E}-01$ & $3.46 \mathrm{E}-01$ \\
\hline $\mathrm{T} 1-204$ & $1.88 \mathrm{E}+00$ & $6.10 \mathrm{E}-03$ & $5.37 \mathrm{E}-01$ & $8.05 \mathrm{E}-01$ & $1.35 E+00$ & $3.23 E+00$ \\
\hline $\mathrm{Pb}-210$ & $3.01 \mathrm{E}+00$ & $6.13 E+01$ & 1. $22 \mathrm{E}+03$ & $5.05 \mathrm{E}+03$ & $6.32 \mathrm{E}+03$ & $6.33 E+03$ \\
\hline$B i-207$ & 4. $11 E+03$ & $4.02 \mathrm{E}-02$ & $8.89 \mathrm{E}-01$ & $4.05 \mathrm{E}+00$ & 4. $98 \mathrm{E}+00$ & 4.11E+03 \\
\hline $\mathrm{Po}-209$ & $8.86 \mathrm{E}+00$ & $2.90 E+01$ & $3.66 \mathrm{E}+02$ & 8. $25 \mathrm{E}+02$ & I. $22 \mathrm{E}+03$ & $1.23 E+03$ \\
\hline $\mathrm{Ra} a-226$ & $4.83 E+03$ & $2.39 E+01$ & $2.21 \mathrm{E}+02$ & $6.64 \mathrm{E}+02$ & $9.09 \mathrm{E}+02$ & $5.74 \mathrm{E}+03$ \\
\hline $\mathrm{Ra}-228$ & $3.07 E+03$ & $1.53 E+02$ & $2.29 E+02$ & $6.74 \mathrm{E}+02$ & 1. $06 \mathrm{E}+03$ & $4.12 \mathrm{E}+03$ \\
\hline
\end{tabular}


HNF-EP-0884

Rev. 1

\begin{tabular}{|c|c|c|c|c|c|c|}
\hline \multirow[t]{2}{*}{ Nuclide } & \multirow{2}{*}{$\begin{array}{c}\text { External } \\
\text { (mrem } / y_{3} \text { per } \\
\left.\text { Ci } / \mathrm{m}^{3}\right)\end{array}$} & \multicolumn{4}{|c|}{ Internal } & \multirow{2}{*}{$\begin{array}{c}\text { Total } \\
\left(\mathrm{mrem} / Y_{3} \text { per }\right. \\
\left.\text { Ci } / \mathrm{m}^{3}\right)\end{array}$} \\
\hline & & Inhalation & $\begin{array}{c}\text { Soil } \\
\text { Ingestion }\end{array}$ & Vegetables & SubTotal & \\
\hline Ac-227 & $9.56 \mathrm{E}+02$ & $1.92 \mathrm{E}+04$ & $2.64 \mathrm{E}+03$ & $3.74 E+03$ & $2.56 E+04$ & $2.65 \mathrm{E}+04$ \\
\hline$T h-228$ & $3.56 \mathrm{E}+03$ & $7.63 \mathrm{E}+02$ & $1.16 \mathrm{E}+02$ & $1.57 \mathrm{E}+02$ & $1.04 \mathrm{E}+03$ & $4.60 \mathrm{E}+03$ \\
\hline$T h-229$ & $7.57 \mathrm{E}+02$ & $5.86 \mathrm{E}+03$ & $7.17 \mathrm{E}+02$ & $9.05 \mathrm{E}+02$ & $7.48 \mathrm{E}+03$ & $8.24 \mathrm{E}+03$ \\
\hline $\mathrm{Th}-230$ & 1. $66 \mathrm{E}+00$ & $9.29 \mathrm{E}+02$ & $9.73 \mathrm{E}+01$. & 1. $23 E+02$ & 1. $15 E+03$ & $1.15 \mathrm{E}+03$ \\
\hline $\mathrm{Th}-232$ & $1.76 \mathrm{E}+02$ & 4. $65 E+03$ & $5.28 \mathrm{E}+02$ & $6.71 \mathrm{E}+02$ & $5.85 E+03$ & $6.03 E+03$ \\
\hline $\mathrm{Pa}-231$ & 1. $07 \mathrm{E}+02$ & $4.08 E+03$ & $2.06 \mathrm{E}+03$ & $2.74 E+03$ & $8.88 E+03$ & $8.99 E+03$ \\
\hline $\mathrm{U}-232$ & $6.76 \mathrm{E}+02$ & $2.06 \mathrm{E}+03$ & $2.57 \mathrm{E}+02$ & $8.38 \mathrm{E}+02$ & $3.16 \mathrm{E}+03$ & $3.83 E+03$ \\
\hline $\mathrm{U}-233$ & $7.22 \mathrm{E}-01$ & $3.74 \mathrm{E}+02$ & $4.91 \mathrm{E}+01$ & $1.70 \mathrm{E}+02$ & $5.93 E+02$ & $5.94 \mathrm{E}+02$ \\
\hline $\mathrm{U}-234$ & $2.03 \mathrm{E}-01$ & $3.73 E+02$ & $4.72 \mathrm{E}+01$ & 1. $64 \mathrm{E}+02$ & $5.84 \mathrm{E}+02$ & $5.85 \mathrm{E}+02$ \\
\hline $\mathrm{U}-235$ & $3.74 \mathrm{E}+02$ & $3.45 \mathrm{E}+02$ & $4.57 \mathrm{E}+01$ & $1.58 E+02$ & $5.49 \mathrm{E}+02$ & $9.22 \mathrm{E}+02$ \\
\hline $\mathrm{U}-236$ & $1.08 \mathrm{E}-01$ & 3. $45 \mathrm{E}+02$ & $4.54 \mathrm{E}+01$ & $1.57 \mathrm{E}+02$ & $5.48 \mathrm{E}+02$ & $5.48 \mathrm{E}+02$ \\
\hline $\mathrm{U}-238$ & $6.02 \mathrm{E}+01$ & $3.45 \mathrm{E}+02$ & $4.41 \mathrm{E}+01$ & 1. $53 E+02$ & $5.42 \mathrm{E}+02$ & $6.02 \mathrm{E}+02$ \\
\hline$N p-237$ & $5.17 \mathrm{E}+02$ & 1. $38 \mathrm{E}+03$ & $6.94 E+02$ & $2.74 E+03$ & $4.81 \mathrm{E}+03$ & $5.33 \mathrm{E}+03$ \\
\hline $\mathrm{pu}-236$ & $2.21 \mathrm{E}+00$ & 4. $21 E+02$ & $2.13 E+02$ & $2.69 E+02$ & $9.04 \mathrm{E}+02$ & $9.06 \mathrm{E}+02$ \\
\hline $\mathrm{Pu}-238$ & $7.70 E-02$ & 1. $33 E+03$ & $6.95 \mathrm{E}+02$ & $8.36 \mathrm{E}+02$ & $2.86 \mathrm{E}+03$ & $2.86 \mathrm{E}+03$ \\
\hline $\mathrm{Pu}-239$ & 1. $46 \mathrm{E}-01$ & 1. $48 \mathrm{E}+03$ & $7.89 \mathrm{E}+02$ & $9.48 \mathrm{E}+02$ & $3.22 \mathrm{E}+03$ & $3.22 \mathrm{E}+03$ \\
\hline $\mathrm{Pu}-240$ & $7.51 \mathrm{E}-02$ & 1. $48 \mathrm{E}+03$ & $7.89 \mathrm{E}+02$ & $9.48 \mathrm{E}+02$ & $3.22 \mathrm{E}+03$ & $3.22 \mathrm{E}+03$ \\
\hline
\end{tabular}


HNE-EP-0884

Rev. 1

\begin{tabular}{|c|c|c|c|c|c|c|}
\hline \multirow[t]{2}{*}{ Nuclide } & \multirow{2}{*}{$\begin{array}{c}\text { External } \\
(\mathrm{mrem} / \mathrm{Y} \text { per } \\
\left.\mathrm{Ci} / \mathrm{m}^{3}\right)\end{array}$} & \multicolumn{4}{|c|}{ Internal } & \multirow{2}{*}{$\begin{array}{c}\text { Total } \\
\text { (mrem } / y \text { per } \\
\left.\text { Ci } / \mathrm{m}^{3}\right)\end{array}$} \\
\hline & & Inhalation & $\begin{array}{c}\text { Soil } \\
\text { Ingestion }\end{array}$ & Vegetables & SubTotal & \\
\hline $\mathrm{Pu}-241$ & $2.70 \mathrm{E}-02$ & $2.95 E+01$ & $1.61 \mathrm{E}+01$ & $1.92 \mathrm{E}+01$ & $6.48 \mathrm{E}+01$ & $6.48 \mathrm{E}+01$ \\
\hline $\mathrm{Pu}-242$ & $6.56 \mathrm{E}-02$ & 1. $39 E+03$ & $7.53 \mathrm{E}+02$ & $9.04 \mathrm{E}+02$ & $3.05 E+03$ & $3.05 E+03$ \\
\hline $\mathrm{Pu}-244$ & $9.15 \mathrm{E}+02$ & 1. $39 E+03$ & $7.35 \mathrm{E}+02$ & $8.83 \mathrm{E}+02$ & $3.01 E+03$ & $3.93 E+03$ \\
\hline Am-241 & $2.24 \mathrm{E}+01$ & 1. $51 E+03$ & $8.25 \mathrm{E}+02$ & $1.03 E+03$ & $3.37 \mathrm{E}+03$ & $3.39 E+03$ \\
\hline Am-242m & 3. $35 \mathrm{E}+01$ & 1. $48 \mathrm{E}+03$ & $7.88 \mathrm{E}+02$ & $9.84 \mathrm{E}+02$ & $3.25 \mathrm{E}+03$ & $3.29 E+03$ \\
\hline Am-243 & $4.46 \mathrm{E}+02$ & 1. $51 \mathrm{E}+03$ & $8.27 \mathrm{E}+02$ & $1.03 \mathrm{E}+03$ & $3.37 E+03$ & $3.81 E+03$ \\
\hline $\mathrm{Cm}-243$ & $2.86 \mathrm{E}+02$ & 1. $.00 E+03$ & $5.26 \mathrm{E}+02$ & $6.35 \mathrm{E}+02$ & $2.16 \mathrm{E}+03$ & $2.45 E+03$ \\
\hline $\mathrm{Cm}-244$ & $6.34 \mathrm{E}-02$ & $7.69 \mathrm{E}+02$ & $4.14 \mathrm{E}+02$ & $5.01 \mathrm{E}+02$ & $1.69 \mathrm{E}+03$ & 1. $69 \mathrm{E}+03$ \\
\hline $\mathrm{Cm}-245$ & 1. $.72 \mathrm{E}+02$ & 1. $57 \mathrm{E}+03$ & $8.26 \mathrm{E}+02$ & $9.92 \mathrm{E}+02$ & $3.39 \mathrm{E}+03$ & $3.56 \mathrm{E}+03$ \\
\hline $\mathrm{Cm}-246$ & $5.96 \mathrm{E}-02$ & 1. $57 \mathrm{E}+03$ & 8. $26 \mathrm{E}+02$ & $9.92 \mathrm{E}+02$ & $3.39 \mathrm{E}+03$ & $3.39 E+03$ \\
\hline $\mathrm{Cm}-247$ & $8.83 \mathrm{E}+02$ & 1. $42 \mathrm{E}+03$ & $7.53 \mathrm{E}+02$ & $9.04 \mathrm{E}+02$ & $3.08 E+03$ & $3.96 \mathrm{E}+03$ \\
\hline $\mathrm{Cm}-248$ & $4.50 \mathrm{E}-02$ & $5.52 E+03$ & $2.94 \mathrm{E}+03$ & $3.53 \mathrm{E}+03$ & $1.20 \mathrm{E}+04$ & 1. $20 \mathrm{E}+04$ \\
\hline
\end{tabular}

Nuclides with "D" added to the name include the contributions from short-lived progeny, which are assumed to be in equilibrium at all times. 


\section{HNF-EP-0884}

Rev. 1

Table B-5. Ratio of Intruder Dose Factors for $2500 \mathrm{~m}^{2}$ garden relative to $500 \mathrm{~m}^{2}$ garden."

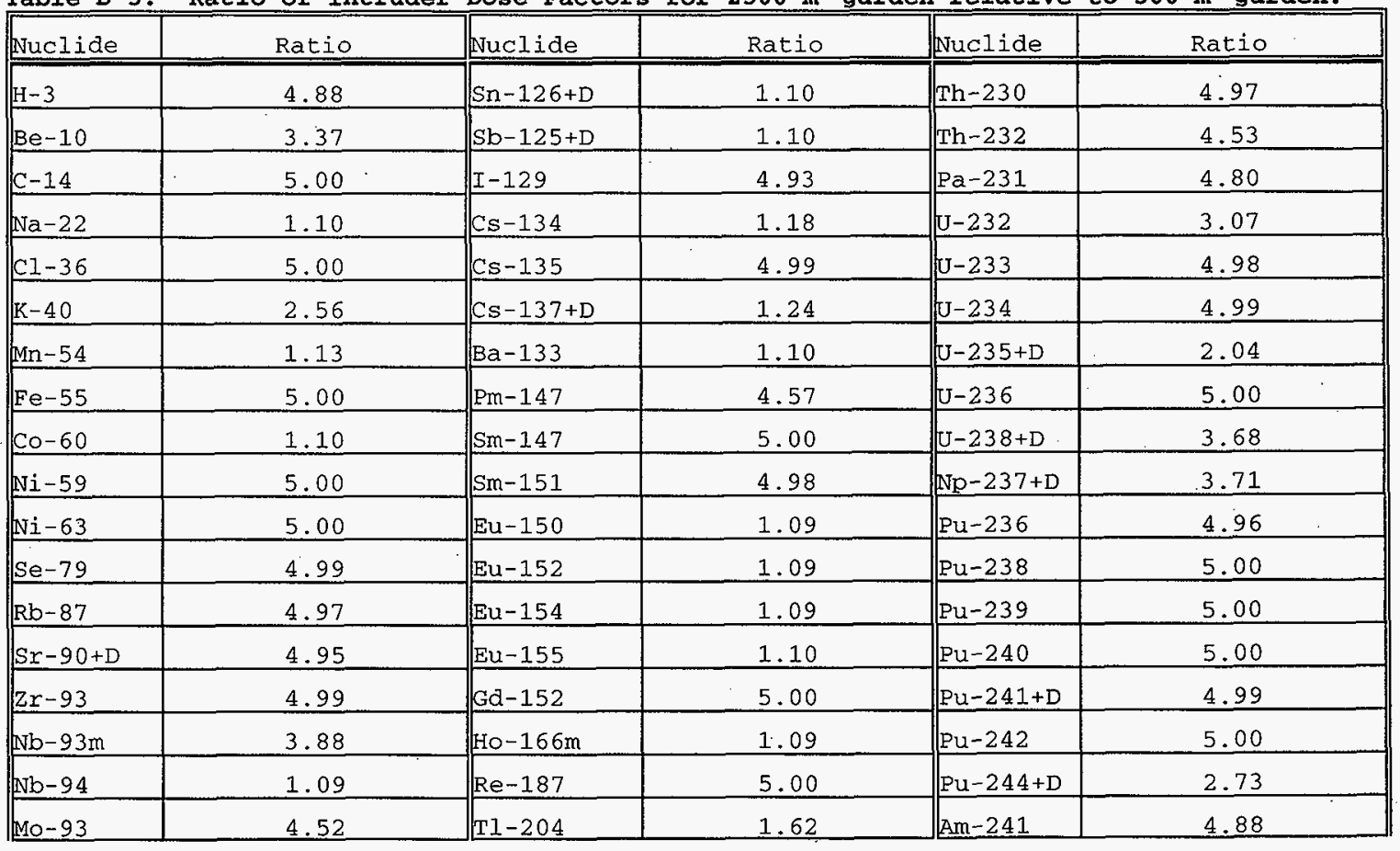




\section{HNF - EP- 0884}

Rev. 1

\begin{tabular}{|c|c|c|c|c|c|}
\hline $\mathrm{T}_{\mathrm{C}-99}$ & 5.00 & $\mathrm{~Pb}-210+\mathrm{D}$ & 4.99 & $A m-242 m+D$ & 4.82 \\
\hline$R u-106+D$ & 1.17 & $B i-207$ & 1.09 & $A m-243+D$ & 3.52 \\
\hline $\mathrm{Pd}-107$ & 5.00 & Po-209 & 4.87 & $\mathrm{Cm}-243$ & 3.53 \\
\hline$A g-108 m+D$ & 1.11 & $R a-226+D$ & 1.25 & $\mathrm{Cm}-244$ & 5.00 \\
\hline $\mathrm{cd}-109$ & 4.51. & $R a-228+D$ & 1.37 & $\mathrm{Cm}-245$ & 4.26 \\
\hline $\mathrm{Cd}-113 \mathrm{~m}$ & 5.00 & $A C-227+D$ & 4.43 & $\mathrm{Cm}-246$ & 5.00 \\
\hline $\operatorname{In}-115$ & 4.95 & $T h-228+D$ & 1.33 & $\mathrm{Cm}-247+\mathrm{D}$ & 2.78 \\
\hline$S n-121 m+D$ & 2.31 & $\mathrm{Th}-229+\mathrm{D}$ & 3.76 & $\mathrm{Cm}-248$ & 5.00 \\
\hline
\end{tabular}

"Nuclides with "+D" added to the name include the contributions from short-lived progeny, which are assumed to be in equilibrium. 
HNF-EP- 0884

Rev. 1

B -14

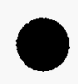




\section{FRT - EP- 0884 \\ Rev. 1 \\ APPENDIX C \\ WASTE FORM RELEASE COMPUTER CODES}

\section{C.1 Overview}

This section provides a brief summary on the waste form release modeling for those sensitivity cases involving computer simulation of the release. More information is given than is justified by the importance of the three sensitivity cases, as later performance assessments will probably be heavily based on this type of simulation.

\section{C.2 Governing Equations}

\section{C.2.1 Mass Conservation of Aqueous Solutes}

Based on the continuum theory, the model can be represented by a set of partial differential equations (PDEs) that describe the mass conservation of solutes in pore fluids. Under the assumption that the rock matrix does not deform, the mass conservation law of solutes can be written as

$$
\frac{\partial\left(\phi S_{w} \rho_{w} C_{i}\right)}{\partial t}=-\vec{\nabla} \cdot \vec{J}_{i}+\sum_{j=1}^{N_{r}} v_{i j} W_{j}, \quad i=1,2, \ldots
$$

where

$$
\begin{aligned}
& \Phi \text { denotes the porosity, } \\
& S_{w} \text { denotes the water saturation, } \\
& \rho_{w} \text { the density of the aqueous solution, } \\
& C_{i} \text { is the molal concentration of solute } i . \\
& J_{i} \text { is the flux of species } i \text {, } \\
& v_{i j} \text { is the stoichiometric coefficient of species } i \text { in } \\
& N_{r} \text { is the number of total reactions, and } \\
& W_{j} \text { is the rate of reaction } j .
\end{aligned}
$$

In general, the reaction rate is a non-linear function of the concentrations. Through the term $w_{j}$, one solute species is nonlinearly coupled with other species. The non-linear partial differential equation (1) simply states that the time rate of change of aqueous species concentrations consists of two parts; one is the contribution of transport and the other is the contribution of all reactions. Assuming the phenomenon of hydrodynamic dispersion can be represented by a Fickian type law, the first term on the right-hand side can be expanded into

$$
-\vec{\nabla} \cdot \vec{J}_{i}=-\vec{\nabla} \cdot\left(-\Phi S_{w} \rho_{w} D_{i} \vec{\nabla} C_{i}+\vec{u} \phi S_{w} \rho_{w} C_{i}\right) \text {, }
$$

where $D_{i}$ is the dispersion coefficient of $i$ and $u$ is the velocity of pore fluid.

The second term at the right-hand side of equation (1) represents all types of reactions, including aqueous speciation, redox reactions, solid precipitation and dissolution, adsorption, etc. In general, chemical reactions can be treated as either equilibrium-controlled or kinetic-controlled. Several of the 


\section{FANF-EP-0884 \\ Rev. 1}

available reaction-transport models can only treat equilibrium reactions (Mangold 1991). In this case, the non-linear equation (1) can be transformed into a linear equation and thus is numerically easier to solve. However, many reactions are kinetically controlled, especially solid dissolution and precipitation reactions. Consequently, both equilibrium and kinetic reactions are included in the model used here. To emphasize this, the reaction term in Equation (1) is split into two parts: one represents the contributions from equilibrium reactions, the other from kinetic reactions

$$
\sum_{j=1}^{N_{r}} v_{i j} w_{j}=\sum_{j=1}^{N_{e}} v_{i j}^{e} w_{j}^{e}+\sum_{j=1}^{N_{k}} v_{i j}^{k} w_{j}^{k},
$$

where $v_{i j}{ }^{e}$ and $v_{i j}{ }^{k}$ are the stoichiometric coefficients in equilibrium reactions and kinetic reactions, respectively, while $W_{j}{ }^{e}$ and $W_{j}{ }^{k}$ are the rates of equilibrium and kinetic reactions, respectively.

To define the mathematical form of the $W^{\prime} s$, note that for any kinetic reaction $j$ involving aqueous and solid species $m$ with the form

$$
\sum v_{m j} B_{m}=0
$$

using the law of mass-action, with activity corrections, the rate can be expressed as

$$
W_{j}^{k}=A_{j} k_{j}\left[\prod_{v_{i j}<0}\left(Y_{i} C_{i}\right)^{\nu_{i j}^{\prime}}-\prod_{v_{i j}>0}\left(Y_{i} C_{i}\right)^{v_{i j} / K_{j}^{e q}}\right]
$$

where $A_{j}$ is a factor. For aqueous reactions, $A_{j}=1$. For solid dissolution and precipitation reactions, $A_{j}$ is the effective reaction surface in unit volume of the porous medium. If we further assume that all solids are spherical grains or can be represented as equivalent spherical grains with radii of $R_{1}$, and that the effective reaction surface is proportional to water saturation then,

$$
W_{j}=4 \pi R_{1(j)}^{2} n_{\lambda(j)} S_{w} k_{j}\left[\prod_{v_{i j}<0}\left(Y_{i} C_{i}\right)^{\prime v_{i j}^{\prime}}-\prod_{v_{i j}>0}\left(Y_{i} C_{i}\right)^{v_{i j} / K_{j}^{e q}}\right]
$$

where $n_{1}$ denotes the number of grains in unit volume of

$$
\begin{aligned}
& k_{j} \text { is the rate constant, and } \\
& v_{i} \text { is the activity coefficient which is a function of } \\
& \text { the concentrations of all species. }
\end{aligned}
$$

There are several formulas, such as Davies equation, B-dot equation, Pitzer's model etc., that can be used to calculate $V_{i}$. The B-dot equation with modifications for neutral species adopted by Wolery (1992) is computationally economic and stable, and can handle moderate salinity; thus it is the most suitable for reaction-transport problems. Although Pitzer's model can handle high ionic strength, computationally it is not feasible for reaction-transport simulations because of its complicated structure and the lack of Pitzer constants for all but a few aqueous species. 


\section{C.2.2 Texture Dynamics}

Dissolution and precipitation reactions can change the volume fractions of solids as a function of time. For spherical grains, the change rate is

$$
\frac{\partial V_{I}}{\partial t}=4 \pi R_{I}^{2} n_{1} \frac{\partial R_{1}}{\partial t}
$$

while

$$
\frac{\partial R_{2}}{\partial t}=\sum_{j} k_{j}\left[\prod_{\nu_{i j}<0}\left(\gamma_{i} C_{i}\right)^{\prime v_{i j}}-\prod_{v_{i j}>0}\left(\gamma_{i} C_{i}\right)^{\nu_{i j} / K_{j}^{e q}}\right] / \rho_{j},
$$

where $V_{1}$ is the volume fraction of solid 1 .

$$
\begin{aligned}
& R_{1} \text { is the change rate in radius of solid } 1 \text {, and } \\
& \rho_{1} \text { is the molar density of } 1 \text {. }
\end{aligned}
$$

Equation (8) serves as the bridge between aqueous phase and solid phases so that the whole system is mass-conserved.

\section{C.2.3 Contaminant Release Rate From Glass} taken as

The equation for the contaminant release rate from glass is

$$
J_{i}=\nu_{i} a_{H^{*}}^{-n(T)} k_{o} e^{\frac{E_{a}}{R T}}\left[1-\left(\frac{Q}{K}\right)^{\sigma}\right]
$$

where $J_{i}$ is the flux of element $i$,

$$
\begin{aligned}
& v_{i} \text { is the stoichmetric coefficient of element } i \text {, } \\
& a_{H_{*}} \text { is the activity of } \mathrm{H}^{+} \text {, } \\
& n \text { is the } \mathrm{pH} \text { power law coefficient, } \\
& \mathrm{T} \text { is the temperature, } \\
& k_{0} \text { is the intrinsic rate constant, } \\
& \mathrm{E}_{\mathrm{a}} \text { is the activation energy, } \\
& R \text {. is the gas constant, } \\
& Q \text { is the ion activity product, } \\
& \mathrm{K} \text { is the pseudoequilibrium constant, and } \\
& \sigma \text { is the average stoichiometric parameter for the }
\end{aligned}
$$

\section{C.2.4 Reactions Considered}

Three types of reactions are considered:

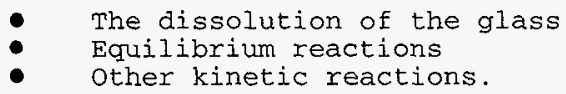

The glass considered in our simulations is LD6-5412, with a formula of the major glass components of $\mathrm{Al}_{0.1535} \mathrm{~B}_{0.094} \mathrm{Ca}_{0.046} \mathrm{~K}_{0.0202} \mathrm{Na}_{0.4208} \mathrm{Si}_{0.6068} \mathrm{O}_{1.2514}$. Flow-through experiments show that two reaction mechanisms are involved in the glass 


\section{HNF-EP-0884 \\ Rev. 1}

dissolution (McGrail 1995). One is the network dissolution reaction

$$
\begin{aligned}
& \text { Glass }+0.5 \mathrm{OH}^{-}+0.45 \mathrm{H}_{2} \mathrm{O}= \\
& 0.0202 \mathrm{~K}^{+}+0.4208 \mathrm{Na}^{+}+0.046 \mathrm{Ca}++0.094 \mathrm{BO}_{2}^{-}+ \\
& 0.154 \mathrm{Al}^{-}(\mathrm{OH})_{3}(\mathrm{aq})+0.2712 \mathrm{HSiO}_{3}^{-}+0.3348 \mathrm{H}_{2} \mathrm{SiO}_{4}{ }^{2-}+ \\
& 2.28 \times 10^{-8} \mathrm{SeO}_{3}{ }^{2-}+1.62 \times 10^{-6} \mathrm{TCO}_{4}^{-3}+3.83 \times 10^{-8} \mathrm{IO}_{3}^{-}+ \\
& 2.72 \times 10^{-5} \mathrm{U}^{-}(\mathrm{OH})_{4}(\mathrm{aq})+1.93 \times 10^{-9} \mathrm{Pu}(\mathrm{OH})_{5}^{-}+ \\
& 2.73 \times 10^{-9} \mathrm{NpO}_{2}(\mathrm{OH})(\mathrm{aq})
\end{aligned}
$$

the other is an ion-exchange reaction

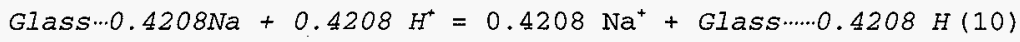

The measured rate constant for reaction (9) at $14^{\circ} \mathrm{C}$ is $3.03 \times 10^{-14}$ $\mathrm{mol} \cdot \mathrm{m}^{-2} \cdot \mathrm{s}^{-1}=1.68 \times 10^{-7} \mathrm{~g} \cdot \mathrm{m}^{-2} \cdot \mathrm{d}^{-1}$, and for Reaction (10) it is $1.74 \times 10^{-11} \mathrm{~mol} \cdot \mathrm{m}^{-2} \cdot \mathrm{s}^{-1}=9.6 \times 10^{-5} \mathrm{~g} \cdot \mathrm{m}^{-2} \cdot \mathrm{d}^{-1}$. Radionuclide release is assumed to only occur via Reaction (9); the release of all radionuclides is assumed to be congruent.

Thirty-eight aqueous species, 14 solid species plus glass were considered in the simulations. The selection of species is based on speciation calculations and observations from glass testing experiments. Table $\mathrm{C}-1$ lists all reactions considered in the simulations, including 21 equilibrium reactions and 16 kinetic reactions.

\section{3 Code Selection}

The selection of AREST-CT for modeling the release rate of contaminants from the glass waste form was based on meeting the criteria and requirements for the disposal system release model (McGrail 1994). The ten codes considered were

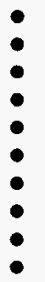
AREST-CT (Engel 1995)
BLT-EC (Mackinnion 1994)
CAT (Kervevan 1994)
CHEQMATE (Haworth 1988)
CHMTRNS (Noorishad 1987)
CIRF-A (Chen 1994)
HYDROGEOCHEM (Yeh 1990)
THCC (Carnahan 1986)
UNSATCHEM-2D (Simunek 1993)
UT-CHEM (Bhuyan 1989).

To be considered, a code must have met the criteria and requirements given in Mann $1995 \mathrm{c}$ and at least $50 \%$ of all requirements given in McGrail 1994. Briefly, the criteria were that the codes would be:

\footnotetext{
- Based on scientific principles Documented Maintained under a software quality management program Allow the use of site and facility specific data Capable of monitoring long simulations.
} 
Rev. 1

\section{Table C-1. List of Reactions Considered in Glass Performance}

Equilibxium Reactions
1. $\mathrm{H}_{2} \mathrm{O}=\mathrm{H}^{+}+\mathrm{OH}^{-}$
2. $\mathrm{CO}_{2}(\mathrm{aq})+\mathrm{H}_{2} \mathrm{O}=\mathrm{H}^{+}+\mathrm{HCO}_{3}{ }^{-}$
3. $\mathrm{HCO}_{3}{ }^{-}=\mathrm{H}^{+}+\mathrm{CO}_{3}{ }^{2-}$
4. $\quad \mathrm{Al}(\mathrm{OH})_{4}^{-}+\mathrm{H}^{+}=\mathrm{AI}(\mathrm{OH})_{3}+\mathrm{H}_{2} \mathrm{O}$
5. $\mathrm{H}_{2} \mathrm{SiO}_{4}{ }^{2-}+2 \mathrm{H}^{+}=\mathrm{SiO}_{2}(\mathrm{aq})+\mathrm{H}_{2} \mathrm{O}$
6. $\mathrm{HSiO}_{3}+\mathrm{H}^{+}=\mathrm{SiO}_{2}(\mathrm{aq})+\mathrm{H}_{2} \mathrm{O}$
7. $\mathrm{BO}_{2}^{-}+\mathrm{H}^{+}=\mathrm{B}(\mathrm{OH})_{3}(\mathrm{aq})$
8. $\mathrm{CaCO}_{3}(\mathrm{aq})+\mathrm{H}^{+}=\mathrm{Ca}^{2+}+\mathrm{HCO}_{3}^{-}$
9. $\mathrm{CaHCO}_{3}{ }^{+}=\mathrm{Ca}^{2+}+\mathrm{HCO}_{3}{ }^{-}$
10. $\mathrm{CaOH}^{+}+\mathrm{H}^{+}=\mathrm{Ca}^{2+}+\mathrm{H}_{2} \mathrm{O}$
11. $\mathrm{UO}_{2} \mathrm{CO}_{3}(\mathrm{OH})_{3}^{-}+4 \mathrm{H}^{+}=2 \mathrm{UO}_{2}{ }^{+}+\mathrm{HCO}_{3}^{-}+3 \mathrm{H}_{2} \mathrm{O}$
12. $\mathrm{UO}_{2} \mathrm{CO}_{3}(\mathrm{aq})^{3}+\mathrm{H}^{+}=\mathrm{HCO}_{3}^{-}+\mathrm{UO}_{2}{ }^{2+}$
13. $\mathrm{UO}_{2}\left(\mathrm{CO}_{3}\right)^{2-}+2 \mathrm{H}^{+}=\mathrm{UO}_{2}^{2+} 2 \mathrm{HCO}_{3}^{-}$
14. $\mathrm{UO}_{2}\left(\mathrm{CO}_{3}\right)_{3}^{4-}+3 \mathrm{H}^{+}=\mathrm{UO}_{2}^{2+}+3 \mathrm{HCO}_{3}^{-}$
15. $\mathrm{UO}_{2} \mathrm{OH}^{+}+\mathrm{H}^{+}=\mathrm{UO}_{2}{ }^{2+}+\mathrm{H}_{2} \mathrm{O}$
16. $\mathrm{UO}_{2}(\mathrm{OH})_{2}(\mathrm{aq})+2 \mathrm{H}^{+}=\mathrm{UO}_{2}{ }^{2+}+2 \mathrm{H}_{2} \mathrm{O}$
17. $\mathrm{UO}_{2}(\mathrm{OH})_{3}+3 \mathrm{H}^{+}=\mathrm{UO}_{2}{ }^{2+}+3 \mathrm{H}_{2} \mathrm{O}$
18. $\mathrm{U}(\mathrm{OH})_{4}(\mathrm{aq})+0.5 \mathrm{O}_{2}(\mathrm{aq})+2 \mathrm{H}^{+}=\mathrm{UO}_{2}{ }^{2+}+3 \mathrm{H}_{2} \mathrm{O}$
19. $\mathrm{NpO}_{2} \mathrm{OH}(\mathrm{aq})=\mathrm{OH}^{-}+\mathrm{NpO}_{2}^{+}$.
20. $\mathrm{NpO}_{2}\left(\mathrm{CO}_{3}\right)^{-}=\mathrm{NpO}_{2}^{+}+\mathrm{CO}_{3}^{2+}$
21. $\mathrm{HSeO}_{3}{ }^{-}=\mathrm{H}^{+}+\mathrm{SeO}_{3}{ }^{2-}$

\section{Kinetic Reactions}

$$
\begin{aligned}
& \text { 1. Glass }+0.5 \mathrm{OH}^{-}+0.45 \mathrm{H}_{2} \mathrm{O}= \\
& 0.0202 \mathrm{~K}^{+}+0.4208 \mathrm{Na}^{+}+0.046 \mathrm{Ca}++0.094 \mathrm{BO}_{2}{ }^{-}+ \\
& 0.154 \mathrm{Al}(\mathrm{OH})_{3}(\mathrm{aq})+0.2712 \mathrm{HSiO}_{3}^{-}+0.3348 \mathrm{H}_{2} \mathrm{SiO}_{4}{ }^{2-} \\
& +2.28 \times 10^{-8} \mathrm{SeO}_{3}{ }^{2-}+1.62 \times 10^{-6} \mathrm{TCO}_{4}^{-}+3.83 \times 10^{-8} \mathrm{IO}_{3} \\
& +2.72 \times 10^{-5} \mathrm{U}(\mathrm{OH})_{4}(\mathrm{aq})+1.93 \times 10^{-9} \mathrm{Pu}(\mathrm{OH})_{5}^{-}+ \\
& 2.73 \times 10^{-9} \mathrm{NpO}_{2}(\mathrm{OH}) \text { (aq) }
\end{aligned}
$$

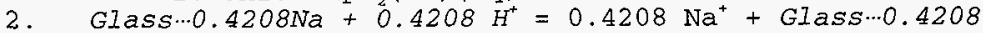

$$
\begin{aligned}
& \text { 3. Quartz }+\mathrm{OH}^{-}=\mathrm{HSiO}_{3}^{-} \\
& \text {4. Calcite }=\mathrm{Ca}^{2+}+\mathrm{CO}_{3} \\
& \text { 5. Albite (high) }+2 \mathrm{OH}^{-}=\mathrm{Na}^{+}+\mathrm{Al}(\mathrm{OH})_{3}(\mathrm{aq})+3 \mathrm{HSiO}_{3}{ }^{-} \\
& \text {6. } \mathrm{K} \text {-feldspar }+2 \mathrm{OH}^{-}=\mathrm{K}^{+}+\mathrm{Al}(\mathrm{OH})_{3}(\mathrm{aq})+3 \mathrm{HSiO}_{3} \\
& \text { 7. Illite }+2.4 \mathrm{OH}^{-}=0.6 \mathrm{~K}^{+}+0.25 \mathrm{Mg}^{2+}+2.3 \mathrm{Al}(\mathrm{OH}) 3(\mathrm{aq}) \\
& \text { 8. Analcime }+0.96 \mathrm{H}^{+}=\begin{array}{c}
3.5 \\
0.96 \mathrm{Na}^{+}
\end{array}+0.96 \mathrm{AL}(\mathrm{OH})_{3}(\mathrm{aq})+ \\
& \text { 9. Chalcedony }=\mathrm{SiO}_{2}(\mathrm{aq}) \\
& \text { 10. } \mathrm{NaAlSi}{ }_{2} \mathrm{O}_{6} \cdot 6 \mathrm{H} 2 \mathrm{O}+\mathrm{OH}^{-}=\mathrm{Na}^{+}+\mathrm{Al}(\mathrm{OH})_{3}(\mathrm{aq})+2 \mathrm{HSiO}_{3}^{-}+4 \mathrm{H}_{2} \mathrm{O} \\
& \text { 1. Phillipsite }+3 \mathrm{H}^{+}=\mathrm{K}^{+}+\mathrm{Ca}^{2+} 3 \mathrm{Al}(\mathrm{OH})_{3}(\mathrm{aq})+5 \mathrm{SiO}_{2}(\mathrm{aq})+ \\
& 3 \mathrm{H}_{2} \mathrm{O} \\
& \text { 12. Tobermorite }+10 \mathrm{H}^{+}=5 \mathrm{Ca}^{2+}+6 \mathrm{SiO}_{2}(\mathrm{aq})+10.5 \mathrm{H}_{2} \mathrm{O} \\
& \text { 13. Gobbinsite }+6 \mathrm{H}^{+}=4 \mathrm{Na}^{+}+\mathrm{Ca}^{2+}+6 \mathrm{Al}(\mathrm{OH})_{3}(\mathrm{aq})+ \\
& \text { 14. Haiweeite }+6 \mathrm{H}^{+}=\mathrm{Ca}^{2+}+6 \mathrm{SiO}_{2}(\mathrm{aq})+8 \mathrm{SiO}_{2} \mathrm{O} \text { (aq) } 2 \mathrm{UO}_{2}{ }^{2+}+8 \mathrm{H}_{2} \mathrm{O} \\
& \text { 15. Schoepite }+2 \mathrm{H}^{+}=\mathrm{UO}_{2}{ }^{2+}+3 \mathrm{H}_{2} \mathrm{O} \\
& \text { 16. } \mathrm{PuO}_{2}(\mathrm{~s})+3 \mathrm{H}_{2} \mathrm{O}=\mathrm{H}^{+}+\mathrm{Pu}(\mathrm{OH})_{5}^{-}
\end{aligned}
$$


The requirements given in Mann 1995c were based on capabilities of the code. The source term codes needed to be capable of:

- Simulating radionuclide release from unstable and stable vitrified waste

- Modelling various chemical processes

Simulating radionuclide releases controlled by solubility limits or adsorption

Accepting specific release rates then simulating the disposal facility release until the inventory was depleted.

The additional requirements listed in McGrail (1994) fit into one of four groups -- physical processes, chemical processes, numerical methods, and functionality. The first two groups contained a list of related principal processes. These processes were expected to affect LLW glass corrosion and the mobility of radionuclides. The numerical method group contained a list of related numerical methods needed to solve the related equations in the first two groups. Functionality covered a variety of program options such as graphical users interface and a software quality management program.

AREST-CT was chosen over the nine other codes because the program out scored the others. All the requirements in McGrail (1994) were given a merit score. This score was based on the importance of the process to modeling the performance of the disposal facility and on the degree of difficulty in adding the capability to an existing code. Codes having a specific capability were assigned the merit score for that capability. All the merit scores for each code were tabulated for a total merit score for the code. Based on the totals, AREST-CT had the largest merit score of 361. The next code had a total score of 264. For the scores of other codes, see McGrail 1994.

\section{C.4 Verification and Benchmarking}

Because AREST-CT is still being developed, its verification, benchmarking, and validation history are short. However, the comparisons between experimental results produced for this interim performance assessment and the AREST-CT calculations for this document give confidence to the validity of the AREST-CT code.

The verification of AREST-CT, Version 1, was done to assure that modules of the program were correctly implemented and worked together (Chen 1995). The verification had two parts. First, specific portions or modules of AREST-CT were unit tested to verify that the modules were performing correctly. Unit testing consists of evaluating individual code modules against hand 
Rev. 1

calculations, analytical solutions, or other existing numerical codes. Each module was unit tested before being implemented into AREST-CT. All modules were considered acceptable for current usage.

The second part of the verification of AREST-CT consisted of testing the computer code as a whole object. At the time of verification, no analytical solutions existed for solving the reaction-transport problems designed for AREST-CT. The code was benchmarked against simulation results from a similar reactiontransport code.

The benchmark test case that was a 1-D idealization of a low-level waste engineered system. The system consisted of 7 solids and 12 aqueous species. Two types of reactions were considered -- equilibrium aqueous reactions and solid dissolution/precipitation reactions. More details on the testing are given in Chen (1995). The results of the test showed that AREST-CT simulations quantitatively compared very well with the analytical solutions and other reactive-transport codes.

Further testing and verification tests will be conducted as the AREST-CT code develops. Future testing will include integration testing for mechanisms of radioactive decay and decay chain in growth, and for 2-D simulation. Plans for code development include increasing the number of grid nodes and decreasingthe size of time steps for the one-dimensional transport case in order to improve convergence. Also the program will be coupled with an unsaturated flow solver. Currently, the program uses the water velocity data from PORFLOW. With the flow solver, AREST-CT will model infiltration velocity changes with porosity as a result of solid dissolution/precipitation reactions. 
FINF-EP-0884

Rev. 1

C- 8 


\section{APPENDIX D \\ MOISTURE FIOW AND CONTAMTNANT TRANSPORT COMPUTER CODES}

\section{D.1 Overview}

This appendix provides detailed information about the moisture flow and transport codes [PORFLOW (ACRi 1994a) and VAM3D-CG (Huyakorn 1994)] used in this performance assessment. The following sections cover the governing equations, the detailed reasons for code selection, verification / benchmarking $/$ validation efforts, and the input decks for the base analysis case.

\section{D.2 Governing Equations}

\section{D.2.1 Overview}

This section discusses the equations important in the calculation of moisture flow and contaminant transport. The first section presents the equations on which the water flow calculations are based. The next section discusses contaminant transport associated with moisture flow. The final section describes moisture movement under diffusive conditions.

\section{D.2.2 Moisture Flow}

Two distinct moisture content regimes are present during contaminant transport: the unconfined aquifer and the vadose zone. In the unconfined aquifer, all the pore spaces are filled with water; that is, the medium is saturated with water. In the vadose zone, by contrast, the pore spaces between the soil particles are only partially filled with water: The vadose zone is unsaturated.

water flow through a saturated porous medium, such as the unconfined aquifer, is governed by the empirical relationship known as Darcy's Law (Freeze 1979) and by the conservation of mass. Darcy's law can be expressed as

$$
\overrightarrow{\mathrm{v}}=-\stackrel{\mathrm{K}}{\nabla \mathrm{h}}
$$

where $v$ is the velocity vector $(L / T)$,

$$
\mathrm{K} \text { is the hydraulic conductivity tensor ( } \mathrm{L} / \mathrm{T} \text { ), and }
$$

By using the conservation of water entering and leaving a volume and by using Darcy's law to relate the hydraulic gradient to the rate at which water enters and leaves the same volume, transient water flow in a saturated porous media can be expressed as

$$
\nabla \stackrel{\leftrightarrow}{\mathrm{K}} \nabla \mathrm{h}]=\mathrm{S} \partial \mathrm{h} / \partial \mathrm{t}+\mathrm{Q}
$$


where $\quad S$ is the specific storage $\left(I^{-1}\right)$ and

$Q$ is the source or sink of moisture $\left(\mathrm{T}^{-1}\right)$.

Darcy's law defines the discharge of water through a cross section of porous media. However, in contamination transport, the average velocity of water flowing through the media is important. This is because contaminants which are not geochemically retarded move with the water. The average velocity of the pore water is determined by dividing the velocity of the water by the porosity of the media. porosity is defined as the ratio of void space to total volume.

In an unsaturated media, the pores are not completely filied with water. Additional effects (capillary forces, the dependence of hydraulic conductivity on moisture content) must be considered. Richards equation (Richards 1931) becomes the governing equation:

$$
\nabla \stackrel{\leftrightarrow}{[\mathrm{K}(\psi)} \nabla \psi]+\partial \mathrm{K}_{z z}(\psi) / \partial z=(\mathrm{d} \theta / \mathrm{d} \psi)(\partial \psi / \partial \mathrm{t})+\mathrm{Q}
$$

where. $K$ is agatin the hydraulic conductivity tensor (L/T), but now depends on the pressure head,

$\psi$ is the pressure head (L) which is dependent on the moisture content $\theta$, and

$\theta$ is the moisture content (dimensionless).

$z$ is the vertical column of moisture (I).

The relationship between the pressure head and the hydraulic head is simply

$$
\mathrm{h}=\psi+\mathrm{z}
$$

For the performance assessment calculations, the hydraulic conductivity tensor is reduced to a single function, with

$$
\begin{aligned}
& K_{1 j}=K, \text { for } i=j \text { and } \\
& K_{i j}=0 \text {, for } i \neq j .
\end{aligned}
$$

The functional dependence of the pressure head on moisture content and of the hydraulic conductivity on pressure head and ultimately on moisture content is discussed in section 3.4.4.3 (Vadose zone Hydraulic Parameters).

For extremely dry conditions, vapor diffusion may be important. In such conditions, water does not move as a collective body but rather as single molecules. Such diffusion can be described by Fick's equation,

$$
\mathrm{dm} / \mathrm{dt}=-\mathrm{D}_{\mathrm{v}} \mathrm{A} \mathrm{dC} / \mathrm{dx}
$$

where $\mathrm{dm} / \mathrm{dt}$ is the mass rate of water vapor diffusion $(M / T)$,

$D_{\mathrm{v}} \quad$ is the effective vapor diffusion coefficient $\left(I^{2} / T\right)$, 


\section{FNV-EP-0884}

Rev. 1

A

C

$d c / d x$ is the cross section area $\left(\mathrm{L}^{2}\right)$.

is the water vapor mass concentration in the gas phase $\left(\mathrm{M} / \mathrm{L}^{3}\right)$, and

is the water vapor mass concentration gradient $\left(M / L^{4}\right)$.

\section{D.2.3 Advective and Diffusive Transport}

The equation for the advective and diffusive transport of contaminants can be viewed as a mass balance on a differential volume. The advective-dispersive equation for solute movement through a porous medium with a constant, steady state flow velocity was developed (codell 1982) for the limiting case of unidirectional advective transport with three-dimensional dispersion in a homogeneous, saturated aquifer,

$$
\begin{gathered}
n_{e} \frac{\partial C}{\partial t}+\left(n-n_{e}\right) \frac{\partial G}{\partial t}+(1-n) \frac{\partial P}{\partial t}+n_{e} u \frac{\partial C}{\partial x}= \\
n_{e}\left|E_{x} \frac{\partial^{2} C}{\partial x^{2}}+E_{y} \frac{\partial^{2} C}{\partial y^{2}}+E_{z} \frac{\partial^{2} C}{\partial z^{2}}\right|+ \\
\left(n-n_{e}\right)\left|E_{x}^{1} \frac{\partial^{2} G}{\partial x^{2}}+E_{y}^{1} \frac{\partial^{2} G}{\partial y^{2}}+E_{z}^{1} \frac{\partial^{2} G}{\partial z^{2}}\right|- \\
n_{e} \lambda C-(1-n) \lambda P-\left(n-n_{e}\right) \lambda G
\end{gathered}
$$

where

$C=$ dissolved concentration in the liquid phase in voids which are interconnected and allow flow [flowing voids] $\left(\mathrm{M} / \mathrm{L}^{3}\right.$ or $\left.\mathrm{Ci} / \mathrm{L}^{3}\right)$,

$G=$ dissolved concentration in the liquid phase in voids which are not interconnected and do not allow flow [non-flowing voids] $\left(\mathrm{M} / \mathrm{L}^{3}\right.$ or $\left.\mathrm{Ci} / \mathrm{L}^{3}\right)$,

$\mathrm{P}=$ particulate concentrations on the solid phase (Mass/Mass or Ci/Mass),

$\mathrm{n}=$ total porosity (dimensionless),

$\mathrm{n}_{\mathrm{e}}=$ effective porosity (dimensionless),

$t=\operatorname{time}(T)$,

$u=$ the $x$-component of groundwater or pore water velocity $(\mathrm{L} / \mathrm{T})$

$E_{i}=$ dispersion coefficient in the flowing voids in the $i$-th (where $i=x, y$, or $z$ ) direction $\left(L^{2} / T\right)$,

$E_{i}^{*}=$ diffusion coefficient in the non-flowing voids in the $i-t h$ direction $\left(\mathrm{L}^{2} / \mathrm{T}\right)$, and

$\lambda=$ decay constant $[=$ ( In 2$) /$ half life $]\left(\mathrm{T}^{-1}\right)$.

Each term in the equation represents some aspect of the solute movement through the porous medium. The first term on the left of the equal sign is the accumulation (storage) of the solute in the liquid phase in the flowing void. The next term is the accumulation in the liquid phase in the non-flowing void. The following term is the accumulation in the solid phase; and 
Rev. 1

the term to the left of the equal sign is $x$-direction advective transport in the flowing voids in the liquid phase. The first term to the right of the equal sign represents the dispersive transport in the flowing voids in the liquid phase in each direction. The next term represents the diffusive transport in the non-flowing voids in the liquid phase in each direction. The last terms are the chemical degradation or radioactive decay in the liquid phase in the flowing void, in the solid phase, and in the liquid phase in the nonflowing void respectively.

Using the following assumptions:

- The dissolved concentration in the non-flowing flows (G) equals the dissolved concentration in the flowing voids (C) for each time and for each position

- The contaminant absorption process can be described by a constant $\left(K=\rho * K_{d} /(1-n)\right)$ representing the ratio between. the contaminant absorbed to the soil matrix (P) and the contaminant dissolved in solution (C)

- The diffusion in the nonflowing void ( $\left.E^{\prime}{ }_{i}\right)$ is comparable with the dispersion in the flowing void $\left(E_{i}\right)$,

the above equation can be simplified to

$$
\frac{\partial C}{\partial t}+\frac{u}{R_{f_{1}}} \frac{\partial C}{\partial x}=\frac{D_{x}}{R_{f_{1}}} \frac{\partial^{2} C}{\partial x^{2}}+\frac{D_{y}}{R_{f_{3}}} \frac{\partial^{2} C}{\partial y_{2}}+\frac{D_{z}}{R_{f_{1}}} \frac{\partial^{2} C}{\partial z^{2}}-\lambda C
$$

in which

$$
\begin{gathered}
\mathrm{D}_{\mathrm{i}}=\mathrm{n} \mathrm{E}_{\mathrm{i}} / \mathrm{n}_{\mathrm{e}} \\
\mathrm{R}_{\mathrm{f}}=\mathrm{n} / \mathrm{n}_{\mathrm{e}}+\left(\rho * \mathrm{~K}_{\mathrm{d}}\right) / \mathrm{n}_{\mathrm{e}}
\end{gathered}
$$

and

and where

$$
\begin{aligned}
& \mathrm{D}_{i}= \text { pseudodispersion coefficient }\left(\mathrm{L}^{2} / \mathrm{T}\right) \\
& \mathrm{R}_{t}=\text { retardation factor (dimensionless) } \\
& \rho=\text { bulk density (M/L }{ }^{3} \text { ) } \\
& \mathrm{K}_{\mathrm{d}}=\text { equilibrium (partition or distribution) coefficient } \\
&\left(\mathrm{L}^{3} / \mathrm{M}\right) .
\end{aligned}
$$

The retardation factor $\left(R_{f}\right)$ is used as a measure of the mobility of constituents in a porous medium.

By making the following substitutions,

and

$$
\begin{gathered}
u^{*}=u / R_{f} \\
D_{i}^{*}=D_{i} / R_{t},
\end{gathered}
$$

the contaminant transport equation can be written as 


$$
\frac{\partial C}{\partial t}+u^{*} \frac{\partial C}{\partial x}=D_{x}^{*} \frac{\partial^{2} C}{\partial x^{2}}+D_{y}^{*} \frac{\partial^{2} C}{\partial y^{2}}+D_{z}^{*} \frac{\partial^{2} C}{\partial z^{2}}-\lambda C
$$

The first equation of this section specifically address the general conditions for saturated flow and solute movement.

However, it can also be applied to the unsaturated zone if minor modifications are made:

- The porosities ( $n$ and $n_{e}$ ) are assumed to be equal to the soil matrix moisture content

- The one-dimensional flow is in the vertical direction.

For this case, the retardation factor is defined by

$$
R_{\mathrm{f}}=1+\left(\rho * K_{\mathrm{d}}\right) / \theta
$$

where $\theta$ is the moisture content of the partially saturated zone and dispersion is only considered in the flow direction.

\section{D.2.4 Vapor Transport}

Some contaminants may move upward from the disposal facility to the surface because they are in the vapor phase. Such movement is governed by Fick's second law,

$$
D \frac{\partial^{2} C}{\partial^{2} z}=\frac{\partial C}{\partial t}
$$

where $C$ is the concentration, $z$ is the distance, $t$ is time, and $D$ is the diffusion coefficient. The solution for concentration $\mathrm{C}$ in the $z$ direction over time $t$ is given by:

$$
\frac{C}{C_{0}}=\operatorname{erfc}\left(\frac{z}{2 \sqrt{D t}}\right)
$$

where erfc is the complimentary error function and $\mathrm{C} / \mathrm{C}_{0}$ is the relative concentration. The mass transport across the surface becomes

$$
\frac{\partial C}{\partial t}=\frac{C_{0}}{\sqrt{4 \Pi D T}} \frac{z}{t} \exp \left[-z^{2} /(4 D t)\right]
$$




\section{HNF $-E P-0884$ \\ Rev. 1}

\section{3 Code History}

\section{D.3.1 PORFLOW}

Many versions of PORFLOW codes have been adapted. for a variety of problems over the past fifteen years. The bibliography of reports describing the code developments and problems to which they have been applied has grown to include about 100 documents. A partial listing of some of these reports is contained in the user documentation for the newest releases (ACRi 1994a; ACRi, 1994b). Many of the available references give detailed technical descriptions of the mathematical. modeling, numerical methods and computational algorithms embodied in the various computer code versions along with pointed discussions of complex engineering problems to which they are applied. This section will provide a brief and accessible description of what the PORFLOW computer code is, what it does, and how it is used for the interim performance assessment of lowlevel tank waste disposal.

The PORFLOW code allows simulation of flow of two fluids and a passive air phase, conductive and convective heat transfer, and transport of up to four dissolved contaminant species in a variably saturated, heterogeneous, anisotropic, fractured porous continuum. The remaining paragraphs in this section chronicle a few major steps in the development of the poRFLOW codes series and exemplify typical past and present usage.

About 30 years ago, Gosman et al. (1969) developed the Nodal Point Integration technique for use in simulating heat transfer and mass transport in a circulating fluid. Nodal Point Integration is used to render a discrete system of simultaneous linear equations from a continuous mathematical model involving coupled partial differential equations. The advantage of Nodal Point Integration over classical finite difference schemes is assurance that the discrete model is conservative at every point of interest (i.e., errors in the amounts of fluid volume, heat, and mass of transported species are sufficiently small at every point in space as well as in the global totals). Use of Nodal Point Integration is one of the defining characteristics of the PORFLOW series of codes.

In the 1970's the Nodal Point Integration technique was used in development of a model for simulating thermally disturbed groundwater movement in the vicinity of a high level radioactive waste repository (Runchal 1979). The computer code was called GWTHERM and was a forerunner to the PORFLOW codes. In the 1980's during the Basalt Waste Isolation Project (BWIP), the twodimensional PORFLO code (KIine 1983; Eyler 1984; Runchal 1985) was developed out of the GWTHERM prototype for use in assessing performance of a deep geologic repository for high level nuclear waste. The PORFLo code was used principally to calculate nearfield estimates of water flow (seepage) rates in the vicinity of the proposed repository, temperature distribution around the repository, and contaminant mass release rates to the far-field 


\section{FINE-EP-0884 \\ Rev. 1}

and/or accessible environment (e.g. in DOE-RL 1982 and Baca 1984). The PORFLo code was limited to saturated media (e.g. a repository at depth, below the water table) and transport of a single dissolved contaminant species.

The PORFLO-3 computer code (Sagar 1990; Runchal 1992) is a three-dimensional generalization of the PORFLO code. In addition to being fully three-dimensional, the PORFLO-3 code is tailored for simulation of flow and transport in saturated and unsaturated media. The PORFLO-3 code also has the conduction and convection heat transfer capabilities, but thermal disturbance is typically not a condition in many of the unsaturated flow modeling applications where the code has been used. For instance, PORFLO3 has been used in three-dimensional predictive modeling of saturated flow and transport of tracers and residual contaminants in support of the remedial investigation process for the $300-F F-5$ groundwater operable unit (DOE-RI 1994a). Estimation of travel times through the vadose (unsaturated) zone from various surface facilities (cribs, trenches) to groundwater for discharged water and various contaminants along with estimation of relative arrival concentrations have been performed with PORFLO-3 models in support of the Iiquid Effluent program (WHC 1990; Reidel 1993; Singelton 1994). Analysis of single shell tank (SST) leaks during waste retrieval operations has been conducted with PORFLO3 models to provide approximate impact on groundwater (Lowe 1993) and later to quantify the umbrella effect of SST's on infiltrating precipitation (Kline 1995a) and further refine estimates of vertical penetration and lateral spreading of leaked contaminants in the vadose zone. The PORFLO-3 code has also been used in analysis of the effectiveness of capillary barriers (Kline 1995b), particularly to assess diversion capacity of a capillary barrier used to limit infiltration of precipitation into a near-surface disposal facility for low-level waste.

The most recent PORFLOW codes (Versions 2.0 and higher) comprise extension of PORFLO-3 to allow two fluids (such as water and $\mathrm{CCl}_{4}$ ) or two phases (such as liquid water and water vapor), in addition to a passive air phase in variably saturated media. These code versions also allow simulation of multiple contaminant species transport, including chain decay. While the capability of simulating simultaneous seepage of two distinct fluids has undergone preliminary testing by Piepho and Runchal (Piepho 1991), some of the newer features (e.g. phase changes, decay chains) implemented in the PORFLOW codes have not been used extensively at Hanford. Most notably PORFLOW has been used to simulate seepage of infiltrating precipitation and simultaneous transport (advection and diffusion) of several dissolved contaminant species through a near-surface disposal facility and underlying vadose zone to groundwater. Contaminant fluxes to groundwater are subsequently postprocessed by an auxiliary computer code to provide dose estimates through various pathways (e.g. intrusion, arinking water) as was done in performance assessment by Kincaid et al. (Kincaid 1995) for Hanford grouted tank waste. The same simulation capabilities have also been used to calculate dose estimates as a means of evaluating impacts of 
disposal system design options on low-level glass waste disposal system performance (Rawlins 1994; Mann 1995d; Kline 1995a). The PORFLOW code used in those grout and glass waste disposal analyses is designated Version $2.394 \mathrm{gr}$ and has been tested extensively by Piepho et al (Piepho 1994). Version 2.394gr of PORFLOW is also the code version used for the present interim performance assessment of low-level tank waste disposal.

\section{D.3.2 VAM3D-CG}

Earliex versions of VAM3D-CG (VAM2D and VAM3D) have been used for Hanford risk assessments. Version 2.4b of VAM3D-CG was used in the Hanford 200 West Area Burial Grounds Performance Assessment (Wood 1994b). Version 3.1 of VAM3D-CG was obtained because of the greater model complexity required for the model for the Environmental Restoration Disposal Facility Performance Assessment (Wood 1995) and for the Hanford sitewide groundwater model (Law 1996). Version 3.1 was used in this interim performance assessment and was also used in the Hanford 200 East Area Burial Ground Performance Assessment (Wood 1996).

\section{D.4 Verification and Benchmarking}

\section{D.4.1 PORFLOW- Verification and Benchmarking}

The version of PORFLOW being used in this analysis, version $2.394 \mathrm{gr}$, has been extensively verified and benchmarked (Piepho 1994). Verification and benchmarking efforts were based on

- Comparing the results of the Version 2.394gr of PORFLOW with-earlier versions of PORFLOW

- Reproducing the results of analytical solutions from other verification problems

- Comparing the results with other codes for complex problems.

PORFLOW Version $2.394 \mathrm{gr}$ was used to run five cases that were used in an extensive verification effort of PORFLOW at the Idaho National Engineering Laboratory (Magnuson 1990) The five case were

Transient unsaturated flow in a one-dimensional vertical column (denoted as problem vt1 by Magnuson)

Transient drawdown of pressure head due to pumping a confined aquifer of constant thickness that is fully penetrated by a well (denoted as vt2) 


\section{FRNE-EP-0884 \\ Rev. 1}

- Steady state two dimensional saturated-unsaturated flow (denoted as bt1),

- Transient two-dimensional unsaturated flow simulating the infiltration of water into relatively dry, heterogeneous soils (bt2)

- Steady-state saturated flow in a porous media with two distinct fractures (bt 3 ).

In each case, there is excellent agreement between the results of Magnuson et al. and those using PORFLOW 2.394gr.

There were four cases against which PORFLOW $2.394 \mathrm{gr}$ could be compared against analytical solutions:

- Case vt1 of Magnuson (1990)

- Case vt2 of Magnuson (1990)

- Two-dimensional nonuniform infiltration into dry homogenous soil (Warrick 1976)

- Mass transport in a two-dimensional groundwater model with a strip source (Cleary 1978).

Again very good agreement was obtained.

Finally as part of the Hanford Grout Performance Assessment (Kincaid 1995-7), the results of PORFLOW 2.394gr and another code, TRACR3D (Travis 1991), were compared for models of the Hanford grouted waste. Again the results show good agreement. Piepho (1994) provides the details.

\section{D.4.2 VAM3D-CG - Verification and Benchmarking}

Version 2.4b of VAM3D-CG (Lu 1994) and Version 3.1 (Lu 1995) were tested by

- Comparing the results of the installed version against those published by the vendor (Huyakorn 1993)

- Benchmarking these versions against results of PORFLO-3 Version 1.0 (Sagar 1990) for Hanford relevant problems.

The tests against the vendor-supplied results included:

- Transient one-dimensional horizontal flow in a soil slab

- Transient vertical infiltration in a soil column

- Transient two-dimensional flow in a rectangular soil slab 


\section{FNNF-EP-0884}

Rev. 1

- Transient two-dimensional transport in a rectangular soil slab

- Three-dimensional transport in uniform groundwater flow.

The benchmarking tests consisted of

- Modeling the $217-U-17$ Crib in the 200 West Area

- Modeling a clay cap.

In all cases, good agreement was found.

\section{5 Field resting}

\section{D.5.1 PORFLOW- Field Testing}

Testing of PORFLOW against Hanford field experiments (Hanford Injection Test) and accidents (T106 Tank Leak) is now being performed.

\section{D.5.2 VAM3D-CG - Field Testing}

Field testing efforts were performed for both Versions $2.4 \mathrm{~b}$ and 3.1. The calibration/validation effort for Version 2.4b (Lu 1993) used data from the Hanford Injection Test experiment (Sisson 1984). The calibration/validation effort for version 3.1 used data from the reevaluation of the Hanford Injection Test Experiment and from new experiments (Fayer 1995b). 
Rev. 1

\section{D.6 Input for Base Analysis Case}

\section{D.6.1 Disposal Facility Model (Concept 1) - PORFLOW}

TITLe base1-1d - base case w.2Dw diffusion(20x base1-1n) for concept 1 LLVW disposal facility with 50 sources (45 canisters)

USER PIEHPO - Mel Piepho of Daniel B. Stephens \& Assoc., Richland, WA 99352; $509-946-6627$

1

GRID 166 by 133 \$ Including PORFLO-3 boundary cells / $2345678911234567892123456789312345678941234567895123456789612345678971234567899 /$ COOR X user specfied

$f$ The following numbers represent the actual poRFLow grid lines in the $x$

direction. It includes 45 canisters, each with a $1.8 \mathrm{~m}$ width

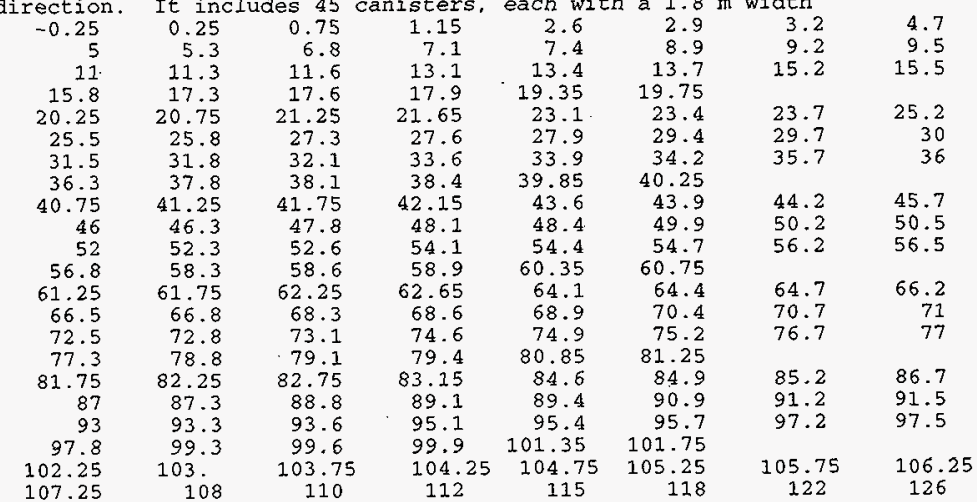

f

SCALE by 0.01

COOR $\mathrm{X}$ user specfied

$-25.75$

485.685 .685$.

1285.1385 .1485 .

2085. 2185. 2285.

165. 235.

785. 885 .

305.385.

985. 1085.

1585. 1685. 1785. 1885.

2385.2485 .2585 .2685$.

3385.3485 .

$\begin{array}{lll}2885 . & 2985 . & 3085 . \\ 3585 . & 3665 . & 3735 .\end{array}$

3185.3285 .

4005.4105 .

4305 . 4405. 4505 .

3805 . 3905 .

4805 .

4105.

$\begin{array}{ll}4605, & 4705 . \\ 5405, & 5505\end{array}$

5605 .

5705 .

5905 .

6005.6105.

6205 .

6305 .

6405 .

6505 .

6605 .

6805 .

6905.

7005.

7105 .

7205.

7805.7905 .

8105.8205.

$\begin{array}{lll}7505 . & 7605 . & 7705 . \\ 8245 . & 8285 . & 8315\end{array}$

8355.8455.

9000 . 9040. 9100 .

$\begin{array}{ll}9395 . & 9410 . \\ 9515 . & 9530 .\end{array}$

9650

9500 .

9635 .

9665

1185.

1985 .

2785 .

4205 .

5005 .

5805 .

8005 .

8555 .

9180 .

9425 .

9440.9455 .9470$.

9485 .

9620 .

9755 .

9795.9850 .

! 1

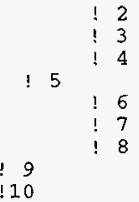

9680 .

9695 .

9710.9725 .

9740 .

975.

1

DATUM $0 ., 0$.

GRAVITY vector: $0,-1$

READ 'base0-0.arc' START in UNEOrmatted mode

TIME $=0$.

1

1 zone definitions from TRACER-3D material type map.

ZONE 1 from $(1,87)$ to $(166,133)$ \$ Backfill Soil

$\mathrm{D}-11$ 
Rev. 1

ZONE 2 from $(1,41)$ ZONE 3 ZONE 4 ZONE 5 ZONE 5 ZONE 5 ZONE 5

ZONE 5

ZONE 5

ZONE 5

ZONE 5

ZONE 5

ZONE 5

ZONE 5

ZONE 5

ZONE 5

ZONE 5

ZONE 5

ZONE 5

ZONE 5

ZONE 5

ZONE 5

ZONE 5

ZONE 5

ZONE 5

ZONE 5

ZONE 5

ZONE 5

ZONE 5

ZONE 6

top of

ZONE 7

ZONE 9

1

ZONE 10 ZONE 10

ZONE 10

ZONE 10

ZONE 10

ZONE 10

ZONE 10

ZONE 10

ZONE 10

I

ZONE 10

ZONE. 10

ZONE 10

ZONE 10

ZONE 10

ZONE 10

ZONE 10

ZONE 10

ZONE 10 I

ZONE 10 ZONE 10

ZONE 10

ZONE 10

ZONE 10

ZONE 10

ZONE 10

ZONE 10

ZONE 10 1

ZONE 10

2ONE 10

ZONE 10

ZONE 10 from $(1,5)$

from $(1,1)$

from $(1,130)$

from $(1,129)$

from $(1,128)$

from $(1,126)$

from $(1,125)$

from $(1,124)$

from $(1,123)$

from $(1,122)$

from $(1,121)$

from $(1,120)$

from $(1,119)$

from $(1,118)$

from $\{1,117\}$

from $(1,116)$

from $(1,115)$

from $(1,114)$

from $(1,113)$

from $(1,112)$

from $(1,111)$

from $(1,110)$

from $(1,109)$

from $(1,108)$

from $(1,107)$

from $(1,106)$

from $(154,87)$

from $(1,103)$

ault

from $(2,101)$

from $(1,98)$

from $(4,89)$

from $(7,89)$

from $(10,89)$

from $(13,89)$

from $\{16,89)$

from $\{19,89\}$

from $(22,89)$

from $(25,89)$

from $(28,89)$

from - $(34,89)$

from $(37,89)$

from $(40,89)$

from $(43,89)$

from $(46,89)$

from $(49,89)$

from $(52,89)$

from $(55,89)$

from $(58,89)$

from $(64,89)$

from $(67,89)$

from $(70,89)$

from $(73,89)$

from $(76,89)$

from $(79,89)$

from $(82,89)$

from $(85,89)$

from $(88,89)$

from $(94,89)$

from $(97,89)$

from $(100,89)$

from $(103,89)$ from $(1,127)$ to $(166,86)$ \$ Hanford-Sandy Seq.

to $(166,40) \$$ Hanford-Gravel Seq.

to $(166,4) \$$ Ringold

to $(7,130) \$$ GRAVEL

to $(13,129)$ \$ GRAVEL

to $(19,128)$ \$ GRAVEL

to $(25,127) \$$ GRAVEL

to $(31,126)$ \$ GRAVEL

to $(37,125)$ \& GRAVEL

to $(43,124) \$$ GRAVEL

to $(49,123)$ \$ GRAVEL

to $(55,122)$ \& GRAVEL

to $(61,121)$ \$ GRAVEL

to $(67,120)$ \$ GRAVEL

to $(73,119) \$$ GRAVEL

to $(79,118)$ \$ GRAVEL

to $(85,117)$ GRAVEL

to $(91,116)$ \$ GRAVEL

to $(97,115)$ \$ GRAVEL

to $(103,114)$ \$ GRAVEL

to $(109,113)$ \$ GRAVEL

to $(115,112) \$$ GRAVEL

to $(121,111) \$$ GRAVEL

to $(127,110)$ \$ GRAVEL

to $(133,109)$ \$ GRAVEL

to $(140,108)$ \$ GRAVEL

to $(147,107) \$$ GRAVEL

to $(154,106) \$$ GRAVEL

to $(155,105)$ \& GRAVEI

to $(153,105) \$$ Crushed Glass between gravel and cement

to $(150,102)$ \$ TOP CONCRETE

to $(150,100) \$$ BF Soil (matrix) above canisters

\begin{tabular}{|c|c|c|c|c|}
\hline$=0$ & $\begin{array}{ll}(5,97) & \$ \\
(8,97) & \$\end{array}$ & & $\begin{array}{l}\text { lass } \\
\text { lass }\end{array}$ & $\begin{array}{l}\text { inisters } \\
\text { inisters }\end{array}$ \\
\hline to & $(11,97)$ & $\$$ & glass & canisters \\
\hline to & $(14,97)$ & $\$$ & glass & canisters \\
\hline to & $(17,97)$ & $\$$ & glass & canisters \\
\hline to & $(20,97)$ & $\$$ & glass & canisters \\
\hline to & 97) & $\$$ & glass & canisters \\
\hline to & $(26,97)$ & $\$$ & glass & canisters \\
\hline to & $(29,97)$ & $\$$ & glass & canisters \\
\hline to & $(35,97)$ & $\$$ & glass & canisters \\
\hline to & 97) & $\$$ & glass & canisters \\
\hline to & $(41,97)$ & $\$$ & glass & canistexs \\
\hline to & $(44,97)$ & $\$$ & glass & canisters \\
\hline to & $(47,97)$ & $\$$ & glass & canisters \\
\hline to & $(50,97)$ & $\$$ & glass & canisters \\
\hline to & $(53,97)$ & $\$$ & glass & canisters \\
\hline to & $(56,97)$ & $\$$ & glass & canisters \\
\hline to & $(59,97)$ & $\$$ & glass & canisters \\
\hline to & $(65,97)$ & $\$$ & glass & canisters \\
\hline to & $(68,97)$ & $\$$ & glass & canisters \\
\hline to & $(71,97)$ & $\$$ & glass & canisters \\
\hline to & $(74,97)$ & $\$$ & glass & canisters \\
\hline to & $(77,97)$ & $\$$ & glass & canisters \\
\hline to & $(80,97)$ & $\$$ & glass & canisters \\
\hline to & $(83,97)$ & $\$$ & glass & canisters \\
\hline to & $(86,97)$ & $\$$ & glass & canisters \\
\hline to & $(89,97)$ & $\$$ & glass & canisters \\
\hline to & $\begin{array}{l}(95,97) \\
(98,97)\end{array}$ & $\$$ & $\begin{array}{l}\text { glass } \\
\text { glass }\end{array}$ & $\begin{array}{l}\text { canisters } \\
\text { canisters }\end{array}$ \\
\hline & o (104, & & glass & $\mathrm{ca}$ \\
\hline
\end{tabular}

$\mathrm{D}-12$ 
Rev. 1

ZONE 10 from $(106,89)$

ZONE 10 from $(109,89)$

ZONE 10 from $(112,89)$

ZONE 10 from $(115,89)$

ZONE 10

1

ZONE 10

ZONE 10

ZONE 10

ZONE 10

ZONE 10

ZONE 10

ZONE 10

ZONE 10

ZONE 10

1

ZONE 12

1

ZONE 13

ZONE 13

ZONE 13

ZONE 13

ZONE 13

ZONE 13

1

ZONE 14

ZONE 14

ZONE 14

ZONE 14

ZONE 14

ZONE 14

ZONE 14

ZONE 14

ZONE 14

ZONE 14

ZONE 14

ZONE 14

ZONE 14

ZONE 14

ZONE 14

ZONE 14

ZONE 14

ZONE 14

ZONE 14

ZONE 14

1

ZONE 14

ZONE 14

ZONE 14

ZONE 14

ZONE 14

ZONE 14

ZONE 14

ZONE 14

ZONE 14

ZONE 14

1

ZONE 14

ZONE 14

ZONE 14

ZONE 14

ZONE 14

ZONE 14

ZONE 14

ZONE 14

ZONE 14

ZONE 14

from $(245,89)$

from $(148,89)$

from $(1,87)$

from (1,89)

from $(31,89)$

from. $(61,89)$

from $(91,89)$

from $(121,89)$

from $(151,89)$

from $(3,89)$

from $(6,89)$

from $(9,89)$

from $(12,89)$

from $(15,89)$

from $(18,89)$

from $(21,89)$

from $(24,89)$

from $(27,89)$

from $(30,89)$

from $(33,89)$

from $(36,89)$

from $(39,89)$

from $(42,89)$

from $(45,89)$

from $(48,89)$

Erom $(51,89)$

from $(54,89)$

from $(57,89)$

from $(60,89)$

from $(63,89)$

from $(66,89)$

from $(69,89)$

from $(72,89)$

from $(75,89)$

from $(78,89)$

from $(81,89)$

from $(84,89)$

from $(87,89)$

from $(90,89)$

from $(93,89)$

from $(96,89)$

from $(99,89)$

from $(102,89)$

from $(105,89)$

from $(108,89)$

from $(111,89)$

from $(114,89)$

from $(117,89)$

Erom $(120,89)$ to $(107,97) \$$ glass

to $(110,97) \$$ glass

to $(113,97) \$$ glass

to $(116,97)$ \$ glass

to $(119,97) \$$ glass

to $(125,97)$ \$

to $(128,97) \$$

to $(131,97)$ \$

to $(134,97)$ \$

to $(137,97)$ \$

to $(140,97) \$$

to $(143,97) \$$

to $(146,97) \$$

to $(149,97)$ \$

glass canisters

glass canisters

glass canisters

glass canisters

glass canisters

glass canisters

glass canisters

glass canisters to $(153,88)$ \& Bottom CONCRETE

to $(2,102) \$$ Vertical CONCRETE

to $(32,102)$ \$ Vertical CONCRETE

to $(62,102) \$$ Vertical CONCRETE

to $(92,102) \$$ Vertical CONCRETE

to $(122,102)$ \$ Vertical CONCRETE

to $(153,102) \$$ Vertical CONCRETE

to $(3,97)$ \&F soil matrix

to $(6,97) \$$ BF soil matrix

to $(9,97)$ \$ BF soil matrix

to $(12,97)$ \$ BF soil matrix

to $(15,97)$ \$ $B F$ soil matrix

to $(18,97)$ \$ $\mathrm{BF}$ soil matrix

to $(21,97) \$ \mathrm{BF}$ soil matrix

to $(24,97) \$ B F$ soil matrix

to $(27,97)$ \$ BF soil matrix

to $(30,97) \$$ BF soil matrix

to $(33,97)$ \$ $B F$ soil matrix

to $(36,97)$ \$ BF soil matrix

to $(39,97) \$ B F$ soil matrix

to $(42,97) \$ B F$ soil matrix

to $(45,97) \$$ BF soil matrix

to $(48,97)$ $\$ \mathrm{BF}$ soil matrix

to $(51,97)$ \$ $\mathrm{BF}$ soil matrix

to $(54,97)$ \$ $B F$ soil matrix

to $(57,97)$ \$ BF soil matrix

to $(60,97)$ \$ BF soil matrix

to $(63,97)$ \$ $B F$ soil matrix

to $(66,97)$ \$ BF soil matrix

to $(69,97)$ \&F soil matrix

to $(72,97)$ \$ BF soil matrix

to $(75,97)$ \$ BF soil matrix

to $(78,97)$ \$ $B F$ soil matrix

to $(81.97)$ \$ BF soil matrix

to $(84,97)$ \$ $B F$ soil matrix

to $(87,97)$ \$ BF soil matrix

to $(90,97) \$$ BF soil matrix

to $(93,97)$ \& $B F$ soil matrix

to $(96,97)$ BF sojl matrix

to $(99,97)$ \& $B F$ soil matrix

to $(102,97) \$$ BF soil matrix

to $(105,97) \$$ BF soil matrix

to $(108,97)$ \& $\mathrm{BF}$ soil matrix

to $(111,97)$ \$ $B F$ soil matrix

to $(114,97)$ BF soil matrix

to $(117,97) \$ B F$ soil matrix

to $(120,97) \$$ BF soil matrix 
Rev. 1

$\begin{array}{lllllll}\text { ZONE } 14 & \text { from }(123,89) & \text { to }(123,97) & \text { BF soil matrix } \\ \text { ZONE 14 } & \text { from }(126,89) & \text { to }(126,97) & \text { BF soil matrix } \\ \text { ZONE 14 } & \text { from }(129,89) & \text { to }(129,97) & \text { B. } & \text { BF soil matrix } \\ \text { ZONE 14 } & \text { from }(132,89) & \text { to }(132,97) & \text { BF soil matrix } \\ \text { ZONE 14 } & \text { from }(135,89) & \text { to }(135,97) & \text { BF soil matrix } \\ \text { ZONE 14 } & \text { from }(138,89) & \text { to }(138,97) & \text { BF soil matrix } \\ \text { ZONE 14 } & \text { from }(141,89) & \text { to }(141,97) & \text { BF soil matrix } \\ \text { ZONE 14 } & \text { from }(144,89) & \text { to }(144,97) & \text { BF soil matrix } \\ \text { ZONE 14 } & \text { from }(147,89) & \text { to }(147,97) & \text { BF soil matrix } \\ \text { ZONE 14 } & \text { from }(150,89) & \text { to }(150,97) & \text { B } & \text { BF soil matrix }\end{array}$

ZONE 14

,

I ZONE 1 - SOIL G-1

/ ZONE 2 - SOIL G-2, Hanford-Sandy seq.

/ ZONE 3 - SOIL G-3, Hanford-Gravel Seq.

$/$ ZONE 4 - SOIL G-4, Ringold-Upper

1,----

ROCK rho $=2.720$

ROCK rho $=2.720$

ROCK rho=2.720

ROCK $r h o=2.720$

ROCK rho $=2.720$

ROCK $r$ ho $=2.720$

ROCK $r h o=2.720$

ROCK $r h o=2.720$

ROCK $r h o=2.720$

ROCK $r h o=2.720$

ROCK $x h o=2.720$

ROCK $r h o=2.720$

tot $=3 * 0.371$

tot $=3 * 0.3578$

tot $=3 * 0.1312$

tot $=3 * 0.1342$

tot $=3 * 0.518$

tot $=3 * 0.518$

tot $=3 * 0.2258$

tot $=3 * 0.371$

tot $=3 * 0.0001$

tot $=3 * 0.2258$

tot $=3 * 0.2258$

tot $=3 * 0.371$
: ZONE 1

: ZONE 2

: ZONE 3

ZONE 4

ZONE 5

: ZONE 6

ZONE 7

: ZONE 9

ZONE 10

ZONE 12

ZONE 13

: ZONE 14

I

HYDRaulic properties: $S S=1$.e-5

HYDRaulic properties: $S S=1 \cdot e-5$

HYDRaulic properties: $S S=1 \cdot e-5$

HYDRaulic properties: $S S=1$.e-5

HYDRaulic properties: SS=1,e-5

HYDRaulic properties: $S S=1 . e-5$

HYDRaulic properties: $S S=1, e-5$

/HYDRaulic properties: $S S=1 . e-5$

HYDRaulic properties: $S S=1 . e-5$

HYDRaulic properties: $S S=1 \cdot e-5$

HYDRaulic properties: $S S=1 . e-5$

HYDRaulic properties: $S S=1 . e-5$

/HYDRaulic properties: $S S=1$.e-5

/HYDRaulic properties: $S S=1 . e-5$

HYDRaulic properties: $S S=1 \cdot e-5$

$(\mathrm{Kx}, \mathrm{Ky}, \mathrm{Kz})=3 * 9467.28(\mathrm{~m} / \mathrm{Yr})$

$(\mathrm{Kx}, \mathrm{Ky}, \mathrm{Kz})=3 * 3690.0(\mathrm{~m} / \mathrm{Yr})$

$(\mathrm{Kx}, \mathrm{Ky}, \mathrm{Kz})=3 * 417.0(\mathrm{~m} / \mathrm{Yr})$

: ZONE 1

$(\mathrm{Kx}, \mathrm{Ky}, \mathrm{Kz})=3 * 27.6(\mathrm{~m} / \mathrm{y} x)$

: ZONE 2

$(\mathrm{Kx}, \mathrm{Ky}, \mathrm{Kx})=3 * 583816.0$ (m/Yr) : ZONE 5

$(\mathrm{Kx}, \mathrm{Ky}, \mathrm{Kz})=3 * 583816.0(\mathrm{~m} / \mathrm{Yr}) \quad$ : ZONE 6

$(\mathrm{Kx}, \mathrm{KY}, \mathrm{Kz})=3 * 1.1834 \mathrm{e}-4(\mathrm{~m} / \mathrm{yr}):$ ZONE 7

$(\mathrm{Kx}, \mathrm{KY}, \mathrm{Kz})=3 * 9467.28(\mathrm{~m} / \mathrm{Yr}) \quad:$ ZONE 7

$(\mathrm{Kx}, \mathrm{Ky}, \mathrm{Kz})=3 * 9467,28(\mathrm{~m} / \mathrm{Yr}):$ : ZONE 9

$(\mathrm{Kx}, \mathrm{Ky}, \mathrm{Kx})=3 * 1 . \mathrm{E}-30 \quad(\mathrm{~m} / \mathrm{Yr}) \quad$ : ZONE 10

$(\mathrm{Kx}, \mathrm{Ky}, \mathrm{Kz})=3 * 1.1834 \mathrm{e}-4(\mathrm{~m} / \mathrm{y} r)$ : zONE 12

$(\mathrm{Kx}, \mathrm{Ky}, \mathrm{Kz})=3 * 1.1834 \mathrm{e}-4(\mathrm{~m} / \mathrm{Yr})$ : ZONE 13

$(\mathrm{Kx}, \mathrm{KY}, \mathrm{Kz})=3 * 9467.28(\mathrm{~m} / \mathrm{yr})$ : ZONE 12

$(\mathrm{Kx}, \mathrm{KY}, \mathrm{Kz})=3 * 9467.28$ (m/Yr) : ZONE 13

$(\mathrm{Kx}, \mathrm{KY}, \mathrm{Kz})=3 * 9467.28(\mathrm{~m} / \mathrm{yr})$ : ZONE 14

/ .

/

MULTiphase: MINImum relative CONDuctivity is $1 . \mathrm{E}-20$ for zoNEs 1 to 14 step 1

MULTiphase: VAN MUAL $\mathrm{n}=2.08$

MULTiphase: VAN MUAL $n=1.868$

MULTiphase: VAN MUAL $n=1.613$

MULTiphase: VAN MUAL $n=1.338$

MULTiphase: VAN MUAL $n=2.661$

MULTiphase: VAN MUAL $n=2.661$

/MULTiphase: VAN MUAL $n=2.08$

MULTiphase: VAN MUAL $\mathrm{n}=1.393$

/MULTiphase: VAN MUAL $n=2.08$

MULTiphase: VAN MUAL $n=2.08$

MULTiphase: VAN MUAL $n=1.393$

MULTiphase: VAN MUAL $n=1.393$

MULTiphase: VAN MUAL $n=1.393$

/MULTiphase: VAN MUAL $n=2.08$

/MULTiphase: VAN MUAL $n=2.08$

MULTiphase: VAN MUAL $n=2.08$

alpha $=6.83$

alpha $=15.66$

alpha $=1.25$

alpha $=1.22$

alpha $=353.66$

alpha $=353.66$

alpha $=6.83$

alpha $=7.61 \mathrm{e}-4$ alpha $=6.83$

alpha $=6.83$

alpha $=7.61 \mathrm{e}-4$

alpha $=7.61 \mathrm{e}-4$

alpha $=7.61 \mathrm{e}-4$

alpha $=6.83$

alpha $=6.83$

a.lpha $=6.83$ sr $=.1213 \quad 0 . \quad$ : ZONE 1

$s r=.06875 \quad 0 . \quad:$ ZONE 2

$s r=.09604 \quad 0 . \quad:$ ZONE 3

$\mathrm{s} r=.16390 .:$ : ZONE 4

$s r=2.703 e-2$ 0.: ZONE 5

$s x=2.703 e-2 \quad 0 .:$ zONE 6 sr $=.1213$ 0. : ZONE 6

$s r=0.00 . \quad$ : ZONE 7

sr $=.1213 \quad 0 . \quad$ : zONE 7

$s r=.1213$ 0. : ZONE 9

sr $=0.00 . \quad$ : ZONE 10

$s r=0.00 .:$ ZONE 12

sr $=0.00 . \quad$ : ZONE 13

$s r=.1213$ 0. : ZONE 12

$s r=.1213 \quad 0 . \quad$ : ZONE 13

sr $=.1213 \quad 0 .:$ ZONE 14 1

TRANsport $C \quad \mathrm{Kd}=0 . \quad \mathrm{Dab}=1.5779 e-2 \quad \mathrm{a}=0.00 \quad \mathrm{~b}=0.0:$ zONE 1 
Rev. 1

TRANsport $C$ TRANSport $C$ TRANsport $C$ TRANsport $C$ TRANsport $C$ TRANsport $C$ TRANsport $C$ TRANsport $C$ TRANsport $C$ TRANsport $C$ TRANsport $C$ 1

TRANsport $\mathrm{C} 2 \mathrm{Kd}=0.0 \mathrm{Dab}=1.5779 \mathrm{e}-2$ TRANsport C2 $\mathrm{Kd}=0.0 \mathrm{Dab}=1.5779 \mathrm{e}-2$ TRANsport $\mathrm{C} 2 \mathrm{Kd}=0.0 \mathrm{Dab}=1.5779 \mathrm{e}-2$ TRANsport C2 $\mathrm{Kd}=0.0 \mathrm{Dab}=1.5779 \mathrm{e}-2$ TRANsport C2 $\mathrm{kd}=0.0 \mathrm{Dab}=1.5779 \mathrm{e}-2$ TRANsport $\mathrm{C} 2 \mathrm{Kd}=0.0 \mathrm{Dab}=1.5779 \mathrm{e}-2$ TRANsport $\mathrm{C} 2 \mathrm{Kd}=0.0 \mathrm{Dab}=1.57788 \mathrm{e}-2$ TRANsport C2 $\mathrm{Kd}=0.0 \mathrm{Dab}=1.5779 \mathrm{e}-2$ TRANsport $\mathrm{C} 2 \mathrm{Kd}=0.0 \mathrm{Dab}=7.88940 \mathrm{e}-30$ TRANsport C2 $\mathrm{Kd}=0.0 \mathrm{Dab}=1.57788 \mathrm{e}-2$ TRANsport $\mathrm{C} 2 \mathrm{Kd}=0.0 \mathrm{Dab}=1.57788 \mathrm{e}-2$ TRANsport C2 $\mathrm{Ka}=0.0 \quad \mathrm{Dab}=1.5779 \mathrm{e}-2$ 1 TRANsport C3 $\mathrm{kd}=0.1 \mathrm{Dab}=1.5779 e-2$ TRANsport $\mathrm{C} 3 \mathrm{Kd}=0.1 \mathrm{Dab}=1.5779 \mathrm{e}-2$ TRANsport C3 Kd=0.1 Dab=1.5779e-2 TRANsport C3 $\mathrm{kd}=0.1 \mathrm{Dab}=1.5779 \mathrm{e}-2$ TRANsport C3 $\mathrm{Kd}=0.1 \mathrm{Dab}=1.5779 \mathrm{e}-2$ TRANsport $\mathrm{C} 3 \mathrm{Kd}=0.1 \mathrm{Dab}=1.5779 \mathrm{e}-2$ TRANsport $\mathrm{C} 3 \mathrm{Kd}=0.1 \mathrm{Dab}=1.57788 \mathrm{e}-2$ TRANsport C3 $\mathrm{Kd}=0.1 \mathrm{Dab}=1.5779 \mathrm{e}-2$ TRANsport C3 $\mathrm{Kd}=0.1 \mathrm{Dab}=7.88940 \mathrm{e}-30$ TRANsport $\mathrm{C} 3 \mathrm{Kd}=0.1 \mathrm{Dab}=1.57788 \mathrm{e}-2$ TRANsport C3 $\mathrm{Ka}=0.1 \quad \mathrm{Dab}=1.57788 \mathrm{e}-2$ TRANsport C3 $\mathrm{Kd}=0.1 \mathrm{Dab}=1.5779 \mathrm{e}-2$ 1

TRANsport C4 $\mathrm{Kd}=0.6 \mathrm{Dab}=1.5779 \mathrm{e}-2$ TRANsport $C 4 \quad \mathrm{Kd}=0.6 \quad \mathrm{Dab}=1.5779 \mathrm{e}-2$ TRANsport $C 4 \quad \mathrm{Kd}=0.6 \quad \mathrm{Dab}=1.5779 \mathrm{e}-2$ TRANsport C4 Kd=0.6 $\mathrm{Dab}=1.5779 \mathrm{e}-2$ TRANsport C4 $\mathrm{Kd}=0.6 \mathrm{Dab}=1.5779 \mathrm{e}-2$ TRANsport C4 $\mathrm{Kd}=0.6 \quad \mathrm{Dab}=1.5779 \mathrm{e}-2$ TRANsport C4 $\mathrm{Kd}=0.6 \mathrm{Dab}=1.5778 \mathrm{e}-2$ TRANsport C4 $\mathrm{Kd}=0.6 \mathrm{Dab}=1.5779 \mathrm{e}-2$ TRANsport $C 4 \quad \mathrm{Kd}=0.6 \mathrm{Dab}=7.88940 \mathrm{e}-30$ TRANsport $\mathrm{C} 4 \mathrm{Kd}=0.6 \mathrm{Dab}=1.57788 €-2$ TRANsport C4 $\mathrm{Kd}=0.6 \mathrm{Dab}=1.57788 \mathrm{e}-2$ PRANsport C4 $\mathrm{Kd}=0.6 \mathrm{Dab}=1.5779 \mathrm{e}-2$ $a=8.500$ $a=8.500$ $a=8.500$ $a=0.000$ $a=0.000$ $\mathrm{a}=0.000$ $a=0.000$ $a=0.000$ $a=0.000$ $a=0.000$ $a=0.000$ $\mathrm{b}=.85:$ ZONE 2 $b=.85: 2$ ONE 3 $\mathrm{b}=.85:$ ZONE 4 $b=0 .:$ ZONE 5 $\mathrm{b}=0$. : ZONE 6 $\mathrm{b}=0 .:$ : ZONE 7 $\mathrm{b}=0$. : ZONE 9 $\mathrm{b}=0 .:$ ZONE 10 $b=0 .:$ ZONE 12 $b=0$. : ZONE 13 $b=0 .:$ ZONE 14 $a=0.00 \quad b=0.0:$ ZONE 1 $\mathrm{a}=8.500 \quad \mathrm{~b}=.85:$ ZONE 2 $a=8.500 \quad b=.85:$ ZONE 3 $a=8.500 \quad b=.85:$ ZONE 4 $a=0.000 \quad b=0 .:$ ZONE 5 $a=0.000 \quad b=0 .:$ ZONE 6 $a=0.000 \quad b=0 .:$ ZONE 7 $a=0.000 \quad b=0 .:$ ZONE 9 $a=0.000 \quad b=0 .:$ ZONE 10 $a=0.000 \quad b=0 .:$ ZONE 12 $a=0.000 \quad b=0 . ; 2 O N E 13$ $a=0.000 \quad b=0 .:$ ZONE 14 I

INITIAL $\mathrm{H}=-.7487$ IN ZONE 1 !!! SOII G-1 /INITIAL $\mathrm{H}=-.8227$ IN ZONE 2 /INITIAL $\mathrm{H}=-3.9454$ IN ZONE 3 IINITIAL $\mathrm{H}=-2.05473$ IN ZONE 4 INITIAL $\mathrm{H}=-.7487$ IN ZONE 5 INITIAL $\mathrm{H}=-.7487$ IN ZONE 6 INITIAL $\mathrm{H}=-.7487$ IN ZONE 7 INITIAL $\mathrm{H}=-.7487$ IN ZONE 9 INITIAL $\mathrm{H}=-.7487$ IN ZONE 10 INITIAL $\mathrm{H}=-.7487$ IN ZONE 12 INITIAL $\mathrm{H}=-.7487$ IN ZONE 13 INITIAL $\mathrm{H}=-.7487$ IN ZONE 14 INITIAL $\mathrm{H}=0.0$ from $(1,1)$ to

$\mathrm{a}=0.00$

$a=8.500$ $a=8.500$

$\mathrm{a}=8.500$ $\bar{a}=0.000$ $\mathrm{a}=0.000$ $a=0.000$ $a=0.000$ $a=0.000$ $a=0.000$ $a=0.000$ $\mathrm{a}=0.000$ $\mathrm{b}=0.0:$ ZONE 1

$\mathrm{b}=.85:$ ZONE 2

$\mathrm{b}=.85:$ ZONE 3 $\mathrm{b}=.85$ : ZONE 4 $\mathrm{b}=0 .:$ : ZONE 5 $\mathrm{b}=0 .:$ ZONE 6 $b=0 .:$ ZONE 7 $b=0 .:$ ZONE 9 $b=0$. : ZONE 10 $b=0 .:$ ZONE 12 $b=0 .:$ ZONE 13 $\mathrm{b}=0 .:$ ZONE 14
$\mathrm{a}=0.00$
$a=8.500$
$\mathrm{a}=8.500$
$a=8.500$
$\mathrm{a}=0.000$
$a=0.000$
$\mathrm{a}=0.000$
$a=0.000$
$b=0.0:$ ZONE 1
$\mathrm{b}=.85:$ ZONE 2
$b=.85:$ ZONE 3
$\mathrm{b}=.85:$ ZONE 4
$\mathrm{b}=0$. : ZONE 5
$\mathrm{b}=0 .:$ ZONE 6
$\mathrm{b}=0 .:$ ZONE 7
$a=0.0000000$
$b=0 .:$ ZONE 9
$a=0.000$
$b=0$ : Z ZONE 12
$a=0.000 \quad b=0$ : ZONE 13
$a=0.000$ I

$(166,1)$ ! bottom 
Rev. 1

INITIAL $C$ is 0 everywhere INITIAL $C 2$ is 0 everywhere INITIAL $\mathrm{C} 3$ is 0 everywhere INITIAL $C 4$ is 0 everywhere 1

\begin{tabular}{|c|c|c|c|c|c|c|}
\hline OUN & $\mathbf{P}$ & & index $=$ & $=$ & -1 & GRAD \\
\hline OIT & $\mathbf{P}$ & east & dex $=$ & $=$ & 1 & $=0.0$ \\
\hline$N$ & $P$ & bottom & dex = & $=$ & -2 & ALIJe \\
\hline & $\mathbf{P}$ & top & dex $=$ & $=$ & 2 & -5.0 \\
\hline $\mathrm{JN}$ & C & west & ex $=$ & $=$ & -1 & $R A D$ \\
\hline & $\mathrm{C}$ & east & & $=$ & & $=0.0$ \\
\hline J & $\mathrm{C}$ & bottom & $\mathrm{ex}=$ & $=$ & -2 & $=0.0$ \\
\hline & C & top & & $=$ & & e $=0.0$ \\
\hline & $\mathrm{C} 2$ & west & hex & $=$ & -1 & GRAD $=0.0$ \\
\hline & $\mathrm{C} 2$ & east & $x$ & : $=$ & & GRAD $=0.0$ \\
\hline & $\mathrm{C} 2$ & bottc & ex & $=$ & -2 & $=0.0$ \\
\hline & $\mathrm{C} 2$ & & $x$ & $=$ & & VALUE $=0.0$ \\
\hline & $\mathrm{C} 3$ & west & ex & : $=$ & -1 & GRAD $=0.0$ \\
\hline & c3 & east & ex & $=$ & & $=0.0$ \\
\hline & $\mathrm{C} 3$ & botto & & $=$ & -2 & $=0.0$ \\
\hline BOUN & C3 & top & $e x$ & $=$ & $?$ & VALUe $=0.0$ \\
\hline & C4 & est & & $=$ & 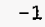 & $D=0.0$ \\
\hline & C4 & & & $=$ & & $=0.0$ \\
\hline & $\mathrm{C}$ & . & & $=$ & -2 & $=0.0$ \\
\hline & $\mathrm{C} 4$ & & & $=$ & & VALUE $=0.0$ \\
\hline
\end{tabular}
1

PROPERTIES FOR P BY GEOMetric MEAN

PROPERTIES FOR C BY HARMONiC MEAN

PROPERTIES FOR C2 BY HARMONiC MEAN

PROPERTIES FOR C 3 BY HARMONiC MEAN

PROPERTIES FOR C4 BY HARMONIC MEAN 1

LOCATE SOURCE 1 from $(3,89)$

LOCATE SOURCE 2 from $(6,89)$

LOCATE SOURCE 3 from $(9,89)$

LOCATE SOURCE 4 from $(12,89)$

LOCATE SOURCE 5 from $(15,89)$

LOCATE SOURCE 6 from $(18,89)$

LOCATE SOURCE 7 from $(21,89)$

LOCATE SOURCE 8 from $(24,89)$

LOCATE SOURCE 9 from $(27,89)$

LOCATE SOURCE 10 from $(30,89)$ 1

LOCATE SOURCE 11 from $(33,89)$

LOCATE SOURCE 12 from $(36,89)$

LOCATE SOURCE 13 from $(39,89)$

LOCATE SOURCE 14 from $(42,89)$

LOCATE SOURCE 15 fxOm $(45,89)$

LOCATE SOURCE 16 from $(48,89)$

LOCATE SOURCE 17 from $(51,89)$

LOCATE SOURCE 18 from $(54,89)$

LOCATE SOURCE 19 from $(57,89)$

LOCATE SOURCE 20 from $(60,89)$ 1

LOCATE SOURCE 21 from $(63,89)$

LOCATE SOURCE 22 from $(66,89)$

LOCATE SOURCE 23 from $(69,89)$

LOCATE SOURCE 24 from $(72,89)$

LOCATE SOURCE 25 from $(75,89)$

LOCATE SOURCE 26 from $(78,89)$

LOCATE SOURCE 27 from $(81,89)$

LOCATE SOURCE 28 from $\{84,89\}$

LOCATE SOURCE 29 from $(87,89)$

LOCATE SOURCE 30 from $(90,89)$

\begin{tabular}{|c|c|c|c|c|c|}
\hline Eo & $(3,97) \$$ & & \multirow{2}{*}{\multicolumn{3}{|c|}{ soil matrix }} \\
\hline & $(6,97)$ & & F so & & $\operatorname{atrix}$ \\
\hline & $(9,97)$ & & & il & atrix \\
\hline to & $(12,97)$ & $\$$ & $\mathrm{BF}$ & soil & matri \\
\hline to & 97) & $\$$ & $\mathrm{BF}$ & soil & matr \\
\hline to & 37) & $\$$ & $\mathrm{BF}$ & soil & matr \\
\hline co & 971 & $\$$ & $\mathrm{BF}$ & so & mat \\
\hline to & 7) & $\$$ & $\mathrm{BF}$ & soil & mat \\
\hline to & & $\$$ & $\mathrm{BF}$ & 1 & mat \\
\hline$=0$ & 7) & $\$$ & $\mathrm{BF}$ & 7) & mat \\
\hline$=0$ & & $\$$ & $\mathrm{BF}$ & & 16 \\
\hline to & & $\$$ & $\mathrm{BF}$ & soil & ma \\
\hline$=0$ & 7) & $\$$ & $\mathrm{BF}$ & soil & $\operatorname{mat}$ \\
\hline to & 7) & $\$$ & $\mathrm{BF}$ & i & nat \\
\hline to & 7) & $\$$ & $\mathrm{BF}$ & so & matr \\
\hline to & 7) & $\$$ & $\mathrm{BF}$ & so & nats \\
\hline to & 7) & $\$$ & $\mathrm{BF}$ & so & matr \\
\hline to & & $\$$ & $\mathrm{BF}$ & so & matr \\
\hline to & & $\dot{\$}$ & $\mathrm{BF}$ & so & matr \\
\hline 0 & & $\$$ & $\mathrm{BF}$ & & mat \\
\hline to & & $\$$ & $\mathrm{BF}$ & & mats \\
\hline co & & $\$$ & $\mathrm{BF}$ & so & mat \\
\hline 0 & & $\$$ & $\mathrm{BF}$ & & mat \\
\hline 0 & & $\$$ & $\mathrm{BF}$ & & mat \\
\hline & & $\$$ & BF & & nat \\
\hline 0 & & $\$$ & $\mathrm{BF}$ & & matr \\
\hline to & & $\$$ & $\mathrm{BF}$ & so & matr \\
\hline to & & $\$$ & $\mathrm{BF}$ & & matr \\
\hline to & & $\$$ & $B F$ & & matr \\
\hline & & & $\mathrm{BI}$ & & \\
\hline
\end{tabular}


I LOCATE SOURCE 31 from $(93,89)$ LOCATE SOURCE 32 from $(96,89)$ LOCATE SOURCE 33 from $(99,89)$ LOCATE SOURCE 34 from $(102,89)$ LOCATE SOURCE 35 Erom $(105,89)$ LOCATE SOURCE 36 from $(108,89)$ LOCATE SOURCE 37 from $(111,89)$ LOCATE SOURCE 38 from $(114,89)$ LOCATE SOURCE 39 from $(117,89)$ LOCATE SOURCE 40 from $(120,89)$ 1 LOCATE SOURCE 41 from $(123,89)$ LOCATE SOURCE 42 from $(126,89)$ LOCATE SOURCE 43 from $(129,89)$ LOCATE SOURCE 44 fxom $(132,89)$ LOCATE SOURCE 45 from $(135,89)$ LOCATE SOURCE 46 from $(138,89)$ LOCATE SOURCE 47 Erom $(141,89)$ LOCATE SOURCE 48 from $(144,89)$ LOCATE SOURCE 49 from $(147,89)$ LOCATE SOURCE 50 from $(150,89)$ 1 $1 /$ TIME STRENGTH $(\mathrm{m} * \star 3 / \mathrm{m} * \star 3-\mathrm{yr})$

/SOUR\# 1 FLOW, 4 set: $(0 ., 0 \ldots, 121.7 .29 e-5,20000 ., 2.92 e-4,40000 ., 2.92 e-3)$ $, \mathrm{C}=0.0, \mathrm{C} 2=0.0, \mathrm{C} 3=0.0, \mathrm{C} 4=0.0$ SCALE .0012346

SOUR\# 1 for $C 39$ pairs on file 'rfprate.dat' $1 \mathrm{C} 2$ is for Tc-99 which has a release rate that is 5 times smaller than $\mathrm{C}^{\prime} \mathrm{s}, \mathrm{C3}$ 's, $\mathrm{C4}$ 's.

/ hence the scale factor is reduced by a factor of 5 if same release file is used.

SCALE .00024691

SOUR\# 1 for C2 5 pairs on file 'rfptcx5.dat. SCALE .0012346

SOUR\# $i$ for $C 339$ pairs on file 'rfprate.dat' SCALE .0012346

SOUR\# $i$ for $C 439$ pairs on file "rfprate. dat. SCALE .0024691.

SOUR\# 2 for $C 39$ pairs on file 'rfprate.dat' SCALE .00049384

SOUR\# 2 for $C 25$ pairs on file 'rfptcx5.dat' SCALE .0024691

SOUR\# 2 for $C 339$ pairs on file 'rfprate.dat' SCALE .0024691

SOUR\# 2 for C4 39 pairs on file 'rfprate.dat' SCALE .0024691

SOUR\# 3 for C 39 pairs on file 'rfprate.dat. SCALE .00049384

SOUR\# 3 for $C 25$ pairs on file 'rfptcx5.dat' SCALE .0024691

SOUR\# 3 for C3 39 pairs on file "rfprate.dat" SCALE .0024691

SOUR\# 3 for C4 39 pairs on file 'rfprate.dat' SCALE .0024691

SOUR\# 4 for C 39 pairs on file 'rfprate.dat' SCALE .00049384

SOUR\# 4 for $\mathrm{C} 25$ pairs on file 'rfptcx5.dat' SCALE .0024691

SOUR 4 for $\mathrm{C} 339$ pairs on Eile 'rfprate.dat' SCALE .0024691

SOUR\# 4 for C4 39 pairs on file 'rfprate.dat' SCALE .0024691.

SOUR\# 5 for $C 39$ pairs on file 'rfprate.dat. SCALE .00049384

SOUR\# 5 for $C 25$ pairs on file 'rfptcx5.dat'

SCALE .0024691

SOUR\# 5 for C3 39 pairs on file 'rfprate.dat'
BF soil matrix

BF soil matrix

$\mathrm{BF}$ soil matrix

BE soil matrix BF soil matrix BF soil matrix $B F$ soil matrix $B F$ soil matrix $B F$ soil matrix BF soil matrix

BF soil matrix BF soil matrix BF soil matrix BF soil matrix BF soil matrix $B F$ soil matrix $\mathrm{BF}$ soil matrix BF soil matrix $\mathrm{BF}$ soil matrix EF soil matrix 


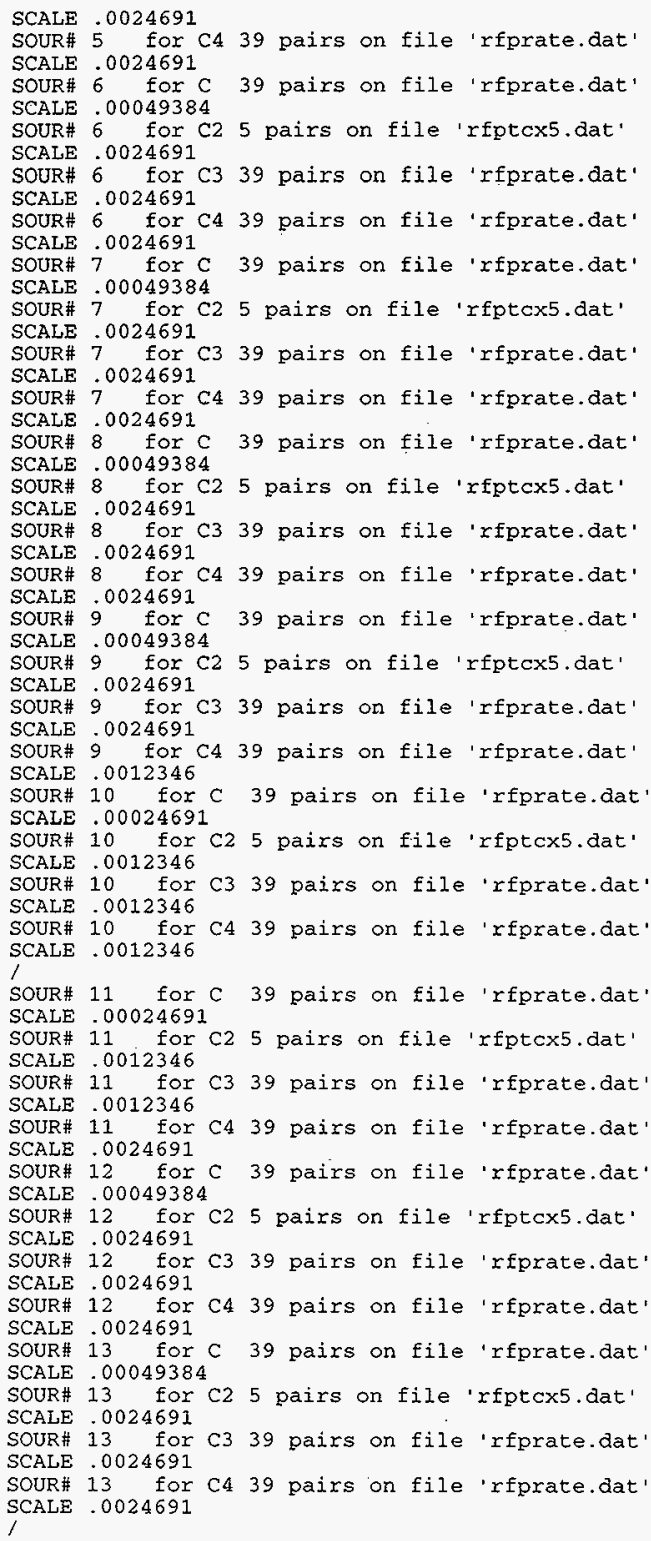


SOUR\# 14 for $C \quad 39$ pairs on file 'rfprate.dat' SCALE .00049384

SOUR\# 14 for $C 25$ pairs on file 'rfptcx5.dat' SCALE .0024691

SOUR\# 14 for C3 39 pairs on file 'rfprate.dat. SCALE .0024691

SOUR\# 14 for C4 39 pairs on file 'rfprate.dat' SCALE .0024691

SOUR\# 15 for $C 39$ pairs on file 'rfprate.dat' SCALE .00049384

SOUR\# 15 for C2 5 pairs on file 'rfptcx5.dat' SCALE .0024691

SOUR\# 15 for C3 39 pairs on file 'rfprate.dat' SCALE .0024691

SOUR\# 15 for $\mathrm{C} 439$ pairs on file 'rfprate. dat' SCALE .0024691

SOUR\# 16 for C 39 pairs on file 'rfprate.dat' SCALE .00049384

SOUR\# 16 for $C 25$ pairs on file 'rfptcx5.dat' SCALE .0024691

SOUR\# 16 for $C 339$ pairs on file 'rfprate.dat' SCALE .0024691

SOUR\# 16 for C4 39 pairs on file 'rfprate.dat' SCALE .0024691

SOUR\# 17 for $C 39$ pairs on file 'rfprate.dat' SCALE .0049384

SOUR\# 17 for $C 25$ pairs on file 'rfptcx5.dat' SCALE .0024691

SOUR\# 17 for $C 339$ pairs on file 'rfprate.dat' SCALE .0024691

SOUR\# 17 for C4 39 pairs on file 'rfprate.dat' SCALE .0024691

SOUR\# 18 for C 39 pairs on file 'rfprate.dat' SCALE :00049384

SOUR\# is for $C 25$ pairs on file 'rfptcx5.dat' SCALE .0024691

SOUR 18 for $\mathrm{C} 39$ pairs on file 'rfprate.dat" SCALE .0024691

SOUR\# 18 for $C 439$ pairs on file 'rfprate.dat. SCALE .0024691

SOUR\# 19 for $C 39$ pairs on file 'rfprate.dat. SCALE .00049384

SOUR\# 19 for $C 25$ pairs on file 'rfptcx5.dat. SCALE .0024691

SOUR\# 19 for $\mathrm{C} 339$ pairs on file 'rfprate.dat' SCALE .0024691

SOUR\# 19 for 4439 pairs on file 'rfprate.dat. SCALE .0012346

SOUR\# 20 for $C 39$ pairs on file 'rfprate.dat' SCALE .00024691

SOUR\# 20 for C2 5 pairs on file 'rfptcx5.dat' SCALE .0012346

SOUR\# 20 for C3 39 pairs on file 'rfprate.dat' SCALE .0012346

SOUR\# 20 for $\mathrm{C} 439$ pairs on file 'rfprate.dat' SCALE .0012346

I

SOUR\# 21 for $C 39$ pairs on file 'rfprate.dat' SCALE .00024691

SOUR\# 21 for $C 25$ pairs on file 'rfptcx5.dat.' SCALE .0012346

SOUR\# 21 for $\mathrm{C} 339$ pairs on file 'rfprate.dat' SCALE .0012346

SOUR\# 21 for $C 439$ pairs on file 'rfprate.dat ' SCALE .0024691

SOUR\# 22 for $C 39$ pairs on file 'rfprate.dat SCALE .00049384

SOUR\# 22 for $\mathrm{C} 25$ pairs on file 'rfptcx5. dat' SCALE .0024691 
SOUR\# 22 for C3 39 pairs on file 'xfprate.dat' SCALE .0024691

SOUR\# 22 for C4 39 pairs on file 'rfprate.dat' SCALE .0024691

SOUR\# 23 for $C 39$ pairs on file 'rfprate.dat' SCALE .00049384

SOUR\# 23 for $C 25$ pairs on file 'rfptex5.dat'

SCALE .0024691

SOUR\# 23 for C3 39 pairs on file 'rfprate.dat' SCALE .0024691

SOUR\# 23 for C4 39 pairs on file 'rfprate.dat' SCALE .0024691

SOUR\# 24 for $C 39$ pairs on file 'rfprate.dat' SCALE .00049384

SOUR\# 24 for C2 5 pairs on file 'rfptex5.dat' SCALE .0024691

SOUR\# 24 for $C 339$ pairs on file 'rfprate.dat' SCALE .0024691

SOUR\# 24 for C4 39 pairs on file 'rfprate.dat' SCALE .0024691

SOUR\# 25 for $C 39$ pairs on file 'rfprate.dat SCALE .00049384

SOUR\# 25 for C2 5 pairs on file 'reptcx5.dat'

SCALE .0024691

SOUR\# 25 for C3 39 pairs on file 'rfprate.dat'

SCALE .0024691

SOUR\# 25 for C4 39 pairs on file 'rfprate.dat

SCALE .0024691

SOUR\# 26 for $C 39$ pairs on file 'rfprate.dat

SCALE .00049384

SOUR\# 26 for $\mathrm{C} 25$ pairs on file 'rfptcx5.dat'

SCALE .0024691

SOUR\# 26 for C3 39 pairs on file 'rfprate.dat'

SCALE .0024691

SOUR\# 26 for C4 39 pairs on file 'rfprate.dat'

SCALE .0024691

SOUR\# 27 for $C 39$ pairs on file 'rfprate.dat' SCALE .00049384

SOUR\# 27 for C2 5 pairs on file 'rfptcx5. dat'

SCALE .0024691

SOUR\# 27 for C3 39 pairs on file 'rfprate.dat' SCALE .0024691

SOUR\# 27 for C4 39 pairs on file 'rfprate.dat' SCALE .0024691

SOUR\# 28 for C 39 pairs on file 'rfprate.dat' SCALE .00049384

SOUR\# 28 for C2 5 pairs on file 'rfptcx5.dat'

SCALE .0024691

SOUR\# 28 for C3 39 pairs on file 'rfprate.dat'

SCALE . 0024691

SOUR\# 28 for C4 39 pairs on file 'rfprate.dat' SCALE .0024691

SOUR\# 29 for $C 39$ pairs on file 'rfprate.dat' SCALE .00049384

SOUR\# 29 for $\mathrm{C} 25$ pairs on file 'rfptcx5.dat'

SCALE .0024691

SOUR\# 29 for C3 39 pairs on file 'rfprate.dat'

SCALE .0024691

SOUR\# 29 for C4 39 pairs on file 'rfprate.dat'

SCALE .0012346

SOUR\# 30 for $C 39$ pairs on file 'rfprate.dat'

SCALE .00024691

SOUR\# 30 for $C 25$ pairs on file 'rfptcx5. dat'

SCALE .0012346

SOUR\# 30 for C3 39 pairs on file 'rfprate.dat'

SCALE .0012346

SOUR\# 30 for C4 39 pairs on file 'rfprate.dat' SCALE .0012346 
SOUR\# 31 for $C \quad 39$ pairs on file 'rfprate.dat' SCALE .00024691

SOUR\# 31 for $C 2$ pairs on file 'rfptcx5.dat'

SCALE .0012346

SOUR\# 31 for $C 339$ pairs on file 'rfprate.dat' SCALE .0012346

SOUR\# 31 for $C 439$ pairs on file 'rfprate.dat'

SCALE .0024691

SOUR\# 32 for $C \quad 39$ pairs on file 'rfprate.dat.

SCALE .00049384

SOUR\# 32 for $C 25$ pairs on file 'rfptcx5.dat'

SCALE .0024691

SOUR\# 32 for C3 39 pairs on file 'rfprate. dat'

SCALE .0024691

SOUR\# 32 for C4 39 pairs on file 'rfprate.dat'

SCALE .0024691

SOUR\# 33 for $C 39$ pairs on file 'rfprate.dat'

SCALE .00049384

SOUR\# 33 for $C 25$ pairs on file 'rfptcxs.dat'

SCALE .0024691

SOUR\# 33 for $C 339$ pairs on file 'rfprate.dat'

SCALE .0024691

SOUR\# 33 for $C 439$ pairs on file 'rfprate.dat'

SCALE .0024691

SOUR\# 34 for $C 39$ pairs on file 'rfprate.dat'

SCALE .00049384

SOUR\# 34 for $C 25$ pairs on Eile 'rfptcx5.dat'

SCALE .0024691

SOUR\# 34 for $\mathrm{C} 339$ pairs on file 'rfprate.dat'

SCALE .0024691

SOUR\# 34 for $C 439$ pairs on file 'rfprate.dat' SCALE .0024691

SOUR\# 35 for C 39 pairs on file 'rfprate.dat'

SCALE .00049384

SOUR\# 35 for $C 2$ pairs on file 'rfptcx5.dat'

SCALE .0024691

SOUR\# 35 for C3 39 pairs on file 'rfprate.dat' SCALE .0024691

SOUR\# 35 for C4 39 pairs on file 'rfprate.dat' SCALE .0024691

SOUR\# 36 for C 39 pairs on file 'rfprate.dat' SCALE .00049384

SOUR\# 36 for $C 25$ pairs on file 'rfptcx5.dat'

SCALE .0024691

SOUR.\# 36 for C3 39 pairs on file 'rfprate.dat'

SCALE .0024691

SOUR\# 36 for C4 39 pairs on file 'rfprate.dat' SCALE .0024691

SOUR\# 37 for $C 39$ pairs on file 'rfprate.dat

SCALE .0024691

SOUR\# 37 for $C 25$ pairs on file 'rfptex5.dat'

SCALE .002469I

SOUR\# 37 for $\mathrm{C} 339$ pairs on file 'rfprate.dat'

SCALE .0024691

SOUR\# 37 for $C 439$ pairs on file 'rfprate.dat' SCALE . 0024691

SOUR\# 38 for $C 39$ pairs on file 'rfprate.dat'

SCALE .00049384

SOUR\# 38 for $\mathrm{C} 25$ pairs on file 'rfptex5. dat'

SCALE .0024691

SOUR\# 38 for $C 339$ pairs on file 'rfprate dat' SCALE .0024691

SOUR\# 38 for $\mathrm{C} 4.39$ pairs on file 'rfprate.dat' SCALE .0024691

SOUR\# 39 for $C \quad 39$ pairs on file "rfprate.dat" SCALE .00049384

SOUR\# 39 for $C 25$ pairs on file 'rfptcx5.dat'

SCALE .0024691

SOUR\# 39 for $\mathrm{C} 339$ pairs on file 'rfprate.dat'

D-21 


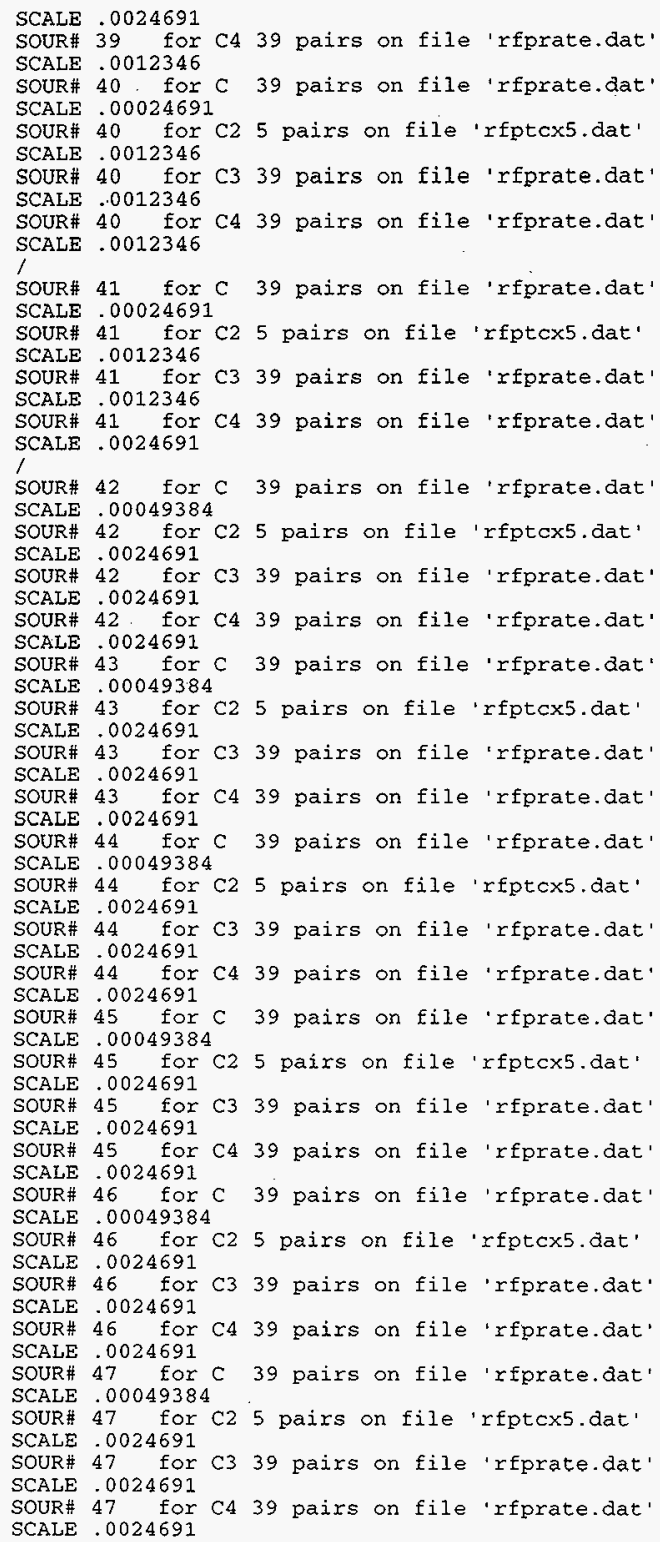


SOUR\# 48 for C 39 pairs on file 'rfprate.dat' SCALE .00049384

SOUR\# 48 for $C 25$ pairs on file 'rfptcx5.dat'

SCALE .0024691

SOUR\# 48 for $\mathrm{C} 339$ pairs on file 'rfprate.dat'

SCALE .0024691

SOUR\# 48 for C4 39 pairs on file 'rfprate.dat'

SCALE .0024691

SOUR\# 49 for $C 39$ pairs on file 'rfprate.dat'

SCALE .00049384

SOUR\# 49 for $C 25$ pairs on file 'rfptcx5. dat'

SCALE .0024691

SOUR\# 49 for C3 39 pairs on file 'rfprate.dat'

SCALE .0024691

SOUR\# 49 for C4 39 pairs on file 'rfprate.dat'

SCALE .0012346

SOUR\# 50 for $C 39$ pairs on file 'rfprate.dat'

SCALE .00024691

SOUR\# 50 for $C 25$ pairs on file 'rfptcx5.dat'

SCALE .0012346

SOUR\# 50 for C3 39 pairs on file 'rfprate.dat'

SCALE .0012346

SOUR\# 50 for C4 39 pairs on file 'rfprate.dat'

I

/

\begin{tabular}{|c|c|c|c|c|c|c|c|c|}
\hline EIXEd & $\mathrm{P}$ & from & $(4,89)$ & to & $5,97)$ & \multirow{2}{*}{\multicolumn{2}{|c|}{$\begin{array}{l}\text { glass } \\
\text { glass }\end{array}$}} & \multirow[t]{2}{*}{ canisters } \\
\hline IXEd & $\mathrm{P}$ & from & $(7,89)$ & to & $8,97) \$$ & & & \\
\hline FIXEd & $\mathrm{P}$ & from & $(10,89)$ & to & $(11,97)$ & \multicolumn{2}{|r|}{ glass } & canisters \\
\hline FIXEd & $\mathrm{P}$ & from & $(13,89)$ & to & $(14,97)$ & \multicolumn{2}{|r|}{ glass } & canisters \\
\hline FIXEd & $\mathbf{P}$ & from & $(16,89)$ & to & $(17,97)$ & $\$$ & glass & canisters \\
\hline FIXEd & $\mathrm{P}$ & from & $(19,89)$ & to & $(20,97)$ & $\$$ & glass & canisters \\
\hline EIXEA & $P$ & from & 122 & to & $(23,97)$ & $\$$ & glass & canisters \\
\hline FIXEA & $\mathrm{P}$ & from & 125 & to & $.97)$ & \multicolumn{2}{|r|}{ glass } & \multirow{2}{*}{$\begin{array}{l}\text { canisters } \\
\text { canisters }\end{array}$} \\
\hline FIXEd & $\mathrm{p}$ & from & 128 & to & $(29,97)$ & \multirow{2}{*}{\multicolumn{2}{|c|}{ glass }} & \\
\hline ' & & & & & & & & canisters \\
\hline FIXEd & $\mathbf{P}$ & from & $(34,89)$ & to & $(35,97)$ & \multicolumn{2}{|r|}{ glass } & canisters \\
\hline FIXEd & $P$ & from & ) & to & $.97)$ & \multicolumn{2}{|r|}{ glass } & canisters \\
\hline FIXEd & $\mathrm{P}$ & from & 14 & to & $(41,97)$ & \multicolumn{2}{|r|}{ glass } & canisters \\
\hline FIXE & $\mathrm{p}$ & from & 9) & to & $, 97)$ & $\$$ & glass & canistexs \\
\hline FIXI & $\mathrm{P}$ & from & 9) & to & .97) & $\$$ & glass & isters \\
\hline FIX & $\mathrm{F}$ & from & 1) & to & ,97) & $\$$ & ass & isters \\
\hline FIX & $\mathrm{P}$ & from & 9) & to & 97) & $\$$ & glass & canisters \\
\hline FIX & P & from & 9) & to & $97)$ & $\$$ & glass & canisters \\
\hline FIXEd & P & from & & to & 97) & $\$$ & glass & canisters \\
\hline FTX & & & & & & & a]ลs & \\
\hline$F I X$ & $F$ & Erom & $(64,89)$ & to & $(65,97)$ & 5 & glass & sters \\
\hline FIY & $\mathbf{P}$ & from & ( & to & $(68,97)$ & $\$$ & glass & sters \\
\hline FIX & $\mathrm{P}$ & from & ( 7 & to & .97 & $\$$ & ass & stexs \\
\hline FIX & $p$ & from & $(7$ & to & 4,97 & $\$$ & ass & ers \\
\hline FIXI & $\mathrm{P}$ & from & $(76,89)$ & to & $(77,97)$ & \$ & glass & canisters \\
\hline FIX & $\mathrm{P}$ & Erom & $(79,89)$ & to & $(80,97)$ & $\$$ & glass & canisters \\
\hline FIX & P & from & 89) & to & $(83,97)$ & $\$$ & glass & canisters \\
\hline$F I X$ & p & from & $(85,89)$ & to & $(86,97)$ & $\$$ & glass & canisters \\
\hline FIX & P & from &, 891 & to & $(89,97)$ & $\$$ & glass & canisters \\
\hline I & & & & & & & & \\
\hline FIX & P & from & $(94,89)$ & to & $, 97)$ & $\$$ & glass & canisters \\
\hline FIX & P & om & $89)$ & to & $(98,97)$ & $\$$ & glass & canisters \\
\hline FIX & P & from & $(100,89)$ & to & $(101,97)$ & 1) & glass & canisters \\
\hline FIX & $\mathrm{P}$ & from & $(103,89)$ & to & $4,97)$ & ) & glass & canisters \\
\hline FIXE & P & from & $(106,89)$ & to & $(7,97)$ & ) \$ & glass & canisters \\
\hline FIXE & $\mathrm{p}$ & from & $(109,89)$ & to & $0,97)$ & ) & glass & canisters \\
\hline FIXEd & P & from & $(112,89)$ & to & $(3,97)$ & ) & glass & canisters \\
\hline FIXEd & $\mathrm{P}$ & from & $(115,89)$ & to & $6.97)$ & ) & glass & canisters \\
\hline FIXEO & P & from & $(118,89)$ & to & $(119,97)$ & $\$$ & glass & canisters \\
\hline 1 & & & & & & & & \\
\hline FIX & P & om & 4,89 & to & $97)$ & ) & lass & isters \\
\hline FIX & $\mathrm{P}$ & om & $(127,89)$ & to & $(128,97)$ & & glass & canisters \\
\hline FIX & p & $\operatorname{com}$ & $(130,89)$ & to & $(131,97)$ & & glass & canisters \\
\hline FIX & $\mathrm{P}$ & om & $(133,89)$ & to & & & & canisters \\
\hline
\end{tabular}




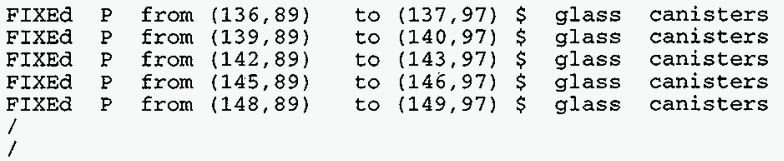

CONVergence for P LOCAL eps $=5,0 e-6$ ITERations $=12$

METHOd is PICARD

MATRIX for $\mathrm{P}=2$ using $\mathrm{ADI}$

MATRIX for $\mathrm{C}=2$ using $A D I$

MATRIX for $\mathrm{C} 2=2$ using $\mathrm{ADI}$

MATRIX for $C 3=2$ using $A D I$

MATRIX for $C 4=1$ using ADI

$/ / \operatorname{RELAX} P=0.32 \quad ! ! ! ! ! ! S=0.5, \quad \mathrm{KR}=0.5, \quad \mathrm{SE}=0.5$

FLUX BALANCE FOR C ON 'basel-1d.flx' FROM (1,1) TO $(166,133)$ EVERY 2000 STEPSS

FLUX BALANCE for C from $(1,87)$ to $(153,101)$ every 2000 steps

FLUX BALANCE for $C$ from $(1,87)$ to $(166,133)$ every 2000 steps

FLUX BALANCE for C from $(1,5)$ to $(166,86)$ every 2000 steps

FLUX BALANCE for $C$ from $(3,89)$ to $(3,97)$ every 2000 steps

FLUX BALANCE for $C$ from $(148,89)$ to $(149,97)$ every 2000 steps

FLUX BALANCE for $C$ from $(150,89)$ to $(150,97)$ every 2000 steps

/HISTORY $(2,2),(20,2),(40,2),(60,2),(78,2)$ on 'base1-1d.his' eve 200 1

FLUX BALANCE for $\mathrm{P}$ from $(1,1)$ to $(166,133)$ every 1000 steps

FLUX BALANCE for $\mathrm{P}$ from $(1,87)$ to $(153,101)$ every 1000 steps

FLUX BALANCE for $P$ from $(1,87$ ) to $(166,133)$ every 1000 steps

FLUX BALANCE for P from $(1,1)$ to $(166,86)$ every 1000 steps

FLUX for C from $(1,87)$ to $(166,87)$ every 200 steps

FLUX for $C$ from $(1,2)$ to $(166,2)$ every 200 steps

FLUX for $\mathrm{C} 2$ from $(1,2)$ to $(166,2)$ every 200 steps

FLUX for C3 from $(1,2)$ to $(166,2)$ every 200 steps

FLUX for C4 from $(1,2)$ to $(166,2)$ every 200 steps

DIAGnostic node at $(46,2)$ every 20 steps

DEBUg leve 1 at step 90000

/

WINDOW from $(1,1)$ to $(165,133)$

SOLVE AUTO 200 YEARS, STEPS=1.e-1 FAC=1.1 MAX 20.0 $1 . e-15 \quad 3.0 \quad 85000$

CONVergence for $P$ LOCAL eps $=1$. 0e-5 ITERations $=12$

SOLVE AUTO 300 YEARS, STEPS $=1 . e-1 \quad$ FAC $=1.1$ MAX $20.0 \quad 1$.e-15 $3.0 \quad 85000$

SAVE U, $V, C, C 2, C 3, C 4, H, S$, MOIS on 'base1-1d.arc' NOW

OUTPUT $U, V, C, H, S$, MOIS NOW

/Degrade the concrete here after 500 years

CONVergence for $P$ LOCAL eps $=5.0$ e-5 ITERations $=12$

HYDRaulic properties: $S S=1 . e-5(\mathrm{Kx}, \mathrm{KY}, \mathrm{Kz})=3 * 417.0 \quad(\mathrm{~m} / \mathrm{yr}) \quad$ : zONE 7

HYDRaulic properties: $S S=1 . e-5 \quad(\mathrm{KX}, \mathrm{KY}, \mathrm{Kz})=3 * 417.0 \quad(\mathrm{~m} / \mathrm{Yr}) \quad$ : $\mathrm{ZONE} 12$

HYDRaulic properties: $S S=1 . e^{-5} \quad(\mathrm{Kx}, \mathrm{KY}, \mathrm{Kz})=3 * 417.0 \quad(\mathrm{~m} / \mathrm{Yr}) \quad$ : $\mathrm{ZONE} 13$

MULTiphase: VAN MUAL $n=1.613$ alpha=1.25 $\mathrm{s} r=.09604 .0 .:$ 2ONE 7

MULTiphase: VAN MUAL $n=1.613$ alpha $=1.25$ sr=.09604:0.: ZONE 12

MULTiphase: VAN MUAL $n=1.613$ alpha $=1.25$ sr $=.09604 \quad 0 .:$ : 2 ONE 13

MULTiphase: VAN MUAL $n=1.613$ alpha= 1.25 s $x=.89604 \quad 0 .:$ ZONE 7

/MULTiphase: VAN MUAL $n=1.613$ alpha $=1.25 \quad$ sr $=.89604 \quad 0 . \quad:$ ZONE 12

/MULTiphase: VAN MUAL $n=1.613$ alpha= 1.25 sr $=.89604 \quad 0 .:$ zONE 13

INITIAE $\mathrm{H}=-.001$ IN ZONE 7 !!! TOP horizontal concrete

INITIAL $\mathrm{H}=-.001$ IN ZONE 12 !!! Bottom horizontal concrete

INITIAL $\mathrm{H}=-.001$ IN ZONE 13 !! Vertical concrete

SOLVE AUTO 500.0 YEARS, STEPS=1.e-1 FAC=1.1 MAX 20.0 1. e-15 $3.0 \quad 85000$

SAVE U, V, C, C2, C3, C4, H, S, MOIS NOW

OUTPUT $U, V, C, H, S$, MOIS NOW

1 Increase the recharge rate from $0.05 \mathrm{~cm} / \mathrm{yr}$ to $.3 \mathrm{~cm} / \mathrm{yr}$ at 1000 yrs

CONVergence for $P$ LOCAL eps $=5$. 0e-5 ITERations $=12$

BOUN $P$ west index $=-1 \quad G R A D=0$

BOUN $\mathrm{P}$ east index $=1$ GRAD $=0.0$

BOUN $P$ bottom index $=-2$ VALUe $=-0.25$ water table

BOUN $\mathrm{P}$ top $\quad$ index $=2$ FLUX $=-3.0 \mathrm{E}-3 \mathrm{~m} /$ year

1

SOLVE AUTO 3000 YEARS, STEPS=1.e-8 FAC=1.1 MAX $10.0 \quad 1 . e-153.0 \quad 85000$

SAVE U, V, C, C2, C3, C4, H, S, MOIS NOW 


\section{FNF-EP-0884 \\ Rev. 1}

OUTPUT U, $V, C, H, S$, MOIS NOW

1

DISABLE FLOW

SOLVE AUTO 6000 YEARS, STEPS $=3 \cdot e-1 \quad F A C=1.1$ MAX OUTPUT $U, V, C, H, S$, MOIS NOW

$4.0 \quad 1 . e-15 \quad 3.0 \quad 85000$

SAVE U, $V, C, C 2, C 3, C 4, H, S$, MOIS NOW

SOLVE AUTO 90000 YEARS, STEPS $=4$.e-0 FAC $=1.1 \mathrm{MAX}$

END

QUIT

$8.0 \quad 1 . e-14 \quad 3.0 \quad 85000$ 
Rev. 1

\section{D.6.2 Unit Ce11 Model - PORFLOW}

TITLe Pexformance Based on a Single Canister: Concept 1 Base Case

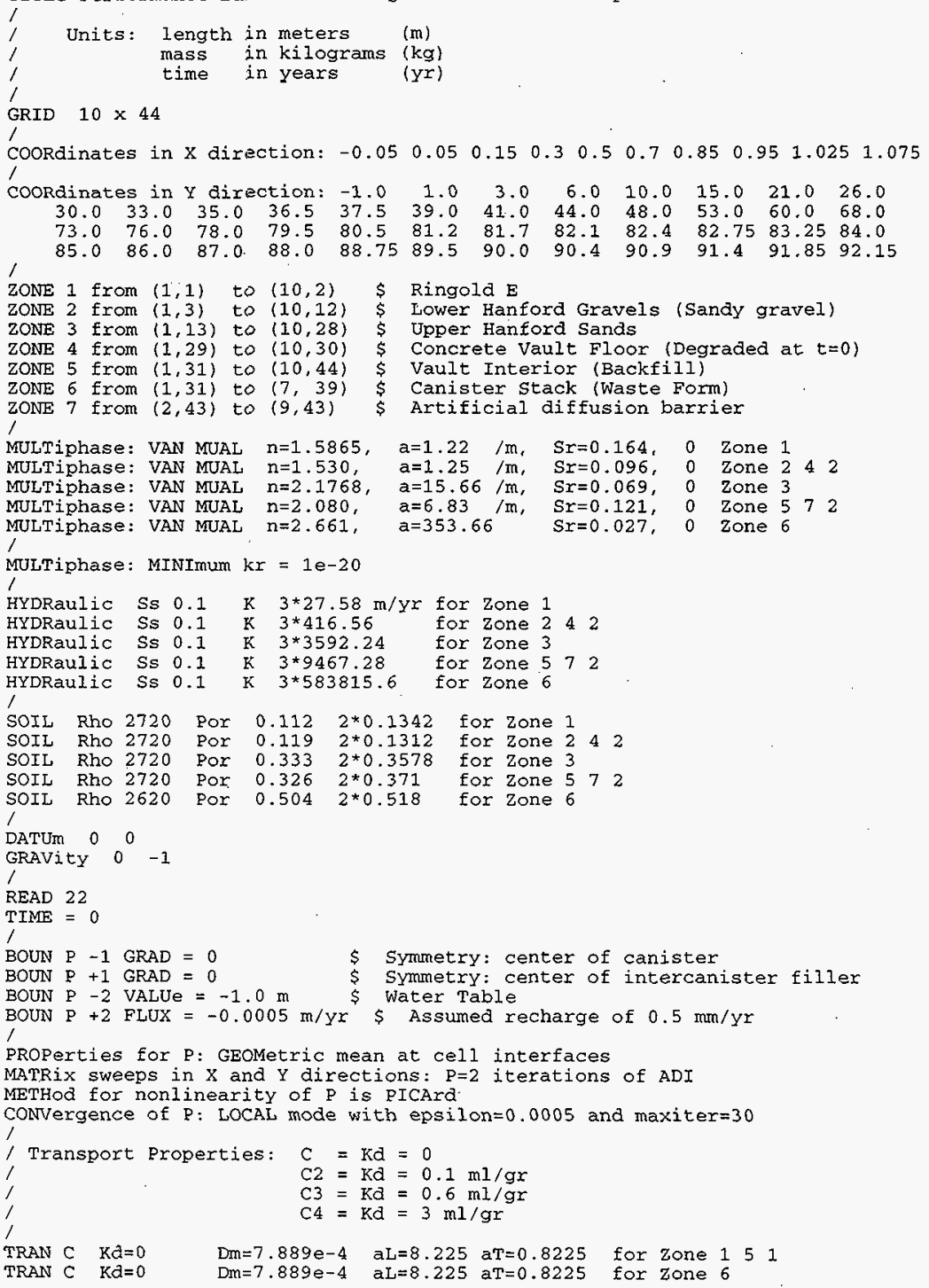




\section{HWF - EP - 0884 \\ Rev. 1}

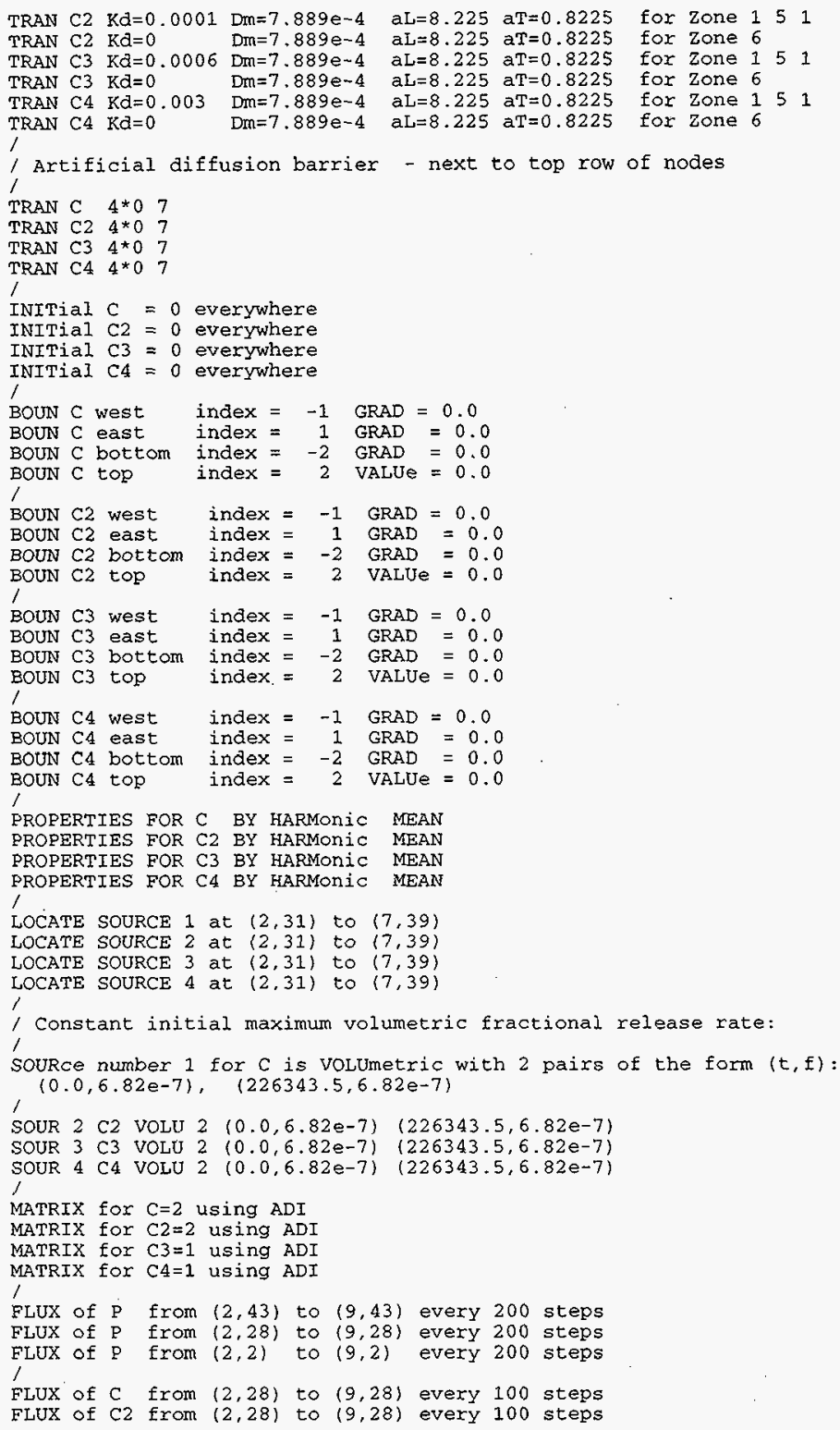




\section{HNF-EP-0884 \\ Rev. 1}

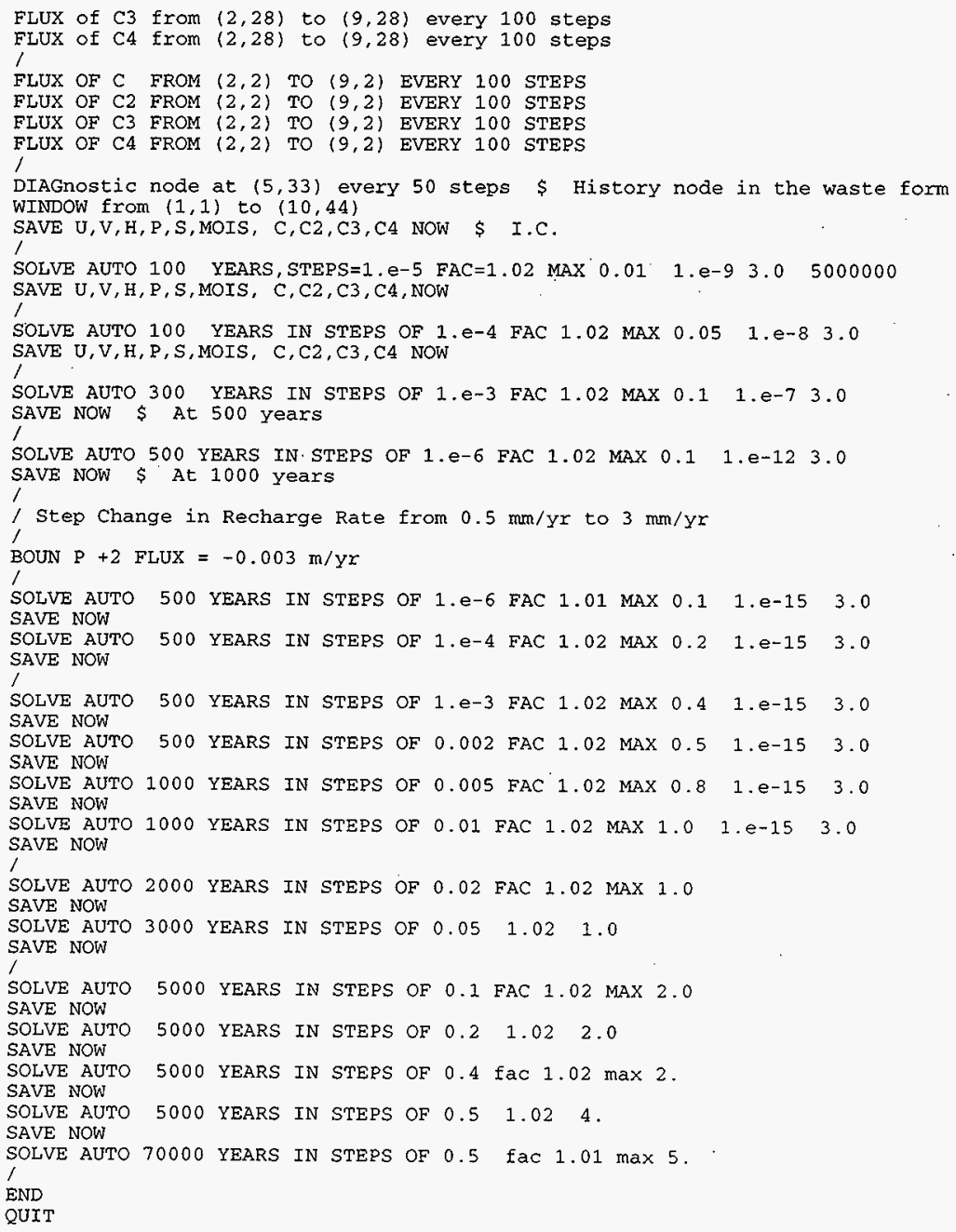


Rev. 1

\section{D.6.3 Pump Mode1 - VAM3D-CG}

Because of the size of the input file, the file is not listed.

\section{D.6.4 Site Groundwater Model}

Because of the size of the input file, the file is not listed.

\section{D.6.5 INTEG}

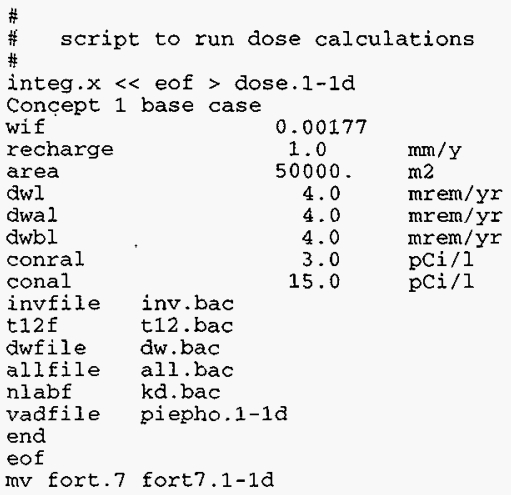


FNNE-EP-0884

Rev. 1

D- 30 


\section{HNF-EP-0884 \\ Rev. 1 \\ APPENDIX E DETAILED RESULTS}

\section{E.1 OVERVIEW}

This appendix presents more information concerning the results of the simulations. There are four sections covering a) vadose zone simulations, b) unconfined aquifer simulations, c) the calculation of dose, and d) simulations of glass dissolution.

Because of the long-time of release from the waste form, the time-dependence of the vadose zone transport and hence of the impacts of the disposal action looks more like a step function than a peak function. The following section provides a mathematical justification for this shape.

For a point source in an infinite one-dimensional homogeneous media, the concentration of contaminants (C) can be expressed as

$$
C(z, t)=\int_{0}^{t} f(T) G(z, t-T) d T
$$

where

$t$ is the time (s) since release,

$\mathrm{z}$ is the distance $(\mathrm{cm})$ from release,

$f(T)$ is the source term of contaminants, and

$G(z, t-T)$ is the Green's function for transport,

$$
G(z, t)=\left(\frac{1}{4 \pi D_{z} t}\right)^{\frac{1}{2}} \exp (-\lambda t) \exp \left[-\frac{(z-u t)^{2}}{4 D_{z} t}\right]
$$

where

$D_{z}$ is the retardation-corrected pseudodispersion coefficient $\left(\mathrm{cm}^{2} / \mathrm{s}\right)$,

$\lambda$ is the decay constant $\left(\mathrm{s}^{-1}\right)$ of the contaminant, and

$u$ is the retardation-corrected pore velocity (cm/s).

Both $\mathrm{D}_{2}$ and $\mathrm{u}$ depend upon the moisture content.

For the unretarded contaminants (in our case, technetium, selenium, and iodine), the release rate for the base analysis case is almost constant, changing less than 1 percent in 20,000 years. Thus the slowly varying release function $f(T)$ can be removed from the integrand, leaving just the integral over the Green's function. This integral results in a step function with the first wave of contaminants followed by hundred of thousands of years of succeeding contaminants.

For the more typical case where the release from the waste form is quick relative to the travel through the vadose zone, 


\section{HNF-EP-0884 \\ Rev. 1}

then it is the Green's function which can be removed from the integrand, resulting in a integral that is just the inventory. The time dependence is a skewed bell-shaped curve.

\section{E.2 VADOSE ZONE SIMULATIONS}

\section{E.2.1 Overview}

This appendix provides more details concerning the computer simulations that were run to determine the contaminant flux to the underground aquifer. The next section contains a brief discussion of the calculation for very long times. The last section summarizes the fluxes for all the computer simulations (Table E-1) as well as figures displaying the contaminant fluxes.

\section{E.2.2 Extension of Calculation to Long Times}

In order to determine the peak impact, calculations of the vadose zone flux must be made for millions of years. However, computer simulations for such long times would not justify their cost. Therefore a simpler approach was used.

As has been shown in previous Hanford calculations, the normalized flux to the aquifer can be approximately calculated based on the $K_{d}=0$ group. By assuming that the release rate continues indefinitely and that the waste form release controls the temporal shape, the normalized flux to the aquifer can be approximately by

$$
\Gamma\left(K_{d}, t \cdot\left[1+\alpha K_{d}\right]\right)=\Gamma\left(K_{d}=0, t\right) .
$$

By comparing the time of occurrence for $\Gamma=10^{-6}$ per year for $\mathrm{K}_{\mathrm{d}}=0$ and $\mathrm{K}_{\mathrm{d}}=3 \mathrm{ml} / \mathrm{g}, \alpha$ is found to be $6.6 \mathrm{l} / \mathrm{mg}$. Figure $\mathrm{E}-1$ compares the $\mathrm{K}_{\mathrm{a}}=3 \mathrm{mg} / \mathrm{l}$ group as found by computer simulations and as predicted using the above simple formula.

\section{E.2.3 Values}

The results of all the vadose zone simulations are displayed in Table E-1 (where cases beginning with 1 were performed with the Concept 1 Full Facility Model, beginning with 2 were performed with the Concept 2 Full Facility Model, and beginning with 3 were performed with the Unit Cell Model.). The results for each simulation are ordered by the value of the $k_{d}$ parameter. Because for most of the simulations, the peak value occurs after the simulations end at 100,000 years, values in the table for half height and for 1 ppm height are given both for the actual peak value and for the peak value in the first 100,000 years.

No figures are given in this section, since the curve shapes 


\section{FINF-EP-0884 \\ Rev. 1}

are so similar. Please see the figures in sections 4.3 through Section 4.6. More explanation of the results is given in Kline 1996 and Piepho 1996.

Figure E-1. Comparison of $\mathrm{kd}=3 \mathrm{mg} / \mathrm{l}$ Using Computer simulations and An Approximation

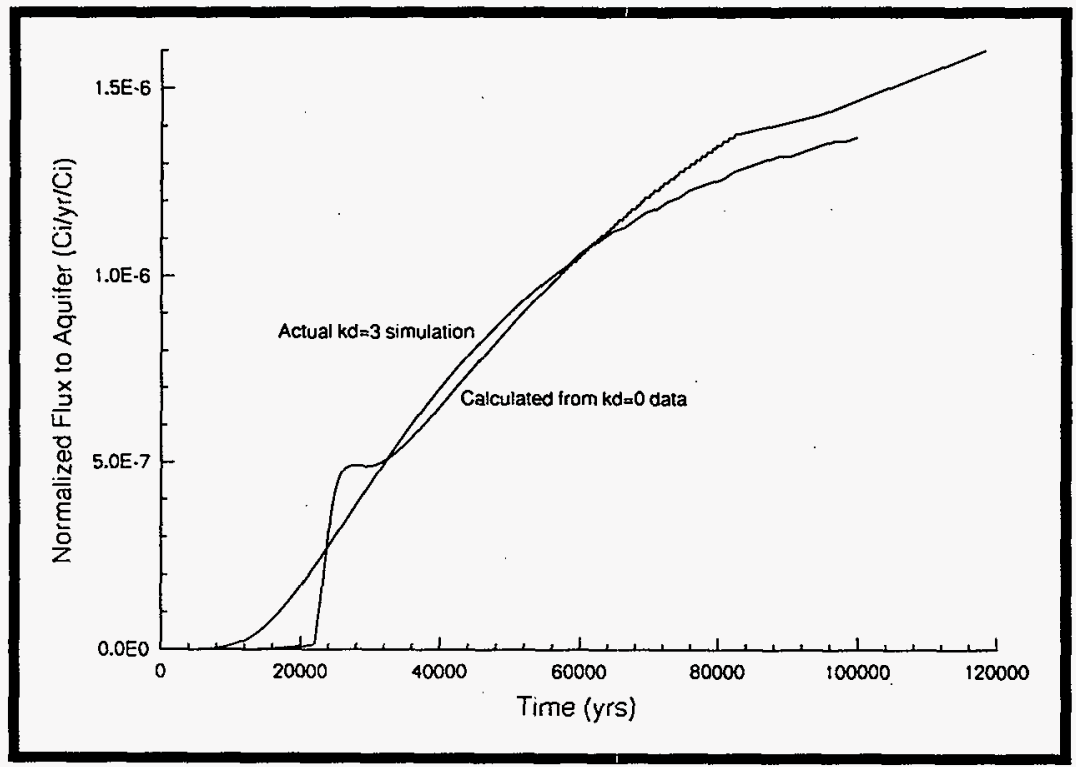




\section{HNF-EP- 0884 \\ Rev. 1}

Table E-1. Summary of Vadose zone Simulations for the Normalized Contaminant Flux Reaching the Unconfined Aquifer. Case numbers reflect archival filenames.

(Values with * Assume Peak Value is $4 \times 10^{-6} \mathrm{y}^{-1}$ )

(Values with \#, Calculated only to 40,000 Years)

(Values in Parentheses Reflect Peak Values in First 100k Years)

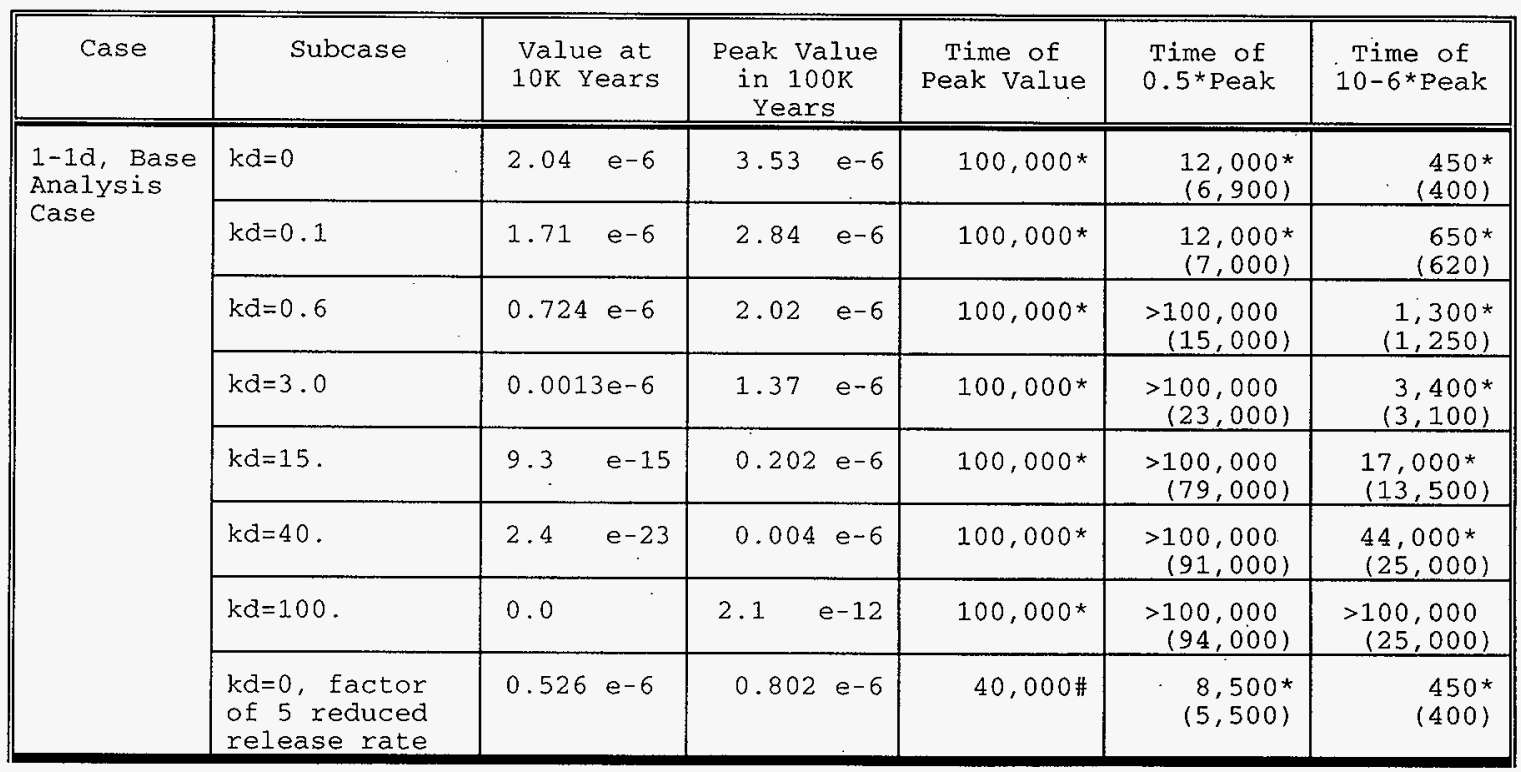




\section{HNF-EP-0 884}

Rev. 1

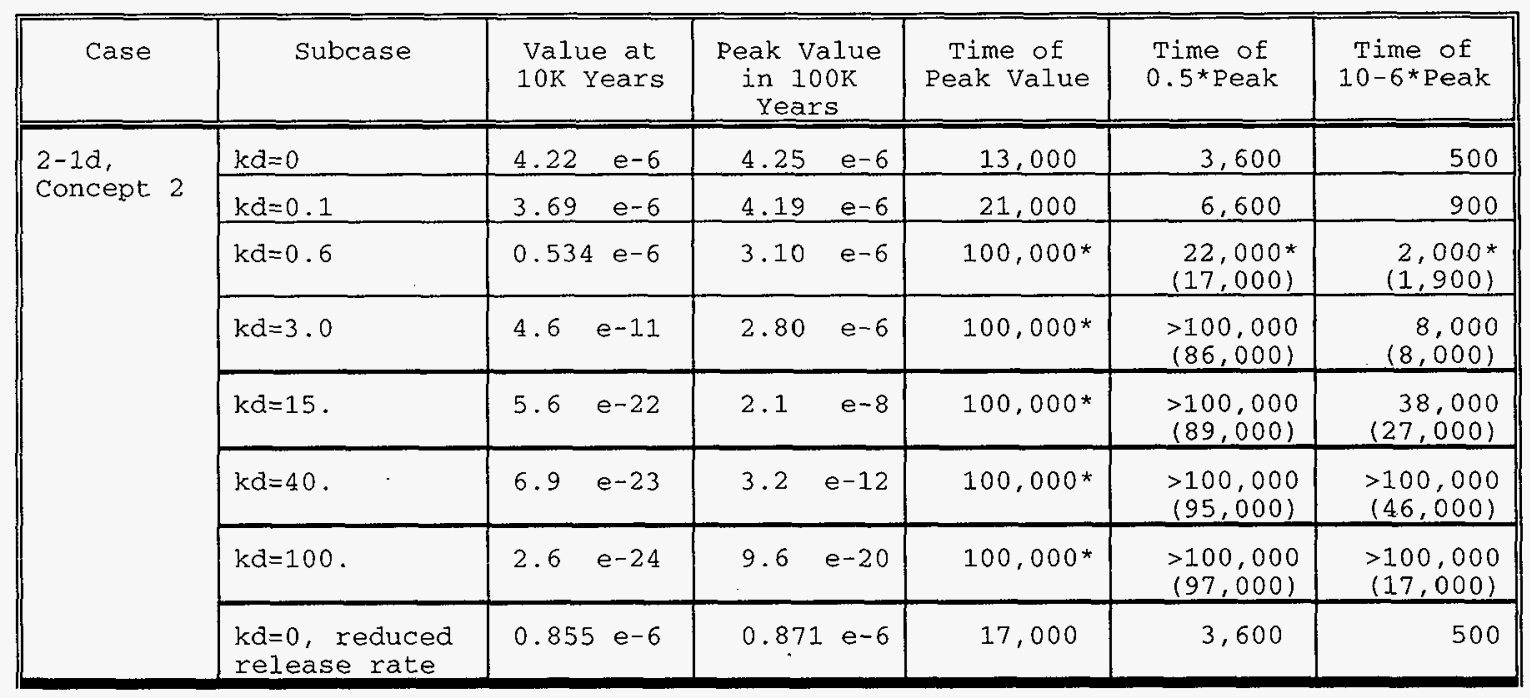




\section{HNF - EP- 0884}

Rev. 1

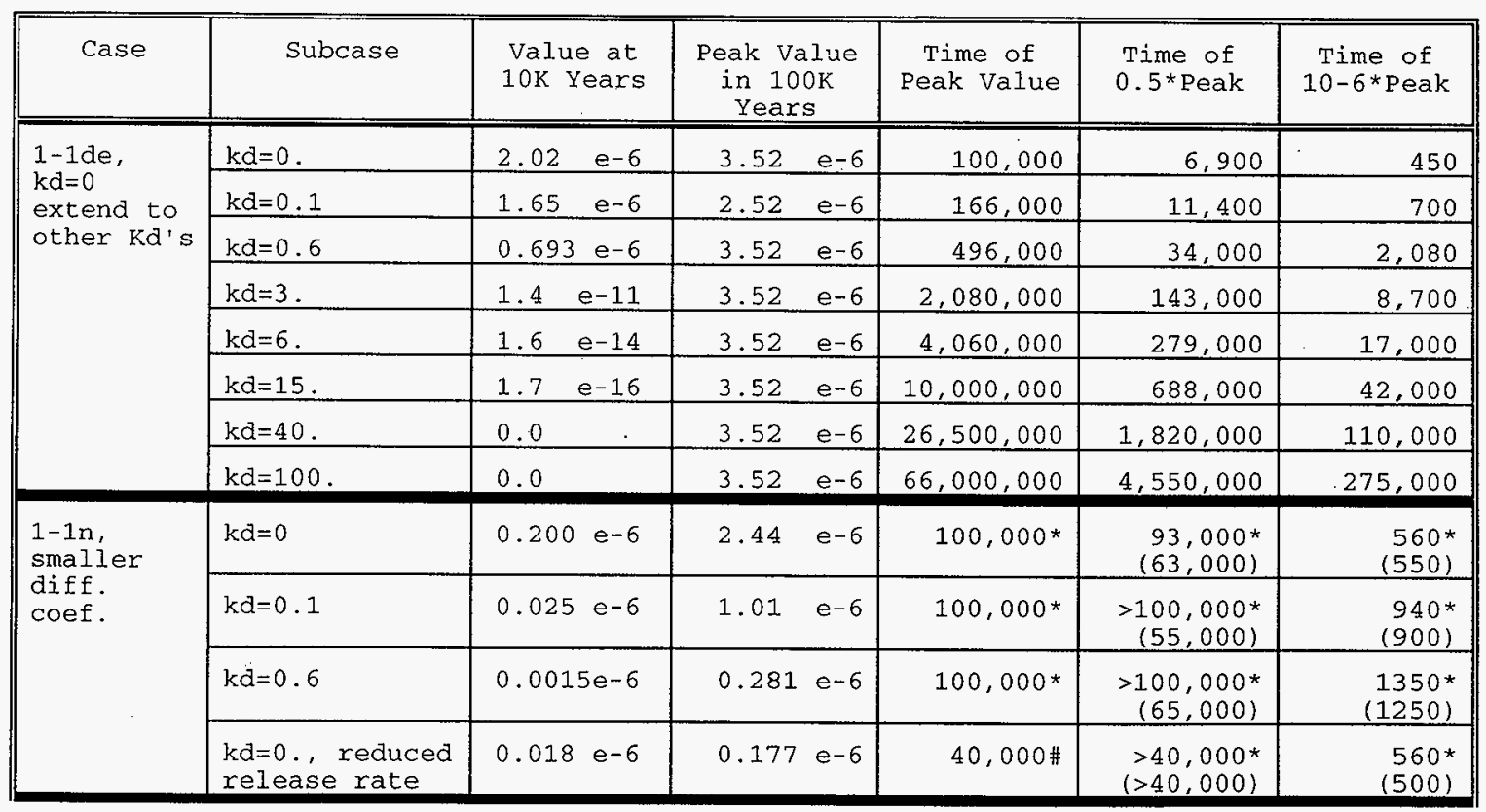




\section{HNF-EP-0 884}

Rev. 1

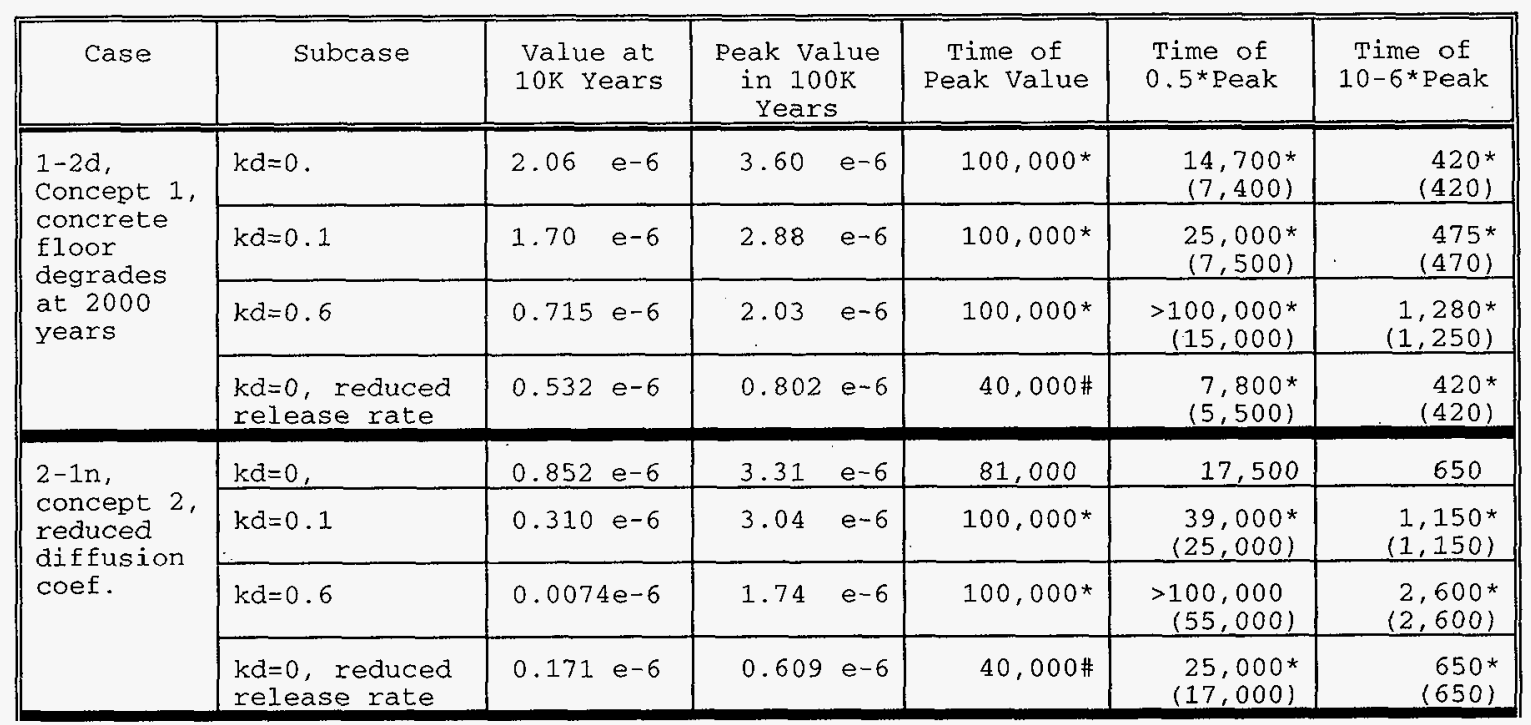


HNF - EP-0884

Rev. 1

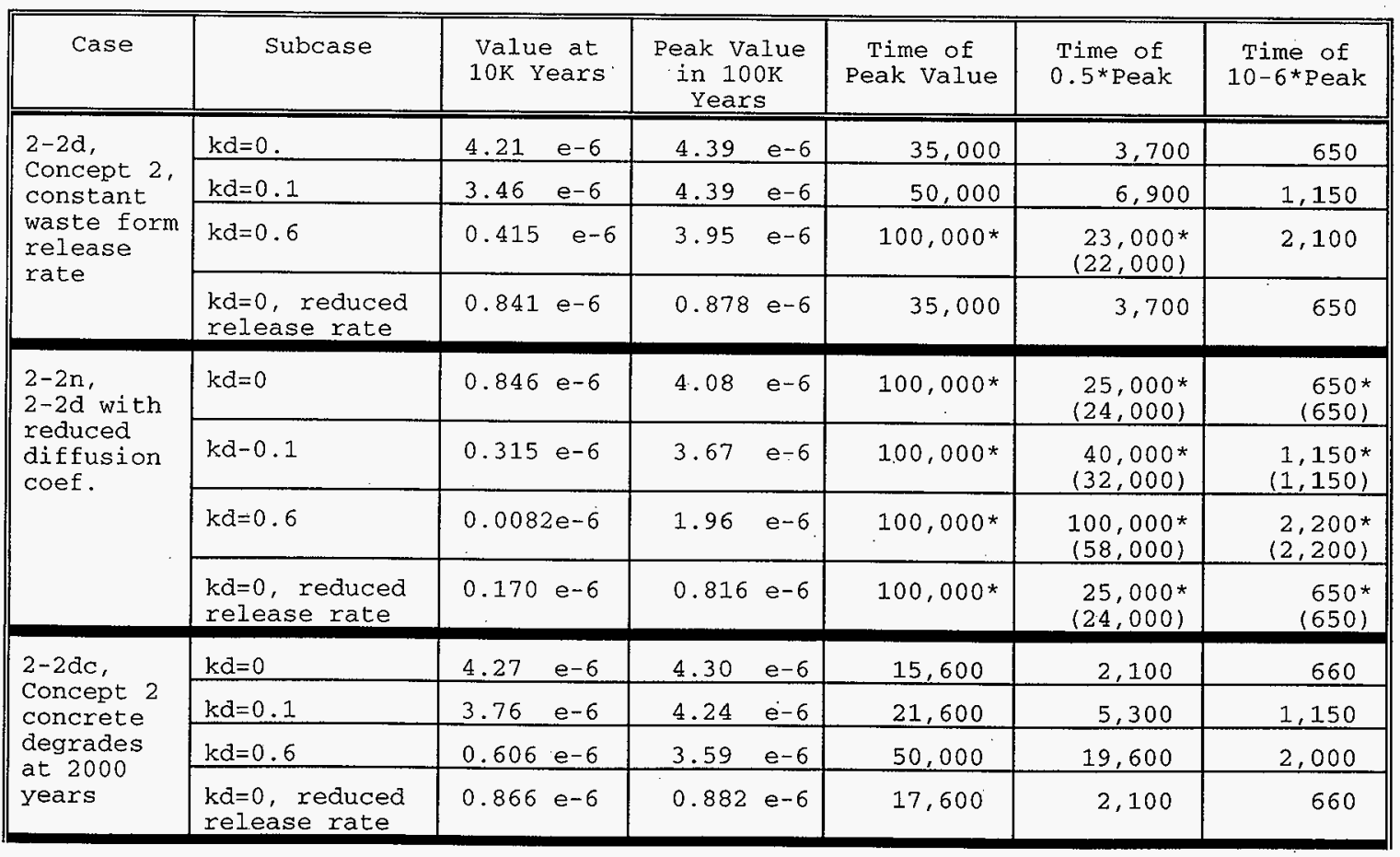




\section{HNE-EP-0884}

Rev. 1

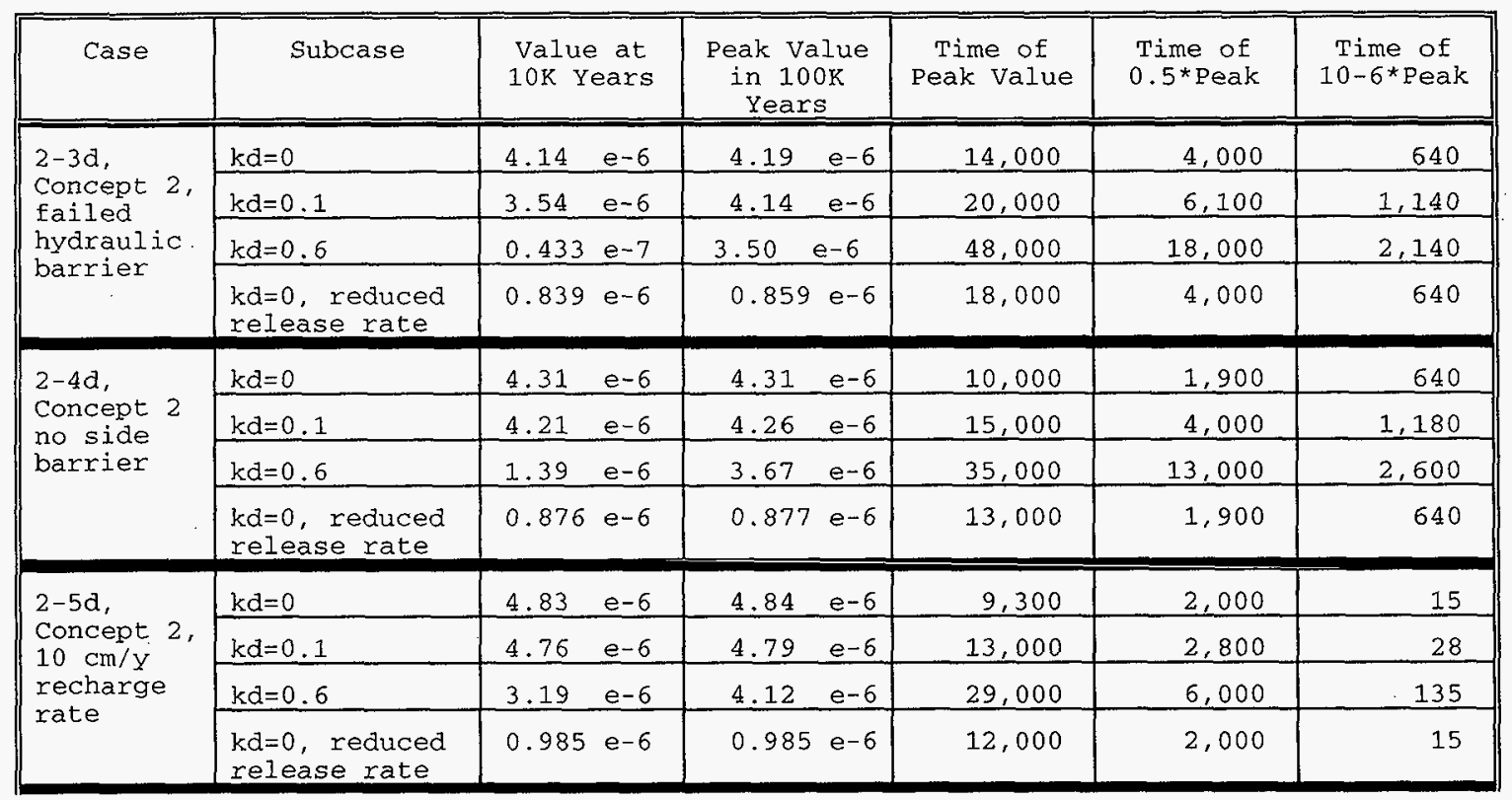


HNF-EP-0884

Rev. 1

\begin{tabular}{|c|c|c|c|c|c|c|}
\hline Case & Subcase & $\begin{array}{l}\text { Value at } \\
10 \mathrm{~K} \text { Years }\end{array}$ & $\begin{array}{c}\text { Peak Value } \\
\text { in } 100 \mathrm{~K} \\
\text { Years }\end{array}$ & $\begin{array}{l}\text { Time of } \\
\text { Peak value }\end{array}$ & $\begin{array}{l}\text { Time of } \\
0 . .5 * \text { Peak }\end{array}$ & $\begin{array}{l}\text { Time of } \\
10-6 * \text { Peak }\end{array}$ \\
\hline \multirow{4}{*}{$\begin{array}{l}2-6 d, \\
\text { Concept } 2, \\
0.5 * \\
\text { dispersion } \\
\text { coef. }\end{array}$} & $\mathrm{kd}=0$ & $4.17 \quad e-6$ & $4.24 \quad e-6$ & 15,000 & 4,000 & 750 \\
\hline & $\mathrm{kd}=0.1$ & $3.52 \quad e-6$ & 4.17 e- 6 & 21,000 & 6,700 & 1,300 \\
\hline & $\mathrm{kd}=0.6$ & $0.418 e^{-6}$ & 3.52 e-6 & 51,000 & 19,000 & 3,000 \\
\hline & $\begin{array}{l}\mathrm{kd}=0 \text {, reduced } \\
\text { release rate }\end{array}$ & 0.846 e- 6 & 0.870 e- 6 & 19,000 & 4,000 & 750 \\
\hline \multirow{4}{*}{$\begin{array}{l}2-7 d \\
\text { concept } 2 \\
2 * \\
\text { dispersion } \\
\text { coef. }\end{array}$} & $\mathrm{kd}=0$ & 4.24 e- 6 & 4.26 e- 6 & 13,000 & 3,600 & 600 \\
\hline & $k d=0.1$ & $3.79 \quad e-6$ & 4.20 e- 6 & 21,000 & 6,000 & 700 \\
\hline & $\mathrm{kd}=0.6$ & $0.676 e^{-6}$ & 3.55 e- 6 & 50,000 & 19,000 & 1,600 \\
\hline & $\begin{array}{l}\mathrm{kd}=0, \text { reduced } \\
\text { release rate }\end{array}$ & 0.860 e- 6 & 0.872 e- 6 & 17,000 & 3,600 & 600 \\
\hline
\end{tabular}


HNF-EP-0884

Rev. 1

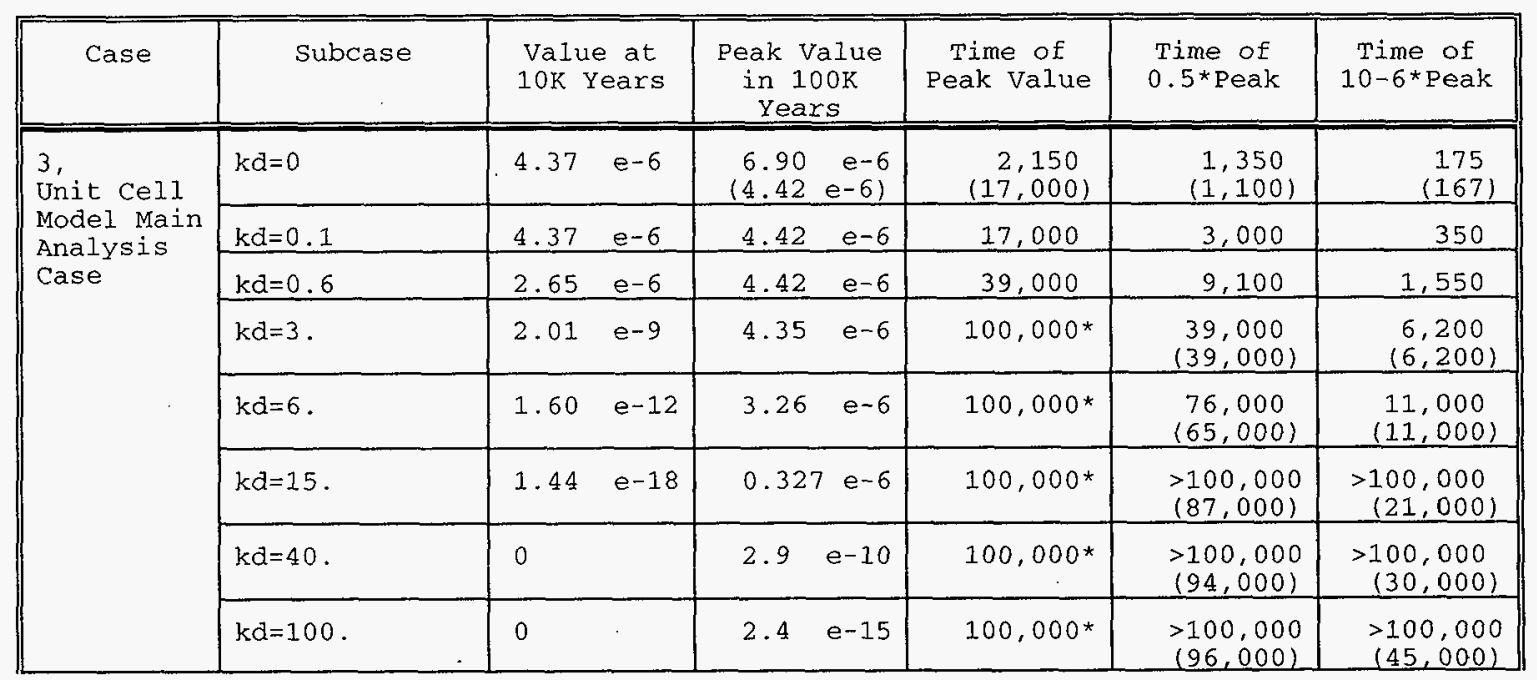


HNF-EP-0 084

Rev. 1

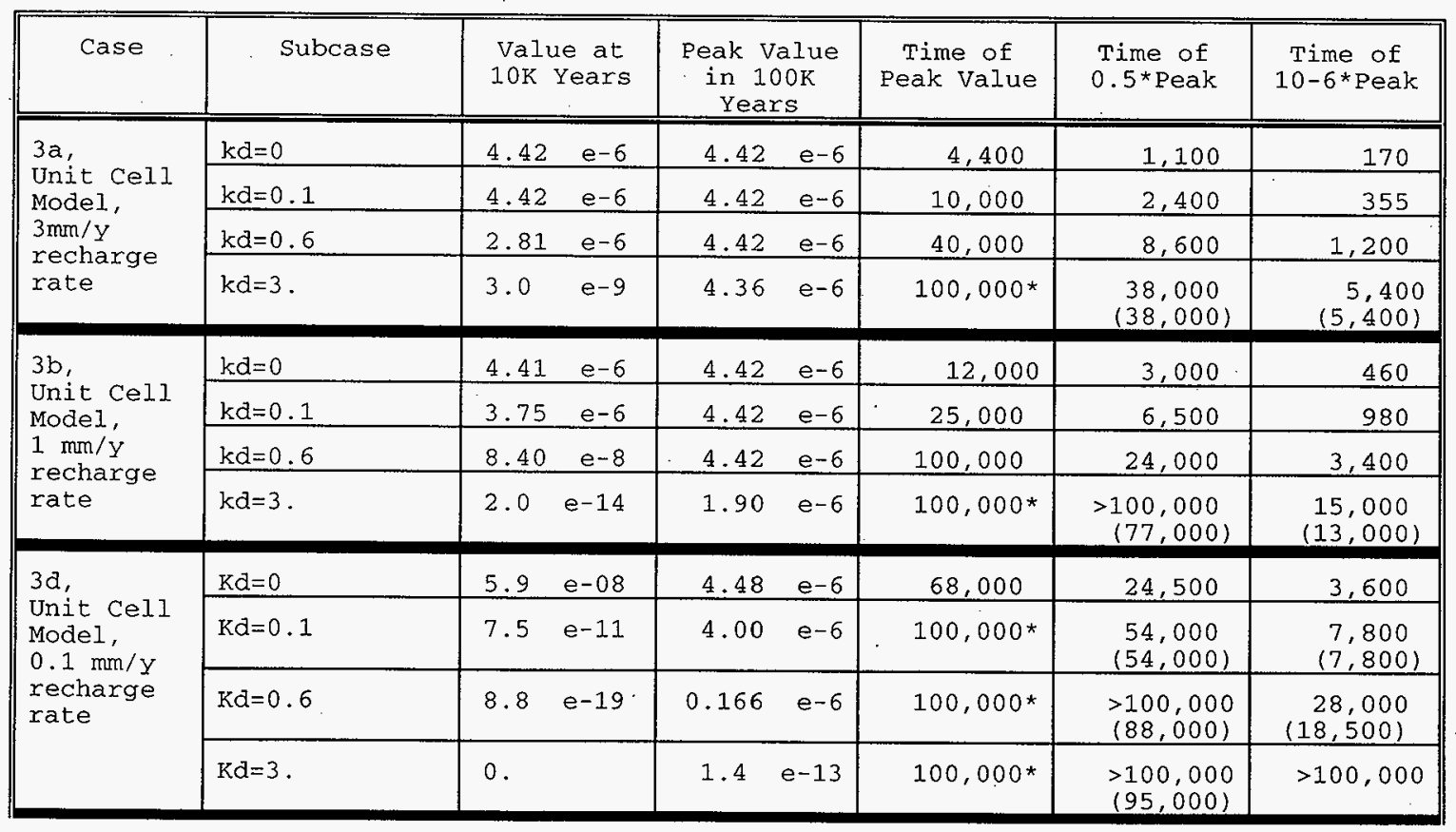


HNF-EP-0884

Rev. 1

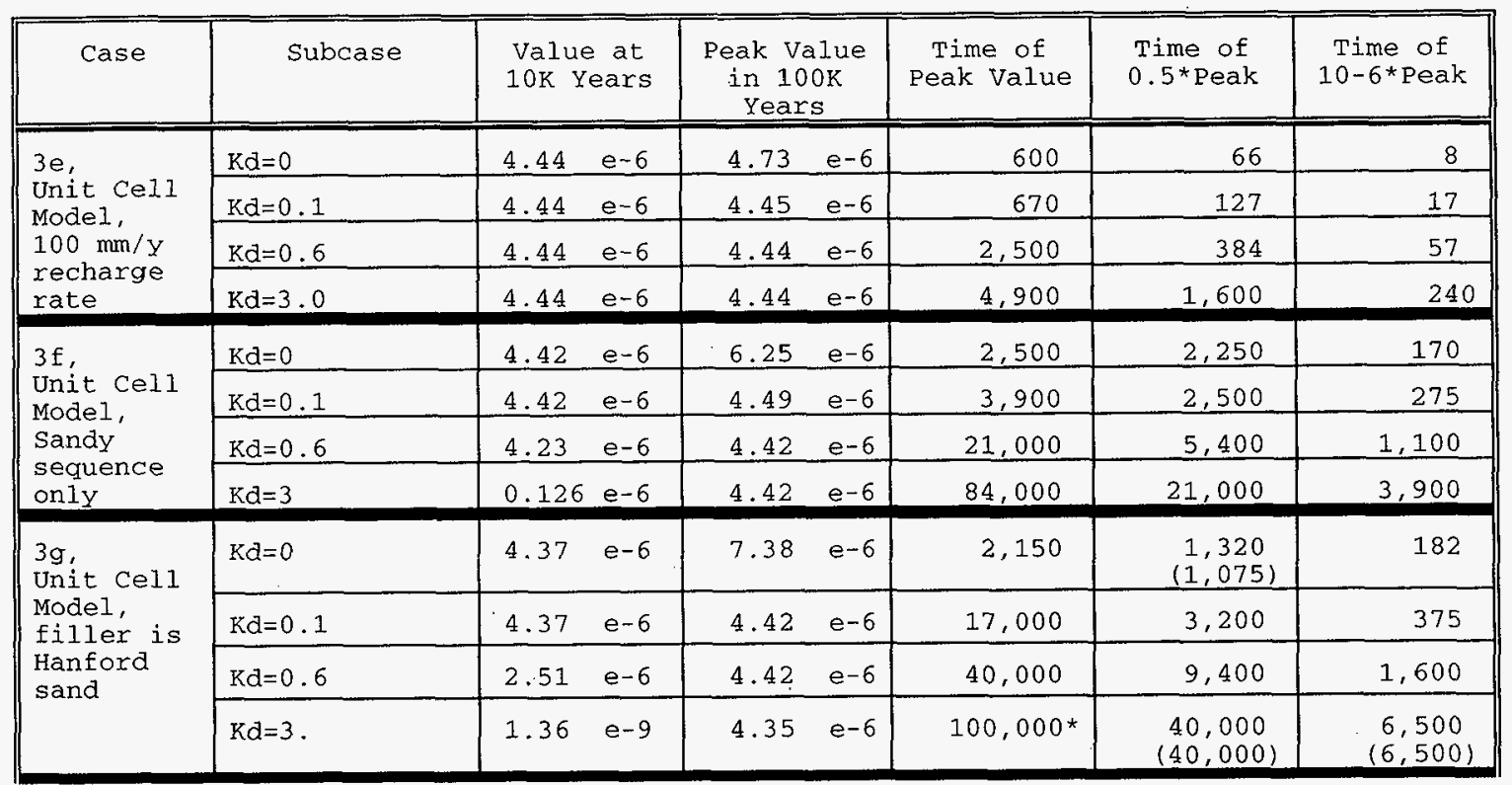


HNF -EP-0 0884

Rev. 1

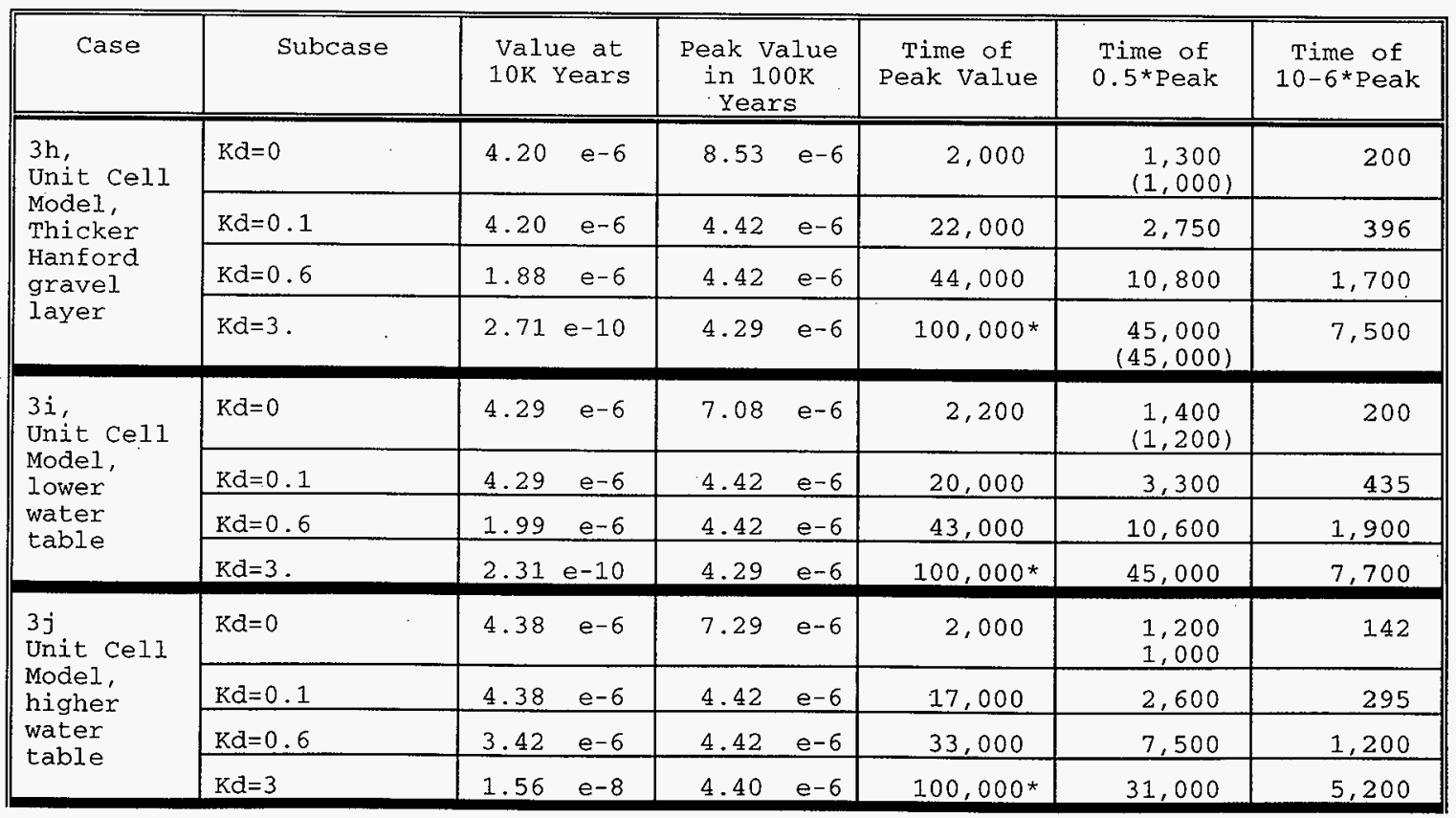


HNF-EP-0 884

Rev. 1

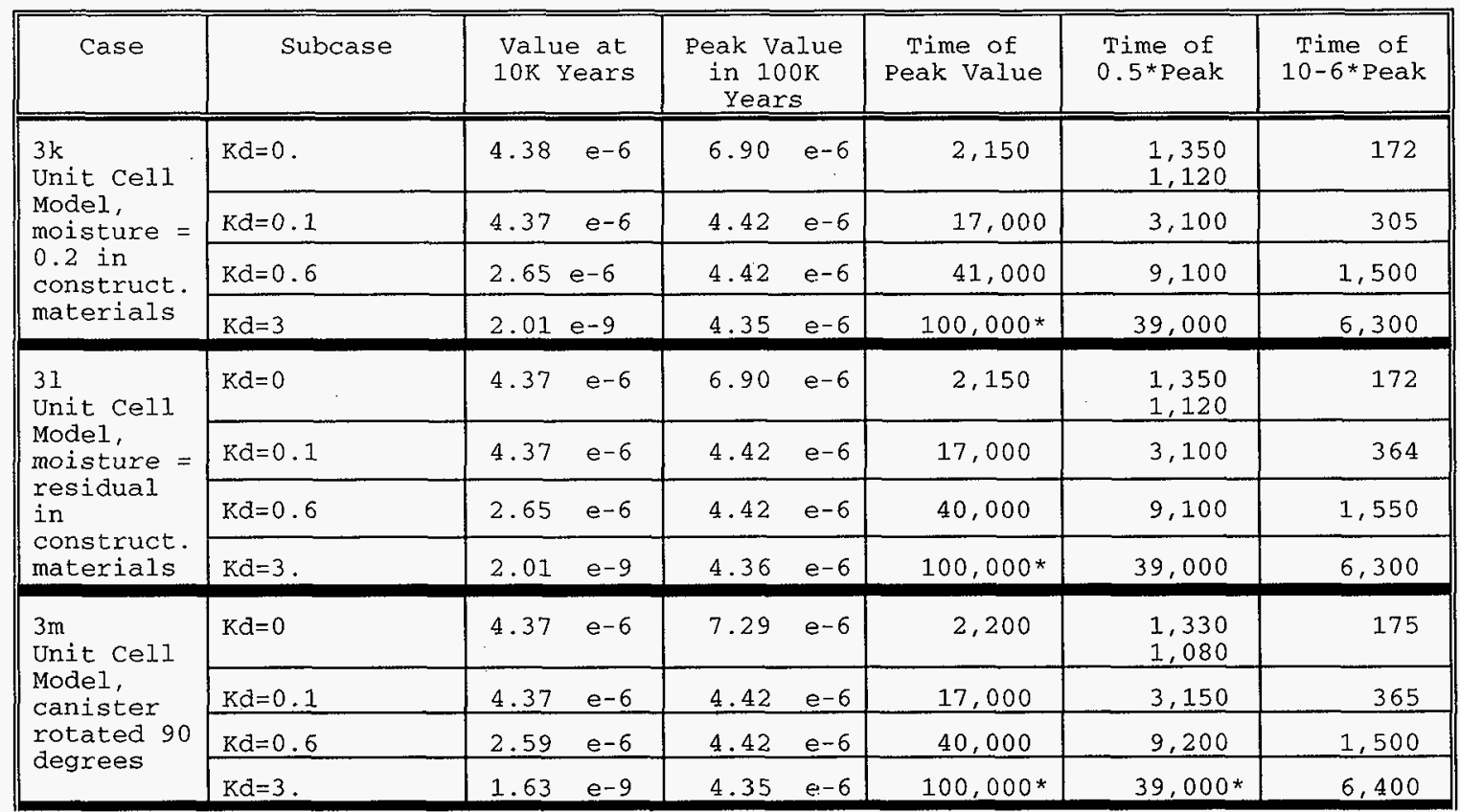


HNF-EP-0884

Rev. 1

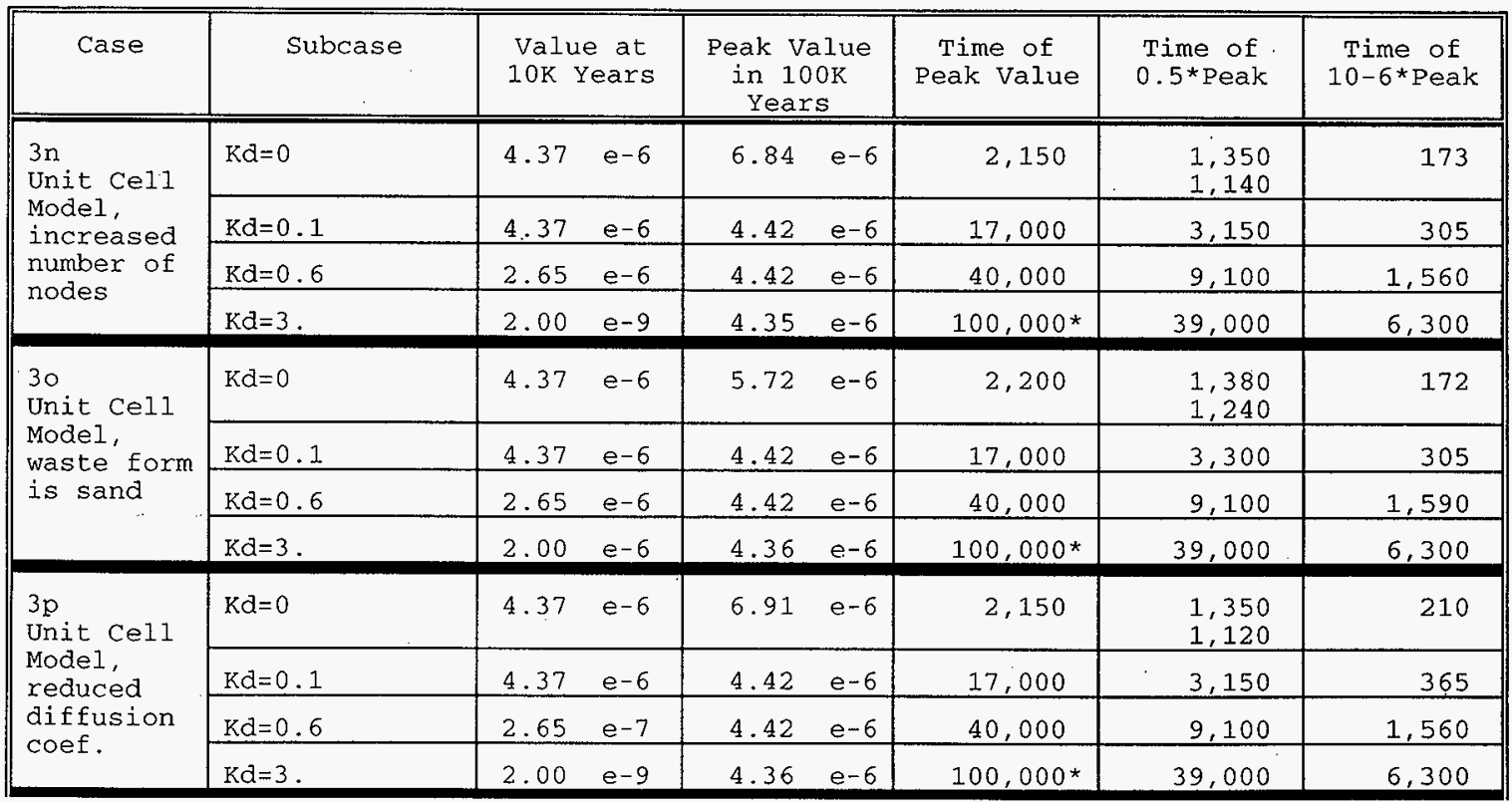




\section{HNF - EP - 0884}

Rev. 1

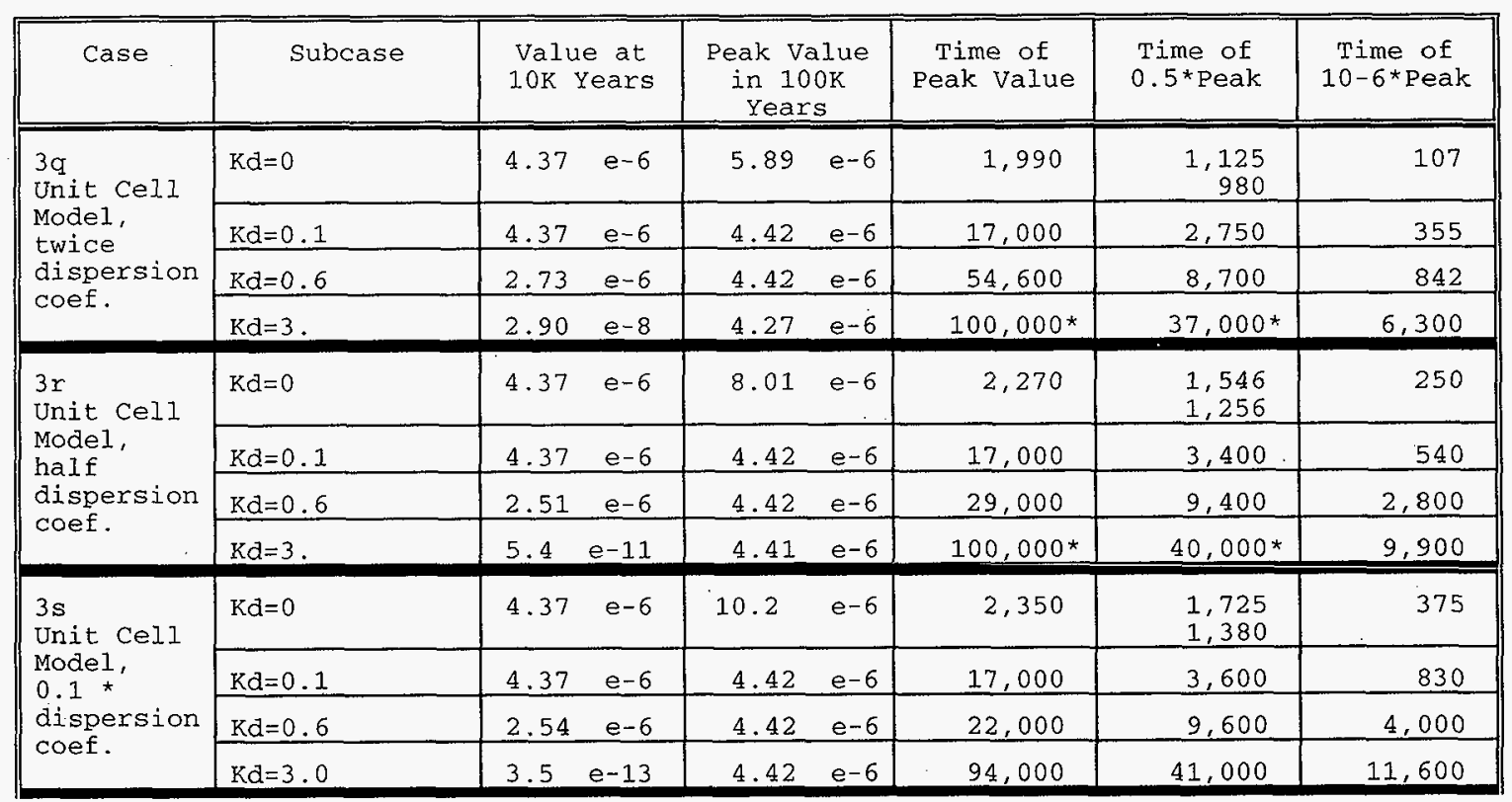


HNF-EP-0884

Rev. 1

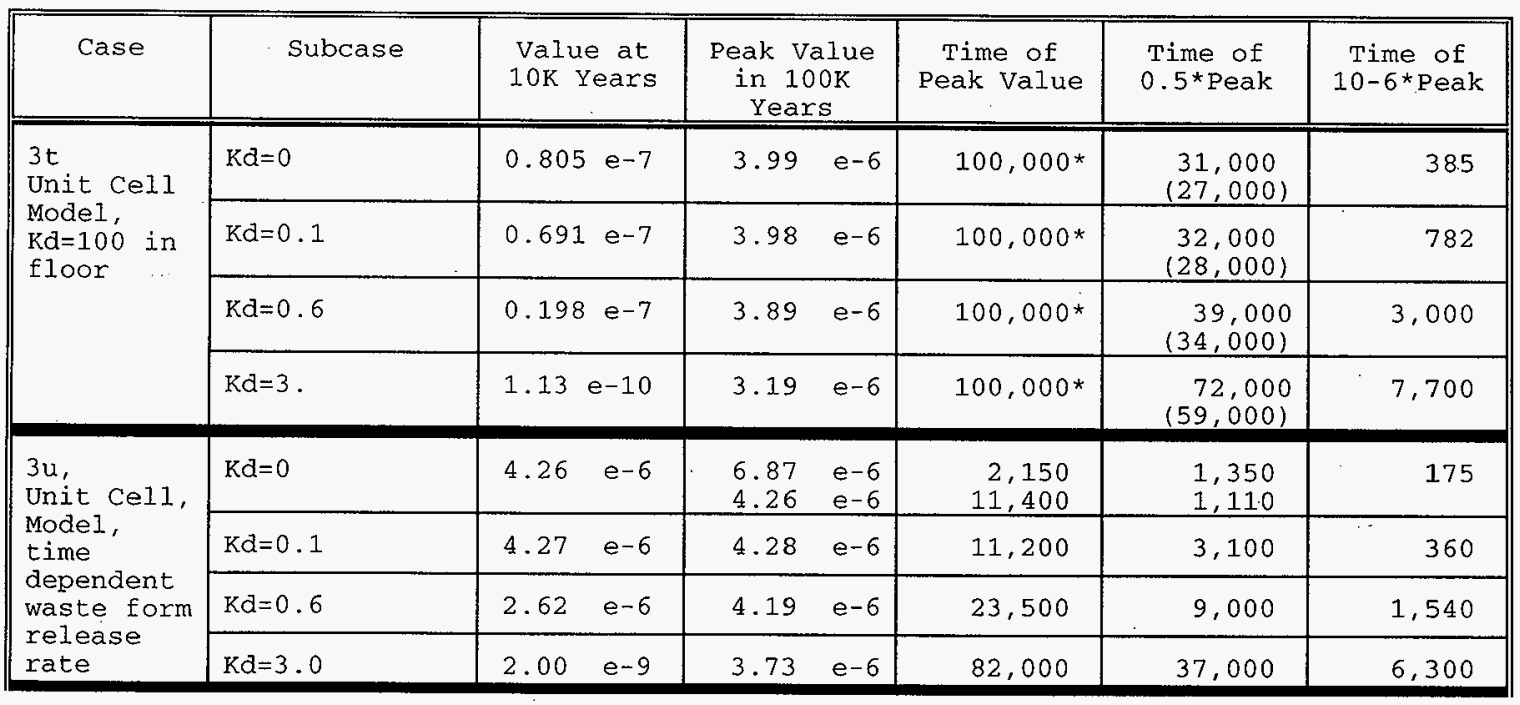


HNF-EP-0884

Rev. 1

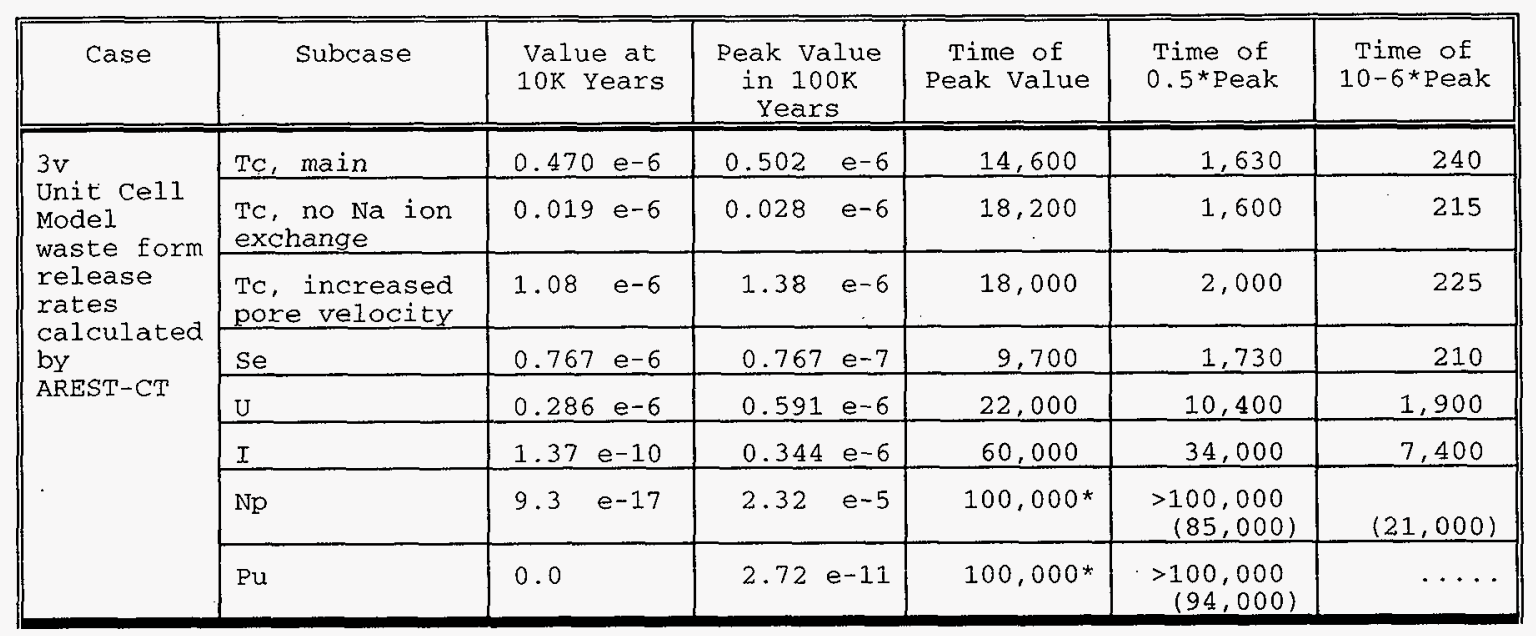


E.3 UNCONFINED AQUIFER SIMULATIONS

Because only a few numbers are used from these simulations, only figures (Figures E-2 through E-7) will be given to give an indication of the breath of the results. For more detailed explanation see Lu 1996.

Figure E-2. Simulated Post-Hanford Operations Water Table and Well Location

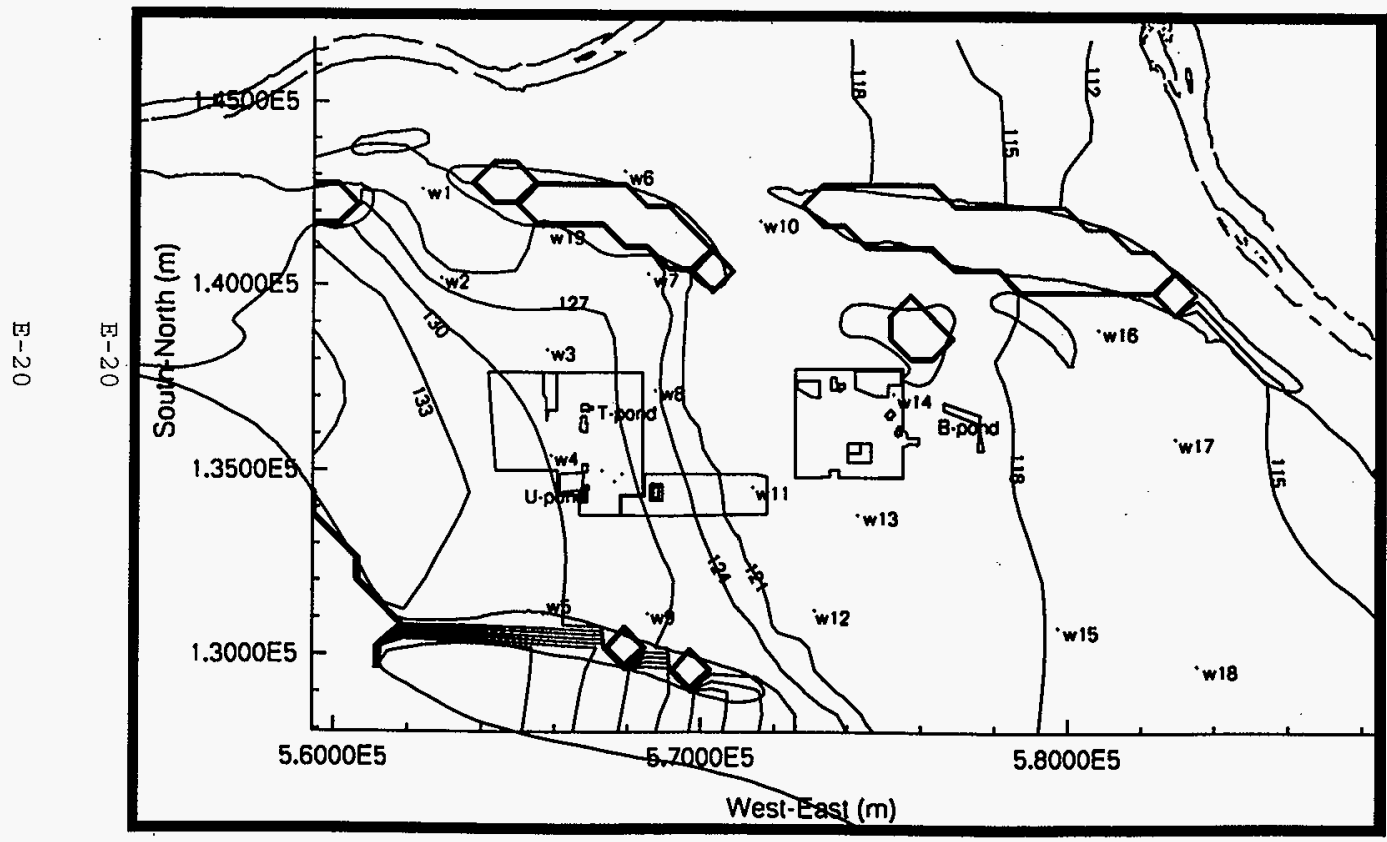


Figure E-3. Simulated Aquifer Thickness - Post Hanford Operations

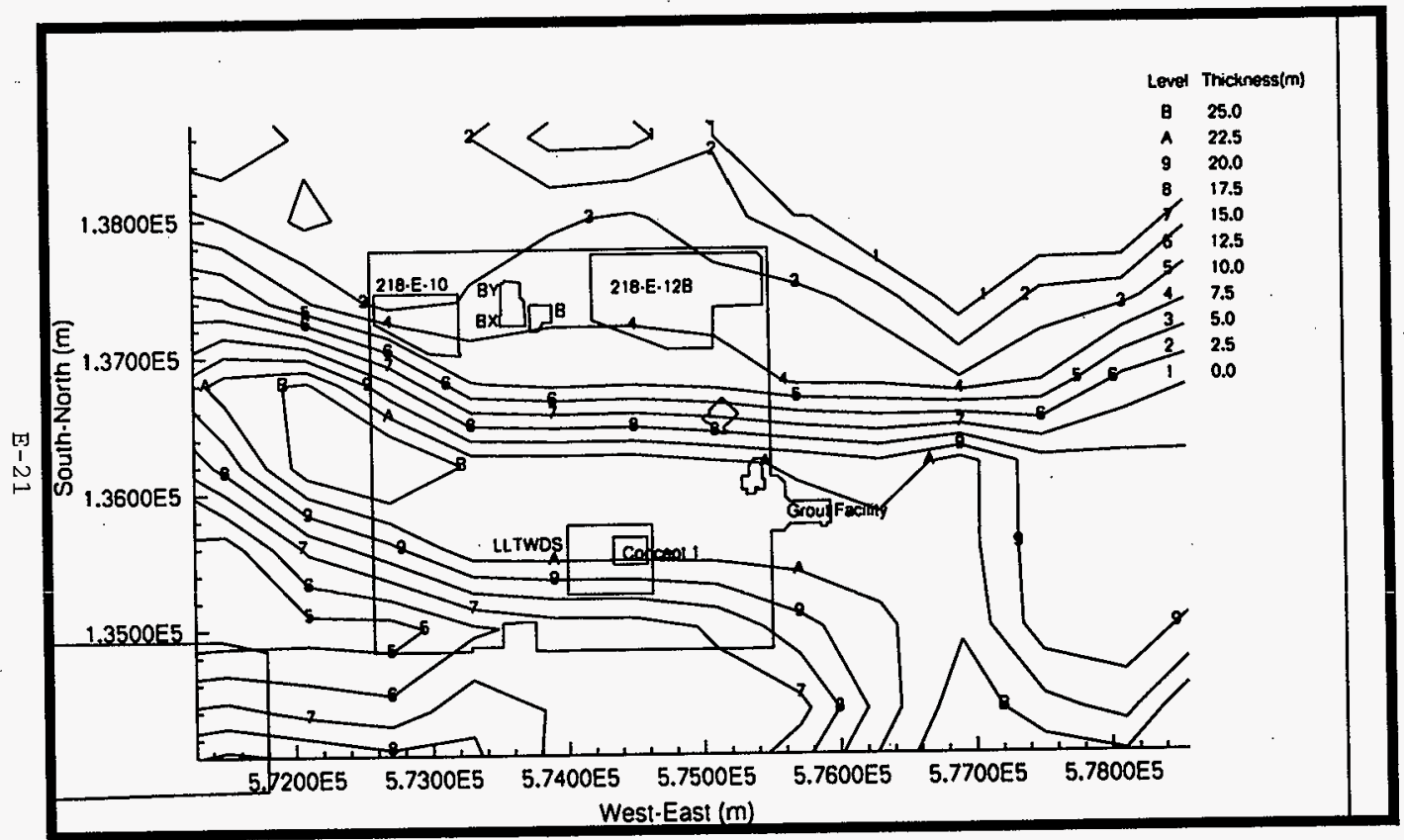


Figure E-4. Simulated streamlines for Various Pumping Rates $\left(10 \mathrm{~m}^{3} /\right.$ day, $50 \mathrm{~m}^{3} /$ day, 100 $\mathrm{m}^{3} /$ day, and $150 \mathrm{~m}^{3} /$ day.
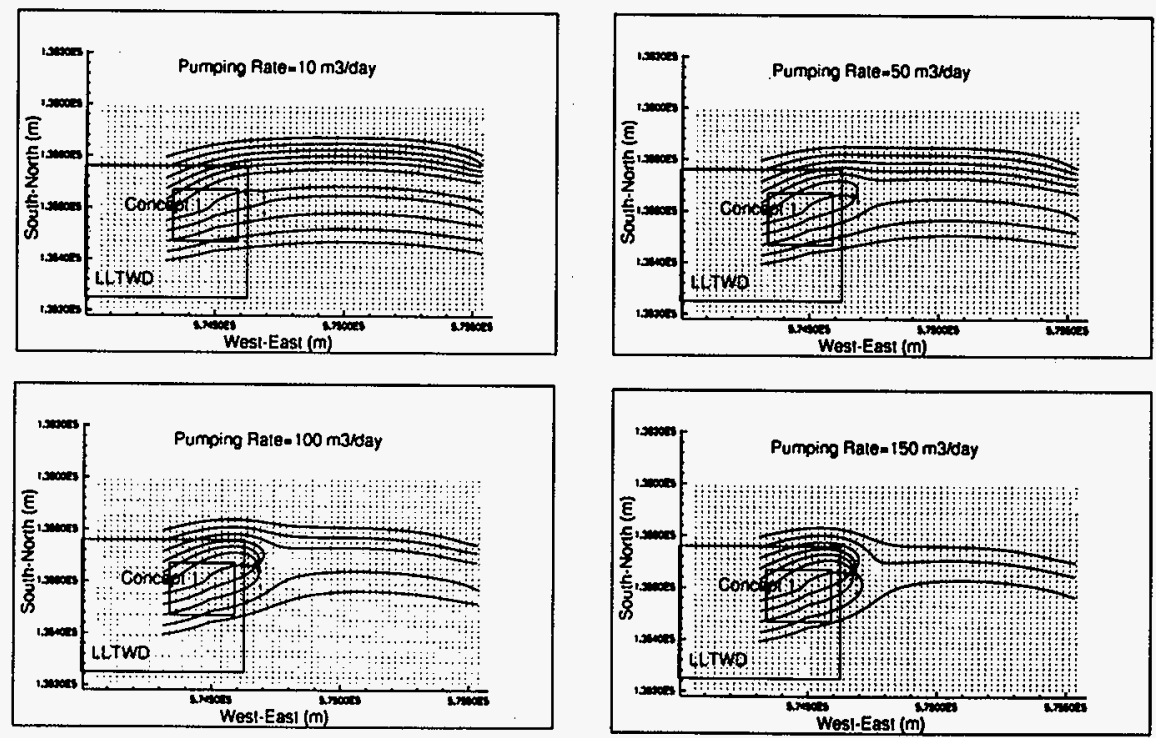
Figure E-5. Simulated Concentration Contour for Concept 2. Assumes concentration of $1 \mathrm{Ci} / \mathrm{m}^{3}$ in the vadose zone and a recharge rate of $1 \mathrm{~mm} / \mathrm{Y}$. since actual recharge is $3 \mathrm{~mm} / \mathrm{y}$, actual concentrations will be 3 times higher

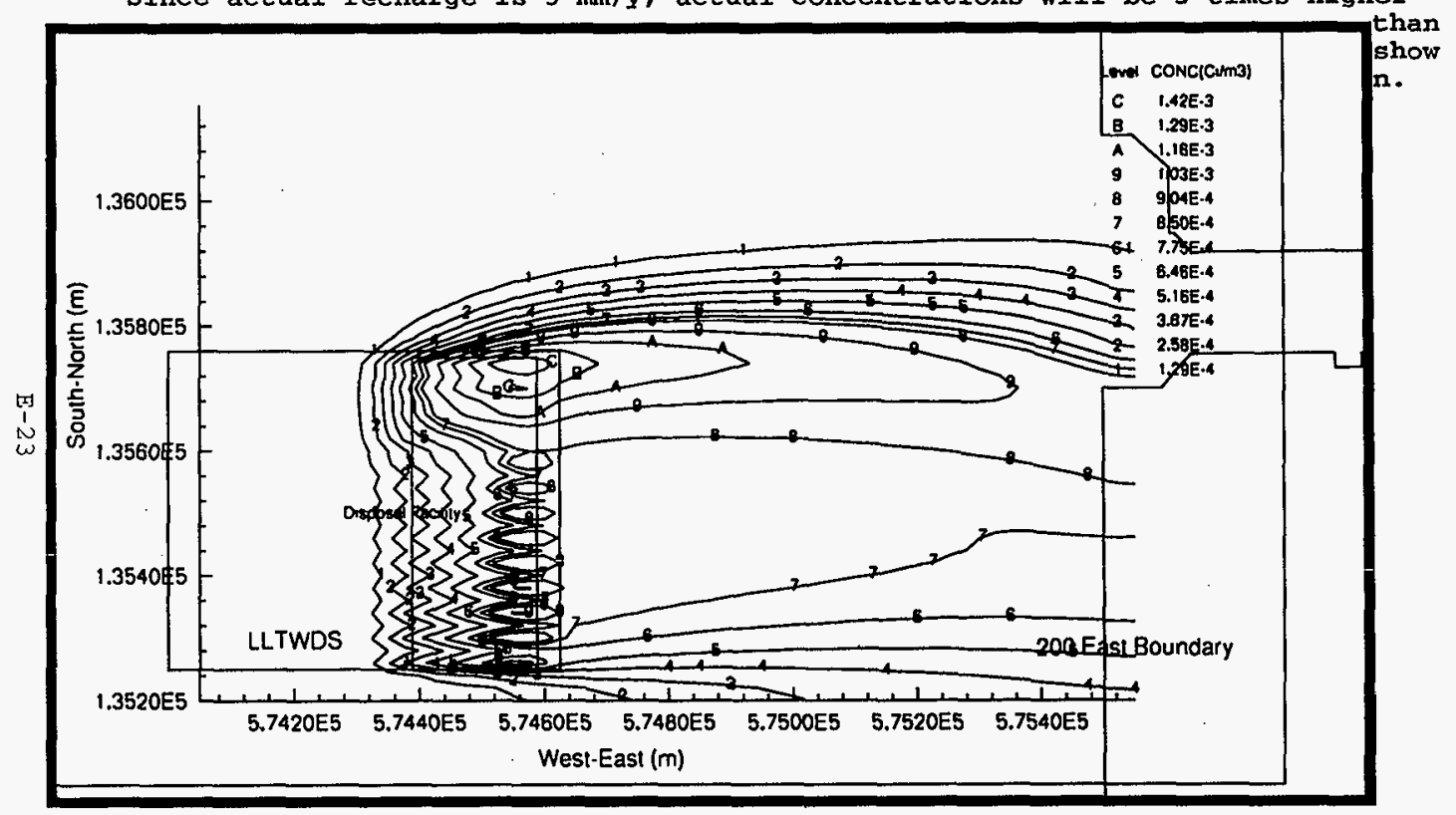


Figure E-6. Simulated Concentration Contour for Irrigation North of the 200 Area. Assumes concentration of $1 \mathrm{ci} / \mathrm{m}^{3}$ in the vadose. zone and a recharge rate of $1 \mathrm{mn} / \mathrm{y}$. Since actual recharge is $3 \mathrm{~mm} / \mathrm{y}$, actual concentrations will be 3 times higher than shown.

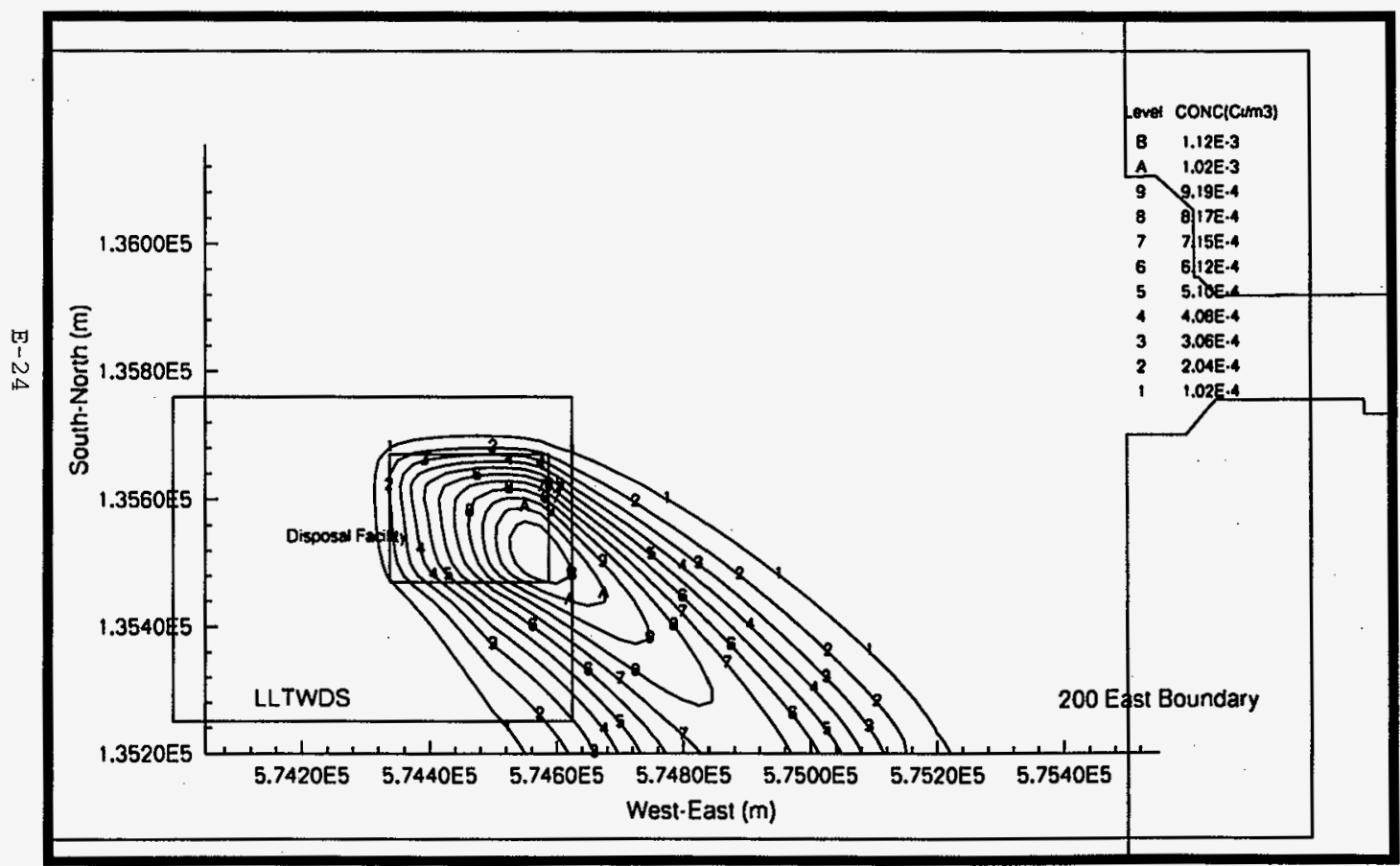


Figure E-7. Simulated Concentration Contour fox Existing TWRs Disposal Facilities. Assumes concentration of $1 \mathrm{ci} / \mathrm{m}^{3}$ in the vadose zone and a recharge rate of $1 \mathrm{~mm} / \mathrm{y}$. Since actual recharge is $3 \mathrm{~mm} / \mathrm{y}$, actual concentrations will be 3 times higher than shown.

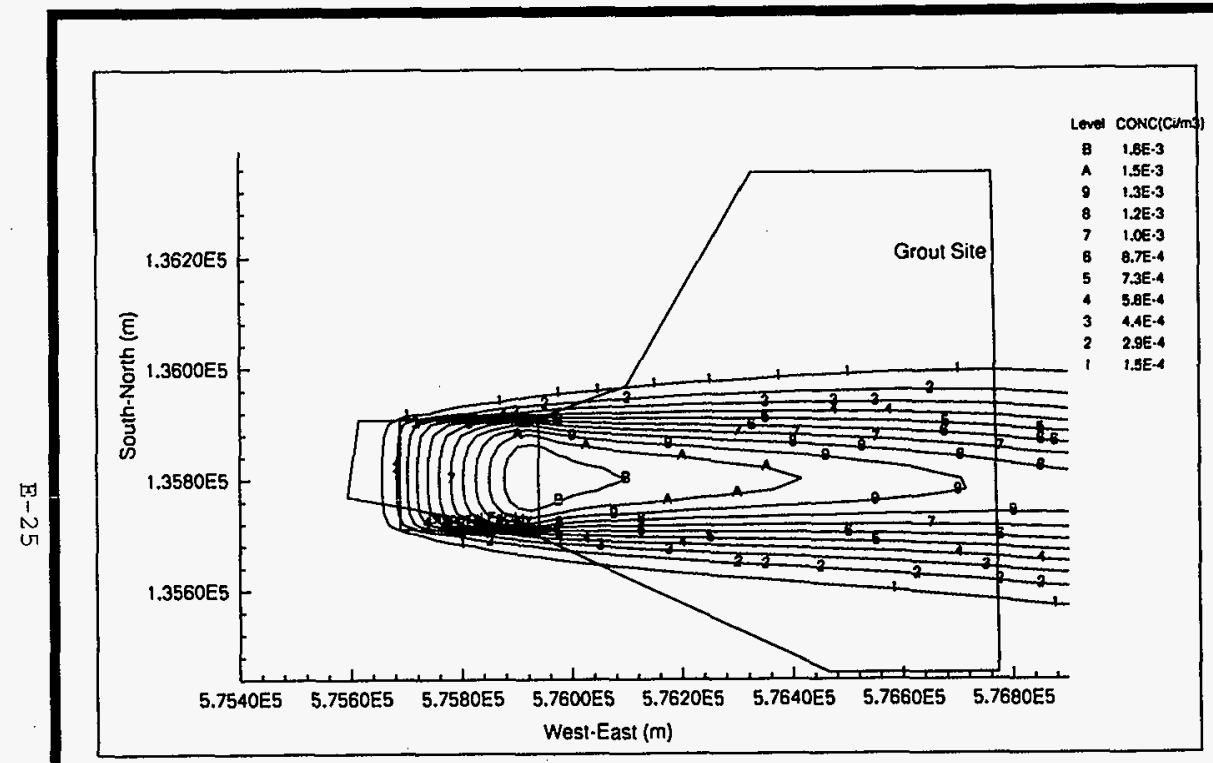




\section{E.4 CALCULATION OF DOSE}

Table E-2 summarizes the calculation of the beta/photon drinking water dose, the alpha concentration in well water, and the al1-pathway dose. Since the time dependence of these impacts follows the time dependence of the vadose simulations, please refer to those figures in sections 4.2 through 4.7 .

Table E-2. Summary of Dose Calculations. Case numbers reflect archival filenames.

\begin{tabular}{|c|c|c|c|c|}
\hline Case & Time & $\begin{array}{l}\text { Beta } \\
\text { Dose } \\
\text { (mrem/y) }\end{array}$ & $\begin{array}{l}\text { Alpha } \\
\text { Conc. } \\
\text { (pci/1) }\end{array}$ & $\begin{array}{l}\text { Al1- } \\
\text { Pathways } \\
\text { Dose } \\
\text { (mrem/y) } \\
\end{array}$ \\
\hline Limit & $10 \mathrm{~K} \mathrm{y}$ & 4.0 & 15. & 25. \\
\hline \multirow[t]{3}{*}{ 1-1d Base Analysis Case } & $10 \mathrm{~K} \mathrm{y}$ & 1.97 & 1.65 & 6.4 \\
\hline & Iimit & $>100 \mathrm{~K}$ & $>100 \mathrm{~K}$ & $>100 \mathrm{~K}$ \\
\hline & $\max$ & $\begin{array}{l}2.7 \\
\text { a } 71 \mathrm{~K}\end{array}$ & e 5.7 & (a) $50 \mathrm{~K}$ \\
\hline \multirow{3}{*}{$\begin{array}{l}\text { 1-1de Base Analysis Case, } \\
\text { vadose zone flux } \\
\text { extended to } 66 \\
\text { million years }\end{array}$} & $10 \mathrm{~K} \mathrm{y}$ & 1.96 & 1.53 & 5.9 \\
\hline & limit & a $750 \mathrm{~K}$ & e $2.2 \mathrm{M}$ & $>66 \mathrm{M}$ \\
\hline & $\max$ & (a) $65 \mathrm{M}$ & $\begin{array}{l}18 . \\
\text { a } 51 \mathrm{M}\end{array}$ & $\begin{array}{l}22 . \\
\text { a } 55 \mathrm{~K}\end{array}$ \\
\hline \multirow{3}{*}{$\begin{array}{l}1-1 d z \text { Concept } 1 \\
\mathrm{flux}=0 \text { for } \mathrm{kd}>0.7\end{array}$} & $10 \mathrm{~K} \mathrm{y}$ & 1.97 & 1.60 & 5.9 \\
\hline & limit & $>100 \mathrm{~K}$ & $>100 \mathrm{~K}$ & $>100 \mathrm{~K}$ \\
\hline & $\max$ & (a) $60 \mathrm{~K}$ & $\begin{array}{c}4.1 \\
\text { @ } 71 \mathrm{~K}\end{array}$ & e $\quad 63 \mathrm{~K}$ \\
\hline \multirow{3}{*}{$\begin{array}{l}\text { 1-1di Concept } 1, \\
\text { Tc inv }=0.2 \text { of base } \\
\text { analysis case }\end{array}$} & IOK $\mathrm{Y}$ & 0.79 & 1.65 & 2.5 \\
\hline & limit & $>100 \mathrm{~K}$ & $>100 \mathrm{~K}$ & $>100 \mathrm{~K}$ \\
\hline & $\max$ & $\begin{array}{l}1.14 \\
\text { (2100K }\end{array}$ & $\stackrel{5.7}{a} 55 \mathrm{~K}$ & $\begin{array}{l}17.2 \\
\text { a } 49 \mathrm{~K}\end{array}$ \\
\hline \multirow{3}{*}{$\begin{array}{l}\text { 1-1dis, Concept } 1 \\
\text { double Se inventory } \\
\text { from base analysis } \\
\text { case }\end{array}$} & $10 \mathrm{~K} y$ & 2.4 & 1.65 & 7.1 \\
\hline & Iimit & $>100 \mathrm{~K}$ & $>100 \mathrm{~K}$ & $>100 \mathrm{~K}$ \\
\hline & $\max$ & $\begin{array}{l}3.1 \\
@ 62 \mathrm{~K}\end{array}$ & $\begin{array}{l}5.7 \\
@ 55 \mathrm{~K}\end{array}$ & $\begin{array}{ll}23{ }^{\circ} \\
\mathrm{a} 50^{\circ} \mathrm{K}\end{array}$ \\
\hline
\end{tabular}


WHC-EP-0884

\begin{tabular}{|c|c|c|c|c|}
\hline Case & Time & $\begin{array}{c}\text { Beta } \\
\text { Dose } \\
\text { (mrem/y) }\end{array}$ & $\begin{array}{l}\text { Alpha } \\
\text { Conc. } \\
\text { (pci/1) }\end{array}$ & $\begin{array}{c}\text { All- } \\
\text { Pathways } \\
\text { Dose } \\
\text { (mrem/y) }\end{array}$ \\
\hline Iimit & $10 \mathrm{~K} y$ & 4.0 & 15. & 25. \\
\hline \multirow{3}{*}{$\begin{array}{l}\text { 1-1diu, concept } 1 \\
\text { double U inventory } \\
\text { from base analysis } \\
\text { case }\end{array}$} & $10 \mathrm{~K} y$ & 2.05 & 3.2 & 6.8 \\
\hline & limit & $>100 \mathrm{~K}$ & $>100 \mathrm{~K}$ & $>100 \mathrm{~K}$ \\
\hline & $\max$ & $a^{3.0} 82 \mathrm{~K}$ & e $62 \mathrm{~K}$ & (a $50 \mathrm{~K}$ \\
\hline \multirow{3}{*}{$\begin{array}{l}\text { 1-1dii, Concept } 1 \\
5 * \text { I inventory from. } \\
\text { base analysis case }\end{array}$} & $10 \mathrm{~K} y$ & 1.97 & 1.65 & 6.4 \\
\hline & Iimit & $>100 \mathrm{~K}$ & $>100 \mathrm{~K}$ & $>100 \mathrm{~K}$ \\
\hline & $\max$ & $\begin{array}{l}3.0 \\
e^{3} 81 \mathrm{~K}\end{array}$ & e. $\begin{array}{l}5.7 \\
55 \mathrm{~K}\end{array}$ & $\begin{array}{l}23.0 \\
\text { e } 50 \mathrm{~K}\end{array}$ \\
\hline \multirow{3}{*}{$\begin{array}{l}\text { 1-1dr, Concept } 1, \\
\text { Tc release rate } \\
\text { reduced by factor } \\
\text { of } 5 \text { from } \\
\text { base analysis case }\end{array}$} & $10 K Y$ & 0.87 & 1.65 & 2.8 \\
\hline & limit & $>100 \mathrm{~K}$ & $>100 \mathrm{~K}$ & $>100 \mathrm{~K}$ \\
\hline & $\max$ & $\begin{array}{c}1.20 \\
\text { a } 41 \mathrm{~K}\end{array}$ & $\begin{array}{l}5.7 \\
\text { a } 55 \mathrm{~K}\end{array}$ & $\begin{array}{l}17.6 \\
\text { e } 49 \mathrm{~K}\end{array}$ \\
\hline \multirow{3}{*}{$\begin{array}{l}\text { 1-1dra Concept } 1 \text {, } \\
\text { release rate reduced by } \\
\text { factor of } 5 \text { from } \\
\text { base analysis case } \\
\text { for all } \\
\text { Kd=0 contaminants }\end{array}$} & $10 \mathrm{~K} y$ & 0.57 & 1.65 & 2.3 \\
\hline & Iimit & $>100 \mathrm{~K}$ & $>100 \mathrm{~K}$ & $>100 \mathrm{~K}$ \\
\hline & $\max$ & $\begin{array}{l}0.99 \\
a \quad 100 \mathrm{~K}\end{array}$ & $\begin{array}{l}5.7 \\
\text { a } 55 \mathrm{~K}\end{array}$ & $\begin{array}{l}17.1 \\
\text { a } 49 \mathrm{~K}\end{array}$ \\
\hline \multirow{3}{*}{$\begin{array}{l}\text { 1-1aku concept } 1 \\
\mathrm{kd}=0 \text { for uranium }\end{array}$} & $10 \mathrm{~K} y$ & 2.1 & 4.6 & 7.1 \\
\hline & $1 \mathrm{imit}$ & $>100 \mathrm{~K}$ & $>100 \mathrm{~K}$ & $>100 \mathrm{~K}$ \\
\hline & $\max$ & $\begin{array}{l}2.9 \\
\quad 76 \mathrm{~K}\end{array}$ & $\begin{array}{l}8.4 \\
0 \quad 71 \mathrm{~K}\end{array}$ & a $50 \mathrm{~K}$ \\
\hline \multirow{3}{*}{$\begin{array}{l}1-1 \mathrm{dk} 0, \text { Concept } 1 \\
\mathrm{kd}=0.1 \mathrm{mg} / 1 \text { for se } \\
\text { and } \mathrm{Tc}\end{array}$} & $10 \mathrm{~K} y$ & 1.66 & 1.65 & 5.5 \\
\hline & Iimit & $>100 \mathrm{~K}$ & $>100 \mathrm{~K}$ & $>100 \mathrm{~K}$ \\
\hline & $\max$ & $\begin{array}{l}2.2 \\
\text { e100K }\end{array}$ & $\begin{array}{l}5.7 \\
055 K\end{array}$ & $\begin{array}{l}21 . \\
\text { (a) } 49 \mathrm{~K}\end{array}$ \\
\hline
\end{tabular}


WHC-EP-0884

\begin{tabular}{|c|c|c|c|c|}
\hline Case & Time & $\begin{array}{l}\text { Beta } \\
\text { Dose } \\
\text { (mrem/y) }\end{array}$ & $\begin{array}{l}\text { Alpha } \\
\text { Conc. } \\
(p C i / i)\end{array}$ & $\begin{array}{c}\text { All- } \\
\text { Pathways } \\
\text { Dose } \\
\text { (mrem/y) } \\
\end{array}$ \\
\hline Limit & $10 K y$ & 4.0 & 15. & 25. \\
\hline \multirow{3}{*}{$\begin{array}{l}\text { 1-1ddoe Concept } 1 \\
\text { DOE dose factors }\end{array}$} & $10 \mathrm{~K} y$ & 1.97 & 1.65 & 6.4 \\
\hline & Iimit & $\geq 100 \mathrm{~K}$ & $>100 \mathrm{~K}$ & $>100 \mathrm{~K}$ \\
\hline & $\max$ & $e^{2.7} 71 \mathrm{~K}$ & a 5.7 & ${ }^{23} \cdot 50 \mathrm{~K}$ \\
\hline \multirow{3}{*}{$\begin{array}{l}\text { 1-1depa concept } 1 \text {, } \\
\text { EPA dose factors }\end{array}$} & $10 \mathrm{~K} \mathrm{y}$ & 2.2 & 1.65 & 7.0 \\
\hline & limit & $>100 \mathrm{~K}$ & $>100 \mathrm{~K}$ & $>100 \mathrm{~K}$ \\
\hline & $\max$ & $\begin{array}{l}3.0 \\
\text { a } 71 \mathrm{~K}\end{array}$ & a $5.75 \mathrm{~K}$ & $\begin{array}{l}23 . \\
052 \mathrm{~K}\end{array}$ \\
\hline \multirow{3}{*}{$\begin{array}{l}\text { 1-1dgen, Concept } 1 \\
\text { GENII dose factors }\end{array}$} & $10 \mathrm{~K} \mathrm{y}$ & 3.0 & 1.65 & 9.9 \\
\hline & Iimit & a $41 \mathrm{~K}$ & $>100 \mathrm{~K}$ & \& $38 \mathrm{~K}$ \\
\hline & $\max$ & $\begin{array}{c}4.2 \\
\mathrm{a} 7 \mathrm{OK}\end{array}$ & e 5.7 & $\begin{array}{l}27 . \\
\text { (a) } 50 \mathrm{~K}\end{array}$ \\
\hline \multirow{3}{*}{$\begin{array}{l}\text { 1-1n. Concept } 1 \\
\text { Diffusion constant } \\
\text { reduced by factor of } \\
20\end{array}$} & $10 \mathrm{~K} \mathrm{y}$ & 0.060 & 0.056 & 0.64 \\
\hline & Iimit & $>100 \mathrm{~K}$ & $>100 \mathrm{~K}$ & $>100 \mathrm{~K}$ \\
\hline & $\max$ & $\begin{array}{l}1.80 \\
\text { (e) } 100 \mathrm{~K}\end{array}$ & $\begin{array}{l}1.85 \\
\text { (a) } 58 \mathrm{~K}\end{array}$ & $\begin{array}{l}16.4 \\
254 \mathrm{~K}\end{array}$ \\
\hline \multirow{3}{*}{$\begin{array}{l}\text { 1-2a, Concept } 1, \\
\text { concrete degrades at } \\
2000 \text { years }\end{array}$} & $10 \mathrm{~K} \mathrm{y}$ & 1.96 & 1.56 & 6.4 \\
\hline & limit & $>100 \mathrm{~K}$ & $>100 \mathrm{~K}$ & $>100 \mathrm{k}$ \\
\hline & $\max$ & $\begin{array}{l}2.8 \\
\text { e } \quad 73 \mathrm{~K}\end{array}$ & $\begin{array}{c}5.7 \\
057 \mathrm{~K}\end{array}$ & $\begin{array}{l}23 . \\
\text { \& } 50 \mathrm{~K}\end{array}$ \\
\hline \multirow{3}{*}{$\begin{array}{l}\text { 1-1dukd, Concept } 1 \\
\text { U daughters have Kd of } \\
\text { uranium }\end{array}$} & $10 \dot{\mathrm{K}} \mathrm{y}$ & 35. & 22. & 68. \\
\hline & Iimit & a $3.4 \mathrm{~K}$ & (c) $8.2 \mathrm{~K}$ & e $5.6 \mathrm{~K}$ \\
\hline & $\max$ & (a) $26 \mathrm{~K}$ & $\begin{array}{l}39 . \\
30 \mathrm{~K}\end{array}$ & $\begin{array}{l}107 . \\
\text { e } 26 \mathrm{~K}\end{array}$ \\
\hline
\end{tabular}


WHC-EP-0 0884

\begin{tabular}{|c|c|c|c|c|}
\hline Case & Time & $\begin{array}{c}\text { Beta } \\
\text { Dose } \\
\text { (mrem/y) }\end{array}$ & $\begin{array}{l}\text { Alpha } \\
\text { Conc. } \\
\text { (pCi/1) }\end{array}$ & $\begin{array}{c}\text { All- } \\
\text { Pathways } \\
\text { Dose } \\
\text { (mrem/y) } \\
\end{array}$ \\
\hline Iimit & $10 \mathrm{~K} y$ & 4.0 & 15. & 25. \\
\hline \multirow{3}{*}{$\begin{array}{l}\text { 1-dCR, Concept } 1 \text {, } \\
\text { impacts at columbia } \\
\text { River }\end{array}$} & $10 \mathrm{~K} \mathrm{y}$ & 0.069 & 0.058 & 0.22 \\
\hline & Iimit & $>100 \mathrm{~K}^{\star}$ & $>100 \mathrm{~K}$ & $>100 \mathrm{~K}$ \\
\hline & $\max$ & $\begin{array}{l}0.095 \\
\text { a } 71 \mathrm{~K}\end{array}$ & $\begin{array}{c}0.20 \\
\text { @ } 55 \mathrm{~K}\end{array}$ & $\begin{array}{c}0.79 \\
\text { e } 50 \mathrm{~K}\end{array}$ \\
\hline \multirow{3}{*}{$\begin{array}{l}\text { 1-1decR, Concept } 1 \\
\text { impacts at Columbia } \\
\text { River, vadose zone } \\
\text { flux extended to } 66 \\
\text { million years }\end{array}$} & $10 \mathrm{~K} \mathrm{Y}$ & 0.068 & 0.054 & 0.21 \\
\hline & Iimit & $>100 K^{*}$ & $>100 K$ & $>100 \mathrm{~K}$ \\
\hline & $\max$ & $\begin{array}{l}0.49 \\
\text { (a } 66 \mathrm{M}\end{array}$ & $\begin{array}{c}0.65 \\
\text { a } 51 \mathrm{M}\end{array}$ & $\begin{array}{r}0.56 \\
@ 66 \mathrm{~K}\end{array}$ \\
\hline
\end{tabular}


WHC-EP-0884

\begin{tabular}{|c|c|c|c|c|}
\hline Case & Time & $\begin{array}{c}\text { Beta } \\
\text { Dose } \\
(\text { mrem/y) }\end{array}$ & $\begin{array}{l}\text { Alpha } \\
\text { Conc. } \\
\text { (pci/1) }\end{array}$ & $\begin{array}{c}\text { All- } \\
\text { Pathways } \\
\text { Dose } \\
\text { (mrem/y) } \\
\end{array}$ \\
\hline Limit & $10 K y$ & 4.0 & 15. & 25. \\
\hline \multirow{3}{*}{$\begin{array}{l}\text { 2-1d, Concept } 2 \text { Main } \\
\text { Analysis Case }\end{array}$} & $10 \mathrm{~K} y$ & 1.11 & 0.27 & 3.3 \\
\hline & limit & $>100 \mathrm{~K}$ & $>100 \mathrm{~K}$ & $\geq 100 \mathrm{~K}$ \\
\hline & $\max$ & $\begin{array}{l}1.12 \\
\text { e. } 15 \mathrm{~K}\end{array}$ & a $2.62 \mathrm{~K}$ & $\begin{array}{l}7.9 \\
\text { (2) } 72 \mathrm{~K}\end{array}$ \\
\hline \multirow{3}{*}{$\begin{array}{l}\text { 2-1de, Concept } 2 \text { Main } \\
\text { Analysis Case, vadose } \\
\text { zone flux extended } \\
\text { to } 66 \mathrm{M} \text { years }\end{array}$} & $10 \mathrm{~K} y$ & 1.14 & 0.78 & 3.4 \\
\hline & limit & (a $3.3 \mathrm{M}$ & $>66 \mathrm{M}$ & $\geq 66 \mathrm{M}$ \\
\hline & $\max$ & $\begin{array}{l}5.0 \\
{[\quad 13 \mathrm{M}}\end{array}$ & $\begin{array}{l}\quad 6.9 \\
\text { (a. } 2.7 \mathrm{M}\end{array}$ & $\begin{array}{l}10.3 \\
\text { (a) } 51 \mathrm{~K}\end{array}$ \\
\hline \multirow{3}{*}{$\begin{array}{l}\text { 2-1di, Concept } 2, \\
\text { Inventory of Tc }=0.2 \\
\text { *base case }\end{array}$} & $10 \mathrm{~K} \mathrm{y}$ & 0.42 & 0.27 & 1.04 \\
\hline & Iimit & $>100 \mathrm{~K}$ & $>100 \mathrm{~K}$ & $>100 \mathrm{~K}$ \\
\hline & $\max$ & $\begin{array}{l}0.45 \\
@ \quad 25 \mathrm{~K}\end{array}$ & $\begin{array}{l}2.6 \\
e .62 \mathrm{~K}\end{array}$ & $\begin{array}{l}6.3 \\
\text { a } 74 \mathrm{~K}\end{array}$ \\
\hline \multirow{3}{*}{$\begin{array}{l}\text { 2-1dr, Concept } 2 \text {, } \\
\text { Tc release rate } \\
\text { reduced by factor of } \\
5 \text { from base analysis } \\
\text { case }\end{array}$} & $10 \mathrm{~K} \mathrm{y}$ & 0.42 & 0.27 & 1.05 \\
\hline & $1 \mathrm{imit}$ & $>100 \mathrm{~K}$ & $>100 \mathrm{~K}$ & $>100 \mathrm{~K}$ \\
\hline & $\max$ & $\begin{array}{l}1.34 \\
\text { e } 99 K\end{array}$ & $\begin{array}{l}2.6 \\
\text { e } 62 \mathrm{~K}\end{array}$ & $\begin{array}{l}8.9 \\
\text { e } 99 \mathrm{~K}\end{array}$ \\
\hline \multirow{3}{*}{$\begin{array}{l}\text { 2-1dra, Concept } 2 \text {, } \\
\text { release rate for } \mathrm{kd}=0 \\
\text { reduced by factor } \\
\text { of } 5 \text { from base } \\
\text { analysis case }\end{array}$} & $10 \mathrm{~K} \mathrm{y}$ & 0.24 & 0.27 & 0.72 \\
\hline & limit & $>100 \mathrm{~K}$ & $>100 \mathrm{~K}$ & $>100 \mathrm{~K}$ \\
\hline & $\max$ & $\begin{array}{l}1.43 \\
\text { a } 99 \mathrm{~K}\end{array}$ & $\begin{array}{l}2.6 \\
\text { (a) } 62 \mathrm{~K}\end{array}$ & $\begin{array}{l}9.0 \\
9 \quad 99 \mathrm{~K}\end{array}$ \\
\hline \multirow{3}{*}{$\begin{array}{l}\text { 2-1dku, concept } 2, \\
\text { uranium has } K d=0\end{array}$} & $10 \mathrm{~K} \mathrm{y}$ & 1.23 & 2.6 & 3.8 \\
\hline & Iimit & $>100 \mathrm{~K}$ & $>100 \mathrm{~K}$ & $>100 \mathrm{~K}$ \\
\hline & $\max$ & $\begin{array}{l}1.24 \\
\text { a } 11 \mathrm{~K}\end{array}$ & $\begin{array}{l}2.7 \\
\text { (a) } 58 \mathrm{~K}\end{array}$ & $\begin{array}{l}7.9 \\
\text { (6) } 72 \mathrm{~K}\end{array}$ \\
\hline
\end{tabular}


WHC-EP -0884

\begin{tabular}{|c|c|c|c|c|}
\hline Case & Time & $\begin{array}{l}\text { Beta } \\
\text { Dose } \\
\text { (mrem/y) }\end{array}$ & $\begin{array}{l}\text { Alpha } \\
\text { Conc. } \\
\text { (pci/i) }\end{array}$ & $\begin{array}{l}\text { All- } \\
\text { Pathways } \\
\text { Dose } \\
\text { (mrem/y) } \\
\end{array}$ \\
\hline Limit & $10 \mathrm{~K} \mathrm{y}$ & 4.0 & 15. & 25. \\
\hline \multirow{3}{*}{$\begin{array}{l}2-1 d k 0, \text { Concept } 2 \\
\mathrm{TC} \text { and se have } \mathrm{kd}=0.1 \\
\mathrm{ml} / \mathrm{g}\end{array}$} & $10 \mathrm{k} y$ & 0.94 & 0.27 & 2.8 \\
\hline & limit & $>100 \mathrm{~K}$ & $>100 \mathrm{~K}$ & $>100 \mathrm{~K}$ \\
\hline & $\max$ & $\begin{array}{l}1.11 \\
\text { e. } 21 \mathrm{~K}\end{array}$ & $a^{2.6} 62 \mathrm{k}$ & $a^{7} .99 \mathrm{~K}$ \\
\hline \multirow{3}{*}{$\begin{array}{l}\text { 2-1n; Concept } 2 \\
\text { Diffusion coefficient } \\
\text { reduced by factox } \\
\text { of } 20\end{array}$} & $10 \mathrm{~K} \mathrm{y}$ & 0.20 & 0.004 & 0.59 \\
\hline & limit & $>100 \mathrm{~K}$ & $>100 \mathrm{~K}$ & $>100 \mathrm{~K}$ \\
\hline & $\max$ & $\begin{array}{c}0.72 \\
\& \quad 65 \mathrm{~K}\end{array}$ & $\begin{array}{c}1.5 \\
99 \mathrm{~K}\end{array}$ & $\begin{array}{c}7.4 \\
\text { (t) } 75 \mathrm{~K}\end{array}$ \\
\hline \multirow{3}{*}{$\begin{array}{l}\text { 2-2d, Concept } 2 \\
\text { Release rate } \\
\text { independent of time }\end{array}$} & $10 \mathrm{~K} \mathrm{y}$ & 1.11 & 0.24 & 3.3 \\
\hline & limit & $>100 \mathrm{~K}$ & $>100 \mathrm{~K}$ & $>100 \mathrm{~K}$ \\
\hline & $\max$ & $\begin{array}{c}1.15 \\
\text { \& } 25 \mathrm{~K}\end{array}$ & $a^{2.9} 72 \mathrm{~K}$ & $\begin{array}{c}8.4 \\
e^{8} 74 \mathrm{~K}\end{array}$ \\
\hline \multirow{3}{*}{$\begin{array}{l}2-2 \mathrm{dc}, \text { Concept } 2 \\
\text { Concrete degrades at } \\
2000 \text { years }\end{array}$} & $10 \mathrm{~K} \mathrm{y}$ & 1.12 & 0.29 & 3.3 \\
\hline & limit & $>100 \mathrm{~K}$ & $>100 \mathrm{~K}$ & $>100 \mathrm{~K}$ \\
\hline & $\max$ & $\begin{array}{c}1.14 \\
\text { d } \quad 16 \mathrm{~K}\end{array}$ & a 2.6 & (a 7.9 \\
\hline \multirow{3}{*}{$\begin{array}{l}2-3 d, \text { concept } 2 \\
\text { Failed hydraulic } \\
\text { barrier }\end{array}$} & $10 \mathrm{~K} \mathrm{y}$ & 1.10 & 0.27 & 3.3 \\
\hline & Iimit & $>100 \mathrm{~K}$ & $>100 \mathrm{~K}$ & $>100 \mathrm{~K}$ \\
\hline & $\max$ & $\begin{array}{c}1.11 \\
\text { e } 14 \mathrm{~K}\end{array}$ & $a^{2.6}$ & $\begin{array}{l}7.8 \\
\text { e } 72 \mathrm{~K}\end{array}$ \\
\hline \multirow{3}{*}{$\begin{array}{l}\text { 2-4d, Concept } 2 \\
\text { No side barrier }\end{array}$} & $10 \mathrm{~K} \mathrm{y}$ & 1.16 & 0.72 & 3.5 \\
\hline & Iimit & $>100 \mathrm{~K}$ & $>100 \mathrm{~K}$ & $>100 \mathrm{~K}$ \\
\hline & $\max$ & $\begin{array}{l}1.17 \\
\Leftrightarrow \quad 13 \mathrm{~K}\end{array}$ & $\begin{array}{r}2.6 \\
\text { e } 59 \mathrm{~K}\end{array}$ & $e^{7.8} 72 \mathrm{~K}$ \\
\hline
\end{tabular}

WHC-EP-0884

\begin{tabular}{|l|l|l|l|l|}
\hline \hline Case & Time & Beta & Alpha & All- \\
\hline
\end{tabular}


WHC-EP-0884

\begin{tabular}{|c|c|c|c|c|}
\hline Case & Time & $\begin{array}{c}\text { Beta } \\
\text { Dose } \\
(\text { mrem/y) }\end{array}$ & $\begin{array}{l}\text { Alpha } \\
\text { Conc. } \\
(\mathrm{pCi} / 1)\end{array}$ & $\begin{array}{l}\text { All- } \\
\text { Pathways } \\
\text { Dose } \\
\text { (mrem/y) }\end{array}$ \\
\hline Limit & $10 \mathrm{~K} \mathrm{y}$ & 4.0 & 15. & 25. \\
\hline \multirow{3}{*}{$\begin{array}{l}2-5 \mathrm{~d}, \text { Concept } 2 \\
100 \mathrm{~mm} / \mathrm{y} \text { recharge rate }\end{array}$} & $10 \mathrm{~K} y$ & 1.37 & 2.0 & 4.2 \\
\hline & Iimit & $>100 \mathrm{~K}$ & $>100 \mathrm{~K}$ & $>100 \mathrm{~K}$ \\
\hline & $\max$ & $\begin{array}{l}1.37 \\
\text { a } 9.3 \mathrm{~K}\end{array}$ & $\begin{array}{l}2.8 \\
\text { (a) } 58 \mathrm{~K}\end{array}$ & $\begin{array}{l}8.1 \\
\text { a } 71 \mathrm{~K}\end{array}$ \\
\hline \multirow{3}{*}{$\begin{array}{l}2-6 d, \text { Concept } 2, \\
0.5 * \text { dispersion coeff } .\end{array}$} & $10 \mathrm{~K} \mathrm{y}$ & 1.09 & 0.20 & 3.2 \\
\hline & 1 imit & $>100 \mathrm{~K}$ & $>100 \mathrm{~K}$ & $>100 \mathrm{~K}$ \\
\hline & $\max$ & $\begin{array}{l}1.12 \\
\text { a } 15 \mathrm{~K}\end{array}$ & a $2.63 \mathrm{~K}$ & a 7.9 \\
\hline \multirow{3}{*}{$\begin{array}{l}2-7 d \text {, Concept 2, } \\
2 * \text { dispersion coeff. }\end{array}$} & $10 \mathrm{~K} y$ & 1.12 & 0.35 & 3.3 \\
\hline & Iimit & $\geq 100 \mathrm{~K}$ & $>100 \mathrm{~K}$ & $>100 \mathrm{~K}$ \\
\hline & $\max$ & $\begin{array}{l}1.13 \\
\text { a } 15 \mathrm{~K}\end{array}$ & $\begin{array}{l}2.6 \\
-61 x\end{array}$ & $\begin{array}{l}7.9 \\
\text { a. } \\
\end{array}$ \\
\hline \multirow{3}{*}{$\begin{array}{l}\text { 2-1dCR, Concept } 2 \\
\text { impacts at Columbia } \\
\text { River }\end{array}$} & $10 \mathrm{~K} \mathrm{y}$ & 0.054 & 0.013 & 0.161 \\
\hline & limit & $>100 \mathrm{~K}^{*}$ & $>100 \mathrm{~K}$ & $\geq 100 \mathrm{~K}$ \\
\hline & $\max$ & $\begin{array}{l}0.055 \\
\text { a } 15 \mathrm{~K}\end{array}$ & $\begin{array}{l}0.126 \\
\text { e } 62 \mathrm{~K}\end{array}$ & $\begin{array}{l}0.38 \\
\text { (e) } 74 \mathrm{~K}\end{array}$ \\
\hline \multirow{3}{*}{$\begin{array}{l}\text { 2-1decR, Concept } 2 \\
\text { impacts at Columbia } \\
\text { River, vadose zone } \\
\text { flux extended to } \\
\text { long times }\end{array}$} & $10 \mathrm{~K} y$ & 0.056 & 0.011 & 0.167 \\
\hline & limit & $>100 \mathrm{~K} *$ & $>100 \mathrm{~K}$ & $>100 \mathrm{~K}$ \\
\hline & $\max$ & $\begin{array}{l}0.25 \\
\text { a } 13 \mathrm{M}\end{array}$ & $\begin{array}{l}0.34 \\
0 \quad 2.7 \mathrm{M}\end{array}$ & $\begin{array}{l}0.50 \\
\text { \& } 51 \mathrm{~K}\end{array}$ \\
\hline
\end{tabular}




\begin{tabular}{|c|c|c|c|c|}
\hline Case & Time & $\begin{array}{l}\text { Beta } \\
\text { Dose } \\
(\text { mrem/y) }\end{array}$ & $\begin{array}{l}\text { Alpha } \\
\text { Conc. } \\
\text { (pCi/l) }\end{array}$ & $\begin{array}{c}\text { All- } \\
\text { Pathways } \\
\text { Dose } \\
\text { (mrem/y) } \\
\end{array}$ \\
\hline Limit & $10 \mathrm{~K} \mathrm{y}$ & 4.0 & 15. & 25. \\
\hline \multirow{3}{*}{$\begin{array}{l}\text { 3j. Unit Cell Model, } \\
\text { water table at } 96 \\
\text { meters }\end{array}$} & $10 \mathrm{~K} \mathrm{y}$ & 4.5 & 7.7 & 14.2 \\
\hline & 1 imit & e $6.7 \mathrm{~K}$ & (a $29 \mathrm{~K}$ & (d) $17 \mathrm{~K}$ \\
\hline & $\max$ & \& $\begin{array}{l}4.5 \\
13 \mathrm{~K}\end{array}$ & $\begin{array}{c}16.5 \\
\text { \& } 42 \mathrm{~K}\end{array}$ & $\begin{array}{r}75 . \\
\text { @ } 42 \mathrm{~K}\end{array}$ \\
\hline \multirow{3}{*}{$\begin{array}{l}\text { 3k, Unit Cell Model, } \\
\text { Initial moisture at } \\
0.2 \text { in for } \\
\text { construction. } \\
\text { materials }\end{array}$} & $10 \mathrm{~K} y$ & 4.4 & 5.9 & 13.4 \\
\hline & Iimit & e 7.2 & (a) $46 \mathrm{~K}$ & (a $22 \mathrm{~K}$ \\
\hline & $\max$ & $a^{4} \cdot 5$ & $\begin{array}{c}15.0 \\
\text { (a) } 49 \mathrm{~K}\end{array}$ & a $\quad 50 \mathrm{~K}$ \\
\hline \multirow{3}{*}{$\begin{array}{l}\text { 31. Unit Cell Model } \\
\text { Initial moisture is } \\
\text { residual in } \\
\text { construction } \\
\text { materials }\end{array}$} & $10 \mathrm{~K} \mathrm{y}$ & 4.4 & 5.9 & 13.4 \\
\hline & Iimit & (a $7.2 \mathrm{~K}$ & e $46 \pi$ & a $22 \mathrm{~K}$ \\
\hline & $\max$ & $\mathrm{a}^{4.5} 15 \mathrm{~K}$ & $\begin{array}{c}15.0 \\
\text { (a) } 49 \mathrm{~K}\end{array}$ & (a) $53 . \mathrm{K}$ \\
\hline \multirow{3}{*}{$\begin{array}{l}3 \mathrm{~m} \text {, Unit cell Model } \\
\text { canisters rotated by } \\
90 \text { degrees }\end{array}$} & $10 \mathrm{~K} y$ & 4.4 & 5.7 & 13.4 \\
\hline & Iimit & (e) $5.2 \mathrm{~K}$ & $\geq 100 \mathrm{~K}$ & (a) $22 \mathrm{~K}$ \\
\hline & $\max$ & $\mathrm{a}^{4.5}$ & $\begin{array}{c}15,0 \\
\text { a } 50 \mathrm{~K}\end{array}$ & (e $52.5 \mathrm{~K}$ \\
\hline \multirow{3}{*}{$\begin{array}{l}\text { 3n, Unit cell Model } \\
\text { doubled number of } \\
\text { lateral nodes }\end{array}$} & $10 \mathrm{~K} \mathrm{Y}$ & 4.4 & 5.9 & 13.4 \\
\hline & Iimit & (a $7.2 \mathrm{~K}$ & (a) $46 \mathrm{~K}$ & e $22 \mathrm{~K}$ \\
\hline & $\max$ & $e^{4.5}$ & $\begin{array}{c}15.0 \\
\text { @ } 49 \mathrm{~K}\end{array}$ & e $530 \mathrm{~K}$ \\
\hline
\end{tabular}


WHC-EP-0884

\begin{tabular}{|c|c|c|c|c|}
\hline Case & Time & $\begin{array}{c}\text { Beta } \\
\text { Dose } \\
\text { (mrem/y) }\end{array}$ & $\begin{array}{l}\text { Alpha } \\
\text { Conc. } \\
(\mathrm{pCi} / 1)\end{array}$ & $\begin{array}{l}\text { All- } \\
\text { Pathways } \\
\text { Dose } \\
\text { (mrem/y) }\end{array}$ \\
\hline Limit & $10 \mathrm{~K} y$ & 4.0 & 15. & 25. \\
\hline \multirow{3}{*}{$\begin{array}{l}\text { 30, Unit cell Model, } \\
\text { waste form has } \\
\text { hydraulic } \\
\text { properties of sand }\end{array}$} & $10 \mathrm{~K} y$ & 4.4 & 5.8 & 13.4 \\
\hline & Iimit & a $7.2 \mathrm{~K}$ & (a $46 \mathrm{~K}$ & (a) $22 \mathrm{~K}$ \\
\hline & $\max$ & a $\quad .5 \%$ & $\begin{array}{l}15.0 \\
a \quad 49 \mathrm{~K}\end{array}$ & $e^{63} 50 \mathrm{~K}$ \\
\hline \multirow{3}{*}{$\begin{array}{l}\text { 3p, Unit Cell Model, } \\
\text { diffusion coefficient } \\
\text { reduced to } 10^{-8} \mathrm{~cm}^{2} / \mathrm{s}\end{array}$} & $10 \mathrm{~K} y$ & 4.4 & 5.9 & 13.4 \\
\hline & limit & e $7.2 \mathrm{~K}$ & e $46 \mathrm{k}$ & (a) $22 \mathrm{~K}$ \\
\hline & $\max$ & $\begin{array}{l}4.5 \\
15 \mathrm{~K}\end{array}$ & $\begin{array}{l}15.0 \\
\text { a } 49 \mathrm{~K}\end{array}$ & $\begin{array}{l}63 \\
0 \quad 50 K\end{array}$ \\
\hline \multirow{3}{*}{$\begin{array}{l}\text { 3q, Unit cell Model, } \\
\text { doubled dispersion } \\
\text { coefficient }\end{array}$} & $10 \mathrm{~K} \mathrm{y}$ & 4.4 & 6.2 & 14.4 \\
\hline & Iimit & a $7.1 \mathrm{~K}$ & e $44 \mathrm{~K}$ & (a) $17 \mathrm{~K}$ \\
\hline & $\max$ & e $\begin{array}{l}4.5 \\
15 \mathrm{~K}\end{array}$ & $\begin{array}{c}15.0 \\
\text { a } 45 \mathrm{~K}\end{array}$ & a $\quad 46 \mathrm{~K}$ \\
\hline \multirow{3}{*}{$\begin{array}{l}\text { 3r, Unit Cell Model, } \\
\text { halved dispersion } \\
\text { coefficient }\end{array}$} & $10 \mathrm{~K} \mathrm{y}$ & 4.3 & 5.7 & 13.3 \\
\hline & Iimit & e $7.4 \mathrm{~K}$ & a $45 \mathrm{~K}$ & a $26 \mathrm{~K}$ \\
\hline & $\max$ & $\begin{array}{l}4.5 \\
@ \quad 14 K\end{array}$ & $\begin{array}{c}15.2 \\
\text { e } 52 \mathrm{~K}\end{array}$ & $\begin{array}{r}65 . \\
\text { (a) } 52 \mathrm{~K}\end{array}$ \\
\hline \multirow{3}{*}{$\begin{array}{l}\text { 3s, Unit cell Model, } \\
\text { One-tenth dispersion } \\
\text { coefficient }\end{array}$} & $10 \mathrm{~K} \mathrm{y}$ & 4.3 & 5.6 & 13.3 \\
\hline & $1 \mathrm{imit}$ & a $7.7 \mathrm{~K}$ & (a $45 \mathrm{~K}$ & (a) $30 \mathrm{~K}$ \\
\hline & $\max$ & $\begin{array}{l}4.5 \\
e^{14 K}\end{array}$ & $\begin{array}{c}15.6 \\
\text { (a } 53 \mathrm{~K}\end{array}$ & $\begin{array}{l}69 . \\
\text { (a) } 53 \mathrm{~K}\end{array}$ \\
\hline \multirow{3}{*}{$\begin{array}{l}\text { 3tuo, Unit Cell Model, } \\
\mathrm{U} \text { has } \mathrm{Kd}=0 \\
\text { everywhere }\end{array}$} & $10 \mathrm{~K} \mathrm{y}$ & 4.6 & 9.7 & 14.2 \\
\hline & Iimit & \& 5.8 & (a) $22 \mathrm{~K}$ & a $46 \mathrm{~K}$ \\
\hline & $\max$ & $\begin{array}{ll} & 4.6 \\
\text { a } & 10.8 \mathrm{~K}\end{array}$ & $\begin{array}{c}15.0 \\
\text { a } 48 \mathrm{~K}\end{array}$ & (a $50 \mathrm{~K}$ \\
\hline
\end{tabular}


WHC-EP-0884

\begin{tabular}{|c|c|c|c|c|}
\hline Case & Time & $\begin{array}{c}\text { Beta } \\
\text { Dose } \\
(\operatorname{mrem} / y)\end{array}$ & $\begin{array}{l}\text { Alpha } \\
\text { Conc. } \\
\text { (pCi/i) }\end{array}$ & $\begin{array}{c}\text { All- } \\
\text { Pathways } \\
\text { Dose } \\
\text { (mrem } / y) \\
\end{array}$ \\
\hline Limit & $10 \mathrm{~K} \mathrm{y}$ & 4.0 & 15. & 25. \\
\hline \multirow{3}{*}{$\begin{array}{l}\text { 3t, Unit Cell Model, } \\
\mathrm{U} \text { has } \mathrm{Kd}=0 \\
\text { everywhere } \\
\text { but in floor where } \\
\mathrm{Kd}=100 \mathrm{ml} / \mathrm{g}\end{array}$} & $10 \mathrm{~K} Y$ & 4.2 & 1.6 & 12.6 \\
\hline & Iimit & e $4.6 \mathrm{~K}$ & $>100 \mathrm{~K}$ & @ $22 \mathrm{~K}$ \\
\hline & $\max$ & $\begin{array}{l}4.2 \\
\text { (e } \quad 7.7 \mathrm{~K}\end{array}$ & $\begin{array}{c}12.3 \\
\text { a } 59 \mathrm{~K}\end{array}$ & a $\quad 50 \mathrm{~K}$ \\
\hline \multirow{3}{*}{$\begin{array}{l}\text { 3ttc, Unit cell Model, } \\
\text { Tc has } \mathrm{kd}=100 \mathrm{ml} / \mathrm{g} \\
\text { in floor }\end{array}$} & $10 \mathrm{~K} y$ & 1.72 & 6.3 & 4.7 \\
\hline & Iimit & $>100 \mathrm{~K}$ & a $46 \mathrm{~K}$ & (a) $24 \mathrm{~K}$ \\
\hline & $\max$ & $\begin{array}{l}3.5 \\
\text { e } 100 \mathrm{~K}\end{array}$ & $\begin{array}{c}15.0 \\
\text { a } 49 \mathrm{~K}\end{array}$ & $\begin{array}{l}60 . \\
\Leftrightarrow \quad 51 \mathrm{~K}\end{array}$ \\
\hline \multirow{3}{*}{$\begin{array}{l}\text { 3t0, Unit Cell model, } \\
\text { Se and Tc have } \mathrm{kd}= \\
100 \mathrm{ml} / \mathrm{g} \text { in floor }\end{array}$} & $10 \mathrm{~K} \mathrm{Y}$ & 0.98 & 6.3 & 3.4 \\
\hline & Iimit & $>100 \mathrm{~K}$ & e $46 \mathrm{~K}$ & e25K \\
\hline & $\max$ & a $3.400 \mathrm{~K}$ & $\begin{array}{c}15.0 \\
\text { a } 49 \mathrm{~K}\end{array}$ & a $\quad 50 . \mathrm{K}$ \\
\hline \multirow{3}{*}{$\begin{array}{l}\text { 3u, Unit Cell Model, } \\
\text { Release rates } \\
\text { proportional to } \\
\text { surface area }\end{array}$} & $10 \mathrm{~K} \mathrm{Y}$ & 4.3 & 5.8 & 13.1 \\
\hline & Iimit & e $7.5 \mathrm{~K}$ & $\geq 100 \mathrm{~K}$ & a $22 \mathrm{~K}$ \\
\hline & $\max$ & $\begin{array}{l}4.3 \\
13 K\end{array}$ & $\begin{array}{c}13.8 \\
\text { e } 45 \mathrm{~K}\end{array}$ & (a) $48 \mathrm{~K}$ \\
\hline \multirow{3}{*}{$\begin{array}{l}\text { 3v, Unit cell Model } \\
\text { Release Rates as } \\
\text { calculated by } \\
\text { AREST-CT }\end{array}$} & $10 \mathrm{~K} y$ & 0.53 & 0.63 & 1.54 \\
\hline & Iimit & $>100 \mathrm{~K}$ & $>100 \mathrm{~K}$ & $>100 \mathrm{~K}$ \\
\hline & $\max$ & $\begin{array}{r}0.56 \\
\text { @ } 14 \mathrm{~K}\end{array}$ & $\begin{array}{c}1.49 \\
\text { a } 32 \mathrm{~K}\end{array}$ & $\begin{array}{c}6.0 \\
\text { a } 47 \mathrm{~K}\end{array}$ \\
\hline
\end{tabular}




\begin{tabular}{|c|c|c|c|c|}
\hline Case & Time & $\begin{array}{c}\text { Beta } \\
\text { Dose } \\
\text { (mrem/y) }\end{array}$ & $\begin{array}{l}\text { Alpha } \\
\text { Conc. } \\
\text { (pci/l) }\end{array}$ & $\begin{array}{c}\text { All- } \\
\text { Pathways } \\
\text { Dose } \\
\text { (mrem/y) }\end{array}$ \\
\hline Limit & $10 \mathrm{~K} y$ & 4.0 & 15. & 25. \\
\hline \multirow{3}{*}{$\begin{array}{l}\text { 3vxi, Unit cell Model } \\
\text { Release Rates as } \\
\text { calculated by } \\
\text { AREST-CT, but no ion } \\
\text { exchange for TC }\end{array}$} & $10 \mathrm{~K} \mathrm{y}$ & 0.20 & 0.63 & 0.47 \\
\hline & Iimit & $>100 \mathrm{~K}$ & $>100 \mathrm{~K}$ & $>100 \mathrm{~K}$ \\
\hline & $\max$ & $\begin{array}{c}0.30 \\
\text { a } 100 \mathrm{~K}\end{array}$ & $\begin{array}{c}1.49 \\
\text { (e) } 32 \mathrm{~K}\end{array}$ & $\begin{array}{l}5.4 \\
\text { e } 48 \mathrm{~K}\end{array}$ \\
\hline \multirow{3}{*}{$\begin{array}{l}\text { 3vpor, Unit Cell Model, } \\
\text { Release Rates as } \\
\text { calculated by } \\
\text { AREST-CT, but } \\
\text { increased pore } \\
\text { velocity }\end{array}$} & $10 \mathrm{~K} \mathrm{Y}$ & 0.97 & 0.63 & 3.0 \\
\hline & Iimit & $>100 \mathrm{~K}$ & $>100 \mathrm{~K}$ & $>100 \mathrm{~K}$ \\
\hline & $\max$ & $\begin{array}{c}1.18 \\
\text { e } 20 \mathrm{~K}\end{array}$ & $\begin{array}{c}1.49 \\
\text { a } 32 \mathrm{~K}\end{array}$ & $\begin{array}{c}7.7 \\
\text { a } \quad 44 \mathrm{~K}\end{array}$ \\
\hline
\end{tabular}

* Limit for beta/photon drinking water dose at columbia River is $1 \mathrm{mrem} / \mathrm{y}$. 


\section{E. 5 WASTE FORM RELEASE CALCULATIONS}

\section{E.5.1 Simulation Domain and Physical Conditions}

Figure E-8. Glass Simulation Domain

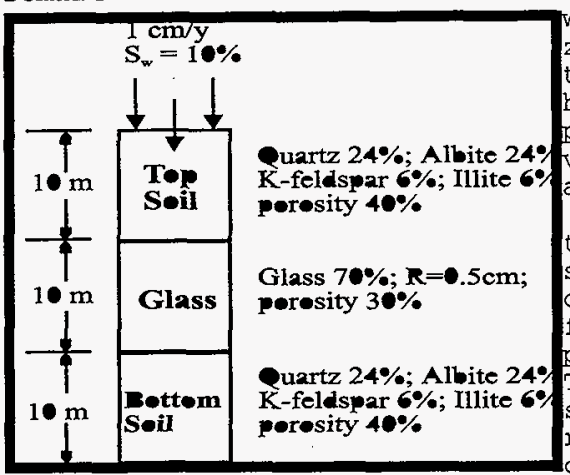

The proposed disposal facility will be located in the vadose zone, about 10 meters beneath the ground surface with a height of 10 meters. Average pore-water velocity in the vadose zone is $1 \mathrm{~cm} / y e a r$, with a water saturation of $10 \%$ (Kline 1995b). The average temperature is about $14^{\circ} \mathrm{C}$. The surrounding soil contains $24 \%$ quartz, $24 \%$ high albite, $6 \% \mathrm{~K}-$ feldspar, and 6\% illite, with a porosity of $40 \%$ (Serne 1993). The glass is assumed to be spherical in shape with a radius of $0.5 \mathrm{~cm}$, and it occupies $70 \%$ of the volume of the waste vault. The facility is modeled as a 1-D column as shown in Figure $E-8$.

\section{E.5.2 Glass Composition and Dissolution Rinetics}

The stoichiometric coefficients for the radioactive elements given in Reaction (9) of Appendix C.2.4 were calculated from the total waste inventory, assuming a uniform glass composition is produced totaling $210,000 \mathrm{~m}^{3}$ (Schmittroth 1995b). For historical reasons, the glass waste shapes were taken as marbles with a radius of $0.5 \mathrm{~cm}$.

\section{E.5.3 Key Results}

Figure E-9 shows the calculated pH in the vault as a function of time and space where the ion-exchange Reaction (10) of Appendex C.2.4 was not considered. Peak pH values occur at the edges of the vault because this is where the glass reaction rate is largest, as is shown in Figure E-10. Glass reaction rates are largest at the interface between the vault and the surrounding soil because diffusive and advective mass transfer lowers the concentration of $S i$ and other glass components in the aqueous phase. Consequently, the chemical affinity for the network dissolution Reaction (9) is larger, resulting in a faster dissolution kinetics. Figure E-10 shows the complex time and spatial dependence of the glass reaction rate that results from the complex interaction between mass transport and chemical reactions. In general, however, the calculations indicate an overall low rate of glass corrosion, as much as three or four 
Figure E-9. Computed pH when Ion Exchange Reaction is NOT Considered.

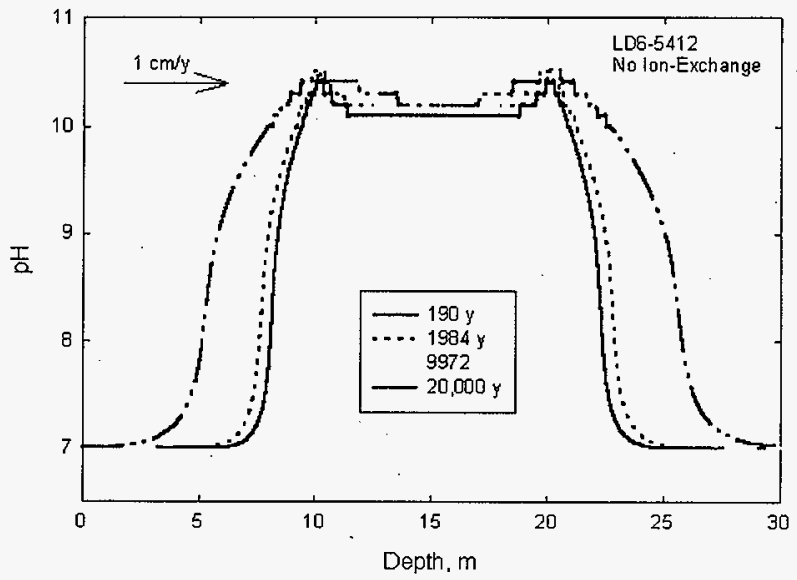

Figure E-10. Glass Dissolution Rate as a Function of Time and Space when NOT Considering Ion Exchange Reaction.

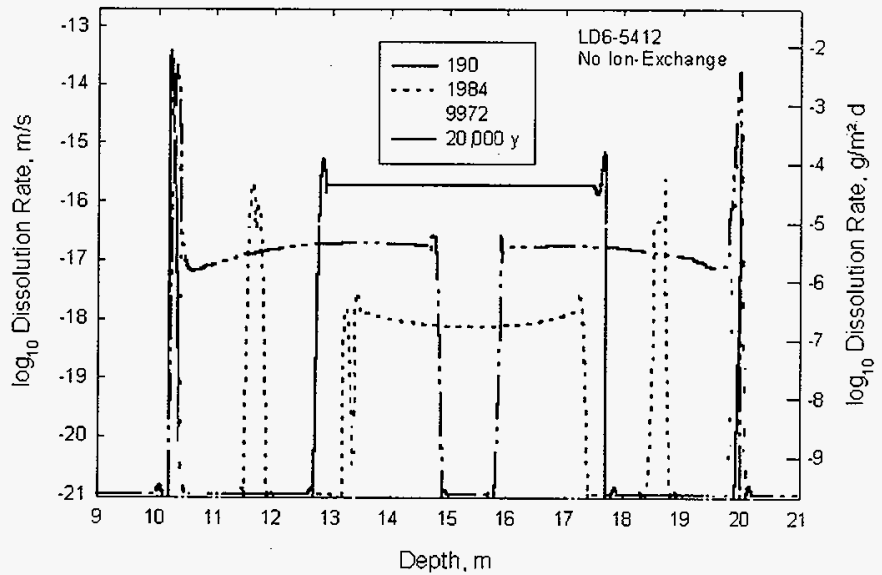


orders of magnitude lower than the forward rate of reaction for LD6-5412 glass at this temperature and average $\mathrm{pH}$ in the vault.

Figure E-11 shows the calculated ${ }^{99} \mathrm{TC}$ concentrations as a function of time and space. Unlike the complex time and spatial dependence found for the glass corrosion rate, the ${ }^{99} \mathrm{Tc}$ concentrations appear smooth and regular, with only a slight peak near the vault edges where the glass reaction rate is highest. The smooth spatial profile for ${ }^{99} \mathrm{Tc}$ results because under the oxidizing conditions in the vault, ${ }^{99} \mathrm{Tc}$ is highly soluble as a pertechnitate $\left(\mathrm{TCO}_{4}{ }^{-}\right)$anion. With no solid phase precipitation to affect the concentration profile, the radionuclide is subject to dispersion by diffusion and advection, which tends to smooth concentration gradients.

The simulation results presented in Figures E-8 through E11 neglected the ion-exchange Reaction (10). The inclusion of this reaction has a dramatic effect on the computed pH profile in the vault, as illustrated in Figure E-12. With ion exchange included, the computed pH in the vault rises to over 12 , nearly two pH units higher than in the simulations without the reaction (Figure E-9). LD6-5412 glass is less stable at $\mathrm{pH}>12$; this is reflected by a marked increase in the calculated glass corrosion rate, as shown in Figure 4-22. With ion exchange included in the simulation, the overall rate of glass corrosion in the vault increases by several orders of magnitude. Although it will not be shown here, the increase in glass corrosion rate increases proportionately the release rate of an element such as ${ }^{99} \mathrm{TC}$, which is highly soluble under these conditions. The release rates of less soluble radionuclides increase or even decrease depending on whether the solubility of any secondary phases that contain the elements increase or decrease at the higher pH.

The large increase in the computed glass corrosion rate in the vault from the ion-exchange reaction mechanism is a clear example in which a computer simulation has identified a significant performance assessment issue that is not observable from laboratory test results. In typical water-saturated, lowtemperature, batch tests with LD6-5412 glass, the sodium ionexchange reaction was identified as a minor secondary reaction that contributed to an enhanced rate of sodium release as compared with the other major glass components, including boron and silicon. The importance of this reaction mechanism to the overall performance of the disposal system was only revealed through computer simulations that properly couple chemical reactions and transport. Now that the importance of this mechanism has been identified, new glasses can be formulated that either eliminate or minimize the sodium ion exchange, and thus significantly improve the overall performance of the disposal system. 
Figure E-11. Calculated Total Aqueous ${ }^{99}$ Te Concentration as a Function of Time and space.

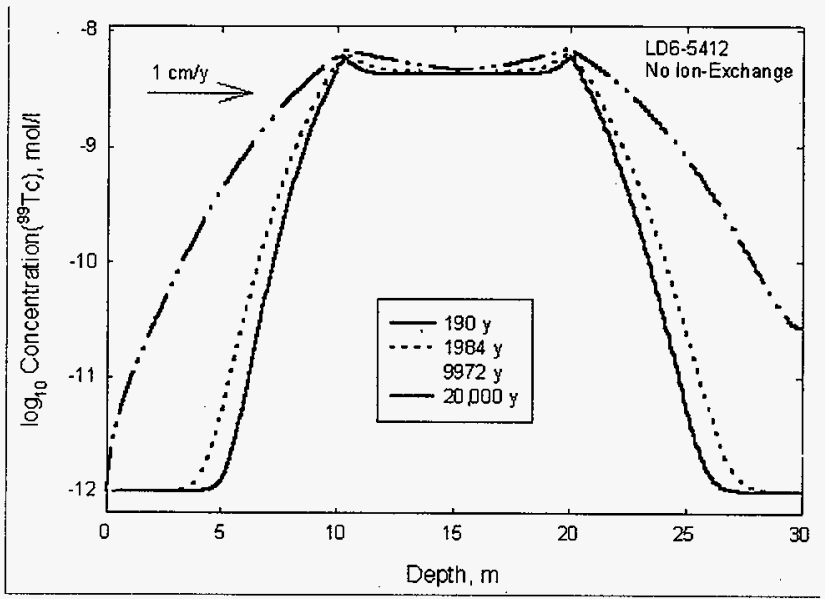

Figure E-12. Computed $\mathrm{pH}$ in Disposal Vault When Ion Exchange Is Included.

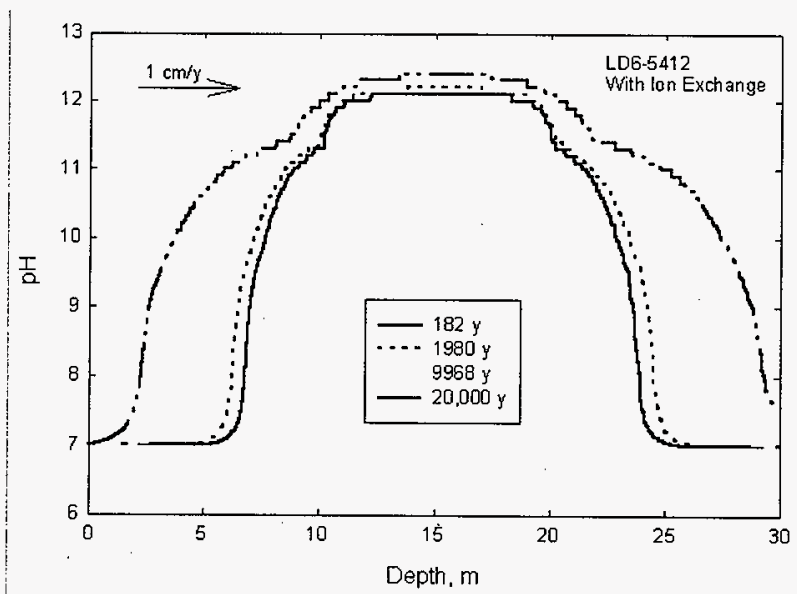


HNF-EP-0884

Rev. 1

\section{APPENDIX I \\ COMIMENTS BY REVIEWERS}

\section{F.1 EXTERNAI REVIEW BOARD}

With the concurrence of the Department of Energy, an external review board was appointed to review the interim performance assessment and the performance assessment activity in general.

\section{F.1.1 Members}

The members of the board were

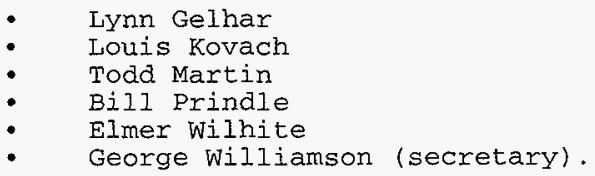

Short biographies are contained in the Appendix A of their report which is reproduced in Section F.1.3.

\section{F.1.2 Board Materials}

The board was supplied with the published version of the Interim Performance Assessment (Mann 1996a), the data on which the performance assessment was based (Mann 1995a), and the definition of the analyses cases (Mann 1995b). The board was also sent the introductory sections of the draft statements of work for FY 1998 through 2003 (the final version published as Mann 1997).

The board met in Richland, washington on April 15 and 16. They had previously submitted their comments on the Interim Performance Assessment to the secretary of the board. At the meeting, presentations were made to the board concerning how the Interim Performance Assessment was generated and what were the plans for the performance assessment activity. The performance assessment team responded to the questions posed by the board. The report of the board is reproduced in the next section. 


\section{HNF-EP-0884}

Rev. 1

\section{F.1.3 Report of the External Review Board}

The report is reproduced as provided by the review board with the exception of page numbers and some minor formating changes. Numbers in curly brackets \{\} (which are not in the original report) are pointers to the responses found in section F.1.4.

\section{COMMENTS AND FINDINGS FROM THE EXTERNAL REVIEW PANEL for the HANFORD LOW-LEVEL TANR WASTE INTERIM PERFORMANCE ASSESSMENT}

May 1997

External Performance Assessment Review Panel

\section{TABLE OF CONTENTS}

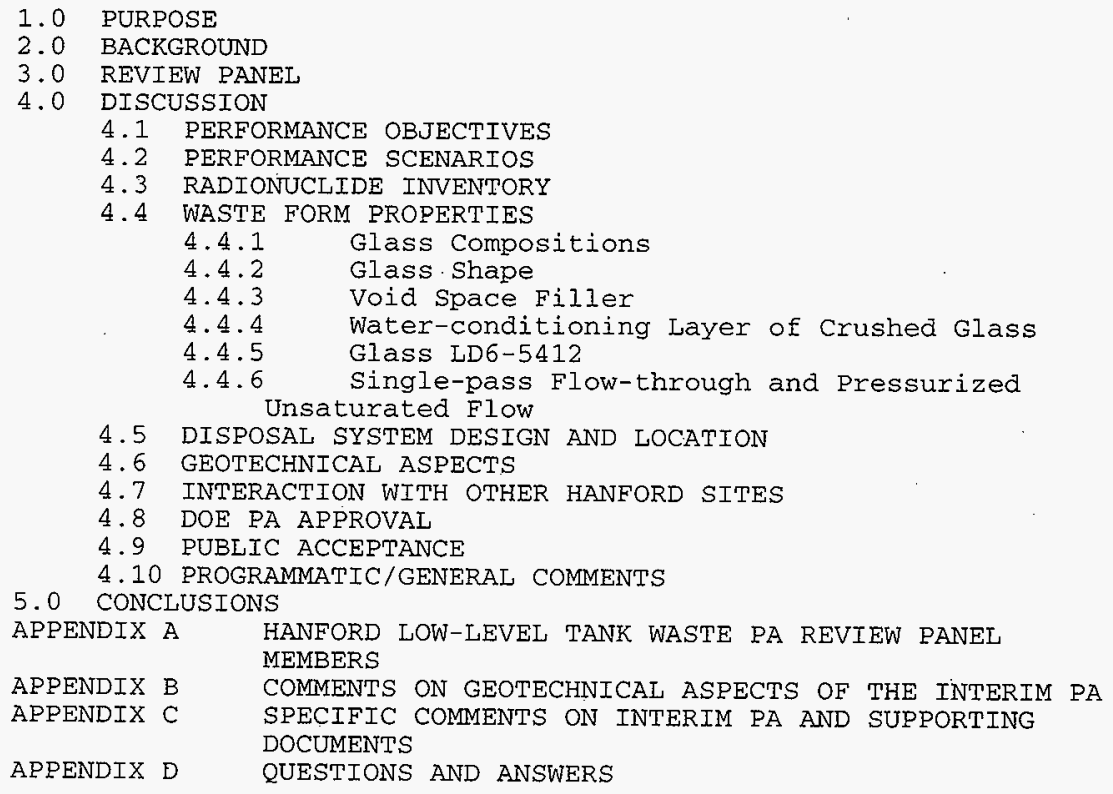




\title{
HNF-EP-0884
}

Rev. 1

\author{
COMMENTS AND FINDINGS FROM THE EXTERNAL REVIEW PANEL \\ for the \\ FIANFORD LOW-LEVEL TANK WASTE \\ INTERIM PERFORMANCE ASSESSMENT
}

\subsection{PURPOSE}

This report will document the results of the external panel review of performance assessment (PA) documentation and a workshop conducted on April 15-16, 1997, in Richland, washington, regarding the treatment and disposal of Hanford low-level tank waste. The panel conducted the review both from a technical and management point of view to provide comments, and recommendations for efficient and cost-effective completion of the PA for disposal of tank waste. Documentation reviewed by the panel included the document Hanford Low-Level Tank Waste Interim Performance Assessment (referred to as interim PA) (WHC-EP-0884), and its major supporting documents, Data Packages for the Hanford Low-Level Tank Waste Interim Performance Assessment (referred to as Data Packages) (WHC-SD-WM-RPT-166), and Definition of the Base Analysis Case of the Interim Performance Assessment

(WHC-SD-WM-RPT-200). Also reviewed was the document, statements of Work for FY 1998 to 2003 for the Hanford Low-Level Tank Waste Performance Assessment Activity, dated March 31, 1997.

\subsection{BACKGROUND}

Over the past 50 years, radioactive and mixed wastes from the production of national defense materials have been stored on the Hanford Site, primarily in below-grade single- and double-shell tanks in the 200 Areas. During the late $1980 \mathrm{~s}$ and early $1990 \mathrm{~s}$, the U.S. Department of Energy (DOE) initiated significant mission changes to proceed with plans to permanently immobilize and dispose of the low-activity fraction of these tank wastes in near-surface low-level tank waste disposal facilities. Current planning envisions the production of immobilized low-activity wastes (LAW) by private companies under contract to the DOE followed by storage and disposal of LAW by the DOE on the Hanford Site in the 200 Area Plateau. Over 200,000 cubic meters of LAW will be disposed of under this plan during the next two to three decades.

DOE Order 5820.2A, Management of Radioactive Wastes, requires that a PA be written and approved before commencement of disposal activities.

\subsection{REVIEW PANEL}

An independent external review panel was contracted by Lockheed Martin Hanford Corporation consisting of the following six individuals. Additional background information is provided in Appendix A. 
Lynn Gelhar - Dr. Gelhar of the Massachusetts Institute of Technology is an internationally-recognized expert in groundwater modeling.

Louis Kovach - Dr. Kovach is a private consultant on nuclear waste management.

Todd Martin - Mr. Martin of the Hanford Education Action League serves on the Hanford Advisory Board.

Bill Prindle - Dr. Prindle is a private consultant and recognized expert on glasses and vitrification.

Elmer wilhite - Mr. Wilhite is an advisory scientist at the Savannah River site and serves as chairman of the U.S. Department of Energy - Headquarters peer review panel.

George Williamson - Mr. Williamson, the former Hanford Low-Level Waste Disposal Project manager, serves as the secretary of the review panel.

\subsection{DISCUSSION}

Based on the review of documentation provided to panel members and the workshop held in Richland, Washington, on April 15-16, 1997, the panel generally agrees that the interim PA addresses many of the issues important in the quantifying the long-term performance of the facility, but that some significant scenarios and processes are not adequately addressed. Consequently, the interim PA findings may be overly optimistic regarding the likelihood that the performance objectives will be met, and may not provide an adequate basis for setting priorities regarding possible additional data collection needed to enhance the reliability of the PA. Furthermore; in some cases, the content and form of the technical documentation needs to be improved to assure technical defensibility. The discussion that follows will be grouped under subjects covering the information needed to prepare, review, and accept a PA. Comments of a general nature that are believed to influence the PA preparation and approval are listed under the "Programmatic/General Comment" section.

Detailed technical editorial and clarification comments regarding specific sections of the interim PA are listed in Appendices B and $C$.

\subsection{PERFORMANCE OBJECTIVES}

The performance objectives used in the PA (described on pages 1-7 and 1-8) are largely appropriate for compliance with DOE Orders. However, two of the performance objectives should be reconsidered due to the revision of DOE Order, Management of Radioactive

Wastes. They are as follows: 


\section{HNF-EP-0884}

Rev. 1

\section{Protection of groundwater resources $\{1\}$}

The revised groundwater protection performance objective is tied to the Site's groundwater protection management plan. The discussion of groundwater protection on pages $1-12$ and 1-13 should be revised to include a discussion of the Hanford groundwater protection management plan and to show how the selected groundwater protection performance objective was derived from the plan.

\section{As low as reasonably achievable (ALARA) $\{2\}$}

Guidance for ALARA determinations will be provided in the new DOE Order 435.1, Radioactive Waste Management. This guidance should be followed as the PA is revised.

\subsection{PERFORMANCE SCENARIOS}

A critical step in PAs is the development of scenarios. It is important that these scenarios be both realistic and bounding; requirements that are often at odds with one another. The ability to effectively meet both of these requirements is extremely important. clear communication of exactly how these two requirements are met is of equal importance. $\{3\}$

With the above in mind, the PA should include a best estimate scenario. This scenario would be based on the most probable performance of waste form, disposal facility, transport through the vadose zone, etc. The PA would take credit for reasonable assumptions (such as performance of the waste form) and dismiss those for which there is less surety (such as using a 15-foot well screen).

The selection of assumption is necessarily a subjective process. Mitigation measures should be taken to assure that the assumptions are reasonable. These include broad and rigorous review. $\{4\}$

Another important mitigation measure is to ensure the PA does not rest too heavily on the accuracy of the best estimate scenario. Given the significant nature of uncertainty in any PA stretching over thousands of years, too much reliance on accuracy in the best estimate scenario is dangerous. To avoid this, the PA should include other scenarios as bounding cases. One of these would be a reasonable worst-case scenario, the other a reasonable best-case scenario. The bounding cases would serve several purposes. First, they bound the analysis in the PA, answering the inevitable questions, "How bad/good can it get?" Second, the broad range of scenarios can help bound the program itself. The tank waste treatment and disposal program has experienced many changes over the years, and will undoubtedly experience more. A $P A$ that could weather these changes with minimal modifications would expedite the program, saving time and money. $\{5\}$ 


\section{HNF-EP-0884}

Rev. 1

The three outlined scenarios form only the basic analytical skeleton for the PA. The PA should have more iterative scenarios between the extreme cases. Other scenarios would be useful for sensitivity purposes, and to give more insight into the risks posed by a broader range of potential outcomes. $\{6\}$

The difference between limited sensitivity cases and sensitivity cases involving change in several parameters or assumptions is important. The most effective, understandable, and analytically sound way to approach the PA is through full scenarios. The current interim PA considers changes of variables in isolation; it does not contain sensitivity cases in which multiple variables deviate. That such multiple deviations are likely emphasizes the importance of considering entire scenarios in sensitivity cases. Isolated variations are appropriate for identifying important variables and their relative sensitivity in PA results, however, such consideration is not sufficient or defensible in making overall PA conclusions. $\{7\}$

One specific scenario that is given little consideration in the current interim PA is catastrophic flooding. Many may summarily dismiss this scenario because of the profound and far-reaching impacts the region would experience over and above exposure to this waste. Still, it is likely that in the time frame under consideration in the interim PA a catastrophic flood is indeed likely. Location of waste, disposal design, and other variables could impact the exposure as a result of catastrophic flood. other variants of the flood scenario presented in the PA should be considered. For example, could a modified flood scenario provide substantially greater infiltration through the waste without exposing the waste and redistributing it? $\{8\}$

\subsection{RADIONUCLIDE INVENTORY}

This subject was not discussed at length in the workshop, however, knowledge of the actual inventory to be placed in the LAW disposal facilities is important, and generally will have a linear relationship on the PA calculation results. The source of Hanford tank inventory information has been a subject of concern for years. It is recommended that the PA work utilize the Kupfer data as the best estimate of the tank waste inventory as soon as possible. $\{9\}$

In addition, consideration of additional inventory sensitivity cases would strengthen the PA. For example, consideration of inhomogeneities in the waste tanks could be done by exploring the impact on groundwater concentrations of simulating more than one row of vaults. $\{10\}$ 


\section{HNF-EP-0884}

Rev. 1

\subsection{WASTE FORM PROPERTIES}

\subsubsection{Glass Compositions}

There are some dangers inherent in dealing with average in-tank waste compositions and average glass compositions. While some blending of waste from tank-to-tank can be done, it is fairly certain that there will be some considerable composition variation in the waste streams to be fed into the immobilization process. Different glass compositions will be required to accommodate these waste stream variations in order to meet the waste product criteria. $\{11\}$

\subsubsection{Glass shape}

With regard to the shape of the waste glass product inside the disposal package, a minimum surface to volume ratio is desired to reduce the concentration of undesirable constituents released to the environment through leaching. Accordingly, wherever possible when producing glass waste form for disposal, making small particles or fragments of glass should be avoided in favor of larger pieces. The worst case is to "frit" or dribble the molten glass into water; this raises the definite possibility of creating a radioactive aqueous secondary waste. Spheres of 2-4 $\mathrm{cm}$. diameter can be readily formed from the molten glass using marble machines without the need for water quenching.

Very large spheres become difficult to make as they require a very long cooling cycle to reduce the stresses that otherwise would cause shattering. Pouring glass "monoliths" by casting the molten glass directly into the disposal package require the cylinarical alloy steel canisters proposed for high-level waste (HLW) disposal; square mild steel boxes would not be suitable as they would soften and sag out of shape. The glass cast into the HLW type of canister is going to crack into blocks, but will still have less surface-to-volume ratio than a package filled with $1 \mathrm{~cm}$. diameter spheres. The costs of glass manufacture and final shaping or sizing will dictate to a large extent the methods chosen by the private companies for final product content and shaping to achieve performance specification requirements. $\{12\}$

\subsubsection{Void space Filler}

If a sulfur-polymer is to be used to fill the void space around the glass waste form, then some study of sulfur-polymer degradation would seem to be in order. \{13\}

\subsubsection{Water-conditioning Layer of Crushed Glass}

It would probably be useful to verify by experiment that a water-conditioning layer of crushed glass in the vault cover would reduce glass corrosion rates under low moisture conditions. $\{14\}$ 


\section{HNF-EP-0884 \\ Rev. 1}

\subsubsection{Glass LD6-5412}

There is no real assurance that glass LD6-5412 is a "best estimate." It would seem advisable to run simulation studies, also, on some of the other glasses that have been proposed as promising for disposing of the Hanford wastes to clarify the bounds. $\{15\}$

\subsubsection{Single-pass Flow-through and Pressurized Unsaturated Flow}

The single-pass flow-through (SPFT) and the pressurized unsaturated flow (PUF) tests are real contributions and better simulate the Hanford disposal site conditions than other tests (i.e., the regular ASTM/ANSI and product consistency test [PCT]) . However, they seem too complicated and require too much judgement to be run as routine product acceptability tests. Some further refinements that would make the tests easier to use by the average technician would seem necessary. $\{16\}$

Much more data is needed on standard waste disposal glasses using the SPFT and PUF tests so the results can be compared with rankings obtained by the traditional glass durability tests. Product leaching tests (i.e., PUF) should be cross-correlated with possible product quality assurance tests (i.e., PCT) for the specific product used. While this may be difficult for a large group of glass forms, it should be attempted for an individual glass form. $\{16\}$

\subsection{DISPOSAL SYSTEM DESIGN AND LOCATION}

Current planning envisions placement of the initial immobilized LAW packages in the four existing vaults constructed by the former Hanford Grout Program followed by construction, operations, and closure of additional facilities located in a site west of PUREX for the majority of the immobilized LAW. Conceptual designs for the disposal facilities have not been developed to date. This subject was not discussed much during the workshop since its overall impact on long-term performance is small compared to other components of the disposal system.

The PA review panel cited a few points for consideration which include the following:

Look and see what others are doing regarding disposal facilities for LAW both nationally and internationally (i.e., the French). $\{17\}$

Verify that it is cost effective to utilize the existing four vaults for the initial storage/disposal of the LAW which may contain the bulk of the 99Tc inventory. \{18\}

It was discovered during an off-line conversation that some of the immobilized LAW product packages produced by the 


\section{Rev. 1}

private vendors may have a small enough radionuclide inventory to allow contact handling compared to the specification limits which would dictate remote handling. This has significant potential cost savings from both a disposal facility design and material handling view point. It may be possible to develop and operate two types of facilities; those that require remote handling and shielding, and those that could be handled in a conventional manner and placed in simple earthen trenches. Future negotiations with the private vendors and appropriate contract language could result in significant future savings to the project. Continued investigation of the merits and risks of this approach should be pursued. \{19\}.

\subsection{GEOTECHNICAL ASPECTS}

Numerous comments and discussion are provided in this report regarding radionuclide transport pathways, analysis concerns, and recommendations for future plans. In addition to the concern that the impacts of glacial flooding is not addressed, comments are provided on recharge and infiltration, performance of a capillary barrier over the disposal site, flow and diffusion in the disposal facility, water vapor diffusion, modeling of the vadose zone, hydraulic properties and dispersion in the vadose zone, aquifer flow and contaminant transport, and source term including decay chain effects. This discussion is provided in Appendix B.

In view of the major uncertainties with key processes and/or parameters as discussed in Appendix B, it is likely that the conclusions presented in the interim PA are optimistic in assessing the likelihood that the disposal action will meet the performance objectives. $\{20\}$

Suggestions to improve the accuracy of the PA process and assure cost effective data collection activities include the following:

- Modify models to address issues discussed in Appendix B.

- Update the integrated site characterization plan with a focus on PA modeling needs also taking advantage of existing geotechnical data (i.e., existing borehole data). $\{21\}$

- Perform expert review of the updated site characterization plan to determine scope of data collection needs, if any. $\{22\}$

\subsection{INTERACTION WITH OTHER HANFORD STTES}

The interim PA is based on early guidance that indicated that the consideration of other sources of radioactive material should be in the PA. Current guidance, however, directs that a separate 


\section{HNF-EP-0884}

Rev. 1

analysis called a "composite analysis," must be performed to account for other sources of radioactive material. The PA should be revised to remove the consideration of these other sources. Alternatively, the composite analysis could be incorporated into the PA. If the latter course is the one chosen, it should be made clear the performance objectives and point of compliance is different for the PA and the composite analysis. \{23\}

As the other sources are considered, it is important to keep in mind that the inventory of radionuclides should be consistent from one source to another. For example, the interim PA indicates that essentially all the I-129 produced at Hanford was trapped from the off gas systems of reprocessing facilities; thus, only a fraction is expected to be in the low-level waste (LLW) analyzed in the interim PA. That would mean that the composite analysis should account for all the I-129 produced by assuming that the trapping medium is buried in one of the burial grounds.

\subsection{DOE PA ARPROVAL}

The U.S. Department of Energy - Headquarters (DOE-HQ) process for approval of PAs is changing. Heretofore, each PA was reviewed for technical quality and consistency by the Peer Review Panel (PRP), a group of technical experts in the PA field. At this time, DOE has formed a review group of Federal employees.

Initially, the Federal group was to review composite analyses and direct the work of the PRP in reviewing PAs. Recently, however, the Federal group has indicated that it will review both the composite analyses and PAs. It is not clear at this time whether the $P A$ review critexia will change. It would be helpful if the PA team could find opportunity to present the PA methodology to the Federal group to get an early indication of whether it will be viewed as acceptable. $\{24\}$

\subsection{PUBLIC ACCEPTANCE}

Public acceptability of the PA is enormously important. The public can be a stumbling block to the PA approval or an effective lobbyist for PA approval. This PA has a particularly ripe opportunity to gain and utilize public support. The public was instrumental in the selection of glass as the low-level tank waste form. If the PA process is carried out with adequate public involvement, it could bolster public support of the PA and the program. $\{25\}$

Following are critical items for gaining public support of the PA.

The PA should not delay the program. It should be funded and conducted to support the time line currently envisioned for tank waste treatment and disposal. \{26\} 


\section{HNF-EP-0884}

Rev. 1

The PA should be conservative enough to bound the program, and reasonable enough to give some realistic expectations of the disposal system's performance. Ideally, the PA would be able to weather almost any programmatic changes with minimal modifications. \{27\}

- The PA must be a credible, defensible document. This aspect of the PA must be emphasized as the public is extremely suspicious of any DOE document that predicts exposure risks. $\{28\}$

- The PA must be effective in communicating its assumptions, analyses, results and uncertainties. If the public is unable to understand the document, acceptance is highly unlikely. $\{29\}$

There are few public concerns for which the PA will not stand more rigorous tests in the DOE approval process. The two exceptions may be the effective communication and the delay to the program. Based on past concerns, the northwest stakeholder community is probably more sensitive to these two issues than DOE.

As the $\mathrm{PA}$ is an iterative process internally, so should it be in the public arena. Obtaining public involvement early and substantively throughout the development of the PA is critical. Sound public involvement helps ensure that the public acceptability items listed above are accomplished by identifying and resolving potential stumbling blocks early. It is not critical to have extensive public involvement programs built into the PA. The Hanford Advisory Board's Major Safety and Waste Management Committee is the appropriate body by which to keep stakeholders involved in the development of the PA. The committee is particularly useful as a gauge of stakeholder interest, allowing $P A$ personnel to judge the need for public workshops, public meetings or focused consultations. It is likely that, if involved early, the public involvement may amount to little more than continued dialogue and review cycles with the committee. $\{30\}$.

It is worth noting the public's tank waste treatment and disposal values as they relate to the PA. The public has clearly stated its desire for "getting. on with" tank waste disposal. Included in this umbrella value is the desire for DOE to proceed with the most practical, timely available technology. This value is balanced with the desire for an environmentally safe waste form. The public has deemed glass to be the waste form most responsive to these values.

Implicit in the above values is the public's recognition that leaving the waste in the tanks is an unacceptable alternative. If the best that can be done with practical, timely, available technology (a sound glass in a well-engineered disposal facility) may still result in a relatively significant dose, it will still likely be accepted. In short, to a certain extent, the best that 


\section{HNF-EP-0884}

\section{Rev. 1}

can be done has to be acceptable.

The possibility that the currently envisioned disposal action will result in a dose that is, indeed, so high as to be publically unacceptable, cannot be dismissed. This would likely throw the program into an intensive and extended technology development phase. However, given public values which value retrieval, treatment, and disposal over study, this scenario is highly unlikely.

\subsection{PROGRAMMATIC/GEMERAL COMMENTS}

It is unfortunate that final waste form and acceptance criteria are still unresolved, as this means, even with the specifications put forth in the Request for Proposal, there are still a number of uncertainties that could cause surprises or less than optimum solutions to disposal issues. In the absence of firm criteria, it is important to supply vendors with as much information about the site and wastes as possible, and it seems that this is being done.

The PA program assumes that the final PA will not be prepared until after the first immobilized waste is produced. This seems to be counter to a new direction that DOE is taking in the revised DOE Order, Management of Radioactive Wastes. In the revised DOE Order, a new requirement has been developed for a "Iife Cycle waste Management Plan." For a new facility, such as the Hanford low-level tank waste disposal facility, the "Iife Cycle Waste Management Plan" must be completed before construction of the facility can begin. The "Life Cycle waste Management Plan" is intended to ensure that a viable path to disposal exists for each waste stream produced by DOE. Thus, an approved PA would be an essential component of the "Life Cycle Waste Management Plan." It would seem to be beneficial to review your program and schedule with DOE-HQ to ensure that the program meshes well with the new DOE order requirements. $\{31\}$

The PA program should establish what are the technical goals of the project, $i . e$., when is the information good enough for the intended purpose. A predictive methodology for the next 10,000 years has an uncertainty by itself.

Continuously refining current data input may have only limited uncertainty improvement in the out years. Any additional new data generation should be evaluated on this sensitivity basis. $\{32\}$

The PA has manifold customers, but the PA development team should not try to customize based on assumed needs. What is important is that the PA should be technically defensible, the rest will take care of itself. $\{33\}$ 


\section{HNF-EP-0884}

Rev. 1

Additional data generation needs should be culled whether they add only additional data with the same scatter, in which case they are not useful or if the new data will significantly reduce current uncertainty, in which case they are important. $\{34\}$

- The PA should indicate both best estimate and bounding information. The relationship between these two values is also a good indication where additional data, if any, will improve the final PA. $\{35\}$

- The waste characterization source information should be switched to the Kupfer data as soon as possible. $\{36\}$

- Conservatism should be properly used (i.e., the current assumption that all of the se will be in the LAW fraction is far too conservative while the assumption for future wells to have a 15 -foot well screen is an undefendable non-conservatism). \{37\}

- All assumptions should be clearly identified and justified at the beginning of the PA, and not buried in the body of the PA. \{38\}

- The current privatization vendor inputs and activity should be more closely integrated with the PA development. \{39\}

The possible "unitization" of the PA should be considered along unit operation basis. Release from glass, release from storage facility, transport in vacose zone and transport in ground water are examples. As additional information becomes available, the adjustments can be made easier on a unitized basis than for the entire PA as a whole. $\{40\}$

- The possibility of a third waste form for separated volatiles and semivolatiles should be considered. As an example, the separated TC may have a much better PA result when co-alloyed to form a binary then reintroduced into the melter feed stream. \{41\}

Selenium partitioning is near-identical to the sulfur partitioning during pretreatment and other processing activity. The current assumption that all of the se would be in the LAW is not only over-conservative, but unrealistic. $\{42\}$

- Volatiles and semivolatiles are not well treated in the PA. In the current processing paths, the off gas scrubbers will collect most of these, and what actually goes out in the stack is not identical to what leaves the melter. As mentioned above, whether these should be continuously reintroduced into the melter feed should be an option (if justified), but not a given. $\{43\}$ 


\section{HNF-EP-0884}

\section{Rev. 1}

- The grout vaults would have to be significantly modified for use as an LAW storage facility. The cost of using a modified versus a new specific facility should be justified based on requirements. $\{44\}$

- While there was indication that the site vadose zone and groundwater studies are starting to be coordinated, the actual picture is still that there are many duplicated uncoordinated efforts in this aspect. Neither the vadose zone nor the ground water will differentiate in isotope transport based on the exact source of the isotopes. \{45\}

It is not clear if other Site's PA reports have been reviewed for comparison of detail, assumptions, and indicated uncertainties. $\{46\}$

\subsection{CONCLUSIONS}

The preparation, review and approval of a PA is a complex and challenging undertaking. The panel members generally agree that many of the issues important to long-term performance of the planned disposal action have been addressed. A notable caveat to this conclusion is the lack of a clear presentation of assumptions and the difficulty a reader has in understanding the sources and reasonableness of data used for the PA preparation since much of the information is in other references or not well justified. Information must be presented in the next issue of the PA justifying the assumptions and subjective choices that have been made.

Future LLW disposal project activities including the preparation and review of the $P A$ need to consider and incorporate the following:

Develop and present a best estimate case as well as bounding cases. This would serve to portray the best estimate of long-term performance of this disposal action as well as presenting how good or bad things could get. $\{47\}$

- The waste form characteristics currently have a great deal of uncertainty due to the preliminary nature of the DOE privatization plans for the production of immobilized LAW. The low-level waste disposal project/technical personnel, DOE, and the private companies need to communicate and share information as much as possible within contract limitations to assure cost-effective success for waste treatment and disposal. $\{48\}$

The lack of long-term geologic stability, as reflected in the likelihood of catastrophic glacial flooding during the period in which the waste will remain hazardous, make the currently proposed site vulnerable to regulatory disqualification for such long-term wastes. $\{49\}$ 


\section{HNF-EP-0884}

\section{Rev. 1}

- The geotechnical aspects of the PA, that is, the analysis describing the release and transport of contaminants through the disposal site, vadose zone, and groundwater needs considerable work to enable an informed reader to clearly understand the assumptions and modeling parameters employed to project the impact of the disposal action over time. The "Integrated Site Characterization Plan" should be updated and reviewed to determine the scope of future data collection needs, if any. $\{50\}$

- The DOE PA review and approval process has recently changed. Project personnel and the PA team should contact the new federal group responsible for reviewing PAs to get an early indication if current plans will be successful for obtaining PA approval. \{51\}

- The project should develop a dialogue with the Hanford Advisory Board as the primary means to assure public participation and acceptance. $\{52\}$

- Project planning needs to consider the new DOE requirements for "Life Cycle waste Management Plan." \{53\} 


\section{HNF-EP-0884}

Rev. 1

\section{APPENDIX A HANEORD LOW-LEVEL TANK WASTE PA REVIEW PANEL MEMBERS}

Lynn Gelhar Ralph M. Parsons Laboratory.

Department of Civil Engineering

Massachusetts Institute of Technology

Cambridge, MA 02139

(617) . 253-7121

fax: (617) 258-8850

email: gelharemit.edu

Professor Gelhar is a nationally and internationally-recognized expert in groundwater modeling. He is currently a professor at the Department of Civil and Environmental Engineering at the Massachusetts Institute of Technology. Dr. Gelhar has been awarded numerous research grants in the area of groundwater hydrology by the U.S. Envixonmental Protection Agency, the National Science Foundation, the U.S. Nuclear Regulatory Commission (NRC), the U.S. Geologic Survey, the American Petroleum Institute, the National Institute of Environmental Health, and the Tennessee River Authority. He has received several highly-prestigious awards and honors from technical and professional societies. Dr. Gelhar has published extensively in peer-reviewed journals such the water Resources Journal, American Society of Civil Engineers, and the Ground Water. He is knowledgeable concerning Hanford modeling efforts as he served on the expert panel at the Hanford vadose zone modeling workshop held March 1993.

Louis Kovach 7000 Huntley Road

Columbus, OH 43229

(614) $846-5710$

fax: (614) 431-0858

email: Louis_kovacharl.gov

Dr. Kovach is a private consultant on nuclear waste management and the president of NUCON International, Inc. He has been involved in various radiochemical processing activities starting in 1968 with consulting for the Atomic Energy Commission, and later to the NRC and the Advisory Committee on reactor safety. Dr. Kovach has chaired various Organization for Economic Cooperation and. Development and Internal Atomic Energy Agency safety groups on post-accident and post-sever accident recovery plans. He is a member of the Hanford Tank Advisory Panel. Dr. Kovach chaired the independent review team for the Tank waste Remediation system (TWRS) environmental impact statement and the Hanford HLW volume reduction independent review. Dr. Kovach is the author of numerous articles and book chapters on nuclear waste management and other pollution control processes.

Dr. Kovach is a visiting lecturer at the Harvard school of Public Heath, a position he has held for 14 years. 


\title{
HNF-EP-0884
}

\section{Rev. 1}

Todd Martin

\author{
Hanford Education Action League \\ 1408 West Broadway Avenue \\ Spokane WA 99201-1902 \\ (509) $326-3370$ \\ fax: (509) 326-2932 \\ email: healtmeaol.com
}

Mr. Martin has been a knowledgeable critic of Hanford activities for a number of years, and serves on the Hanford Advisory Board. He is also a member of the Hanford science and Technology Coordination Group. The disposal of immobilized LAW is a subject of particular interest to Mr. Martin, and his insight would aid the successful deployment of this project.

\section{Bill Prindle 1556 Crestline Drive \\ Santa Barbara CA 93105 \\ (805) 687-0446 \\ fax: (805) 682-6476 \\ email: wprindleaaol.com}

Dr. Prindle is a private consultant. He is retired from corning Glass where he was the Vice President and Associate Director of Technology (1990-1992), and Associate Director of Research, Development, and Engineering (1987-1990). Dr. Prindle was the vitrification expert member on the Hanford Waste Management Technology Advisory Committee, and chaired the External Advisory Panel for the Phase I Source Evaluation Board for LLW melter testing.

Dr. Prindle is a Fellow of the American Ceramic Society and was president of the society in 1980-1981. He was also president of the International Glass Congress XII (1980), and the International Commission on Glass in 1985-1988. He is also a Fellow of the Society of Glass Technology.

Elmer Wilhite

\author{
Westinghouse Savannah River Company \\ Post Office Box 616 \\ Aiken SC 29802 \\ (803) 725-5800 \\ fax: (803) 725-4704 \\ email: elmer.wilhiteesrs.gov
}

Mr. Wilhite is an advisory scientist at the Savannah River Technology center. He serves as the chairman of the DOE-HQ PRP. This panel, chartered in DOE order $5820.2 \mathrm{~A}$, performs the technical review of all LLW PAs submitted to the DOE for approval. In addition, Mr. Wilhite has taken an active role in waste management at the Savannah River site. 


\section{HNF-EP-0884 \\ Rev. 1}

George Williamson 254 Rockwood Drive

Richland WA 99352

(509) 627-4924

email: gwillia524daol.com

Before retiring from the Westinghouse Hanford Company in 1996 , Mr. Williamson was the Project manager of the TWRS Low-Level Waste Disposal Project. He has many years of experience researching and managing the disposal of Hanford low-level tank waste. Mr. Williamson has the unique perspective of understanding the needs of the project as well as the constraints of the TWRS organization. 


\title{
HNF-EP-0884
}

\author{
Rev. 1
}

\author{
APPENDIX $B$ \\ COMMENTS ON GEOTECHNICAL ASPECTS OF THE INTERIM RA \\ by $D x$. Lynn Gelhar
}

\section{GEOTECHNICAL ASPECTS}

\section{Geologic Stabjlity and Glacial Flooding Scenario}

The proposed waste inventory includes substantial amounts of long-lived nuclides which will remain hazardous for tens of thousands of years, and within that time frame it is likely that the proposed site will be inundated by glacial flooding, as has occurred frequently in the very recent geologic past (as recent as 13,000 years ago). The consequences of the likely event of catastrophic glacial flooding are not being taken very seriously (only a short paragraph at the end of Chaptex 4). The flooding could result in exosion which exhumes the waste storage facility, making it directly accessible at the surface. For example, what would be the consequences of a child adopting a waste marble as a plaything? The 200 Area seems that it could be particularly vulnerable to flooding effects being just downstream from the gap between Gable Mountain and Gable Butte. \{101\}

It would seem sensible that areas of the Hanford site which may be less vulnerable to flooding effects be considered in siting the facility. Another approach would be to alter the waste composition so that the waste material would produce minimal hazard after 1,000 years. It is important for management to recognize that the lack of long-term geologic stability, as reflected in the catastrophic flooding potential, makes the currently proposed site vulnerable to regulatory disqualification for such long-lived wastes. \{102\}

\section{Form of Presentation and Technical Defensibility}

The overall organization of the documents seems well thought-out and logical, but in several places, the intended message does not come through very well. The documents are very uneven in the degree of details that is provided; in many places, crucial facts are left out, whereas other parts seem to be unnecessarily detailed. The interim PA and supporting documents (Data Packages and Definition of Base Analysis Case) rely too heavily on references to other documents without offering any explanation or assessment of the information from those sources. There seems to be many assumptions, ambiguities, uncertainties, and subjective choices which are hidden away in secondary or tertiary references. This makes it extremely difficult for the reader to develop any independent judgement about the adequacy of the assumptions regarding processes and parameters incorporated in the interim PA. In many cases, the form of the graphical presentation of the modeling results is not at all useful to a reader trying to assess the reliability of the results and the likely controlling process. Some specific suggestions about how 


\section{HNF-EP-0884}

\section{Rev. 1}

the document could be improved are noted in the technical comments that follow, but technical editing is not part of the panel's responsibility. In many cases the Grout Program PA is cited as a basis for parameter values adopted, without any explicit justification. This would not seem to be a technicallydefensible approach since the Grout PA apparently was found to be inadequate. The individual contributors to the documents need to think carefully about what information a technically-informed reader needs in ordex to be able to assess the soundness of the results. This information must be provided in the interim $\mathrm{PA}$ and supporting documents with explicit discussions acknowledging and justifying the assumptions and subjective choices that have been made. The natural tendency of modelers is to avoid or suppress such ambiguities in favor of the precise mathematical details of a computer code. A formal internal technical review process should be instituted to assure that adequate technical information is included in the PA documents. Such critical reviews need to be done by peers in the same technical specialty to assure that the nuances of the discipline are understood and appropriate technical information is included. \{103\}

\section{Geotechnical Issues and Concerns}

The key geotechnical concerns regarding the interim PA are discussed by reference to the path that water may take through the waste facility and the surrounding natural subsurface environment. The discussion focuses on process and parameter uncertainties which may not be adequately reflected in the interim PA.

\section{Recharge and Infiltration}

The source of water which could enter the facility and transport waste to the water table is precipitation which has averaged around $160 \mathrm{~mm} / \mathrm{yr}$ over the last 50 years. In the interim $\mathrm{PA}$, it was assumed, based on the recommendation of Rockhold (1995), that the near-surface Hanford Barrier would effectively limit the water infiltration rate above the waste facility to $0.5 \mathrm{~mm} / \mathrm{yr}$ over the next 1,000 years, after which the rate is assumed to increase to $3 \mathrm{~mm} / \mathrm{yr}$. The recommendation of Rockhold (1996) which is based on eight years of lysimeter measurements complemented by computer simulations, seems to represent the most favorable vegetative cover (deep-rooted sagebrush), and presumes that the Barrier's 1,000 year design life will assure that infiltration is limited to $0.5 \mathrm{~mm} / \mathrm{yr}$ over that period. No explicit consideration of changes in climate, vegetation, or soils (wind erosion) are included though such changes are likely in the 1,000 year period; it would seem that the infiltration rate could easily increase an order of magnitude or more as a result of such changes during that period. In view of such uncertainties, it does not seem reasonable to describe the $0.5 \mathrm{~mm} / \mathrm{yr}$ value as conservative ( $\mathrm{p}$. 13. Data Packages). The value of $3 \mathrm{~mm} / \mathrm{yr}$ used after 1,000 years (out to 100,000 years or more) also is not conservative; Rockhold (1996) recommends a natural recharge of 5 to $25 \mathrm{~mm} / \mathrm{yr}$ for vegetation ranging from sagebrush to grasses under current 


\section{HNF-EP-0884 \\ Rev. 1}

climatic conditions. Major climate changes can be anticipated over the next 100,000 years. At the extreme, glacial flooding could produce an infiltration rate on the order of the saturated hydraulic conductivity $\left(10^{7} \mathrm{~mm} / \mathrm{yr}\right.$ for the backfill soil). Even under current climatic conditions, the effects of plausible transient infiltration events could also produce greatly increased infiltration. If a major winter snow accumulation (say, $100 \mathrm{~mm}$ water content) melts over a few days when there is essentially no evapotranspiration, this would correspond to an infiltration rate on the order of $104 \mathrm{~mm} / \mathrm{yr}$. How does the Hanford Barrier and the gravel capillary break function under such transient conditions? \{104\}

Contrary to the recommendation of Rockhold (1996), the interim PA assumes that the infiltration rate of $0.5 \mathrm{~mm} / \mathrm{yr}$ applies over the entire modeled surface area extending beyond the Hanford Barrier to the edge of the modeled area. Rockhold (1996) recommends using $75 \mathrm{~mm} / \mathrm{yr}$ at the edge of the Hanford Barrier, but only in the Data Packages ( $p .13$ ) do we find an attempt to justify the assumption to disregard this recommendation. It is very likely that there will be some surface runoff and/or lateral subsurface flow from the barrier which increases the infiltration rate at the edge of the barrier. Certainly there is no justification for neglecting the increased infiltration corresponding to natural recharge outside of the barrier-covered area. Moisture entering from the natural surroundings can have a crucial influence on the rate of transport from the waste facility because of the natural tendency for lateral flow in these heterogeneous stratified sediments, as discussed in more detail below. Even in the backfill material beneath the Hanford Barrier but above the capillary break, such lateral flow could be significant because typical construction would likely create some layering in the soil. On p. 44 of the Definition of Base Analysis Case we find, inappropriately identified as a "calculational assumption, " the statement (Table 14-1) that the initial moisture content of the natural vadose zone soils was determined by the initial recharge rate. What initial recharge rate was actually used and what are the corresponding initial moisture contents in each zone? \{105\}

\section{Capillary Barrier}

The gravel capillary break/barrier above the waste storage vault is intended to function as a sloping roof which diverts infiltrating water around the stored waste. Though the numerical modeling indicates that this capillary barrier is quite effective, there is little field experience with large facilities of this kind that establishes the effectiveness of such barriers of the long periods involved here. This flow configuration with fine soil over coarse soil is one that is known to be particularly susceptible to flow instabilities which create narrow channels through which water moves rapidly and once such channels are established, water tends to enter the preferential flow paths repeatedly (e.g., see Glass, 1991). This mechanism of flow channeling is not represented in the vadose zone flow numerical model which considers only homogeneous zones. The 


\section{HNF-EP-0884}

Rev. 1

possibility of failure of the capillary barrier by flow in preferential channels is not even mentioned in the PA documents. Such failures of the capillary barrier system would be most likely under transient high infiltration events as noted above. The interim PA claims to look at a sensitivity case representing failure of the capillary barrier, but that case is so poorly described as to make it impossible to judge whether the tested situation is meaningful. Even if one looks into Piepho (1996) (p. 8), it is not possible to discover what configuration and condition was actually tested. Which half of the gravel was replaced by backfill soil $2 / 3$ of the way down from the apex? What is the actual configuration used and why does this make sense? The functioning of the capillary barrier likely will be very sensitive to the contrasting unsaturated flow properties of the backfill and gravel soils used in the model, but there is no discussion of the basis for selecting the adopted parameters of those materials (Table 3-4) in the interim PA documents. It is unacceptable to simply refer to the Grout PA for justification of the parameter values selected without any discussion of the rationale for or limitations of the selections. The interim PA should include and discuss graphs contrasting the unsaturated hydraulic characteristics of the different materials represented in the vadose zone model (Tables $3-3$ and $3-4$ ); plots of both tension versus moisture content and conductivity versus tension are very helpful to understand the behavior of the flow at the interfaces between different materials. What happens to the gravel capillary barrier under saturated conditions that could be produced by glacial flooding? It is likely that the interim PA modeling results are an overly optimistic representation of the long-term effectiveness of the capillary barrier. \{106\}

\section{Flow and Diffusion in the Facility}

The vadose zone flow modeling seems to be predicting that very little liquid water will flow into the waste storage vaults, judging from the strong sensitivity of the transport result to the molecular diffusion coefficient (Figure 4-23). Because of the very limited graphical presentation of the results (Figure 4$9)$, it is not possible for the reader to sense of how much flow is passing through and around the storage facility. A graph showing the vertical water flux distribution into the facility across the top of the waste vaults should be included. Streamline patterns should also be used more effectively to quantitatively demonstrate the flow conditions; uniformly spaced streamlines originating at the top of the model, where a uniform flux of $0.5 \mathrm{~mm} / \mathrm{yr}$ was applied, would portray the portion of the inflow which is diverted around the waste. Figures 4-6 through 4-9 present only the uninteresting part of the flow pattern; closely spaced streamlines originating very near the apex (left boundary) would illustrate how much water enters the waste vaults and how it moves through the vaults. The graphs should also present both moisture content, tension, and concentration as this makes it easier for the reader to visualize the influence of discontinuities in the hydraulic characteristics. Detailed plots for the Concept 2 simulations mentioned on p. 4-36 should also be 


\section{HNF-EP-0884}

Rev. 1

included. Saturation plots such as Figure $4-9$ can be misleading because they do not show the absolute amount of moisture which controls solute transport via molecular diffusion according to the unnumbered equation at the bottom of $p .3-25$ of the interim $\mathrm{PA}$. That equation seems to be incorrect; the minus sign preceding the 10 is wrong according to $\mathrm{p}$. E-A-4 of the Data Packages. This error is repeated on $\mathrm{p} .27$ of the Definition of Base Analysis Case. Certainly, the diffusion coefficient does not decrease with increasing moisture content as indicated by the equation on $p$. 3-25. This equation is presented with no justification other than a nonspecific reference to the Grout PA. There must be some discussion of the basis for the diffusion relationship adopted, and its limitations and uncertainties. There seems to be some mix-up in the sensitivity analysis on the diffusion coefficient. In Table 3-15 (p. 3-74) it is indicated that the diffusion coefficient was increased from $1.25 \times 10-7$ to $1 \times 10-6 \mathrm{~cm} 2 / \mathrm{sec}$ whereas the results in Figure $4-23$ indicate a decrease to 0.05 times the base case. Judging from the strong sensitivity seen in Figure 4-23, the increase could produce adverse results. Why aren't the results for the increased diffusion coefficient presented? The diffusion coefficient issue is further confused by the fact that two different definitions of dispersion/diffusion coefficient are implied by the discussions in D.2.3 (interim PA, Appendix) and $p . E-A-3$ of the Data Packages. Effectively, they differ by a moisture content multiplier, and because moisture content is apparently very small in the vaults, this can be an important difference. The code kludge mentioned on $p .3-63$ and discussed on $p .2$ of Piepho (1996) does not clarify this matter. Which form of the diffusion coefficient is represented by the equation on $p .3-25$ ? $\{107\}$

\section{Water Vapor Diffusion}

Because the vadose zone modeling indicates that the capillary barrier is very effective in diverting infiltrating liquid water around the waste, it is important to consider the possibility of diffusive transport of water vapor into the facility through the soil gas. Under isothermal conditions, water vapor will diffuse through the medium from areas of low tension to areas of high tension if there is gas-filled pore space. This water vapor transport can be represented, to first approximation, by simply modifying the unsaturated hydraulic conductivity at high tension. Appendix $\mathrm{D}$ of the interim PA (p. D-2) briefly mentions the mechanism of water vapor diffusion, but does not indicate that this effects has been incorporated in the model. Certainly, the adopted van Genuchten relationship for the unsaturated hydraulic conductivity (p. 3-24) does not represent this effect. Increased moisture in the facility would lead to increased diffusion of solutes because of the increase of the effective molecular diffusion coefficient and increased gravity-driven advection because the unsaturated hydraulic conductivity is increased. \{108\} 


\section{HNF-EP-0884}

Rev. 1

\section{Vadose zone Modeling}

The description of the finite difference grid used in the vadose zone simulations is inadequate. Only by ferreting out Piepho (1996, p. 3) can one find a graphic showing the grid used, but in that figure the crucial detail of the grid in and above the waste vaults can not be seen. Information on the grid detail, particularly in areas of sharp contrast in hydraulic properties, is crucial for the reader to be able to judge the potential accuracy of the simulations. Graphics which show the grid detail in areas of the capillary barrier and the waste vault are absolutely essential to supplement the limited word descriptions on p. 3-62. The graphics should show grid detail in relation to a clear delineation of all of the different material zones actually represented in the model, along with a table that 1 ists the flow and transport properties of all of the different zones. It is certainly not reasonable or appropriate to expect the reader to decipher the input file listings in Appendix D. A particular concern is the grid resolution in the backfill material between the waste canisters. On $p .3-62$, it is indicated that a 1 x 9 (horizontal to vertical?) grid was used in the backfill between the canisters and that the contaminant releases are, in some unspecified fashion, "...considered to be at the surface of the waste containers." Is this a flux boundary condition? It is difficult to see how one can expect much accuracy in representing diffusive transport calculations using only a single grid point. Apparently, sensitivity to grid spacing has been tested only for the less realistic cell model (Table 4-32); Piepho (1996) does not say anything about testing for grid effects for the full facility models. Graphics showing the grid and a table specifying the flow and transport parameters actually used in each zone.are also required in the case of the cell model (Figure 3-8). Why is the contaminant source volumetrically distributed (p. 3-65); is the waste form taken to be permeable; how is its permeability arrived at? Also, it is unclear how the PORFLOW code was actually interfaced with ARESTCT (p. 3-56). What is the basis for the AREST-CT setup described on $p .3-81$ ? What is the flow configuration and what does the grid look like? What is the basis for the assumed "pore velocity" of $1 \mathrm{~cm} / \mathrm{yr}$ ? Appendix $\mathrm{C}$ tells nothing about what was actually done and why. $\{109\}$.

\section{Vadose Zone Hydraulic Properties}

As water moves down through and around the waste facility, it enters the undisturbed Hanford formation, a heterogeneous imperfectly layered system of predominantly sand and gravel formed as a result of glacial flooding. The interim PA. represents this heterogeneous layered system as two thick homogenized layers, an upper sandy zone and a lower gravely zone, each of which is assumed to be hydraulically homogeneous and isotropic. The actual data in Appendix I of Appendix 0 of the Data Packages show large variations of hydraulic properties within the two thick layers. Many studies, including work at the Hanford Site (Kline and Khaleel, 1995), have shown that such 


\section{HNF-EP-0884}

Rev, 1

layered heterogeneous soils behave anisotropically in bulk, with the hydraulic conductivity parallel to the layers (horizontal) being larger than that in the vertical. Furthermore, the degree of anisotropy is found to increase rapidly with increasing tension or decreasing moisture content, becoming very large in dry soil of the kind encounter under natural conditions at Hanford. Consequently, the infiltrating water diverted around the waste by the capillary barrier is very likely to move back beneath the vaults, creating moist conditions under the waste facility which will reduce the travel time through the vadose zone. In contrast, the interim PA simulations show the diverted water moving primarily moves downward (see Figure 4-9) leaving a dry wake below the facility and slowing the migration of contaminants through the vadose zone. It is difficult to understand why this effect of the fine-scale layering in the vadose zone was not considered in the interim PA. An option to handle tension-dependent anisotropy is already available in PORFLOW (Kline and Khaleel, 1995), so that it should be relatively simple to test the influence of lateral flow under the facility. Kline and Khaleel (1995, Figure 1) indicate anisotropy ratios of over 1,000 even for relatively moist soils (tensions less than $50 \mathrm{~cm}$ ). It may not be possible to precisely predict the degree of anisotropy, but there are some data on the variability of unsaturated conductivity that could be used to get a plausible estimate. That would certainly seem better than to ignore a mechanism that is know to influence vadose zone water movement at Hanford. When anisotropy effects are included, it will likely be necessary to extend the modeled domain to encompass more undisturbed terrain (with its larger infiltration [recharge] rate) because water from that wetter environment will also tend to be drawn in under the facility. Because of subtle layering in the backfill material, some water may also tend to move back under the Hanford Barrier. A vertical capillary break extending down from the end of the Hanford Barrier may need to be constructed to prevent this. \{110\}

There are substantial unacknowledged uncertainties in the vadose zone hydraulic data presented in Appendix O (Data Packages) which form the basis for Table 3-3 of the interim PA. First, it is likely that recovery and disturbance of samples is more of a problem with gravely materials than with sands. Open-work gravels are likely to be destroyed or filled with fines during sample processing. This may greatly decrease the permeability relative to in situ values in the gravels. Second, the gravel correction procedure ( $p$. O-6) adopted from Bouwer and Rice (1983) likely is suitable only for a limited amount of gravel. What evidence is there that these corrections are suitable for the very high gravel content of the Hanford gravel samples? These corrections can significantly reouce saturated conductivity and porosity; possibly the unusually low values of porosity and saturated conductivity used for the Hanford gravel (Table 3-3) are related to this potential problem. The uncorrected values of saturated conductivity and porosity should also be include in Appendix 1 of Appendix 0 to allow the reader to judge the importance of this effect. Third, the van Genuchten method which 


\section{HNF-EP-0884}

\section{Rev. 1}

was used to predict unsaturated hydraulic conductivity from moisture retention curves and saturated conductivity has been demonstrated to be quite unreliable for a variety of soils (Yates et al., 1992, Figure 1C) and for Hanford formation soils (Khaleel et al., 1995, Figure 6); predicted unsaturated conductivities can range over at least 4 orders of magnitude relative to observed unsaturated conductivity with the largest errors occurring for the dry conditions of interest in the interim PA. It would be better to put much more weight on samples where unsaturated conductivity was measured directly in the range of tension or moisture content of interest. The samples for which direct measurements of unsaturated conductivity are available should be identified in Appendix 1 of Appendix 0 . Finally, the recommend values (Table 3-3) for the homogenized zones where obtained by taking arithmetic averages of the van Genuchten parameters. Why is this a sensible procedure when dealing with nonlinear processes of this type? stochastic upscaling analysis leading to macro anisotropy is a more defensible way of aggregating the data. In that context, the cross-correlation between the parameters will play a significant role; the univariate statistics discussed in Appendix 0 only partly characterize the variability the vadose zone flow properties. Obviously the sensitivity analysis in the interim PA (p. 459), involving the interchange of the properties of the thick homogenized layers only for the cell model, is practically meaningless as far as reflecting the large uncertainties in the unsaturated hydraulic properties. \{111\}

\section{Dispersion in the Vadose zone}

Field-scale dispersive mixing in the vadose zone can be an important process producing dilution which can decrease concentrations and early arrival which, in the case of decay species, can lead to higher concentrations. The interim PA is devoid of any discussion of the basis for selecting the dispersion parameters. There is a passing reference on $p$. 3-25 to "the dispersion coefficient of the contamination was taken to $0.1 *$ travel length in the direction of travel," but we are not told what value was actually used and why. The statement is incorrect on first principles; apparently they have in mind the longitudinal dispersivity, which, when multiplied by the velocity, produces the longitudinal dispersion coefficient, and have adopted an old, largely discredited, rule-of-thumb which has been used for saturated flow. There is no discussion of whether this choice is appropriate for the dry unsaturated conditions of the site or what the uncertainties may be in this choice. Yet the sensitivity analyses considered only a minor change in dispersion coefficient (by a factor of 2) only for concept 2, and the less realistic cell model (p. 4-61), and even in those cases no graphical results are presented to show the influence on the breakthrough curve. The data summary for unsaturated longitudinal dispersivity in Chapter 5 of Gelhar (1993) could serve as a guide to the selection of appropriate values, though those field studies likely are for smaller scale, wetter conditions. $\{112\}$ 


\section{HNF-EP-0884}

\section{Rev. 1}

Based on theoretical analysis of macrodispersion in unsaturated media, it is predicted that the longitudinal dispersivity could increase dramatically as the soil become drier. Only in Piepho (1996) do we discover that a longitudinal dispersivity (p. 2 , improperly called the longitudinal dispersion coefficient) of 8.5 $\mathrm{m}$ was apparently used in the Definition of the Base Analysis Case, but on p. 9, we find statements that for sensitivity cases of $1 / 2$ and 2 times the base case, values of $42.5 \mathrm{~m}$ and $170 \mathrm{~m}$ respectively were used. What was actually used in the base case? In the Definition of the Base Analysis Case, "values for dispersion" (p. 44) are ludicrously classified as "calculational assumptions; " by this logic every numerical value used in the model could be described as a calculational assumption. In Piepho (1996, p. 2), we discover that dispersion was actually neglected entirely in the disposal facility itself because ". . these relatively large values of dispersion would overstate the release from the disposal facility...". The dispersivity for the backfill may indeed be smaller than that of the more heterogeneous natural materials, but that is no reason to neglect a real phenomenon which may increase the release. A defensible approach would be to assign a dispersivity that is an order of magnitude lower in the backfill material, and see how the results are altered. Because the dispersion coefficient is the product of the velocity and the dispersivity, if the velocity in the waste facility is very small there will be little effect. This would be much better than neglecting the process entirely; velocities need not be very large before dispersion dominates diffusion.

All of the machinations in the interim $P A$ regarding the dispersion coefficient leave an impression of a lack of familiaxity with even the most rudimentary concepts of fieldscale dispersive transport in porous media and a lack of proper attention to detail, thereby serving to discredit the work. The interim PA simulations presume that the dispersivity is the same for all of the transported species. Recent theoretical developments and field experiments have shown that the dispersivity of solutes undergoing heterogeneous linear equilibrium sorption can be significantly larger than the dispersivity of a nonsorbing (conservative) solutes. The aquifer tracer experiment reported by Garabedian et al., (1987) indicates that the dispersivity for a sorbed tracer is an order of magnitude larger than that of the non-sorbed tracer. Simulations of solute transport in the context of performance assessment for a low-level radioactive waste disposal site (Talbott and Gelhar, 1994) show that, for sr90, the concentration at an offsite point of potential exposure would be 10 orders of magnitude larger when heterogeneous sorption enhancement of dispersion is included as compared with the traditional case of an unaffected dispersivity. Though it is not known how important this dispersion enhancement mechanism is in the vadose zone, it seems prudent to consider the possibility of such dispersivity enhancement. There is no mention of the possibility of dispersion enhancement for sorbed species in the interim PA or supporting documents. This is a serious omission because this mechanism could produce larger 


\section{HNF-EP-0884}

Rev. 1

releases to the groundwater in the cases where the half-life of the species is of the same magnitude as their travel time to the water table.

\section{Sorption in the Vadose zone}

The adopted $\mathrm{kd}$ values (Table $3-5$ ) do not reflect some effects and uncertainties inherent in the information of Appendix $Q$ of the Data Packages. Different interpretations of this information could lead to significantly different best estimate values as illustrated by the following examples.

Looking first at $U$, which dominates the alpha release (Figure 417), we see from Table 6.1 that there is an important decrease of Kd with moisture content. Regardless of whether the "\%

saturated" means saturation or moisture content, the lowest value (seven percent) is most appropriate for the dry conditions under the waste facility. This suggests that best estimate of $0.1 \mathrm{ml} / \mathrm{g}$ rather than 0.6 used in the simulations, and that does not take into account the gravel correction recommended on p. Q-iii. For the Hanford gravel which has well over 50 percent gravel in most sample (Appendix O) it would be reasonable to reduce the $\mathrm{Kd}$ to 0.05 , and in view of the fact the Trench 8 soil, a loamy sand, likely contains a fair amount of fines, a further reduction in the Hanford sand may also be appropriate. The very high value of $\mathrm{Kd}(79.3 \mathrm{ml} / \mathrm{g})$ reflects the high silt and clay content of this soil and indicates the likely importance of soil grain size distribution in affecting $\mathrm{Kd}$. Appendix $\mathrm{Q}$ should include actual grain size distributions (or at least summary textural information as in Appendix 1 of Appendix 0) for all of the samples, so that the reader could more explicitly assess such effects. Looking at I (Table 2.1), it becomes evident that there are two populations represented there, one eolian surface material, Rupert sand, tested with synthetic aqueous phase (the last six samples), and the other three samples of subsurface materials, tested with formation water which are more likely to be representative of soil beneath the waste facility. The average of the first three samples gives an average kd of 1.1 $\mathrm{ml} / \mathrm{g}$ (compared with $3 \mathrm{ml} / \mathrm{g}$ in Table 3.3 ), and this does not take any account of unsaturation effects. Judging from the $U$ unsaturated column experiments, this reduction could be a factor of 5 , so we have $0.2 \mathrm{ml} / \mathrm{g}$ and for the Hanford gravel this would gravel correct to $0.1 \mathrm{ml} / \mathrm{g}$. $\{113\}$

These examples show that equally plausible, technicallydefensible interpretations of the data can yield Kd best estimate values that are an order of magnitude lower than those used in the interim PA calculations. Of course, there are large uncertainties in all of the estimates because of the small sample size and the limited understanding of the unsaturated and gravel effects, among other things. Appendix $P$ reviews of the many of the complications in determining appropriate field kd values and lays out some general plans to resolve some of the issues. However, this material does not address what is likely the most important and difficult issue, i.e., how to representatively 


\section{HNF-EP-0884 \\ Rev. 1}

sample and analyze this highly heterogeneous medium to arrive at bulk Kd that will properly reflect the sorptive properties of an entire zone or geologic layer in the model. This issue has been addressed in the case of saturated flow via stochastic upscaling theory (Gelhar, 1993, section 5.4); it is found that the effective bulk kd should be simply the arithmetic mean, and that spatial variability of $\mathrm{kd}$ can dramatically enhance the longitudinal dispersivity of a heterogeneously-sorbed contaminant, particularly when there is a negative correlation between $k d$ and hydraulic conductivity variations. The key point is that in order to predict the dispersivity enhancement, one must appropriately measure the $\mathrm{kd}$ and hydraulic conductivity on the same laboratory samples so that this correlation can be evaluated. The picture is more complicated in the unsaturated flow case because the variation in velocity is affected by the flow conditions (moisture content) and the variation in $\mathrm{Kd}$ is, according to the $U$ column experiments, also dependent on moisture content.

Furthermore, a dry vadose zone may be sorptively advantaged in the sense that water may tend to be moving primarily through the finer grained more sorptive materials because coarse materials tend to have lower unsaturated conductivity at high tension or low moisture content. Such effects can not be represented without information on the interrelationship between unsaturated flow and sorptive properties. It would seem to be a relatively simple matter to modify the unsaturated sorption column experiments to be able to simultaneously determine unsaturated hydraulic conductivity and moisture retention relationships.

\section{Aquifer Flow and Contaminant Transport}

The degree of mixing and dilution as contaminants move into and with the groundwater flow to the well at $100 \mathrm{~m}$ is a very important element of the PA calculations; in the interim PA, almost 3 orders of magnitude concentration reduction is attributed to processes in this zone. One of the reasons for this concentration reduction is the dilution caused by assuming that contaminated water is mixed with clean water at the well as a result of withdrawing water from the aquifer through a $5 \mathrm{~m}$ long well screen. The fact that a $5 \mathrm{~m}$ well screen was assumed it is not stated in the interim PA or supporting documents; it was ascertained through discussions with Fred Mann. This well screen length seems to be much longer than would be required to supply the amount of water used by a single household from this very permeable aquifer; a $1 \mathrm{~m}$ long screen is more plausible. The consequence of decreasing the screen length to $1 \mathrm{~m}$ would be roughly a five-fold increase in concentrations. Another important factor which controls the degree of mixing in the aquifer (not in the well), is the vertical transverse dispersivity used in the transport calculations in the aquifer. The dispersivities used in the aquifer transport calculations do not seem to be specified in the interim PA, Data Packages, or Definition of Base Analysis Case; the only dispersivities given for the aquifer model seem to be in Lu (1996, p. 17) based on 


\section{HNF-EP-0884}

\section{Rev. 1}

fitting the large tritium plumes extending to the Columbia (longitudinal dispersivity $30.5 \mathrm{~m}$, transverse horizontal. $3.0 \mathrm{~m}$, transverse vertical $3.0 \mathrm{~m})$. It is very doubtful that there is any justification for using such an extremely large vertical dispersivity in these stratified sediments; all reliable field experiments indicate vertical transverse dispersivities in such materials are on the order of a mm or less (Gelhar et al., 1992; Van der Kamp et al., 1994). Larger values usually represent inadequate vertical resolution of sampling (in-well mixing which is likely the case in the long-screened monitoring wells at Hanford) or inadequate vertical resolution in the numerical transport model. Vertical discretization may be a problem in the interim PA work, but since the grid spacing in the vertical is not given, one can't tell. The vertical transverse dispersivity is an important parameter because it is the dominant in situ mixing and dilution mechanism in this situation with slowly varying contaminant input. Due to vertical dispersion, the solute will mix over a zone with thickness on the order of the square root of the product of the vertical dispersivity and the distance traveled $(100 \mathrm{~m}$ to the well). If the vertical dispersivity is $3 \mathrm{~mm}$ the mixed zone is around $0.6 \mathrm{~m}$; if the vertical dispersivity is $3 \mathrm{~m}$, as was apparently used in the interim PA calculations, the mixed zone would be represented as being 30 times thicker, and because the mass flux into the aquifer is fixed, the in situ concentration is 30 times lower than the realistic case. The $30.5 \mathrm{~m}$ longitudinal dispersivity is probably too high, judging from the Columbus experiment; a value of around $10 \mathrm{~m}$ would be reasonable for this heterogeneous aquifer. However, longitudinal dispersion is not likely to be very important because of the quasi-steady nature of the plume. Enhancement of longitudinal dispersion for heterogeneously-sorbed species, as discussed above in the vadose zone, is also likely in the aquifer. Another factor that has an important influence on the amount of dilution in the aquifex is the ratio of the vertical flux of contaminated water (from the vadose zone) to the horizontal specific discharge in the aquifer. Because the hydraulic gradient is decently known the main source of uncertainty regarding aquifer flow characteristics is the horizontal hydraulic conductivity in the site area. The unusually low effective porosity used in the interim PA calculation $(0.1$, Table $3-6)$ may be artificially accelerating the arrival of contaminants at the well, but this is not likely to significantly affect the overall results because the travel time in the aquifer is so small compared to the vadose zone. The calculations of aquifer contaminant transport were based on the assumption of a uniform input flux of contaminant over the area of the facility (Lu, 1996, p. 32) aquifer. A graph showing the spatial distribution of the modeled contaminant flux from the vadose zone is needed to judge the appropriateness of this assumption. The effects of the aquifer contaminant transport factors discussed here are not addressed in the sensitivity studies in the interim PA. \{114\} 


\section{HNF-EP-0884}

Rev. 1

\section{Source Term and Decay Chains}

The numerical coefficient (4.4) in Table 3-8 seems to be incorrect; it should be 3 . Half-lives and curies remaining at 1,000 and 10,000 years should be included in Table 3-1 to better portray the long-term hazard reflected in the waste inventory. From the discussion in the interim PA $(3.5 .1,4.3 .4)$, it is not entirely clear how the normalized response results from each of the flow and transport modeling components are brought together to produce the final concentration or dose result, and why this is a sensible approach. There should be a more explicit description of what is done in the interim PA calculations as represented by the response equation on $p .3-61$. What is the rationale for using elaborate flow and transport models which provide spatial distributions of water and contaminant fluxes (strictly the term flux should be used for per unit area per unit of time quantities) and then average out this information in using the response equation? It seems that significant numerical dilution could be introduced through this approach. This approach would seem to have difficulty consistently handling the more realistic case in which recharge rate is not uniform over the entire surface and the higher natural recharge is drawn in under the facility to some degree. What recharge rate does one divide by in that case and what area should be used? What is the rationale for dividing by the recharge rate at 10,000 years ( 3 $\mathrm{mm} / \mathrm{yr}, \mathrm{p} .3-61)$ ? Does this mean that the concentrations calculated in the first 1,000 years (recharge $=0.5 \mathrm{~mm} / \mathrm{yr}$ ) are effectively diluted by six times the actual amount of water? It also seems that the approach being used, which apparently does all of the decay chain calculation external to the flow and transport simulations, may have some limitations in cases where the daughters and parents have significantly different decay rates, Kds and dispersivities, or when the $\mathrm{Kd}$ changes in space (say, differs between the Hanford sand and the Hanford gravel). some limitations of this type seem to be alluded to on $p .15$ of Mann (1996). There may not be significant approximations involved, but because it is difficult to see exactly how this is being done, one can't be sure. It might be helpful to illustrate, in a brief appendix, how this works for a simple decay chain example with ID transport equations in which transport parameters are different for each species. If there are significant limitations to the approach, it would not seem wise to build the entire PA effort around this framework. \{115\}

\section{Overall Assessment and Future Plans}

In view of the major uncertainties with key processes and/or parameters as discussed in section 3 of this appendix, it is felt that the conclusions of chapter 5 may be overly optimistic in assessing the likelihood that the facility will meet the performance objectives. It is very likely that the results of these calculation are largely determined by a number of assumptions and subjective choices, most of which are hidden from scientific purview by the shear volume and dispersed, ill-focused nature of the substantive technical support information. The 


\section{HNF-EP-0884 \\ Rev. 1}

sensitivity analyses in Chapter 4 provide some interesting insights about what factors affect the outcome of the models. The alternative vadose zone models of different complexity are helpful in providing some insight into possible model behavior, but if a potentially pertinent process is not represented in any of the models, it will be difficult to say much about the importance of that process. The interim PA makes an effort to use the modeling results and their sensitivities to guide the planning of data collection activities. This overall approach, of course, makes sense, but in the present form may be providing misguided direction if the models do not incorporate processes that will actually dominate the behavior of the system. $\{116\}$

The full characterization plan (Reidel, 1995, only section 2 is in the Data Package, Appendix I), which apparently is the basis for current data collection plans, makes frequent reference to Piepho (1995) as the basis for setting priorities in terms of data collection. Piepho (1995) presents a statistical methodology based on regression for ranking the importance of selected transport parameters, but these results are not meaningful because of the limited number of parameters considered, and because the resulting rankings will depend on subjectively assigned PDFs (Table 1) which may not derive explicitly from lab or field data (as in the case of the dispersivity), or represent the ranges seen in lab data (as for Kd). A fundamental conceptual flaw in this approach is the failure to recognize that the parameters needed in the model are aggregated effective quantities representing the overall effect (say sorption) of a large block or zone of soil that internally involves very complex heterogeneity which can never feasibly be characterized in full detail. In the case of sorption in a saturated system we know, from stochastic upscaling theory, that the effective $\mathrm{kd}$ is the arithmetic average, and then the appropriate estimate of the effective Kd would be just the average of the pertinent lab Kd values from that zone and the uncertainty in the model parameter is the uncertainty in the estimate of the mean. Regardless of what the probability distribution of $\mathrm{Kd}$, the uncertainty in the mean is proportional to the standard deviation divided by the square root of the number of independent sample. Thus, we have a basis for judging how further sampling will reduce the uncertainty in a given model parameter. This, coupled with the sensitivity of the pertinent model output to the model parameter, gives a systematic basis for setting priorities in data collection. In the traditional deterministic approach to modeling, as taken in the interim PA, the link between data collection and model parameters is ad hoc or, at best, tenuous (as in the unsaturated hydraulic properties where arithmetic averages of the van Genuchten parameters are arbitrarily. adopted). Some technically defensible upscaling procedure (stochastic or otherwise) is required to provide this link.

The following short-term (one year) steps are suggested to improve the accuracy and effectiveness of the PA process and to assure cost effectiveness of the data collection activities: 


\section{HNF-EP-0884 \\ Rev. 1}

(1) The PA modeling should be modified to address the process and parameter issues identified in section 3 of this appendix, and the sensitivity work expanded to treat these factors. Some of the issues can be addressed simply by changing some input characteristics (e.g., vapor diffusion); these changes could be incorporate in the september 1997 version of the interim PA. Other cases may require changes to the code and grid (e.g., lateral moisture inflow from the surroundings); these should be approached as relatively simple screening calculations which are used to assess the importance of the process in defining data gaps, and to decide whether the refinements are need for the preliminary PA.

(2) In parallel with the above modeling modifications, an updated integrated site characterization plan, focusing specifically on the PA modeling needs, should be developed using the existing geotechnical data. Judging from Figure 2-5 of Reidel (1995), there are many boreholes in the general 200 East Area which should be usable at least to define the range of hydrogeologic conditions that could be expected at the site. This report should be a selfcontained integrated presentation of the field and laboratory information (geologic, hydrologic and geochemical) and its use to parameterize the PA model. The report should consider the interim PA modeling results with the modifications in 1) above and should develop updated recommendations regarding the data collection needs for PA and cost thereof. This report should be reviewed by a panel of outside geotechnical experts familiar with vadose zone characterization and its use in parameterizing models. This report along with the panel's recommendations would form the basis decisions on the scope and cost of the data collection program.

\section{References}

Garabedian, S.P., I.W. Gelhax and M.A. Celia, "Large-Scale Dispersive Transport in Aquifers: Field Experiments and Reactive Transport Theory, "Parsons Lab Report 315, R88-01, MIT, dated January 1988 .

Gelhar, Lynn W., "Stochastic Subsurface Hydrology, " Prentice Hall, 390 pp., dated 1993.

Glass, R. J., Laboratory research program to aid in developing and testing the validity of conceptual models of flow and transport in unsaturated porous media, SAND 89-2359C, Sandia National Laboratory, Albuquerque, NM, dated 1991.

Khaleel, Raziuddin, John F. Relyea, and James L. Conca, "Evaluation of van Genuchten-Mualem Relationship to Estimate Unsaturated Hydraulic Conductivity at Low Water Contents, "Water Resources Research, Section 31(11), pages 2659-2668, dated 1995. 


\section{HNF-EP-0884}

\section{Rev. 1}

Talbott, M. E., and L. W. Gelhar, "Performance Assessment of a Hypothetical Low-level waste Facility: Groundwater Flow and Transport Simulation," U.S. Nuclear Regulatory Commission Report NUREG/CR-6114, Vol. 3, dated 1994.

Van der Kamp, G., L. D. Luba, J. A. Cherry, and H. Maathuis, "Field Study of a Long and Very Narrow Contaminant Plume," Ground Water, Section 32(6), pages 1008-1016, dated 1994 .

Yates, S. R., M. T. Van Genuchten, A. W. Warrick, and F. J. Leij, "Analysis of Measured, Predicted, and Estimated Hydraulic Conductivity Using the RETC Computer Program," Soil Science Society of American Journal, Section 56, pages 347-354, dated 1992 . 


\title{
HNF-EP-0884 \\ Rev. 1
}

\author{
APPENDIX C \\ SPECIFIC COMMENTS ON INTERIM PA AND SUPPORTING DOCUMENTS \\ by Dr. Louis Kovach \\ (comments by others specifically noted)
}

The review has been performed on a sequential basis as the information is presented in document WHC-EP-0884 Rev. 0, dated September 1996, Hanford Low-Level Tank Waste Interim Performance Assessment, and its Data Packages for the Hanford Low-Level Tank Waste Interim Performance Assessment, document WHC-SD-WM-RPT-166, Rev. 0, dated August 3, 1995. When the review of the main document includes background information from the Data Packages, it is so indicated.

\section{Interim PA Comments}

\section{Section 1 Review}

Section 1.5 .2 .5

It is not clear from the description whether the disposal facility is analyzed by itself or for its contribution to the existing ground water contamination. While this may be covered later, it would be important to state here which method is used. $\{201\}$

Section 1.5.2.6

Same comment as above. $\{202\}$

\section{Section 2 Review}

Section 2.2 .3 .2

The demography numbers and forecasts are inconsistent with the TWRS Environmental Impact statement (EIS). \{203\}

Section 2.2 .3 .4

The proposed TWRS complex will have at least two low-level facilities and the high level facility may be combined with one of the low-level facilities. $\{204\}$

Section 2.2.5.4.2

Is the Geomatrix 1966 data use appropriate? $\{205\}$

Section 2.2 .6 .4

Are the groundwater hydrology descriptions for the time of operation of the disposal facility, and are they consistent with other current predictions (e.g., TWRS EIS)? $\{206\}$ 


\section{HNF-EP-0884 \\ Rev. 1}

Section 2.3 .3

The waste removal values appear to be different than in the TWRS EIS. $\{207\}$

Section 2.3.4. Subpoints 1 and 3

The current TWRS scenario for Phase II of privatization is out of tank sludge washing. $\{208\}$

Section 2.3.7 (Bill Prindle)

Why shouldn't the certification process address product testing in addition to monitoring the waste immobilization process? It would seem that a case could be made that meeting the waste product criteria is more important than monitoring how the product was prepared. $\{209\}$

Section 2.4 .2

While the reference case is a glass-type LAW form, it does not have to be glass. $\{210\}$

\section{Section 3 Review}

Section 3.2.1 (E1mer Wilhite)

The process (i.e., radionuclide screening) of deciding which radionuclides should be considered in the $\mathrm{PA}$ is not described. The PA must document the full set of radionuclides considered and any processes used to reduce that set to a smaller one for detailed calculations. $\{211\}$

Sections 3.2 .2 and 3.2 .3

These values should be eventually replaced by the data from the best basis inventory estimates (Kupfer, et al.) being compiled, in the mean time, several isotope concentration estimates should be cross checked against the current Kupfer values. $\{212\}$

Section 3.2.3.4

The melter volatilization and off gas capture values are continuously mishandled at the site. \{213\}

Neither continuous recycle from the off gas scrubbers nor assumption of total loss from the scrubbers is correct. It should be evaluated, whether captured in the scrubber, volatiles and semivolatiles should be reincorporated into one or the other proposed waste forms or solidified in a separate manner (e.g., TC alloyed to metal, I-129 converted to AgI, PbI). \{214\} 


\section{HNF-EP-0884 \\ Rev. 1}

Section 3.2 .4

A current program of preparing best estimates for tank by tank inventory should be available by the end of fiscal year 1997. $\{215\}$

Section $3.3 \cdot 3.3$

Land use scenarios should be cross checked against and be consistent with the TWRS EIS. $\{216\}$

Has any evaluation been made in regard to Native American water usage? (See DOE Environmental Justice Regulations). $\{217\}$

Section 3.3.4.2 (Elmer Wilhite)

The glass corrosion mechanism is discussed. It is not clear whether the forward rate or the saturated rate is used in the source term calculations. If the saturated rate is used, there should be a discussion of the saturation of the infiltrating water as a function of infiltration rate. In other words, is the infiltration rate used in the $\mathrm{PA}$ slow enough that saturation occurs? $\{218\}$

Section 3.3 .6

Is this section consistent with the TWRS EIS? \{219\}

Section $3.4 \cdot 4.3$

There are current studies in regard to transport in the Hanford vadose zone. Are any of those findings being included in this evaluation? How is the existing vadose zone contamination included in the evaluation? $\{220\}$

Section 3.4 .4 .4 and Table $3-5$

These values do not appear to be consistent with the values used in the TWRS EIS. $\{221\}$

Section 3.4 .5 .5

It is unlikely that a LAW container can be filled to less than one percent void volume. If necessary, the void volume definition should be given. Some vendors may propose a liner for the container to help prevent glass cracking. $\{222\}$

Section 3.4.6

Has there been a review of any other countries' experience with LLW disposal facility design? \{223\}

From the reference materials, it appears that all of the discussed design features are based on site postulations. Is it 


\section{HNF-EP-0884}

\section{Rev. 1}

implied that there is no international experience in this area. If the other site experience has been reviewed, where is a lessons learned description and comparison with site based design features? $\{224\}$

Section 3.4 .6 .7

Are these the same vaults that are being proposed for storing spent nuclear fuel? \{225\}

Section 3.4 .6 .8

If the NRC assumption is that concrete structures degrade in 500 years, why is the sensitivity study uses immediate and 2;000 year degradation? $\{226\}$

\section{Section 3.4 .7}

If the particular disposal site is undisturbed for long periods of time, one would expect natural vegetation to reach an equilibrium level, such vegetation equilibrium, if anything should decrease the recharge rate rather than increase it. of course, natural events such as range fires would also occur periodically so the recharge rate may vary also on the basis of natural occurrences. $\{227\}$

Section 3.4 .8 .2

Sentence problem in last paragraph on page 3-43. \{228\}

Section 3.4 .8 .2

There should be an explanation for the great divergence for $T c$ in the site GENII value and that of the DOE library. More widespread use is not a technical explanation. $\{229\}$

Section 3.4 .8 .3

Has the Native American all pathways dose conversion factor been considered? $\{230\}$

Section 3.4 .8 .4

Is this consistent with the values given in the TWRS EIS? \{231\}

Section 3.4 .8 .6

Typo in second sentence. "Are" should be "and." \{232\}

Section 3.4 .8 .6

Jenquin data. I am puzzled by the description. Why are the increased "calculated over measured" yield values cause changes in half life? $\{233\}$ 


\section{HNF-EP-0884}

\section{Rev. 1}

Sections 3.5 .2 .2 .5 and $3.5 .2,3.4$

At least for codes that we are using for NRC licensed facilities, an extensive and formal QA program defined validation is requixed. Considering that there will be NRC involvement with this project also, does the validation methodology satisfies current NRC criteria? $\{234\}$

Section 3.5 .2 .3 .6

Was this code involved in the estimation of the $S$ farm leakage? Do the recent vadose zone isotope movement issue, and the commensurate studies have any lessons learned impacts? \{235\}

Section 3.5 .2 .4 .2

This section answers one of the earlier questions (1.5.2.5), however, the recent vadose zone isotope transport problems have to be considered before finalization of the code(s) for this application. $\{236\}$.

Section 3.5 .5 .2

The Native American impact scenarios seem to missing in all cases. DOE has a special requirement to include such impact analysis for all environmental documentation. \{237\}

Section 3.5 .5 .3

What is the basis for assuming that the melter volatilized I-129 will be or can be released to the atmosphere? With the particular sensitivity toward iodine releases at the Site, how can one justify to purposefully release iodine, even if calculated concentrations would be minimal? It should also be kept in mind that the scrubber solution will most likely accumulate the iodine (and some other halides), and any release would take place from such, more concentrated sources. Has the release mechanism assumption been checked with SRP, West Valley, and other international melter operations where actual operating data is available? $\{238\}$

Section 3.5 .5 .3

From a long term PA standpoint, what is the specific concern with Cs -137 content? $\{239\}$

Section 3.5 .5 .6

There are operating LLW repositories around the world. Is there any information from those operations that can be used to compare or even validate the codes on real systems? $\{240\}$

Section 3.5 .5 .9

One of the issues I am aware of that affects the surface area of 


\section{HNF-EP-0884}

Rev. 1

the glass and, therefore, the release rate, is cooling related cracking of the waste form in the metal storage container. Has anyone looked at the possibility of using a chemically inert liner (such as graphite or carbon felt) which would permit better relief of expansion or contraction stresses, and reduce the potential of the increase in glass surface area? $\{241\}$

Section $3.5,5.10$

The OECD has performed in the near past an international exercise in kd evaluation. Was information from that activity used to cross-check Kd values used at the site? \{242\}

Section 3.5 .5 .10

Are the Kd values used in this exercise consistent with that used in the TWRS EIS? $\{243\}$.

Section 3.6 .2

I have recently participated in the assessment of an activity at PNNL (C-106 vendor sample preparation), and my personal findings in that case indicate that the QA program that followed is not well instilled in the personnel using it. I would feel much more comfortable if the QA program used in this exercise is audited. Such audit should not only be "expected," but a basic requirement for any safety related code and methodology development. As an example, the PNNL QA program requires the development of a QA plan for special projects which involve non-routine work. If that $Q A$ program is, in fact, followed there should be a QA plan for this project. I would like to review the specific QA plan relating to the ongoing performance assessment work. $\{244\}$

Section 3.6 .7

I am troubled by the wording in this paragraph. It states that an advisory board will be created in the future, and in the following sentence it states that this document has been reviewed by such a panel and the document revised on the basis of their comments. I would be interested in looking at their comments and the comment resolution. $\{245\}$

\section{Section 4 Review}

Section 4.2

How do these scenario effects compare to the values in the TWRS EIS? The Native American scenario is missing: $\{246\}$

Section 4.2 .3 .2

It appears that the Sn-126 contribution falls below the Cs-137 at 200 years and not 300 years. $\{247\}$ 


\section{HNF-EP-0884}

\section{Rev. 1}

Section 4.2 .3 .4

The relative potential contribution of Sn 126 to the dose begs the question: Are there realistic technically feasible and cost effective methods of removing this isotope from the LAW waste feed prior to vitrification. It is greatly troubling that the major contributors to the dose (i.e., TC and $S n$ ) are the least characterized from the tank waste and cause the greatest uncertainty in the PA. $\{248\}$

There are' several ways that this problem can be addressed. One way is to get as much available international experience data as possible. Another way is to better scrutinize available processes knowledge for the removal of these isotopes either from the liquid phase process or the off gas scrubber system.

It is also questionable if these isotopes should be included in the LAW waste form if they can be separated from the rest of the material. The site is stuck on the two waste form groove, even if there are numerous indications of problems with such assumption. Anything that shows limiting PA should be evaluated for separation and possible inclusion in less release prone matrix or potential inclusion in the HLW waste form. This is also true for $\mathrm{TC}$ and $\mathrm{Se}-79$ in the groundwater impact.

Thus, what is the sensitivity of the PA to these possible reductions of the limiting isotopes and what is the cost trade off of going to the removal path? $\{249\}$

Sections 4.6 .2 .2 and 4.6 .3

The question is, again, how much of the international experience has been reviewed and what are the lessons learned? $\{250\}$

Section 4, General Comment

The scaling of the figures can be misleading. In such presentations, the ere should be a broken line indicating that the discontinuity in the data presentation (starting with zero and then switching to log scale). \{251\}

\section{Section 4.7}

There should a be a best estimate also given in addition to the sensitivity studies. It is not clear if the base case represents the best estimate or not. $\{252\}$

Section 4.8 .2

This is indicative of what feedback is important for the appropriate process design and what impacts need to better defined to reduce the uncertainty of the PA. How is this data integrated into the overall TWRS process? What are immediately definable steps? Example could be immediate additional characterization data for the critical analytes TC, Sn-126, 


\section{HNF-EP-0884}

\section{Rev. 1}

Se-79, etc. How does one prioritize needs which could be included in TFA or science studies financed outside the current TWRS budget? There is data from power reactor accident evaluation studies with simultaneous release of iodine and cesium, and the potential pool scrubbing effect in BWRs and alkali sprays for PWRs. Has this data been reviewed and incorporated into the estimates of scrubber collection efficiency? Has data been obtained from operating melters from other countries in regard to iodine scrubbing efficiency or accumulation in the off gas system scrubbers from which better best case estimates can be prepared, and the overall uncertainty of the PA reduced? $\{253\}$

Section 4.9

Is this still correct based on the recent issues with the groundwater contamination? $\{254\}$

Section 4.10

What is the relationship of the base case to the best current estimate? $\{255\}$

\section{Section 5 Review}

Section 5 , General Comment

In addition to the performance objective and single value estimated impact, the range of reasonably possible should also be shown. The uncertainty in some of the scenarios is too large to present only a single value "estimated" impact. $\{256\}$

Section 5.2.4 (Elmer wilhite)

Table 5-3 does not seem to correspond with the data presented in Table 4-34 on page 4-78. For example, in Table 4-34, the sum of doses from fission products is about $7.4 \mathrm{mrem} /$ year while the same value in Table $5-3$ is $2.0 \mathrm{mrem} /$ year. $\{257\}$

Section 5.2 .4

It is obvious that the uncertainty affects most strongly the groundwater scenario, which currently is approximately estimated at one half of the performance objective, but the well screen length assumption is difficult to defend. $\{258\}$

Section 5.5 .3

I strongly recommend the collection and utilization of the relevant international experience based technical data. \{259\}

On page 16 of the Data Packages, the important parameters for intruder doses are described. Two of the values used do not 


\section{HNF-EP-0884}

\section{Rev. 1}

correspond to those used in other Hanford PAs. The well diameter of $12 \mathrm{~cm}$. is smaller than the $30 \mathrm{~cm}$. value used in other PAs, and the garden size of 500 square meters is smaller than the 2,500 square meters used in other Hanford PAs. The rationale for using different values in the various Hanford PAs should be clearly stated. (Elmer Wilhite) $\{260\}$

In the Definition of the Base Analysis Case of the Interim Performance Assessment, on page 21, it is stated that the container material is assumed to have no effects on hydraulics or on chemical retardation. As it should be expected that the containers will, in fact, degrade with time, consideration should be given to consider the effect of container degradation (i.e., rust) on the migration of contaminants from the disposal site. (Elmer Wilhite) $\{261\}$

On page 24 , it is stated that all concrete structures degrade to gravelly sand at 500 years. This assumption seems to be conservative. However, if the hydraulic properties of the concrete are changed to be consistent with gravelly sand after 500 years, is there a possibility that this will, in effect, act as if a capillary break had been installed around the waste? (Elmer wilhite) $\{262$ )

On page 31, a glass corrosion rate is stated at pH 9.5. Does pH 9.5 match the expected condition the disposal unit? (Elmer Wilhite) $\{263\}$ 


\title{
HNF-EP-0884
}

\author{
Rev. 1
}

\section{APPENDIX D QUESTIONS AND ANSWERS}

\section{Response to Questions Posed by Jeff Voogd During the Meeting}

Can you recommend methods to balance conservatism in the assumptions and scenarios needed for technical and public acceptance with desires to present results that represent best estimates?

Present a set of cases which span the range from best estimates to reasonably conservative to strongly conservative or worst case. Interpret the results, taking into account the relative uncertainties.

Can you provide recommendations to balance the drive to collect data versus the ability to use assumptions or sensitivity studies to reduce costs?

A minimum set of data must be collected to provide assurance that the simulation of the site is reasonably realistic. Beyond that, sensitivity analyses should be used to aid in the decision making process as to what additional data, if any, are needed.

Does the board have a set of recommended end points for data collection?

It is difficult to develop end points for data collection a priority. As stated above, it should be expected that a minimum set of data would be needed to ensure that the site is being reasonably represented. Because many potentially important process and parameter uncertainties are not incorporated, it is not appropriate to use the interim PA results to draw conclusions regarding data needs. 


\section{HNF-EP-0884}

Rev. 1

\section{F.1.4 Responses to Board Comments}

Responses to the items noted in the panel's report follow.

1. When the performance objectives were determined for this performance assessment, there was no guidance to use the Site's groundwater protection management plan as a source of information. The latest version (1995) of the "Hanford Site Ground-Water Protection Management Plan" (DOE-RL-89-12, Revision 2) is silent on protection of groundwatex in the future,

2. The performance assessment activity will follow the guidance of DOE Order 435.1 (the successor to DOE Order 5820.2A) once it is implemented.

3. A major finding of the expert review panel is the need to provide both best estimate analyses as well as suitable bounding analyses. The performance assessment team agrees that this is the correct approach and the performance assessment activity is being modified accordingly.

Data collection efforts for the performance assessment activity are being modified so that data can be gathered that support both types of analyses. In the next major revision of the performance assessment, separate scenarios will be chosen as best-estimates and as reasonably bounding.

4. The performance assessment team agrees that broad and rigorous review is important. Both in the draft version and now in the published version (June 1997) of the "Statements of Work for FY 1998 to 2003 of the Hanford Low-Level Tank Waste Performance Assessment Activity", HNF-SD-WM-PAP-062, Rev. 2, each document (including those defining and justifying data to be used in the performance assessment) have a separate review activity. In addition, a separate independent review panel is planned.

5. As noted in item 3, having separate bounding cases will be adopted by the performance assessment team. Providing an indication of "what will not happen" will give many a better basis for decision than attempting to predict exactly events many thousands of years in the future.

6. As this was the first performance assessment performed for immobilized low-activity tank waste, only a limited number of scenarios were considered. With the understanding of these analyses, a better definition of scenarios can be performed in the future. Future performance assessments will use more scenarios in order to provide the reader with greater insight.

7. Isolated variations of parameters was emphasized in this performance assessment were emphasized as this was the first performance assessment to study waste having a time of 


\section{HNF-EP-0884}

\section{Rev. 1}

release significantly longer than the travel time of the most mobile radionuclides. Thus the intent was to identify important variables and their relative sensitivity in PA results. Multiple variations (for example, changing the description of the vadose zone stratigraphy) were limited because of the lack of prior knowledge to select the most meaningful set of sensitivity scenarios.

With the knowledge gained from this analysis, future performance assessments will rely more on changing scenarios or systems, rather than varying parameters.

8. As shown in Section 2.2.6.3 of the Performance Assessment, even if the largest dam on the Columbia River (Grand Coulee Dam) collapses, the resulting catastrophic flood would not reach the disposal site. However, such a collapse would have extremely dire conditions in the Pacific Northwest, killing tens of thousands of people if not more. In order for a catastrophic flood to reach the disposal site, then a volume of water that would reshape the topography of the entire region is necessary. The consequences of such an event on the disposal site (Section 4.12) compared to the consequences for the entire region of related events is beyond the scope of this analysis.

9. The performance assessment effort has committed to use the effort of the TWRS Characterization Program (referred to as Kupfer) in future revisions. The performance assessment team has worked closely with the TWRS Characterization Program for over two years. The first publically available report of the TWRS Characterization program is due out in september 1997.

10. Future revisions of the performance assessment will model the inhomogeneities of inventories. With the tank by tank estimates from the TWRS Characterization Program combined with the order of retrieval, inventory in the immobolized low-level waste as a function of time of immobilization will be determined. The analysis in this performance assessment suffers because the necessary tank by tank information is not yet available.

11. It is recognized that there will be variations in waste compositions and waste form formulations as the immobilization spans many years. For this first analysis of the immobilized waste form, the simplest approach was used. Future performance assessments will contain scenarios involving a larger variety of waste forms.

12. The glass shape will be determined by the vendors. The performance assessment team will maintain communications with the vendors to determine what glass shapes that they will be supplying to the Department of Energy.

13. The vendors will determine what filler material will be used 


\section{HNF-EP-0884}

\section{Rev. 1}

around the glass waste form inside the metal container. The disposal facility operators will determine what fill material will go around the metal containers inside the disposal facility. Sulfur-polymer cement is no longer being considered for either situation. The performance assessment team will analyze likely filler materials based on conservations with the vendors and with the disposal facility design team.

14. An experimental verification of the usefulness of a waterconditioning layer of crushed glass is contained in the "Statements of Work for FY 1998 to FY2003 of the Hanford Low-Level Tank Waste Performance Assessment" as activity S1W03384.

15. LD6-5412 was not treated as a "best-estimate" for the waste form. Discussions with the vendors of the waste form indicate that they will NOT be using LD6-5412. The LD6-5412 glass was used in the sensitivity cases to provide an indication of how a low-level glass waste form might behave in the disposal facility. LD6-5412 was chosen as there exists more publically available data on this low-level waste glass than for any other. Activities (particularly the waste form activities S1W03000 - S1w03160) in the "Statements of Work for FY 1998 to FY2003 of the Hanford Low-Level Tank Waste Performance Assessment" are designed to accumulate the similar level of information for the various vendor glasses as was achieved for LD6-5412.

16. The determination of what tests are to be used in product acceptance testing is neither a performance assessment nor a Disposal Program activity. Rather product acceptance is the responsibility of the Waste Intregration Team under DOE. The DOE Tank Focus Area has identified the need to standardize such tests and to determine the crosscorrelation of such tests with more standard PCT tests.

The performance assessment activity takes pride that significant development of the SPFT and PUF tests were done with performance assessment funding.

17. The Systems Engineering activity which is responsible for engineering studies is investigating various low-activity waste disposal options both nationally and internationally. In particular, the French experience is being extensively investigated.

18. "The Alternatives Generation and Analysis Report for Immobolized Low-Level Interim storage Architecture", WHC-SDW465-AGA-001, Rev. O clearly showed that the grout vaults were the most cost effective solution for the storage of the immobilized low-activity waste that is produced. An alternatives and generation analysis report (HNF-SD-TWR-AGA004 ) is being prepared this fiscal year looking at the entire storage/disposal period. 


\section{HNF-EP-0884}

\section{Rev. 1}

19. These concepts are being pursued through "The Alternatives Generation and Analysis Report for Immobolized Low-Activity Waste Disposal", HNF-SD-TWR-AGA-004, to be released in September 1997.

20. Because the travel time in the vadose zone for the most important radionuclides for dose is so much less than the expected release time from the waste, the plateau value for the dose is determined not from geotechnical considerations but rather from waste form processes. Therefore, although there are improvements that need to be made in the geotechnical area, such improvements are unlikely to increase the estimated maximum dose.

21. Although the activities for vadose zone characterization are still heavily based on the integrated site characterization plan ("Characterization Plan for the Proposed TWRS Complex", WHC-SD-WM-PLN-109, July 1995), information from the interim performance assessment analysis and from other Hanford vadose zone efforts have changed priorities as given in the newest statement of work document. In addition, the Tank Waste Remediation System (TWRS) is attempting to coordinate all of its vadose zone activities as part of a larger Hanford coordination effort.

22. There are plans for an independent review of the coordinated TWRS vadose zone characterization activities. Seperate review tasks are included in the statements of work.

23. The Hanford Composite Analysis is scheduled to be released in December 1997. To provide an indication of what such an analysis might show, an analysis of interacting sources was included in this document. Performance assessments produced after the Hanford Composite Analysis is published will reference the results of that report.

24. Following this recommendation, DOE-RL staff have already made contacts with headquarter staff to determine a path forward given the proposed change from DOE Order 5820.2A to DOE Order 430.1 . Additional routes to determine how to transition from one oxder to the other are being pursued.

25. The performance assessment team will increase its effort to increase public involvement and the public's understanding of the issues underlying immobilized low-activity tank waste disposal.

26. The performance assessment activity is being structured so that it should not delay the program. Novel approaches are being considered to ensure that the performance assessment document does not hinder privatization or disposal.

27. The performance assessment activity will follow both a bestestimate approach as well as a reasonably bounding approach. In addition, future performance assessments will be written 


\section{HNF-EP-0884}

Rev, 1

so that analyses identify key features and determine the limitations of such features.

28. Defensibility of the performance assessment is extremely important to the performance assessment team. Defensibility of the data and approach was a major goal for the interim performance assessment. In producing this performance assessment, the performance assessment team found that certain data (waste form release rates, well screen height) need better justification and that certain methods (using the base analysis case, emphasizing parameter variation) must be replaced (using both best-estimate and reasonably bounding cases, emphasizing scenario variations).

29. Because of its regulatory nature, the performance assessment is highly restricted in its format. The performance assessment team attempted to make the document more readable for the lay reader. The team realizes that it has a very long way to go.

30. The performance assessment team has encouraged DOE to present Hanford low-level tank waste performance assessment information to the safety and Waste Management Committee of the Hanford Advisory Board. A few presentations have been made. The team will recommend that more presentations be made.

31. The time at which a performance assessment covering Hanford low-activity tank waste will be sent to headquarters is being rethought. It is likely that such a performance assessment will be sent earlier than shown in Table 5-6.

32. The performance assessment team agrees that gathering more data without significantly reducing uncertainty is unacceptable. The approach taken in determining what data should be collected was 1) to identify the questions that needed to be answered 2) to determine what information was needed to answer those questions, and 3) to determine whether information already existed for that area. As the analyses have proceeded, new areas for data collection have been discovered, but many more have been closed.

33. As noted in item 28, defensibility of the document is key to the program.

34. Agreed, see note 32 .

35. Agreed, see note 27.

36. Agreed, see note 9.

37. The goal of the performance assessment activity is to define the values of all parameters used in the performance assessment. It is recognized that certain parameters (for example, the well screen height) are not defended adequately 


\section{HNF-EP-0884}

\section{Rev. 1}

in this document while others (for example, the partitioning of se between high-activity and low-activity waste) are being investigated so that values can be justified.

38. The order of presentation was our interpretation of the format guidance given by the Peer Review Panel. We agree with the comments that a discussion of the major assumptions belongs in the first chapter.

In succeeding performance assessments we will better organize the document so that readability is not compromised at the expense of format. A prime example of this will be placing a discussion of major assumptions in the first chapter. Such a section (Section 1.6) has been added to this performance assessment.

39. Members of the performance assessment team are already receiving training to allow them greater access to vendor information. There is a commitment both at the DOE and contractor level to increase communication between the performance assessment team and the vendors.

40. An attempt was made to "unitize" the analysis in this performance assessment (discussions of inventory, transport through the vadose zone, transport through groundwater, and dosimetry effects were each treated separately in Chapter 4). However, the presentation was not sufficiently orientated toward this philosophy so that the reader realized this approach. Succeeding performance assessments will attempt to better modulize not only the analysis but also its presentation.

41. A third waste form is being considered by DOE. However, the present plan is to dispose of such a waste form as immobilized high-activity waste and therefore is not subject to the analysis done for the immobilized low-activity waste.

42. When the performance assessment activity started, the importance of selenium was not known to the engineering staff. Therefore, they could provide little guidance as to how selenium would partition between the high-activity and low-activity waste streams. Information is now being obtained that will allow an accurate representation of how selenium will split. Such information will be used in future performance assessments. The refocusing of staff effort on determining how selenium partitions should be viewed as a success of the iterative performance assessment approach where conservative assumptions are used where knowledge is weak or lacking, the consequence determined; and if necessary, more information is gathered to better define the answer.

43. The offgas issue is one that has to be worked with the vendors. It is unknown at present whether the vendors will 


\section{HNF-EP-0884 \\ Rev. 1}

recycle such material, return it to DOE, produce a third waste form (see note 41), or treat it as waste (in which case they have the responsibility for disposal). The performance assessment team will be actively working with the vendors on determining a path forward.

44. An analysis has been performed. See item 18 .

45. The performance assessment team is working actively in making both the integrated Hanford site groundwater activity and the integrated Hanford site vadose zone activity a success. We admit that much more coordination is needed.

46. Other sites' performance assessments have been used, particularly those of Savannah River site. For example, performance objectives of each of the sites were used. Although not shown in the performance assessment, experience of other sites has been used in our data collection activities. For example, the work at the Savannah River site on TC getters was followed up as was the work at the Nevada Test Site on no-flow zones. The use of C1 tracers to estimate recharge is another area which grew from investigating the approaches of others.

47. Agreed, see item 27.

48. Agreed, see item 39.

49. Disagree. Although there is the likelihood of catastrophic glacial flooding this alone should not disqualify the currently proposed site. Because of the uncertainities in any statements about the future, regulatory bodies stress the continuation of present conditions unless there are convinving arguments. For example, in the NRC's branch technical position on performance assessment metholodology (NRC 1997 - 3], "the staff reccommends that new site conditions that may arise directly from significant changes to existing natural conditions, processes, and events do not need to be quantified in $L L W$ performance assessment modeling." Thus the Nuclear Regulatory Commission in their regulation of the commercial low-level waste disposal site which lies nearby on the Hanford plateau just southwest of the proposed site and the Department of Energy in their regulation of the low-level radioactive waste burial grounds just north of the proposed site have not considered such catastrophic floods.

50. The preparation and review of the performance assessment made clear limitations in the present analysis and presentation. The performance assessment team will attempt to better present and justify paradigms, models, and data values in the next version so that both the informed and general reader can understand what was done.

The characterization plan will be redone as part of the 


\section{HNF-EP-0884 \\ Rev.1}

planning activity for the borehole drilling activity. In addition, as part of the Hanford site integrated vadose zone activity, data quality objective activities are occurring.

51. Agreed, see item 24.

52. Agreed, see item 30.

53. Agreed. Efforts to understand the implications of the proposed DOE Order 435.1, "Radioactive Waste Management", are underway.

101. Recent guidance from the Department of Energy is to focus on the next 1,000 years with the results for a period out to 10,000 years used to optimize design. Thus the effects of a catastrophic flood which may occur many tens of thousands of years in the future were not fully analyzed.

The amount of effort to be expended for such a scenario will be based on guidance from the Department of Energy and the feedback from the Northwest public.

102. As noted in the response to comment 49 , there already exists a commercial low-level radioactivity waste burial ground just southwest of the proposed site and DOE low-level burial grounds to the north. In addition, the staff of the NRC has also reviewed this performance assessment and have not raised this issue. Thus vulnerabilities due to regulatory disqualification are thought to be minimal.

It should be recognized that any location in the entire Columbia Basin with the exception of basalt interiors will undergo extreme destruction if another catastrophic flood occurs. Past catastrophic floods locally move 10 's of cubic miles of soils, creating channels hundreds of feet deep.

The performance assessment team is committed to analyze all risks that the public and the regulatory system deem important.

103. The performance assessment team recognizes that the presentation of material can be improved. The team will strive to be sure that the improvement occurs.

Because of the large amount of information needed for a performance assessment, it is difficult to judge how much detail should be included in a document and how much should be referenced. The present approach was to put as much as possible in the "Data Packages for the Hanford Low-Level Tank Waste Interim Performance Assessment." Because this approach was used for the first time, the next version of the "Data Packages" should be a significant improvement in both form and content. The performance assessment team will certainly use the comments in improving the documents. 


\section{HNF-EP-0884}

Rev. 1

Presenting modeling results is difficult because of the amount of information that could be portrayed. We will use the comments to attempt to provide more useful information to the reader.

Because this performance assessment was produced early in the program's life, there was little time to independently obtain all the data needed for the performance assessment. Therefore the grout performance assessment was used as a source of data. Although the Peer Review Panel could not formally find the grout performance assessment "technically adequate" because it lacked a best-estimate case, the data in the grout performance assessment were of high quality.

Formal internal reviews will be part of the succeeding performance assessments. The current program planning document has a formal internal review step for each document that will be part of the next set of data packages. For some activities, a formal external review is also included.

104. The recharge rate for the first 1,000 years were based on the design specifications of the Hanford surface barrier. The proposed design, now being tested, was created to meet the design specifications considering all of the various events outlined in the comment. The performance assessment team will follow the results of both the continuing design effort and the research/development effort to better understand how the surface barrier is likely to work.

The value of natural recharge after the first 1,000 years may be a bit too low. However, it is unlikely to be as high as $25 \mathrm{~mm} /$ year. Lysimetry, tracer, and simulations along with plant studies will be used to produce better estimates of recharge which will be used in future performance assessments. However, the effect of recharge rates as high as $100 \mathrm{~mm} /$ years were calculated and are discussed in section 4.7 .4 .

The guidance on producing performance assessments is to use current climate conditions. Although the climate is likely to change significantly in the future, it is beyond the scope of the performance assessment to analyze such changes.

Recharge at the Hanford Site occurs because of quick melting after a major winter snow accumulation. Actual recharge events occur only a few days every decade. Thus the Hanford Barrier was designed with this process as the main driving force. Testing so far indicates that the constructed prototype is working very well during the potential recharge events we have experienced since its construction.

105. Rockhold (1996) assumes that the Hanford Barrier would be built atop the disposal facility and would have sloping regions to fit with the surface features. This is the design of the prototype. However, conceptual designs for 


\section{HNF-EP-0884}

Rev. 1

the disposal facility have no such slopes. The Hanford Barrier does not work by diverting the water around a region. Rather the barrier works by storing the moisture until the vegetation can evapotranspire the moisture. Therefore, it was acceptable not to use the high-recharge areas of the sloped features.

The performance assessment team will use the information on disposal facility design, actual Hanford Barrier experience, and recharge research to estimate the expected recharge. As disposal facility layout becomes better known, the treatment of end effects will be performed.

The initial moisture content, unfortunately, was not presented in the performance assessment. Because changing the initial moisture content had so little effect on the simulated results, the authors chose not to present the information.

106. The authors of the performance assessment recognize the limitations of the sand-gravel capillary barrier. Much more research/development is needed for such a disposal facility component. Although not extensively presented in the performance assessment, reference was made to calculations (Piepho 1996) that showed the rather small effect of preferential flows on estimated contaminant fluxes.

As noted above (note 103), the grout performance assessment was a source of data because this performance assessment was done early in the life of the program. The planned data collection efforts do include extensive efforts on measurements and understanding of near-field materials.

Because the sand-gravel capillary barrier is untested, sensitivity cases were performed without such a disposal facility component.

Comments concerning the presentation of materials (in particular, the use of graphs to display unsaturated conductivity and moisture retention data) will be seriously considered in future performance assessments.

107. The performance assessment team has learned much in performing the analyses. Some data were not explicitly collected during the modeling process (for example, flux into the disposal facility) which it is now clear should have been captured and presented. A better understanding of the moisture flow and its presentation in the document is highly desirable. In addition, future versions of the performance assessment will have fuller depictions of moisture flow and contaminant transport inside the vault area.

The role of diffusion inside the disposal facility is uncertain. Efforts in fiscal year 1997 are attempting to 


\section{HNF-EP-0884}

\section{Rev. 1}

bound the question and define an approach to measure the data necessary to resolve it. Such understanding and data will be used in future performance assessments.

108. The performance assessment agrees the water vapor may be an important mechanism for transferring water into the disposal facility. The same effort mentioned in note 107 is looking at this possibility. It is also attempting to discover the importance of the mechanism for outflow.

109. Graphics showing the model simulations will be improved in the next performance assessment. In addition, more sensitivity cases will be run to determine the adequancy of modeling assumptions (such as grid spacing and number of elements used). Because a mechanistic approach was used for the base analysis case for waste form release (the same release rate for all time and for all spatial points) based on the specifications of the RFP, little effort was spent in justifying the model.

The AREST-CT modeling of the waste form release rate (as sensitivity cases) assumed an infiltration rate (1 mm/yr or $10 \mathrm{~mm} / \mathrm{yr}$ ) and glass waste forms the size of marbles in a porous media. These calculations supplied a time dependent flux condition to the PORFLOW unit cell calculations.

Future performance assessments will be based on more realistic modeling which will simulate the waste form produced by the vendor as it degrades over time.

110. The effect of tension-dependent anisotrophy will be included in future performance assessments. As part of the plan code selection process, the ability to handle this process will be mandated. An option of vertical capillary break is being considered in facility design.

111. Hydraulic data collection activities for future performance assessments will use the information supplied to provide better estimate of hydraulic properties. Already, data have been obtained for more gravelly soils and compared with the Bouwer and Ricer correction procedure (Khaleel and Relyea, in press). Values for unsaturated conductivity and moisture retention will be based on new measurements and will result from simultaneous fitting of such measurements for all moisture contents of interest. Stochastic upscaling leading to macroanistropy (with cross-correlations between parameters) will be used in data collection activities for future performance assessments.

112. Little is known about dispersive mixing at Hanford. An effort in fiscal year 1997 should provide a better documented basis for future performance assessments. This performance assessment simply varied the value to determine its effect. 


\section{HNF-EP-0884 \\ Rev. 1}

113. The moisture dependence of $\mathrm{kd}$ was found after values were recommended for use in the performance assessment. It is believed that the Kd used in the performance assessment for $U$ is appropriate for the conditions expected. However, this is an area which the performance assessment is funding and better answers will be forthcoming.

114. As already noted, the justification of the 5 meter well screen height is nonexistent in the performance assessment. This is the value normally used in Hanford performance assessments and its lack of justification demonstrates complacency in not documenting the experience of local drillers and of local health deparments. In future performance assessments, this important number will be defended. (A nonscientific sampling indicates that a 40 foot height might, in fact, be more typical).

Future versions of groundwater flow and contaminant transport will rely on to-be-selected Hanford Site groundwater model that is to be used on all Hanford analyses. These concerns will be passed on.

115. Agreed, the numerical coefficient is incorrect. It should be 3 . This is a typo.

The suggested revision to the inventory table will be considered for future performance assessments.

Because the travel time in the groundwater from one side of the disposal facility is so small compared to the vadose zone travel time which itself is small compared to the waste form release time, spatial variations in the flux entering the groundwater are integrated out when performing the effective time integral.

The "module" or "unitized" approach used in this performance assessment was obviously not communicated clearly enough. Future performance assessments will be written to more clearly explain the approach, the approximations, and their effect. Because the contaminant flux reaches a plateau after many thousands of years independent of whether the recharge rate is $0.5 \mathrm{~mm} /$ year or $3.0 \mathrm{~mm} /$ year, it seems most appropriate to use the $3 \mathrm{~mm} /$ year value. However, the point is well taken, the amount of water passing through the plane between the vadose zone and the groundwater should be explicitly calculated and used.

The non-explicit calculation of daughters is a limitation of this approach. Calculations in future performance assessments will explicitly take the effect of daughters into account. Because of the uranium $\mathrm{Kd}$ is so low compared to other actinide Kds, the effect will be small before 10,000 years.

116. The criticism of the geotechnical data and modeling is 


\section{HNF-EP-0884 \\ Rev. 1}

valid. However, as shown in the analysis because of the very long release times given for the waste form, the travel in the vadose zone provides delay rather than a change in contaminant flux (and hence dose). Therefore the conclusion of the performance assessment is fairly robust. A major caveat on this is the amount of dilution caused by groundwater flow and extraction. If, indeed, atypical well screen heights are used, then the results would be nonconservative.

201. The performance objectives are for an added burden. The last sentence in the paragraph mentioning Table 1-1 has been modified, "Performance objectives presented in Table 1-1 are values in additional to any existing amounts or background." Footnote $b$ to Table 1-1 has been modified has been modified to read. "... Values given are in addition to any existing amounts or background."

202. See note 201 .

203. The 1990 Census figures used for Benton and Franklin Counties are the same (Figure 2-4 of the PA and Table 4.6.2 of the EIS). The differences come in how the information is broken down. The PA gives populations of the various cities and towns in 1990 and estimated in 1993 whereas the EIS provides an estimated of the total Tri-Cities population from 1890 to 1994. The figures are consistent for 1993 if the EIS figure for total Tri-Cities population is the sum of the population in Benton and Franklin Counties. Since the EIS does not forecast population, the PA and EIS forecasted populations are not different. Although the data are presented in different ways and stress different

subcategories, the information in the two documents are consistent.

204. The statement contained in the performance assessment reflected thinking prior to the privatization. The paragraph has been deleted.

205. The citation in the reference section is misspelled. It has been corrected.

206. Both the TWRS EIS and this performance assessment use the VAM moisture flow and contaminant transport code (although different versions). Both documents are based on the Hanford Site groundwater model developed by the Hanford site Environmental Restoration contractor.

207. The retrieval fractions are expressed differently. The wording in the performance assessment (volumes for each series of single-shell tank) is directly out of the TPA Agreement. The wording in the EIS (per cent retrieved) translates those volumes to an approximate percentage. 


\section{HNF-EP-0884}

Rev. 1

208. The text has been changed to indicate that the three steps are for the first phase of processing (2002 through 2010 ) and that the second phase ( 2010 through 2025) may be different.

209. The product acceptance section has been rewritten reflecting the current strategy, following the comments of Joe Westsik (see Appendix F.8, item 11). Note that it is likely that there will be some product testing in the product acceptance process.

210. The water conditioning layer depends not only on whether the waste form is a glass but also on its performance. The paragraph has been rewritten to indicate that this component is only a possibility.

211. After the first sentence of section 3.2.1, the following section was added to explain the screening performed by Schmittroth 1995.

"This prescreening effort included the calculation of the quantity of all isotopes produced during materials production at Hanford (see Section 3.2.3.2), a simple onedimensional steady state calculation of the transport of such isotopes through Hanford's vadose zone (both with accepted Hanford-relevant $\mathrm{K}_{\mathrm{d}} \mathrm{s}$ as well as $\mathrm{K}_{\mathrm{a}}=0$ ), the conversion of groundwater concentrations to drinking water doses (see section 3.3.6), and the calculation of inadvertent intrusion using the homesteader scenario (see Section 3.3.3.4.3)."

212. Agreed, see note 9.

213. The only use of off-gas was in the inventory of I-129. Although the position of the engineering staff is that there will be little I-129 due to volatilization during $\mathrm{Pu}$ separation, tank storage, and immobilization, the performance assessment assumes that $10 \%$ of the original produced amount is disposed in the immobilized waste form. This assumption was made (as stated in the text) to determine whether I-129 is important to disposal impacts. It was not.

The performance assessment team will better treat volatilization once the vendors' plans become known.

214. The present performance assessment assumes that volatilization is unimportant, hence putting a higher amount of radionuclides into the immobilization waste than may actually occur. The methods used to handle volatiles and semivolatile materials will be established by the private vendors. The performance assessment team will incorporate such methods into the models used in subsequent performance assessments. 


\section{HNF-EP-0884}

Rev. 1

215. Agreed. Future performance assessments will use the tank by tank inventory data.

216. Future Hanford land-use scenarios are in a state of flux. The "Draft Hanford Remediation Action Environmental Impact Statement and Comprehensive Land Use Plan", DOE/EIS-0222D, dated August 1996 provides the Hanford Site's future land use plan. However, due to public feedback, the plan is undergoing revision. The performance assessment team is attempting to follow all of the activities in land use planning (including both local zoning and federal designation of the Hanford Reach as a wild and scenic river.) The scenarios used in the current performance assessment are consistent with scenarios used in other Hanford performance assessments with the use of the 200 Area in the future.

217. The issue of environmental justice is treated explicitly in environmental impact statements (see section 5.19 of the TWRS Final EIS). Future performance assessments will, however, investigate the impact on Native Americans now that scenarios for that community are being standardized.

218. As stated in the introduction to these paragraphs (Section 3.3.4), the contaminant release rate used in the calculations is specified elsewhere. The reference has been changed to section 3.4 .5 .4 so to eliminate one link in the pointer chain.

Simulations and experiments indicate that the first phase of glass corrosion is relatively quick (using the time scale of the performance assessment). Thus, it is the "saturated" rate which will dominate the performance assessment as shown in the sensitivity case which simulated glass corrosion from first principles rather than using the RFP values. An additional sensitivity study was done to determine the impact of changing the infiltration rate.

219. Both the EIS and the PA used drinking water standards as performance objectives for protecting groundwater. Procedures, codes, and data are somewhat different but are consistent.

220. On-going studies of vadose zone contamination studies are not explicitly included in this performance assessment. Existing Vadose zone contaminant will be covered under the Hanford SIte Composition Analysis which is scheduled to be published in December 1997.

However, such studies have been and will be used in the Hanford site data collection activities. Some (for example, remeasurement and reanalysis of the 1980's injection experiment) are being funded and lead by the performance assessment team. 


\section{HNF-EP-0884}

\section{Rev. 1}

221. The TWRS EIS did use different values than this performance assessment. The values used in this performance assessment were the result of a study funded by the performance assessment to obtain the best estimated values for chemical effects that would impact low-activity tank waste disposal. The EIS team choose to use earlier, less complete data. Subsequent analysis for the Hanford Site Composite Analysis shows that the Kds used in this performance assessment are still valid with the exception of I-129 whose kd value would be reduced by 5 . Such a reduction of the I Kd value does not materially affect the conclusions of the performance assessment.

222. The vendors indicate that they do intend to meet the void requirement by using small particle non-waste form material. Future performance assessments will use the information supplied by the vendors on their waste forms to better model the waste form and package.

223. The system engineering and design staff are investigating designs from other countries, particularly those of France. (See response to comment 17.)

224. The disposal facility concepts were developed by the performance assessment team based on engineering studies for the grout facility, solid waste facilities, and for vitrified waste (in sulfur-cement) disposal facilities. Now that the program is entering into the phase where the engineering staff is joining with architect-engineers, the performance assessment team will be able to rely on more formal designs.

225. The Canister storage Building in the northwest corner of the 200 Area will be used to store spent fuel. The grout vaults on the far eastern side of the 200 East Area were to be used to dispose of low-level grouted double-shell tank waste. The facilities are different in structure and location.

226. Varying the effective life of concrete walls serve different purposes. Modeling no effective life for the concrete walls provides the engineering staff the on the value of the concrete walls for long-term environmental impact. Thus designs with different types of walls can be envisioned.

Modeling the effective life as much longer than 500 years was to determine whether water trapped in a vault could act as a strong driving function once the water is released.

The simulations show little sensitivity to either situation.

227. Agree. Recharge events at the Hanford site occur only a few times each decade. This performance assessment thus uses an average rate over many decades. Once the near-surface zone is passed, then such a more continuous process describes the moisture flow. 


\section{HNF-EP-0884}

Rev. 1

228. Agreed, the phrase "over 50 years" was repeated. It has been fixed.

229. GENII treats the stomach wall and the stomach as separate organs (thus adding doses) whereas other dosimetry models treat them as an unit.

230. Native American scenarios were not included in this performance assessment as standardized scenarios have not been developed. As part of the Columbia River Comprehensive Impact Assessment such scenarios are being developed and will be available for future performance assessments.

231. No discussion of inadvertent intrusion could be found in EIS. The EIS [Appendix D (Anticipated Risk)] covers operational scenarios, atmospheric release scenarios, and ground/surface water exposures.

232. Agreed, fixed.

233. Calculations using fission yields provide atoms of Se-79 per atom of $\mathrm{U}-235$. Based on systematics, this quantity is probably known to $30 \%$. To express the results of the calculation in units of Curies of Se-79 to grams of U-235 (the units normally used in measurement), the half-life of Se-79, the atomic weight of U-235, and Advorgado's number must be known. The latter two are well known. Thus the discrepancy between fission yield calculations and measurements is likely to result from an incorrect halflife. A new evaluation (March 1997) in the U.K. (as yet unpublished) provides the half-life of se-79 as 650,000 years, agreeing with the conclusion that the 100,000 year value is low.

234. NUREG-1199 ("Standard Format and Content of a license application for a Low-Level Radioactive Waste Disposal Facility"), NUREG-1200 ("Standard Review Plan for the review of a license application for a Low-Level Radioactive Waste Disposal Facility"), and draft NUREG-1573 ("Branch Technical Position on a Performance Assessment Methodology for a LowLevel Radioactive Waste Disposal Facilities") are silent on the extent of validation. Because the codes are used to simulate conditions thousands of years into the future, validation in the strict sense is impossible. The best that can be done is to compare simulation results to short-term experiments. Both the AREST-CT and PORFLOW codes have undergone such testing. The codes that will be used in future performance assessments will have more testing as the performance assessment team expands the experimental data base.

235. No. The STOMP code, rather than the PORFLOW code, was used for the SX Tank Farm simulations. These simulations show the importance of understanding what processes must be modeled. In particular, the SX Tank Farm experience showed 


\section{HNF-EP-0884}

Rev. 1

the importance of near-field chemical and physical conditions on the vadose zone from tank leaks. For example, the fluid leaking from the SX tank had a high density and high temperature. The ionic content of the waste may have overcame the geochemical properties of the vadose zone. The performance assessment team is closely following the lessons learned from the sx modeling as well as other modeling being performed on the Hanford Site.

\section{Agreed.}

237. Agreed. Future performance assessments will include Native American scenarios, especially as the parameters for those scenarios are now obtaining wide-spread acceptance.

238. The volatilization of iodine was provided by the engineering staff to the performance assessment team. The performance assessment team, in order not to overlook a potential issue, increased the amount of iodine estimated by the engineering staff. The performance assessment team will interact with the private vendors to determine the actual amount of iodine going into the waste form. If the iodine is not recycled to the waste form, then the vendors will be responsible for disposing of it as with other secondary radioactive waste. There is no assumption that the iodine will be released to the atmosphere, just that it will not be in the immobolized low-activity product.

239. The sensitivity case for increased Cs-137 inventory was included for inadvertent intruder scenarios, where Cs-137 is important in the few hundred year time frame.

240. The major uncertainties in the facility design referred to in section 3.5.5.6 are not the computer codes but the lack of the design. Sensitivity cases were performed to provide the design staff information on the importance of various features to long-term impacts.

International experience will be used to better validate the computer codes used. However, such experience is very limited and usually not very applicable to the disposal of low-level glass waste forms in an arid environment.

241. With the privatization of the immobilization, the vendors will determine the best way to reduce cracking. The performance assessment team will follow their efforts to determine the viability of their estimates and the effects on the long-term durability of the waste form.

242. Because of the local nature of $\mathrm{Kds}$, the OECD report (although reviewed for releavance) was not used in establishing kd values. Rather the extensive Hanford experimental data base was used for the expected conditions (low ionic content, neutral to slightly basic, low organic content but high carbonate content.) 


\section{HNF-EP-0884}

Rev. 1

243. The $\mathrm{kds}$ used in the PA come from a more complete data base than the ones used in the EIS. The major difference is that the Kd for Uranium in the EIS was taken to be 0 , while in the PA it was taken to be $0.6 \mathrm{mg} / 1$ based on the experimental data base.

244. The work being performed at PNNL for the performance assessment work is covered under a general quality assurance plan. For future performance assessments, the data collected will be performed at QA level 2 with supporting calculations at $Q A$ level 3. Note that previous data collected by PNNL for the performance assessment was done at QA level 3 .

The for waste form effort at Argonne National Laboratory supporting the performance assessment activity was just audited (April 1997) and was found to be compliant.

245. The external review board mentioned in section 3.6 .7 is the board which provided the comments in this section (Appendix F. 1). The sentence was incorrectly written in the original relase with the board having already provided their review. As the board has now provided their review, the sentence is now correct.

246. As noted in response 321 , the EIS did not present inadvertent scenarios. No Native American scenarios were included in this performance assessment because of a lack of standardized scenarios. Because of their "traditional activities" would not intrude on the waste, the residential scenario should be bounding for Native Americans.

247. Agreed. Number changed Erom " $300 "$ to " 200 ".

248. The value for an iterative set of performance assessments is that they can be used to identify problems and concerns so that these problems and concerns can be addressed. One of the main purposes of this performance assessment was to identify concerns as early as possible. Thus the finding that Sn-126 could be a problem should be seen as a strength of this effort.

249. The Department of Energy as well as the systems engineering staff of the Site's contractor are using the performance assessment to address these questions.

250. As noted above (response 223), the design staff is using international experience.

251. The comment on axes presentation will be considered in future performance assessments. The aim is NOT to mislead the reader.

252. Because of the lack of knowledge on the disposal facility design and the waste form performance, the terminology of 


\section{HNF-EP-0884}

Rev. 1

"best estimate" was not used. Also by having one case (rather than the two suggested by this review board), some parameters (for example, certain kds) were conservatively chosen rather than best-estimates. Future performance assessments will have a true best-estimate case as well as a reasonably bounding case.

253. The initial version of the performance assessment is already being used in a number of areas involving TWRS, including characterization, facility design, and relationship to vendors. The performance assessment is not seen just as a regulatory compliance tool, but as a document that has wide and important impact on many different TWRS areas.

254. The brief compliance analysis here was intended to provide an indication of what a full analysis (expected in December 1997) will show. This analysis assumes that each tank farm will be compliant with the all-pathways dose requirements. Thus changes in tank farm compliance would change the calculated results in this section.

255. Because data are being gathered (particularly waste form information), it is difficult to provide a snapshot that is more valid than the one documented in the performance assessment. Information gathered since the initial release of the performance assessment do not significantly change any of the calculated results.

256. Agreed. The performance assessment team in future documents will produce both a best-estimate and reasonably possible cases.

257. Table 4-34 provides an estimate of the dose assuming that the waste was placed directly in the groundwater. Thus no retardation due to the vadose zone is included. Table 5-3 includes the effect of the vadose zone (including retardation).

258. The well screening height was not well defended in this performance assessment. Future performance assessments will provide relevant local practice to justify the value used in such future documents. However, based on conversations the value used in this performance assessment is conservative considering local practices.

259. Agreed.

260. Comments on earlier Hanford Site performance assessments suggested that the values used for borehole diameters and garden sizes were not conservative enough. To determine the sensitivity of these values, less conservative values than previous used in Hanford performance assessments were used. The well diameter will be based on documented local experience. The area of the garden farm is more difficult since most farms in the region are fairly large. However, 


\section{HNF-EP-0884}

\section{Rev. 1}

this value too will be based on documented local experience.

261. Container degradation will be included in future performance assessments. Since the material to be used in the containers is not known (the request for proposal only states metal), it was premature to perform detailed estimates. The effect, however, is thought to be small.

262. Because the facility designs were only conceptual, detailed degradation scenarios were not developed. Data collection efforts are planned to obtain inform on how expected materials will degrade.

It is expected that the degraded concrete will act hydraulically different from the filler material surrounding the waste forms and will act as a sort of a capilliary barrier. That is why current data collection activities are striving to understand how the components of the disposal facility will degrade and what influence wach component will have on the others.

263. The $\mathrm{pH}$ inside the disposal facility will be spatially and temporally dependent. It will depend on the amount of infiltration as well as on the rate of the sodium-hydrogen ion exchange reaction for the particular waste form. Based on various calculations, an estimate of 9.5 is not inappropriate. 


\section{HNF-EP-0884}

Rev. 1

\section{F.2 Department of Energy - Richland Operations}

The interim performance assessment was produced to meet the needs of the Department of Energy to determine as early as possible the potential impacts of the disposal of immobilized low-activity tank waste. Phil Lamont is the current RL Project Monitor for the TWRS Storage and Disposal Subproject. Doug Hildebrand is the current Hanford representative on the newly created board which replaces the Peer Review Panel. italics.

For each comment, the response follows and is presented in

\section{F.2.1 Phil Lamont} brackets.

Responses are after each comment and are enclosed in curcly

DOE-RL MAJOR COMMENTS ON HANFORD LOW-LEVEL TANK WASTE INTERIM PERFORMANCE ASSESSMENT, WHC-EP-0884, REV 0

Summarized below are the major comments from DOE-RL on "Hanford Low-Level Tank Waste Interim Performance Assessment, WHC-EP-0884, Rev 0". Page numbers provided after each comment refer to locations in the text that prompted the comment. However, in most cases other text is also related to the comment.

\section{Major Comments}

1. Explain how this performance assessment compares with ILAW disposal performance predictions in the TWRS EIS (and why additional performance assessment work needs to be done). $(p 1-3)$

Environmental impact statements (EISS) and performance assessments (PAs) serve different needs. However, because they are both a form of risk assessment, they also share many features. The purpose of an EIS is to provide information concerning a number of alternatives, so that a choice can be made among those alternatives. Therefore the assessment tends to be more relative and the amount of technical detail is less than in a PA. A PA, on the other hand, is intended to provide "reasonable assurance" (DOE $O$ $5820.2 a$ ) or "reasonable expectation" (draft DOE O 435.1) that a particular set of actions will meet performance objectives. Because the TWRS EIS covered so many different actions, there is significantly less detail in that EIS on the ILAW disposal action than in this performance assessment.

Additional effort beyond the TWRS EIS is needed to provide the level of assurance required by DOE regulation. In addition, the more detailed analysis in the PA supports detailed decisions on Phase II waste form specifications, 


\section{HNF-EP-0884}

Rev. 1

disposal facility design, and waste acceptance criteria.

A new section in the text (1.2.2.7) has been added on the EIS; "1.2.2.7 Environmental Impact statement for the Tank Waste Remediation System (DOE 1996b)

"The TWRS EIS investigated the environmental and human health impacts for various options dealing with the Hanford tank wastes. Among the options investigated were leaving the wastes in the tanks, removing the wastes from the tanks and separating the wastes to various degrees and then disposing the waste on- or off-site. Because of the nature and scope of the EIS, the EIS sometimes contains different assumptions than were used in this interim performance assessment and the level of calculational detail in the EIS is less than the interim performance assessment."

2. Explain whether or not any requirements in the draft order 435.1 are foreseen to impact the performance measures and objectives as developed for this PA or the overall logic for preparation and submittal of PAs. (piv)

A draft version of the revision of DOE's order (DOE Order $5820.2 a$ ) on radioactive waste management is now out for review. Although this draft (DOE order 435.1 ) places more requirements on the management of radioactive waste management, there are relatively few changes on the performance assessment activity. The most significant change are that the time of compliance is now explicitly stated (as 1,000 years) and that the Peer Review Board has been replaced by a group of federal employees as the technical review board.

The text of the interim performance assessment has been changed to indicate where the new order may have some effect. In the executive summary (ES-I), the following text was added: "DOE Order. 5820.2A is being revised. The existing drafts require similar information and effort as required by DOE Order 5820.2A. The preliminary and final performance assessments will follow the DOE regulations then in effect."

3. Explain/recommend whether DOE should or needs to seek a waiver from Ecology for low-energy beta emitters in the estimation of radionuclide concentration limits to meet drinking water dose limits. (p1-13)

Based on the "Environmental Impact statement of the Tank Waste Remediation System" (DOE 1996b) which was issued by both the Department of Energy and by the Washington State Department of ECology (WSDOE) which used the EPA regulations rather than WSDOE requirements for low-energy beta emitters, the issue of different limits for low-energy beta emitters seems mute. 


\section{HNF-EP-0884}

\section{Rev. 1}

No change in the text (which includes this discussion) seems to be needed.

4. Provide a more detailed explanation of how the 6-inches of precipitation per year (in the form of time-dependent, short-term transient events) translates into an extremely small recharge in the vadose zone. In other words, explain the "water balance" as a function of depth below the ground. $(\mathrm{p} 2-27 / 32, \mathrm{p} 3-10)$

A more detailed explanation on recharge is added just after the first paragraph of Section 2.2.6.5: "As noted in Section 2.2.4, most of the precipitation at Hanford falls in the winter and spring and this amount of precipitation is very smal1. Because of the dry conditions at Hanford, most of the precipitation is stored in near-surface soils until used by plants or until evaporated during the hot summer months. Natural plants have adapted to use all the water in the near-surface zone. Because of the large storage capacity of the near surface soils, water quite rarely (just a few days per decade) exits downwards from this near-surface zone. Such rare events typically occur following the rapid melting of a snow pack."

5. Explain whether this report addresses performance measures set out in 10CFR61. (p2-45)

The performance measures set out in 10 CFR 61 were not explicitly considered in setting the performance objectives of the interim performance assessment. However, the requirements of $D O E$ Order 5820.2A are very similar to those required under the NRC process. The requirement that the waste be considered a class $C$ waste under $10 \mathrm{CFR} 61$ is a program-imposed constraint and not required by DOE order $5820.2 \mathrm{~A}$.

6. Amplify the explanation of the two disposal unit concepts, i.e., provide a better "blow up" of the various layers from the surface of the ground down to the bottom of the vaults. Current figures are difficult to decipher. Also, there needs to be more explanation on how the features are addressed in actual calculations. For example, are the effects of the crushed glass layer actually computed in the base case or other cases, and how beneficial are the effects? The performance of this barrier never seems to be described. (p2-46/48, p3-36/7, p3-51)

Only a minimal description of the disposal unit concepts was given in the interim performance assessment. This was intentional since the performance assessment team was the source of the concepts with very limited information provided by the engineering staff. Therefore the team did not (and still does not) want to bias detailed engineering choices concerning the many components of the disposal facility design. 


\section{HNF-EP-0884 \\ Rev. 1}

The effect of crushed glass has not been calculated. Insufficient funding was available for this modeling exercise.

7. Provide simplified calculations to "scope" the effects of tank-to-tank variability especially in Tc-99 variability. There will probably not be much mixing particularly at the start of processing of DST wastes in Phase 1; therefore, ILAW with "high" concentrations of Tc from selected DSTs could wind up in the vaults. (What was assumed for the Grout Vault PA based on early projected Grout Feeds?) Section 3.2 .4 seems to indicate $T_{C}$ could vary by as much as 100X from tank-to-tank, but later in the report a factor of 2 was mentioned. (p3-7, p3-20, p3-82)

As stressed in the performance assessment, the waste was assumed to be averaged over the entire processing history. At the time of the writing of the interim performance assessment (and even at the time of this revision) it is unclear what the amount of variability in TC inventory will be and where the initial inventory will be placed. However, following the analysis summarized in section 4.10 and assuming that the existing four empty vaults built for the grout program are used for disposal of low-level tank waste. then a rough estimate of the groundwater impact is to ratio the actual TC inventory to be placed in the vaults to the average TC inventory.

A sensitivity case was run to determine what the effect would be if the waste loading was reduced by a factor of 2 . This case is more focused on the possibility of the vendor being limited on the amount of waste that can be placed in the waste form rather than package to package variations in inventory.

Variability in TC inventory remains an important issue:

8. It seems doubtful that the glass corrosion rate could approach the forward rate in stage three, unless the solution is highly supersaturated in stage two and suddenly vast quantities of $\mathrm{SiO} 2$ start precipitating out. (This seems unlikely in a heterogeneous system.) Please discuss experimental evidence for such a dramatic rebound of corrosion rates. Also, please discuss the 7-day PCT test in terms of stage, i.e., are actual rates likely to be higher or lower than the 7-day average. (p3-15)

Experiments performed for our activity at both ANL and PNNL as well as earlier work (Van Iseghem and B. Grambow, "The Long-Term Corrosion and Modeling of Two Simulated Belgian Reference High-Level Waste Glasses" in Scientific Basis for Nuclear Waste Management XI, Materials Research Society, Pittsburgh, 1988 and W.L. Ebert and J.K. Bates "A Comparison of Glass Reaction at High and Low Glass Surfacelsolution Volume", Nuclear Technology 104(1993) 372) indicate that the 


\section{HNF-EP-0884}

\section{Rev. 1}

glass dissolution rate can approach the forward rate in some circumstances.

The 7-day PCT (Product Consistency Test) is designed as its name implies to test the consistency of glass quality. It was not designed to measure the quality of the glass. Especially in the conditions expected in the disposal facility, a quick test in a saturated environment at $p H=7$ is unlikely to provide accurate estimates of long-term (hundreds of years) estimates of glass dissolution under very dry conditions with the $p H$ exceeding 10 . The actual release of contaminants could be higher or lower than the 7 day PCT test.

9. It would be helpful to the reader if the Tables in Section 3.4 were expanded to include both the base analysis case parameters and the corresponding sensitivity cases. (p3-18, etc)

The authors made the choice to highlight the base analysis case in the tables and allow the text to give background information. The text in section 3.4 does provide a summary of the sensitivity cases for each class of parameter, while Section 3.5 .5 attempts to provide a more comprehensive view of the sensitivity cases. Your comment will be considered when preparing future performance assessments.

10. Scoping calculations should be included to address the issue of whether or not glass release rates are controlled to less than the specification value by limits on water infiltration rate. $(\mathrm{p} 3-32,3-53,3-81,4-42,4-64)$

Scoping calculations which address the issue of whether or not glass release rates are limited by water infiltration rate have been performed. They indicate that the infiltration rates must be much less than $0.01 \mathrm{~mm} / \mathrm{yr}$. However, such small rates may exist if the water diverter and gravel side walls work as predicted. We plan to perform such calculations once ARREST is modified to more accurately calculate the flow of moisture into the waste forms. Such work depends on on-going work by Charlie Kincaid as well as Pete McGrail. As the facility concept has not been reviewed by the engineering staff and supporting physical parameters are not yet determined, the authors of the interim performance assessment thought it wise to raise the issue and not to prematurely determine the exact magnitude of the effect.

11. Explanation of release rate needs to be clarified relative to the Privatization Specifications, i.e., when the release rate for other radionuclides is used, then do you assume TC has been removed from the waste via pretreatment to achieve a factor of 5 less, or what. (p3-32/33, 3-53) 


\section{HNF-EP-0884 \\ Rev. 1}

Sections describing release rate were reviewed to make sure that the reader clearly understands what release rate is being used (i.e. whether the one stated in the RFP or the one in the base analysis case). The discussion in section 3.4.5.3 (p. 3-32/33) is a generic discussion and pertains to any release rate as Iong as the release rate obeys the very general assumptions. The discussion in section 3.5.1.2 on the base analysis case is misleading. The sentence has been change to "The contaminant release rate from the waste form for all elements is that given in the TWRS Privatization specifications (DOE 1996a) for all elements other than TC. This means that the TC release rate in the base analysis case is 5 times higher than the $T c$ release rate given in the RFP." A similar statement has been modified in section 3.4.3 (Key Assumptions). Phrases clarifying which RFP release rate was being used were placed in other sections as well.

12. Provide a reference to the calculations that show a temperature rise of only 1 degree $C$. This seems extremely small. $\quad(\mathrm{p} 3-35)$

The rise was calculated to be less than $7^{\circ} \mathrm{C}$. The text has been changed and the reference to McGrail 1994 has been added.

13. Explain fillex material in more detail including performance role. $(\mathrm{p} 3-39)$

There is no section 2.4.5.5. Thus the sentence referring to this section has been deleted. Inside a new paxagraph as been added. "The type of filler material has not been chosen. Its main function is to fill the voids between containers and hence minimize subsidence. A secondary purpose can be to act as a higher conductivity path for moisture flow than the waste form packages. By performing such a role, less moisture would be available for waste form dissolution."

14. It seems illogical to assume that the surface barrier fails at 1,000 years and to assume that the capillary barrier does not fail. Please explain and clarify. (pp3-39/41)

As stated in this section (3.4.6.8), the surface barrier is thought to degrade because it is made of man-made barriers and because of plant and animal intrusion. The capillary barrier (as stated) is made only of natural materials and is significantly below the surface. It is, in fact, under a natural rip-rap barrier that has been shown to eliminate plant and animal. intrusion. The capillary barrier could fail if its components would mix lbut as stated experiments show that this is unlikely for many thousands of years even considering shaking caused by earthquakes) or if there were subsidence in the vault (but as stated calculations show that this has Iimited impact). 


\section{HNF-EP-0884 \\ Rev. 1}

15. The reason for assuming a $1 \mathrm{~mm} / \mathrm{y}$ infiltration rate for the sensitivity case. where the surface barrier lasts forever instead of $0.5 \mathrm{~mm} / \mathrm{yr}$ to correspond to the base case performance of the surface barrier for 1,000 years is unclear. A case based on $0.5 \mathrm{~mm} / \mathrm{yr}$ forever should be calculated in order to offer a direct way to assess the performance need/benefit of the 1,000 year barrier. Also, consider running a case for a slow, linear degradation of the surface barrier, e.g., over 10,000 years. (p3-43, p3$72, \mathrm{p} 3-79)$

Future performance assessments will have a wider variety of recharge scenarios. The reason for choosing a $1 \mathrm{~mm} / \mathrm{yr}$ infiltration rate was so that comparisons could be made with internal calculations in the grout performance assessment which used the $1 \mathrm{~mm} / \mathrm{yr}$ rate. To test the effectiveness of the surface barrier (which caused $0.5 \mathrm{~mm} / \mathrm{yx}$ infiltration rate for the first 1,000 years and then $3 \mathrm{~mm} / \mathrm{yr}$ thereafter), a case using $3 \mathrm{~mm} / \mathrm{yr}$ infiltration rate was run. This case showed that the plateau dose was hardly affected by the lack of the surface barrier and that the travel time was only slightly decreased. We have no basis for assuming a slow, linear degradation of the surface barrier, e.g., over 10,000 years. Moreover, the calculations show that the plateau dose is insensitive to infiltration rates and modeling such changing infiltration rates are extremely expensive to modeling because of the changing boundary conditions.

16. Of the three dose conversion libraries mentioned, explain which one would be technically the most correct, or if it is not possible to determine this, then explain which one is most conservative and justify the actual choice if not the most conservative. (p3-44)

Section 3.4.8.2 (p 3-43/44) was intended to make a technical selection among the dose conversion libraries. The choice (to use the DOE internal dose conversion library and the EPA external dose conversion library) was made over a year before the dose calculations reported in the performance assessment were made. The point is now mute as the DOE guidance for future performance assessments is to use the $E P A$ libraries. If the EPA internal dose conversion library had been used instead of the DOE library, the groundwater and all-pathways dose would have increased by only 108, a difference much smaller than other important unknowns.

17. The pictorial representation of the eight steps for the groundwater pathway is an excellent conceptual aid, but it appears to need revision. It is inconsistent with later figures which imply that water diverted by the sand-gravel barrier does not remix with contaminated water leaving the facility. Also, the figure should show water plus contaminants mixing with ground water as the contaminated water enters the unconfined aquifer. The figure should also show groundwater plus contaminants moving down the gradient 


\section{HNF-EP-0884}

\section{Rev. 1}

to a well. (p3-52)

The water diverted around the facility does mix with the water leaving the facility. By looking at the moisture content plots in figures $4-7$ and $4-8$ one sees that there is some mixing.

Step 6 of Figure 3-6 has been reworded to state, "The contaminants move down gradient in the unconfined aquifer, they mix with the groundwater, diluting the contaminant concentration."

18. Explain why PORFLo can't "go all the way", i.e., start with a time-dependent precipitation scenario as a surface condition and include computation of the performance of the surface barrier, rather than start with the infiltration rate to the capillary barrier. In fact, at least one such calculation should be done to verify the reasonableness of the assumed net infiltration rate to the subsurface facility. If this has been done, then describe in more detail. (p3-58)

In theory, PORFLOW could "go all the way." However, PORFLOW does not efficiently handle such a highly time-dependent problem. Codes such as UNSAT-H, which are supported by the performance assessment project, are much more efficient for modeling this sort of problem. The performance assessment plans to use UNSAT-H more in future performance assessments as the surface barriers become better defined.

19. A table that provides base case and sensitivity case definitions plus the performance objectives that were calculated for each case would be very helpful as not all performance parameters were calculated for each case, apparently. (p3-71)

The caption to Table 3-15 has been expanded to indicate performance objectives that are calculated in the sensitivity cases. "Except for intrusion scenarios, the performance measures calculated were the drinking water dose and the all-pathways dose. For the intrusion scenarios, the acute and continuous doses were calculated."

20. Clarify when it was assumed that the waste was in the form of marbles for performance calculations. Mechanistic waste form release rate cases should be done for "monolithic" waste forms and for marbles of total equivalent mass. This should allow bracketing of the effects of waste form surface area. (p3-74)

Table 3-15 and Section 3.5.5.9 are modified to indicate that all deterministic calculations were performed assuming the waste was in the form of marbles. This conceptual model was an artifact of the earlier engineering studies that used marbles as the reference design. There was not funding 


\section{HNF-EP-0884 \\ Rev. 1}

during the interim performance assessment to perform a monolithic calculation. Further waste form modeling will be based on monolithic waste forms as this structure is what the private vendors are indicating that they will produce.

21. The single case (base or sensitivity) that would be deemed to represent the closest case to "most probable" out of all the cases should be identified and a complete set of objectives should be calculated for this case. However, if another set other than what was run is deemed more appropriate for the "most probable" set (even if some bounding assumptions are judged appropriate), then this case should be run and included in the IPA. (pp3-71-76, etc.)

The base analysis case was intended to be a compromise between a "most probable case" and a case that would not take excessive computation time but would be somewhat conservative. Because so much information (type of waste form, quality of waste form, location of facility, design of facility) are not known, the authors of the interim performance assessment did not believe that exerting great efforts on defining and then modeling a "most probable case" was the best use of funds. As more information is gathered, a "best estimate case" will be developed for future performance assessments. However, even for such a case, conservative compromises will be made as so not to drive up needlessiy the cost of the performance assessment activity.

22. The possibility that the release of some radioactive constituents are limited to less than the specificationbased release rate due to solubility effects should be evaluated and discussed. Solubility limits might have a major impact on the net flux of specific radionuclides in the vadose zone to the groundwater. (p3-81)

The waste form used for the sensitive cases was based on the low-level waste glass LD5-5412. The private vendors have indicated that they will use a different glass and processing scenario for their waste form. The performance assessment will perform tests on vendor-supplied waste forms using Hanford wastes to determine important elemental release rates:

When deterministic calculations are used in future performance assessments, the goal is to model the contaminant release from the waste form and from the vault as accurately as possible. Thus the effects of solubility, secondary phase formation, $p H$, and the amount of moisture present will all explicitly be included in the calculation.

23. The basis for $\$ n-126$ appearing in the ILAW waste form should be provided. Many non-alkali metals are insoluble in alkaline solutions. If $\mathrm{Sn}$ is insoluble, it should report to the HLW fraction. (p4-9) 


\section{HNF-EP-0884}

\section{Rev. 1}

At the time the interim performance assessment was written, the importance of $S n-126$ was not known. The TWRS engineering staff could not provide the performance assessment team with a documented justification whether sn126 would end in high activity waste or low-activity waste. As more information is generated concerning into which waste stream Sn will partition, that information will be used in future performance assessments.

24. Additional explanation of the well is needed, i.e., location of the intake, how much dilution, if any, of contaminated water is assumed to occur, and the impact of well configuration details on exposure or even on groundwater "average" contamination levels relative to arinking water standards. How much depth of the groundwater is assumed to be contaminated at the well? (p4-23, p4-25, 4-29)

There is no discussion of the well except that its location was defined in section 3.3.6. Therefore a new paragraph has been added in Section 3.4.8.3 (Drinking Water and AlIPathways Dose Conversion Factor):

"Water taken from a well is not just taken at the point of maximum contaminant concentration in the ground water, but rather over an interval. Based on the grout performance assessment (Kincaid 1995-8), a well screen depth of 4.6 meters is used. Hand calculations shown that in the 100 meters of travel in the ground water, the contaminants will experience little vertical dispersion. Thus the screen depth is assumed to contain all of the contaminants contained in the entire height of the groundwater at the well location."

A better explanation of the treatment of ground water flow and take up is expected in future performance assessments.

25. It is unclear why the areal density of the waste, i.e., differences in concept 1 and 2 , would have any impact on the intruder exposure. What difference does it make if the intruder actually drills into the waste boxes themselves? $(\mathrm{p} 4-12)$

If the inadvertent intruder drills only into a waste container, then there will be no difference between concept 1 and concept 2 values. However, because the drilling is random and the average of wastes were used, the volume used in the calculations include filler material as well as waste form. It should be noted the assumption of using averaged inventory values has a very much larger impact on estimated dose than does averaging over filler material and waste form.

26. Provide additional explanation of the reasons for the shape of curves which show flux to the aquifer, i.e., why the normalized flux versus time isn't a step function. Explain 


\section{HNF-EP-0884}

\section{Rev. 1}

what controls the rate of rise and the height of the peak or plateau. (p4-14/16)

The last paragraph of Section 4.3.2.1 (Overview - Vadose. Zone Transport" has been modified to read:

"This type of shape results from the length of time during which contaminants are released from the disposal facility being very much longer than the travel time for those

contaminants in the vadose zone. Thus the temporal shape of the contaminant flux at the bottom of the vadose zone is determined from the time dependence of the release from the waste form (or waste disposal facility) rather than from the time dependence of vadose zone transport. Appendix E.1 contains a mathematical justification of this effect. This "step" shape is different from the quickly rising, slowly decaying peaked shapes often seen in performance assessments. The shape of the rise of the "step" function is mainly governed by the same parameters (dispersion, travel time, and travel distance) that provide the width of typical vadose calculations."

27. The concept of the unit cell is unclear and deserves further explanation since the concept is utilized extensively. (P415)

A pointer back to Section 3.5.3.3 (Unit Cell Model) is given on page 4-15. Section 3.5.3.3 has been expanded to provide more background on the model:

"The Unit Cell Model is used to model sensitivity cases. Thus the model is very much simpler than the disposal facility model just discussed. This two-dimensional model treats a thin vertical slice one container ( 1.8 meter) wide and six containers high of the disposal facility model. The sand-gravel capillary barrier and the concrete roof are not modeled. Kline 1996 gives full details."

28. Moisture content and flow line figures are unclear. For example there seems to be no correspondence between stream lines and moisture content, which implies that even where there should be relatively more water flowing, the saturation is still low. Is the distance between streamlines inversely proportional to the flux? (p4-18)

Moisture content and flow line figures in Figures 4-6 through 4-9 are intended to show different things. Moisture content gives the amount of saturation (saturation = moisture content divided by the maximum amount of moisture in that material). Thus one obtains an idea of how this important variable is changing as a function in time in the simulation. The flow lines describe how arbitrary water molecules would move in the simulation. Thus one obtains an idea how water moves. Unfortunately, it was not possible to electronically include these figures into the text and hence 


\section{HNF-EP-0884 \\ Rev. 1}

the reproduction is poor.

29. It is not clear what purpose a projection of performance over 10E08 years serves. Wouldn't this exceed the geologic life of the Pasco Basin? (p4-35)

Calculations and projections for time periods over 10,000 years are just to provide the reader will an understanding that the calculations to 10,000 years have not been adjusted so that a sharp increase exists just beyond the end of the calculations. As a massive flood is expected to occur in the Columbia Basin within in the next 100,000 years, projections based this time have limited usefulness.

30. Additional explanation of the differences on vadose zone transport for Concepts 1 and 2 is needed, especially since the barrier is assumed to fail after 1,000 years in both cases. (p4-36)

As noted on page 4-36, the causes for differences between concept 1 and 2 are given later in the document (section 4.6.2.4). The intent of this section was to quickly discuss the results from concept 2 modeling to give a reference for sensitivity studies which used concept 2 as the base case.

31. The concept of normalized flux to the unconfined aquifer is somewhat unclear, particularly why normalized fluxes reach the same asymptotic values for different infiltration rates. $(p 4-66)$

Normalized contaminant flux to the unconfined aquifer is the flux to the unconfined aquifer divided by the amount of that contaminant initially in the disposal facility. Thus the effect of inventory can be removed from this part of the discussion. The normalized fluxes reach an asymptotic value because the release rate in the unit cell model) are uniform as a function of time. The calculations are showing that the same amount of material is leaving the vadose zone as is entering it at these iong times. For the full disposal model cases, the contaminant release rate changed as a function of time (because the surface area of the waste form changed) and hence the normalized flux had this time dependence imposed upon it.

32. The performance evaluation chapter starts by promising discussion of changes needed to meet performance objectives, but it was previously understood that the base case met performance objectives. Please clarify (p5-1)

The paragraph in section 5.1 (Overview) has been changed:

"This chapter compares the estimated impacts from Chapter 4 with the performance objectives established in Chapter 1. It also discusses items required by DOE guidance for this chapter (changes needed to meet the performance objectives, 


\section{HNF-EP-0884}

Rev. 1

waste acceptance criteria, and future work that is planned).

33. Briefly explain how chlorine content can be used to determine infiltration rate. (p5-8)

As chlorine is very soluble in soils, most of the chlorine was washed away from our soils when the soils were laid down as the result of the catastrophic floods. However, over the last $\sim 10,000$ years chlorine has been deposited on the surface. The chlorine is then carried down into the vadose zone. By analyzing the amount of chlorine as a function of depth, the transport of chlorine can be determined and hence the infiltration rate can be inferred over long time periods.

34. Provide additional explanation of the factors that control flux of waste and flux of radionuclides from the surface to the unconfined aquifer, i.e., explain the characteristic dimensionless parameters and their approximate values (including boundary conditions) that determine the solutions to the transport equations (even if the equations are solved numerically). (p3-16)

Additional explanations of the factors that control flux of waste and flux of radionuclides from the surface to the unconfined aquifer are given in Appendix $D$. This appendix also explains the characteristic parameters. The authors of the interim performance assessment choose to put such details in the appendix as not to deter most readers.

35. Explain the mixing scenario assumed for the mixing of contaminated water entering the unconfined aquifer. It is not clear what the concentration distribution is in the groundwater below and downstream of the disposal facility is after blending with contaminated flux from the vadose zone. $(\mathrm{p} 4-23)$

See answer to comment 24 .

PEL $4 / 29 / 97$

IPACOM

In addition, comments written in his copy of the interim performance assessment were also addressed, but are not detailed here. 


\section{HNF-EP-0884}

Rev. 1

\section{F.2.2 Comments of Doug Hildebrand}

April 7, 1997

SUBJECT: COMMENTS ON HANFORD LOW-LEVEL TANK WASTE INTERIM PERFORMANCE ASSESSMENT EXECUTIVE SUMMARY.

1) Page iii, section I, second paragraph, first and fourth sentences. Provide definitions for the words permanently and immobilized. Permanently probably should be something like long term. Immobilized should be replaced with some description of the waste forms that may be used (e.g., glass or grout or some combination). The words permanently and immobilized would imply that an analysis is not needed - yet in the following sections the principle investigators proceed to describe how $4.4 \mathrm{ppm} / \mathrm{yr}$ contaminant release rate from the waste form and how the dose of $23 \mathrm{mrem} / \mathrm{yr}$ will be observed in the future.

The word "permanently" was deleted.

The Department of Energy has chosen to refer to the waste form of the low-activity fraction of the Hanford tank waste as "immobilized." Only with the awarding of the contract for Phase $1 b$ of the TWRS Privatization Effort (scheduled for May 1998) will the department know what the specific form of the waste will be. Conversations between DOE and the vendors indicate that glass will be the likely waste form, but the vendors have until the end of 1997 to officially inform DOE. Therefore, the phrasing used in the interim performance assessment should not change.

2) Page vii, section B, first paragraph - time of compliance of 100,000 years needs to be 1,000 years. Current guidance in conducting the composite analysis is only 1,000 years. The 10,000 years currently only applies for High level geologic repository, TRU-WIPP site, and up to 10,000 years to shed light on the first 1,000 years when one would observe the peak dose. The information beyond the 1000 years may be provided as information.

AlI performance objectives for the interim performance assessment were determined using a structured process that included public comment. Thus the performance objectives were established long before writing of the interim performance assessment began. As the interim performance assessment was being edited, the Department of Energy began releasing drafts of documents that establish 1,000 years as the time of compliance. Because the new order on radioactive waste management (DOE O 435.1) is stil1 undergoing review and hence may change and because a structured process was used in establishing the performance objectives, the performance objectives used in the interim performance assessment will not change. However, a discussion of the new position will be briefly covered in 


\section{HNF-EP-0884}

\section{Rev. 1}

the main text of the interim performance assessment (Section 1.5.1). Performance objectives for future performance assessments will again be determined through a structured process which will include requirements and guidance of the Department of Energy.

3) Page vii, Section B, second paragraph, include peak dose of $23 \mathrm{mrem} / \mathrm{yr}$ to occur in 50,000 years into table ES-1 as information. Also provide the error statistics for the 23 mrem/yr (i.e., probably exceed the $25 \mathrm{mrem} / \mathrm{yr}$ standard for some time period out at 50,000 years, or indicate to origin of the conservatism in this single estimate.

The authors of the report chose to place only the values at compliance times in the executive summary tables. The maximum values are included in the executive summary text. The authors still believe that this is the best approach. To make an exception for the all-pathways number but not for the other numbers would be inconsistent. To place the maximum value for each performance measure would significantly dilute the attention to the actual compliance numbers.

The Interim Performance Assessment was prepared early in the life of the project. It is too early to put forth uncertainty estimates. However, it is unlikely that the all-pathways dose estimate would be known to better than 10 \% and so the all-pathway dose estimate plus one sigma uncertainty estimate would likely exceed 25 mrem in a year. Future performance assessments will include uncertainty estimates for both data and models.

4) Page viii, Section C, second paragraph - time of compliance appears as 500 years yet in the DOE order 5820.2 a number of 100 is used. Is the 500 years being used as time of compliance or is a time of compliance 100 yrs but 500 years into the analysis ${ }^{126} \mathrm{Sn}$ is the main contributor to the intruder dose? State the bases for the 500 years.

The time of compliance of 500 years was chosen for the inadvertent intruder scenario following guidance from the Nuclear Regulatory Commission and following the pattern established by all the previous assessments for Hanford waste performed under DOE Order 5820.2A. Section 1.5.2.4 of the main text has a discussion of this important topic.

5) Page viii, Section D, first paragraph - time of compliance of 10,000 years again. This time of compliance is not consistent with the composite analysis. Time of compliance is 1000 years and the information provide beyond 1,000 years is to be used as information only.

See the response to comment 2 .

6) Page viii, Section D, - provide discussion on DOE Order 


\section{HNF-EP-0884}

Rev. 1

$5820.2 \mathrm{a}$ standards of $25 \mathrm{mrem} / \mathrm{yr}$ at 100 meters down gradient and all pathways and the protection of groundwater per other federal state and local standards (i.e., Washington state Department of Ecology Water quality standards for Ground waters of the state of Washington WAC 17e-200) and how the facility will or will not be protective to these standards.

The basis for the groundwater protection is discussed in Section 1.5.2.5 of the main report. A more detailed discussion is in "Performance objectives of the Tank Waste Remediation System Low-Level Waste Disposal Program," WHCEP-0826, Rev. 1, January 1995.

The structured approach for determining this performance objective (as well as all others) included considerations of standards established by the state of Washington.

Discussions were held with the Washington state Department of Ecology on groundwater protection standards.

General: The executive summary was provided to summarize conclusions reached in the interim performance assessment activity. Details for the rationale for specific performance objectives are discussed in the main text and in the references. 


\section{HNF-EP-0884}

\section{Rev. 1}

\section{F.3 Nuclear Regulatory Commission}

As part of the NRC's ruling on the classification of the tank waste, the Engineering and Geosciences Branch of the Division of Waste Management read the document. By letter (see Section F.3.1), the staff first requested a meeting to address a series of questions. By receiving a response to their letter (see Section F.3.2), the request for the meeting was dropped. In June 1997, the Department of Energy received a letter from the Director, office of Nuclear Material Safety and safeguards of the Nuclear Regulatory Commission, (see Section F.3.3) that given the preliminary nature of the interim performance assessment the preliminary finding of the NRC staff was that safety requirements comparable to the performance objectives set out in 10 CFR Part 61 Subpart $C$ would be satisfied.

\section{F.3.1 Letter from NRC Requesting Additional Information}

Mr. Donald D. Wodrich

Office of Tank Waste Remediation System

U. S. Department of Energy

Richland Operations office

P. O. BOX 550 MSIN S7-50

Richland, WA 99352

SUBJECT: REQUEST FOR ADDITIONAL INFORMATION - HANFORD INCIDENTAL WASTE CLASSIFICATION

Dear Mr. Wodrich:

U.S. Nuclear Regulatory Commission staff along with our

contractor, the Center for Nuclear Waste Regulatory Analyses, are in the process of reviewing the "Technical Basis for

Classification of Low-Activity waste Fraction from Hanford site Tanks" (Technical Basis), WHC-SE-WM-TI-699, Rev. W, as requested in the November 7, 1996, letter from J. Kinzer, U.S. Department of Energy (DOE), to C. Paperiello, U.S. Nuclear Regulatory Commission. In the process of reviewing the Technical Basis, we have also examined several of the supporting references, including the "Hanford Low-Level Tank Waste Interim Performance Assessment" (Interim PA), WHC-EP-0884, dated september 16, 1996. With respect to the Interim $\mathrm{PA}$, we have identified several issues that need to be resolved before NRC staff can fully evaluate your request for agreement that the Hanford tank waste planned for disposal on-site is incidental waste that would not be subject to NRC licensing authority. These comments address the effects of certain assumptions, models, or parameters on dose calculations with respect to meeting the third of the incidental waste classification criteria set forth in the March 2; 1993, letter from R. Bernero, NRC, to J. Lytle, DOE. The comments are listed in the Enclosure.

In order to facilitate the expedited review schedule requested in 


\section{HNF-EP-0884}

Rev. 1

the November 7 letter, we would like to attempt to resolve these issues in a meeting (face-to-face, or through telecon or videocon) with you and with the PA staff that authored the Interim PA document. Please contact ej.ther Jennifer Davis at (301) 415-5874, or Richard Weller at (301) 415-7287 to set up a meeting. We would appreciate it if the meeting could be held very soon, as we are working to meet your scheduled completion date of April 1997.

$$
\text { sincerely, }
$$

Engineering and Geosciences Branch

Michael J. Bell, Chief Division of Waste Management

Office of Nuclear Material Safety And Safeguards

Enclosure: As stated

CC: J. Kinzer (w/encl) 


\section{HNF-EP-0884}

Rev. 1

\section{SPECIFIC COMMENTS FROM REVIEW OF THE "HANFORD LOW-LEVEL TANK WASTE INTERIM PERFORMANCE \\ ASSESSMENT," WHC-EP-0884, REVISION 0}

1. The Interim PA provides a value of an initial fractional radionuclide release rate of $4.4 \times 10^{6}$ for all radionuclides except ${ }^{99} \mathrm{TC}$. Which has a rate of $8.8 \times 10^{7}$ (Pp. IV and 3-32). These values for the fractional radionuclide release rate may be unrealistically low for the disposal facility. The Interim PA assumes that the fractional radionuclide release rates are limited by the fractional bulk dissolution rate of the glass. However, it is not clear how the fractional release rates for ${ }^{99} \mathrm{Tc}$. A highly soluble nuclide, could be much smaller than the other isotopes in the glass. These values should be justified. For example, Kerrisk (1984) presents a detailed model for calculating fractional radionuclide release rates for vitrified pressurized water reactor high-level waste for 10 important radionuclides expected in the waste, based on nuclide solubilities, recharge rates, background concentrations of silica, and other factors. A similar evaluation would be appropriate for the Tank waste Remediation System waste.

Additionally, the bulk dissolution rate for glass does not necessarily determine the dissolution rate for high-solubility fission products in the glass (such as ${ }^{99} \mathrm{TC}$ and ${ }^{129} \mathrm{I}$ ), because many of these nuclides may have the ability to diffuse out of the glass, and may, therefore, have high release rates. These processes are not included in the Interim PA.

2. The $K_{d}$ value for $I(p .3-27$, Table 3-5) appears to be nonconservative. As standard practice, I is generally considered to be unretarded, i.e., $\mathrm{K}_{d}-\mathrm{l} \mathrm{L} / \mathrm{kg}$. (See also Sheppard and Thibault, 1990.) The value presented in the Interim PA, $K_{d}-3$ $\mathrm{L} / \mathrm{kg}$ is somewhat higher. This difference is expected to significantly affect the results. The value used should be altered or justified.

3. Some of the all-pathways dose conversion factors (DCFs) in the Interim PA ( $p$. B-56, Table B-3) appear to be low compared with DCFs for other arid sites (LaPlante, et al., 1995). The Interim $P A$ should include a more detailed technical justification for the selection of the CFS, because evaluation of disposal facility performance are expected to be very sensitive to the values selected.

4. The derivation of the relative radionuclide release rate (pp. 333 and 3-34) may require modification. The equation in the center of page $3-33$ describes the absolute radionuclide release rate (in $\mathrm{Ci} / \mathrm{Yr}$ ) for the waste form as :

$$
\operatorname{RRR}(t)=S(t)=I(t) / V(t)
$$

Where:

$$
\begin{gathered}
\mathrm{RRR}(t)=\text { the radionuclide release rate }(\mathrm{C} 1 / \mathrm{t}) \\
F-84
\end{gathered}
$$




\section{HNF-EP-0884 \\ Rev, 1}

$$
\begin{aligned}
T & =\text { the time } \\
C & =\text { the constant corrosion rate }(I / t) \\
S(t)= & \text { the surface area of the waste form as a function of } \\
& \text { time }\left(1^{2}\right) \\
I(t)= & \text { the radionuclide inventory in the waste form as a } \\
& \text { function of time (Ci) } \\
V(t)= & \text { the volume of the waste form as a function of time } \\
& \left(1^{3}\right)
\end{aligned}
$$

Assuming that this equation is correct, the relative (or fractional) radionuclide release rate, FRRR(T), i.e., the fraction of radionuclide inventory release rate per unit time would be given by:

$$
\operatorname{FRRR}(T)=\operatorname{RRR}(t) / I(t)-C * S(t) / V(t)
$$

The waste area to volume ration is expected to increase with time due to corrosion of the waste form and cracking due to formation of corrosion products. Because FRRR(t) is directly proportional to the waste area to volume ration, this quantity would be expected to increase with time. On page 3-34, there is an expression for FRRR(t) that decreases with time. This consideration should be included in the Interim PA, because performance is likely to be highly sensitive to radionuclide release rate.

5. The Interim PA methodology is deterministic, and single values (sometimes best values) of parameters are used. The reviewers are concerned that if the range of measured parameter values were incorporated into the Interim PA, some performance limits might be exceeded. Uncertainty analyses should be performed in addition to the sensitivity analyses presented in the Interim PA.

6. There is insufficient justification for the assumption that the capillary barrier will be intact for 1000 years. The performance of this barrier will degrade with time. Similarly, the Interim PA assumes that the concrete vaults will be intact for 500 years. This assumption seems to be based on a U.S. Nuclear Regulatory Commission Branch Technical Position which specifies that the maximum credit that can be allowed for concrete structures is 500 years. A site-specific justification should be provided for this assumption, since occurrence of earthquakes and other natural events must be accounted for.

7. The infiltration rate of $0.5 \mathrm{MM} / \mathrm{yr}$ for the first 1000 years and $3 \mathrm{~mm} / \mathrm{yr}$ thereafter has not been adequately justified. These values may be unrealistically low, and contribution from lateral subsurface flow during storms has been neglected.

8. The release rate calculation appears unrealistic in that the dissolution time for the entire inventory is based on dissolution in still water. In flowing water, waste dissolution will be faster because the fresh water will provide for continuous attack on the waste form. The Interim PA acknowledges that performance results are dependent upon the release rate (pp. 3-32 and 3-35).

$$
F-85
$$




\section{HNF-EP-0884}

\section{Rev. 1}

The dissolution time calculations should be justified or alter

9. The Interim PA uses an equation which appears to consider that the quantity of radionuclides transported to the base of the vades zone is dissolved in a volume of water equal to the annual recharge (p. 3-61). This would be unrealistic and

nonconservative, particularly for the second design option in which the vaults are interspersed by soil. The volume of water will be the portion of annual recharge that actually flows over the waste. The concentration calculated by the flow and transport code would appear to be more justifiable.

10. Flow and transport modeling neglects heterogeneity within layers, thereby omitting consideration of spatially distributed flow.

\section{REFERENCES}

Kerrisk, J.F., "Solubility Iimits on Radionuclide Dissolution at a Yucca Mountain Repository." LA-9995-M5, Los Alamos

National Laboratory, Los Alamos, NM, 1984.

LaPlante, P.A., S.J. Maheras, and M.S. Jarzemba, "Initial Analysis of Selected Site Specific Dose Assessment Parameters and Exposure Pathways Applicable to the Groundwater Release Scenario at Yucca Mountain, "CNWRA 95 018, Center for Nuclear Waste Regulatory Analyses, San Antonio, TX. 1995.

Sheppard, M.I., and D.H. Thibault, "Default soil/solid Iiquid Partition Coefficients, $K$, for Four Major Soil Types: A Compendium, "Health Physics, Vol. 59, No. 4, pp. 471-482, 1990 . 


\section{HNF-EP-0884}

\section{Rev. 1}

\section{F.3.2 Response to NRC Letter}

The following letter was sent to the NRC.

Department of Energy

Richland Operations of fice

P.O. Box 550

Richland, Washington 99352

97-TWR-003

Michael J. Bell, Chief

Engineering and Geosciences Branch

Division of Waste Management

Office of Nuclear Material Safety and safeguards

U.S. Nuclear Regulatory Commission

washington, D.C. 20555

Dear Mr. Bell:

REQUEST FOR ADDITIONAL INFORMATION - HANFORD INCIDENTAL WASTE CLASSIFICATION

Reference: NRC letter from Michael J. Bell, to Donald D. Wodrich, RL, "Request for Additional Information - Hanford Incidental Waste Classification," dated February 6 , 1997.

As requested in the above reference, attached is our response to your review comments of the "Hanford Low-Level Tank Waste Interim Performance Assessment, "WHC-EP-0884, Revision 0, dated September 16 , 1996. On February 12, 1997, copies of the document referenced in the attached responses, "Data Package for the Hanford Low-Level Tank Waste Interim Performance Assessment, "WHC-SD-WM-RPT-166, Revision 0, dated August 1994, were transmitted.

It is my understanding that this information. meets your needs and that a meeting on this subject is not needed at this time. If you have any questions or need additional information, please contact me on (509) $376-6550$.

\section{Sincerely,}

Don Wodrich, Senior Technical Advisor

TWR : DDW

office of Tank waste Remediation System

At tachment

CC w/attach:

c. Peterson, NHC 


\section{HNF-EP-0884}

\section{Rev. 1}

Response to Specific Comments from the Review of the "Hanford Low-Level Tank Waste Interim Performance Assessment," WHC-EP-0884, Revision 0

(Comments contained in the letter from Michael J. Bell, NRC)

1a. The comments suggest that the initial fractional release rate of $4.4 \times 10^{-6}$ for all radionuclides except ${ }^{99} \mathrm{TC}$, which has a rate of $8.8 \times 10^{-7}$ may be unrealistically low.

The actual waste form to be disposed is undergoing negotiation between the Department of Energy and two private vendors selected for phase 1 immobilization. Since the waste form is unknown, the base analysis case of the interim performance assessment used the specifications that were included in the request for proposal [RFP] (and now included in the contracts). Please note that for the base case, the release rate for TC is taken as $4.4 \times 10^{-6}$.

Although this release rate is very low, experiments at the Argonne and Pacific Northwest National Laboratories have shown for a variety of low-level radioactive glass waste forms, this rate can be achieved for the temperatures and pHs expected in the disposal facility.

The initial rate will be determined by a 7-day PCT test and hence should be indicative of the forward rate of glass dissolution. Multi-year. experiments at Argonne and Pacific Northwest Laboratories on LD6-5412, a typical low-level waste glass, show that the initial rate is indeed conservative for both Stage II and III of the glass dissolution process.

In adition, to using the release rate specifications, computer simulations based on experimental data for LD6-5412 were performed. These calculations documented in the interim performance assessment show that the predicted release rate is much lower than required in the RFP.

1b. The comments state that the release rate for TC may not be lower than for other components. For the base case of the interim performance assessment, the release rate for Tc was assumed to be the same as for other elements. The lower rate for Tc release in the RFP could be met in a variety of ways. The most likely way is to separate the TC from the waste to be immobilized, as the specifications require the release rate calculated relative to the amount of material supplied to the vendor and not to the amount in the waste form. However, from the perspective of a performance assessment, the effect is the same as shown by the sensitivity cases.

1c. The comments suggest that bulk glass dissolution does not necessarily determine the dissolution rate for high-solubility nuclides, which may be released at much higher rates by diffusion. The only element that has been observed in experiments at Argonne and Pacific Northwest National Laboratories to be released faster than bulk dissolution is 


\section{HNF-EP-0884 \\ Rev. 1}

sodium. Experiments with actual vendor glasses are planned to determine whether the fission product nuclides are also subject to this release mechanism. Recent experiments at Argonne National Laboratory suggest that TC may be bound in some of the secondary phases that are formed from dissolution of LD6-5412 and FLLW-1.

2. The comments note that the $\mathrm{Kd}$ for iodine is usually taken to be 0 and that the interim performance assessment used $3 \mathrm{~L} / \mathrm{kg}$. Kd values for the important elements are based on experiments using Hanford soils (see "Distribution Coefficient Values Describing Iodine, Neptunium, Selenium, Technetium, and Uranium Sorption to Hanford Sediments" by D.I. Kaplan and R.J. Serne, PNL-10379, Sup. 1 - March 1995. This document as well as others forming the data base for the interim performance assessment are contained in "Data Packages for the Hanford Low-Level Tank Waste Interim Performance Assessment, "WHC-SD-WM-RPT-166, Rev. 0 - August 1995). Subsequent measurements and reanalysis confirmed that a non-zero Kd is appropriate for Hanford soils, although the value of 3 may be a bit too high.

Argonne National Iaboratory is measuring Tc release from LD6-5412 glass this year. Both Argonne and Pacific Northwest National Laboratories will measure release rates of actual vendor glasses made using actual Hanford tank waste starting next year.

3. The comments state that dose conversion factors in the interim performance assessment appear to be low compared to other arid sites and should be documented. The dose conversion factors are documented in "Data and Assumptions for Estimates of Radiation Doses for the Glass Low-Level Waste Interim Performance Assessment, P.D. Roadman, WHC-SD-WM-TI-707 - June 1995. This document as well as others forming the data base for the interim performance assessment are contained in "Data Packages for the Hanford Low-Level Tank Waste Interim Performance Assessment," WHC-SD-WM-RPT-166, Rev. 0 - August 1995. The values used are consistent with the values used in other Hanford risk assessments. Both the values and methods used were reviewed by the Hanford Environmental Dose Oversight Panel.

4. The comments note that the surface area to volume of the waste form should increase with time due to corrosion and cracking. noted in the performance assessment, the simple assumption of uniform decrease in dimensions was used. As more is known about the waste form and its processing, cracking and other events will be included into the performance assessments.

5. The comments note that interim performance assessment used point values and provided sensitivity studies. The comments suggest that an uncertainty analysis be performed. The interim performance assessment was produced in order to provide confidence that the disposal of Hanford low-activity tank waste could be performed. Because it was produced so early in the project, many items (waste form, disposal facility location and 


\section{HNF-EP-0884}

Rev. 1

design) were not known. Reasonable assumptions based on other projects were used for the estimation of values for the base case. Sensitivity cases were defined to determine the impact of these assumptions. For the performance assessments to be submitted for regulatory review, uncertainty analyses will be done.

6. The comments note that the surface barrier is assumed to be intact for 1,000 years and that the concrete structure for 500 years. Neither the surface barrier nor the concrete structures have been designed. The results from sensitivity studies assuming no credit for such structures are very little different from the base case where credit for such structures is taken. The parameters (including design life) for the surface barrier come from work on the Hanford barrier ("Prototype Hanford Surface Barrier: Design Basis Document," D.R. Myers and D.A. Duranceau, BHI-0007 - November 1994). Research on the Hanford surface barrier is continuing. As the design of the disposal facility progresses, analyses to determine the degradation of the structure will occur. However, until design does start, assumptions based on other projects were thought suitable for the interim performance assessment.

7. The comments suggest that the infiltration rates are not adequately justified. The effect of lateral subsurface flow during storms has been neglected. The rates were taken from "Estimate of the Natural Ground Water Recharge for the

Performance Assessment of a Low-Level Waste Disposal Facility the Hanford Site" by M.L. Rockhold, M.J. Fayer, C.T. Kincaid, and G.W. Gee, PNL-10508, March 1995. (This document as well as others forming the data base for the interim performance assessment are contained in "Data Packages for the Hanford LowLevel Tank Waste Interim Performance Assessment, " WHC-SD-WM-RPT166, Rev. 0 - August 1995). The value for the first 1,000 years is based on the design specifications of the Hanford surface barrier. Testing of this surface barrier is continuing at Hanford and so far is meeting its specifications (even under a separate test having precipitation rates of three times normal). The long-term infiltration rates are based on an extensive program at Hanford which has been very favorably reviewed by outside groups. The results of a program including long-term tracer measurements, lysimeter measurements, and computer simulations will be used in the performance assessments created for regulatory review.

The cause of infiltration at the Hanford site has been extensively studied. Lateral flow is seen at hanford but its cause is suspected to be from geologic and hydraulic phenomena (non-horizontal layers, anisotropic hydraulic tensors) rather than storm related events. Once a disposal site is selected, characterization of vadose zone properties will allow a better answer to these concerns.

8. The comments indicate that the release calculations are 


\section{HNF-EP-0884}

\section{Rev. 1}

unrealistic because they are based on dissolution is [sic] still water. Because of the low infiltration rates, the waste if not in still water is in an environment in which the water hardly moves. The base analysis case assumes the forward rate of glass dissolution provides the maximum rate since it is based on distilled water. Moreover, the simulations of glass dissolution do assume flowing water but at rates consistent with water infiltration. These calculations show that the system is diffusion dominated with a very small advective component.

9. The comments note that the contaminants are assumed to be diluted using the area of the disposal facility, not of the waste packages. The computer model used in the base analysis case was a full facility model. The results of these simulations clearly show that the water and contaminants do spread laterally enough to cover the gaps between vaults in the alternate layout design. In fact, the calculations are conservative, since the lateral dispersion will extend beyond the area of the disposal facility.

10. The comments note that the vadose zone modeling neglects heterogeneity within layers. This is true. The site of the disposal action has not yet been determined. Once the site(s) have been determined, then site characterization will be performed. The effect of any preferred flow paths will be determined. 


\section{HNF-EP-0884}

Rev. 1

F.3.3 Letter from NRC on Classification of Hanford Low-Activity Tank Waste Fraction

Mr. Jackson Kinzer, Assistant Manager

office of Tank waste Remediation System

U.S. Department of Energy

Richland Operations office

P.O. Box 550

Richland, WA 99352

SUBJECT: CLASSIFICATION OF HANFORD LOW-ACTIVITY TANK WASTE FRACTION

Dear Mr. Kinzer:

The U.S. Regulatory Commission has received your letter dated November 7, 1996 requesting NRC agreement that the Hanford tank waste planned for removal from the tanks and disposal on-site is incident waste [i.e., not high-level waste (HLW)] and, therefore, would not be subject to NRC licensing authority. In response to your request, NRC and contractor staff [Center for Nuclear Waste Regulatory Analyses (CNWRA)] have reviewed the "Technical Basis for Classification of LowActivity waste Fraction from Hanford Site Tanks" (Technical Basis Report) and supporting documents, including the "Hanford Low-Level Tank Waste Interim Performance Assessment" [Interim Performance Assessment (PA)] to determine whether there is reasonable assurance. that the tank waste slated for disposal as low-activity waste (LAW) meets the incident waste classification specified in the March 2, 1 letter from R. Bernero, NRC, to J. Lytle, U.S. Department of Energy (DOE).

Criterion One from the March 1993 letter specifies that "... wastes have been processed (or will be further processed) to remove key radionuclides to the maximum extent that is technically and economically practical." To comply with this criterion, available separation technologies were identified for each of the major radionuclides of interest and individually evaluated to determine the status of the technology and the radionuclide removal efficiency. Three separate technologies were deemed both technically and economically practical. Currently, it is expected that all three will be used. The three technologies include a simple solids-liquids separation removal of transuranic waste from selected tanks and single-cycle ion exchange removal of cesium-137 from certain wastes. Approximately $3.1 \times 10^{17} \mathrm{~Bq}(8.5 \mathrm{MCi})$ of activity will remain in the LAW, which corresponds to about 2 percent of the estimated $15.6 \times 10^{18}$ $\mathrm{Bq}$ ( $422 \mathrm{MCi}$ ) generated at the Hanford Site (based on a December 31 , 1999 decay date).

NRC staff concludes that the available separation processes have been extensively examined to determine those that are both technically and economically practical, and that the residual 2 percent of the activity generated at the Hanford site represents the maximum amount of separation currently technically and economically practical for this case. It is considered that Criterion one for classifying the Hanford site LAW fraction as incidental waste will be met if the waste management plan presented in the Technical Basis report is followed. 


\section{HNF-EP-0884}

\section{Rev. 1}

Note that if actual radionuclide inventories, either in the tanks or following separation, are significantly higher than or different in character from those projected, compliance with this criterion will require re-evaluation by NRC.

Compliance with Criterion Two, "... waste will be incorporated in a solid physical form at a concentration that does not exceed the applicable concentration limits for Class C [low-level waste] as set out in 10 CFR Part 61." was determined using the estimated total vitrified waste volume $\left(158,000 \mathrm{~m}^{3}\right)(42,000,000$ gallons $)$ in conjunction with projected radionuclide activities. From these calculations, which NRC staff verified, the vitrified waste form is expected to meet the limits for Class $C$ or less, as specified. Note that molten metal processing is also considered for the IJAW form. This method would considerably decrease the total waste form volume such that the waste classification could be affected. If the radionuclide inventories in the IAW are significantly higher than those projected in the Technical Basis report, or if the waste form type or total volume are altered, reevaluation of conformance with this criterion will be necessary.

To evaluate Criterion Three "... wastes are to be managed, pursuant to the Atomic Energy Act, so that safety requirements comparable to the performance objectives set out in $10 \mathrm{CFR}$ Part 61 , Subpart C are satisfied.", an Interim PA was prepared. The DOE PA was performed to the requirements of DOE Order 5820.2A, "Radioactive waste Management," dated september 26, 1988. This order is similar to the 10 CFR Part 61 performance objectives.

The Interim PA is the first of three PAs planned and is somewhat preliminary; it was conducted before selection of a disposal facility site and design, specific treatment alternatives, LAW form, or a complete and verified radiological and chemical characterization of the contents of the Hanford tanks. Our review identified a number of specific issues and concerns associated with the Interim PA, documented in the February 6, 1997 Request for Additional Information (RAI) from M. Bell, NRC, to D. Wodrich, DOE, \{note added: this letter is reproduced in section $F .3 .1\}$ and discussed in the enclosed CNWRA report. DOE's responses to the RAI constitute Appendix B to the CNWRA report \{note added: this letter is reproduced in section F.3.2\}. Many of the RAI comments cannot be fully resolved until the site, facility design, and solidification process are selected. It is expected that uncertainties and concerns identified with respect to the Interim PA can be satisfactorily addressed in subsequent PAs.

Although the Interim PA is preliminary it indicates that the performance objectives of Part 61 will be met. Consistent with the preliminary nature of this Interim PA, the staff's preliminary finding is that Criterion Three appears to be satisfied. As the disposal facility is chosen, the disposal facility design is completed, treatment alternatives are selected, the LAW form is determined, and proper characterization of the contents of the tanks is confirmed, the various assumptions and input parameters are likely to be further refined. Please submit future PAs as supplements to the Technical Basis report so that they can be reviewed to confirm the current analysis and resolve any outstanding issues. 


\section{HNF-EP-0884}

\section{Rev. 1}

Based on the preliminary information provided in the DOE Technical Basis report and the Interim PA, the staff's preliminary finding is provisional agreement that the LAW portion of the Hanford tank waste planned for removal from the tanks and disposal on-site is incidental waste and is, therefore, not subject to NRC licensing authority. Staff considers that the information presented is not sufficient to make an absolute determination at this time. Note that if Hanford tank waste is not managed using a program comparable to that set forth in the Technical Basis report, or the current characterization of tank contents is not confirmed, the incidental waste characterization must

be revisited by DOE and the NRC consulted. As a fundamental element of the incident waste classification, DOE must ensure the contractors perform LAW separation and disposal do so in accordance with the criterion set forth in the March 1993 letter and the approved Technical Basis report.

Successive PAs should be submitted as supplements to the Technical Basis report so that they can be reviewed to confirm the current analysis and resolve any outstanding issues. Other specific changes that would necessitate DOE re-evaluation and further consultation include, but are not limited to, the following:

1) Continuing characterization of tank waste results in a determination that the radionuclide inventory in the HLW tanks is higher than or different from that used to develop the Technical Basis Report and the Interim PA. This would affect the resolution of all three criteria.

2) The IAW fraction of the Hanford tank waste is not vitrified, or the final volume of waste is significantly different from that projected in the Technical Basis report. The waste form is a determining factor in classification of waste as Class A, B, or C (Criterion Two) and would also impact PA (Criterion Three).

3) Final selection of the LAW disposal site, or changes to site characterization paxametexs will affect the resolution of Criterion Three.

If you have any questions about the details of this letter, please contact Michael Bell of my staff at (301) 415-7286.

Sincerely,

Carl J. Paperiello, Director

Office of Nuclear Material Safety and Safeguards 


\section{HNF-EP-0884}

Rev. 1

\section{F.4 U.S. Department of Navy}

Reactor compartments from decommissioned submarines from the U.S. Navy are disposed in the northern part of the 200 East Area. Because of this disposal action, the U.S. Navy has performed a series of environmental studies in that region.

F.4.1 Letter from Us Navy

5090

Ser $2310 / 1118$

U. S. Department of Energy

Richland Operations office

Attn: T. K. Teynor

Director, Waste Programs Division

P.O. BoX 550, MSIN $57-55$

Richland, WA 99352

Gentlemen:

Puget Sound Naval Shipyard has reviewed a copy of the Hanford LowLevel Tank Waste Interim Performance Assessment, WHC-EP-0884 (Tank Waste PA) and provides comments in enclosure (1). Comments are provided per reference (a) which requested a response by March 30 , 1997. Comment 4. of enclosure (1) is intended to provide consistency with the Draft 200 East Area Low level Burial Ground Performance Assessment (woods 1996), and the shipyard requests to be informed of specific text changes in resolution to this comment. Faxing of revised pages is sufficient. I can be reached at (360)$476-8544$.

Sincerely

Department

J. R. WRZESKI

Head, Reactor Engineering Division

Nuclear Engineering and Planning

By direction of the Shipyard Commander

Ref :

(a) WHC letter 9654293 of September 24,1996

Encl:

(1) Comments to Hanford Low-Level Tank Waste performance Assessment 


\section{HNF-EP-0884}

Rev. 1

COMMENTS TO HANFORD LOW-LEVEL TANK WASTE INTERIM PERFORMANCE ASSESSMENT

Ref (a): NAVSHIPYD PUGET ltr 5090/5 Ser 2300.1/1188 of 5 Jul 96

1. Section 3.4 .5 .4 on page $3-32$ specifies a 1.4 E-13 ( $\left.\mathrm{s}^{-1}\right)$ initial fractional radionuclide release rate for non- ${ }^{99} \mathrm{TC}$ isotopes for use in the base case analysis. This rate is equated to a initial radionuclide release rate of $4.4 \mathrm{ppm} / \mathrm{yr}$ in the subject section (first bullet). Table $3-8$ on page $3-34$ provides a formula which results in an initial radionuclide release rate of $[4.4 / \mathrm{T}] \mathrm{ppm} / \mathrm{yr}$ (at time $=0$ ), vice $4.4 \mathrm{ppm} / \mathrm{yr}$. The constant $T$ is a large value, and so the formula does not appear to be consistent with the earlier text. Please clarify.

2. In section 4.3 .2 .5 on page 4-21 at the beginning of third paragraph, "10,00 years" is a typographical error which probably should be " 10,000 years".

3. In Appendix D, section D.3.2 (page D-8) at the end of the first (and only) paragraph, "Hanford East Area" appears to be a typographical error which probably should be "Hanford 200 East Area".

4. In Appendix E, figure E-2 on page E-20 depicts a 119-120 meter. elevation above mean sea level for the water table at the 218E-12B Burial Ground. This corresponds to a de-saturated condition under Trench 94 consistent with predictions from Rhoads et al., 1994. In 1995, groundwater monitoring wells adjacent to the trench were either dry or showed aquifer thickness of less than 1 meter, at about 122 meters above mean sea level. This is not consistent with the 5 meter thick aquifer predicted for this site in figure E-3 on page E-21. Comment 1.a of enclosure (1) of reference (a) noted a similar inconsistency in the Draft 200 East Area Low level Burial Ground Performance Assessment (wood, 1996). This comment was resolved by Westinghouse Hanford Company in proposed text changes provided to the Shipyard on July 31, 1996. Similar text is proposed below for addition as a footnote to figure E-3 of the Tank Waste Performance Assessment with the footnote keyed to the $218-E-12 \mathrm{~B}$ Burial Ground:

"A study to evaluate the potential for transport of nickel radioisotopes from the 218-E-12B Burial Ground (Rhoads et al. 1994) postulated unsaturated sediments beneath this site, rather than the 5 meter thickness predicted in this analysis. The postulation was based on two-dimensional CFEST simulations under an assumption of a low recharge condition and supported by the measurements of adjacent wells. However, the desaturation condition should be limited to the vicinity of the 218-E-12B Burial Ground. Further details can be found in wood 1996." 


\section{HNF-EP-0884}

\section{Rev. 1}

\section{F.4.2 Response to letter}

1. The commenter is correct. The multiplicative factor in Table 3.8 is incorrect, it should be 3 . The calculations were performed with the proper value, as can be determined by comparing the cases with constant release rate with the cases using the formula given in Table 3.8 .

2. The commenter is correct. "10,00" should be "10,000".

3. The commenter is correct. "Hanford East Area Burial Ground" should be "Hanford. 200 East Area Burial Ground"

4. The commenter's point is noted. However, rather than placing the comment as a footnote to a figure caption in an appendix, the following text was added in the main body of the text at the end of section of section 4.3.3.

"Large-scale Hanford groundwater modeling for conditions far in the future is just beginning to undergo extensive review. Some discrepancies are to be expected. For example, a study to evaluate the potential for transport of nickel radioisotopes from the $218-\mathrm{E}-12 \mathrm{~B}$ Burial Ground (Rhoads et al. 1994) postulated unsaturated sediments beneath this site located in the northern part of the 200 East Area (as contrasted to the 5 meters predicted in this analysis). The postulation was based on two-dimensional CFEST (Gupta 1987) simulations under an assumption of a low recharge condition and supported by the measurements of adjacent wells. However, the desaturation condition should be limited to the vicinity of the 218-E-12B Burial Ground, because of the basalt structure being much nearer the surface at the burial ground."

The reference Rhoads 1994 will be added

Rhoads 1994, K. Rhoads, B.N. Bjornstad, R.E. Lewis, S.S. Teel, K.J. Cantrell, R.J. Serne, L.H. Sawyer, J.I. Smoot, J.E. Szecsody, M.S. Wigmosta, and S.K. Wurnster, Estimation of the Release and Migration of Nickel Through Soils and Groundwater at the Hanford Site 218-E-12B Burial Ground, PNL-9791, Pacific Northwest Laboratory, Richland, Washington, 1994. 
HNF-EP-0884

Rev. 1

\section{F.5 Dewey A. Burbank}

Dewey Burbank is a Principal Engineer for the SGN Eurisys Services Corporation with responsibilities in the Systems Definition and Design Activities of the Low-Level Tank Waste storage and Disposal Project.

His comments were the following (with the responses in curly brackets \{\}):

1. Page 2-25, Figure 2-10. Map latitude axis is incorrect. The Washington-Oregon border is on the 46 th parallel; the parallel north of Spokane is the 48th. \{Figure was corrected.\}

2. Page 2-48, Sec. 2.4.4, second bullet. Typo, should read "To wick moisture away..." ("way" was changed to "away"\}

3. Page 3-15, Sec. 3.3.4.2, last paragraph, 2nd sentence. Typo, should read "...release rate is not necessarily proportional to..." \{"proportionally" was changed to "proportional" \}

4. Section 3.4.6.5, and Figure 3-5. Vault package array layouts are not consistent with design assumptions for storage and disposal projects. Based on conversations with Eiholzer, we have been assuming that the spacing between containers would be held to the $10 \mathrm{~cm}$ originally described in Concept 1 (Eiholzer 1995). However, Eiholzer 1996 and the PA held the centerline spacing constant. We need to be better coordinated on this in the future. \{There will be no change in document, but coordination will be improved.\}

5. Page 3-53, sec. 3.5.1.2, second bullet. Suggest that this assumption be elaborated on, perhaps add "(e.g., no agricultural irrigation)." This also touches upon the discussion we had about the need to better explain the different nature of the two analysis cases, where the assumptions used for the base case are separate and distinct from those used for the intrusion cases. (Second bullet changed to "The future land use is as a protected area, without artificial recharge (for example, no irrigated farming occurs)"

6. Page 4-53, sec. 4.6.3.2, 3rd paragraph, first sentence. Something is missing here; "... no diverter is present (in or over?) the vault area..." (The sentence is changed to "... when no diverter is present over the vault area,"

7. Page 4-75, Sec. 4.9, second paragraph, last sentence. Check grammar here; either "... disposal of waste..." or "...disposed waște..." woula read more clearly. SSentence changed to ".... the impacts of catastrophic events on disposed waste are not significant. " 


\section{HNF-EP-0884}

\section{Rev. 1}

8. Page 5-4, Sec. 5.2.7, first sentence. The reference to 6 to 13 percent of tank waste refers to the minimum order quantities in the privatization RFP. The capacity of the existing grout vaults is only about 5.6 percent of the total. (Reference: Array \#1, page B-63 of ILAW Storage AGA for individual vault capacity, and Page A-6 of the AGA for total package count). \{Both references in section 5.2 .7 will be changed to reflect the better estimate of the waste that may go to the grout vaults.\} 


\section{HNF-EP-0884}

Rev. 1

\section{F.6 Kathleen Rhoads}

Kathleen Rhoads is a Senior Research Scientist at the Pacific Northwest National Laboratory. She performed the Hanford Environmental Dose Oversight Panel review [Rhoads 1996] of the interim performance assessment as required by the local Department of Energy office.

italics):

Her comments were the following (with the responses in

1) The PA analysis needs to tie the results to "standard" methods adopted by HEDOP (including Paul as a member of the panel). In the case of this document, the demonstration that the methods used for the PA were equivalent to those previously approved by HEDOP are in the technical background document rather than in the $\mathrm{PA}$ itself, which makes the connection less visible than would be desirable. However, I don't consider that a serious enough flaw that I would refuse to approve the calculations. Paul [Rittmann] is aware that I have some concerns about his use of the spreadsheet approach (although as yet, he hasn't been concerned enough about them to mend his ways!). In the end, the quality of the results is the bottom line, and he has demonstrated in several documents that there aren't any substantial differences between his method and those approved by the panel. I've been willing to approve them on that basis, and because these documents usually come to me as an afterthought when the opportunity for substantial reworking is past.

Comment is noted. An attempt will be made to better tie the efforts for succeeding performance assessments to "standard" methods.

2) The use of DOE dose factors for internal exposure pathways and the EPA FGR 12 dose factors for external exposure pathways (sec. 4.8.4) is inconsistent, but again not a fatal flaw since both sets are based on essentially the same models (and in fact, were developed by the same organization). However, in the future, DOE is recommending use of the EPA FGR 11 and FGR 12 dose factors for 10 CFR 834 compliance calculations, and the site should standardize on those just to avoid confusion. Although I don't think this is a serious enough issue to request that it be changed before your impending publication date, I would recommend revising the calculations to use EPA dose factors throughout in your next version of the document. That should be straightforward because Paul has them in a database that he uses with his spreadsheet. 


\section{HNF-EP-0884}

Rev. 1

Before calculations for the interim performance assessment were begun, an evaluation was performed to find the best library of conversion coefficients. Sensitivity calculations were performed to demonstrate the effect of using different libraries.

Guidance from the Department of Energy seems to be solidifying around the EPA library. Therefore, once the guidance becomes official, we will use such guidance. 


\section{HNF-EP-0884 \\ Rev. 1}

\section{F.7 Jeffry A. Voogd}

Jeff Voogd is the current Program Manager for the TwRS storage and Disposal Program. He thus has program responsibilities for this document. He had similar responsibilities for the Performance Assessment of Grouted-Double Shell Tank Waste Disposal at Hanford (Kincaid 1995).

His comments were the following (with the responses in italics:

Comments on WHC-EP-0884, Hanford Low-Level Tank Waste Interim.

Performance Assessment

1. pg 1-4, There was also the PSW Performance Assessment, PNL6152, Long-Term Performance Assessment of Grouted

Phosphate/Sulfate Waste from N Reactor Operations, April 1987, G.H Stewart et al

A reference to this performance assessment has been added in section 1.2.2:

\section{"1.2.2.2 Long-Term Performance Assessment of Grouted} Phosphate/sulfate Waste from $N$ Reactor Operations (stewart 1987). This performance assessment forms the basis of the environmental assessment (DOE 1986a) for the disposal of lowlevel radioactive waste generated by decontamination operations and other activities associated with the operation of the $N$ Reactor on the Hanford Site. Since this performance assessment predates the DOE Order on radioactive waste management, the review was through the review of the environmental assessment."

2. pg 1-6, Several items have changed,

- ICD 15 is the proper ICD

- the product acceptance is part of WIT activities not LLW Disposal subproject

Accepted, a revised version replaces the other version.

3. pg 2-42, this chart has been updated to reflect the privatization phases

Accepted, the most recent version will be used.

4. pg 3-7, 3.2.4, Please reconsider the assumption of uniform waste mixtures. The variation of the Tc inventory within the waste and the implications to the TWRS disposal program needs to be considered. It is quite possible that the majority of the Tc inventory would be processed during phase 1 of privatization and that Phase 2 or all of Phase 2 would not be completed. The sensitivity case shown on pg 3-72, (section $3.5 .5 .3, \& 4.82$ ) do not address a higher concentration gradient or waste loading for the water soluble constituents that would be preferentially delivered in Phase 1 of privatization. 


\section{HNF-EP-0884}

\section{Rev. 1}

There is insufficient information at the time of the revision of the interim performance assessment to provide a meaningful tank by tank estimate. The standard TWRS Inventory Project are scheduled to publish the first estimates in september 1997. However, future performance assessments will most certainly take this important effect into account.

5. Pg 3-9, 3.3.3.2, 4th paragraph. It is probably not correct to say "little irrigation occurs in the Horse Heaven Hills..." There has been a considerable increase in the use of arip and circle irrigation in the hills for vegetables and grapes.

The paragraph as been rewritten as follows:

"Like the Central Plateau, the Horse Heaven Hills (which are south of the Hanford Site) are near, but at a significantly higher elevation than, the Columbia River. Although the amount of irrigation is increasing at certain locations, relatively little irrigation occurs in the Horse Heaven Hills because of the relatively high energy cost (hence economic cost) of bringing water to the surface. Dry-land farming continues to be the main use for the land of the Horse Heaven Hills."

6. Pg 3-73, This PA was attempting to identify response to variations in parameters. However as noted in the independent review panel meetings, there is merit to providing a bounding and best estimate analysis. It would be helpful to group or identify the sensitivity cases that support a best estimate, a bounding estimate or an evaluation of parameter.

The comments of the independent review panel were excellent in regard to providing a best estimate and a bounding analysis. Because of the early state of the disposal project, such analyses are not meaningful at this time. However, for future performance assessments, a best-estimate case (with associated uncertainty cases) as well as reasonable bounding analysis will be performed.

7. Pg 3-79, 3.5.5.5; Since the boreholes and geotechnical data requests are critical path for revision of the PA it would help to clarify this section. Please establish a stronger link between the sensitivity studies and the data being requested via borehole drilling. For example in paragraph 2 it is stated "This is an indirect way to study the influence of the hydrologic parameters." Several questions arise; is there a direct way? what are the hydrologic parameters of interest? Which of these parameters are being addressed by the sensitivity cases? What constitutes a bounding condition? How do these sensitivity cases reflect the those hydrologic parameters and the bounding condition?

The paragraph in question deals with moving the position of the top of the unconfined aquifer. By dropping the word "groundwater" from the sentence "This is an indirect way to study the influence of the groundwater hydraulic parameters.", 


\section{HNF-EP-0884}

Rev. 1

the impression is left that the hydraulic properties being investigated are those in the vadose zone. However, because the top of the unconfined aquifer is in the Ringold Formation just before the bottom of the highly conductive Hanford formation, by moving the top of the aquifer one is effectively changing the properties of the unconfined aquifer. 


\section{HNF-EP-0884}

\section{Rev. 1}

\section{F.8 Joseph A. Westsik, Jr.}

Joe Westsik is a Program Manager at the Pacific Northwest National Laboratory. He was the project manager for the Grout Performance Assessment (Kincaid 1995). He is presently leading the technical effort on waste acceptance.

His comments were the following (with the responses in curly brackets \{\}$)$ :

1. Executive Summary, I. 2nd Para. The word "concentration" in the last sentence is better stated as the largest "inventory". This is also consistent with the last paragraph in section 1.2.1 of the introduction. \{accepted\}

2. Throughout the document, references to the TWRS Privatization RFP can be updated to recognize that contracts with BNFI and Lockheed Martin Advanced Environmental Services (LMAES) have been signed. Specifications for the immobilized low-activity waste (ILAW) are included in the contracts. \{accepted, changes made in sections ESII, 1.2.1, others\}

3. Section 1.6, 7th bullet and elsewhere. Appendix A now contains the ILAW product specifications from the TWRS Privatization contracts with BNFI and LMAES. \{accepted\}

4. Section 2.2.3.4. Consider mentioning the interim storage of spent fuel and immobilized high-level waste. (A sentence has been added after the reference to Figure 2-3. "A building (The Canister storage Building) is being built just west of B-plant which will store spent nuclear fuel and the immobilized highlevel tank waste until a federal geological repository is ready to receive such waste."

5. Figure 2-7 on p 2-17. Revise figure to show proposed disposal facility rather than Grout Treatment Facility. \{accepted\}

6. Section 2.2.6.5, 2nd para. In the last sentence, mechanisms is misspelled. Also, can you state that "no mechanisms are known to exist ..." rather than "no mechanisms are assumed to exist ..."? \{spelling corrected and sentence is restated.\}

7. Table 2-3 on p 2-39. Last line, add closing ") " after pCi/l for radium. \{done\}

8. Section 2.3.1, 3rd para and elsewhere. The word 'pretreated' is used here and many other places in the document to describe chemical and physical separations to form the HLW and LAW streams. "Pretreated" may be understood on the Hanford site but "chemical and physical separations" is more descriptive for the average reader. Recommend replacing the word 'pretreated' from as much of the document as possible. This is consistent with section 2.3.4 which used the word "separations".

accepted, changes made in Sections ESI, ESII, 2.2.3.4, 2.3.1, $2.3 .4\}$ 


\section{HNF-EP-0884}

Rev. 1

9. Section 2.3.4. 'Pretreat' and 'pretreatment' are used to cover a number of chemical processes. It would help to be more descriptive. For example, the TWRS privatization contracts require the private contractors to separate CS, Tc, Sr, TRU, and entrained solids to the extent required to meet the ILAW product specifications in the contracts. \{The authors believe that this detail is not necessary, especially considering that the exact amount of separation is not known. When future performance assessments are prepared, then vendor-specific information should be available.

10. Section 2.3.4 item 2. Clarify that the three bulleted items are from the Berneo letter as requirements for the incidental waste classification. \{The phrase "Berneo 1993 requires" was added. $\}$

11. Section 2.3.7. The TWRS Privatization contracts describe the product acceptance process in the requirements for the "Products and Secondary Wastes Plan" to be prepared by the Private Contractors during Phase $1 \mathrm{~A}$ and implemented during Phase 1B. A product acceptance strategy has been prepared by DOE. Implementing the strategy requires a product acceptance process which includes development and maintenance of product specifications, Private Contractor qualification testing and evaluation prior to production, DOE verification testing prior to production, Private Contractor certification testing and reporting during production, and DOE acceptance testing according to a Product Acceptance procedure during production and operation of the storage/disposal facility. The Private Contractors will be required to conduct analyses, testing, inspections, and demonstrations to qualify and certify their products. Analysis refers to engineering or scientific calculations or reasoning. Demonstrations include proof-of principle work and process control records during production. Inspections refer to non-destructive examination, and testing refers to destructive examination or measurement.

The paragraph on certification has been deleted and replaced with the following:

"The TWRS Privatization contracts describe the product acceptance process in the requirements for the "Products and Secondary Wastes Plan" to be prepared by the Private Contractors during Phase $1 \mathrm{~A}$ and implemented during Phase $1 \mathrm{~B}$. product acceptance strategy has been prepared (Westsik 1997). Implementing the strategy requires a product acceptance process which includes development and maintenance of product specifications, Private contractor qualification testing and evaluation prior to production, DOE verification testing prior to production, Private contractor certification testing and reporting during production, and DOE acceptance testing according to a Product Acceptance procedure during production and operation of the storage/disposal facility." ?

Westsik 1997, J.H. Westsik; Jr. and P.L. Miller, "preliminary 


\section{HNF-EP-0884}

\section{Rev. 1}

Product Acceptance Strategy for ILAW, IHLW, Intermediate Products, and Secondary Wastes, "WIT-097-036, Pacific Northwest National Laboratory, Richland, washington, January 1997.

12. Section 2.4.2, 3.5.3.2, and elsewhere. "Canisters" is frequently used in the document to describe the packaged ILAW product. Canisters typically refers to the HLW canisters destined for the HLW repository. To avoid potential confusion, I recommend using "packages" or "containers" rather than "canisters" to refer to the ILAw packages only. "Containers" has been used instead, changes made in Sections $2.4 .2,2.4 .4$, others

13. Section 2.4.6, first para. Use 'envisioned' rather than 'envision' in the second sentence. \{corrected\}

14. Section 3.2.3.4. It is not clear to what extent separation of TC, Cs, Sr, TRU, and entrained solids required of the Private Contractors is included in the inventory estimates. For example, separation of $\mathrm{Cs}$ and $\mathrm{Sr}$ currently in the capsules is mentioned, but any further separations to meet TWRS privatization contract requirements are not discussed.

A new paragraph has been added (Section 3.2.3.4). "Note that the above discussion does not include any information from the private vendors awarded the contracts (BNFL and Lockheed Martin Advanced Environmental Services). That information is expected to be available in May 1998. Their separation plans may be different from that given in shelton 1995. Future performance assessments will be based on published information from the private vendors."

14. Section 3.2.4, last sentence. Last 'at' should be 'are.' \{corrected\}

15. Section 3.3.3.3, 1st para on p 3.11. Correct next to last sentence before bullets. Irrigation on the 200 Areas was not considered. \{corrected\}

16. Section 3.3.5. The level of detail in describing the transport mechanisms in inconsistent. The description of water vapor diffusion in 3.3.5.2 seems to be about the right level of detail to provide the necessary understanding. Section 3.3 .5 .3 in particular lacks descriptions of the mechanisms themselves.

\{The authors feel that the level is appropriate.\}

17. Section 3.4.4.4. Referrals to Kaplan references can be reduced ( $I$ count 13). Also, the dates include 1995, 1995a, and 1995b but the references only have $1995 \mathrm{a}$ and 1995b. (Number of references have been reduced, dates have been corrected.)

18. Section 3.4.4.4, para 1. The reader is referred to section 3.3.5.3 for additional information on the geochemical retardation factor. That section doesn't provide any 


\section{HNF-EP-0884}

\section{Rev. 1}

significant information that couldn't simply be added to 3.4.4.4 rather than having to leaf back through the pages.

\{Link to Section 3.3.5.3 has been deleted.\}

19. Section 3.4.4.5, para 1. Remove 'to be' from the second sentence such that it reads 'The hydraulic parameters used are from ...' \{corrected

20. Figures 3.3 and 3.4. The numerical codes in the figures are not clear. TThese are the best figures available. The authors apologize that they are inadequate. However, revised figures are not available for inclusion in the document

21. Section 3.4.5.2. Additional details regarding the ILAW form and container can be added to increase confidence in the packaging. For example, filler material is to be added to reduce the void space, therefore reducing the potential for subsidence. The details can be gleaned from the specifications (see for example 2.2.2.1, 2.2.2.2, 2.2.2.3, 2.2.2.5, $2.2 .2 .14,2.2 .2 .18,2.2 .2 .22$, and 2.2 .2 .23 ).

The sentence "Filler material is to be added to reduce the void space to less than $1 \%$ of the original container volume." was added. Since minimal credit is being taken for the packaging and since little is presently known about what packaging the vendors will use, the authors feel that the level of detail. is sufficient.\}

22. Section 3.4.6.1. Last sentence in para 1. use 'thought' rather than 'though.' (corrected\}

23. Section 3.4.6.2. 1st para. Add' ')' to '(28.7' feet in the next to last sentence. \{corrected\}

24. Section 3.4.8.2. 2nd para. Fix second sentence. \{The sentence has been changed to "These dose factors reflect a committed dose over a period of 50 years."

25. Section 3.4.8.4 5th para. The assumption that $90 \%$ of the waste remains with the waste form may be ok for the driller scenario. However, for the homesteader scenario. I would expect that more of the waste would be free of the waste form because of the extra irrigation and the erosion due to tilling the soil. \{After 1,000 years, less than 18 of the waste will have been released from the waste form according to the waste form specifications. Assuming $10 \%$ release seems to be conservative even under extra irrigation and tilling. However, this assumption will be investigated in future assessments.

26. Section 3.4.8.5 last para. This paragraph is discussing the results of a sensitivity case which is out of place here. Simply state that the soil concentrations are lower which will reduce doses but time spent tending the garden increase, increasing the doses. Move the discussion of results to 


\section{HNF-EP-0884}

\section{Rev, 1}

Chapter 4. \{agreed. This discussion was moved to section $4.2 .3 .5\}$

27. Section 3.4.8.6, para 1. Second sentence should read "The half lives and other decay data used ... ." . agreed. "are" changed to "and"

28. Table 3-12. The column headed 'Number of Alpha Emitters' should have only integer values. \{agreed suggest leaving zero values blank. \{kept 0 rather than suggested blank\}

29. Section 3.5.1.1. Last paragraph. Second sentence. Add 'disposal facility' before 'concept 2. ' \{agreed\}

30. Section 3.5.1.2. Ist para. Next to last sentence should read 'The approach used in ... .' rather than 'approached.' \{agreed\}

31. Section 3.5.2.2.1 1st para. In the second sentence use 'assume' rather than 'assumes.' \{agreed\}

32. Section 3.5.2.2.2. Stating the scores doesn't provide much insight into the code selection. It would be much better to discuss why AREST-CT scored higher than the others. Appendix C. 3 doesn't list the scores of the other codes considered as promised in the last sentence. \{The paragraph as been rewritten as:

"AREST-CT was selected because it best meets the criteria and requirements for the disposal system release model (McGrail 1994) and the general code requirements (Mann 1995c). Ten source codes were considered (See Appendix C.3). Whereas some of the codes were comparable to AREST-CT in their ability to describe the physical processes important for the near-field, their ability to describe chemical process was significantly inferior. Similarly, the codes whose strength was in their ability to model chemical processes were weak in their ability to model the physical processes. AREST-CT also scored high in numerical methods and functionality."

33. Section 3.5.2.2.3. Check spacing after periods. In the last sentence, 'More detailed documentation ... is found ... .' \{agreed. "are" changed to "is". Space added after third period.

34. Section 3.5.5.1, 1st para. Last sentence should start 'Sections 3.5.5.2 through ...' rather than 'Sections 3.5.3.2 ...' .' agreed

35. Section 3.5.5.6. It would be good to run a sensitivity case in which the packages are close packed with no filler between packages. \{Once packing strategies are determined, further sensitivity studies would be appropriate and will be conducted. 


\section{HNF-EP-0884}

Rev. 1

36. Section 3.6.6. Check spelling of van Genuchten. \{spelling corrected to "van Genuchten"; the document was checked for the correct spelling of his name.\}

37. Section 4.2.3.1, 1st para. The statement is made that the waste is uniformly distributed in the disposal facility. Does this mean that the waste is distributed into the filler between packages such that the concentration in the waste form is reduced? Or, does it mean that within the waste forms, the waste is uniformly distributed, both intra waste package and inter waste package? or something else? Please clarify. TThe phrase "i.e, the waste is averaged over the volume of the containers and of the filler material" is added. Also a new sentence follows: "This averaging is consistent with assuming that the placement of the well is random within the area over the disposal facility vault." \}

38. Section 4.2.3.1 2nd para and earlier sections. The assumption that, because the waste remains within the waste form, it is not available for ingestion or inhalation needs further justification. \{disagree. Materials trapped in glass or a similarly performing waste form will not release their contents to air (for inhalation) or be digested.)

39. Figure 4-1. The tin and total doses share the same line format in the figure. (A different printer was used which makes the lines distinct.

40. Table 4-1 and elsewhere. In the grout PA, we were asked to address Cs-135. I don't see it being considered in any of the calculations here. \{Screening scenarios from Schmittroth 1995 indicated that because of its high retardation factor, Cs-135 would not be significant for hundreds of millions of years, a time which is far beyond our ability to estimate consequences.\}

41. Section 4.2.3.2, 1st para. For clarity, consider qualifying dose statements to be 'dose due to Cs-137.' \{agreed. "dose" was changed to "dose due to ${ }^{137} \mathrm{Cs}$ " twice in the first paragraph to make distinction between total dose and dose due to Cs clearer.

42. Section 4.2.3.2, 2nd para. Last sentence on page 4-6. Is the increase of 11 a multiplicative or additive increase?

multiplicative. The text is changed to "This increase by a factor of $11 \ldots$..."

43. Section 4.2.3.7. This section doesn't make much sense until it is clarified that, for the intruder scenarios, the radionuclides are assumed to be distributed through both the waste form and any backfill material such that the radionuclide concentrations are reduced relative to their concentrations in the waste form as manufactured. That assumption is not conservative and requires justification beyond the bounding assumption of drilling through the undiluted waste form itself. Your statement that the dose depends on the amount of waste 


\section{HNF-EP-0884}

\section{Rev. 1}

brought to the surface is correct. The critical variables then become the diameter of the core, the height of the waste, and the concentration in the waste. Areal density is only a parameter because of the calculation assumption. \{True. A sentence has been added to remind the reader of the calculational assumption, "As noted in section 4.2.3.1, the waste is assumed to be averaged over both the containers and the filler material."

44. Section 4.3.2.4, para 5. In the second sentence, 'set' should be 'sets.' \{agreed

45. Section 4.3.2.5 3rd para. In first sentence, '10,00' should be '10,000.' \{agreed\}

46. Figure 4-22. This figure needs additional discussion and perhaps reformatting to change scales. It is not clear what is shown and how it relates to the discussion in the text. \{A statement is added at the beginning of section 4.5 .2 pointing to Appendix $\mathrm{E}$ for a fuller description of the waste form simulations.

47. First paragraph on page 4-50. Next to last sentence, 'mush' should be 'much.' \{corrected\}

48. Section 4.7.3, 3rd para. Uranium is modeled to be strongly sorbed by the concrete. Is this just for the 1000 to 2000 years that the vault is assumed to be intact or are the sorptive properties assumed to last for longer times? \{Because this is a chemical reaction which is assumed to operate for very long times, the sorption is assumed to last for the length of the simulation.

49. Section 4.8.3.1, 1st para. Something is missing from 3rd sentence. \{accepted. "I and" replaced by "Land". \}

50. Section 5.2.2, 2nd para. The word 'measures' is not clear in the first sentence. ("measures" changed to "performance measures (i.e., impacts)" which is the term used to describe the various calculated impacts. ?

51. Section 5.2.4 1st para. The last sentence could be reworded "Retardation of uranium isotopes while migrating through the engineered disposal system and natural vadose zone is important in achieving the alpha-emitting radionuclides performance measure." (accepted\}

52. Section 5.2.7, 1st para. In the last sentence, 'inial' should be 'initial.' \{accepted\}

53. Section 5.5.3.4, 3rd para. The reason for determining chlorine content is not clear. \{reworded from "... chlorine content as a function of depth and infiltration rates as a function of time" to "chlorine content as a function of time (and hence determine long-term infiltration rates over the past 13,000 


\section{HNF-EP-0884}

\section{Rev. 1}

$$
\text { years). "\} }
$$

54. This document is an excellent demonstration of your well thought out and executed program! Good work! \{no comment needed\} 


\section{HNF-EP-0884 \\ Rev. 1}

\section{F.9 Other Changes}

1. The Table of Contents, List of Figures, and the List of Tables have been updated to include changed section and page numbers.

2. The latest version of the Hanford Environmental Report (Dirkes 1996) is cited rather than the year earlier version (Dirkes 1995). The text was updated in Sections 2.2.10.1, 2.2.10.2, and 2.2 .10 .4 .

3. Miscellaneous spelling corrections were made.

4. A discussion of the Hanford Site Compliance Assessment was added to the section on Hanford Performance Assessments (Section 1.2 .2 ). It reads

"1.2.2.6 Compliance Assessment for Hanford Site. In recommendation $94-2$ to the Secretary of the Department of Energy [DNFSB 1994], the Defense Nuclear Facilities Safety Board noted the need for a risk assessment that investigated the environmental impacts of all radioactive waste disposal actions or leaks at a DOE Site. The first version of this analysis is due to be published by December 1997. The authors of the compliance assessment are working with the authors of the previous performance assessments to maximize consistency in data and methods."

5. A discussion of the draft guidance documents for DOE 0435.1 was added in the section on guidance documents (Section 1.4):

"DOE is in the process of revising the DOE order on radioactive waste management. Because the draft documents concerning the new order (DOE $O$ 435.1) are subject to change, the documents listed above were used as the main sources of guidance."

A paragraph in Section 1.5 (Performance objectives) was also added:

"The proposed revision of the DOE order on radioactive waste management was not considered in setting the performance objectives because the revision is still undergoing review as this document is being written. The major changes caused by the order revision would be in the time of compliance for environmental protection being reduced from 10,000 years to 1,000 years."

6. A paragraph was added to the section on public involvement, noting the membership of Todd Martin on the External Review Board,

"A member of the Hanford Advisory Board (Todd Martin) was a member of the external review board (see Appendix.F.1) which commented on the interim performance assessment and the performance assessment activity." 


\section{HNF-EP-0884}

\section{Rev. 1}

7. Section 1.6 on the contents of the document has been expanded to include Appendix F.

"Appendix $\mathrm{F}$ contains the comments received on the initial release of the Interim Performance Assessment as well as the responses to those comments."

8. Just below Table 3-4, "bulk density" should be replaced by "particle density". Noted by Raz Khaleel in e-mail note $1 / 16 / 97$.

9. The label of the third column of Table 3-12 was changed from "End of Decay Chain" to "Next Long-lived Daughter".

10. Change title page to add current DOE and PHMC project managers.

11. The paragraph on review of the interim performance assessment (Section 3.6 .7 ) was rewritten to describe the review actual received.

"Various individuals and organizations have commented on the first version of the interim performance assessment. Their comments (as well as the responses to those comments) are displayed in Appendix F.

An external advisory board (Professor Lynn Gelhar, Dr. Louis Kovach, Todd Martin, Dr. Bill Prindle, and Dr. Elmer Wilhite with George Williamson serving as secretary) was especially form to review the performance assessment activity and, in particular, the interim performance assessment. The qualifications of this board are given in Appendix F.1. Their report is shown in Appendix F.1.3, while the responses to their comments are in Appendix F.1.4.

Others who provided comments were Phil Lamont and Doug Hildebrand of the Richland Operations office of the Department of Energy, the Washington state Department of Energy, staff of the Nuclear Regulatory Commission, the U.S. Department of the Navy, and four Hanford employees (Dewey Burbank, Dr. Kathleen Rhoads, Jeffrey Voogd, and Joseph Westsik). Their comments and the responses are also contained in Appendix F." 
Department of Energy, RL Philip E. Lamont

Defense Nuclear Facility Safety Board Suite 700, 625 Indiana Avenue, N.W. Washington, D.C. 2004

John T. Conway

Fluor Daniel Northwest (15)

Frederick M. Mann (15) H0-31

Lockheed Martin Hanford Company (6)

Russell J. Murkowski H5-03

Jeff A. Voogd (5) H5-03

Lockheed Martin Services, Inc.

Correspondence Control A3-01

Nuclear Regulatory Commission

Mail Stop T-706

11545 Rockville Pike

Rockville, MD 20852-2738

Jennifer Davis

pacific Northwest National Laboratory (2)

Charles T. Kincaid K9-33

B. Peter McGrail K6-81

Washington State Department of Ecology

1315 West 4th Avenue

Kennewick, WA 99336

Alisa Huckaby 


\section{FNN-EP-0884 \\ Rev. 1}

DISTRIBUTION LIST FOR NOTIFICATION OF REVISED DOCUMENT

(* Indicates also received Appendix F)

Daniel B. Stephens \& Associates, Inc. 1845 Terminal Drive, Suite 200

Richland, WA 99352

M.G. Piepho

Department Of Energy

EM-45

20400 Century Blvd.

Germantown, MD 20874

Julie Dambrosia
Hanford Education Action League 1408 West Broadway Avenue

Spokane, Washington 99201-1902

Todd Martin *

Lockheed Martin Hanford Company (4)

Harry L. Boston

G3-21

J.O. Honeyman

S7-81

Russell J. Murkowski

H5-03

J.A. Voogd

H5-03
Department Of Energy - RL (13)

C.V. Banks

S7-53

N.R. Brown

K6-51

D.D. Button

A.K. Crowell

C. Haass

R.A. Gilbert

R.D. Hildebrand

L.A. Huffman

G.H. Sanders

K.M.Thompson

W.J. Taylor

C.D. West

D.D. Woodrich

Flour Daniel Hanford (2)

A.M. Umek

$57-40$

D.J. Washenfelder

S7-40

$\mathrm{K} 6-51$

S7-55

S7-51

K6-51

$\mathrm{H} 0-12$

K6-51

S7-53

H0-12

$\mathrm{K} 6-51$

S7-52

S7-50
Lockheed Martin Services, Inc. (2)

Niall W. Kline

H0-31

Correspondence Control A3-01
Lynn Gelhar *

Numatec Hanford Company (3)

Ed Fredenburg

H5-61

J.S. Garfield

H5-49

C.A. Petersen

H5-27
Flour Daniel Northwest (5)

Terry A. Carlson

H5-27

Raziuddin Khaleel

Frederick M. Mann

Raymond J. Puigh

Paul D. Rittmann
H0-31

H0-31

H0-31

H0-31
Oregon State Department of Energy

Nuclear Safety Division

625 Marion St. NE

Salem, Oregon 97310

Dirk Dunning 
Pacific Northwest National Laboratory (8)

Yueting Chen

M.J. Fayer

Daniel I. Kaplan

E.M. Murphy

Stephen P. Reidel

K. Rhoads *

M.L. Rockhold

$\mathrm{K} 2-40$

$\mathrm{K} 9-33$

K6-81

K3-61

K6-81

$\mathrm{K} 3-54$

K9-33

Joseph H. Westsik, Jr, *

Puget Sound Naval Yard

NRRO

Bremerton, WA

M. French *

Rust Federal Services Hanford

Marcus I. Wood

H6-06

SGN Euisys Services Corp.

Dewey A. Burbank, Jr. *

Southwest Research Institute

6220 Culebra Road

San Antonio, TX 78284

B. Sagar

Washington State Department of Ecology

PO Box 1386

Richland WA 99352

J. Grantham

Washington State Department of Ecology

1315 West 4th Avenue

Kennewick, WA 99336

Suzanne L. Dahl
Westinghouse Savannah River Company P.O. Box 616

Aiken, South Carolina 29802

Elmer Wilhite *

Louis Kovach *

700 Huntley Road

Columbus, OH 43229

Bill Prindle *

1556 Crestline Drive

Santa Barabara, CA 93105

George F. Williamson *

254 Rackwood Drive

Richland, WA 99352 
HNF-EP - 0884

Rev. 1

dist-iv 